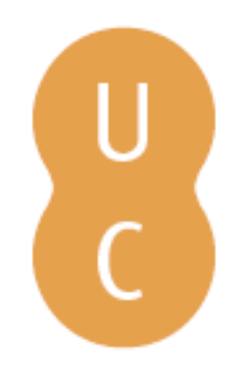

\title{
pompalina
}

\section{Máscaras dos Césares: teatro e moralidade nas vidas suetonianas}

Autor(es): $\quad$ Brandão, José Luís Lopes Publicado por: Centro de Estudos Clássicos e Humanísticos; Imprensa da Universidade

URL

persistente: URI:http://hdl.handle.net/10316.2/2320

DOI: $\quad$ DOI:http://dx.doi.org/10.14195/978-989-721-068-6

Accessed : $\quad$ 26-Apr-2023 16:27:54

A navegação consulta e descarregamento dos títulos inseridos nas Bibliotecas Digitais UC Digitalis, UC Pombalina e UC Impactum, pressupõem a aceitação plena e sem reservas dos Termos e Condições de Uso destas Bibliotecas Digitais, disponíveis em https://digitalis.uc.pt/pt-pt/termos.

Conforme exposto nos referidos Termos e Condições de Uso, o descarregamento de títulos de acesso restrito requer uma licença válida de autorização devendo o utilizador aceder ao(s) documento(s) a partir de um endereço de IP da instituição detentora da supramencionada licença.

Ao utilizador é apenas permitido o descarregamento para uso pessoal, pelo que o emprego do(s) título(s) descarregado(s) para outro fim, designadamente comercial, carece de autorização do respetivo autor ou editor da obra.

Na medida em que todas as obras da UC Digitalis se encontram protegidas pelo Código do Direito de Autor e Direitos Conexos e demais legislação aplicável, toda a cópia, parcial ou total, deste documento, nos casos em que é legalmente admitida, deverá conter ou fazer-se acompanhar por este aviso.

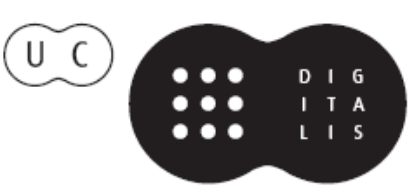




\section{Máscaras dos Césares}

teatro e moralidade nas Vidas suetonianas

\section{José Luís Brandão}

IMPRENSA DA UNIVERSIDADE DE COIMBRA 


\section{HVMANITAS SVPPLEMENTVM • ESTUDOS MONOGRÁFICOS}

ISSN: $2182-8814$

Apresentação: esta série destina-se a publicar estudos de fundo sobre um leque variado de temas e perspetivas de abordagem (literatura, cultura, história antiga, arqueologia, história da arte, filosofia, língua e linguística), mantendo embora como denominador comum os Estudos Clássicos e sua projeção na Idade Média, Renascimento e receção na actualidade. 


\section{Máscaras dos Césares}

teatro e moralidade nas Vidas suetonianas

\section{José Luís Brandão}


Todos os volumes desta série são sujeitos a arbitragem científica independente.

Autor

José Luís Lopes Brandão

Título

Máscaras dos Césares: teatro e moralidade nas Vidas suetonianas

EDITOR

Imprensa da Universidade de Coimbra

Annablume

Centro de Estudos Clássicos e Humanísticos

EDIÇÃo

$1 \mathrm{a} / 2009$

Coordenador Científico do Plano de Edição

Maria do Céu Fialho

Conselho Editorial

Maria de Fátima Silva, Francisco de Oliveira, Nair Castro Soares

Director Técnico da Colecção

Delfim F. Leão

Concepção Gráfica e Paginação

Rodolfo Lopes

IMPRESSÃO

Simóes \& Linhares, Lda.

Av. Fernando Namora, no 83 - Loja 4

3000 Coimbra

Obra Realizada no Âmbito das Actividades da UI\&D Centro de Estudos

Clássicos e Humanísticos

Universidade de CoImbra

FACUlDade De Letras

TeL: 23985998 I | FAX: 239836733

ISBN: 978-989-8281-14-2

ISBN DigITAL: 978-989-721-068-6

DOI: http://dx.doi.org/10.14195/978-989-721-068-6

Depósito Legal: 296298/09

@ Imprensa da Universidade de Coimbra

@ Annablume

Publicado no Âmbito do Programa POCI 2010 - Fundação para a Ciência e Tecnologia.

Reservados todos os direitos. Nos termos legais fica expressamente proibida a reprodução total ou parcial por qualquer meio, em papel ou em edição electrónica, sem autorizaçáo expressa dos titulares dos direitos. É desde já excepcionada a utilização em circuitos académicos fechados 


\section{Sumário}

Preâmbulo

Nota Prévia

INTRODUÇÃo

Parte I. A construção das VIDAs

1. Antecedentes das Vidas dos Césares 33

1.1.Suetónio e a erudição $\quad 33$

1.2. As fontes ao serviço da intenção biográfica 37

2. A apresentação ao leitor $\quad 55$

2.1. Per tempora / per species $\quad 55$

2.2. Virtutes/uitia $\quad 57$

2.3. O estilo de Suetónio $\quad 60$

$\begin{array}{ll}\text { 3. Meios de captação do leitor } & 71\end{array}$

3.1. Sedução do leitor $\quad 71$

3.1.1. Sugestão de realismo $\quad 71$

$\begin{array}{ll}\text { 3.1.2. Rumores e anedotas } & 73\end{array}$

3.1.3. A força do cómico 76

3.1.4. A intervenção directa do autor no texto 81

3.2. Apelo às emoções $\quad 83$

3.2.1. A generalização $\quad 84$

3.2.2. A organização em crescendo 85

Parte II. O teatro das VIDas 93

1. A ascensão: spes imperii $\quad 97$

1.1. Ascensão gloriosa 97

1.1.1. Júlio César: um predestinado 97

1.1.2. Octávio: o cruel vingador de César $\quad 102$

1.1.3. Galba: o destruidor da dinastia júlio-cláudia 106

1.1.4. Vespasiano: o imperador que veio do Oriente 109

1.1.5. Tito: amor e delícias do género humano 114

1.2. Ascensão controversa 117

1.2.1. Tibério: um herdeiro de segunda escolha 117 
1.2.2. Calígula: o filho de Germânico

1.2.3. Nero: o filho de Agripina 124

1.2.4: Otão: um companheiro de Nero $\quad 125$

1.3. Ascensão inglória 128

1.3.1. Cláudio: uma carreira sem dignidade $\quad 128$

1.3.2. Vitélio: a carreira de um Glutão 130

1.3.3. Domiciano: um irmão menor 131

2. Conquista e recepção do poder supremo 135

2.1. A vitória da ambição de uma família 135

2.2. A pretexto da salvação do estado 140

2.3. A "farsa" de Tibério 144

2.4. Sucessão e crime 147

2.5. Aclamação farsesca 150

2.6. A mudança radical de comportamento 157

3. Teatro e Poder 159

3.1. O culto do espectáculo: do conveniente ao escandaloso 159

3.2. Política e espectáculo 166

3.3. Teatro e moralidade 171

3.3.1. Ostentação de virtudes $\quad 173$

3.3.2. Os vícios como espectáculo $\quad 180$

4. Vida e drama 199

4.1. As voltas da Fortuna e suas consequências biográficas 199

4.2. Carácter e progressão dramática 211

4.2.1. Construção da imagem de um tirano 211

4.2.2. Construção da imagem de um bom príncipe 239

4.2.3. Construção da imagem de um imperador incapaz 249

4.3. Comédia e carácter 252

5. Acta est fabula 271

5.1. As boas mortes 271

5.2. Morte e castigo 276

5.2.1. O ferro: o sacrifício do tirano 276

5.2.2. O veneno: mortes suspeitas $\quad 297$

5.2.3. Suicídio: a morte como necessidade 300

5.3. Morte e redenção 306

5.4. Aplauso e pateada 308

6. Do teatro dos Césares ao teatro de Suetónio 317 
1. Caracterização pela ascendência 331

1.1. Herança positiva 331

1.2. Herança negativa $\quad 335$

1.3. A negação dos genes 338

2. Retratos falantes 341

2.1. Retrato físico 341

2.2. O adorno 352

3. Juízo sobre actos e palavras 357

3.1. Os "freios" de um imperador: a moderatio e a abstinentia 358

3.1.1. Atitude face ao poder: da moderatio à ciuilitas, clementia e pietas 358

3.1.2: Atitude face às riquezas: da abstinentia à liberalitas 368

3.2. A defesa dos bons costumes: a dignitas e a castitas 372

$\begin{array}{ll}\text { Conclusão } & 383\end{array}$

Bibliografia 393

I. Edições integrais 393

II. Edições parciais comentadas $\quad 394$

III. Índice suetoniano $\quad 395$

IV. Estudos 395

Índices

I. Índice de personalidades e lugares históricos 417

II. Índice de autores antigos 441

III. Índice analítico 475 
(Página deixada propositadamente em branco) 
Aos meus pais

e

ao Prof. Doutor Walter de Medeiros 
(Página deixada propositadamente em branco) 


\section{Preâmbulo}

Quando folbeamos os muitos romances históricos que todos os dias aparecem sobre o Império Romano, reconhecemos amiúde ecos de Suetónio - o autor das Vidas dos Césares é, de facto, uma das fontes obrigatórias para o início do principado até finais do séc. I d.C. Seguindo um método diferente do da bistoriografia latina, quer na forma, quer no conteńdo, eprivilegiando uma exposição mais caracterológica que cronológica, o biógrafo ilustra o seu ponto de vista sobre cada governante com um manancial de curiosidades, anedotas e ditos de espirito que fazem a delicia dos leitores de todos os tempos e fornecem informaçôes preciosas aos historiadores modernos. Suetónio permite, assim, colmatar com elementos ditos biográficos a tradição historiográfica sobre os imperadores Júlio-Cláudios, os breves antagonistas da crise de 68-69 d.C. e os Flávios. Em Máscaras dos Césares. Teatro e moralidade nas Vidas suetonianas, procuramos perceber a forma como o biógrafo escreve história, como apresenta e manipula as personagens, como julga os governantes e como condiciona o juizo dos leitores.

O conteúdo do presente volume corresponde à dissertação Suetónio e os Césares: teatro e moralidade, apresentada à Faculdade de Letras da Universidade de Coimbra (2003). Procurámos, contudo, adaptar o texto ao grande público, aligeirando notas aqui, traduzindo mais e esclarecendo conceitos ali, alterando a estrutura acolá, de modo a fugir um pouco a um formato demasiado académico, sem, no entanto, afectar o produto da investigação, agora colmatado com algumas achegas posteriores.

Acompanha este trabalho uma dívida de gratidão para com várias instituiçôes e pessoas que deixaram a sua marca nas diversas fases, segundo se tratava de investigar, de redigir ou de publicar. Devemos, antes de mais, salientar o apoio dos professores e funcionários do Instituto de Estudos Clássicos da Faculdade de Letras da Universidade de Coimbra, que continuamente nos incentivaram e facultaram os meios para levarmos a cabo esta tarefa. No que diz respeito a docentes de outras Universidades, estamos gratos à Doutora Cristina Pimentel e ao Doutor Nuno Simöes Rodrigues da Universidade de Lisboa pelas sugestöes e material bibliográfico que gentilmente nos facultaram; aos professores Louis Callebat e Philippe Moreau, pelo acolbimento e orientação na Universidade de Caen; ao professor Paolo Fedeli por igual mercê na Universidade de Bari. Os periodos de investigação no estrangeiro não teriam sido possiveis sem o apoio da Fundacãa Calouste Gulbenkian e da Faculdade de Letras da Universidade de Coimbra. Agradecemos também a mediação neste processo o o acompanhamento dos Doutores José Ribeiro Ferreira, Maria de Fátima Silva e Francisco Oliveira. Pela partilha do trabalho em terras estrangeiras estamos gratos aos Doutores Luisa Ferreira, Paulo Sérgio Ferreira e Cläudia Teixeira. Entre os muitos que nos prestaram generosa ajuda das mais diversas formas, uma palavra de gratidão à Doutora Nair Soares, pela indicaşão de bibliografia e pistas de trabalho; ao Doutor António Rebelo, pelo apoio no campo da informática; à Dra Zélia Sampaio Ventura, pelo acompanhamento sempre tão amigo de todo o processo; à Dra Luisa Braga, pela 
solicitude com que nos incentivou; à Dra Ana Balula, ao António dos Santos e à Elvira Correia, por se terem enredado generosamente no nosso labor.

Ao Centro de Estudos Clássicos e Humanisticos e à sua Coordenadora, Doutora Maria do Céu Fialho, e, de igual modo, à novíssima biblioteca online Classica Digitalia (http://classicadigitalia.uc.pt) e ao seu promotor Doutor Delfim Leão, expresso a meu mais profundo reconbecimento pelo interesse e empenho com que acolheram a publicação, que fica assim tão valorizada. No processo final de revisão e formatação, agradeço o prestimoso trabalho dos incansáveis Drs. Alia Rodrigues e Rodolfo Lopes, a quem este volume muito deve.

Cumpre-nos ainda salientar o fundamental apoio dos que nos estão mais próximos: pais e irmãos. Imensa é a divida de gratidão que temos para com o nosso orientador, Doutor Walter de Medeiros, que, incansável e paciente, ao longo destes anos, nos tem brindado com a preciosa dádiva da amizade e um continuado incentivo.

Bem hajam! 


\section{Nota PRÉVIA}

Para os excertos das Vidas dos Césares adoptamos a edição teubneriana de Ihm; eventuais alteraçôes vêm indicadas em nota. Quanto à citação de obras de autores antigos, seguimos, para os latinos, as abreviaturas do Oxford Latin Dictionary de Glare; para os gregos, as do Greek-Englisn Lexicon de H. G. Liddell $\mathcal{\sigma}^{\circ}$ R. Scott. Nos casos em que tal não foi possivel, procurámos adoptar critérios semelhantes aos daqueles dicionários.

Os autores latinos ou gregos e os passos citados figuram no indice de autores antigos (II). Mas, dado o teor da obra de Suetónio, achámos útil incluir, em separado, um indice de personalidades e lugares históricos (I), no qual se procura identificar cada entrada com brevíssimos apontamentos biográficos ou topográficos: aqui se apresenta também uma meia dúzia de personagens miticas, mas que, na antiguidade, fundiam lenda e história na tradição dos fundamentos da civilização ocidental. Além destes, acrescentámos também um indice analitico dos conceitos mais relevantes (III).

Quanto aos autores modernos, citamo-los apenas pelo nome e ano de publicação; aduzimos, no entanto, informação suplementar quando se trata de uma edição integral (ed.), ou de uma edição comentada de uma Vida em particular (com.), ou do index, para os distinguir dos estudos e facilitar, assim, a identificação da obra entre as quatro categorias em que dividimos a bibliografia. As siglas das publicações periódicas são, sempre que possivel, as de L’Année Philologique. 
(Página deixada propositadamente em branco) 


\section{INTRODUÇÃo}

Ao encetar a tarefa de escrever as Vidas dos Césares, Suetónio tem plena consciência do caminho que escolhe. Historiografia e biografia representavam modelos diferentes de abordagem. $\mathrm{O}$ método antigo dos annales revela-se desadaptado ao tratamento do governo dos imperadores. Se, durante a República, se fazia história à volta da rotação anual dos cônsules, no Império, a unidade política é definida pelo tempo da duração de cada principado. Se, durante a República, prevalecia o registo dos acontecimentos e feitos levados a cabo pela comunidade do senatus populusque Romanus, com o advento do Império cresce o protagonismo da figura do princeps daquela colectividade: a pessoa do imperador, com os seus vícios e virtudes, torna-se o principal agente da história - e o registo biográfico impõe-se naturalmente. Nada se ganha já com o saudosismo da República. O senador Tácito ainda estabelece uma contraposição moralizadora entre passado e presente, virtude e decadência moral, mas a administração imperial evoluiu por um caminho que não tem retorno: a extensão do Império assim o exige. ${ }^{1}$ Suetónio, cavaleiro e funcionário imperial, é um produto da nova ordem instituída por Augusto, e escolhe um modelo que, à partida, assenta numa tradição diversa da dos historiadores. ${ }^{2}$ Tácito, empenhado na história de Roma do século I, acabara de escrever os Annales; Suetónio opta pela biografia, género mais humilde, mas mais adequado ao governo de um só homem. Por outro lado, o modelo biográfico suetoniano também se distingue do seguido por Tácito no seu Agricola.

Não seria razoável buscar um modelo único para o método biográfico adoptado por Suetónio. Muitas das características do seu trabalho se encontram em desenvolvimento ao longo da história da literatura greco-latina. Entre os precursores da biografia em prosa, podem contar-se, além da saga heróica, as formas líricas que se concentram no tratamento de uma personalidade: hinos,

\footnotetext{
${ }^{1}$ Vide Bradley, K. R. 1985b, 265.

${ }^{2}$ Sobre a adequação da biografia à história dos imperadores, vide Syme, R. 1980, 104-128; Grimal, P. 1986, 729-130; Giva, M. A. 1990, 535-559.
} 
ditirambos, cantos fúnebres, encómios, epinícios, elegias. Discursos e cantos fúnebres são potenciais biografias. A própria tragédia, enquanto «representação de vidas e discursos de heróis», como a define um lexicógrafo bizantino, ${ }^{3}$ será a transformação da biografia sagrada em forma dramática. ${ }^{4}$

Em meados do século $V$, os escritos biográficos aparecem na mesma altura em que surgem os primeiros livros de geografia, genealogia e história política. $\mathrm{O}$ poeta Íon de Quios escreve na primeira pessoa sobre personalidades que conheceu (como Címon, Ésquilo e Sófocles), e não negligencia curiosidades que farão as delícias da biografia. Nos fragmentos sobreviventes do seu trabalho (Epidemiai), Íon manifesta interesse por contemporâneos ilustres, gosto do anedótico e do pormenor realista, e chega mesmo a inserir traços físicos. Hecateu de Mileto, geógrafo e genealogista, apresenta, de igual modo, relatos na primeira pessoa e interessa-se pelas genealogias orientais. Cílax de Carianda, além de escrever, com um cunho autobiográfico, sobre explorações geográficas, terá composto uma biografia de Heraclides, tirano de Mílasa. Segundo Momigliano, tal facto deve-se à influência persa, em cujo território a autobiografia estava na moda. ${ }^{5}$ Estes três escritores vivem na zona de influência oriental: Ion e Hecateu na Jónia, Cílax viaja pelo golfo Pérsico. Sofrem influência das crónicas de reis, de carácter autobiográfico. ${ }^{6}$ Tal como o poeta Íon, também o prosador Estesímbroto, natural de Tasos, no Egeu, regista a impressão que lhe causaram figuras dominantes da vida pública ateniense do tempo. No seu trabalho sobre Temístocles e Péricles, Estesímbroto refere costumes pessoais, pormenores anedóticos, explora o episódico e o sensacional, faz citações directas e mistura vida privada com vida pública. Além disso, inclui nos seus trabalhos registos biográficos de poetas do passado - um currículo que, de algum modo, lembra o de Suetónio, embora Estesímbroto não escreva também sobre grandes políticos do passado. Stuart aponta razões religiosas e cívicas para a resistência dos Gregos à biografia dos políticos - a ideia da exaltação do Estado prevalece sobre o indivíduo. ${ }^{7}$ Neste

${ }^{3}$ Etymologicon magnum 763.58 .

${ }^{4}$ Como afirma Stuart, D. R. 1928, 15-16. Uma das teorias da origem da tragédia prende-se com a comemoração de personalidades singulares: celebrações miméticas junto aos túmulos de heróis, cantos fúnebres, ritos de culto dos antepassados; vide STuart, D. R. 1928. Desta sorte, a biografia apresentar-se-ia, no início, em íntima relação com uma representação mimética e teatral. Objecta-se que esta teoria, além de não explicar os problemas implícitos na origem da tragédia, enferma do facto de tal género não evocar os heróis mortos, enquanto mortos, uma vez que, por essência, se alimenta das desgraças que viveram, ao ponto de os devolver momentaneamente à vida, como afirma VAra Donado,J. 1996, 14. De qualquer modo, quer num caso, quer no outro, mantém-se uma certa conexão entre drama e biografia. Opinião diferente tem Momigliano, A. 1993, 38-39: para este autor, contar a vida, do nascimento à morte, é o oposto da atitude trágica. Também considera problemática a relação entre biografia e comédia, pois, embora as comédias de Aristófanes contenham muito material biográfico e autobiográfico, não deram nenhum contributo especial para as biografias de Cléon, Sócrates ou Eurípides.

${ }^{5}$ Vide Momigliano, A. 1990, 5-16. Este autor lembra que, ao contrário dos Gregos, os Persas, para estabelecerem direitos legais, davam muita importância à citação de documentos.

${ }^{6} \mathrm{O}$ rei Dario tem uma espécie de Res gestae, materializada na inscrição de Behistun.

${ }^{7}$ Vide Stuart, D. R. 1928, 44-55. Sintomático é o facto de os inimigos de Fídias o acusarem de colocar, no combate contra as Amazonas, figuras masculinas com os traços do artista e os de Péricles - uma profanação da glória do divinizado Teseu (Plutarco, Per. 31); e de os Gregos 
ambiente floresce a história, de que são testemunho as obras de Heródoto e Tucídides. Mas gradualmente irá desaparecer esta supremacia do colectivo sobre o individual. ${ }^{8}$

Tanto quanto se sabe, à parte a vida de Heraclides, tirano de Mílasa, da autoria de Cílax, a biografia propriamente dita dá os primeiros passos, na Grécia do século IV, sob a forma de encomium em prosa, como é o caso do Evágoras de Isócrates e do Agesilau de Xenofonte. ${ }^{9}$ Ao contrário do lamento fúnebre, o encomium põe o seu foco na vida. A estrutura mais ou menos fixa, as preocupações retóricas e os pormenores anedóticos não servem a intenção de fazer obra histórica, mas de elogiar o herói e, através da exposição das suas virtudes, apontá-lo como modelo para os concidadãos. Omitem-se os pormenores não dignificantes, como o assassínio da figura elogiada. ${ }^{10}$ Tanto no Agesilau como no Evágoras se trata o carácter como algo acabado, que se manifesta desde criança; ambas as obras pressupõem que os traços da personalidade são iluminados pelas acções. Mas enquanto Isócrates, em vez de agrupar os feitos sob virtudes específicas, mistura a parte descritiva na narrativa, Xenofonte separa-as: depois de uma narrativa cronológica inicial dos feitos de Agesilau, em que pontua o discurso com expressões de aprovação (1), Xenofonte passa a uma exposição através de rubricas, encabeçadas por virtudes, sob as quais cataloga o seu material exemplificativo (2-9). Agesilau integra pormenores da vida privada, não por simples curiosidade, mas para ilustrar qualidades morais. ${ }^{11}$ Procuraremos demonstrar que também Suetónio, ao contrário de uma opinião bastante divulgada, não cede simplesmente às curiosidades, mas coloca esses pormenores ao serviço da imagem moral que,

apagarem, segundo Tucídides, o dístico da trípode oferecida por Pausânias a Febo - onde o general celebrava o seu comando na vitória sobre o inimigo persa, e se apresentava como autor da oferta votiva - e escreverem os nomes das cidades que participaram na empresa e na dedicação da trípode (Tucídides, 1. 132). E Demóstenes, no século IV, há-de lamentar o costume do seu tempo de atribuir a honra da vitória aos comandantes, em vez de à comunidade no seu todo (23.198).

${ }^{8}$ No século IV, o homem já não é visto tanto como elemento do Estado, mas mais como um indivíduo: o realismo da arte de Praxíteles e Lisipo reflecte esta nova atitude. As escolas de retórica e as escolas filosóficas desenvolvem a arte de falar do indivíduo, seja ele um terceiro, ou seja o próprio sujeito da enunciação. Os retóricos exploram o encomium; os filósofos, a biografia idealizada de monarcas e filósofos. Vide Stuart, D. R. 1928, 128-129; Momigliano, A. 1993, 102.

${ }^{9}$ Uma "quasi biografia”, nas palavras de Stuart, D. R. 1928, 19. Isócrates apresenta o seu trabalho como directo descendente do encomium; e Xenofonte acentua que o seu Agesilau é um louvor, não um lamento pela morte do monarca espartano (Ages. 10.3).

${ }^{10}$ Isócrates (Ev. 71) omite o assassínio de Evágoras: diz que ele viveu uma longa vida e escapou às enfermidades. A deficiência física de Agesilau (era coxo) determina a omissão do aspecto físico, enquanto a beleza e robustez física - crescentes, em Evágoras, à medida que ele se tornava um homem (22-23) - permitem cumprir o requisito do retrato físico.

11 Sobre o conteúdo e as características retóricas do Agesilau de Xenofonte e do Evágoras de Isócrates, vide Stuart, D. R. 1928, 60-90; Momigliano, A. 1993, 49-52. Nota Wallace-Hadrill, A. 1984, 71: "It is merely perverse to suggest that when Suetonius employed the same scheme on emperors, because it was a non-narrative method it must have been the product of the scholarly biographical tradition». 
sobre o biografado, pretende transmitir ao leitor.

Mas outras aproximações à biografia ocorrem na mesma época. Entre elas, outra obra de Xenofonte, os Memoráveis (Apomnemoneumata, cuja tradução latina adequada será Commentarii): aí encontramos uma compilação das conversas filosóficas de Sócrates, referências ao seu aspecto físico, à sua vida frugal e gostos simples e às suas actividades diárias. Trata-se de uma defesa de Sócrates, que apresenta mais um desenvolvimento dos pensamentos do filósofo, aplicados ao contexto político do tempo, do que as palavras do próprio (procedimento também usado na Apologia de Sócrates). A presença da ficção na biografia é uma tendência desenvolvida igualmente na Ciropedia, na qual Xenofonte não tem a intenção de descrever a pessoa histórica, mas de compor uma biografia romanceada, que apresenta Ciro como o produto de uma educação ideal. A coroar a vida deste modelo de reis, sobrevém uma morte serena e sábia, entre considerações sobre a imortalidade da alma. ${ }^{12}$

Além destas "experiências" de biografia,${ }^{13}$ também a historiografia, embora privilegie os sucessos políticos, ao reconhecer a importância do indivíduo, parece, por vezes, cruzar-se com a biografia: Teopompo, nas Filípicas, centradas, como o nome indica, em Filipe da Macedónia, inclui referências aos vícios e virtudes, e digressões sobre pormenores considerados biográficos. Éforo, nas histórias de Alexandre e nos Diádocos, apresenta excertos de historiografia centrada em indivíduos. Xenofonte inclui, na Anábase, retratos de generais. ${ }^{14}$

Aos peripatéticos se tem atribuído a fama do aperfeiçoamento da biografia. ${ }^{15}$ Em resultado do interesse pelos caracteres, estas Vidas centram-se na análise dos tipos humanos. A caracterização da pessoa, já contida no encomion, torna-se mais objectiva: uma biografia formal. Não será por acaso que se incluem nesta escola filosófica três dos quatro biógrafos gregos considerados precursores do De uiris illustribus de Suetónio, segundo nos diz Jerónimo, no prefácio do seu livro homónimo: Hermipo, Sátiro e Aristóxeno (Antígono de Caristo, nomeado em segundo lugar, é um académico). Aristóxeno de Tarento (nas palavras de Jerónimo, longe omnium doctissimus), discípulo de Aristóteles da primeira vaga, tem sido considerado, por isso, o introdutor da chamada biografia peripatética: ${ }^{16}$ escreve Vidas de homens, que incluíam Vidas

${ }^{12}$ Contrariamente ao testemunho de Heródoto, 1.214, segundo o qual Ciro morreu em combate.

${ }^{13}$ Assim designa Momigliano, A. 1993, 62-64, os registos biográficos e autobiográficos anteriores aos peripatéticos.

${ }^{14}$ Políbio, 16.7-9, critica Teopompo por incluir relatos inverosímeis e prodígios; e acusa Éforo e Teopompo (juntamente com Timeu) de usarem a imaginação para suprir a falta de conhecimentos militares (12.25 f-h). Vide Ullman, B. L. 1942, 32.

${ }^{15}$ Entre os seguidores desta escola, a biografia tende a reflectir o interesse pela pesquisa histórica e pela filosofia ética, na linha do livro IV da Ética a Nicómaco de Aristóteles e do impulso do estudo dos caracteres, cujo seguidor mais célebre é Teofrasto.

${ }^{16}$ Stuart, D. R. 1928, 129-132 e 135, contesta tal atribuição e prefere classificá-lo como membro de um grupo que é o resultado de um processo evolutivo. Momigliano, A. 1993, 73-76, considera-o um aristotélico não convencional, que parece nutrir mais simpatia por Pitágoras (de cujos seguidores fizera parte) do que por Sócrates, Platão ou Aristóteles. Acrescenta que Aristóxeno terá sido o primeiro a considerar as anedotas como parte essencial da biografia. 
de Pitágoras, Sócrates e Platão. Mas outros autores dessa geração floresceram. Clearco escreve um encomium de Platão, o que mostra que aquele antigo género continua popular. Dicearco, representante da aplicação da noção de bios a uma nação, expõe a Vida da Grécia. Fénias, também discípulo de Aristóteles, escreve sobre Tiranos da Sicília, com intuitos moralizantes: para demonstrar os excessos do absolutismo, os tiranos são usados como exemplos de vida sumptuosa. ${ }^{17}$

A biografia peripatética tende a obedecer a um esquema mais ou menos fixo: nascimento, juventude e carácter, realizações e morte - momentos acompanhados de reflexão moral. De modo diferente dos encomiastas, que se debruçam sobre figuras do seu conhecimento pessoal (ou figuras lendárias, cujo tratamento era apenas retórico), para os peripatéticos são biografáveis tanto figuras de um passado distante como contemporâneos. ${ }^{18}$

Apesar de mais verídica e realista que o encomium - pois tem em conta os aspectos negativos, faz um retrato físico mais sistemático, refere o vestuário e os gostos pessoais -, é corrente (com base em preconceitos modernos) criticar-se a biografia peripatética por valorizar pouco a cronologia e descurar o contexto, por se polvilhar de anedotas, de pitoresco e divagações, só para divertir o leitor, por dar crédito a lendas, aceitar material de fontes duvidosas. ${ }^{19}$ A narrativa dos portentos que se geram à volta do nascimento, como prenúncio do brilhante futuro, torna-se um lugar-comum, transmitido, entre outros, acriticamente. $\mathrm{O}$ rigor histórico não era essencial. É curioso que Dúris, suposto discípulo de Teofrasto, se afaste da distinção aristotélica entre poesia e história, e acuse Éforo e Teopompo de não estarem à altura dos factos que narram, por falta de mimesis e hedone na sua escrita. ${ }^{20}$ Ora, para Aristóteles (Po.1459a 17ss), a hedone é resultante da unidade de acção que distingue precisamente a mimese épica e trágica da narrativa histórica. A Vida de Eurípides de Sátiro, escrita

17 Townend, G. B. 1967, 81-82, com base em uma observação de Stuart, propõe Fénias de Éreso como possível modelo de Suetónio, com um argumento que nos parece precário: porque escreveu vidas não só de poetas e filósofos, mas também de tiranos da Sicília, sem cair no habitual tom de panegírico (Vide n. 11). StuART, D. R. 1928, 132-134, menciona a obra Tiranos da Sicília como precursora dos Césares de Suetónio, e não como modelo. Cizex, E. 1977, 27 n. 95, pelo contrário, diz que nada justifica a hipótese de que Fénias seja o modelo de Suetónio.

${ }^{18}$ Vide Stuart, D. R. 1928, 156. Além disso, não se faz biografia apenas de políticos e generais, mas de tiranos, artistas, filósofos e poetas: Sátiro escreveu Vidas de monarcas, políticos, oradores, poetas e filósofos, entre as quais uma Vida de Eurípides, recentemente descoberta; Hermipo de Esmirna é autor de um vasto trabalho sobre filósofos, poetas e legisladores; Aristóxeno inclui no seu currículo Vidas de tocadores de flauta; e Dúris de Samos, pertencente à geração que se seguiu à de Aristóxeno e confesso discípulo de Teofrasto, escreveu Vidas de pintores.

${ }^{19}$ Multiplicaram-se as recolecções de anedotas: Fénias tem livros deste género sobre a morte de homens ilustres que antecipam o trabalho de Titínio Capitão, no século I-II d. C. Aristóxeno não se livra da reputação de amante de escândalos. Mas há quem considere que o seu retrato de Sócrates seria o contrapeso realista dos retratos idealizados de Platão e Xenofonte: vide STUART, D. R. 1928, 138-143. O fragmento descoberto de Sátiro revela os seus méritos como estilista, mas uma ausência total de espírito crítico.

${ }^{20}$ FHG 2.469.1 Muller. Vide Ullman, B. L. 1942, 38-39; Foucher, A. 2000, 776-777. Para este autor, a acusação de Dúris equivale a dizer (através de palavras aristotélicas e um pensamento não aristotélico) que falta tragédia ao relato histórico de Éforo e Teopompo. 
em forma de diálogo, insere-se, contra o que seria de esperar, numa tradição literária e parece revelar o intuito de importar a atmosfera dramática para a biografia, a fim de a tornar mais viva. ${ }^{21}$

A escola peripatética tem o mérito, no entanto, de desenvolver a biografia: delineia os seus métodos e os tópicos. Stuart demonstra que, na Vida de Eurípides de Sátiro, já está presente o esquema organizativo que encontramos nas Vidas de Suetónio - a organização cronológica abreviada, no início e na parte final; categorias em vez de cronologia no delineamento da figura ao chegar à idade adulta -, bem como os tópicos essenciais de abordagem; mas, acrescenta Stuart, Sátiro não seria certamente o único a usar tal esquema. ${ }^{22}$ Também é verdade que esta biografia transmite informação relevante sobre a cultura humana e inicia a discussão sobre as fontes e influências dos filósofos e homens de letras. ${ }^{23}$

Se os peripatéticos são largamente responsáveis pelo desenvolvimento deste género de biografia, a prática não se confina àquela escola: um dos seus famosos cultores foi, como dissemos, o filósofo académico Antígono de Caristo (um dos mencionados precursores de Suetónio) que escreveu sobre filósofos. Sátiro e Hermipo, considerados embora peripatéticos, trabalham principalmente em Alexandria. Em relação à biografia helenística, as dúvidas são, portanto, mais que as certezas. A biografia, sem fronteiras bem definidas, parece subsistir ao longo da história e ser aproveitada, com os mais diversos fins, pelas várias correntes de pensamento, cuja marca vem, por fim, a ostentar, quer a influência socrática, peripatética, académica, alexandrina, quer outra.

Podemos encontrar também vestígios da evolução de uma biografia propriamente itálica. $^{24} \mathrm{~A}$ biografia latina parece nascer para ilustrar o provérbio: de mortuis nil, nisi bonum. As neniae, primitivos lamentos fúnebres, integravam referências às virtudes do defunto. As canções de banquetes, carmina conuiualia, segundo nos diz Cícero, ${ }^{25}$ existiram até ao tempo de Catão e celebravam as virtudes dos heróis desaparecidos. Típico de um atrium romano, e manifestação da pietas familiar, são as imagines dos antepassados, acompanhadas dos tituli que as identificam e enumeram os cargos políticos e militares das pessoas representadas. Este género reúne, assim, elementos gerais da biografia: antepassados, descendentes, honras e aparência física. O titulus e o elogium continham o esqueleto biográfico, desenvolvido pelas laudationes

${ }^{21}$ Como sugere Stuart, D. R. 1928, 179. De facto, Aristóteles, Po. 1447 b 10-11, menciona os mimos e os diálogos socráticos como géneros fautores de mimese (por meio da linguagem) em prosa.

${ }^{22}$ Vide Stuart, D. R. 1928, 185-186.

${ }^{23} \mathrm{O}$ que abre a porta a acusações de plágio. Além disso, Sátiro deduz muitos dos pormenores biográficos sobre Eurípides a partir das tragédias deste autor, o que é um método caracteristicamente peripatético, como assinala Momigliano, A. 1993, 80-81.

${ }^{24}$ Vide Stuart, D. R. 1928, 189-220.

${ }^{25}$ Tusc. 4.2.3; Brut., 19.75. Segundo Momigliano, A. 1990, 92-93, as canções de banquete poderão ter desaparecido devido à legislação contra os mala carmina, talvez por terem degenerado em canções destinadas a ferir inimigos. 
funebres. Estas adquirem forma literária, ganham um elevado estilo de oratória que faz lembrar o encomium grego, aproximam-se das normas de uma biografia formal e tornam-se uma verdadeira instituição romana durante a República e o Império. Entre os elogiados contavam-se mulheres ilustres: Júlio César faz o elogio da tia Júlia; e Octávio, da avó Júlia, irmã de César. ${ }^{26}$ Como se verifica pelo conteúdo do discurso de César em louvor da tia, transmitido por Suetónio, e do de Nero em louvor de Cláudio, segundo o testemunho de Tácito, ${ }^{27}$ a laudatio inclui o elogio dos antepassados do extinto, como tópico essencial do início do discurso, tal como já acontecia no encomium grego; e, no tocante ao defunto, refere o seu cursus honorum e as res gestae. Devia certamente referir pormenores tanto da vida pessoal e doméstica como da carreira pública. Esta forma cresceu em Roma, independentemente da influência grega, mas com um percurso paralelo. A continuidade desta prática literária resulta da preservação das laudationes nos arquivos de família e do seu uso como modelos e fontes de futuros trabalhos. ${ }^{28}$ Trata-se de uma forma de exaltação moral que influenciará a biografia romana.

A biografia, como género, existe em Roma desde o tempo de Gaio Graco. ${ }^{29}$ Vários políticos tentaram a autobiografia com intuitos propagandísticos. ${ }^{30}$ Dois cultores são mencionados por Tácito $(A g$. 1$)$ : M. Emílio Escauro e P. Rutílio Rufo, que se debruçavam não só sobre os facta, mas também sobre os mores. Abundam os Commentarii de uita sua, durante a República e o Império. Os Commentarii de César alcançaram grande fortuna pela sua qualidade literária. Mas também Augusto compõe, além das Res gestae, treze livros De uita sua; Tibério e Cláudio fazem o mesmo. Uns e outros terão encontrado os tópicos de desenvolvimento já formulados nas laudationes. ${ }^{31}$ Foram libertos e clientes os principais autores da antiga história da biografia romana. ${ }^{32} \mathrm{~A}$ biografia memorial de um protector, de um amigo ou de um familiar é vista em Roma como uma forma de laudatio: tal é o caso, no Império, da biografia

${ }^{26}$ Suetónio, Jul. 6.1; Aug. 8.1.

${ }^{27}$ Ann. 13.3.1. Tácito conta que, enquanto Nero elogiava os antepassados de Cláudio, a cultura do defunto e a segurança externa do Estado durante o seu principado, todos o escutavam com gravidade, mas, quando passou a elogiar a prouidentia e a sapientia do imperador, ninguém foi capaz de conter o riso, apesar da elegância do discurso, composto por Séneca.

${ }^{28}$ Como afirma Stuart, D. R. 1928, 240.

${ }^{29}$ Vide Bardon, H. 1952, 108-115; Badian. E. 1966, 13-26.

${ }^{30}$ Mas, como nota Momigliano, A. 1993, 14, o que existia na antiguidade era a noção de vida: a palavra "autobiografia" é invenção moderna. Os Romanos escreviam De uita sua.

${ }^{31}$ Segundo Lewis, R. G. 1991, 3650-3652, há razão para crer que M. Escauro, nos três livros De uita sua, Sula, nos seus vinte e dois livros sobre a sua carreira, e Augusto, nos De uita sua, seguiram o modelo oratório das laudationes, apresentado por Cícero nos discursos forenses.

32 Cornélio Epicado completou a autobiografia de Sula: cf. Suetónio, Gram. 12. Voltacílio Pitolau celebrou, ao modo biográfico, as façanhas de Pompeio Magno e do pai deste, Pompeio Estrabão: cf. Suetónio, Rhet. 27; sobre a identidade deste biógrafo, vide LEwis R. G. 1966, 271-273; Treggiari, S. 1969, 264-266. Tirão foi liberto e biógrafo de Cícero; Júlio Márato escreveu registos da vida de Augusto, em que referia aparência física e presságios relacionados com o nascimento, como se lê em Suetónio, respectivamente $A u g .79 .2$ e 94.3. Vide Bardon, H. 1952, 270-276; BALDwin, B. 1983, 66-68. 
de Trásea Peto, da autoria de Aruleno Rústico, e de Helvídio Prisco, da autoria de Herénio Senecião.

O problema de um modelo a designar para a biografia suetoniana tem suscitado diversas tentativas de solução. Houve quem, desejoso de acentuar a originalidade romana, tentasse provar que, para a formulação das rubricas, Suetónio se inspirou nas secções das Res gestae de Augusto, não na forma monumental, mas na versão documental que encontrava nos arquivos. ${ }^{33}$

Parece mais lógico supor que Suetónio seja o herdeiro de uma longa tradição do que siga um modelo único, e que adopte elementos tradicionalmente gregos e tradicionalmente romanos: Suetónio era um conhecedor da cultura helénica e escreveu monografias em grego; mas também prezava, como veremos, a restauração de antigos costumes romanos. O próprio biógrafo, segundo o testemunho de Jerónimo, ${ }^{34}$ indica uma lista - ilustrativa, decerto, não exaustiva $a^{35}$ - dos seus predecessores gregos e latinos, o que contribui para equilibrar a balança das influências e das lutas entre a originalidade latina e a imitação dos Gregos: entre os latinos, menciona Varrão, Santra, Higino e Cornélio Nepos.

M. Terêncio Varrão é autor de uma obra monumental, na linha dos tradicionais arquivos dos átrios: Imagines ou Hebdomades, talvez a mais antiga obra ilustrada da antiguidade. ${ }^{36}$ Transfere, assim, para a esfera pública da erudição, uma matéria que era privada: as imagines das famílias aristocráticas. ${ }^{37}$ De Santra pouco se sabe. ${ }^{38}$ Mas, além de biógrafo, era tragediógrafo. ${ }^{39}$ Quanto a Higino, Suetónio menciona-o de passagem, em De grammaticis, sem citar os seus escritos. ${ }^{40}$ Cornélio Nepos, membro do círculo de Pompónio Ático, além de ser autor de três livros de história universal, antecipou Plutarco: teve a ideia de escrever uma colecção de biografias em que comparava gregos e

${ }^{33}$ Vide Stuart, D. R. 1928, 226-227; Giua, M. A. 1990, 543.

${ }^{34}$ No prefácio ao seu próprio De uiris illustribus (fr. 1 Reifferscheid).

${ }^{35}$ Como observa Stuart, D. R. 1928, 135. A divisão simétrica do cânone dos predecessores em quatro gregos e quatro latinos será, segundo este autor (p.193), devida, em parte, aos métodos de organização de Suetónio.

36 Composta por quinze livros, continha setecentos retratos de homens célebres, acompanhados, para cada caso, de um epigrama de louvor e resumo da vida e obra. O texto poético seria completado com discussões eruditas em prosa, como notas de rodapé. Aulo Gélio, 3.11, refere discussões sobre a cronologia de Homero e Hesíodo.

${ }^{37}$ Ali figuravam gregos e romanos; não só homens de letras, mas também monarcas, políticos, comandantes, artistas. Também escreveu três volumes de autobiografia (De uita sua). No De poetis daquele polígrafo poderá Suetónio ter encontrado inspiração para o seu De uiris illustribus. Vide Baldwin, B. 1983, 79 e 83; Jenkinson, E. 1967, 4-5; Momigliano, A. 1993, 96-97.

${ }^{38}$ Suetónio conheceria, por certo, o juízo de Marcial, 11.2.6: lectores tetrici, salebrosum ediscite Santram. Também Quintiliano, Inst. 11.2.46, refere a sua resistens ac salebrosa oratio. Santra terá provavelmente contribuído com um De uiris illustribus ou um mais restrito De poetis, ou até com ambos, uma vez que Suetónio o refere em Ter. 4, e Gram. 14.4; vide Baldwin, B. 1983, 83-84.

${ }^{39}$ Vide BARdon, H. 1952, 297-298 e 328.

${ }^{40}$ Gram.20. Vide com. de Kast ER, R.A. 1995, 205-214. Aulo Gélio, 1.14.1; 1.21.2; 16.6.14, louva o seu trabalho de grammaticus e diz que ele escreveu seis volumes de De uita rebusque inlustrium uirorum. Vide BALDwin, B. 1983, 84. 
romanos; incluía mesmo alguns cartagineses e persas. ${ }^{41}$ Revela consciência da distinção entre história e biografia. ${ }^{42}$ Um traço da erudição helenística é o gosto que Nepos mostra de incluir cartas nas suas biografias, como fará o seu seguidor. $\mathrm{Na}$ linha da tradição peripatética, escreve para divertir e moralizar: característica que também Suetónio apresenta. Mistura os capítulos relativos à vida privada com os da vida pública e os que seguem a ordem cronológica com os de carácter sistemático. ${ }^{43}$

Esta versatilidade e erudição aplicada à história de grandes políticos romanos tem continuidade, do lado grego, em Nicolau de Damasco ${ }^{44}$ e Plutarco e, do lado latino, em Plínio-o-Velho, Titínio Capitão e Suetónio. A Plutarco cabe, no prefácio ao seu Alexandre, distinguir a historiografia da biografia: enquanto aquela relata as grandes empresas, a biografia prende-se com factos menores, como uma simples palavra ou gesto - historicamente pouco significativos, mas mais importantes para iluminar o carácter do que grandes batalhas, preparativos militares, assédios de cidades. Plutarco desculpa-se, deste modo, das omissões de certos factos históricos com a necessidade de ser selectivo e de se cingir ao essencial: as características individuais. Esta contingência partilha-a com Suetónio.

A biografia revela-se, como dissemos, o género mais indicado para historiar o governo de Roma imperial, em que havia concentração das instituições do Estado na pessoa do imperador: pelo que as qualidades do carácter do príncipe - as virtudes e os vícios - se reflectem na condução da história. ${ }^{45} \mathrm{O}$ próprio

${ }^{41}$ Da colectânea sobrevive, completa, a parte dos generais estrangeiros, além de duas Vidas (Catão Maior e Ático) e alguns fragmentos da parte dos historiadores. Além disso, imitou Varrão, ao publicar uma espécie de album de homens ilustres, cujos retratos eram acompanhados de um epigrama. O seu De uiris illustribus e as suas Vidas de Catão e de Cícero serão fontes de Suetónio.

${ }^{42}$ Pel. 1.1: Pelopidas Thebanus, magis historicis quam uulgo notus. Cuius de uirtutibus dubito quem ad modum exponam, quod uereor, si res explicare incipiam, ne non uitam eius enarrare, sed historiam uidear scribere. Nepos parece aludir ao conceito de subalternidade atribuído à biografia: Prol. 1.1: Non dubito fore plerosque, Attice, qui hoc genus scripturae leue et non satis dignum summorum uirorum personis iudicent, cum relatum legent, quis musicam docuerit Epaminondam aut in eius uirtutibus commemorari, saltasse eum commode scienterque tibiis cantasse - mas o problema reside na estranheza ou reprovação que os costumes gregos possam despertar em confronto com a grauitas romana. Vide Tuplin, C. 1979, 124-142; Momigliano, A. 1993, 99 n. 40; Giua, M. A. $1990,536-537$.

${ }^{43}$ Afirma Wardle, D. 1994, 18: «The overall structure of Atticus anticipates that of Diuus Iulius, Augustus and Caligula, so it seem that Nepos offered a basic structure which Suetonius could adapt for his emperors». Mas só a estrutura, porque Nepos é encomiástico. Vide STUART, D. R. 1928, 228. Nas vidas de Epaminondas, Agesilau e Ático, tenta fazer uso da retórica e de um estilo elevado, prática que tem como antecedentes o encomium grego e a laudatio latina. Vide Jenkinson, E. 1967, 1-15; Cizek, E. 1977, 28-29; Tuplin, C. 1979, 145-151; Momigliano, A. $1993,97-99$.

${ }^{44}$ Nicolau de Damasco, contemporâneo de Augusto, é autor de uma história universal, biografia e autobiografia: sobrevivem fragmentos da sua biografia de Augusto e da sua autobiografia. Vide Baldwin, B. 1983, 85-87; Momigliano, A. 1993, 9. Steidle suspeita que Nicolau de Damasco terá escrito uma biografia completa de Augusto; Momigliano, A. 1993, 112 e 118, acha, ao invés, que se trata de uma biografia parcial.

${ }^{45}$ Com o Império, tornava-se impraticável respeitar o princípio historiográfico de Catão de 
Tácito verbaliza as dificuldades por que passa a historiografia tradicional, na nova situação política: seja por ignorância ou alheamento dos cidadãos em relação às decisões políticas, seja por adulação ou por ódio aos chefes, a verdade é atraiçoada, e os relatos para a posteridade ficam marcados pela hostilidade ou pelo servilismo (Hist. 1.1); por outro lado, num Império pacificado e não expansionista, a falta de matéria nobre da antiga historiografia - como guerras infindáveis, expugnações de cidades, destituição de reis, lutas sociais - leva os próprios historiadores a lançarem mão de assuntos que, tradicionalmente, eram objecto da biografia ${ }^{46}$ - o que provoca o esbatimento da destrinça entre dois géneros, que foram sempre considerados distintos, mas nunca tiveram fronteiras bem delimitadas.

$\mathrm{Na}$ linha de Varrão, também Plutarco, nas Vidas, e Tácito, no Agricola, ${ }^{47}$ reforçam a aproximação entre biografia e imagines. A biografia é uma forma de tornar imortal a representação física, que é efémera. A parte o caso das autobiografias, a biografia, antes de se centrar nos imperadores, tende para a oposição senatorial. Mas transformar a biografia em veículo de transmissão de ideias filosóficas e políticas heterodoxas poderia tornar-se perigoso durante o Império. ${ }^{48}$ Por outro lado, era imprevisível a reacção de um imperador perante o biógrafo de imperadores anteriores: havia o perigo de escrever a palavra errada, ou ser interpretado de forma hostil. ${ }^{49}$ Talvez por isso, Suetónio, o primeiro escritor latino a aplicar a biografia aos imperadores, termina as Vidas dos Césares com uma apreciação moral favorável aos Antoninos ${ }^{50}$ - parece uma forma de transmitir a mensagem, sem correr riscos demasiados. De qualquer modo, a

fazer história dos acontecimentos sem nomear os protagonistas; cf. Cornélio Nepos, Ca. 3.4.

${ }^{46}$ Ann. 4.32-33. Para Díon Cássio já não existe este dilema: organiza a sua obra segundo o esquema dos annales, mas não hesita em usar elementos biográficos. Vide GiUA, M. A. 1990, 544-550.

${ }^{47}$ Stuart, D. R. 1928, 243-253, considera que o Agricola de Tácito tem semelhanças quer com a tradição encomiástica grega, quer com a latina, sem, com isso, deixar de conter elementos pessoais. Vide Giva, M. A. 1990, 539-541. Esta autora observa (555-557) que Tácito, com o seu Agricola, acaba por aceitar a biografia, mas usa-a, consoante a linha dos malogrados antecessores Aruleno Rústico e Herénio Senecião, no contexto da oposição senatorial: reconstitui a história do principado de Domiciano sem o tornar protagonista, mas publica-a depois da morte deste imperador.

${ }^{48}$ Basta lembrar, no principado de Domiciano, as consequências que as laudationes de Trásea Peto e Helvídio Prisco acarretaram para os autores, Aruleno Rústico e Herénio Senecião. Cf. Suetónio, Dom. 10.3; Díon Cássio, 67.13.2; Tácito, Ag. 2; Plínio, Ep. 1.5.

${ }^{49}$ Como sugere Baldwin, B. 1983, 80-81. Suetónio menciona o historiador (Cremúcio Cordo, segundo Tácito, Ann. 4.34-35, e Díon Cássio, 57.24.3), que foi condenado por Tibério por dizer que Cássio e Bruto tinham sido os últimos dos Romanos (Tib. 61.3). Mesmo alguns estudiosos modernos vislumbram sinais velados de crítica em Suetónio: CARnEY T.F.1968,7-24, vê nas Vidas dos Césares uma série de críticas indirectas a Adriano; e Cizek, E. 1977, 181-192, crê que certos conselhos discretos foram mal recebidos pelo imperador e, por isso, contribuíram para a desgraça de Suetónio. Opinião contrária têm Bradley, K. R. 1976, 245-253, e Gascou, J. 1984, 758-773. O historiador francês demonstra que, nos Césares de Suetónio, os aspectos favoráveis a Adriano predominam largamente sobre os desfavoráveis.

${ }^{50}$ Dom. 23.2: Ipsum etiam Domitianum ferunt somniasse gibbam sibi pone ceruicem auream enatam, pro certoque habuisse beatiorem post se laetioremque portendi rei publicae statum, sicut sane breui euenit abstinentia et moderatione insequentium principum. 
libertas, entendida como relativa liberdade de expressão, é, para Suetónio, um dos tópicos por vezes referido na avaliação dos imperadores.

Há uma série de relatos laudatórios sobre as vítimas de Nero e dos Flávios ${ }^{51}$ que podem ter influenciado Suetónio, sobretudo nos efeitos dramáticos com que o biógrafo descreve as mortes mais violentas. ${ }^{52}$ Temas recorrentes em Suetónio - como a origem familiar e antepassados, o lugar de nascimento, acompanhado de presságios da fortuna futura, infância, a entrada na vida pública, aspectos de governação, obras públicas e jogos oferecidos, campanhas, aspectos da vida privada, cena de morte - constituíam a base das laudationes. ${ }^{53}$ Esta forma tradicional, cultivada pela retórica, parece deixar, em Suetónio, reflexo em alguns passos em particular: têm carácter laudatório a abordagem de Germânico, no início da Vida de Calígula, e de Druso, no início da Vida de Cláudio, e a forma de começar a Vida de Tito. ${ }^{54}$ Além disso, a ideia da felicidade e da bênção, o topos do macarismos do encomium grego, com paralelo na laudatio latina, ${ }^{55}$ parece estar presente em Suetónio, quando refere a felicitas como atributo que, desde o início, se manifesta nos bons imperadores (como Augusto, Vespasiano ou Tito) ${ }^{56}$ e a infelicitas nos maus (como Nero); ${ }^{57}$ quando abençoa os bons com uma boa morte e condena os maus a uma morte terrível e solitária, como veremos a seu tempo.

O discurso retórico com objectivo oposto ao da laudatio - a uituperatio - tinha igualmente grande tradição em Roma e incluía os mesmos itens. ${ }^{58}$

${ }^{51}$ Fânio escreve sobre occisi aut relegati a Neroni: cf. Plínio, Ep. 5.5.2. Titínio Capitão, ab epistulis, que fez carreira nos principados de Domiciano, Nerva e Trajano, continuou a ligação entre biografia e imagines, pois tinha em casa retratos de Bruto, Cássio e Catão, que viriam acompanhados de laudationes em verso. Escreveu relatos da morte de vários amigos: exitus illustrium uirorum (um género em voga): cf. Plínio, Ep. 8.12.5. O próprio Plínio escreve de ultione Heluidi Prisci (o jovem) (Ep. 9.13; 5.8).

${ }^{52}$ Embora certos motivos ocorram já em escritos gregos sobre a morte de reis ou generais: vide Lewis, R. G. 1991, 3657-3659.

${ }^{53}$ Temas que aparecem também em obras como o Panegírico de Trajano, da autoria de Plínio-o-Moço, ou nas Res gestae de Augusto,como nota, naintr. ao seu comentário, Warmington, B. H. 1999, Ix. Segundo Lewis, R. G. 1991, 3661-3662, que acentua a influência autóctone em Suetónio, a colocação da aparência física associada ao relato da morte (imediatamente antes ou imediatamente depois) é um reflexo da tradição dos discursos fúnebres.

${ }^{54}$ Como nota Lewis, R. G. 1991, 3643; 3648; 3655. O caso de Vitélio, o Velho (p. 3643), parece-nos pouco paradigmático, porque Suetónio refere a laudatio, mas não a usa. Nota LEwis (3664) que a apresentação do material relativo a Tito faz lembrar o encomium grego.

${ }^{55}$ Como procura demonstrar Stuart, D. R. 1928, 242-243; vide também, do mesmo estudo, 85 ss.

${ }^{56}$ Aug. 94.1: (...) quibus futura magnitudo eius et perpetua felicitas sperari animaduertique posset. Ves. 5.5: At in Achaia somniauit initium sibi suisque felicitatis futurum... Ideia semelhante ocorre em Tit. 1: (...) tantum... uel ingenii uel artis uel fortunae superfuit. A felicidade de Tibério revela-se ilusória - Tib. 5: (...) et quod mox simulacrum Felicitatis ex s. c. publicatum ibi sit. Sed...

${ }^{57}$ Nero 6.2: Eiusdem futurae infelicitatis signum euidens die lustrico extitit.

${ }^{58}$ Segundo LEwis, R. G. 1991, 3643-3657, Suetónio, ao descrever as carreiras pré-imperiais, parece seguir um modelo semelhante aos das laudationes e uituperationes forenses de Cícero, mas muito mais antigo: apresenta semelhanças com o encomium e os tratados de retórica gregos, mas tem um conteúdo e uma estrutura tipicamentes romanos e moldados às exigências da vida pública romana. 
O próprio Suetónio é autor de uma monografia sobre termos de insulto, escrita em grego. As acusações pormenorizadas de depravação, muitas vezes sem fundamento, tradicionais no contexto da luta política republicana - basta recordar as acusações de homossexualidade passiva e adultério, feitas a César pelos seus inimigos políticos, entre os quais Cícero (Jul. 49-52), e a Augusto, por Sexto Pompeio e António (Aug. 68-69) - transitam para a oposição aos imperadores: não falta quem acuse Domiciano de ter sido iniciado sexualmente por Nerva (Dom. 1.1). A reacção aos frequentes libelos transforma-se em critério para testar a clementia do governante. ${ }^{59}$

A dificuldade em encontrar um modelo para a biografia suetoniana torna-se manifesta na diversidade de soluções apresentadas pelos críticos. ${ }^{60}$ Todos, no entanto, estão de acordo no que respeita ao desenvolvimento precedente. Constatamos que, ao longo da história da biografia, existem modelos diferentes, quanto ao conteúdo, como biografia encomiástica ou vituperatória e biografia que apresenta vícios e virtudes, biografia histórica e biografia ficcional, biografia política, filosófica ou moral; e quanto à forma, biografia em diálogo e biografia narrativa, autobiografia e biografia de terceiros, biografia que respeita a cronologia, biografia que prefere a organização através de rubricas e biografia que combina os dois métodos. $\mathrm{O}$ género foi-se adequando às necessidades dos tempos e aos objectivos dos diversos autores. No esquema usado por Suetónio não se consegue descortinar nem especial inovação, nem especial dependência de um autor em particular. ${ }^{61}$ Mais do que seguir este ou aquele modelo, Suetónio parece fazer o cruzamento da tradição biográfica greco-latina, no seu ponto de chegada, com a evolução do governo da Roma imperial do primeiro século d. C: o resultado são as Vidas dos Césares.

A biografia tem sido considerada o parente pobre da historiografia; e Suetónio fica a perder pelo inevitável cotejo com a genialidade de Tácito. ${ }^{62}$

${ }^{59}$ Apareceram as crónicas escandalosas dos imperadores, sobretudo os anteriores a Nerva: Fânio terá escrito um De sceleribus Neronis, muito útil, de certo, para o gosto de Suetónio, que vai precisamente debruçar-se, em grande parte, sobre os probra ac scelera do imperador histrião e criminoso; vide BALDwin, B. 1983, 66-100.

${ }^{60} \mathrm{Na}$ opinião de LEo, F. 1901, a biografia, no período helenístico e romano, apresentava, em geral, dois modelos distintos: as Vidas dos políticos e generais estavam normalmente organizadas de forma cronológica, enquanto as Vidas dos filósofos, artistas e poetas se apresentavam organizadas de forma sistemática. Segundo a tese de LEO, Suetónio, ao organizar de forma sistemática as Vidas dos Césares, transfere para homens de acção um tipo de biografia alexandrina, que era usada normalmente em escritores e artistas, e fora importada para Roma por Varrão. É uma ideia sedutora, que teve algum êxito, mas que enferma de uma busca de simplificação e tem sido, por isso, posta em causa: vide STUART, D. R. 1928, 186-187; intr. à ed. das Vies des douze césars, Ailloud, H. 1931-1932, xxv-xxxiı; Della Corte, F. 1967, 199-200; Momigliano, A. 1993, 87-88 e 105 ss; Wallace-Hadrill, A. 1984, 70. Quanto a outras soluções, Stuart, sem negar, por sua vez, a influência grega, insiste na influência da laudatio funebris; STEIdLE, W. 1951, acentua as ligações ao encomion e ao psogos gregos; LEWIs, R. G. 1991, aponta a oratória forense, cujo modelo se manifesta nos discursos de Cícero. Para síntese analítica das teorias, vide intr. ao com. de Wardle, D. 1994, 18; intr. ao com. de Guastella, G. 1992, 11-12 n.3.

${ }^{61}$ Como afirma, na intr. ao seu com., Lindsay, H. 1995, 5.

${ }^{62}$ Vide Bradley, K. R. 1985b, 255. 
Regra geral, faz-se uma abordagem histórica da exposição do biógrafo, o que leva o texto de Suetónio, como diz Guastella, no seu comentário à Vida de Calígula, a ser mais desmembrado que estudado no seu conjunto. ${ }^{63}$ Mas é lícito que nos interroguemos sobre a razão que levou Suetónio, o eruditissimus e o contubernalis de Plínio-o-Moço ${ }^{64}$ o competente funcionário imperial, que acumulara os cargos de a studiis, de a bibliothecis, de ab epistulis, ${ }^{65}$ a escolher um género considerado menor, quando tinha ao seu dispor quer o material necessário para obras de grande fôlego e rigor, quer os conhecimentos retóricos para tal requeridos. Ora a razão está em que Suetónio não pretende emular Tácito, mas escrever biografia.

${ }^{63}$ Vide com. de Guastella, G. 1992, 13-14. Por exemplo, Gascou, J. 1984, que se situa mais na perspectiva do historiador que na do estudioso da literatura (p. XII), diz claramente que segue, para o estudo das fontes do biógrafo, a ordem cronológica, e não a de Suetónio (p. 10).

${ }^{64}$ Plínio, ao solicitar a Trajano, para o amigo, o ius trium liberorum, descreve-o nestes termos: Suetonium Tranquillum, probissimum honestissimum eruditissimum uirum (Ep., 10.94.1). Além disso, ao interceder em seu favor na compra de um campo, considera-o contubernalis seu (1.24.1) e scholasticus (1.24.4). É ainda recordado por Plínio em Ep. 5.10 e 10.95. Sobre a possibilidade de Suetónio ter pertencido, graças à influência de Plínio, ao consilium principis de Trajano, vide Tissoni, G. G. 1965, 222-245, particularmente, 241; Della Corte, F. 1967, 27 n. 48.

${ }^{65} \mathrm{O}$ estudo da carreira de Suetónio sofreu grande impulso com a descoberta, em 1950, nas escavações do Foro de Hipona, dos fragmentos de uma inscrição, reconstituída e publicada por Marec, E. \& Pflaum, H. G. 1952, 76-85, que veio confirmar algumas conjecturas de Sanders, H. A. 1944, 113-123, sobre a carreira do biógrafo. Tratava-se, talvez, da base de uma estátua do biógrafo, derrubada quando este caiu em desgraça (por volta de 121-122 d.C.), juntamente com o prefeito do pretório Septício Claro (cf. História Augusta, Hadr. 11.3). Como acentua Della CoRTE, F. 1954, 133-136, os dados da inscrição apontam para dois tipos de carreira, a sacerdotal e a administrativa. Vide tentativas de reconstituição da carreira do biógrafo: Grosso, F. 1959, 263-296; Baurain, C. 1976, 124-144; Townend, G. B. 1961a, 99-109; DAck, E. Van't 1963, 177-184; McDermott, W. C. 1971, 92-95; Baldwin, B. 1975a, 22-26; ID. 1975b, 61-70; ID. 1997, 254-256; Brugnoli, G. 1993, 47-61; Lindsay, H. 1994, 454-469. Vide análise das teorias em Della Corte, F. 1967, 9-28 e 219-231; Birley, A. R. 1984, 245-246. 
(Página deixada propositadamente em branco) 
Parte I

A Construção das Vidas 
Como sublinhámos na introdução, Suetónio não escreve história, mas Vidas de figuras históricas. Importa agora entender a forma como o biógrafo organiza e apresenta ao leitor o conjunto de informações sobre os imperadores. Porque se trata de um relato histórico, a indicação de fontes, ainda que sejam escassas, vagas e tendenciosas, suporta as afirmações de Suetónio. Salienta-se a importância da documentação, dos testemunhos arqueológicos e epigráficos e das citações à letra e um interesse por aspectos muito mais variados do que os do historiador tradicional. Neste sentido, Suetónio parece estar mais próximo da mentalidade do historiador moderno do que da do historiador antigo. ${ }^{1}$

Por outro lado, a profusão de pormenores biográficos dá vida ao texto. Ora Suetónio parece usar a erudição para captar a atenção do leitor. Conhecedor do gosto do seu público pelo típico italum acetum, pelo romanesco de uma bella fabella, pelas curiositates da vida dos ricos e famosos e pelos escândalos da vida social, o biógrafo procura seduzir os curiosos. ${ }^{2}$ Em vez do estilo elevado da história, adopta um estilo desadornado e conciso. A estrutura do relato, funcional e adequada, submete-se não à cronologia, mas aos diversos aspectos, divididos por tópicos, da personalidade dos biografados. Suetónio não se mostra subserviente dos factos históricos: a narração dos grandes acontecimentos históricos reduz-se em favor da descrição da personagem. Os grandes eventos ilustram os vários aspectos da pessoa do biografado: ele é o centro e o critério de selecção ou exclusão de material. Por isso, sempre que necessário, Suetónio não hesitará em fraccionar ou repetir os acontecimentos, em atribuir um valor exagerado a acontecimentos menores, em transformar certos feitos em exempla, mesmo que, para isso, seja preciso deslocá-los do seu contexto político ou cronológico. ${ }^{3}$

Não é nossa preocupação imediata julgar as aptidões históricas de Suetónio, que terão de ser vistas à luz da época: o biógrafo não se mostra, segundo conclui Gascou, ${ }^{4}$ nem mais nem menos imparcial que Tácito. Por outro lado, mais do que julgar os seus méritos artísticos, importa agora perceber a sua forma de chegar ao leitor.

\footnotetext{
${ }^{1}$ Como nota Gascou, J. 1984, 545-547.

${ }^{2}$ Vide Cizek, E. 1977, 41-42.

${ }^{3}$ Vide Gascou, J. 1984, 343-446; Grimal, P. 1986, 729; Lounsbury, R. C. 1987, 80-89; Wallace-Hadrill, A. 1984, 8-22.

${ }^{4}$ Vide Gascou, J. 1984, 675-677 e 707-708.
} 


\section{Antecedentes das VIDAS dos Césares}

\subsection{Suetónio e a erudição}

É comum, entre os historiadores da literatura, encarar Suetónio mais como erudito arquivista, recolector de anedotas e gramático pedante do que como biógrafo ${ }^{5}$ e valorizar excessivamente o esquema usado pelo autor em detrimento do conteúdo das Vidas. Tal preconceito poderá ter origem em um exagerado biografismo: através da análise das informações de Plínio e da Suda (que o apresenta como grammaticus), considerava-se Suetónio amarrado, pela sua maneira de ser, aos arquivos imperiais, submerso em documentos, e estudava-se o biógrafo a partir do âmbito dos seus cargos. ${ }^{6}$

Quando Plínio-o-Moço classifica Suetónio de eruditissimus (Ep. 10.94.1), está a usar uma das vagas designações existentes para o estudioso de antiquária, uma designação moderna para uma realidade antiga. ${ }^{7}$ Este tipo de estudo interessa-se por minudências do passado, eventos fora do vulgar, monstruosidades, histórias locais, listas de magistrados, nomes próprios, leis, costumes; pela ostentação, em suma, de erudição como um fim em si. ${ }^{8}$ Se olharmos aos títulos do catálogo das obras de Suetónio na Suda, verificamos que os seus interesses e âmbito de investigação se enquadram neste tipo de pesquisa. ${ }^{9}$

Como linhas principais da erudição helenística temos a edição e comentário de textos; a colecção de antigas tradições de cidades, regiões, santuários, deuses e instituições; a descrição sistemática de monumentos e cópia de inscrições; compilação de biografias; cronologia. As listas bibliográficas incluídas por Suetónio nos studia e eloquentia, que lembram a erudição alexandrina, permitem ao biógrafo elaborar uma história da cultura de César a Domiciano. ${ }^{10}$ Suetónio aparece como conhecedor de uma arte

${ }^{5}$ Como observa Levi, M. A. 1937, 18-19.

${ }^{6}$ Vide Macé,A.1900,110-198 e 237-239; Dalmasso, L.1906, 80 n. 2; Wallace-Hadrill, A. 1984, 73-96.

${ }^{7}$ Os antiquários dos sécs. XVII e XVIII, ao usarem a designação antiquarius para os seus trabalhos, inserem-se na linha das Antiquitates de Varrão. A noção era vagamente expressa na época helenística e romana por expressões como criticus, philologus, polyistor, grammmaticus, doctus, litteratus, eruditus. A designação mais apropriada é archaeologus e encontra-se em Platão, Hp.Ma., $285 \mathrm{~d}$, segundo o qual, a arqueologia inclui, entre outros assuntos, genealogias de heróis, tradições acerca da fundação de cidades. Sobre a relação de Suetónio com a antiquária, vide Wallace-Hadrill, A. 1984, 126-129, e Della Corte, F. 1967, 143-164.

${ }^{8}$ Banidos pela pesquisa histórica tradicional, aqueles temas começaram a ser objecto de estudo dos sofistas: Hípias escreve sobre nomes de nações e Crítias transcreve constituições de várias cidades. A oposição entre archaeologia e historia não se manteve. Arqueologia passa a designar, na época helenística e romana, um trabalho de história arcaica ou uma história desenvolvida desde as origens: assim acontece em Dionísio de Halicarnasso e em Flávio Josefo. Vide Momigliano, A. 1990, 58-60.

${ }_{9}$ Vide tentativas de reconstrução da enciclopédia Prata de Suetónio em Della Corte, F. 1967, 233-245, e Brugnoli, G. 1968, 137-184.

${ }^{10}$ Vide Brandẽo, J. L. 2005b, 55-67. 
que existe em Roma desde Varrão ${ }^{11}$ e que ele coloca ao serviço dos seus objectivos.

Característico da pesquisa antiquária é o uso extenso de cartas, inscrições e monumentos. Suetónio, graças aos seus cargos administrativos, tem à sua disposição os arquivos imperiais (embora tal não prove, à partida, que os consulte). ${ }^{12}$ Além disso, Suetónio serve-se de provas arqueológicas, mas com um objectivo que vai além do gosto pelo passado: por exemplo, uma estatueta de Augusto criança, com a inscrição Thurinus, mostra que era este o seu cognomen e acentua assim a humildade da sua origem. ${ }^{13}$ Coleccionar velharias é um gosto próprio da antiquária partilhado por Augusto. Também ele faz colecção de raridades antigas, como ossos enormes (provavelmente de animais pré-históricos), encontrados em Cápreas, e designados por ossos de gigantes e armas de heróis ${ }^{14}$ - mas não é apenas uma curiosidade, é um exemplo da modéstia com que o imperador decorava a sua casa, em oposição às acusações que lhe faziam de ceder ao luxo.

Também, ao descrever o incêndio de 64, o ponto de vista do antiquário vem ao de cima, para lamentar as perdas irreparáveis que o sinistro causou à história do povo romano. ${ }^{15}$ Mas a acentuação dos danos visa também agravar o crime de Nero contra os muros da pátria.

Por outro lado, enquanto o historiador está interessado em grandes e memoráveis façanhas, eventos particulares significativos, com causas e consequências, o antiquário explora, não o individual, mas no modelo geral, o mos, as práticas e os hábitos da vida diária, como roupas, jogos, deuses que se veneram, etc. ${ }^{16}$ Mas o biógrafo não se fica pela exposição erudita, pois tais considerações lhe abrem caminho à apreciação moral. Nas Vidas dos Césares, Suetónio avalia o papel dos imperadores na destruição ou preservação do tradicional modelo de vida romano. Interessa-se pelo impacto que cada imperador tem, como indivíduo, nesse modelo: daí dependerá a imagem que vai deixar transparecer. O bom imperador preocupa-se com o mos maiorum, com a restauração das tradições antigas, como é o caso de Augusto; ${ }^{17}$ o mau irá corromper as tradições e costumes, como sucede com Calígula e Nero.

${ }^{11}$ Como observa Lewis, R. G. 1991, 3662. Varrão herda o espírito sistemático da antiquária helenística e publica vinte e cinco volumes de Antiquitates rerum bumanarum e dezasseis de Antiquitates rerum diuinarum; vide Momigliano, A. 1990, 54-71.

${ }^{12} \mathrm{O}$ que parece ser muito do seu agrado é a citação de cartas de Augusto, de quem refere até pormenores de grafia (Aug. 88).

${ }^{13}$ Aug. 7.1. Suetónio ofereceu a estatueta a Adriano, que a passou a venerar entre os Lares do seu quarto.

${ }^{14}$ Aug. 72.3: (...) excoluit rebusque uetustate ac raritate notabilibus, qualia sunt Capreis immanium beluarum ferarumque membra praegrandia, quae dicuntur gigantum ossa et arma heroum.

${ }_{15}$ Nero 38.2: Tunc praeter immensum numerum insularum domus priscorum ducum arserunt hostilibus adhuc spoliis adornatae deorumque aedes ab regibus ac deinde Punicis et Gallicis bellis uotae dedicataeque, et quidquid uisendum atque memorabile ex antiquitate durauerat.

${ }^{16}$ Como afirma Wallace-Hadrill, A. 1984, 128.

${ }_{17}$ Augusto faz várias reformas para voltar ao estado primordial: 31.2 o calendário; $35.1 \mathrm{o}$ senado; 40.2 as assembleias; 40.5 o uso da toga. Vide Wallace-Hadrill, A. 1984, 139-141. 
Uma característica deste tipo de pesquisa é a ordenação sistemática, ao contrário da história, que privilegia a ordenação cronológica. ${ }^{18} \mathrm{Nas}$ suas obras, sejam elas sobre palavras, instituições ou biografias, Suetónio elabora o comentário palavra a palavra, isto é, por entradas, como num ficheiro. Assim acontece com as palavras de insulto, que divide em tipos e, para cada uma, cita os passos da literatura onde o termo ocorre. Assim acontece com o tratado sobre os jogos, com divisão e citação de exemplos.

$\mathrm{O}$ mesmo se passa com as biografias. O De uiris illustribus subdivide-se em: De poetis; De oratoribus; De historicis; De philosophis; e De grammaticis et rhetoribus. ${ }^{19}$ No De grammmaticis et rhetoribus, encontramos uma introdução e uma série de entradas: mas aqui as palavras comentadas são nomes próprios. Amplas citações ilustram os factos das vidas. O mesmo método vamos encontrar, em larga escala, nas Vidas dos Césares. A construção da biografia de cada imperador divide-se numa série de rubricas, introduzidas por palavras-chave. Apesar de uma aparente continuidade, a sequência da narrativa é marcada pela introdução de novos tópicos, por vezes anunciados discretamente. Assim, foge da exposição cronológica do historiador tradicional para a divisão por títulos e comentário acompanhado de exemplos vários. ${ }^{20}$

Alguns tratados eruditos parecem deixar rasto nas rubricas das Vidas dos imperadores, como é o caso das monografias sobre os jogos, sobre o calendário ou sobre os defeitos físicos. ${ }^{21}$ Nas Vidas dos Césares, há uma profusão de informações sobre espectáculos, em detrimento da administração. ${ }^{22} \mathrm{~A}$ um funcionário da administração imperial é natural que interessem mais as instituições que permitem a manutenção do Estado do que o alargamento para além das suas fronteiras. A harmonia do Estado é mantida mediante panis et circenses, fundamentais na propaganda imperial. Além disso, os jogos são festivais religiosos, servem para aplacar os deuses. ${ }^{23} \mathrm{E}$ seria cómodo usar material de que já dispunha da monografia anterior. ${ }^{24}$ Mas Suetónio não se restringe à erudição: a presença ou ausência de jogos, os excessos ou a contenção lançam luz sobre o carácter dos imperadores: permitem avaliar, como veremos, se o imperador é liberal ou avaro, se é regrado ou perdulário, se incentiva ou reprime a licenciosidade dos actores. A infâmia agrava-se, quando o próprio imperador se torna auriga e histrião, como Nero.

${ }^{18}$ Prática adoptada por Varrão nas suas Antiquitates.

${ }^{19} \mathrm{O}$ De uiris illustribus é geralmente considerado anterior às biografias imperiais. BALDwin, B. 1983, 380, pelo contrário, rejeita tal datação relativa, sem apresentar uma razão de peso para tal atitude.

${ }^{20}$ Vide Stuart, D. R. 1928, 230; Wallace-Hadrill, A. 1984, 43-44.

${ }^{21}$ Vide Della Corte, F. 1967, 158-159; intr. ao com. de Wardle, D. 1994, 15-17.

$22 \mathrm{O}$ programa legislativo de Augusto é vago (Aug. 34), excepto no que se refere aos espectáculos (Aug. 45). É mais precisa a descrição dos jogos quinquenais estabelecidos por Domiciano (Dom. 4.4) do que as campanhas desenvolvidas no Reno e no Danúbio (Dom. 6.1).

${ }^{23}$ Cf. Juvenal, 10.78-81; Plínio, Pan. 33.

${ }^{24}$ Vide Della Corte, F. 1967, 100-110. Graças ao Despectaculis (5) de Tertuliano, podemos fazer uma ideia do conteúdo da monografia perdida de Suetónio sobre os jogos. Tertuliano diz-nos que Suetónio enumera os festivais, por quem foram instituídos, em que dias, para que deuses; os vários tipos de espectáculos: circo, teatro, atléticos, de gladiadores; e outras rubricas também presentes nasVidas dos Caesares. 
Outra monografia perdida versava sobre o calendário. Também nas Vidas dos Césares Suetónio se ocupa não só da reforma operada por Júlio César, que acertou o calendário pelo curso do sol, ${ }^{25}$ mas também refere várias mudanças no nome dos meses. ${ }^{26}$ Contudo, também neste aspecto, Suetónio se não limita a registar curiosidades: a mudança da designação do nome do mês é integrada na exemplificação do espírito tirânico de César, Nero e Domiciano, ao passo que, em Augusto, se apresenta como mais uma medida administrativa do imperador, enquanto Pontífice Máximo, com a explicação de que se não tratava do mês do nascimento (Setembro), mas do mês em que obtivera o seu primeiro consulado e as mais importantes vitórias. Além do mais, tal decisão é, por assim dizer, ratificada. Um senador proporá, como honra póstuma, que se transfira a designação do mês de Augustus para o de Setembro, precisamente por ser o do aniversário do imperador defunto (Aug. 100.3).

Se outro tratado se detinha sobre os uitia corporalia («males do corpo»), também nas Vidas dos Césares não faltam referências às doenças dos príncipes, ${ }^{27}$ com uma enumeração dos pormenores físicos que denota preocupação de realismo - mas que tem também outros objectivos. Os defeitos físicos eram, na época, mais significativos do que hoje nos possa parecer, dada a importância da fisiognomonia. ${ }^{28} \mathrm{Um}$ fisiognomonista, chamado por Narciso, o famoso liberto de Cláudio, para estudar os traços de Britânico, afirma sem hesitação que, não este, mas Tito, que estava perto, seria imperador (Tit. 2). Embora não pareça restringir-se aos ensinamentos da fisiognomonia, ${ }^{29}$ ao analisar os defeitos físicos, Suetónio pretende fazer luz sobre os morais. $\mathrm{O}$ retrato físico de Calígula encontra-se na parte em que se descreve o monstro, isto é, onde se referem os uitia, que são incomparavelmente mais numerosos que as virtudes. ${ }^{30}$ Os traços físicos - que Calígula exagera em frente ao espelho, para provocar terror - são o resultado psicofísico da desordem mental (Cal. 50-51). Nesse sentido, o aspecto tem interesse enquanto denuncia o carácter do homem que está à frente dos destinos do Império.

Mas, apesar da similitude de método verificável entre as Vidas e os outros trabalhos, a perspectiva antiquária está subordinada, como nota Wardle, a uma análise por categorias não antiquárias. As técnicas do comentário erudito

${ }^{25} \mathrm{Jul}$. 40.1: annumque ad cursum solis accomodauit.

${ }^{26} \mathrm{O}$ quintilis para Iulius (Jul. 76.1); o sextilis para Augustus (Aug. 31.2); Nero dá o nome ao mês aprilis (Nero 55); Domiciano chama Germanicus ao mês de Setembro, nome que tomou depois do triunfo sobre os Catos e os Dácios, e Domitianus ao de Outubro, mês do seu nascimento (Dom. 13.3).

${ }^{27}$ Augusto sofria dores devido a pedra na bexiga, e padecia do fígado (Aug. 80; 81.1); Cláudio sofria do estômago (Cl. 31); Galba tinha graves problemas nas articulações das mãos e dos pés e apresentava uma hérnia descomunal (Gal.21); Domiciano era calvo, e por isso, deformis (Dom. 18.1); Otão disfarçava a calvície com uma peruca (Otho 12.1); Vespasiano, embora saudável, preocupava-se em manter a boa forma com fricções na garganta e nos membros e em fazer dieta uma vez por mês (Ves. 20).

${ }^{28}$ Vide Couissin, J. 1953, 234-256, е Sток, F. 1995, 109-135.

${ }^{29}$ Vide Baldwin, B. 1983, 498-501. Gascou, J. 1984, 592-616, contesta a aplicação desta teoria aos retratos de Suetónio.

${ }^{30}$ Vide balanço dos traços positivos e negativos de Calígula em Cizek, E. 1977, 103-104. 
podem levar ao arranjo por categorias, mas estas são colocadas ao serviço da intenção biográfica. Se a organização através de rubricas tem origem na intenção erudita de informar e não de mouere, a forma como Suetónio dispõe as rubricas e o material que as integra visa desencadear emoções. ${ }^{31}$

Embora o propósito moralizador seja tradicionalmente atribuído a Tácito e Plutarco, e negado a Suetónio, cremos, no entanto, que o biógrafo dos Césares não é apenas um erudito curioso: não usa a erudição pela erudição, mas como meio para transmitir uma mensagem moral e política. ${ }^{32} \mathrm{O}$ esquema adapta-se à transmissão, de forma sistemática e inteligível, de um código moral; e os pormenores e as anedotas não são simplesmente amontoados, nem valem apenas como curiosidade, mas são seleccionados e dispostos de modo a realçarem a imagem de cada imperador, como Suetónio a quer transmitir.

\subsection{As fontes ao serviço da intenção biográfica}

Enfrentamos agora um dos aspectos mais difíceis no que toca à biografia suetoniana. Que Suetónio se serviu de fontes variadas sugere-o o facto de se lhes referir com expressões como sunt qui putent, multi, alii, quidam, nonnulli. Mas ficamos a saber, também, por força destas mesmas expressões, que predominam as indicações genéricas e vagas. Teremos de fazer fé na honestidade do biógrafo probissimus, segundo Plínio. Nenhum autor, que posteriormente o cite, o malsina como inventor de patranhas. ${ }^{33}$

Mas aquelas referências literárias, documentais, epigráficas, arqueológicas, mais ou menos vagas, que aqui e além pontuam o discurso, garantem verosimilhança às palavras do biógrafo, enquanto estabelecem a conexão com o referente empírico pré-textual. Por isso, apesar de não serem muito numerosas, as referências às fontes justificam a sua abordagem. Ao averiguarmos o contexto em que Suetónio cita as suas fontes e os objectivos com que o faz, ${ }^{34}$ verificamos que não se trata de mera exibição de erudição.

A rubrica respeitante ao lugar de nascimento de Calígula (Cal. 8) encerra a mais interessante discussão das fontes de toda a obra de Suetónio. Começa por apresentar a teoria do poeta Lêntulo Getúlico (mais tarde implicado numa conspiração e executado), segundo o qual, Calígula teria nascido em Tíbur. De seguida, expõe a de Plínio-o-Velho, que o faz nascer em Ambitárvio, para lá de Confluentes, sustentada com uma prova arqueológica: um altar com a inscrição ob Agrippinae puerperium ("pelo parto de Agripina»). Depois, cita uns versos que o dão como nascido no acampamento ${ }^{35}$. Finalmente, apresenta a sua própria opinião, fundamentada in actis, de que ele nasceu em Âncio. A seguir, vai fazer a refutação sucessiva das afirmações anteriores. O próprio Plínio contradiz Getúlico: acusa-o de mentir por adulação, ao fazer o imperador nascer na cidade

\footnotetext{
${ }^{31}$ Com. de Wardle, D. 1994, 19; vide também 75-76; 94-95.

${ }^{32}$ Como sublinha Giua, M. A. 1990, 543-544.

${ }^{33}$ Vide Baldwin, B. 1983, 191.

${ }^{34}$ Vide Baldwin, B. 1983, 101-213; Gascou, J. 1984, 3-339.

${ }^{35}$ Cal. 8.1: In castris natus, patriis nutritus in armis / iam designati principis omen erat. TAYLOR, A. 1945, 408-410, procura demonstrar que se tratava de uma fórmula própria dos enigmas.
} 
de Hércules (Cal. 8.2). Contra Plínio, apresenta Suetónio a cronologia (ratio temporum): Germânico partiu para a Gália depois do nascimento do filho (Cal. 8.3). Acrescenta-lhe uma discussão de carácter linguístico, baseada nos seus conhecimentos de grammaticus, para refutar a prova do altar (ob Agrippinae puerperium): puerperium tanto poderia designar nascimento de um menino como de uma menina. Cita ainda uma carta de Augusto à neta Agripina, que prova que Gaio só aos dois anos saiu de Roma (Cal. 8.4). Quanto aos versos que o fazem nascer no acampamento, não lhes dá crédito, por serem anónimos. ${ }^{36}$ Tira a conclusão lógica de que restat et publici instrumenti auctoritas («resta a autoridade dos documentos públicos). ${ }^{37}$ Acrescenta ainda uma razão psicológica: o amor de Calígula por Âncio, que o leva a querer mudar para esta cidade a corte (sedem ac domicilium imperii). Compreende-se esta preocupação de rigor. Refutar alguém como Plínio exigiria provas convincentes (Cal. 8.5). ${ }^{38}$ Suetónio usa aqui os seus conhecimentos linguísticos, ${ }^{39}$ não por mera erudição, mas para averiguar a verdade histórica.

Um gérmen de crítica se vislumbra a propósito das origens de Vitélio, onde os testemunhos se dividem conforme se trate de aduladores ou detractores. Entre os primeiros, cita-se um libellus de um incerto Q. Elógio (Vit. 1.2); ${ }^{40}$ entre os segundos, Cássio Severo. ${ }^{41}$

Polémica nas fontes se manifesta também a propósito das origens de Augusto. O biógrafo declara que, além das informações de António, não encontrou outras sobre os antepassados da linha paterna: uma afirmação da seriedade da sua investigação, mas que representa também uma forma de não confirmar as insinuações acerca da origem humilde do bisavô e do avô. ${ }^{42}$

${ }^{36}$ Quod ii sine auctore sunt. Mas Suetónio nem sempre adopta este critério, pois, a propósito do ímpio "Festim dos doze deuses", levado a cabo por Augusto (Aug. 70.1), cita uns versos sine auctore: vide BALdwin, B. 1983, 160. Mas a situação não é a mesma. No caso de Augusto, os versos são vistos como uma prova suplementar que confirma a acusação de António, enquanto em Calígula estão em contradição com outras fontes de maior credibilidade.

37 Trata-se dos acta populi ou acta diurna ou acta Vrbis, uma espécie de gazeta oficial, publicada desde o final da república, onde se registavam acontecimentos públicos de Roma, cerimónias, discursos, execuções capitais etc. Vide GAscou, J. 1984, 485-487; Coninck, L. DE 1991, 3683 n. 48. Gascou, J. 1984, 544-545, salienta que se trata do germe de um método histórico moderno, que confronta os dados da tradição com os dos documentos e faz prevalecer a veracidade dos documentos oficiais sobre a das outras fontes: Getúlico pode ser tendencioso, Plínio pode equivocar-se.

${ }^{38}$ Há quem veja aqui uma tentativa de corrigir, com fundamento, o texto de Tácito, Ann. 1.41.2, que apresenta Calígula in castris genitus: vide BALdwin, B. 1983, 160. Mas será mais correcto falar de distanciamento em relação à tradição: vide intr. ao com. de WARDLE, D. 1994, $55-56$.

${ }^{39}$ Almeida, J. M. 1959, 87-88 e 117-118, salienta o valor desta discussão para o estudo da semântica e do léxico latinos.

${ }^{40}$ Se é que se trata de um nome próprio e não do comum elogium: vide BALDwin, B. 1983, 185 e 211 n. 206. Segundo Gascou, J. 1984, 463, o interesse de Suetónio por questões genealógicas explica o recurso a esta fonte rara.

${ }^{41}$ Fonte da época de Augusto que mostrava tendência para a uituperatio: cf. Tácito, Ann. 1.72.3; 4.21.3.

${ }^{42}$ Nec quicquam ultra de paternis Augusti maioribus repperi. 
Em Aug. 3.2, usa o testemunho de Cícero, que recomenda ao irmão o pai de Augusto, ${ }^{43}$ como modelo de governador de província. Volta a citar o triúnviro (Aug. 4.2) sobre a baixa condição do bisavô materno e junta-lhe a confirmação espirituosa de Cássio de Parma, um dos assassinos de César.Já no final da Vida, a perspectiva é gloriosa: os presságios que anunciaram o nascimento de um rei e do facto de Augusto ter escapado a uma matança decretada pelo senado firmam-se no testemunho do liberto de Augusto, Júlio Márato (Aug. 94.3); sobre a prodigiosa concepção que faz de Augusto um filho de Apolo, cita-se o Theologumenon de Asclepíades de Mendes (Aug. 94.4), e sobre um prodígio da infância que relaciona Augusto com o Sol, apresenta-se o testemunho de Gaio Druso (Aug. 94.6). ${ }^{44}$

Nota-se por vezes a rejeição de fontes ou tradições anteriores. Diz-se, em Cal.17.1, que Calígula iniciou sozinho o consulado em Lugduno, não por arrogância ou negligência, como alguns pensam, mas por desconhecimento da morte do colega ${ }^{45}$ Também em Cal. 19.3, Suetónio se distancia da tradição para introduzir um novo tipo de fonte: as memórias familiares. A propósito da construção da ponte de barcas em Baias, depois de apresentar o argumento da maioria (scio plerosque existimasse) refere o que, quando puer, ouvira ao avô, o qual, por seu turno, já recolhera a versão oral de íntimos do palácio: o espectáculo seria uma auersio ominis, destinada a contrariar uma predição desfavorável do astrólogo Trasilo. ${ }^{46}$

Suetónio demonstra gosto por provas arqueológicas. No que diz respeito à infância de Tibério, refere-se, como artefactos dignos de um museu, os presentes que lhe deu Pompeia, irmã de Sexto Pompeio, e que ainda se podiam ver em Baias. ${ }^{47}$ Esta indicação pode ter significado político - a proximidade com a família de Sexto Pompeio liga Tibério, na sua origem, à oposição senatorial. A propósito das origens dos Flávios, invocam-se as estátuas na Ásia, que atestam a integridade de Sabino, pai deste imperador (Ves. 1.2). ${ }^{48}$ Sobre Tito apresentam-se testemunhos arqueológicos (estátuas, retratos e inscrições) como prova do excepcional desempenho enquanto tribuno militar na Germânia. ${ }^{49}$ Uma estatueta de Octávio menino, que o biógrafo ofereceu a

${ }^{43}$ Q. fr. 1.121.

${ }^{44}$ Segundo Gascou, J. 1984, 461-462, não há razão para crer que se trate do filho de Tibério (que pronunciou um elogio fúnebre de Augusto), nem do irmão de Tibério, pois estes não tinham o praenomen de Gaio.

45 Vt quidam opinantur, superbia neglegentiaue. Também Díon Cássio, 59.24.2, desculpa Calígula. Vide intr. ao com. de Wardee, D. 1994, 55.

${ }_{46}$ Vide Gascou, J. 1984, 512-513 n. 229; Wardle, D. 1994, 55-56.

${ }^{47}$ Tib. 6.3: (...) durant ostendunturque adhuc Bais.

${ }^{48} \mathrm{O}$ uso do imperfeito manebant pode significar que as estátuas já não existiam na altura da redacção das Vidas ou sugerir que o autor testemunhara a sua presença no local. GAscou, J. 1984, 534, opta pela segunda hipótese, dada a possibilidade de Suetónio ter feito parte da comitiva de Plínio, governador da Bitínia entre 111 e 113.

49 Tit. 4.1: sicut apparet statuarum et imaginum eius multitudine ac titulis per utramque prouinciam. A familiaridade de Suetónio com a Germânia e Britânia sugere, na opinião de Syme, B. 1981, 105-117, uma viagem, que, por sua vez, GAscou, J. 1984, 519-520, considera desnecessária para explicar tais referências. 
Adriano (Aug. 7.1), regista o nome de Thurinus, usado pelo imperador na sua meninice. Mais sinistra é a referência ao local das execuções em Cápreas, a rocha de onde Tibério mandava precipitar os condenados (Tib. 62.2). ${ }^{50}$ Salienta-se o pitoresco de um lugar amaldiçoado pelas atrocidades do imperador.

O biógrafo usa ainda as memórias pessoais acerca da estima que muitos devotavam ao controverso Nero. Suetónio apresenta o seu próprio testemunho - adulescente me (Nero 57.2) - sobre o êxito que, vinte anos depois da morte do imperador, obteve entre os Partos alguém que se fez passar por ele. Na Vida de Domiciano, Suetónio evoca também as suas recordações me adulescentulum memini (Dom. 12.2) - a propósito do exagerado rigor na aplicação do imposto sobre os Judeus, para exemplificar até que ponto chegava a avidez do imperador.

Um número considerável de citações sustenta a caracterização dos biografados. Uma citação literal - um excerto seleccionado do elogio fúnebre de César a sua tia Júlia (Jul.6.1) - faz referência à origem real e divina da família e contribui para fundamentar a vaidade e a ambição de César e é, desde logo, coerente com a Vida no seu todo. Para fundamentar a grave suspeita (Jul.9.1) de que César, em 65 a. C., tenha conspirado com Crasso para atacar o senado e instaurar a ditadura, Suetónio apela ao testemunho da bistoria de Tanúsio Gémino, ${ }^{51}$ aos edicta de Marco Bíbulo ${ }^{52}$ e refere uma possível alusão a esse facto numa carta de Cícero a Áxio (Jul. 9.2)..$^{53}$ Tanúsio explica a razão do fracasso da intentona. Curião pai, uma fonte usada em situações desfavoráveis, ${ }^{54}$ precisa o sinal combinado: César deixaria cair a toga do ombro. A estes junta ainda o testemunho de Marco Actório Nasão, fonte hostil a César. ${ }^{55}$ Tais depoimentos têm continuidade na análise caracterológica de César que precede a narrativa da guerra civil (Jul. 30). Para se não limitar à causa imediata do conflito, a expulsão do senado dos tribunos da plebe, Suetónio deixa claro que esse é o pretexto de César, mas outras as causas: Asínio Polião transmite umas palavras suspeitas, proferidas por César depois da vitória de Farsalo. ${ }^{56} \mathrm{O}$ testemunho é valioso: sendo Asínio Polião uma fonte favorável, torna-se mais credível se

${ }^{50} \mathrm{O}$ chamado "salto de Tibério" ainda hoje é apontado pelos guias turísticos locais. O com. de Lindsay, H. 1995, 169-170, sugere que Suetónio visitou o local. Gascou, J. 1984, 539, nega tal visita: o biógrafo pretenderia apenas, com um pormenor pitoresco, corroborar a realidade histórica destes crimes..

${ }^{51} \mathrm{Um}$ enfadonho autor de annales, segundo o testemunho de Séneca, Ep. 93.11. Gémino será autor de uma narrativa contínua desde as origens (de acordo com informações referentes ao período da monarquia, citadas por Macróbio, 1.16.33) até ao seu tempo e terá sido um dos últimos autores de annales da República. Vide Bardon, H. 1952, 264-265.

${ }_{52}^{5}$ Três vezes colega de César: como edil em 65 , pretor em 62 e cônsul em 59.

${ }^{53}$ A expressão in quadam ad Axium epistula parece sugerir que Suetónio não a leu, mas confiou numa fonte onde a carta seria referida: vide Townend, G. B., 1982, na sua intr. ao com. de Butler, H. E. \& Cary M. 1927 (1993), xi.

${ }^{54}$ Autor de um diálogo contra César: vide Bardon, H. 1952, 282-283.

${ }^{55}$ Bardon, H. 1952, 284. Sobre o gosto de Suetónio por fontes raras, vide Gascou, J. 1984, 458ss.

${ }^{56}$ Jul. 30.4: 'Hoc uoluerunt; tantis rebus gestis Gaius Caesar condemnatus essem, nisi ab exercitu auxilium petissem.' 
afirma algo em desfavor de César. Mais ainda, Polião é testemunha ocular do início de todo o processo - Plutarco coloca-o entre os acompanhantes de César à passagem do Rubicão. ${ }^{57} \mathrm{~A}$ causa profunda, a ambição de poder, é ancorada na autoridade de Cícero (De officiis 3.82), a propósito de uns versos das Fenícias de Eurípides, que César constantemente repetia..$^{58}$ Ao colocar esta opinião em último lugar, Suetónio dá-lhe peso. ${ }^{59}$ Era necessário fundamentar bem este episódio que explica o rumo futuro da vida de César e que, em última análise, levará à instauração do principado. E, mais à frente, em abono de umas frases insolentes (inpotentiae uoces) contra a República, reveladoras do espírito tirânico do ditador, cita-se Âmpio, um pompeiano dos mais acérrimos. ${ }^{60}$

No que respeita a suspeitas de tirania em Augusto, além da referência ao uso de uma couraça debaixo da toga, aduz-se a informação de Cremúcio Cordo, fonte hostil ${ }^{61}$ para atestar o novo costume de revistar os senadores que eram recebidos pelo príncipe (Aug. 35.2). Mas, no caso deste imperador acentua-se a demarcação dos erros de César: refere-se um grauissimus edictus a censurar a adulatio dos espectadores, que, no teatro, o aclamavam como dominus (Aug. 53.1).

$\mathrm{Na}$ caracterização de Augusto nota-se a presença das fontes hostis só até determinado ponto. Sobressai António, que o acusa de uma fuga covarde do campo de batalha (Aug. 10.4) e de não ser capaz de olhar o exército em linha de combate (Aug. 16.2). Outra fonte hostil é Aquílio Nigro, ${ }^{62}$ que acusa Augusto

${ }^{57}$ Plutarco, Caes. 32.7. Em 46.1-2, também este autor cita as palavras de César, pronunciadas depois da batalha de Farsalo; e acrescenta que foram traduzidas do grego por Asínio Polião. Vide GAscou, J 1984, 159-172, o qual pensa que Suetónio, no tocante à guerra civil, se inspirou numa tradição favorável a César, mas demarcada do Corpus Caesarianum, e deixou as críticas para os capítulos sobre a vida privada. Essa tradição poderá entroncar em Asínio Polião, fonte preferida de Suetónio, por ser favorável e, ao mesmo tempo, um tanto imparcial.

${ }^{58}$ E que o próprio Cícero verteu para latim: 'nam si uiolandum est ius, <regnandi> gratia/ uiolandum est: aliis rebus pietatem colas' (Jul. 30.5). São palavras descontextualizadas de um longo discurso: vide Morgan, L. 1997, 39-40.

${ }^{59}$ No que respeita ao governo, entre as medidas de César ad ordinandum rei publicae statum, Cícero é de novo citado a propósito do aumento das penas financeiras: para os parricidas, $u t$ Cicero scribit, a perda de todos os bens, enquanto os outros criminosos perdiam metade (Jul.42.3). Mas o passo suscita dúvidas. Para MAcÉ,A. 1900, 291-292, a colocação infeliz da referência (ut Cicero scribit) na frase sugere que se trata de uma interpolação de um glosador, com base no Pro Caecina (34). Vide D’Anna, G. 1954, 109.

${ }^{60} \mathrm{Jul}$.77: 'Nibil esse rem publicam, appellationem modo sine corpore ac specie. Sullam nescisse litteras, qui dictaturam deposuerit. Debere homines consideratius iam loqui secum ac pro legibus habere quae dicat.' César menciona Âmpio em Civ., 3.105, e Cícero, Att., 8.11b, e Fam., 6.12, apresenta-o como biógrafo de homens corajosos. Na sua obra, incluía uma biografia de César, publicada certamente depois da morte deste, dado o conteúdo daquelas afirmações, como nota Bardon, H. 1952, 284. Sobre as implicações políticas das afirmações de César, vide Morgan, L. 1997, 23-40; Gascou, J. 1984, 463-464.

${ }^{61}$ A sua obra - Annales de rebus Augusti - , que exaltava a memória de Bruto, Cássio e Cícero, foi proibida por um senato-consulto no tempo de Tibério (o historicus referido em Tib. 61.3) e reabilitada por Calígula (Cal.16.1). Este passo mostra que escreveu sobre o principado, e não só sobre as guerras civis, e que se recusa participar na idealização de Augusto, que então se desenhava: vide Traenkle, H. 1980, 231-241.

${ }^{62}$ Outra das fontes raras de Suetónio; vide Gascou, J. 1984, 460. 
do assassínio do cônsul Hírcio, durante o combate (Aug. 11). Outra ainda é Júlio Saturnino, ${ }^{63}$ evocado a propósito da dureza e falta de clemência de Octávio durante as proscrições do triunvirato (Aug. 27.2). Ainda neste capítulo se cita o próprio Augusto, De uita sua, a apresentar a sua versão, pouco convincente, sobre a morte do pretor Quinto Gálio, quando, no dizer de Suetónio, fora torturado e morto devido a uma infundada suspeita de Octávio (Aug. 27.2). Estas fontes denunciam a crueldade de Octávio, enquanto triúnviro.

A propósito do ódio de Tibério contra os familiares (Tib. 50.1) e, concretamente, da deterioração da relação de Tibério com a mãe, referem-se uns codicilli de Augusto sobre o azedume e rigidez de carácter do enteado (Tib. 51.1). Para provar que o papel de Sejano não era tão determinante como se dizia, Suetónio cita, com o intuito de o contestar, um excerto de Tibério, $D e$ uita sua (Tib. 61.1), em que este justifica de forma não convincente a execução do célebre prefeito. Entre as condenações injustas, conta-se a de um poeta, executado porque injuriou Agamémnon numa tragédia, ${ }^{64}$ e um historiador, que sabemos ser o referido Cremúcio Cordo, ${ }^{65}$ por ter dito que Bruto e Cássio foram os últimos dos Romanos. ${ }^{66}$

A propósito do afastamento voluntário de Tibério para Rodes, Suetónio refere uma intervenção de Augusto no senado, queixando-se de ter sido abandonado (Tib. 10.2), e, transcreve um excerto de uma carta do mesmo a negar ao genro a tutela dos filhos que abandonara ${ }^{67} \mathrm{E}$, para desculpar o prudentíssimo príncipe (Tib. 21.3) da escolha de Tibério como sucessor, Suetónio menciona razões de Estado e transcreve excertos da correspondência de Augusto que elogiam os méritos militares de Tibério e o apontam como único socorro do povo romano. ${ }^{68}$ Esta nota positiva em relação a Tibério é atenuada a seguir, quando Suetónio fundamenta, com a transcrição do início do testamento de Augusto, a ideia de que este o teria nomeado sucessor por necessidade e não por escolha. ${ }^{69}$

${ }^{63}$ Gascou, J. 1984, 460-461, duvida de que esta fonte rara seja, como alguns crêem, do tempo de Adriano.

${ }^{64}$ Parece tratar-se de Mamerco Escauro. Tácito, Ann. 6.29.3, aponta outras razões: a amizade de Sejano e o ódio de Mácron.

${ }^{65}$ Porque no-lo diz Tácito em Ann. 4.34.1, e Díon Cássio, 57.24.2-4. Os seus escritos serão reabilitados por Calígula; cf. Cal. 16.1 .

${ }^{66}$ Cita-se ainda, no mesmo capítulo, um uir consularis, autor de Annales, que tem sido identificado com Servílio Noniano. Servílio Noniano seria, juntamente com Aufídio Basso e Séneca pai, uma das fontes desfavoráveis, seguidas por Suetónio e Tácito, para os principados de Tibério a Cláudio. Pensa-se que Aufídio Basso era apenas um homem de letras, mas Servílio Noniano foi cônsul e depois procônsul da África. Vide Baldwin, B. 1983, 154; GAscou, J. 1984, 251-279.

${ }^{67}$ Tib.11.5: (...) admonitus est: 'dimitteret omnem curam suorum, quos tam cupide reliquisset'.

${ }^{68}$ Segundo Gascou, J. 1984, 543, Suetónio restabelece, graças ao documento em primeira mão, a verdade histórica, distorcida pela hostilidade dos historiadores em relação a Augusto e a Tibério. Há quem veja nesta preocupação de citar documentos de Augusto uma tentativa de correcção de Tácito, Ann. 1.10.6-7, no que respeita à sucessão: vide Townend 1967, 89.

${ }^{69}$ Tib. 23: 'Quoniam atrox fortuna Gaium et Lucium filios mibi eripuit, Tiberius Caesar mibi ex parte dimidia et sextante heres esto.' 
Um sonho de Séneca, referido através de um vago ferunt (Nero 7), associa a natureza de Nero à do tio Gaio Calígula. A auctoritas dos grandes escritores prolonga-se também para o âmbito onírico. $\mathrm{O}$ sonho de Séneca tem peso semelhante ao de Cícero sobre os dotes sobrenaturais de Augusto (Aug. 94.9).

Sobre a infância de Cláudio, Suetónio cita um libellus do próprio, onde ele descreve a dureza do seu preceptor $(C l .2 .2) \cdot{ }^{70}$ Mas a principal fonte desta fase é Augusto, de quem se reproduzem vários excertos de cartas a Lívia $(C l$. 4) sobre as deficiências do neto. É desencantada opinião do imperador, que reconhece, no entanto, as capacidades literárias do rapaz. Augusto atesta assim as contradições de Cláudio, largamente exploradas na biografia.

Ao descrever a incompetência de Cláudio como juiz, o biógrafo refere as suas memórias pessoais: aquilo que ouviu aos mais velhos $(C l$. 15.3) sobre o abuso dos advogados. Em Cl. 21.2, cita as Historiae de Cláudio para provar as suas contradições. ${ }^{71}$ Não parece inverosímil que o biógrafo se tenha servido dos escritos de Cláudio na redacção dos capítulos 18 a 25, sobre a reforma administrativa. ${ }^{72}$ Mas, em $\mathrm{Cl}$. 25, completa essa informação com referência a edictos, fruto, talvez, de pesquisa nos arquivos.

Com as fontes também se atestam virtudes. Ao tratar a indulgência de César no tocante às ofensas de poetas hostis, além de mencionar Gaio Mémio e Licínio Calvo, Suetónio acrescenta Catulo, com um subentendido que hoje entendemos (Jul. 73). Como ainda não citou versos ofensivos do Veronense, diz apenas que foram os escritos contra Mamurra, e, sem se alongar, pressupõe que todos sabem que se trata do carme 29. De modo semelhante, para ilustrar a moderatio e a clementia do ditador (Jul.75), regista que suportou de bom ânimo o infame livro de Aulo Cecina e os poemas assaz maledicentes de Pitolau. ${ }^{73}$ No entanto, não transcreve os ataques, como faz no capítulo 49. Mas, em boa verdade, estes autores deixam de ser fontes para passarem a fazer parte de informação. Não são aqui tomados como testemunhas, ao passo que, em Jul. 49, os excertos sublinham os acontecimentos relatados. Agora, o assunto é a reacção clemente de César em relação aos autores, não a reacção destes às acções de César.

No que diz respeito à clementia e ciuilitas, anunciadas em Aug. 51.1, Suetónio ilustra a primeira com uma citação de uma carta a Tibério sobre a

${ }^{70}$ Dificilmente será a autobiografia de Cláudio, que tinha oito livros: talvez se trate de uma carta ou qualquer escrito privado: vide com. de Guastella, G. 1999, 143.

${ }^{71} \mathrm{O}$ imperador celebra de novo os Jogos Seculares, a pretexto de terem sido realizados muito cedo por Augusto, mas, nas Historiae, afirma que este fez cuidadosamente a contagem dos anos. Vide Gascou, J. 1984, 508.

72 Assim pensa Momigliano, A. 1932, 317-318, com o argumento de que, em Cl. 25, se refere, como efectiva, uma reforma das milícias equestres, que, na realidade, não teve êxito. Ora só o autor da reforma a indicaria: ou porque, quando a citava, ela ainda não tinha caído no esquecimento ou para atenuar a sua rejeição.

${ }^{73}$ A obra de Cecina seria liber querellarum sobre a mitis clemensque natura de César: cf. Cícero, Fam. 6.5-8. Cecina era pompeiano. César deixou-o viver, mas não regressar a Itália. Vide Bardon, H. 1952, 283. Portanto, também aqui Suetónio é demasiado benevolente com César. Pitolau poderá ser o liberto e biógrafo de Pompeio Estrabão e Pompeio Magno. Vide Bardon, H. 1952, 272 n. 11; Baldwin, B. 1983,112-113; 118-119; Lewis R. G. 1966, 271-273; Treggiari, S. 1969, 264-266. 
condescendência para com os que diziam mal do imperador (Aug. 51.3). Para exprimir o consenso na atribuição do título de Pai da Pátria e a sinceridade do afecto dos proponentes, o biógrafo prescinde dos relatos históricos em proveito da toada sentimental da citação, no estilo directo, do discurso de Valério Messala, bem como a resposta ipsis uerbis de Augusto (Aug. 58.2). Não se trata apenas de ornamentos de erudição: Suetónio procura sugerir a sinceridade da afeição que os méritos de Augusto haviam já granjeado. ${ }^{74}$

Grande relevo dá também o biógrafo às virtudes e vícios da vida privada. Para relatar os vícios de César, Suetónio segue, naturalmente, fontes hostis. Sobre a reputação de sodomita de César (Jul. 49), cita invectivas de teor sexual do poeta Licínio Calvo; de Dolabela; de Curião pai; de Bíbulo; de Marco Bruto, um dos algozes, que, por sua vez, cita um certo Octávio. ${ }^{75}$ Como opiniões mais credíveis, apresenta Mémio, que contra César pronunciou discursos violentos; ${ }^{76}$ cita as cartas de Cícero e umas palavras irónicas que o orador disse a César quando este defendia, no senado, a causa da filha de Nicomedes. ${ }^{77} \mathrm{Com}$ os versos jocosos dos soldados no triunfo gaulês, ${ }^{78}$ o biógrafo, implicitamente, dá o facto como provado.

A corrupção de mulheres ilustres, entre as quais as mulheres de Gneu Pompeio, é corroborada pela acusação que Curião pai e filho, apoiados por multi, fazem a Pompeio de ter casado, por ambição do poder, com a filha do homem a quem chamara Egisto (Jul.50.1). Sobre os rumores de que a amante, Servília, concedia a César também os favores da filha Tércia, Suetónio cita um espirituoso jogo de palavras de Cícero. ${ }^{79} \mathrm{~A}$ propósito do adultério com mulheres das províncias, transcreve, de novo, uns versos do triunfo gaulês. ${ }^{80} \mathrm{~A}$ respeito dos amores às rainhas, com quem César foi muito perdulário, evoca-se o testemunho desfavorável de Marco Actório Nasão sobre a ligação, menos conhecida, com a rainha Ênoe da Mauritânia e sobre os donativos feitos a ela e ao marido (Jul. 52.1). Na controvérsia sobre a filiação de Cesarião, refere-se a opinião de alguns gregos, entre os quais se poderá incluir Plutarco ou uma das suas fontes, ${ }^{81}$ a propósito das semelhanças físicas. Mas, à afirmação de António, de que César o reconhecera como filho, como saberiam os seus amigos Mácio e

${ }^{74}$ Como se dissera em Aug. 57.1. Vide Gascou, J. 1984, 218-220 e 549. Deve tratar-se de uma citação das Memórias ou da autobiografia de Valério Messala Corvino.

${ }^{75} \mathrm{O}$ biógrafo cita termos isolados, mas significativos ('paelex reginae'; 'sponda interior regiae lecticae'; 'stabulum Nicomedis'; 'Bithynicum fornix') que fariam parte da invectiva política: vide Gascou, J. 1984, 549.

${ }^{76} \mathrm{E}$ com quem César mais tarde se reconciliou, tal como sucedeu com o poeta Licínio Calvo, já referido, e Catulo: cf. Jul. 73.

77 Jul. 49.3: 'Remoue,' inquit, 'istaec, oro te, quando notum est, et quid ille tibi et quid illi tute dederis.' Como nota MAcÉ, A. 1900, 297-298, Suetónio dá a última palavra a Cícero.

78 Jul. 49.4: 'Gallias Caesar subegit, Nicomedes Caesarem: / Ecce Caesar nunc triumphat qui subegit Gallias, / Nicomedes non triumphat qui subegit Caesarem.'

${ }^{79}$ Jul. 50.2: 'Quo melius' — inquit — 'emptum sciatis, tertia deducta.'

${ }^{80} \mathrm{Jul}$ : 51: 'Vrbani, seruate uxores: moechum caluom adducimus. / Aurum in Gallia effutuisti, bic sumpsisti mutuum.'

${ }^{81}$ Cf. Caes. 49.10. Ant. 54.4; 71.2; 81.2. Vide Baldwin, B. 1983, 117-118. 
Ópio, ${ }^{82}$ contrapõe Suetónio um livro que Ópio escreveu a negar a paternidade (Jul. 52.2). Ao colocar esta opinião em último lugar, Suetónio parece sugerir que é a sua. Suetónio termina a questão dos amores de César recapitulando e generalizando a impudicitia e os adulteria, com um excerto dos discursos de Curião sobre a fama de César como sodomita e adúltero. ${ }^{83}$

No que respeita à vida privada de Augusto, o próprio aparece a indicar a razão do divórcio em relação a Escribónia. ${ }^{84}$ Em Aug. 63.2, cita-se António a acusar Augusto de ter feito sucessivas promessas de casamento, com fins políticos, no tocante à sua filha Júlia. Quanto à vida sexual de Augusto, o testemunho de Sexto Pompeio, Marco António e Lúcio António (Aug. 68) apresenta-o como efeminado, na sua juventude, e prostituído a César e Hírcio. Sobre os muitos adultérios, Suetónio evoca, mais uma vez, o testemunho de António, onde abunda o turpilóquio (Aug. 69.2). As cartas de António são ainda referidas como prova de um jantar secreto chamado "Festim dos doze deuses" (Aug. 70.1), a propósito do qual se citam ainda uns versos anónimos. A conhecida hostilidade destas fontes fala por si. Mas, quanto à acusação de que Augusto era viciado no jogo dos dados, Suetónio dá-a como provada ao transcrever (Aug. 71.2-4) excertos de duas cartas a Tibério e uma à filha, em que o próprio confessa de forma natural este vício.

A contrastar com os desmandos sexuais, atesta Suetónio para César, baseado em Marco Catão, a moderação na bebida, ${ }^{85}$ e, em Gaio Ópio, amigo de César, a indiferença, quase proverbial, pela comida (Jul. 53). Sobre os hábitos alimentares de Augusto, Suetónio cita três excertos de cartas suas (Aug. 76) e sobre a exemplar moderação no vinho (Aug. 77) segue a informação de Cornélio Nepos. ${ }^{86}$ Também esta é uma nota importante para a definição da personagem.

Augusto é sobretudo visto como um moralizador e como restaurador de costumes. Para ilustrar até onde ia a sua parcimónia em ceder, sem justa causa, a cidadania romana a qualquer estrangeiro, citam-se duas cartas com a

82 Ópio é um amigo íntimo de César e responsável pela correspondência. A obra de Ópio sobre César seria largamente panegírica. (cf. Cic. Q. fr 3.1.8; Gell. 17.9.1). Figura em Jul. 72, a ilustrar a facilitas e indulgentia de César para com os amigos. Segundo Townend, G. B. 1987, 325-342, Suetónio parece dever a Ópio o esquema de abordagem de César, e dos seus sucessores, em termos das suas características dominantes, ilustradas com anedotas retiradas da sequência cronológica.

${ }^{83} \mathrm{Jul}$.52.3: At ne cui dubium omnino sit et impudicitiae et adulteriorum flagrasse infamia, Curio pater quadam eum oratione 'omnium mulierum uirum et omnium uirorum mulierum' appellat. Vê-se que é uma fonte parcial, exageradamente hostil, que leva o biógrafo a contradizer-se a si próprio, pois afirmara em 49.1: Pudicitiae eius famam nibil quidem praeter Nicomedis contubernium laesit.

${ }^{84}$ Aug. 62.2: 'Pertaesus - ut scribit - morum peruersitatem eius.' Talvez se trate do De uita sua: vide Gascou, J. 1984, 177-178 n. 12; 504. Para António (Aug. 69.1), as razões são exactamente opostas: Escribónia é que acusava Augusto de imoralidade.

${ }^{85}$ O que é notável, vindo de um apreciador de vinho, segundo Plutarco, Ca.Mi. 6.1-2. Baldwin, B. 1983, 113, afirma que Suetónio talvez cite esta fonte para corrigir Plutarco, visto este registar duas vezes que Catão apelida César de bêbedo: Cat. Mi. 24.1; Brut. 5.2.

${ }^{86} \mathrm{O}$ fragmento citado por Suetónio reflectirá a guerra de propaganda entre Octávio e António: vide Geiger J. 1980, 112-114. 
recusa deste privilégio, uma a Lívia e outra a Tibério, que o requeriam para uns seus protegidos (Aug. 40.3). Sobre a selecção de pessoas para os jantares e tratamento dos libertos, de acordo com o seu estatuto social, Suetónio evoca, com aprovação (Aug. 74), o testemunho de Valério Messala ${ }^{87}$ e o do próprio Augusto (certamente De uita sua) sobre a excepcional permissão para a sua mesa, dada, por mérito, ao liberto Mena, que lhe entregara a esquadra de Sexto Pompeio. Tal decisão reflecte a moral social preconizada por Augusto (e pelo biógrafo). Suetónio, que, nas Vidas, dá especial importância aos espectáculos, sinal de liberalidade (cf. Aug. 41.1), refere palavras de Augusto das Res gestae (embora não cite explicitamente a obra) sobre o número de jogos que deu em seu nome e em nome dos que não tinham recursos (Aug. 43.1). ${ }^{88}$ Sobre a moralização dos jogos, cita um edicto (Aug. 44.3) a proibir a presença das mulheres nos espectáculos de luta. Este imperador é também citado, sem se referir o lugar, ${ }^{89} \mathrm{em}$ Aug. 42.2, com medidas impopulares sobre a distribuição de trigo, para provar que estava mais preocupado com o bem comum do que com a popularidade. Em Aug. 64.2, no contexto da severidade da educação dada à filha e à neta, no rígido respeito do mos maiorum, regista-se uma carta de Augusto a repreender L. Vinício pelo atrevimento de vir saudar a sua filha a Baias. Assim se absolve Augusto da suspeita de que uma educação descuidada estaria na origem do desvario das Júlias e se acentua a desventura do pai, relatada a seguir. ${ }^{90}$

No que respeita ao aspecto físico de Augusto, Suetónio cita, com dúvida, as palavras de Júlio Márato, liberto de Augusto, que o apresenta mais alto do que era na realidade (Aug. 79.2). $\mathrm{Na}$ descrição da arrogância do carácter de Tibério, a autoridade é Augusto, que o tentara desculpar junto do senado, dizendo naturae uitia esse, non animi («que se tratava de vícios da natureza, não do carácter») (Tib. 68.3).

Acerca da elegante e esplêndida eloquência de César, procura Suetónio o testemunho do maior especialista: Cícero, no seu Brutus ${ }^{91}$ (Jul. 55.1), e numa carta a Cornélio Nepos (Jul. 55.2). Sobre as suas orationes, segue o julgamento de Augusto, que considera o Pro Quinto Metello publicado pelo estenógrafo e não por César (Jul. 55.3) e que julga de autenticidade duvidosa os dois discursos Apud milites in Hispania. De Asínio Polião recebe a informação suplementar de que César nem sequer teve tempo para proferir o segundo daqueles discursos (Jul. 55.4). Para atestar a pureza do estilo dos Commentarii de César, o biógrafo evoca de novo a autoridade de Cícero, no Brutus ${ }^{22}$ (Jul. 56.1-2), e de Hírcio ${ }^{93}$ (Jul. 56.3). Já no que diz respeito à verdade histórica,

${ }^{87}$ Autor de um De bello ciuili e De Romanis familiis.

${ }^{88}$ Opinião diferente têm Macé, A. 1900,142-143, e Levi, M.A.1937, 16. Gascou, J. 1984, 523-524, acha que, face às semelhanças verbais de vários passos, não há hoje dúvidas de que Suetónio se serviu das Res Gestae, embora de forma selectiva.

${ }^{89}$ Provavelmente o De uita sua: vide Gascou, J. 1984, 562 n. $406 ; 748$ n. 251.

${ }^{90}$ Aug. 65.1: Sed laetum eum atque fidentem et subole et disciplina domus Fortuna destituit.

${ }^{91} 252 ; 261$.

92262.

${ }^{93}$ Opinião expressa no prefácio do livro VIII de De bello Gallico, que, como se sabe, é da sua autoria. 
socorre-se do juízo de Asínio Polião que contesta a veracidade de César com verosímil imparcialidade. ${ }^{94} \mathrm{~A}$ adesão de Suetónio a esta censura poderá explicar a ausência dos Commentarii como fonte. Finalmente refere-se (Jul. 56.7) uma carta de Augusto a Pompeio Macro a vetar a publicação dos trabalhos menores de César (Laudes Herculis, Oedipus e Dicta collectanea).

Sobre a clareza do estilo de Augusto e a sua aversão ao arcaísmo, cita Suetónio vários excertos de cartas a Tibério, a António e à neta Agripina (Aug. 86). Em Aug. 87, refere ainda expressões curiosas, retiradas das cartas de Augusto. As considerações sobre a grafia (Aug. 87.3) e sobre um código por ele usado (Aug. 88) parecem sugerir a consulta de cartas autógrafas - a força da expressão Notaui et in chirographo («verifiquei também no manuscrito») (Aug. 87.3) contribui para sugerir verosimilhança ao relato. ${ }^{95}$

O biógrafo serve-se várias vezes de Cláudio como fonte para a sua própria falta de senso ( $C l .38 .3 ; C l .39 .2)$. E, como contraprova, indica o livro intitulado Moron epanastasis ( A revolta dos tolos»), a demonstrar stultitiam neminem fingere («que ninguém pode fingir estupidez»). ${ }^{96}$

A narrativa da morte dos biografados é um dos locais onde se concentra maior ocorrência, por vezes polémica, de versões diversas. Para provar que o aparecimento em Cápua de uma inscrição a anunciar a morte de César não é história inventada, Suetónio apoia-se na autoridade de Balbo, amigo íntimo de César (Jul. 81.2) ${ }^{97}$ A descrição linear do ditador termina com referência a fontes anónimas (tradiderunt) que transmitem a famosa exclamação, em grego, a Bruto: «Também tu, meu filho?!» (Jul. 82.2). Versões discordantes informam os relatos das mortes de Tibério (Tib. 73.2), de Calígula (Cal. 58.2), de Cláudio (Cl. 44.2-3), de Galba (Gal. 20.1). O relato da morte de Domiciano não é polémico, mas Suetónio completa-o com o testemunho de uma fonte oral: o escravo (Dom.17.2) que assistira ao assassínio.

${ }^{94} \mathrm{Jul}$. 56.4: Pollio Asinius parum diligenter parumque integra ueritate compositos putat, cum Caesar pleraque et quae per alios erant gesta temere crediderit et quae per se, uel consulto uel etiam memoria lapsus perperam ediderit; existimatque rescripturum et correcturum fuisse. $\mathrm{O}$ último período redunda numa tentativa, por parte de Asínio Polião, de escusar ou antes mitigar as faltas de César à verdade histórica e num esforço de simpatia que dá credibilidade às pouco elogiosas palavras anteriores. De qualquer modo, como nota BALsdon, J. P. 1957, 19-28, os escritos de César não são história (annales ou historiae), mas commentarii; e o juízo correcto sobre as obras de César tem de estar entre a visão dos que rejeitam por completo as palavras de César e os que crêem que tudo o que ele diz é verdade.

${ }^{95}$ Levi, M. A. 1937, 14-15, é de opinião que as cartas de Augusto deviam estar publicadas juntamente com as de M. António, e as observações sobre a grafia e criptografia de Augusto fariam parte de informação independente (como a de Quintiliano, Inst. 1.7.22), pelo que a pesquisa de Suetónio nos arquivos, para as cartas de Augusto, não era necessária. BALdwin, B. 1983, 139, parece aceitar as implicações desta teoria. Pelo contrário, GAscou, J. 1984, 471ss, com base no significado de notaui, aceita um manuseamento efectivo (Aug. 87.3).

${ }_{96}$ Que tem sido identificado com a Apocolocyntosis de Séneca. Mas, argumenta Baldwin, B. 1983, 171, esta teria sido escrita depois da morte de Cláudio, enquanto aquele livro teria aparentemente surgido durante o seu principado.

${ }^{97}$ Cf. Jul. 78.1: Balbo aparece, segundo alguns (quidam putant), ligado a mais uma das causas do assassínio: quando César se não levantou perante os membros do senado. Suetónio pode ter encontrado o testemunho de Balbo nas suas Memórias; cf. Sidónio Apolinar, Ep. 9.14.7. 
A linearidade da narrativa da morte de Nero (Nero 47-49) poderá assentar num género existente: exitus illustrium uirorum («mortes de varões ilustres»). De qualquer modo, no texto, aparecem informações arqueológicas precisas sobre a localização da casa de Fáon (Nero 48.1) ${ }^{98}$ e o túmulo dos Domícios (Nero 50). O relato heróico da morte de Otão (Otho 11) deve-se certamente ao pai do biógrafo, Suetónio Leto, angusticlavo da décima terceira legião, que será certamente a fonte principal desta Vida e que terá contribuído para a imagem favorável daquele imperador.

Em suma, Suetónio cita e mistura fontes de todo o género: rumores; relatos de testemunhas oculares, documentos de arquivos familiares ou públicos, cartas familiares. Apresenta, como provas arqueológicas, estátuas, inscrições, grafitos, objectos, monumentos, lugares. Cita-se este tipo de fontes aparentemente para rebater opiniões de outros - sejam eles declarados, como o defunto Plínio, ou omitidos, como as fontes de algumas divergências na tradição e que aparecem reflectidas nos textos de Plutarco e Tácito -, quando acha que o assunto é controverso, quando o facto é menos conhecido ou quando quer tornar verosímil uma afirmação. Onde o biógrafo parece demonstrar maior precisão e crítica é a propósito do momento e lugar do nascimento (Aug. 5 ss; Tib. 5; Cl. 2.1; Gal.4.1; Ves. 2.1; Tit. 1; Dom. 1.1). ${ }^{99}$

As fontes literárias podem ser usadas como anónimas: a indicação do nome não é prioritária. Mas os autores nomeados pertencerão todos ao tempo de César e Augusto. ${ }^{100}$ É no Diuus Iulius que Suetónio cita mais autoridades para apoiar as suas afirmações. Em diversos passos da Vida de César, Suetónio evoca fontes literárias, mas, por outro lado, o confronto com as outras Vidas faz ressaltar a ausência de fontes não literárias - que provavelmente não existiam em abundância: o período era conturbado e os incêndios frequentes; Plutarco também não as cita - nem mesmo os acta senatus, de cuja publicação Suetónio refere o início (Jul. 20.1). Há fontes favoráveis e fontes hostis, analistas tradicionais, biógrafos e coleccionadores de anedotas. A maior parte das citações fundamentam qualidades importantes do carácter de César: a propensão para a tirania, a libido, em contraste com a moderação na comida e na bebida, uma boa cultura literária, e clemência em relação aos inimigos. $\mathrm{O}$ relato torna-se mais verosímil quando se apresentam fontes hostis a defender

${ }^{98}$ Curiosos posteriores procuraram esta casa com base em informações do texto de Suetónio, como revela uma inscrição moderna, descoberta e transladada para o claustro do cenóbio de S. Paulo em Roma, em 1756: trata-se de um dístico elegíaco (embora não tenha essa disposição) Hoc specus excepit post aurea tecta Neronem, / nam uiuum inferius se sepelire timet - acompanhado de um titulus posterior - reperta prope Anienem inter Salariam et Nomentanam uiam in suburbano Phaontis liberti nunc "la Serpentara", illinc centum fere abhinc annis Nazanum auecta deinde Romam mense Octobris anno MDCCLVI. Ambos apresentam flagrantes semelhanças com o texto de Suetónio: o distíco é decalcado de Nero 48.3-4 e o titulus de Nero 48.1; vide Thomasson, B. E. 1969, 715-717.

${ }^{99}$ Vide com. de Guastella, G. 1992, 102.

${ }^{100}$ Menciona-se Flávio Josefo (Ves. 5.6), mas apenas como um jovem cativo que profetiza sobre o futuro imperial de Vespasiano. O próprio Josefo menciona o mesmo facto em BJ. 3.8.9. 
virtudes e fontes favoráveis a apontar os vícios. Parecem evitar-se as fontes históricas mais reconhecidas, como Salústio, Lívio e o próprio César. Mas, embora Suetónio não pareça fazer distinção entre as fontes que cita, porquanto apresenta lado a lado fontes de género e valor diverso, para a época de Júlio César, há uma autoridade incontestável. Não será por acaso que Cícero é o autor mais frequentemente invocado nesta vida. ${ }^{101}$

$\mathrm{Na}$ Vida de Augusto, as fontes literárias continuam presentes a atestar aspectos importantes da vida do imperador, mas a polémica, que surge muitas vezes na Vida de César e se mantém nos capítulos iniciais da Vida seguinte, esbate-se. A única fonte, verdadeiramente hostil, citada com abundância é, ainda assim, António. ${ }^{102}$ Predominam os escritos de Augusto, sobretudo as cartas. ${ }^{103}$ Estas ganham maior autoridade, quando se verifica que se não citam cartas de qualquer outro sucessor. ${ }^{104} \mathrm{~A}$ frequência do uso de escritos de Augusto contrasta também flagrantemente com a ausência do recurso aos escritos de

${ }^{101}$ Vide D’Anna, G. 1954, 108-110; McDermott, W. C. 1980, 485-495; Townend, G. B., 1993, na sua intr. ao com. de Butler, H. E. \& CAry M. 1927 (1993), x.

${ }^{102}$ As fontes literárias (Cássio de Parma; Aquílio Nigro; Júlio Saturnino; Cremúcio Cordo; Valério Messala; Cornélio Nepos; Júlio Márato; Gaio Druso; e Asclepíades de Mendes) são todas contemporâneas de Augusto. Para Levi, M. A. 1937, 19-22, representam talvez citações em segunda mão e escondem a verdadeira fonte; e, à parte Asclepíades, são citados em relação a particulares secundários das suas obras. Dos nomes referidos, Aquílio Nigro, Júlio Saturnino,Júlio Márato e Gaio Druso são conhecidos somente através da notícia de Suetónio. Levi considera Cremúcio Cordo uma fonte provável para a parte das guerras civis, que é hostil a Augusto; para a parte da vida privada, Suetónio terá seguido uma fonte posterior à vida de Augusto, talvez Aufídio Basso ou Servílio Noniano. Diferente opinião parece ter Schwartz, J. 1948a, 159-162, uma vez que apresenta Cremúcio Cordo como fonte de Aug. 30, um capítulo favorável sobre a actividade urbanística de Augusto. GAscou, J. 1984, 241-242, contesta a redução, proposta por LEVI, a duas fontes e rejeita a ideia de uma obediência acrítica às fontes por parte do biógrafo.

${ }^{103}$ Vide LANA, I. 1975, 437-458. Neste artigo se apresenta uma relação de todas as citações dos escritos de Augusto nas Vidas dos Césares. Só na Vida de Augusto o autor enumera 45 passos: 23 citações em forma directa; 10 em forma indirecta; e 12 por assunto. As cartas prevalecem: 18 passos delas retirados.

${ }^{104}$ Aqui Suetónio segue a prática dos seus contemporâneos, pois vários fazem referência às cartas de Augusto, mas nenhum deles cita cartas de qualquer dos imperadores de Tibério a Domiciano: vide Wallace-Hadrill, A. 1984, 91-96. Levi, M. A. 1937, 1-24, parece adoptar a posição dos que advogam que Suetónio se não serviu de fontes de arquivo, nem de grande pluralidade de autores (como fazem pensar as variadas citações), mas que terá seguido somente duas fontes bem informadas; que não pesquisou nos arquivos as cartas de Augusto; que não teve acesso às Res gestae e que cita sobretudo em segunda mão. De Coninck, L. 1980-1981, 387-401; ID. 1983 (v. p. 216-218); ID. 1991,3675-3699, é de opinião que Suetónio não terá feito uma pesquisa sistemática nos arquivos, uma vez que as suas citações das cartas de Augusto não diferem muito de outros autores que não tinham a posição privilegiada do secretário (ab epistulis) de Adriano; as referências indirectas a documentos desmentem a preocupação de uma pesquisa sistemática, e os vários equívocos, que poderiam ser evitados com a consulta de documentos, sugerem que os não leu. Para BALdwin, B. 1983, 48, a familiaridade com a correspondência de Augusto não prova o acesso ou o uso dos arquivos imperiais. Diferente opinião tem GAscou, J. 1984, 465 ss., especialmente 502, que defende o uso, por parte do biógrafo, de documentos em primeira mão e dos manuscritos das cartas de Augusto, embora não de forma sistemática; mas WALlACE-Hadrill, A. 1984, 92, alerta para o perigo de cair nos preconceitos modernos sobre os arquivos confidenciais de governo e do seu uso pelos historiadores. 
César, na primeira das Vidas. O biógrafo mostra que tem conhecimentos precisos das cartas de César (Jul. 56.6), mas não as indica como fonte. Parece haver uma cedência de Suetónio ao fascínio da figura de Augusto: entre as fontes documentais, os escritos do fundador do principado predominam e arrastam-se até à Vida de Nero. O facto de Suetónio descrever o código usado nas cartas secretas de César sugere que tenha consultado os autógrafos, mas o biógrafo não o diz explicitamente, como faz no caso das cartas de Augusto e dos poemas de Nero (Nero 52).

$\mathrm{Na}$ vida de Tibério, há uma nítida diminuição, quer das fontes literárias, quer documentais, ${ }^{105}$ decréscimo que continua pelas vidas seguintes. Na Vida de Cláudio, as únicas fontes nomeadas são Augusto e o próprio Cláudio. Com o terminar desta dinastia, as Vidas tornam-se consideravelmente menos extensas: por conseguinte há muito menor indicação das fontes.

Ficam provados os uitia naturae de Tibério quer pela opinião autorizada de Augusto, quer pelas várias anedotas relatadas de origem obscura. ${ }^{106}$ Suetónio terá também usado, como fontes, Aufídio Basso e Servílio Noniano. No caso de Calígula, os autores concordam que Suetónio seguiu, para os capítulos do monstrum, uma ou várias fontes hostis. Além do Bellum Iudaicum e das Antiquitates Iudaicae de Flávio Josefo, supõe-se que o reinado de Calígula era coberto pelos anais de Aufídio Basso, e eventualmente os de Servílio Noniano, pelas Memórias de Agripina e, para o final do principado, por Clúvio Rufo,

105 Como causa desta diminuição tem-se apontado a desgraça de Suetónio por volta de 121-122, que lhe interromperia o acesso aos arquivos imperiais: vide Townend, G. 1959, 285-293; ID. 1967, 79-81; Syme, B. 1981, 105-117. Segundo Townend, G. B. 1959, 285-293, o afastamento de Suetónio acontece depois da publicação das Vidas de César e de Augusto, quando o biógrafo já tinha reunido grande parte do material para as Vidas de Tibério, de Calígula e de Cláudio. Bowersock, G. W. 1969, 119-125, defende que o grupo de Vidas, que vai de Galba a Domiciano, foi o primeiro a ser escrito, no tempo de Trajano. Mas Bradley, K. R. 1973, 257-263, rejeita a proposta de BowERsock e argumenta que a introdução à Vida de Galba (Gal.1) constitui uma transição da descrição das reacções à morte de Nero (Nero 57) para o período dos quatro imperadores. Também BALDwin, B. 1983, 469-484, critica a tentativa de Bowersock de estabelecer a cronologia das Vidas com base em dados linguísticos. A ampla citação de cartas de Augusto, em contraste com a progressiva diminuição na indicação das fontes e na extensão das Vidas, pode ser sinal de um especial interesse de Suetónio pelo período de Cícero e de Augusto, domínio em que se tornara especialista, como notam Wallace-Hadrill, A. 1984, 50-59, e De Coninck, L. 1991, 3699. Bradley, K. R. 1985b, 263, prefere salientar, em vez de um declínio, um progressivo aumento do cuidado na selecção do material por parte de Suetónio ao compor as Vidas dos Césares, tomando como critério, para encorpar mais ou menos as biografias, a noção de ideal imperial.

${ }_{106} \mathrm{O}$ relato das torpezas de Tibério em Cápreas (Tib. 42-45) apresenta semelhanças com Tácito (Ann. 1.4.; 4.57; 4.67; 6.46; 6.51), o que faz pensar em uma fonte comum desaparecida. $\mathrm{O}$ facto de nem Díon Cássio nem os dois Plínios se referirem a tais rumores, e de estes crimes aparecerem em Suetónio e em Tácito associados ao secretismo do lugar, aponta para uma fonte panfletária, aceite pelos sucessores, que eram da família de Germânico: vide Martin R. 1991, 153-157. Segundo Buttrey, T. V. 1973, 52-63, Suetónio ter-se-á inspirado, para a descrição dos escândalos sexuais de Tibério em Cápreas, nas cenas eróticas representadas em fontes de carácter numismático: as medalhas conhecidas como spintriae. GAscou, J. 1984, 540-541, contesta esta tese, porque a descrição de Suetónio se não coaduna com os motivos representados nessas peças. 
apontado como fonte também para o principado seguinte ${ }^{107} \mathrm{~A}$ hostilidade de Suetónio para com Cláudio teria determinado a escolha das suas fontes: a Apocolocyntosis de Séneca fornecia pormenores pitorescos e satíricos. ${ }^{108}$ Para este principado, Suetónio teria à disposição historiadores: além de Clúvio Rufo, o testemunho de Plínio-o-Velho, cuja obra histórica perdida continua a das Histórias de Aufídio Basso, que terminava precisamente no decurso do principado de Cláudio. ${ }^{109}$ Plínio, juntamente com Clúvio Rufo e Fábio Rústico, será certamente também fonte da $V i d a$ de Nero, ${ }^{110}$ e dos imperadores de 68-69 d. C. (Galba, Otão, Vitélio). ${ }^{111}$ Clúvio Rufo é referido (Nero 21.2) apenas como consularis, a servir de arauto a Nero, talvez por ser demasiado favorável ao imperador. Ao defender que Nero desejava o incesto com a mãe (Nero 28.2), Suetónio usa uma versão diferente da de Tácito, ${ }^{112}$ que, seguindo Clúvio Rufo, atribui a iniciativa a Agripina. ${ }^{113}$ A respeito da continuidade de Otão em relação à política de Nero, Suetónio diz que o efémero imperador usa o nome do velho amigo em documentos e nas primeiras cartas, ut quidam tradiderunt (Otho 7.1). Plutarco $(O t h o, 3.2)$ identifica esta fonte com

${ }^{107}$ Há quem pense ser Clúvio Rufo o mencionado por Flávio Josefo, AJ 19.91-92, no contexto da morte de Calígula: vide Momigliano, A. 1932, 293-336. Este autor afirma que Clúvio Rufo é a fonte comum de Suetónio e Díon Cássio para Calígula e Cláudio. A lacuna do texto de Tácito, nestes dois principados, não permite saber se também ele o seguiu. Townend, G. B. 1960, 98-120, encontra várias citações em grego que ocorrem em contexto hostil (Cal. 22.1; 22.4; 29.1 e 47 e em Cl. 15.4; 40.3 e 42.1), as quais só poderiam provir de um escritor de crónicas escandalosas (um género menor), provavelmente Clúvio, pois era hábito, entre os escritores de Annales, traduzirem o grego para latim. Vide ID. 1961b, 227-248. Mas tal opinião é contestada por Wardle, D. 1992, 466-482. Em seu entender, nem todo o grego citado por Suetónio aparece em contexto hostil e Clúvio Rufo era um escritor de Annales, não de crónicas escandalosas. Gascou, J 1984, 281-293, refuta os argumentos quer de Momigliano, quer de Townend, por se basearem em premissas frágeis. Vide intr. ao com. de WARDLE, D. 1994, 30-54.

${ }^{108}$ Renard, M. 1937, 5-13, refere diversos exemplos de paralelismo entre aquela obra de Séneca e a Vida de Cláudio.

${ }^{109}$ Vide Momigliano, A. 1932, 293-336. Este autor procura demonstrar que Suetónio e Díon usaram a mesma fonte para o período de Messalina: Clúvio Rufo. Para o período seguinte acrescenta Plínio, sem afastar a contribuição do primeiro. Esta teoria é contestada por GAscou, J. 1984, 281-293.

${ }_{110}$ Vide Momigliano, A. 1932, 323-336; intr. ao com. de Warmington, B. H. $1999^{2}$, xi-xii.

${ }^{111}$ Vide intr. ao com. de Murison, Ch. L 1992, xii.

${ }_{112}$ Ann. 14.2. Suetónio seguiu talvez a versão de Fábio Rústico.

${ }^{113}$ Existem, nesta Vida, omissões que, segundo BALDwin, B. 1983, 178-179, sugerem polémica com o historiador: a conspiração de Pisão, ao contrário do que sucede com Tácito, é referida de passagem (Nero 36.1); Tigelino está flagrantemente ausente; Séneca é indulgentemente tratado; o seu suicídio, forçado por Nero (35.5), não vem ligado à conjura de Pisão e é ignorada a sua apologia de Nero pela morte da mãe; a perseguição aos cristãos (Nero 16.2) figura entre as medidas boas de Nero e desligada do incêndio de Roma (em 64 d. C.); e, por outro lado, a versão de Nero incendiário é apresentada como indiscutível (Nero 38). Mas as omissões relativas a Séneca e Tigelino, a atribuição da culpa do incêndio exclusivamente a Nero, e não aos cristãos, podem explicar-se, como também acontece com Sejano, pelo critério da biografia, que tende a centrar-se no imperador. $\mathrm{O}$ facto de Suetónio referir apenas de passagem a conjura de Pisão não prova qualquer tipo de polémica: revela apenas diferença de método. 
Clúvio Rufo. Para a vida de Otão, a par da fonte oral (o pai do biógrafo), naturalmente favorável, Suetónio deve ter usado também uma fonte literária: muito provavelmente Júlio Secundo. ${ }^{114}$ A referida obra de Plínio (Historiae a fine Aufidi Bassi) terá sido ainda usada como uma das fontes para o início das Vidas dos Flávios. ${ }^{115}$ Mas, à parte a breve referência a Plínio (Cal. 8), a completa ausência destes autores de peso mostra o quanto a indicação das fontes é pouco importante para Suetónio. O biógrafo não se sente obrigado a fundamentar todas as afirmações principais.

É verdade que o juízo do biógrafo reflecte, em geral, a origem fortemente senatorial destas fontes. Mantém-se a tradicional hostilidade aos imperadores que mais afrontaram a poderosa ordem. Exceptua-se Otão, em quem foi determinante a influência do pai do biógrafo. Este efémero imperador recebe da parte de Suetónio um tratamento mais favorável do que o que lhe concede o senador Tácito; e, por consequência, a figura de Galba, imperador ligado ao senado, aparece mais negra do que nas outras fontes sobreviventes. ${ }^{116}$

Uma característica de Suetónio é a citação literal: transcreve excertos (por vezes apenas palavras isoladas) e dá-lhes um valor demonstrativo. Tal preocupação pode parecer-nos banal nos nossos dias, como observa Gascou, mas Suetónio afasta-se dos historiadores tradicionais do seu tempo: Tácito quase só reproduz discursos, refeitos pelo seu génio retórico, e raramente cita cartas; Plutarco segue a tradição dos historiadores na composição dos discursos. ${ }^{117}$

$\mathrm{Na}$ biografia, nem sempre os documentos oficiais são a melhor prova, como nota o biógrafo (Aug. 57.1): omitto senatus consulta, quia possunt uideri uel necessitate expressa uel uerecundia («não transcrevo os senatos-consultos, porque podem parecer ditados por obrigação ou por deferência»). Uma simples carta familiar pode dizer mais sobre o biografado do que muitos edictos. Mas mesmo a alusão a edictos prende-se essencialmente com a caracterização moral dos biografados. ${ }^{118}$ De qualquer modo, Suetónio parece usar mais fontes do que cita. Serviu-se certamente de obras de propaganda ou de circunstância, panfletos, panegíricos, recolhas de belas palavras, colecções de anedotas, memórias e outros escritos.

O facto de não haver preocupação sistemática de indicar as fontes - no balanço das Vidas o número de citações é reduzido - também contribui para desmentir a tese de que Suetónio escreve como simples erudito. Não se pretende negar que Suetónio o seja, mas as Vidas dos Césares não se reduzem a uma obra de erudição. A maior parte das fontes indicadas figura em contextos que se prendem com uma fundamentação de importantes qualidades do carácter e só

${ }^{114}$ Trata-se do ab epistulis de Otão e, segundo se pensa, autor de uma biografia deste imperador; cf. Plutarco, Oth. 9.3. Parece que teria sido o primeiro procurador equestre ab epistulis, o que não deixaria de ter algum significado para Suetónio: vide GAscou, J. 1984, 295-316.

${ }^{115}$ Vide intr. aos coms. de Braithwaite, A. W. 1927, xiii-xiv; de Jones, B. W. 1996, x-xiii; e de Cesa, M. 2000, 9-10.

${ }_{116}$ Vide com. de Venini, P. 1977, 5; Gascou, J. 1984, 301-302.

${ }^{117}$ Gascou, J. 1984, 546-548.

${ }^{118}$ Cf. Aug. 28.1; Aug. 31.5; Aug. 44.3; Aug. 89.2; Cl. 11.3; Nero 4. 
uma minoria aparece em contexto meramente informativo.

Mas, além das fontes que referimos, escassas no cômputo geral, Suetónio, sem elaborar longos discursos, transcreve falas das suas personagens no discurso directo e indirecto - essas sim, em abundância, pois, na linha do que nos diz Plutarco no prefácio do seu Alexandre (1), um evento menor ou um dito de espírito dizem mais sobre o carácter do que grandes batalhas. 
(Página deixada propositadamente em branco) 


\section{A APRESENTAÇÃo AO LEITOR}

\subsection{Per tempora / per species}

No que respeita à organização do trabalho, Suetónio pretende fazer algo diferente de Tácito, que privilegia a cronologia, na linha dos antigos Annales dos pontífices. Para o autor das Vidas, a cronologia é secundária e, por isso, utilizada sobretudo antes da ascensão ao Império e no relato da morte. Usa-se como um método útil para fazer resumos de acções ou acontecimentos que o biógrafo não considera de particular relevância para a definição da personagem objecto da biografia. Perdeu-se a dedicatória das Vidas a Septício Claro ${ }^{119}$ e os capítulos iniciais da Vida de César - aí encontraríamos provavelmente as linhas gerais do plano de trabalho. Mas, no texto sobrevivente, desde cedo se torna claro o uso que Suetónio pretende dar à cronologia: Ordo et summa rerum, quas deinceps gessit, sic se habent (Jul. 34.1) («O resumo pela ordem das acções, que ele a seguir praticou, é o seguinte»). Com a hendíadis ordo et summa, 'a súmula ordenada', sugere Suetónio o papel que pretende dar à cronologia nas Vidas, ao mesmo tempo que introduz uma subdivisão na biografia de César: seguem-se factos apresentados cronologicamente por meio de uma narrativa acelerada. Mas, mais à frente, adopta outra forma de exposição: Talia agentem atque meditantem mors praeuenit. De qua prius quam dicam, ea quae ad formam et habitum et cultum et mores, nec minus quae ad ciuilia et bellica eius studia pertineant, non alienum erit summatim exponere (Jul. 44.4) («Realizava e projectava ele tais acções quando a morte o surpreendeu. Antes de falar desta, não será inoportuno expor aqui, em traços gerais, o que à sua figura e ao vestuário e à apresentação e aos costumes e, não menos, o que às suas ocupações civis e militares disser respeito»).

A partir daqui, o relato apresenta-se sistematizado por tópicos: predomina a descrição. Está, portanto, delineada a distinção entre per tempora e per species, como é explicitada na Vida de Augusto: Proposita uitae eius uelut summa, partes singillatim neque per tempora, sed per species exsequar, quo distinctius demonstrari cognoscique possint ${ }^{120}$ («Apresentado que foi uma espécie de resumo da sua vida, vou agora prosseguir com os vários aspectos, um por um, não pela ordem cronológica, mas através de rubricas, para que se possa tornar mais evidente quer a exposição, quer a compreensão»).

Suetónio mostra claramente o seu objectivo: distinctius demonstrari cognoscique. Implicitamente, sugere que uma narração cronológica não faculta uma tão límpida explanação e percepção do carácter dos biografados; e que só o método per species (por rubricas) se adapta plenamente ao seu objecto de estudo, pois permite concentrar maior quantidade de informação sobre a pessoa do imperador. Com aquela breve explicação, Suetónio predispõe o leitor para um quadro mental de tipo académico: apresenta-se um tema em cabeçalho, como uma entrada de enciclopédia, que depois é ilustrado com os factos que

${ }^{119}$ Como testemunha João Lido, de Mag. 2.6.

${ }^{120}$ Aug. 9.1; cf. Aug. 61.1, onde enumera, como veremos, as rubricas tratadas e a tratar. 
o comprovam. Relatos cronológicos tem o leitor à disposição nos escritos dos historiadores, como Tácito. Portanto os acontecimentos, quando organizados na sua ordem cronológica, irá apresentá-los summatim; os diversos aspectos da vida serão analisados singillatim. E esta posição continua a reiterá-la na biografia de Tibério: Ceterum secreti licentiam nanctus et quasi ciuitatis oculis remotis, cuncta simul uitia male diu dissimulata tamdem profudit; de quibus singillatim ab exordio referam (Tib. 42.1) («Mas, tendo encontrado a conivência do retiro e com os olhares da cidade, por assim dizer, afastados, deu largas, por fim, de uma assentada, a todos os vícios há longo tempo mal dissimulados; desses vícios vou eu agora falar, um a um, desde o início»).

A referência aos uitia é pretexto para introduzir uma série de species que irão ser tratadas uma por uma (singillatim). Este tipo de exposição pode tornar-se demasiado longo, quando as species se multiplicam. Nesse caso, é preciso seleccionar as que melhor sirvam de exempla para determinado aspecto: Singillatim crudeliter facta eius exsequi longum est; genera, uelut exemplaria saeuitiae, enumerare sat erit ${ }^{121}$ ("Analisar, um por um, os seus actos de crueldade tornar-se-ia longo; será suficiente enumerar, a título de exemplo, os tipos de violências»).

É summatim que Suetónio apresenta os grandes acontecimentos que são o objecto tradicional da história e com a qual o biógrafo não pretende competir. ${ }^{122}$ Por conseguinte, a guerra da Gália, apesar da sua importância na vida de César, vem condensada em um parágrafo. ${ }^{123}$ Mas é singillatim que se analisam as virtudes militares (Jul. 57-67), para explicar a dedicação dos soldados (Jul.68) e a autoridade inquestionável do general (Jul. 69-70).

Como a cronologia é posta em segundo lugar ou sacrificada, os acontecimentos podem sair da sua ordem temporal para se distribuírem pelas várias rubricas. Mesmo os grandes acontecimentos históricos tornam-se, muitas vezes, dependentes das species e são arrancados do seu contexto, para funcionarem apenas como exempla. É o caso da morte de Trásea Peto. Enquanto o historiador Tácito apresenta um relato minucioso das causas e circunstâncias (Ann. $16.21 \mathrm{ss),} \mathrm{Suetónio} \mathrm{menciona-a} \mathrm{apenas} \mathrm{para} \mathrm{ilustrar}$ a crueldade gratuita de Nero e as mortes sob pretextos fúteis, e retira-a do contexto da oposição estóica. ${ }^{124}$ Para o biógrafo Suetónio, o que está em causa

${ }^{121}$ Tib. 61.2. Cf. Cl. 29.1: Ac ne singillatim minora quoque enumerem; e Cal. 37.3: Ac ne singula enumerem.

${ }^{122}$ Tibério, segundo Suetónio, usa este método na sua autobiografia, o Commentarius de uita sua, pois se diz que summatim breuiterque composuit: Tib. 61.1.

${ }^{123} \mathrm{Jul}$. 25.1, ao passo que outro biógrafo, adoptando um método diferente, Plutarco, se alonga: Caesar, 18-27. Este tipo de informações poderia o leitor encontrá-las nos Commentarii de César. Já no que diz respeito a tais obras, Suetónio se mostra mais prolixo ao fazer o balanço das críticas (Jul. 56, 1-4), porque isso está dentro do objecto de estudo de um autor erudito de biografias literárias. Vide Wallace-Hadrill, A. 1984, 10-15; Cizek, E. 1977, 49-52; Della Corte, F. 1967, 191-193; Townend, G. B. 1967, 84-86; Grimal, P. 1986, 730; Lounsbury, R. C. $1987,79-81$.

${ }^{124}$ Nero 37.1. Trásea Peto foi eliminado porque tinha tristior et paedagogi uultus. Este pormenor de natureza marginal aponta para a tradicional descrição dos estóicos como tristes. Suetónio deve tê-lo encontrado numa das fontes: vide com. de Warmington, B. H. 1999, 70-71. Para 
não é explorar a conjuntura histórico-política - do máximo interesse para um historiador -, mas fazer uma abordagem ética: demonstrar até onde ia a crueldade de Nero. Por isso, usa normalmente a narrativa cronológica para acontecimentos que antecedem a subida ao trono imperial; a partir desse momento, privilegia a abordagem per species, que só abandona para a narração da morte. Por vezes, dentro das species existe uma cronologia relativa, o que implica, em termos narrativos, uma série de analepses para tratar os tópicos $a b$ initio. Mas Suetónio segue de preferência a gradatio dos exempla, dos menos para os mais significativos, segundo o âmbito da rubrica em questão. ${ }^{125}$

Como em Jul. 44.4, também em Aug. 61.1 Suetónio resume o que expôs anteriormente e introduz o que se segue. ${ }^{126}$ Isto é, para tornar mais clara a organização per species, serve-se de um recurso retórico: ${ }^{127}$ a partitio ou diuisio, usada por vários escritores latinos, entre os quais Cícero, ${ }^{128}$ e presente já na biografia antiga, no Epaminondas de Cornélio Nepos, ${ }^{129}$ como também na Ciropedia (1.1.6) de Xenofonte e no Evágoras (22) de Isócrates. ${ }^{130}$ A distribuição das rubricas, no âmbito mais alargado, opera-se entre virtudes e vícios, que depois ainda se poderão subdividir, em alguns casos, em vida pública e vida privada. ${ }^{131}$

\subsection{Virtutes / uitia}

Decorrente da organização per species, a distinção entre virtudes e vícios tende a condicionar a distribuição das rubricas e a classificação de grande parte das acções dos imperadores. Já vimos que, para Tibério, Suetónio, a determinada altura, se propõe claramente tratar os vícios singillatim (Tib. 42.1). Mas há dois imperadores em cujas Vidas a bipolarização uirtutes / uitia se torna mais explícita: Calígula e Nero. As contradições e os excessos que a história

uma análise de exemplos do sacrifício da cronologia e do esmagamento da perspectiva histórica devido à escolha literária de Suetónio, vide GAscou, J 1984, 390-436.

${ }^{125}$ Vide CizeK, E. 1977, 118-120.

${ }^{126}$ Quoniam qualis in imperis ac magistratibus regendaque per terrarum orbem pace belloque re p. fuerit, exposui, referam nunc interiorem ac familiarem eius uitam quibusque moribus atque fortuna domi et inter suos egerit a iuuenta usque ad supremum uitae diem.

${ }^{127}$ Introduzido por Hortênsio na oratória romana, segundo nos diz Cícero, Brut. 302: Attuleratque minime uulgare genus dicendi duas quidem res quas nemo alius, partitiones, quibus de rebus dicturus esset, et...; cf. Div. Caec. 45; Inv. 1.31. Vide Lewis, R. G. 1991, 3663-3664.

${ }^{128}$ Sabe-se que Suetónio admirava Cícero, talvez por influência de Quintiliano. Basta pensar que uma das obras perdidas, referenciadas na Suda, é uma defesa do De republica de Cícero contra os ataques de Dídimo. Sobre o ciceronianismo e o segundo classicismo de Suetónio, vide Della Corte, F. 1967, 29-53, e Cizek, E. 1977, 14-25.

${ }^{129}$ Ep. 1.4: Quare dicemus primum de genere eius, deinde quibus disciplinis et a quibus sit eruditus, tum de moribus ingeniique facultatibus et, si qua alia memoria digna erunt, postremo de rebus gestis, quae a plurimis animi anteponuntur uirtutibus.

${ }_{130}$ Segundo Townend, G. B. 1967, 84-87, é o método do gramático transformado em biógrafo. Vide Wallace-Hadrill, A. 1984, 44-49; Warmington, B. H. 1999, ix.

${ }^{131}$ A partir de Iul. 44.4 e Aug. 61.1, estabelece-se a distinção entre vida pública e vida privada. Mas esta separação está longe de ser absoluta e fica diluída na oposição entre virtudes e vícios, como sugere CizeK, E. 1977, 62-64. Vide intr. ao com. de WardLe, D. 1994, 27. 
conservou destes imperadores permitem uma melhor aplicação do esquema. $\mathrm{Na}$ Vida de Calígula, desde o capítulo 15 que se expunham as virtudes; a seguir, vem o lado negro, assim introduzido: Hactenus quasi de principe, reliqua ut de monstro narranda sunt (Cal. 22.1) ("Até aqui falámos, por assim dizer, de um príncipe; quanto ao resto, temos de narrá-lo como quem fala de um monstro»). $\mathrm{E}$ a lista, que se prolonga até ao capítulo 55, inclui um retrato psicofísico (Cal. 50) perfeitamente adequado ao monstrum, e apresenta os excessos e crimes que acabaram por inspirar aos súbditos a vontade de o matar. ${ }^{132} \mathrm{~A}$ oposição uirtutes / uitia é apresentada expressivamente por princeps /monstrum. Mas trata-se de um método de exposição que se pretende científico, ao ponto de apresentar a interpretação dos factos numa lógica de causa-efeito, como é o caso da tentativa de explicação racional, baseada em comportamentos observados, para o desequilíbrio mental que torna Calígula um monstrum. ${ }^{133}$

Também no caso de Nero se assiste à divisão da Vida em parte boa e parte má: Haec partim nulla reprehensione, partim etiam non mediocri laude digna in unum contuli, ut secernerem a probris ac sceleribus eius, de quibus debinc dicam (Nero 19.3) («Estas acções - em parte não merecedoras de qualquer censura, em parte merecedoras até de não pequeno louvor - agrupei-as em conjunto, para as separar das torpezas e dos crimes de que, a partir de agora, vou falar»). A oposição concretiza-se entre nulla reprehensione... non mediocri laude digna, por um lado, e probra ac scelera, por outro.

Estrutura semelhante se observa na Vida de Domiciano. Mas Suetónio, que viveu ainda no principado deste imperador, ${ }^{134}$ apresenta uma oposição entre virtudes e vícios mais diluída e flexível, que sugere antes evolução psicológica. Por isso, antes de enumerar as virtudes, o biógrafo adverte o leitor para as condicionantes da viragem: Circa administrationem autem imperii aliquamdiu se uarium praestitit, mixtura quoque aequabili uitiorum atque uirtutum, donec uirtutes quoque in uitia deflexit: quantum coniectare licet, super ingenii naturam inopia rapax, metu saeuus (Dom. 3.2) («No que diz respeito à administração do Império, mostrou-se inconstante durante algum tempo, mesmo com uma mistura equilibrada de virtudes e vícios, até que perverteu mesmo as virtudes em vícios: tanto quanto se pode conjecturar, mais do que as suas tendências naturais, a penúria tornou-o ávido, o medo, cruel»). O biógrafo tenta sondar a psicologia de Domiciano e formula uma coniectura para explicar os vícios principais. Mais adiante, depois de apresentada a boa gestão do Império (Dom.4-9), o biógrafo dispõe-se a introduzir a parte negativa deste principado: Sed neque in clementiae neque in abstinentiae tenore permansit, et tamen aliquanto celerius ad saeuitiam desciuit quam ad cupiditatem (Dom. 10.1) («Mas nem permaneceu no respeito da clemência nem do desinteresse, e, no entanto, inclinou-se mais rapidamente para a crueldade do que para a cobiça»). Neste caso, neque permansit sugere

${ }_{132}$ Cal. 56.1: Ita bacchantem atque grassantem non defuit plerisque animus adoriri.

${ }^{133}$ Cal. 51.1: Non inmerito mentis ualitudini attribuerim diuersissima in eodem uitia, summam confidentiam et contra nimium metum. Nam qui deos tanto opere contemneret, ad minima tonitrua et fulgura coniuere, caput obuoluere, at uero maiore proripere se e strato sub lectumque condere solebat.

${ }^{134}$ Cf. Dom. 12.2: me adulescentulum memini. 
que se dá uma mudança em termos cronológicos, semelhante à que aconteceu com Tibério na altura da sua retirada para Cápreas. ${ }^{135}$ Também Domiciano começou por ser bom (Dom. 4-9) e depois passou a ser mau (Dom. 10-15), o que evidencia uma evolução negativa. ${ }^{136}$

A verdade é que, com justificação cronológica ou apenas metodológica, no caso de Tibério, Calígula, Nero e Domiciano, as uirtutes, por aparecerem imediatamente a seguir à narração cronológica que antecede a subida ao poder e serem seguidas depois pela listagem, geralmente mais longa, dos uitia, são abafadas ou esquecidas. Assim, a imagem que perdura é negativa. ${ }^{137}$ Estes são os imperadores eminentemente maus. Cláudio apresenta uma alternância de aspectos positivos e negativos, com tendência para os segundos, a acentuar a incoerência que o biógrafo lhe atribui. Vitélio é totalmente mau, quase não tem traços positivos. Completamente diferente é Tito, alcunhado logo de início de amor ac deliciae generis humani (Tit. 1).

Depois de descrever a sua conduta brutal (Tit. 6.2 - 7.1), o biógrafo acentua a mudança e antecipa a conclusão sobre o balanço das virtudes e dos vícios: At illi ea fama pro bono cessit conuersaque est in maximas laudes, neque uitio ullo reperto et contra uirtutibus summis (Tit. 7.1) («Mas a esta má reputação sobrepôs-se uma boa imagem e transformou-se em coro dos maiores elogios, quando nenhum vício the foi encontrado e, pelo contrário, as virtudes mais elevadas»).

Tanto este como Augusto apresentam traços negros antes da ascensão ao trono, mas a imagem que perdura é positiva. No meio fica César, onde as species positivas e negativas aparecem contrabalançadas e a reputação de tirania é, por assim dizer, expiada e reabilitada depois da narrativa da morte, com as reacções de pesar do povo. ${ }^{138}$

Portanto, um método de aspecto convincente, isento e científico - uma exposição de erudito que afecta o distanciamento de um clínico (como se vê em Cal. 51.1; Dom. 3.2) e uma aparente impassibilidade na enumeração dos factos ${ }^{139}$ - permite classificar as boas e más acções de um imperador, mas também condicionar a ideia geral que Suetónio sobre ele quer transmitir. Vícios e virtudes são tomados separadamente e exemplificados por uma lista mais ou menos longa de acções e anedotas. Acções que, para um historiador, como Tácito, constituiriam o essencial da trama narrativa, aparecem, em Suetónio, dispersas sob cabeçalhos de virtudes e de vícios e reduzidas a exempla de demonstração. ${ }^{140}$ Para Suetónio, as acções, tomadas em si mesmas, surgem como manifestações exteriores e acessórias do essencial, que são as virtudes e

${ }^{135} \mathrm{Cf}$. Tib. 42.2. Uma mudança apenas aparente e exterior, pois se tratava de uitia male diu dissimulata. Ora também Domiciano tende para a dissimulatio (Dom. 2.2; 18.2).

${ }^{136} \mathrm{Na}$ realidade, Suetónio força a cronologia e coloca na primeira parte do principado acontecimentos que ocorreram na última, como é o caso do castigo da vestal Cornélia (Dom. 8.4). Vide Gascou, J. 1984, 399-400, e 411-414.

${ }^{137}$ Vide Gascou, J. 1984, 695-696.

${ }^{138}$ Vide Cizek, E. 1977, 106-118; Della Corte, F. 1967, 79-80.

${ }^{139}$ Vide Gascou, J. 1984, 683-688.

${ }^{140}$ Como afirma Wallace-Hadrill, A. 1984, 71; vide ainda 141-145. 
os vícios. As acções, embora históricas, têm uma importância que não deriva directamente do seu valor histórico. ${ }^{141}$ Mas, juntamente com as anedotas, estão ao serviço das opções estético-literárias de Suetónio, pois permitem "colorir" as species e dar vida concreta ao que é apenas abstracto - as virtudes e os vícios. Realmente, sem acções e ditos reveladores da personalidade, virtudes e vícios seriam abstracções vazias. ${ }^{142}$

\subsection{O estilo de Suetónio}

Do juízo expresso em De grammaticis 10, podemos deduzir que Suetónio não aprecia o estilo arcaizante de Salústio. ${ }^{143}$ Cita um dos seus grandes modelos, Asínio Polião, que repreende a exagerada afectação de arcaísmo do estilo salustiano, e Ateio Filólogo, que aconselha o discurso acessível, corrente e natural e censura a obscuridade de Salústio. ${ }^{144}$ Admite-se que Tácito seja, de algum modo, um imitador de Salústio. ${ }^{145}$ Mas já vimos que Suetónio não pretende rivalizar com Tácito: opta por um género diferente.

Nas Vidas dos Césares, Suetónio sugere razões para a sua adesão implícita ao genus elegans et temperatum («estilo elegante e comedido») de Augusto (Aug. 86), ${ }^{146}$ que evita as sententiarum ineptiae («tolices das fórmulas afectadas») e conditorum uerborum... fetores («o fedor dos termos obscuros»); que condena quer os amaneirados quer os antiquários de caírem em vícios contrários entre si; que censura Mecenas pelo que chama myrobreche cincinni («ornamentos perfumados»); que reprova a Tibério a busca de exoletae... et reconditae uoces («palavras caídas em desuso e obscuras»); que ataca António por escrever quae mirentur potius... quam intellegant («mais para o admirarem do que para o entenderem»). O capítulo termina com um excerto de uma carta, onde

${ }^{141}$ Daí que pequenos acontecimentos sejam muitas vezes colocados no mesmo plano de grandes acontecimentos; que se apresentem pequenas causas para grandes efeitos; e que muitos acontecimentos se transformem em pequenos exempla, não mais do que manifestações de uma natureza, como demonstra Gascou, J. 1984, 390-436.

${ }^{142}$ Os vícios de Tibério só se podem comprovar apoiados em realizações concretas; isto é, depois de deixarem de ser dissimulata, é que são tratados singillatim ab exordio (Tib. 42.2).

${ }^{143}$ Suetónio aparta-se de Quintiliano na estima que este manifesta por Salústio, entre outros passos, em Inst. 10.1.101-102. Vide Dalmasso, L. 1906, 7-10; D’Anna, G. 1954, 137-145.

${ }^{144}$ A aversão não é tanto ao arcaísmo, pelo arcaísmo, mas à obscuritas, como nota D'AnnA, G. 1954, 103-104.

${ }^{145}$ Sobretudo no início de carreira, na elaboração da biografia de Agrícola, segundo a opinião de Perrochat, P. 1935,261-265. Neste artigo se põem em evidência as semelhanças do Agricola de Tácito com o Iugurtha de Salústio no uso do infinitivo de narração, na imitação de expressões e do mesmo esquema de frase, na combinação da frase nominal com o infinitivo de narração. Nas obras seguintes, Historiae e Annales, Tácito afasta-se mais de Salústio e evolui para um estilo mais pessoal; mas a importância do Agricola é justamente a de nos permitir ligar Tácito à escola de Salústio, para deixar, ao mesmo tempo, perceber a sua originalidade. Mais longe vai Ducroux, S. 1978, 901 295-315. Este autor, comparando os retratos dos dois autores, fala de uma verdadeira aemulatio de Salústio no vocabulário, na sintaxe e nos temas dos retratos de Tácito.

${ }^{146}$ Como observa D’Anna, G. 1954, 94-95, nenhum outro imperador merece a Suetónio uma análise tão precisa e tão extensa em relação ao estilo. 
Augusto faz a depreciação destas duas tendências opostas, confluentes em António: 'Tuque dubitas, Cimberne Annius ac Veranius Flaccus imitandi sint tibi, ita ut uerbis, quae Crispus Sallustius excerpsit ex Originibus Catonis, utaris? an potius Asiaticorum oratorum inani[bu]s sententiis uerborum uolubilitas in nostrum sermonem transferenda?' (Aug. 86. 3) (“E tu hesitas sobre se deves imitar Ânio Cimbro ou Verânio Flaco, de forma a usares termos que Salústio Crispo recolheu das Origens de Catão, ou se deves antes transportar para a nossa linguagem a verborreia das sententiae frívolas dos oradores asiáticos?’»). Sai reforçada a ideia da oposição a um género arcaizante obscuro, cujo expoente máximo é Salústio e os cultores Tibério e Marco António. É igualmente contestado o artificialismo, representado por Mecenas.

Através das palavras de Augusto, Suetónio aparta-se, deste modo, de duas tendências principais de seu tempo: o aticismo arcaizante, cujo símbolo vivo é Probo, ${ }^{147}$ e o asianismo da nova moda, cultivada por Séneca e pela escola de Lucano, ${ }^{148}$ e continuada, depois da morte deste, pela viúva, Póla Argentária, e pelo historiador Fábio Rústico. Suetónio, por um lado, censura o estilo de Tibério, que, apesar de seguir Messala Corvino (aticista moderado), era obscurecido por uma afectação e purismo excessivos (Tib. 70.1) e, por outro, ao louvar uma das poucas virtudes de Calígula, a eloquência, contemporiza com o julgamento do príncipe sobre «a escrita demasiado delicada e trabalhada» de Séneca: «simples exercícios de declamação e areia sem cal». ${ }^{149}$ Séneca é ainda implicitamente censurado por, na linha das suas tendências retóricas, ter afastado Nero do estudo dos antigos oradores. ${ }^{150}$ Por exclusão de partes, Suetónio coloca-se entre as duas tendências: o estilo que Asínio Polião e Augusto aconselham, e que Cícero atribui a César. ${ }^{151}$ Apesar de admirador de Cícero, Suetónio não segue na forma o Arpinate: prefere um estilo simples, claro e eficaz. ${ }^{152}$

${ }^{147}$ Provavelmente ainda operante durante o império dos Flávios: vide D’Anna, G. 1954, 157-170.

${ }^{148} \mathrm{Na}$ intr. ao seu com. à Vida de Nero, Warmington, B. H. 1999, xiii, sugere que deve ser deliberado o carácter lacónico de Suetónio sobre Séneca, a conspiração de Pisão e as vítimas literárias daquele imperador, dada a antipatia do biógrafo por Lucano e Séneca enquanto figuras literárias. Mas o certo é que também, na Vida de Augusto, não menciona Virgílio nem Horácio, nem o destino de Ovídio; apesar de referir Catulo, na Vida de César (Jul. 73), e Cornélio Galo, na Vida de Augusto (Aug. 66.2) — este último como prefeito do Egipto e não como poeta. BALDwin, B. 1983, 382-383, sugere que as omissões podem antes ser vistas como itens diferidos para as biografias literárias (que, segundo este autor, teriam sido publicadas mais tarde). No entanto, as omissões parecem-nos mais ditadas pela centralização das Vidas na pessoa do biografado e por exigências estruturais internas (da disposição das rubricas) do que por antipatias pessoais ou pelo desejo de distribuir o material pelas várias obras.

${ }^{149}$ Cal. 53.2. Sentença próxima da de Quintiliano: Inst. 10.1 .125 ss, que define o estilo de Séneca como corruptum et omnibus uitiis fractum dicendi genus. Vide D’Anna, G. 1954, 87 e 175-176.

${ }^{150}$ Nero 52. Vide D’Anna, G. 1954, 174-176.

${ }^{151}$ Jul. 55.1: ... aitque [Cicero ad Brutum 261] eum [scil. Caesarem] elegantem, splendidam quoque atque etiam magnificam et generosam quodam modo rationem dicendi tenere. Vide D'ANNA, G. 1954, 110-111.

152 Vide D’Anna, G. 1954, 94-102; Della Corte, F. 1967, 36-39 e Cize к, E. 1977, 14-20. 
Não faria muito sentido, neste tipo de estudo, comparar o estilo de Suetónio com o de Tácito: trata-se de dois géneros diferentes. A escrita de Suetónio não está povoada de poeticismos, arcaísmos, sintaxe elíptica ou muito elaborada, onde se buscam os ornamentos oratórios. Não se trata, portanto, do estilo de um historiador antigo. Mas, mais importante do que saber o que Suetónio não é, importa tentar perceber o que ele é realmente. Suetónio prefere um estilo claro e conciso, mas desadornado. Sobretudo tem particularidades que um historiador preferiria evitar: o uso de termos e expressões em grego, a inclusão de vocabulário técnico e a citação literal de documentos.

Com efeito, o grego está continuamente presente ao longo das várias Vidas: não só palavras isoladas, mas também versos de Homero, da tragédia, da comédia, epigramas, etc. ${ }^{153}$ Os historiadores preferem traduzir para latim os termos estrangeiros. Mas o facto de Suetónio transcrever as palavras dos imperadores como foram pronunciadas, em latim ou em grego, contribui para caracterizar a cultura do protagonista e conferir realismo ao texto. ${ }^{154}$

Quanto aos termos técnicos, Suetónio mostra-se preciso. ${ }^{155}$ Relevantes são os termos que se relacionam com a sua actividade de funcionário imperial, com instituições e com a administração do Império. ${ }^{156}$ Outros são directamente transliterados do grego e aspiram à precisão, não à elevação do estilo.

Suetónio desenvolve o oposto dos discursos ficcionais dos historiadores: prefere citar documentos à letra. Utiliza, como já vimos, diversas cartas de Augusto e de Cícero, edictos, discursos, acta, inscrições, invectivas, versos ditos nos triunfos. ${ }^{157}$ Os documentos comprovam factos; e o biógrafo prefere antepor acções a palavras das belas-letras. A propósito da adopção de Pisão por Galba, Tácito encontra um pretexto para ditar um discurso sobre a excelência do sistema

Segundo Cizek, E. 1977, 187, as críticas aos arcaizantes podem, de algum modo, envolver o imperador Adriano.

${ }^{153}$ Segundo Townend, G. B. 1960, 98-120, estas citações estão relacionadas com fontes hostis, usadas por Suetónio: ponto de vista que é rejeitado por WARdLE, D. 1992, 466-482. Vide Berthet, J. F. 1978, 314-334.

154 Berthet, J. F. 1978, 314-334, procura demonstrar que as citações de Homero (maioritariamente da Ilíada) correspondem à situação psicológica em que se encontra o imperador ao pronunciá-las.

${ }^{155}$ Onde Tácito usa, por exemplo, um vago ambigere (Hist. 1.24: de parte finium cum uicino ambigenti), Suetónio prefere um termo menos áulico, mas mais preciso: litigare (Otho 4.2: quidem etiam de parte finium cum uicino litiganti, adbibitus arbiter, totum agrum redemit), termo que manteve no vocabulário culto das línguas românicas esse sentido jurídico preciso; onde Tácito emprega o poético mucrones (Hist. 1.27: strictis mucronibus rapiunt), Suetónio usa o termo militar apropriado: gladii (Otho 6.3: inter faustas aclamationes strictos gladios ad principia deuenit).

${ }^{156}$ É o caso de rationarium (Aug. 28.1); procurator ducenarius (Cl. 24.1) - pertenciam a esta categoria os cargos administrativos que Suetónio exercia; amanuensis (Nero 44.1; Tit. 3.2); tribunus angusticlauius (Otho 10.1) - o posto que o pai do biógrafo, Suetónio Leto, tinha na décima terceira legião; instrumentum imperii (Ves. 8.5); officium (Vesp. 14); ordinatio (Dom. 4.2); formalis epistula (Dom. 13.2); fiscalis (Dom. 9.3). Vide Wallace-Hadrill, A. 1984, 20 n. 29.

157 Wallace-Hadrill, A. 1984, 19-22, faz notar que se trata do estilo eficiente de um erudito antigo. 
adoptivo; ${ }^{158}$ Suetónio regista apenas o gesto de Galba e as palavras formulares do ritual da adopção (filiuumque appellans); tudo isto num ritmo rápido: um acumular de acontecimentos introduzidos por repente: ... repente e media salutantium turba adprehendit fliiumque appellans perduxit in castra acpro contione adoptauit, ne tunc quidem donatiui ulla mentione facta (Gal. 17) («Subitamente, arrebatou-o do meio da multidão que o vinha saudar e, chamando-lhe filho, levou-o para o acampamento e adoptou-o diante da parada; e nem sequer então se fez qualquer menção ao donativo»). Neste excerto há uma sucessão de acontecimentos que termina de forma algo desconcertante, com um quebrar de expectativas e um dado inesperado. Depois daquele repente, nada fazia supor o final da frase introduzido por ne tunc quidem. Esperar-se-iam uma ou mais acções realizadas e não uma que o imperador não realizou. Mas esta negação é um modo de realçar o elemento que para o biógrafo é essencial: a auaritia de Galba. ${ }^{159}$ Parece uma forma de estranhamento adoptada pelo biógrafo; mas, para alguns autores, será apenas sinal de um arranjo descuidado da frase: como se ele a começasse antes de a pensar inteiramente e depois a sobrecarregasse de retoques. ${ }^{160}$

Mas, se não seria adequado encarecer grandezas de estilo, também não parece acertado acreditar à partida na inépcia estilística de um biógrafo com o êxito de Suetónio nem avaliá-lo só em função de Tácito: o assunto, de resto, não é pacífico. ${ }^{161} \mathrm{O}$ estilo conciso de Suetónio permite-lhe acumular acontecimentos e informações sem se tornar pesado. Por outro lado, um estilo adornado não conviria ao carácter escabroso de certas informações, como

${ }^{158}$ Hist. 1.15.1: Igitur Galba, adprehensa Pisonis manu, in hunc modum locutus fertur...

${ }^{159} \mathrm{O}$ ponto central, para Suetónio, desta sucessão de acontecimentos é a parte final: a avareza de Galba em não dar aos soldados o donativo costumado nestas situações, facto que irá precipitar o seu fim e favorecer as manobras a Otão. Vide Della Corte, F. 1967, 111-134.

160 Para SAge, P.1979a, 499-524, Suetónio cria estruturas descuidadas, que apenas exteriormente se assemelham às belas construções de Tito Lívio ou de Tácito. Enquanto este utilizou as estruturas com fins artísticos, Suetónio usa-as como forma cómoda de exposição. Em ID. 1979b, 18-50, afirma-se que a escrita de Suetónio se distingue pelo seu carácter negativo, porque só excepcionalmente utiliza meios expressivos tão essenciais como a variação dos tempos, da posição dos verbos, a utilização da parataxe e hipotaxe. Pelo que, se isso não torna Suetónio necessariamente mau, também não faz dele um grande artista. Assenta também na comparação com Tácito a afirmação de Ailloud, H. 1931-1932, xxxviII-Xliı (intr. à ed.), sobre a incapacidade de Suetónio para fazer melhor: reconhece-lhe, contudo, o mérito de ser claro, preciso e breve e de não cair nos vícios dos seus contemporâneos: a retórica, o purismo, o preciosismo, a afectação de arcaísmo. ЕктоR, J. 1980, 317-326, acentua a fraqueza estilística de Suetónio, embora faça notar que tal pecha se não deve à sua impreparação, mas aos objectivos do biógrafo: apresentar uma enumeração completa dos factos com precisão e clareza, sem buscar efeitos artísticos nem se preocupar com evitar a monotonia.

${ }^{161}$ Lounsbury, R. C. 1991, 3751 n. 8, critica precisamente SAge por se preocupar em demonstrar que Suetónio não é Tácito, em vez de mostrar o que Suetónio de facto é. Na sua ed., Bassols de Climent, M. 1970, XlviI-XlviII, parece afastar-se da tendência para a comparação pejorativa com Tácito, ao afirmar que as características apontadas ao estilo de Suetónio (claro, conciso, polido e ao mesmo tempo seco, impessoal, desprovido de relevo e movimento emocional, monótono, mais próximo do estilo de um homem de negócios do que do de um escritor), soam mais a elogio do que a censura, se tivermos em conta que se demarca do gosto da época em que escrevia e o êxito que obteve entre os antigos. 
sucede com a exposição da vida sexual de alguns imperadores. Os tópicos das rubricas acabam por determinar o nível de língua a usar. O turpilóquio usado nas censuras que António faz à vida sexual de Augusto, ${ }^{162}$ com termos que sugerem a obscenidade do mimo, distingue-se da linguagem de tom quase épico utilizada na narrativa da passagem do Rubicão (Jul.31.2-32), ou da morte de Nero, que analisaremos adiante. Ora a variação do nível de língua, segundo os sujeitos da enunciação e os contextos, contribui, como acontece no romance de Petrónio, para imprimir realismo às Vidas de Suetónio, ao aproximá-las da variedade dos actos de linguagem da vida real.

Se Suetónio não cria longos discursos, introduz, no entanto, na narrativa ditos célebres, expressões, frases da conversa corrente que tornam as situações mais convincentes e autênticas. Chega, em breves trechos, a dar a palavra aos protagonistas, criando uma espécie de diálogo. Um exemplo interessante é o relato da hesitação de Tibério em assumir o governo do Império:

Principatum, quamuis neque occupare confestim neque agere dubitasset, et statione militum, hoc est ui et specie dominationis assumpta, diu tamen recusauit impudentissimo mimo, nunc adbortantis amicos increpans ut 'ignaros, quanta belua esset imperium, nunc precantem senatum et procumbentem sibi ad genua ambiguis responsis et callida cunctatione suspendens, ut quidam patientiam rumperent atque unus in tumultu proclamaret: 'aut agat aut desistat!' Alter coram exprobraret ceteros, quod polliciti sint tarde praestare, se $<d>$ ipsum, quod praestet tarde polliceri. Tandem quasi coactus et querens miseram et onerosam iniungi sibi seruitutem, recepit imperium; nec tam aliter, quam ut depositurum se quandoque spem faceret. Ipsius uerba sunt: 'dum ueniam ad id tempus, quo uobis aequum possit uideri dare uos aliquam senectuti meae requiem'. ${ }^{163}$

«Ao principado,embora não hesitasse em ocupá-lo imediatamente e em exercê-lo - tomou até para si uma guarnição de soldados, o que lhe conferia poder e uma forma de soberania - recusou-o longo tempo com um mimo francamente descarado; ora invectivando os amigos que o exortavam, por não fazerem ideia 'do tamanho do monstro que era o poder imperial'; ora mantendo em suspenso, por meio de respostas ambíguas e hábil hesitação, os senadores que insistiam e se lhe arrojavam aos joelhos, a ponto de alguns perderem a paciência e um deles proclamar no meio da agitação: 'É pegar ou largar!' Outro disse-lhe, cara a cara, em tom de censura, que 'os outros demoravam a cumprir o que tinham prometido, mas ele demorava a prometer o que já cumpria'. Finalmente, como que forçado e queixando-se da infeliz e pesada servidão que lhe era imposta, aceitou o império, desde que não deixasse de poder acalentar a esperança de um dia o abandonar. São estas as palavras do próprio: 'até eu chegar à idade em que

${ }^{162}$ Aug. 69.2: 'Quid te mutauit? quod reginam ineo? uxor mea est? nunc coepi an abbinc annos nouem? Tu deinde solam Drusillam inis? ita ualeas, uti tu, hanc epistulam cum leges, non inieris Tertullam aut Terentillam aut Rufllam aut Saluiam Titiseniam aut omnes. An refert, ubi et in qua arrigas?'Adoptamos a forma interrogativa (uxor mea est?), de acordo com a proposta de KRAFT, K. 1967, 496-499, defendida, mais tarde, por Moles, J. 1992, 245-247.

${ }^{163}$ Tib. 24. Optámos por alterar a pontuação usualmente adoptada. Deslocámos a vírgula — diu tamen recusauit, impudentissimo mimo...- como sugere a unidade do paralelismo de nunc adhortantis amicos increpans .... / nunc precantem senatum et procumbentem ... suspendens. 
vos possa parecer justo dar algum repouso à minha velhice'».

Progressivamente, o narrador vai-se anulando. No que diz respeito à distância, há um crescendo na mimese. Começa por usar o discurso narrativizado, o estado mais distante, para transcrever a renitência de Tibério - diu tamen recusauit - e a insistência dos amigos - adhortantis amicos; aumenta, a seguir, o grau de mimese (e de ocultação do narrador) com a transcrição da resposta do imperador no discurso transposto para o estilo indirecto: increpans ut ignaros quanta belua esset imperium'; volta ao discurso narrativizado, no jogo entre o senado e Tibério: precantem senatum; ambiguiis responsis. $\mathrm{O}$ aumento da tensão, com a perda de paciência de uns quidam, é marcado pelo discurso citado, ou discurso directo, a forma mais mimética, na concepção de Platão, ${ }^{164} \mathrm{em}$ que Suetónio cede (ou finge ceder) totalmente a palavra a um que eleva a voz no meio do ruído de fundo provocado pelo tumulto do senado: «aut agat aut desistat!». Este brado é o climax que restabelece o silêncio e a ordem. E o narrador, numa fase descendente, volta a usar o discurso transposto de um outro que censura Tibério (exprobraret... polliceri); e depois o discurso narrativizado, para os queixumes de Tibério (querens... seruitutem). Mas logo volta a usar o discurso transposto, desta vez para o indirecto livre, caracterizado pela ausência de verbo declarativo (nec tam... faceret), alardeando assim o distanciamento irónico do narrador. E, para terminar em alta, emprega de novo o discurso directo, reforçado pela introdução: Ipsius uerba sunt («São estas as palavras do próprio»).

Nas Vidas, o momento mais alto é o da morte, que aparece frequentemente como a interpretação global da vida. A morte surge, assim, como o lugar onde o ethos definitivamente se realiza e se revela. ${ }^{165}$ Compreende-se que Suetónio revele as maiores capacidades estilísticas precisamente na narração da morte: é aí que o biógrafo introduz mais variedade e mais cor na sua escrita, de forma a tornar esse momento mais dramático. ${ }^{166}$

A narrativa das mortes por causas naturais têm em comum a referência ao agravamento da doença, às derradeiras acções e às palavras dos imperadores que pressentem a chegada do fim e se preparam para ele com discursos claros sobre o valor da sua vida. Maior naturalmente é o dramatismo nas mortes violentas. Este é o fim destinado aos que o mereceram: o abuso de poder que leva a que se considere justa a morte de César (iure caesus) (Jul. 76.1), aplica-se também a outros que tiveram o mesmo tipo de morte, como Calígula e Domiciano. A morte de César (Jul. 82) é descrita através de um acumular de orações e particípios ligados, além das muitas copulativas, por deinde e simul a sugerir a precipitação dos acontecimentos. Da morte de Calígula (Cal. 58), Suetónio prefere dar duas versões introduzidas por alii ...alii. A primeira

${ }^{164}$ Cf. Platão, R. 392c-394b. Este só adopta dois níveis: narrativa sem imitação (é o poeta que fala ao transmitir as falas das personagens); narrativa por meio da imitação (o poeta oculta-se nas palavras das personagens). Os três tipos de discurso são, como é sabido, de Genette, G. 1972, 189-193.

${ }^{165}$ Vide Pennacini, A. $1984,103-111$.

${ }^{166}$ Vide Gascou, J. 1984, 685 n. 29. Vide Baldwin, B. 1983, 507-511. 
versão recorre à antítese e ao quiasmo, a sugerir a acção coordenada dos agressores. ${ }^{167}$ As reacções de Calígula são dadas por particípios, com alguma variação (dante, respicienti, iacentem, contractisque membris, clamitantem). A defesa do imperador, pela guarda germânica, aparece no final, apresentada de forma paralela à acção dos atacantes: (accucurrerunt, interemerunt). Suetónio consegue assim transmitir a fúria dos atacantes e a rapidez do combate, que num instante fica concluído; mas também a brutalidade, com a morte de alguns executores e mesmo senadores inocentes e a nota de que houve assassinos que lhe trespassaram os órgãos genitais. ${ }^{168}$ Também a morte de Galba (Gal. 20) se organiza em duas versões paralelas (Sunt qui tradant ... Plures autem prodiderunt). Nas duas se inclui um discurso directo. Destaca-se o pormenor da solidão de Galba na morte, visto que nenhum dos presentes lhe presta ajuda; e o dado dramático de um auxílio que chega tarde, porque os soldados se enganaram no caminho. $\mathrm{O}$ impressionante relato dos ultrajes feitos à cabeça de Galba, que anda de mão em mão até se voltar a reunir ao corpo, é digno de nota pelo macabro realismo e crueza da linguagem. O dramático do assassínio de Domiciano reside no facto de que, depois de tantas cautelas - pois suspeitava qual o ano, o dia e a hora da sua morte (Dom. 14.1) -, esta surge quando, por um engano nas horas, já não era esperada. A uma primeira parte, que contém uma narrativa simples, Suetónio acrescenta o testemunho do puer que conta a resistência de Domiciano e a luta corpo a corpo: as reacções desesperadas, quase simultâneas, são indicadas com recurso ao ablativo absoluto. ${ }^{169}$ A narrativa da morte de Vitélio é a história de um linchamento. Os ultrajes sucedem-se, expressos sobretudo por ablativos absolutos. Predomina o assíndeto. Para justificar o conteúdo dos insultos sobre os vícios corporais do imperador, o biógrafo aproveita para fazer a sua descrição física - um elemento estático dentro de uma narração e caso único nas cenas de morte de Suetónio. No final, a brutalidade da morte é sugerida por recurso ao superlativo e à assonância em $i$ (minutissimis ictibus excarnificatus) (Vit. 16-17). São requintes de violência, narrados com mórbida insistência que o historiador Tácito evitaria. Mas de violência se tratava. É a viva expressão do realismo de Suetónio, que não cala os pormenores mais repulsivos.

A cena antológica de morte é a de Nero, ${ }^{170}$ talvez a melhor seç̧ão narrativa

167 a tergo Chaeream.../Sabinum... ex aduerso; ceruicem... percussisse/...traiecisse pectus. Também quiasmo entre a primeira e a segunda versões: Chaeream.... Sabinum / Sabinum... Chaeream; bem como entre percussisse... 'hoc age' e 'Accipe ratum'... discidisse. Para cada versão, um discurso directo e, na parte que une as duas versões, repete. As acções dos executores são relatadas no perfeito — infinitivo na dependência de Alii tradunt: percussisse, traiecisse / petisse, exclamasse, discidisse; indicativo, quando as versões confinam e se ergue a voz do narrador principal: confecerunt, adegerunt.

${ }^{168}$ Vide Lounsbury, R. C. 1987, 84-86.

169 Dom. 17.2: arrepto deductoque ad terram Stephano, dum modo ferrum extorquere, modo quanquam laniatis digitis oculos effodere conatur.

${ }^{170}$ Nero 47.3-49.4. Vide D’Anna, G. 1954, 182-190; Townend, G. B. 1967, 93-95; Lounsbury, R. C. 1987, 72 . 
de Suetónio e seguramente a mais conhecida. ${ }^{171}$ É notável a sua vivacidade no que respeita quer aos pormenores quer ao estilo. $\mathrm{O}$ estilo vivo é dado pelas orações curtas e mudanças abruptas de construção, com frequente recurso ao ablativo absoluto. As impressões, apresentadas do ponto de vista de Nero, reproduzem (Nero 48), ${ }^{172}$ com realismo, o medo de um fugitivo perseguido: um tremor de terra e um raio geram um ambiente de terror que deixa Nero aterrado (pauefactus); o clamor contra ele das tropas no campo pretoriano; as observações e perguntas dos que com ele se cruzam (obuii uiatores) acerca da sorte dele próprio; o cheiro do cadáver abandonado na rua; o cavalo assustado; o lenço que cai e lhe desvela o rosto; um pretoriano que o reconhece e o saúda. Já na casa de Fáon, as sensações de medo são substituídas pela consternação da perda da dignitas: o avanço pelo canavial, com as roupas a substituir a passadeira de púrpura; o fosso de extrair areia onde recusa esconder-se, num assomo de derradeira dignidade; a preparação de uma entrada secreta (dum clandestinus ad uillam introitus pareretur); o beber água do charco; a penosa e humilhante entrada (quadripes) na casa por um buraco escavado; o modesto colchão do leito e a velha capa a servir de coberta; o pão sordidus que rejeita; a água tepida de que bebe um pouco; a ironia da habitação final do construtor da Domus Aurea. No capítulo $49,{ }^{173}$ seguem impressões do desespero e da aceitação da

${ }^{171}$ D’Anna, G. 1954, 190-194, para quem a variedade estilística de Suetónio se fica a dever à influência de fontes diversas, atribui a elevação do estilo deste relato à influência de uma fonte melhor. Gascou, J. 1984, 685 n. 29, critica D'Anna por não ter percebido que a diferença estilística de Suetónio se explica pela oposição entre as species e a narrativa cronológica: nas primeiras, o biógrafo tende a ser mais repetitivo do que na narrativa cronológica. Vide Lounsbury, R. C. 1987, 26.

172 Sed reuocato rursus impetu aliquid secretioris latebrae ad colligendum animum desiderauit, et offerente Phaonte liberto suburbanum suum inter Salariam et Nomentanam uiam circa quartum miliarium, ut erat nudo pede atque tunicatus, paenulam obsoleti coloris superinduit adopertoque capite et ante faciem optento sudario equum inscendit, quattuor solis comitantibus, inter quos et Sporus erat. Statimque tremore terrae et fulgure aduerso pauefactus audiit e proximis castris clamorem militum et sibi aduersa et Galbae prospera ominantium, etiam ex obuiis viatoribus quendam dicentem: 'bi Neronem persequuntur,' alium sciscitantem: 'ecquid in urbe noui de Nerone?' equo autem ex odore abiecti in uia cadaueris consternato, detecta facie agnitus est a quodam missicio praetoriano et salutatus. $V t$ ad deuerticulum uentum est, dimissis equis inter fruticeta ac uepres per harundineti semitam aegre nec nisi strata sub pedibus ueste ad <a>uersum uillae parietem euasit. Ibi hortante eodem Phaonte, ut interim in specum egestae harenae concederet, negauit se uiuum sub terram iturum, ac parumper commoratus, dum clandestinus ad uillam introitus pararetur, aquam ex subiecta lacuna poturus manu hausit et: 'baec est,' inquit, 'Neronis decocta.'

173 Tunc uno quoque binc inde instante ut quam primum se impendentibus contumeliis eriperet, scrobem coram fieri imperauit dimensus ad corporis sui modulum, componique simul, si qua inuenirentur, frusta marmoris et aquam simul ac ligna conferri curando mox cadaueri, flens ad singula atque identidem dictitans: 'qualis artifex pereo!' Inter moras perlatos a cursore Phaonti codicillos praeripuit legitque se hostem a senatu iudicatum et quaeri, ut puniatur more maiorum, interrogauitque quale id genus esset poenae; et cum comperisset nudi hominis ceruicem inseri furcae, corpus uirgis ad necem caedi, conterritus duos pugiones, quos secum extulerat, arripuit temptataque utriusque acie rursus condidit, causatus nondum adesse fatalem horam. Ac modo Sporum hortabatur ut lamentari ac plangere inciperet, modo orabat ut se aliquis ad mortem capessendam exemplo

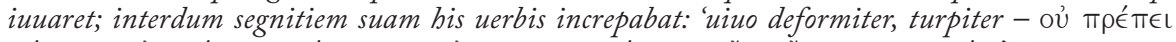

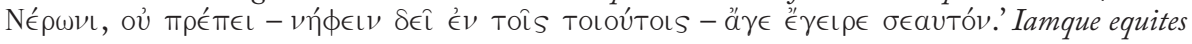


inevitabilidade do destino: a ordem de abertura da sua cova; a macabra aferição pelo próprio corpo; o cuidado na recolha dos elementos para a preparação do seu mox cadauer; as ordens dadas a chorar e a célebre frase, expressiva da psicologia de Nero, - 'Qualis artifex pereo!' («Que artífice morre comigo!»); a chegada do despacho que o declara inimigo público; a percepção da morte que o espera; a verificação do fio dos punhais; a hesitação modo... modo. Subitamente, há um corte neste acumular de acontecimentos e sensações. Como se todos ficassem à escuta de algo terrível que se aproxima: Iamque equites appropinquabant, quibus praeceptum erat ut uiuum eum adtraherent. Quod ut sensit trepidanter effatus... («Já os cavaleiros se aproximavam, aos quais tinha sido ordenado que o arrastassem vivo. Pois que tal ouviu, a tremer declamou...»). E segue-se um verso da Ilíada. De certo modo, Nero está a morrer como sempre viveu: na procura, como artifex, de uma existência épica, resultante da sua megalomania, que o faz misturar a ficção com a realidade e que o fez cantar as chamas de Roma, que, segundo Suetónio, ele próprio teria ateado. Uma existência que contrasta com a caracterização de um Nero mal vestido, fugitivo e aterrorizado (nudo pede atque tunicatus; pauefactus; clandestinus; conterritus; e trepidanter effatus).

A precipitação que se segue ao espetar do ferro na garganta, com a ajuda de Epafrodito, é sugerida pela concisão da frase: a acção do centurião que irrompe e simula estancar a ferida é expressa por particípios em dativo e um ablativo absoluto de permeio (... irrumpenti centurioni et paenula ad uulnus adposita in auxilium se uenisse simulanti...), que, colocados, na frase, entre o adjectivo que qualifica o estado do príncipe e as suas derradeiras palavras, destacadas em último lugar (semianimis adhuc... non aliud respondit quam: 'sero' et: 'baec est fides'), concentram o sujeito daquelas acções com o destinatário da resposta de Nero. Assim, o principal sujeito da enunciação, Nero, em quem a acção se centra, vê frustrar-se o afã do centurião, que, por breves instantes, chega tarde de mais e perde a oportunidade de capturar, com vida, o imperador caído em desgraça - como sugerem a nota de que simulou vir em auxílio e as palavras sarcásticas do moribundo. Nero, finalmente liberto da ansiedade e do terror, que se adensara com a necessidade da morte, constata que escapou, in extremis, ao castigo reservado aos inimigos públicos, cuja descrição (em 49.2) o deixara conterritus.

Toda a narração é uma sinestesia encarada do ponto de vista de Nero. Há sensações visuais, de que se destaca o raio, a visão do cadáver abandonado e a leitura do despacho do senado que ele praeripuit legitque; sensações auditivas, como o trovão, o clamor dos soldados, as observações dos transeuntes e o tropel dos cavalos; sensações olfactivas, como o cheiro do cadáver; sensações tácteis, como o roçar da roupa pela caverna estreita e o verificar do fio dos punhais; e, finalmente, sensações gustativas, como a água do charco, a água tépida e o pão que ele rejeitou. Mas, depois da morte, Suetónio transfere para o exterior o ponto de vista das impressões e Nero torna-se a fonte dessas sensações: Atque

appropinquabant, quibus praeceptum erat ut uiuum eum adtraberent. Quod ut sensit, trepidanter

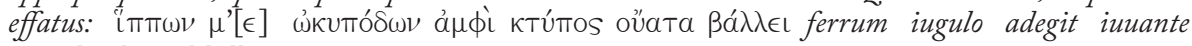
Epaphrodito a libellis. 
in ea uoce defecit, extantibus rigentibusque oculis usque ad horrorem formidinemque uisentium ( $« \mathrm{E}$, com estas palavras, expirou, com os olhos a sair das órbitas e vidrados a ponto de provocar horror e medo a quem o via»).

Verificamos que Suetónio apresenta relatos famosos pelo realismo cru e relatos famosos pela beleza e dramatismo da narrativa. Encontramos também vários níveis de linguagem. Podemos concluir que a arte de Suetónio se não poderá avaliar tanto por uma forma original de escrita, mas pela selecção do material, pela organização e estruturação das Vidas, pelo tratamento do pormenor que vai até ao mais escabroso, pela capacidade, enfim, de dar vida real às Vidas dos Césares já envoltas em mito. O biógrafo consegue deleitar o leitor e mesmo desencadear emoções fortes. 
(Página deixada propositadamente em branco) 


\section{Meios de Captação do leitor}

Por serem estruturadas maioritariamente através de rubricas, as biografias poderiam gerar uma leitura enfadonha, obrigatória apenas por amor à erudição ou necessidade de consulta específica sobre determinado assunto. Verificamos, ao invés, que as Vidas dos Césares são agradáveis ao leitor comum. Suetónio não esquece que a obra se destina a ser lida. Repetidas são as afirmações retóricas de não querer enfadar quando o material abunda. ${ }^{1}$ Mas, mais do que isso, o biógrafo manobra, de modo subtil, a arte da persuasão, através da sedução dos sentidos e do estímulo dos afectos do leitor. Se a abordagem per species condiciona à partida a estrutura e impõe enumerações, o biógrafo procura tornar este tipo de exposição agradável, de modo a cativar o interesse. O intuito de deleitar parece presidir à exposição (breve, clara e verosímil) de anedotas, de curiosidades e do Italum acetum com que recheia as Vidas; à forma como dá vida aos Césares, contando os pormenores mais variados sobre as personagens, mesmo os mais escabrosos; ao modo como encadeia as rubricas e dá ao leitor a ilusão de que está a ler uma narrativa continuada. $\mathrm{O}$ propósito de apelar às emoções do leitor parece determinar a qualidade e a ordem das species e da exposição dos factos no interior destas: o valor relativo que se dá aos factos em função da imagem do imperador; uma sucessão aparentemente cronológica, mas virada para surtir determinado efeito, através da sugestão de uma mudança ou evolução no comportamento dos protagonistas; a retenção de informação para a apresentar no momento em que provoca mais impacto; a procura de finais dramáticos, sobretudo com as cenas de morte e suas circunstâncias processos subtis que quebram a monotonia e visam a empatia do leitor.

\subsection{Sedução do leitor}

\subsubsection{Sugestão de realismo}

$\mathrm{Na}$ narrativa da morte de Nero apresentam-se, como vimos no final do capítulo anterior, dados precisos sobre a exacta localização da casa de Fáon, ${ }^{2}$ sobre as roupas do príncipe, ${ }^{3}$ sobre a aproximação à casa, sobre os arranjos para o possível acolhimento do imperador. $\mathrm{O}$ ambiente de conturbação social é reproduzido com realismo através da menção do cadáver em decomposição na rua e das interpelações dos viandantes (Nero 48), realidades que Tácito evitaria mencionar. O historiador, tal como Plutarco, tende a fugir ao trivial, ao lugar-comum, aos pormenores sórdidos e vis. Mas a verdade é que todos estes elementos fazem parte da vida. Sem eles, podemos ter literatura artística, mas não temos realismo. Concede-se geralmente a Suetónio o mérito de dar

${ }^{1} \mathrm{Jul}$. 68.4: ne de pluribus referam; Aug. 51.1: Ne enumerem; Aug. 66.3: ne de pluribus referam; Tib. 2.1: Sed ut praecipua commemorem; Tib. 61.2: Singillatim... exequi longum est; genera... enumerare sat erit; Gal.3.1: exequi longum est... breuiter attingam. Vide Gascou, J. 1984, 243.

2 ... inter Salariam et Nomentanam uiam circa quartum miliarium.

3 ... nudo pede atque tunicatus, paenulam obsoleti coloris superinduit adopertoque capite et ante faciem optento sudario. 
à antiga Roma e aos imperadores uma existência convincente, ainda que uma ou outra história individual nos pareça suspeita. O leitor, por sua vez, apreende os resultados como reais ${ }^{4}$ e sente-se motivado pela curiosidade, ingrediente necessário para fruir a leitura.

No esforço para conferir vida real às suas personagens, Suetónio não descura as informações mais pitorescas sobre a vida pessoal dos imperadores. Por vezes chega mesmo a pequenos pormenores: por exemplo, ao analisar os dotes físicos e morais de Tito, não se esquece de referir a sua rapidez de escrita, o jeito para imitar letras de outros, que o levava a confessar que podia ser um grande falsário (Tit. 3.2).

As recordações pessoais do biógrafo conferem verosimilhança: o aparecimento de um falso Nero, quando era adulescens; ${ }^{5}$ a inusitada inspecção, por razões fiscais, de um nonagenário (para que se pudesse averiguar se era circunciso e, portanto, judeu, sujeito ao imposto sobre os praticantes desta religião) que presenciou quando era adulescentulus; as histórias que ouvira contar ao avô sobre Calígula, quando ainda era puer, ${ }^{6}$ e o que seu pai contava amiúde sobre Otão (Otho 10.1). Certas descrições de lugares sugerem um testemunho visual: como a indicação precisa da terra de origem da família de Vespasiano (Vesp. 1.3); a localização da casa onde fora criado Augusto, em Velitras (Aug. 6), da casa onde nasceu Galba (Gal. 4.1), e da casa de Lívia, chamada ad Gallinas (Gal. 1.1); indicações sobre o lugar das execuções ordenadas por Tibério em Cápreas (Tib.62.2). Estes elementos fazem apelo à curiosidade do leitor, sugerem veracidade e contribuem para tornar a sociedade recriada em uma Roma verosímil. Ao longo dos oito livros, através do modelo da biografia antiga, Suetónio integra a história da Roma imperial desde César até Domiciano, analisada na perspectiva da vida de cada imperador: não só a história política - por vezes, como vimos, grandes factos desta natureza são apenas resumidos -, mas também a história cultural.

Poderá hoje considerar-se com alguma estranheza a importância que o biógrafo dá aos omina. Mas os sonhos, os sinais e os presságios são mais do que vãs efabulações: fazem parte integrante da vida dos imperadores, sobretudo os mais crédulos, e condicionam, por vezes decisivamente, muitos acontecimentos. Daí a preponderância que tinham alguns astrólogos, como é o caso de Trasilo na corte de Tibério. Domiciano tenta esconjurar os presságios sobre o seu fim: na manhã do dia da sua morte anunciada, ao provocar o sangue de uma verruga da fronte, exclama: 'Vtinam, inquit, hactenus!' ('oxalá - disse ele - seja quanto baste!’») (Dom. 16.2.). Calígula lança uma ponte de barcas entre Baias e Putéolos, para esconjurar um presságio sobre a sua subida ao trono (Cal. 19.3). As crenças pessoais, por estranhas que sejam, a incrédula reacção aos auspícios, ou as atitudes contraditórias tornam as personagens mais humanas: o pragmático César mostra-se céptico aos presságios (Jul. 59), mas segue as crenças populares na escolha do cavalo (Jul. 61); parece coerente

\footnotetext{
${ }^{4}$ Como sugere Townend, G. B. 1967, 91-96.

${ }^{5}$ Nero 57.2. Mas não refere outros que apareceram anteriormente.

${ }^{6}$ Cal. 19.3: sed auum meum narrantem puer audiebam...
} 
que o religioso Augusto mostre medo dos trovões e dos raios (Aug. 90), mas tal temor é exagerado em Tibério, apesar de este negligenciar os deuses e as religiões (Tib. 69); pavor que é superlativado em Calígula, embora também revele desprezo pelos deuses (Cal.51.1). A irreligiosidade de Tibério e Calígula leva-os a voltarem-se para a astrologia (Tib. 69.1; Cal. 57.2); Nero desdenha a religião, mas é devoto da Deusa Síria, que, depois, acaba por ultrajar, para se devotar a uma estatueta de uma menina, que usava como amuleto (Nero 56). Cláudio, pelo contrário, é cuidadoso no cumprimento das cerimónias ( $\mathrm{Cl}$. $22.1 ; 46.1)$. São homens de carne e osso, mais ou menos dominados pelas suas superstições pessoais ou conformados à religião tradicional.

Mas está patente também um universo cultural onde o mito e a realidade por vezes se confundem. Acentua-se a ligação entre o sobrenatural e a vida pessoal de cada imperador e a intervenção do sobrenatural na história humana através das crenças do governante. A ascensão e queda de Galba aparece directamente relacionada com o favor e desfavor dos deuses. E esta caracterização biográfica de tipo "religioso" parece estar associada a uma caracterização "trágica" do protagonista. $^{7}$

\subsubsection{Rumores e anedotas}

Outra forma de cativar o leitor e contribuir para apresentar uma Roma viva é contar os boatos que corriam. É frequente apontar-se a Suetónio a pecha de atribuir acriticamente demasiado valor aos rumores. ${ }^{8}$ Muitas das anedotas referidas podem até ser falsidades, mas a verdade é que circulavam e, por isso, são reais e contribuem para recriar o ambiente social de Roma. O público da antiguidade, como o dos nossos dias, não resistia a uma boa intriga sobre as personalidades públicas. Quanto piores e mais mal-amados eram os imperadores, mais escabrosos eram os rumores que circulavam. Sobretudo no círculo dos senadores, a impotência que sentiam degenerava em maledicência velada. O boato (existimabatur) de que Galba pretendia reduzir a dois anos a duração dos cargos dos senadores e dos cavaleiros e atribuí-los unicamente aos que os não almejavam ( Gal. 15.1) é colocado por Suetónio (cujas fontes são, como vimos, sobretudo senatoriais) entre as piores intenções do imperador. Os rumores, por serem mais provocantes, aparecem frequentemente no final de uma série que se pretende intensificar ou servem de prova, tal como um facto averiguado.

A maledicência de carácter sexual era comum na invectiva política. Suetónio, conhecedor do êxito de poetas como Marcial e Juvenal, tem, segundo Baldwin, o mérito de transpor, em larga escala, este tema da poesia epigramática e satírica para a biografia. ${ }^{9}$ A história do comportamento homossexual de César começa por ser, no início da vida, apenas um rumor que o associa a Nicomedes da Bitínia (boato amplificado, logo a seguir, pelo facto de Júlio o jovem se dirigir

\footnotetext{
${ }^{7}$ Assim pensa Brugnoli, G. 1987, 40.

${ }^{8}$ Vide Della Corte, F. 1967, 157; Gascou, J. 1984, 339.

${ }^{9}$ Vide Baldwin, B. 1983), 501 ss. Vide Gascou, J. 1984, 703-706.
} 
de novo para aquela região); ${ }^{10}$ torna-se, mais tarde, em facto comprovado, no que diz respeito à intimidade (contubernium) com o monarca, ${ }^{11}$ para terminar como certeza absoluta, agravada pela generalização dos actos homossexuais passivos (impudicitia) e dos adulteria, que o tornam «o homem de todas as mulheres e a mulher de todos os homens» (Jul. 52.3). No culminar do tema da sedução das mulheres ilustres, está o rumor (existimabatur) de que Servília, amante de César, lhe concedia também os favores da própria filha, Tércia (Jul. 50.2): a notícia é confirmada com um gracejo de Cícero. Também sobre Otão correm rumores: consta (traditur) que tinha hábitos efeminados, se depilava e usava capachinho (Otho 12.1).

Quanto ao boato dos meninos de Tibério, em Cápreas, a quem o príncipe chamava pisciculi (Tib.44.1), e outros indescritíveis actos pedófilos do imperador, o próprio Suetónio os considera dificilmente credíveis (uix ut referri audiriue, nedum credum fas sit), mas nem por isso deixa de os expor cruamente. E, no cúmulo do relato, com fertur se introduz o sacrilégio e crueldade exercidos sobre um minister do sacrifício, que é sodomizado, juntamente com o irmão, para acabarem os dois com as pernas quebradas ( $T i b$. 44.2). Entre os meninos de Tibério estava Vitélio, o que fez correr o boato (existimatus) de que o pai deste ascendeu na carreira pública corporis gratia do filho (Vit.3.1).

Perante a constatação do facto de que Calígula beijava em público o pantomimo Mnester (Cal. 55.1) - acaso uma manifestação de apreço pela sua arte -, compreende-se que corresse o boato (fertur) de comércio carnal (Cal. 36.1). O rumor de que Calígula desflorara a irmã Drusila (Cal. 24.1) aparece confirmado pelo grande afecto que Calígula devota à irmã. E o simples boato (affirmant) da existência de manchas nas roupas de Nero, ao sair da liteira, é a última prova apresentada para sustentar a evidência (nemo dubitauit) de que o imperador é culpado de práticas incestuosas (Nero 28.2), ainda que Tácito diga que a iniciativa foi de Agripina (Ann. 14.2). Torna-se, por isso, verosímil o facto, narrado por autores não duvidosos, de que Nero fizera apreciações estéticas sobre o cadáver da mãe (Nero 34.3).

Também é estimulante saber que um austero imperador cede às paixões. Augusto não escapa à fama de, na juventude, ter hábitos efeminados e se prostituir por dinheiro (Aug. 68), acusação que o visado desmente com a conduta posterior (Aug. 71.1). Já os seus adultérios não são apresentados como rumor, e a justificação de que se não tratava de libido, mas de um meio de espionagem, provoca ao leitor um sorriso irónico. Mas a veracidade do facto é sustentada com argumentos pouco credíveis: a invectiva política da parte de António. ${ }^{12}$ Além disso, o rumor (in fabulis) sobre o escandaloso e ímpio festim secreto, com os convivas travestidos de deuses, em que Octávio faz o papel de Apolo

\footnotetext{
${ }^{10} \mathrm{Jul}$.2: non sine rumore prostratae regi pudicitiae; quem rumorem auxit intra paucos rursus dies repetita Bithynia...

${ }^{11}$ Jul. 49.1: Pudicitiae eius famam nibil quidem praeter Nicomedis contubernium laesit.

${ }^{12}$ Aug. 69.1. A acusação de arrebatar do triclínio a mulher de um cônsul, à frente do marido, levá-la para o quarto e reconduzi-la ao lugar com as orelhas vermelhas e o cabelo em desalinho conta-se, com maior reprovação, do monstrum Calígula (Cal.36.2).
} 
(Aug. 70), ou as virgens (ut ferunt) que a própria esposa lhe proporciona (Aug. 71.1), contribuem para retratar um Augusto com pés de barro e comprovar os adultérios que «nem sequer os amigos negavam» (Aug. 69.1) e aos quais o imperador permaneceu agarrado (circa libidines haesit) (Aug. 71.1). O biógrafo apresenta, sobre o príncipe, rumores com um fundo de verdade, tal como o que se refere ao vício do jogo dos dados. ${ }^{13}$ Mas contribui para os minimizar o facto de nem o imperador nem os amigos negarem tais vícios.

Muitos rumores crescem a partir da crueldade e excentricidade dos imperadores e espelham o medo generalizado sob o domínio de tiranos. Corria o boato (creditur) de que Tibério fez dar a morte a Germânico, por intermédio de Pisão, legado na Síria (Tib. 52.3). As mortes por ordem de Nero são escândalos sociais e políticos: não mais que parricídios e assassínios (parricidia et caedes), descritos no decurso de seis longos capítulos (Nero 33-38). A fama de tal crueldade gera naturalmente outros boatos, como o de dar a comer homens vivos (creditur) a um polyphagus que devorava carne crua. ${ }^{14} \mathrm{E}$, perante a arrogância do imperador em dizer que nenhum dos príncipes anteriores fazia ideia do que the era permitido, tornam-se bastante credíveis, e ganham estatuto de factos verídicos, os rumores sobre a sua culpabilidade no incêndio de Roma e a visão romanesca de um Nero, em trajo de cena, a cantar no alto da torre de Mecenas, no Esquilino. ${ }^{15} \mathrm{O}$ testemunho dos rumores e maledicência sobre este imperador são os epigramas e grafitos divulgados por toda a Urbe (Nero 39). Também a loucura de Calígula tem por cúmulo um rumor (traditur), o de que tencionava nomear cônsul o seu cavalo (Cal. 55.3).

Ninguém gosta de impostos, e ainda menos se são elevados. A rapina dos imperadores também dá origem a boatos. Conta-se (dicitur) que Nero, ao saber que uma matrona estava vestida da proibida púrpura numa das suas récitas, mandou despojá-la das roupas e dos bens (Nero 32.3). A cobiça de dinheiro (pecuniae cupiditas) de Vespasiano é já antecipada com o rumor de que extorquira duzentos mil sestércios a um jovem para quem obtivera o laticlavo (Ves. 4.3). Mas nem sempre os boatos servem para acentuar um aspecto negativo. Como nota Cizek, o facto de aquele procedimento de Vespasiano ser apresentado como rumor parece contribuir para evitar um retrato demasiado desfavorável de um imperador bom. ${ }^{16}$ Esta ideia parece confirmar-se, pois, mais à frente, este vício é, no essencial, ilustrado com boatos: (creditur) que ele empregava os procuradores mais rapaces, para, depois de enriquecerem, os condenar; (dicebatur) que os usava como esponjas que encharcava e que depois espremia; (tradunt) que se tratava de um vício de natura; e, por outro lado (sunt contra qui opinentur) que ele foi obrigado à rapina pela carência do erário e do fisco. ${ }^{17}$ Efeito positivo tem

${ }^{13}$ Aug. 71.1: Aleae rumorem nullo modo expauit lusitque simpliciter et palam...

${ }^{14}$ Nero 37.2. Sobre o significado de Polyphagos, vide Littman, R. J. 1976, 369; Baldwin, B. 1977, 406-409; com. de Bradley, K. R. 1978, 225.

${ }^{15}$ Nero 38. Tácito distingue entre o facto do incêndio e os rumores que se levantaram (Ann. 15.38.1 e 40.2). Vide Gascou, J. 1984, 443-444.

${ }^{16}$ Cizek, E. 1977, 142-143.

${ }^{17}$ A exemplificação do vício termina assim com o abrandamento da censura, reforçado ainda pela constatação — quod et ueri similius uidetur - de que ele fez bom uso do que adquirira mal 
igualmente o rumor (ut uulgo iactatum sit etiam), colocado no final da vida de Otão, e por isso no clímax da Vida, que o absolve da morte de Galba com o nobre motivo: de que queria restaurar a República (Otho 12.2).

O valor atribuído aos rumores parece estar associado ao gosto do romanesco que os gera. $\mathrm{O}$ vulgo prefere uma boa história à verdade histórica. No que diz respeito ao triângulo amoroso de Nero - Popeia - Otão, os rumores espalham-se (Otho 3): (creditur certe) que Otão, apaixonado por Popeia, não só não recebeu os enviados de Nero, que a vinham buscar, mas inclusive chegou a fechar as portas a Nero, enquanto este ameaçava e suplicava. ${ }^{18} \mathrm{O}$ dístico sobre o malogrado amante, relegado para um desterro sob a aparência de uma honra (o cargo de governador da Lusitânia), revela o impacto que o caso teve no público de Roma.

Ao apresentar estas histórias, Suetónio sabe que o leitor não as esquecerá e, ao ligá-las a determinados traços dos imperadores, dá-lhes valor ético. Podem ser apenas rumores ou maledicência, mas correspondem à leitura que Roma fazia, por vezes certamente exagerada, da pessoa de cada césar. Neste sentido, o imperador é visto como um actor diante do público de Roma que ora aplaude, ora pateia. Além disso, os rumores contribuem para a persuasão do leitor: se se explora o seu conteúdo, servem para acentuar determinados vícios, como é o caso de Nero $;^{19}$ se se explora o seu estatuto de simples boatos, podem contribuir para atenuar determinado defeito, como observámos a propósito de Vespasiano. ${ }^{20}$

Trata-se, por outro lado, de ceder a um gosto, um tanto mórbido, do público de todas as sociedades, que prefere acreditar nas versões mais extremistas. $\mathrm{O}$ frequente apelo aos rumores, sobretudo os que se referem à crueldade $\mathrm{e}$ prepotência dos imperadores, tem o efeito dramático de sugerir um ambiente de terror, suspeição e insegurança e expressam as revelações e incertezas que marcam o avanço do protagonista em direcção à catástrofe..$^{21}$

\subsubsection{A força do cómico}

Uma das formas mais eficazes de cativar o leitor é provocar o riso. Suetónio, que usa o sentido de humor nos seus variados níveis, ${ }^{22}$ transcreve factos e ditos cómicos e ele próprio faz comentários humorísticos. $\mathrm{O}$ chiste de mais baixa extracção tem uma fonte inesgotável nos ataques políticos de ordem sexual.

(Ves.16.2-3); e pelo capítulo seguinte, que o apresenta como liberalissimus.

${ }_{18}$ Plutarco, Gal. 19.3-20.1, e Tácito, Ann. 13.45-46, apresentam versões diferentes e mais sóbrias. O romance de Otão com Popeia aparece, em Tácito, Hist.1.13.3, como uma suspeita de Nero, que, por isso, afasta o rival.

${ }_{19}$ PAuw, D. 1980, 91-93, nota que as expressões impessoais e fontes não identificadas aparecem maioritariamente em contexto negativo.

${ }^{20}$ Observações já anteriormente por nós publicadas: vide Brandão, J. L. 2002, 331-339.

${ }^{21}$ Brugnoli, G. 1987, 46, associa o uso dos rumores, por parte de Suetónio, a uma estrutura trágica: «(...) penso que anche su questa tecnica possa avere influito il gusto dello schema "tragico": se è vero che in ogni dramma che si rispetti i sospetti e i dubbi che si affollano sulla pista su cui il protagonista corre verso la sua catastrofe sono, come si sa, generalmente espressi in forma di ambigua diceria e spesso da spalle del tutto insignificanti e mai storicizzabili».

22 Vide Baldwin, B. 1983, 511-513. 
Um exemplo do sentido de humor do biógrafo é a forma curiosa de apresentar os vários testemunhos no que se refere à relação de César com Nicomedes da Bitínia (Jul. 49): salienta que omite certas afirmações da invectiva, por serem menores, mas acaba por transcrevê-las. Inicia uma espécie de jogo com o leitor: diz omitto («deixo de lado»), mas transcreve os versos licenciosos de Licínio Calvo. Dir-se-ia que não resiste à tentação de ver incluída na biografia a expressão paedicator Caesaris («sodomizador de César»). A seguir, afirma praetereo («passo à frente»), no que respeita aos discursos de Dolabela e de Curão pai, mas depois, como quem muda de ideias ou prevê a súbita curiosidade do leitor, cita-os (in quibus... dicunt), para referir as apóstrofes do primeiro - paelex reginae («rival da rainha») e sponda interior regiae lecticae («leito da liteira real») - e de Curião - stabulum Nicomedis («lupanar de Nicomedes») e Bithynicus fornix («bordel da Bitínia»). Continua a afirmar missa facio edicta Bibuli («não faço caso dos edictos de Bíbulo»), mas de novo os cita (quibus) no que se refere ao epíteto de «rainha da Bitínia» e acrescenta uma nota importante sobre as aspirações tirânicas de César: "ele antes amou um rei, agora ama um reino». ${ }^{23}$ Aduz ainda o testemunho de Marco Bruto, um dos assassinos, que, por sua vez, conta que um certo Octávio, por brincadeira, saudara Pompeio como rex e César como regina. Com um Sed de charneira, chama a atenção do leitor para a série de informações que se seguem e sugere, assim, que se vão aduzir opiniões mais dignas de crédito: assim estabelece, gradativamente, alguma diferença entre informação menos credível e informação mais séria. Começa por Mémio, que pronunciou discursos violentos contra César, ${ }^{24}$ cita a acusação de que César era, juntamente com outros rapazinhos, escanção de Nicomedes. Acrescenta testemunhos de Cícero retirados das cartas, a propósito do descendente de Vénus in Bithinia contaminatus, e mesmo umas palavras irónicas que, no senado, o orador disse a César, quando este defendia a causa da filha de Nicomedes: «toda a gente conhecia bem o que cada um dera ao outro». ${ }^{25} \mathrm{E}$, para finalizar, os versos jocosos dos soldados no triunfo gaulês, onde se vê que, mais que na pederastia, a crítica zombeteira se centra na passividade: Gallias Caesar subegit, Nicomedes Caesarem: / ecce Caesar nunc triunphat qui subegit Gallias, / Nicomedes non triunphat qui subegit Caesarem («César submeteu as Gálias, Nicomedes submeteu César. / Eis que triunfa agora César, que submeteu as Gálias, / mas não triunfa Nicomedes, que submeteu César»). E, assim, com a forma da exposição divertida que adoptou, Suetónio sublinha o cómico da matéria exposta: a sujeição sexual do invencível César. ${ }^{26}$

A seguir (Jul. 50), o âmbito alarga-se: apresenta-se um César pronus et sumptuosus in libidines, que seduz mulheres ilustres, tema coroado com a graça de Cícero sobre Tércia, filha de Servília. Vemos que nem as mulheres das províncias

\footnotetext{
${ }^{23}$ Bithynicam reginam, eique antea regem fuisse cordi, nunc esse regnum.

${ }^{24}$ Mais tarde César reconciliou-se com ele, tal como com os poetas Licínio Calvo e Catulo: cf. Jul. 73.

25 'Remoue - inquit - istaec, oro te, quando notum est, et quid ille tibi et quid illi tute dederis.'

${ }^{26}$ Não parece que o capítulo seja tão entediante como sugere BALDwin, B. 1983, 503. Mas a reacção do próprio crítico mostra que o texto não deixa o leitor indiferente.
} 
lhe escapam, o que lhe valeu os versos do triunfo gaulês: Vrbani, seruate uxores: moechum caluom adducimus. I Aurum in Gallia effutuisti, hic sumpsisti mutuum (Jul. 51) («Homens da Urbe, guardem as vossas mulheres: trazemos connosco o adúltero careca. / Na Gália, fornicaste o ouro; aqui, tiveste de contrair um empréstimo»). E enfim, por generalização, habitual em Suetónio, apresenta-se um retrato de síntese com recurso a um expressivo quiasmo, onde o que está em questão já não é bissexualidade, mas a promiscuidade: At ne cui dubium omnino sit et impudicitiae et adulteriorum flagrasse infamia, Curio pater quadam eum oratione omnium mulierum uirum et omnium uirorum mulierem appellat (Jul. 52.3) («Mas para que ninguém duvide de que alastrava a sua má fama quer de pederasta passivo, quer de adúltero, Curião pai, em determinado discurso, chama-lhe homem de todas as mulheres e mulher de todos os homens»). É um monumento ao Italum acetum, onde o biógrafo denota o seu gosto do escândalo e da maledicência que o leitor poderá censurar, mas não deixará de ler nem esquecerá facilmente. A prova do êxito de Suetónio é que estas informações se tornaram famosas e, juntamente com os ditos célebres, são das primeiras coisas que se aprendem sobre César, quer se queira, quer não.

O topos da vida sexual acarreta um cómico obsceno, do tipo usado no mimo, pelo género de vocabulário que suscita; como é o caso do excerto de uma carta de António a Augusto ${ }^{27}$ ou a designação que Domiciano dá ao acto sexual. ${ }^{28} \mathrm{O}$ próprio biógrafo, na descrição das práticas sexuais de Nero, explora o sentido obsceno de conficere («submeter, possuir»). ${ }^{29}$

Há vários exemplos de cómico farsesco, onde não faltam termos escatológicos e em que os imperadores se tornam verdadeiros bufões. Vitélio ostenta saciedade com um ructus (Vit. 7.3), o que está de acordo com a sua característica dominante: a gula destemperada e sórdida (Vit. 13.3). Calígula manda calar a vizinhança para não perturbar o descanso do seu cavalo Incitatus, a quem trata como um opulento cortesão e quer fazer cônsul (Cal.55.3.); indica como senha «Vénus» e «Priapo» e faz gestos obscenos quando apresenta a mão a beijar ao tribuno Cássio Quérea (Cal.56.2). Cláudio, no principado de Calígula, é objecto da troça dos bobos da corte ( $C l .8)$; quando se torna imperador, corre o boato de que pensa publicar um edicto a dar licença para a libertação de gases à mesa, depois de saber que um convidado tinha passado mal por se conter $(\mathrm{Cl}$. 32); não abandona o triclínio senão empanturrado e encharcado em vinho; e tinham de lhe aliviar o estômago enfiando-lhe uma pena na garganta (Cl.33.1). Nero urina sobre a Deusa Síria (Nero 56). Vespasiano é atacado com nabos em África (Ves. 4.3) e lança um imposto sobre a urina, cuja colecta dá a cheirar ao filho Tito, para lhe demonstrar que não cheira à matéria de origem (Ves. 23.3). Domiciano fecha-se sozinho a caçar moscas com um estilete, de modo que, ao visitante que perguntou quem estava com o imperador, Víbio Crispo

\footnotetext{
${ }^{27}$ Aug. 69.2: depois de uma série de perguntas em que emprega o poliptoto baseado em inire, termina com o verbo arrigere.

${ }^{28}$ Dom. 22: clinopale, isto é, 'ginástica de cama'.

${ }^{29}$ Nero 22: cum affatim desaeuisset, conficeretur a Doryphoro liberto. Vide BALdwin, B. 1983, 511-513.
} 
respondeu: ne muscam quidem («nem uma mosca sequer!») (Dom. 3.1). São relatados vários ditos e eventos sobre o medo e a desconfiança de Cláudio $(\mathrm{Cl}$. 35-37), bem como sobre a sua imbecilidade e incongruência (Cl. 38-40).

Mais subtil é o cómico dos nomes com que os imperadores foram apelidados, devido a determinado traço de carácter. Pompeio chamava Egisto a César, porque este lhe seduzira a esposa Múcia (Jul.50.1). Augusto, depois de se vestir de Apolo no "Festim dos doze deuses", em época de carestia, foi denominado Apollo Tortor («Apolo Esfolador»), uma das designações com que o deus era venerado na cidade, pois comentava-se que os deuses tinham devorado todos os cereais (Aug. 70.2). Tibério foi metaforicamente apelidado pelo vulgo de Calípides (figura grega proverbial, por correr sem sair do sítio), pelo facto de se preparar muitas vezes para partir de Roma e desistir à última hora (Tib. 38); pela sua avidez do vinho, já no exército, em vez de Tiberius Claudius Nero, lhe chamavam Biberius Caldius Mero (Tib. 42.1), ${ }^{30}$ e, mais tarde, Caprineus («caprino»), pelas suas alegadas torpezas em Cápreas (Tib. 43.3). Vitélio, por ter sido criado entre os prostitutos de Tibério, ficou para sempre marcado com a alcunha de Spintria ("prostituto») (Vit. 3.2). Vespasiano, obrigado a recorrer a expedientes indignos da sua categoria social, para manter a quantia exigida pelo censo, foi alcunhado «condutor de mulas», antes de aceder ao império (Ves. 4.3) e, mais tarde, «comerciante de peixe salgado» (por parte dos habitantes de Alexandria) pela sua avareza (Ves. 19.2). Tito, pelo seu comportamento antes de ser imperador, foi apelidado de «outro Nero» (Tit. 7.1). O velho Galba é apelidado de Cupido por antífrase, quando a sua cabeça, completamente calva, é passeada na ponta de um pau (Gal. 20.2). O biógrafo regista ainda o cómico resultante da exploração do significado de vários nomes próprios: César, diz Cícero, favorecerá Servília na compra de terrenos, com uma Tertia: isto é, desconto de uma terça parte ou em troca da filha da amante (Jul. 50.2); ${ }^{31}$ Cláudio diz que apresentará, nos jogos, o gladiador Palumbus («Pombo»), se o conseguir agarrar (Cl.21.5); se Ahenobarbus tem uma barba de bronze, não é de admirar que tenha uma boca de ferro e um coração de chumbo segundo diz o orador Licínio Crasso (Nero 2.2); os Romanos clamam por Vindex, o revoltoso, fingindo chamar um dos seus escravos; e escrevem nas colunas que o canto de Nero despertou os Galli, jogando com o nome da ave e o do povo (gauleses) onde começou a revolta (Nero 45.2). ${ }^{32}$

Suetónio sublinha os jogos verbais resultantes da ambiguidade de certas palavras: subigere, 'submeter', em sentido militar e sexual, como vimos acima

${ }^{30}$ Jogo com o verbo 'beber' (bibere), com o hábito romano de beber vinho quente (caldus) e com a fama de ébrio que ganhava quem bebia vinho puro (merus), uma vez que este devia ser misturado com água.

${ }^{31} \mathrm{Jul}$. 50.2: Sed ante alias dilexit Marci Bruti matrem Seruiliam, cui et proximo suo consulatu sexagiens sestertium margaritam mercatus est et bello ciuilli super alias donationes amplissima praedia ex auctionibus hastae minimo addixit; cum quidem plerisque uilitatem mirantibus facetissime Cicero: 'Quo melius', inquit 'emptum sciatis, tertia deducta'; existimabatur enim Seruilia etiam filiam suam Tertiam Caesari conciliare. Vide Almeida, J. M. 1959, 105.

32 Sobre estas manifestações de espírito a propósito dos nomes, vide Reekmans, T. 1992, 194-203. 
(Jul. 49.4); tollere, no sentido de 'levantar' e de 'eliminar';33 orbis no sentido de 'tambor' (tocado por um cinaedus) e de 'mundo' (identificando o cinaedus com Octávio); ${ }^{34}$ morari aplicado a Cláudio, no sentido de 'habitar' (em latim) e, com o longo, 'fazer tolices' (em grego); ${ }^{35}$ adamato, no sentido de 'por ser objecto do amor' (em latim) e 'livre: sem compromisso matrimonial' (em grego) segundo uma graça de Vespasiano ${ }^{36}$ Arci no sentido de 'arcos' (latim vulgar, em vez de arcus) ou de 'basta' (em grego), num grafito contra as construções de Domiciano. ${ }^{37} \mathrm{Um}$ jogo semelhante existirá na resposta de Vespasiano a Méstrio Floro, quando este o admoestara de que não deveria pronunciar plostrum, mas plaustrum: na manhã seguinte, o imperador saúda-o pelo nome de Flaurus, que perde, assim, a associação a flos, 'flor', e se liga ao grego phlauros, isto é, 'insensato'. ${ }^{38}$

Muitas vezes é o próprio biógrafo quem manifesta espírito nos seus comentários, como é o caso dos jogos oferecidos por Tibério: «todos magníficos, a expensas da mãe e do padrasto». ${ }^{39}$ Ironiza com a suposta moralidade de Catão: introduz a posição do austero moralista, sobre o suborno às centúrias para a eleição de Bíbulo, com a nota maliciosa de que «nem sequer Catão se opôs», porque se tratava de «uma corrupção a bem da República» (Jul.19.1). Sublinha o inopinatum da acção de Calígula, quando, feitos os preparativos para um sacrifício, imolou o sacrificador. ${ }^{40}$ Acentua o erro pedagógico de Séneca de afastar Nero do estudo dos oradores antigos, com o comentário, irónico, por certo, de que pretendia conservar por mais tempo a admiração do pupilo pelo mestre. ${ }^{41}$ Nota que Nero mandou despojar uma matrona, que se apresentava vestida de púrpura - e acrescenta -: «não só da roupa... mas também dos bens» (Nero 32.3). Quando elogia a forma como Tito capta as simpatias de todos, não deixa de notar que é «coisa muito difícil para quem detém o poder» (Tit. 1). Sobre a versatilidade de Calígula, comenta que é «tão dotado para as outras coisas, mas não sabe nadar» (Cal. 54.2).

O riso é apotropaico e funciona como uma espécie de castigo para o mal. Depois de descrever os desacatos nocturnos de Nero, Suetónio apresenta o imperador incógnito a ser duramente sovado por um cônsul (Nero 26.2). E perante a tirania artística de Nero, não deixa de provocar riso ver o espontâneo

${ }^{33}$ Aug. 12: ... alii ornandum tollendumque iactassent; Nero 39.2: 'Quis negat Aeneae magna de stirps Neronem / sustulit hic matrem, sustulit ille patrem?' Vide AlmeIdA, J. M. 1959, 104-105.

${ }^{34}$ Aug. 68. Vide Almeida, J. M. 1959, 105-106.

${ }_{35}$ Nero 33.1: nam et 'morari' eum desisse inter homines producta prima syllaba iocabatur. Vide Almeida, J. M. 1959, 17 n. 11 e 70.

${ }^{36}$ Segundo a interpretação que Reenmans, T. 1992, 210 n. 74, faz de Ves. 22: ... admonente dispensatore, quem ad modum summam rationibus uellet inferri: 'Vespasiano', inquit, 'adamato'.

${ }^{37}$ Dom. 13.2. O que quer dizer que, para o jogo verbal funcionar, o ditongo ei, em grego, já em finais do século primeiro, soaria de modo semelhante ao $i$, como sublinha Almeida, J. M. 1959, 71-72.

${ }^{38}$ Ves. 22. Vide Almeida, J. M. 1959, 72-73.

${ }^{39}$ Tib. 7.1: cuncta magnifice, inpensa matris ac uitrici.

${ }^{40}$ Cal.32.3. Vide Reenmans, T. 1992, 230.

${ }^{41}$ Nero 52: a cognitionem ueterum oratorum Seneca praeceptor, quo diutius in admiratione sui detineret. 
Vespasiano a dormir durante os recitais (Ves. 4.4). A avareza proverbial de deste imperador é publicamente desfrutada pelo arquimimo que, no funeral do imperador, faz o papel do defunto. ${ }^{42}$ Mas o seu bom humor, ilustrado com muitos ditos de espírito (Ves.22-23), contribui para atenuar o vício da avareza e favorecer a imagem do governante.

Muitos outros exemplos de cómico se poderiam apontar. Um elemento comum à maior parte deles é que se prendem com juízos morais: ridendo castigat mores.

\subsubsection{A intervenção directa do autor no texto}

A forma como Suetónio expõe os factos pode fazer pensar que não intervém directamente no texto. ${ }^{43}$ Mas tal distanciamento é aparente e deve-se à sobriedade e discrição com que opera. O biógrafo prefere afectar uma atitude científica e objectiva, isto é, procura dar a impressão de que evita todo o juízo moral. Numa primeira análise, o texto de Suetónio parece um relatório positivo, onde predomina a observação directa e relação dos factos (cf. Tib. 42.1: de quibus... ab exordio referam) e a enumeração (cf. Tib. 61.2: enumerare sat erit). Afecta objectividade, quando explica psicologicamente os vícios de Domiciano como fruto da carência e do medo (Dom. 3.2); os de Calígula como resultado da total atrevimento e demasiado medo (Cal. 51.1); e, de certo modo, os de Cláudio por ser medroso e desconfiado (Cal.35.1).

$\mathrm{Na}$ enumeração, Suetónio parece apagar-se por trás dos factos que relata, mas a apreciação vai aparecendo de forma mais ou menos velada. Evidente é o juízo moral contido na distinção entre o «príncipe» e o «monstro» Calígula (Cal. 22.1); entre os «factos não merecedores de repreensão ou até dignos de um claro louvor» e os «actos infames e criminosos» de Nero; ${ }^{44}$ na transformação operada em Tibério, que se entrega aos uitia que durante longo tempo dissimulara (Tib. 42.1); em Domiciano, que passa da "clemência» e «respeito pelo alheio» para a «crueldade» e «avidez de riquezas» (Dom.10.1); ou em Tito, que transita anterior má fama para os maiores louvores, ou seja, dos vícios para as virtudes (Tit. 7.1).

Como se vê pela selecção de termos designativos de virtudes e vícios, a própria escolha do vocabulário adoptado desde logo revela um juízo feito. É, pois, sob a designação de impudicitia - eufemismo para passividade sexual ${ }^{45}$ que Suetónio se refere à relação de César com Nicomedes da Bitínia e de Nero com Doríforo (Nero 29). É o eco, em Suetónio, do lugar-comum da diatribe contra a homossexualidade, sobretudo passiva: de modo que soa a elogio dizer que Cláudio se «absteve completamente de machos» (Cl.33.2). Tais observações implicam uma moralidade que será o objecto de estudo na terceira parte deste livro. Por agora, detemo-nos nas observações directas do biógrafo no seu texto.

${ }^{42}$ Ves. 19.2. A anedota do arquimimo é uma cauillatio através da depranata imitatio: vide ReEkmans, T. 1992, 194.

${ }^{43}$ Assim pensa Townend, G. B. 1967, 92-93.

${ }^{44}$ Nero 19.3. Na intr. ao com. de Bradley, K. R. 1978, 14, encontramos a crítica à posição dos que pensam que Suetónio não expressa juízo sobre os Césares.

${ }^{45}$ Vide Veyne, P. 1990, 179. 
Além de numerosas intervenções na primeira pessoa, ${ }^{46} \mathrm{o}$ biógrafo expressa directamente o seu juízo, com alguma frequência, no início de uma rubrica ou de uma série de rubricas, para determinar a conclusão geral a tirar. Se passarmos em revista os "cabeçalhos", verificamos que Suetónio não se abstém e que é mais directo do que à primeira vista possa parecer. Louva a moderatio e clementia de César no trato com os inimigos (Jul.75.1); mas censura-o pela falta de abstinentia («respeito pelo alheio») nos cargos militares e civis (Jul. 54.1); considera que os «actos e ditos» e o «abuso do poder absoluto» tornam justa a sua morte (Jul. 76.1); e expõe a sua «desmesura» e «arrogância» (Jul. 77). De Augusto, diz que nunca empreendeu guerras «sem serem justas e necessárias» (Aug. 21.2); que era um príncipe «mais benéfico que ambicioso» (Aug. 42.1); que deu provas de «clemência» e de «urbanidade» (ciuilitas) (Aug. 51.1) e pode-se, por isso, concluir: Pro quibus meritis quanto opere dilectus sit facile est aestimare ${ }^{47}$ («perante tais merecimentos é fácil julgar o grau da estima que lhe era dedicada»). Depois de expor os vícios da vida privada de Augusto (Aug. 68-71), o biógrafo conclui: In ceteris partibus uitae continentissimum constat ac sine suspicione ullius uitii ${ }^{48}$ («nos restantes aspectos da vida consta que foi muito sóbrio e sem suspeita de algum vício»). Em Tibério, pelo contrário, denuncia a crescente tendência para a tirania-Paulatim principem exercuit (Tib. 33) -, que já anunciava a posterior mudança no comportamento (cuncta simul uitia male dissimulata tandem profudit) e faz o historial dos vícios ab exordio (Tib. 42.1); acentua a infamia (Tib. 44.1); a viragem "para a extorsão» (Tib. 49.1); apresenta uma visão diacrónica da «natureza cruel e fria» (Tib. 57.1). De Calígula, Suetónio assinala que foi turpis a fazer e desfazer casamentos (Cal.25.1), que era possuidor de uma «crueldade de carácter» (Cal. 27.1); que «agravava os actos mais monstruosos com a atrocidade das palavras» (Cal.29.1); que agia para com tudo e todos com «inveja», "perversidade», "arrogância», "crueldade» (Cal. 34.1); que "não poupou nem a sua pudicitia nem a dos outros» (Cal. 36.1); que «superou o engenho de todos os perdulários» (Cal. 37.1) e, exauridos os recursos, se virou para a rapina (Cal. 38.1). Afirma de Cláudio que «não lhe faltava autorictas nem dignitas no aspecto» (Cl. 30), mas «que era por natureza cruel e sanguinário» (Cl.34.1); que primava pela «falta de memória e de reflexão» (Cl. 39.1). De Nero assinala a demonstração de «liberalidade», «clemência»e «amabilidade» (Nero 10.1), para depois, na parte negativa, acentuar os vícios opostos: petulantia, libido, luxuria, auaritia, crudelitas (Nero 26.1); diz que "progressivamente enveredou às claras pelos maiores vícios» (Nero 27.1); que se tornou profanador da sua pudicitia (Nero 29); que, quando gastou os recursos, «se virou para a calúnia e extorsão» (Nero 32.1); que «começou por Cláudio os parricídios e assassínios» (Nero 33.1); «e não assolou com menor crueldade os de fora de casa e os estranhos» (Nero 36.1). De Galba, diz o biógrafo que governou a Hispânia Tarraconense «de forma variável e desigual» (Gal. 9.1), mas que, quando imperador, o precedia «uma fama tanto

\footnotetext{
${ }^{46}$ Analisadas por Gascou, J. 1984, 242-249.

${ }^{47}$ Aug. 57.1.

${ }^{48}$ Aug. 72.1.
} 
de crueldade como de avareza» (Gal.12.1). Começa por apresentar Otão «desde a primeira juventude, pródigo e atrevido» (Otho 2.1) e «cúmplice dos planos e segredos» de Nero (Otho 3.1), para depois estabelecer o contraste entre o coragem na morte, por um lado, e os defeitos físicos e os costumes efeminados, por outro (Otho 12.1). De Vitélio, Suetónio realça os vícios da crueldade e da gula (Vit. 13.1). O veredicto do julgamento sobre a actuação de Vespasiano salienta a sociabilidade e clemência (Ves. 12) daquele cujo único defeito é a «avidez de dinheiro» (Ves. 16.1), mas que, paradoxalmente, se mostra «assaz generoso para toda a gente» (Ves. 17) e «muito amável»(Ves. 22). Considera Tito «amor e delícias do género humano» (Tit.1), ainda que este, no início, «tenha dado azo a suspeitas de crueldade e também sumptuosidade» (Tit.7.1); e frisa que, depois da mudança no comportamento, é «assaz benevolente por natureza» (Tit. 8.1). A administração do Império por parte de Domiciano é avaliada como uma mistura de virtudes e vícios, a tender para os segundos (Dom. 3.2); e denuncia-se mudança de comportamento da "clemência» para a «crueldade» e do «respeito pelo alheio» para a "ganância» (Dom. 10.1); acentua-se a «crueldade não apenas grande, mas também astuta e inesperada» deste imperador (Dom.11.1) e a sua libido nimia (Dom.22).

Além destas apreciações seleccionadas, muitas outras existem, mais ou menos directas. De modo que os exempla que se lhes seguem ficam automaticamente subordinados ao juízo de valor - o que contradiz a afectação de objectividade por parte do biógrafo e a tese da alegada impassibilidade de Suetónio. ${ }^{49}$ Embora sugira distanciamento em relação ao que narra, Suetónio sabe aonde quer levar o leitor e dá-lhe pistas de leitura para os factos que vai relatar. Um título, com as palavras-chave escolhidas entre virtudes e vícios reconhecidos e apresentado no local certo, condiciona tudo o que se diz a seguir. Quando as acções do imperador surgem em cena, os pré-juízos adquirem consistência real e as virtudes e os vícios deixam de ser abstracções.

\subsection{Apelo às emoções}

Os exemplos apontados não visam apenas deleitar: Suetónio pretende suscitar a indignação ou a empatia. ${ }^{50}$ Muitos dos factos seleccionados têm peso só por si. Embora o incesto não fosse tão ímpio para os antigos como para nós, as relações incestuosas de Calígula, que chega a prostituir as irmãs (Cal. 24), não deixam o leitor impassível. Mas o biógrafo também se serve de processos que contribuem para potenciar a intensidade dos factos. A generalização e a gradação são recorrentes nas Vidas. A primeira permite tornar em essencial (traço de carácter) o que é apenas pontual. A segunda permite organizar as

${ }^{49}$ Estes juízos de valor, claramente formulados, contradizem a tese de ЕктоR, J. 1980, 317-326, de que Suetónio se mantém impassível e objectivo ao contar os factos, por mais escabrosos que sejam, e que não intervém directamente no texto. Sobre a intervenção directa de Suetónio no texto e a simulação de objectividade, vide Cizek, E. 1977, 143-145; Gascou, J. 1984, 677-689.

${ }^{50}$ Vide Gascou, J. 1984, 689-706; Baldwin, B. 1983, 516. 
Vidas numa progressão, que se manifesta ao nível da revelação do carácter e do fornecimento da informação pertinente, em direcção à catástrofe ou à redenção, de forma a conduzir as emoções do leitor para um fim determinado.

\subsubsection{A generalização}

A generalização é uma prática habitual em Suetónio. ${ }^{51}$ É uma forma de acentuar o impacto de um acto isolado, na mira de sublinhar o juízo do biógrafo sobre determinado césar.

Suetónio generaliza, quando afirma que os reis aliados fundaram, «cada qual no seu reino», cidades com o nome de Cesareia, ${ }^{52}$ o que aumenta a popularidade de Augusto. O efeito contrário visa empolgar os exemplos da crueldade de Tibério. O biógrafo assume, desde logo, que seria fastidioso enumerar os factos um por um (Tib. 61.2), e transforma casos particulares em gerais, quando se refere à execução de condenados no primeiro dia do ano e aos filhos que acusam os pais; ${ }^{53}$ mistura o tratamento das obras de um poeta e de um historiador destruídas, ao atribuir às obras de ambos a agravante de já serem conhecidas de Augusto, ${ }^{54}$ e refere em conjunto condenados que se suicidaram, se feriram ou se envenenaram e foram conduzidos para a prisão ainda palpitantes. ${ }^{55}$ Emblemático é o caso da violação das virgens: tem maior impacto atribuir genericamente a immaturae puellae (Tib. 61.5) a violação pelo carrasco antes da execução, para contornar o costume (era considerado nefasto estrangular virgens), facto que só terá acontecido com a filha de Sejano, como afirma Tácito, Ann. 5.9.2. De modo semelhante, tem maior peso dizer que Nero manda retirar (e lançar às latrinas) as estátuas de todos os vencedores de jogos (Nero 24.1), quando Díon Cássio (63.8.5) só refere a mutilação das estátuas do citaredo Pâmenes. Com o mesmo intuito, no que respeita a Galba, Suetónio estende a «alguns ilustres de uma e outra ordem» a condenação à mínima suspeita e sem os ouvir ( $\mathrm{Gal}$. 14.3), irregularidade que, segundo Tácito (Hist. 1.6.1), terá acontecido com Cingónio Varrão e Petrónio Turpiliano. Sobre o uso que Otão faz do cognome de Nero, é mais convincente invocar um testemunho plural - quidam tradunt (Otho 7.1) -, embora se deva estar a referir a Clúvio Rufo (cf. Plutarco, Oth. 3.2). Ganha maior dramatismo dizer que, dos assassinos de César, nonnulli se suicidaram com o mesmo punhal com que atacaram o ditador, mas Plutarco (Caes. 69.3) atribui tal acto apenas a Cássio.

Está implícito o âmbito do género e a forma como Suetónio organiza o seu material. O biógrafo não se mostra escravo dos factos históricos, antes

${ }^{51}$ Vide Townend, G. B. 1967, 87; Baldwin, B. 1983, 256-257; Gascou, J. 1984, 450-456.

${ }^{52}$ Aug. 60. Além disso, não se trata propriamente de fundação, mas, na sua maior parte, de mudança de nome. Vide Gascou, J. 1984, 232-235.

${ }^{53}$ Tỉ. 61.2. Só se conhece um caso para cada situação: Tácito, Ann. 4.70.1, diz que Tício Sabino, amigo de Germânico, foi acusado e executado nas calendas de 28, e, em Ann. 4.28.1, informa que Víbio Sereno teve como acusador o filho do mesmo nome.

${ }^{54}$ Tib. 61.3. Trata-se de Mamerco Escauro (cf. Tácito, Ann. 6.29.3, e Díon Cássio, 58.24.3-5) e Cremúcio Cordo (cf. Tácito, Ann. 4.34-35): só as do segundo eram conhecidas de Augusto (cf. Díon Cássio, 57.24.3).

55 Tib. 61.4; situações diferentes entre si, que Gascou, J. 1984, 452-455, procura destrinçar. 
os instrumentaliza ao serviço da mensagem: a ilustração do carácter de cada imperador. A importância dos acontecimentos não é estatística. Um facto único, se significativo - como a violação de uma virgem que vai ser executada -, pode valer por muitos e, na linha da introdução à Vida de Alexandre de Plutarco, é importante para definir o carácter de um imperador. A generalização constitui uma forma de Suetónio potenciar certos factos, transformando em geral (mos) o que é particular (factum): qualquer acto, por acidental que seja, é manifestação da essência do indivíduo. Poderá ser um processo contestado do ponto de vista do historiador, mas a narrativa adquire maior pathos.

\subsubsection{A organização em crescendo}

Suetónio não acumula a informação simplesmente ao correr da pena. Como fazer uma narração cronológica não era o objectivo do biógrafo, o processo que vai seguir é o da acumulação progressiva, em crescendo, de forma a criar uma espécie de progressão.

$\mathrm{O}$ crescendo pode ser indicado por expressões, como advérbios; ${ }^{56}$ comparativos; ${ }^{57}$ expressões sugestivas da progressão do tempo; ${ }^{58}$ verbos que indicam intensificação ou degeneração; ${ }^{59}$ etc. Muitas vezes, os crescendos são reforçadas por adversativas, ou por negações como nec, nullus, nibilo, ou por verbos que exprimem mudança: conuertit, conuersus. Mas o que verdadeiramente estabelece a gradação é a qualidade dos factos: as acções mais horrendas de Tibério, Calígula, Nero e Domiciano tendem a ser apresentadas em último lugar; enquanto para Augusto, Vespasiano e Tito se apresentam no final as mais favoráveis.

A gradação pode aparecer numa frase, numa rubrica, num conjunto de rubricas, ao longo de uma vida ou ao longo de várias vidas. Como exemplo de gradação num período, temos a seguinte da Vida de Calígula: Vestitu calciatuque et cetero habitu neque patrio neque ciuili, ac ne uirili quidem ac denique bumano semper usus est (Cal. 52) («Roupas e calçado e restante trajar nunca usou o tradicional do seu país, nem o habitual dos cidadãos, nem masculino, nem sequer humano»). Outro exemplo é a enumeração dos presentes distribuídos por Nero durante os jogos: Sparsa et populo missilia omnium rerum per omnes dies: singula cotidie milia auium cuiusque generis, multiplex penus, tesserae frumentariae, uestis, aurum, argentum, gemmae, margaritae, tabulae pictae, mancipia, iumenta atque etiam mansuetae ferae, nouissime naues, insulae, agri (Nero 11.2) («Todos os dias se atiravam ao povo brindes de todo o género: por dia, um milhar de aves

${ }^{56}$ Paulatim (Tib. 33; Nero 27.1; Gal. 9.1).

57 maiora etiam indicia (Jul. 63); Maiore adhuc ac turpiore infamia (Tib. 44.1); Nibilo lenior (Tib. 56); nec minore saeuitia foris (Nero 36.1); ad maiora palam erupit (Nero 27.1); damnosior (Nero 31.1); saeuior (Dom. 10.5); contemptius (Dom.11.2).

${ }^{58}$ Procedente mox tempore (Tib. 49.1); in puero... aliquanto magis in principe (Tib. 57.1); In paucis diebus (Tib. 60)... mox (Tib. 61.1); aliquam diu ... donec (Dom. 3.2); inter initia (Dom. 9.1); ab iuuenta (Dom. 12.3)... principatus uero adeptus (Dom. 13.1)

${ }^{59}$ Auxit intenditque saeuitiam (Tib.62.1); Immanissima facta augebat (Cal.29.1); ad saeuitiam desciuit (Dom.10.1); ea fama et confirmata et aucta est (Gal.12.2). 
de cada espécie, muitas provisões, senhas de trigo, roupas, ouro, prata, gemas, pérolas, quadros, escravos, bestas de carga e até feras amestradas; por último, navios, blocos de apartamentos, terras»).

Os exemplos de gradação em uma rubrica são comuns: como a narração dos crimes sexuais de Tibério em Cápreas (Tib. 44); ou a morte de Agripina (Nero 34). Ao longo de vários capítulos evolui a intriga homossexual de César com Nicomedes (Jul. 2; 49.1; 52.3).

A gradação torna-se particularmente significativa na parte das Vidas que se debruça sobre os vícios dos Césares. Os vícios dos maus imperadores tendem a ser apresentados em clímax e os dos bons em anticlímax. A demonstração deste processo ao longo das diversas Vidas é a essência do trabalho de Cizek. ${ }^{60}$ Importa agora perceber a forma como Suetónio sugere tal crescendo. Na Vida de Tibério, depois da retirada para Cápreas, a gradação vai sendo sublinhada nitidamente pelas expressões dos “cabeçalhos". ${ }^{61} \mathrm{Na}$ biografia de Nero, a gradação dos vícios torna-se bem explícita. O biógrafo sugere que tais defeitos se manifestam de forma gradual, primeiro às escondidas (Nero 26.1); depois às claras: Paulatim uero inualescentibus uitiis iocularia et latebras omisit nullaque disimulandi cura ad maiora palam erupit (Nero 27.1) («Mas gradualmente, com o crescimento do vícios, deixou-se de brincadeiras e segredos e, sem nenhuma preocupação em dissimular, irrompeu às claras nas maiores enormidades»). Altera a cronologia de modo a que depois do casamento farsesco de Nero com Esporo, a quem «teve por esposa» (Nero 28.1), figurem as núpcias com Doríforo, onde se diz que o imperador prostituiu a sua pudicitia, ao fazer de mulher (Nero 29). ${ }^{62}$ Em relação ao carácter perdulário (Nero 30.1) destaca com um comparativo (damnosior) a situação em que foi «mais danoso», ${ }^{63}$ e deixa para o último grau da rapina a dilapidação dos templos. ${ }^{64}$ Também os crimes de sangue deste imperador são enumerados, ao longo de vários capítulos, num crescendo que põe em realce as motivações cada vez mais absurdas e arbitrárias, destacando-se, no termo, por uma adversativa, o atentado contra a pátria (Nero 33-38). ${ }^{65} \mathrm{Um}$ crescendo muito semelhante se descobre na narrativa dos actos do monstrum Calígula (Cal.22-49), sobretudo no que respeita à crueldade (Cal.26.4), acentuada por recurso ao superlativo - Saeuitiam ingenii per haec maxime ostendit ("desta forma, mostrou ao máximo a crueldade de carácter») (Cal. 27.1) -, e a um superlativo

${ }^{60}$ Cizek, E. 1977, 118-134, ilustra este processo nas Vidas dos Césares, à excepção das Vidas de Cláudio, de Vespasiano e Domiciano, nas quais não encontra gradações, mas antes uma narrativa linear; e na Vida de Tito põe em relevo a gradação descendente dos vícios.

${ }^{61}$ Etiam sellaria excogitauit (Tib. 43.1), maiore adhuc infamia flagrauit (Tib. 44.1), feminarum quoque, et quidem illustrium capitibus quanto opere solitus sit inludere (Tib. 45), mas sobretudo procedente mox tempore etiam ad rapinas conuertit animum (Tib. 49.1). E, em nova progressão sobre a sua natureza saeua ac lenta (Tib. 57.1), sed aliquanto magis in principe eluxit (Tib. 57.1); mox in omne genus crudelitatis erupit (Tib.61.1), auxit intenditque saeuitiam (Tib.62.1).

${ }^{62}$ Quando a ordem cronológica destes acontecimentos terá sido a inversa: vide VERDière, R. $1975,17-19$.

${ }^{63}$ Nero 31.1: Non in alia re tamen damnosior quam in aedificando.

${ }^{64}$ Nero 32.4: Vltimo templis compluribus dona detraxit...

${ }^{65}$ Nero 38.1: Sed nec populo aut moenibus patriae pepercit. Vide Gascou, J. 1984, 697-700. 
intensificado pela semântica do verbo - Immanissima facta augebat atrocitate uerborum ( «agravava os actos mais monstruosos com a atrocidade das palavras») (Cal. 29.1): a crueldade parece culminar, já no final, na nefanda atrocitas (Cal. 48.1). Em Domiciano, o aumento da crueldade, depois da vitória na guerra civil movida por L. António, é sugerido por um comparativo (saeuior) (Dom. 10.5). Para conseguir este efeito, Suetónio sacrifica a cronologia relativa das execuções ao longo deste principado. ${ }^{66}$

Assim, o material não é acumulado ao acaso, mas disposto de forma a provocar um maior impacto no leitor e a sublinhar a impressão que Suetónio quer transmitir sobre o imperador: sacrifica-se a ordem cronológica em favor da ordem crescente de intensidade e do escândalo que provoca. ${ }^{67} \mathrm{E}$ assim que, no remate de uma série de factos sobre a devassidão de Nero, se menciona a suspeita de incesto (Nero 28.2). Assim também o relato das torpezas de Tibério em Cápreas é intensificado com a «aviltamento mais torpe» do caso dos «meninos de tenra idade» (Tib. 44). Depois de ler todas as loucuras de Calígula, que, inclusivamente, quereria nomear cônsul o seu cavalo (Cal. 55.3), o espírito do leitor está persuadido da necessidade de se fazer justiça (Cal. 56.1); e prepara-se a narrativa da morte. Também no fecho das crueldades de Vitélio se diz que «foi suspeito da morte da mãe» (Vit. 14.5).

Uma mais ampla gradação, ao longo de uma Vida no seu todo, é visível sobretudo nas biografias de Tibério e de Domiciano, nas quais se sugere uma gradual progressão para o mal. Suetónio procura, por vezes, sugerir uma evolução ou ruptura no comportamento dos imperadores, o que contribui para os tornar personagens mais complexas e enriquecer a trama narrativa. Para os antigos, o carácter é imutável: o que muda é o comportamento. Nos maus imperadores, essa evolução corresponde a um "retirar da máscara". É o revelar do ethos que já estava latente. Em Tibério o tirano vai-se manifestando gradualmente, ${ }^{68}$ embora mais inclinado, a princípio, para o bem público. Com a partida para Cápreas Tibério dá largas aos vícios «há longo tempo mal dissimulados» (Tib. 42.1). A benevolência que anteriormente granjeara ficara a dever-se à simulação da moderatio ${ }^{69}$ só quem o conhecia bem, como o mestre de retórica, se podia aperceber da sua verdadeira natureza (saeua ac lenta natura). Fica sugerida uma revelação do carácter em termos cronológicos, ${ }^{70}$ que acentua o efeito de ilusão / desilusão do leitor.

$\mathrm{Na}$ Vida de Domiciano, encontramos expressa uma evolução cronológica semelhante à de Tibério, uma mudança de atitude em determinado momento da vida. Suetónio coloca a tónica na mudança progressiva de atitude e, desde

${ }^{66}$ Como demonstra Gascou, J. 1984, 411-413.

${ }^{67}$ Suetónio adopta uma disposição mais “impressionista” que cronológica: GAscou, J. 1984, 400-414, dá o elenco dos passos. Vide Cizek, E. 1961, 355-360.

${ }_{68}$ Tib.33.1: Paulatim principem exercuit praestititque etsi uarium diu...

${ }^{69}$ Tib. 57.1: ... cum adhuc fauorem hominum moderationis simulatione captaret. Cláudio, pelo contrário, tenta fazer crer que a sua stultitia era simulada, mas não consegue persuadir ninguém: Cl. 38.2.

${ }^{70}$ Sublinhada por: procedente mox tempore (Tib. 49.1). Uma cronologia forçada como prova Gascou, J. 1984, 408-410. Para uma análise da biografia, vide Baldwin, B. 1983, 250-266. 
logo, ao introduzir a narrativa do período bom, faz saber que, na administração do Império, se mostra, durante muito tempo, inconstante, até cair nos vícios da rapina e da crueldade, devido à carência e ao medo (Dom. 3.2). A mudança de comportamento propriamente dita dá-se entre a afirmação de que, a princípio, tinha horror ao sangue e que não deu lugar a suspeitas de cupiditas e auaritia (Dom.9.1) e a constatação de que não manteve nem a clementia nem a abstinentia, mas que descambou para os vícios opostos: a crueldade e a cobiça (Dom. 10.1). Com efeito, Suetónio caminha para a revelação de um retrato de desmesurada crueldade. ${ }^{71}$

$\mathrm{Na}$ Vida de Calígula e de Nero, há, a determinada altura, uma divisão entre aspectos bons e aspectos maus, mas a sugestão geral que fica no leitor é a de uma progressão cronológica. Embora, na Vida de Calígula, se faça uma divisão metodológica em virtudes e vícios, ${ }^{72}$ a verdade é que esta cisão diz respeito mais à actividade imperial do que a uma apresentação global da personalidade de Gaio Calígula. ${ }^{73}$ Com efeito, já antes se mencionara a natura cruel e infame (Cal. 11). Além disso, de forma coerente com a notável dissimulação, que Calígula já manifestava no principado de Tibério (Cal. 10.2), a parte boa da governação (Cal. 13-21) fica subordinada a uma capacidade de representação, que esconde o seu verdadeiro carácter (Cal. 15). A fase relativa ao monstrum corresponde, assim, à revelação do Calígula real.

Também em Nero o processo é semelhante. Embora a grande divisão desta Vida se faça, como na de Calígula, entre acções neutras ou louváveis e «infâmias e crimes» (Nero 19.3), a verdade é que o biógrafo enceta a narrativa da parte má a explicar a origem do gosto pelo canto (Nero 20.1) e da paixão pelos cavalos (Nero 22.1). Ora tais aptidões já vêm sendo sugeridas desde o início, através do carácter do avô (Nero 4), da educação que recebeu, em casa da tia Lépida, com um dançarino e um barbeiro por pedagogos (Nero 6.3) e no modo empenhado (constantissime fauorabiliterque) como participa no jogo equestre denominado "Tróia" (Nero 7.1). Estas características e a desmesurada crueldade estavam patentes no presságio do preceptor, Séneca, que sonhara que educava Gaio César (Nero 7.1). De modo semelhante a Calígula, mas mais ampliado, a dissimulatio explica o fingimento teatral de virtudes (Nero 9-10).

Como consequência do tratamento per species, que acarreta o tratamento dos mesmos exemplos em rubricas diferentes, há factos que nos parecem contraditórios. Nero mostra-se modelo de piedade filial no elogio fúnebre de Cláudio (Nero 9), mas à frente aparece como cúmplice da morte do antecessor (Nero 33.1); demonstra pietas pelo facto de passear de liteira com a mãe em público (Nero 9), mas verificamos, mais tarde, que manchas na roupa denunciam práticas incestuosas com Agripina durante os referidos passeios (Nero 28.2); e um agravamento do relacionamento levará ao matricídio (Nero 34). A majestosa recepção a Tiridates (Nero 13) revela-se, afinal, um espectáculo ruinoso (Nero 30.2). Há como que um engano do leitor e só mais tarde é reposta a verdade.

\footnotetext{
${ }^{71}$ Dom. 11.1: Erat autem non solum magnae, sed etiam callidae inopinataeque saenitiae.

${ }^{72}$ Cal. 22.1: entre princeps e monstrum.

${ }^{73}$ Como assinala, no seu com., Guastella, G. 1992,156-157.
} 
Nestes quatro imperadores, o facto de a governação começar com acções claramente positivas e terminar com factos atrozes, sugere uma degradação, que, associada à desproporção entre a quantidade de factos louváveis e censuráveis (que são mais numerosos), começa por provocar desilusão e, por fim, conduz à indignação. Neste processo, concorre, como vimos, uma frequente indicação de rumores não confirmados.

Efeito contrário tem a organização das Vidas de Augusto, Tito e Otão, nas quais os factos positivos apresentados em último lugar conquistam a simpatia do leitor. Estas mudanças, até certo ponto forjadas por Suetónio, na medida em que nem sempre correspondem a uma evolução rigorosamente cronológica, cortam a monotonia da exposição e enriquecem a trama narrativa. De modo diverso, na Vida de Cláudio, a alternância de motivos favoráveis e desfavoráveis sugere a incoerência e a fraqueza do imperador. A distribuição do material pelas rubricas leva a que o leitor tenha de ajustar constantemente os seus próprios juízos: as aparências do início podem não corresponder a uma realidade definitiva.

Portanto, tomada no seu todo, a estrutura das Vidas, em termos retóricos, é constituída por gradatio ou clímax, que culmina no momento da plenitude do biografado, isto é a morte, lugar da revelação plena do ethos. ${ }^{74} \mathrm{O}$ fim da vida tende a surgir como resposta a uma tensão que se vai acumulando e como restabelecimento do equilíbrio e da ordem. Suetónio parece desejar que, no momento da morte, o leitor tenha chegado ao cúmulo do sentimento, do pathos, que o levará a ver a morte ora como um castigo, ora como o normal terminar de uma existência digna, ora como uma injustiça ou um crime que requer nova expiação.

Preparada uma série de sinais ominosos, a morte é seguida da reacção das classes sociais à notícia do falecimento. É aí que vai incidir a expiação, o derradeiro momento de remissão. Suetónio tende, segundo Baldwin, a terminar as Vidas de forma dramática. ${ }^{75}$ Ora esse final, frequentemente o último período do texto, procura sugerir, mitigar ou acentuar o significado da morte e, consequentemente, da vida. Um sensível número de Vidas termina com referências ao destino, em que este se cruza com uma culpa pessoal: assim na Vida de César fica a ideia de que um destino trágico perseguiu os conjurados (alius alio casu periit), ao ponto de alguns (segundo a generalização introduzida pelo biógrafo) se suicidarem com o mesmo punhal com que profanaram (uiolauerant) o ditador. ${ }^{76}$ Também o termo da Vida de Calígula insere a sua morte violenta num destino trágico ao qual não podiam fugir, pois, segundo as palavras exageradas do biógrafo, todos os Césares que tinham o praenomen de Gaius (Cal. 60). A morte ultrajante de Vitélio é encarada como realização

\footnotetext{
${ }^{74}$ Vide Pennacini, A. 1984, 87.

75 Baldwin, B. 1983, 488-491.

${ }^{76} \mathrm{Jul}$. 89: Percussorum autem fere neque triennio quisquam amplius superuixit neque sua morte defunctus est. Damnati omnes alius alio casu periit, pars naufragio, pars proelio; nonnulli semet eodem illo pugione, quo Caesarem uiolauerant, interemerunt.
} 
dos presságios: ${ }^{77}$ a interpretação do significado do presságio do galo que lhe subira para a cabeça (Vit. 18) encerra esta $V i d a$, a demonstrar que o fado se cumpriu. O último parágrafo da $V i d a$ de Cláudio apresenta-nos um príncipe conhecedor do seu destino (Cl. 46.1). Também a Vida de Vespasiano, depois de uma digna morte, termina com a interpretação do horóscopo sobre o tempo de vida do reino dos filhos (Ves. 25): esta Vida não se encerra em si mesma, mas é continuada na dinastia. A encerrar a Vida de Domiciano e as Vidas dos Césares, o presságio de uma gralha indica o restabelecimento do equilíbrio (Dom.23.2).

Esta procura de finais dramáticos por parte de Suetónio parece visar a catarse do leitor e incutir um sentimento de justiça. Mas, muitas vezes, não há uma explicação lógica para os acontecimentos. Não se trata apenas de culpa: também o destino pesa - e é trabalho vão tentar fugir-lhe.

Num plano mais alargado, podemos adivinhar uma gradação ao longo de várias Vidas. Porque cada biografia tende a centrar-se na pessoa do biografado, há acontecimentos que são relatados de modo diferente de Vida para Vida. No relato da morte de Tibério, a culpa de Gaio aparece como uma das suposições (Tib. 73.2), mas, na Vida de Calígula, acrescentam-se várias provas da suspeição, o que aumenta a veracidade do rumor (Cal. 12.2-3). No que respeita aos crimes de Nero, o biógrafo diz que começaram pelo assassínio de Cláudio, com o qual terá sido conivente (Nero 33.1). Este é, na verdade, um dado novo, algo surpreendente para o leitor, porque, no relato da morte de Cláudio (Cl.44), não fora insinuada a cumplicidade do sucessor, mas simplesmente a iniciativa de Agripina. Delineia-se uma espécie de destino trágico, no sentido de propensão para o parricídio, que cai sobre a dinastia júlio-cláudia e que se vai adensando, de geração em geração, até à sua perda. De modo algo semelhante, só na Vida de Domiciano é que o leitor fica a saber que este imperador mandou abandonar o irmão Tito, como se já estivesse morto, antes que ele expirasse (Dom.2.3).

Tal progressão para a catástrofe parece assentar não apenas na tradicional tara atribuída à dinastia júlio-cláudia, mas talvez também no preconceito mais genérico e pessimista de que uma degradação ocorre nas dinastias. Verifica-se um processo degenerativo que se agrava, a partir de Tibério, até provocar a ruína da dinastia fundada por Augusto. O mal é intrínseco: reside na natureza dos Césares. A natureza cruel (natura saeua) é o traço mais comum nos piores imperadores: Tibério (Tib. 57.1), Calígula, ${ }^{78}$ Cláudio (Cl. 34.1), a culminar em Nero, onde os vícios da natura se multiplicam (petulantia, libido, luxuria, auaritia, crudelitas). ${ }^{79}$ Em Nero, a degeneração é agravada pela contaminação do carácter dos Domícios (Nero 1.2). Nero assume em si os vícios paternos ampliados ao último grau, o que o leva a projectar «muitas monstruosidades que não destoam da sua natura» (Nero 43.1). Entre os Flávios, Domiciano representa a degeneração pelos vícios da ingenii natura (Dom. 3.2), como fica claro desde o primeiro momento da Vida de Vespasiano, onde se antecipam os vícios pelos

\footnotetext{
77 Vit. 9... quibus ostentis par respondit exitus.

${ }^{78}$ Cal.11; um pendor que estaria na base da sua saeuitia ingenii (Cal.27.1).

${ }^{79}$ Nero 26.1: ... sed ut tunc quoque dubium nemini foret naturae illa uitia, non aetatis esse.
} 
quais Domiciano será castigado: a avidez de dinheiro e a crueldade (Ves.1.1). Se a ganância (cupiditas) da natura de Vespasiano era polémica entre as fontes (Ves. 16.3), em Domiciano, a propensão para pilhagem (rapacitas) é um traço da essência; e a grande benevolência de Tito (Tit. 8) contrasta com a saeuitia do irmão mais novo. Com o último membro das dinastias se atinge também o clímax de uma progressão degenerativa em direcção à catástrofe. Estes são exemplos de elementos que garantem o nexo de continuidade entre as Vidas e mostram as vantagens de uma leitura integral e sucessiva dos Doze Césares.

Através do sonho de Domiciano, Suetónio encerra as Vidas dos Césares com uma nota de esperança no advento de um Estado mais afortunado e mais feliz, graças ao «desprendimento e moderação dos príncipes que lhe sucederam» (Dom.23.2). Haja ou não adulação aos Antoninos, o optimismo do biógrafo, que surge no derradeiro momento, faz assentar um Estado melhor em duas virtudes essenciais, para que o imperador se não torne um tirano rapace e cruel.

Dos três elementos que distinguem a narrativa dramática, o relevo, o movimento e a mise en scène, ${ }^{80}$ encontramos aqui presente sobretudo o terceiro. Constatamos que, ao nível das estruturas, Suetónio domina a arte da mise en scène, isto é, como, com vista a efeitos dramáticos, faz a apresentação privilegiada dos factos decisivos. Verificamos que existe uma certa progressão dramática ao longo das Vidas: ${ }^{81}$ o facto de a biografia se centrar em uma personagem particular faz com que esta possa, por vezes, transformar-se num protagonista trágico. ${ }^{82}$ Tal progressão orientada para um fim confere às Vidas uma unidade de acção semelhante, mutatis mutandis, à que Aristóteles atribui à tragédia e à epopeia..$^{83}$ Trata-se da subversão, que Ullman atribui aos historiadores antigos, da distinção aristotélica entre história e poesia, uma vez que este tipo de história relata, não só o que aconteceu, mas também o que poderia acontecer; trata também do geral, o objecto da poesia, isto é, o que é verosímil ou necessário que determinado homem diga ou faça; ${ }^{84}$ e serve-se, como a tragédia, dos sentimentos da compaixão e do temor, com vista à catharsis. ${ }^{85}$

${ }^{80}$ Assinalados por Chausserie-Laprée, J. P. 1969, 341-342. Este autor não considera Suetónio na sua análise.

${ }^{81}$ Ao contrário do que afirma, na intr. à sua ed., Ailloud, H. 1931-1932, xL: «Nul souci de la perspective, nul sens de la progression dramatique: tout est noyé dans une énumération froide, sans accent ni relief».

82 Segundo Giva, M. A. 1990, 553-555, um elemento "teatral”, herdado da historiografia de tradição latina, entra na composição das biografias e é especialmente explorado no pendor trágico das cenas de morte e na análise psicológica, que se manifesta no topos da degeneração dos comportamentos, no topos da simulação. BrUGNOLI, G. 1987, 51, compara o protagonista do género histórico-biográfico ao herói do mito, isto é, ao protagonista trágico.

${ }^{83}$ Cf. Aristóteles Po. 1459 a 17 ss.

${ }^{84}$ Cf. Aristóteles, Po. $1451 \mathrm{~b} 27$.

85 Cf. Aristóteles, Po. 1449b 27. A história trágica, segundo Ullman, B. L. 1942, 25-53, remonta com maior propriedade a Isócrates do que aos peripatéticos; tem a função de dar prazer e elevar o leitor; sofreu a influência da retórica; e, ao afastar-se da história científica moderna, ganha em sedução. 
(Página deixada propositadamente em branco) 
Parte II

O Teatro das Vidas 
É inegável a importância do teatro no Império e o seu papel na propaganda imperial. As Vidas dos Césares reflectem esta realidade, dada a frequência das alusões aos espectáculos em geral e ao teatro em particular. Suetónio parece, por vezes, estabelecer relação entre algumas Vidas e o conteúdo de dramas que são do conhecimento geral do seu tempo. ${ }^{1}$ É verosímil que queira sugerir a associação de determinados acontecimentos e palavras a topoi dramáticos que informam a consciência colectiva: lugares-comuns da comédia e da tragédia fazem parte do substrato cultural, à luz do qual um romano vê e organiza o mundo. Ter por referência as expectativas culturais do público é caminho seguro para o êxito. Suetónio aflora algumas vezes a ideia da associação da vida a uma peça de teatro, mais concretamente a um mimo: no sentido geral do mimus uitae de Augusto, ${ }^{2}$ ou no de fingimento, como o impudentissimus mimus de Tibério (Tib. 24.1). Tal contaminação não é estranha à própria historiografia. Já se queixava o próprio Tito Lívio (5.21.9) de que as narrativas históricas estavam pejadas de efabulações mais adequadas ao ambiente do teatro. Há composições trágicas baseadas em acontecimentos e figuras históricas e há narrativas históricas que parecem ter origem em representações dramáticas de determinados eventos. ${ }^{3}$

Suetónio, como vimos, não se alonga a descrever os grandes feitos históricos, que prefere resumir, mas centra a narrativa na personagem do biografado, procurando determinar os traços do carácter através de pequenas acções ou palavras. Em consequência, acaba por dar maior valor aos dramas pessoais. As Vidas resultam numa peça, com princípio, meio e fim, em que o biografado é o protagonista. O enredo está, como é natural, dependente dos factos e dos relatos das fontes, mas o biógrafo parece acentuar o dramatismo, por vezes através de uma conveniente distorção histórica. Não se relatam todos os acontecimentos e acções, mas acentuam-se, numa perspectiva mais ética que política, os que dizem respeito ao protagonista e são significativos para desenhar o seu carácter. Tal implica um duplo processo de abstracção e selecção que se aproxima do conceito aristotélico de mimese.

Já vimos que, em termos estruturais, Suetónio passa para segundo lugar a cronologia e coloca-a ao serviço da sua intenção. O método das species, com os exempla de acções e ditos, permite a elaboração de cenas, que, colocadas sucessivamente, transmitem ao leitor, como vimos no último capítulo da primeira parte, uma ideia de progressão, de modo a sugerir a evolução de um drama em vista de um fim determinado. Difícil será discernir se o dramatismo resulta da realidade histórica em si, ou das fontes, ou se é produto da intencionalidade do biógrafo na busca de uma apresentação mais artística.

${ }^{1}$ Como sugere Cizer E. 1975a, 480-485.

${ }^{2} \mathrm{~A}$ acreditar no corrector antigo do codex Parisinus 5801, $P^{2}$ (Beroaldus), correcção adoptada por Ailloud, H. 1931-1932 e Bassols de Climent, M. 1970 - Aug. 99.1: et admissos amigos percontatus, 'ecquid iis uideretur mimum uitae commode transegisse'. Nos codd. encontra-se minimum, pelo que Iнм, M. 1908, apresenta uma solução de compromisso mi[ni]mum.

${ }^{3}$ Uma fonte importante será a fabula praetexta. Vide Wiseman, T.P.1978,1-16 ; Rodrigues, N. S. 2005, 216. 
Suetónio apresenta uma personagem principal - o imperador -, em volta do qual se organiza a Vida; procura desenhá-la directamente, através das rubricas descritivas, e indirectamente, através das suas acções e dos seus ditos mais significativos. Preocupa-se em representar as diversas facetas do seu carácter e a forma como estas contribuem para o avanço da acção. Com o protagonista contracena uma galeria de outras personagens, mas que aparecem apenas na medida em que têm importância para a caracterização da personagem principal. Podemos até encontrar um esboço de coro na uox populi, pela forma como comenta as acções do protagonista ou interage com ele.

Depois da leitura das diversas Vidas, o leitor fica com a ideia de que há uma estrutura que, no essencial, se repete. No conjunto das Vidas, podemos considerar três grandes ciclos: um primeiro, constituído pelo conjunto das Vidas da dinastia Júlio-Cláudia (primeiros seis livros); um segundo, constituído pelos três imperadores fugazes de 68-69 - Galba, Otão, Vitélio; e um terceiro constituído pelas três biografias dos Flávios. Parece sugerido um arranjo em trilogia, pois cada um destes três ciclos constitui também, em si, uma trilogia. Se a primeira não comporta apenas três Vidas, é, no entanto, constituída por um número múltiplo de três. 
(Página deixada propositadamente em branco) 


\section{A ASCENSÃo: SPES IMPERII}

\subsection{Ascensão gloriosa}

Depois da apresentação dos antepassados de cada biografado e da referência ao local e à data de nascimento, o biógrafo introduz um relato, mais ou menos extenso, da carreira política e das realizações que antecedem a ascensão ao trono imperial. A narrativa da infância e juventude dos imperadores, embora elaborada numa perspectiva mais cronológica, vai incluindo pistas de análise do carácter que prenunciam o destino futuro. Há narrativas mais ou menos heróicas, mais ou menos edificantes. César, Augusto, Galba e Vespasiano são protagonistas de uma ascensão gloriosa: aparecem, de algum modo, como predestinados para uma missão importante.

\subsubsection{Júlio César: um predestinado}

A juventude de César é acima de tudo heróica. O carácter intrépido do protagonista desenha-se desde o princípio: uma ambição desmedida, que se manifesta numa contínua procura de atingir o lugar supremo. A primeira nota, a seguir à perda do pai, refere-se à sua função religiosa de flamen Dialis, que, de certo modo, o torna sagrado e intocável, como se fora pertença de Júpiter. Depois, surge a ideia da oposição a Sula e ao partido aristocrático. O carácter de predestinado manifesta-se quer na intercessão das Vestais, e dos seus aliados, que lhe conseguem o perdão de Sula, quer, depois, no vaticínio do próprio ditador sobre o perigo para o partido dos optimates: nam Caesari multos Marios inesse (Jul.1.3) («é que o íntimo de César esconde muitos Mários») - juízo que Suetónio faz claramente derivar siue diuinitius siue aliqua coniectura («ou da inspiração divina ou de um pressentimento»). Estas referências têm tanto mais importância quanto sabemos o relevo que Suetónio dá às profecias, aos sinais ominosos, aos sonhos e à religião em geral. ${ }^{4}$ Estão já patentes características que aparecem nas etapas decisivas da vida de César. Este apresenta-se como um protegido da Fortuna: o próprio tem consciência disso.

A par da sua boa estrela, surge também outra faceta que irá marcar o herói para toda a vida: a de efeminado. $\mathrm{O}$ rumor de que, enviado à Bitínia para pedir apoio, se prostituiu a Nicomedes, imediatamente seguido da alusão a feitos notáveis que lhe valeram a coroa cívica na tomada de Mitilene (Jul. 2), faz Baldwin pensar no topos do guerreiro grego valoroso e sodomita. ${ }^{5}$

A capacidade de voltar a seu favor os acontecimentos adversos é espelhada no episódio do rapto dos piratas - a quem, depois de pago o resgate, persegue e inflige o castigo com que os tinha ameaçado -, e a iniciativa do general manifesta-se em arrolar de moto próprio tropas auxiliares para expulsar da

${ }^{4}$ Cf. Plínio-o-Moço, Ep. 1.18. Vide Macé A. 1900, 59-62; Della Corte, F. 1967, 55-76; Cizek, E. 1977, 165-167; Wallace-Hadrill, A. 1984, 189-198; Baldwin, B. 1983, 359-361; Gascou, J. 1984, 444-450.

${ }^{5}$ Vide Baldwin, B. 1983, 222. 
província da Ásia o general de Mitridates. Aparecem, deste modo, agrupados em um trecho de acção rápida dois episódios diversos que contribuem para a lenda do general. Paralelamente se sabe que estava em formação a sua eloquência: o rapto deu-se quando se dirigia para a ilha de Rodes, a fim de ter lições de Apolónio Mólon. ${ }^{6}$ A decisão de ajudar as cidades aliadas ${ }^{7}$ é tomada na ilha, preocupado em não parecer ocioso. Assim apresenta Suetónio o guerreiro culto, predestinado e sedento de acção. Acresce a habilidade do político, quando obteve o cargo de tribuno militar: a busca do apoio popular é visível no restabelecimento do poder tribunício, limitado por Sula (Jul.5).

Estas características do herói culto e valente são as de um rei mítico. Tal pretensão é confirmada pelo elogio fúnebre que César faz de sua tia Júlia, no qual destaca a ascendência real e divina da família. Suetónio transcreve um excerto onde o próprio César exalta o carisma da realeza, resumido na frase final: ${ }^{8}$ Est ergo in genere et sanctitas regum, qui plurimum inter homines pollent, et caerimonia deorum, quorum ipsi in potestate sunt reges (Jul. 6.1). («'É inerente à estirpe a santidade dos reis, que entre os homens têm maior poder, e a sacralidade dos deuses, em cuja autoridade se fundamentam os próprios reis'»). Trata-se da fundamentação genealógica das pretensões manifestadas mais tarde (Jul. 79). Este passo supre, de algum modo, a rubrica dos antepassados (que se perdeu), porque acena em retrospectiva ao carácter ambicioso de César. É o próprio biografado que se insere na linhagem real e divina.

Outro episódio vem revelar os objectivos do biografado. César, questor na Hispânia Ulterior, junto ao templo de Héracles, em Gades, chora perante uma estátua de Alexandre, por não ter feito nada de memorável, embora tivesse a idade em que o Macedónio já dominava o mundo. Suetónio nota que César decidiu regressar imediatamente (continuo) a Roma ad captandas quam primum maiorum rerum occasiones in urbe ("para aproveitar quanto antes as oportunidades de maiores feitos na Urbe»). Paralelamente, na noite anterior, sonhara que violava a mãe (Jul. 7.1-2). Não será por acaso que estes acontecimentos vêm juntos em Suetónio, pois, em Plutarco, surgem em datas e circunstâncias diferentes e separados entre si. ${ }^{9}$ César é colocado junto a um herói mítico (Héracles) e um herói histórico (Alexandre). Tomado em conta o

${ }^{6}$ Jul. 4.1. Plutarco, Caes. 1.8, coloca o rapto no regresso da Bitínia, em 78 a.C. Suetónio, ao situá-lo na viagem para Rodes, em 75-74 a.C., é mais plausível. Sabemos por Plutarco, Caes. 2.6, e Veleio, 2.42.3, que o governador da Ásia, a quem César pede autorização para castigar os piratas, era Iunco. Ora este governou a Ásia em 74. Vide com. Butler, H. E. \& CARY M. 1927, 46-47; Canfora, L. 2000, 9-14; Baldwin, B. 1983, 222.

${ }^{7}$ De que Suetónio, Jul. 4.2, é a única fonte. Vide Canfora, L. 2000,13.

${ }^{8}$ Vide Canfora, L. 2000, 17-18.

9 1) Plutarco, Caes. 11.5-6, e Díon Cássio, 37.52.2, situam a comparação com Alexandre durante a pretura; Suetónio, Jul. 7.1, situa-a durante a questura, o que é mais provável, se se tomar por medida a igualdade com a idade de Alexandre: a questura atingia-se aos 30 anos e a pretura aos 40.2) Plutarco situa o acontecimento vagamente na Ibéria e não insiste no particular do templo de Héracles. 3) Para Plutarco, o pranto resulta da leitura de uma história de Alexandre e não da visão da estátua. 4) Plutarco, Caes. 32.9, situa o sonho da violação da mãe na noite antecedente à passagem do Rubicão. Vide com. de Butler, H. E. \& CARy, M. 1927, xv e 51; CANFora, L. 2000, 19-20. 
valor que Suetónio dá aos presságios oníricos, a sacralidade do lugar faz com que o sonho da violação da mãe seja aqui uma espécie de incubatio. Na mente do leitor, forma-se logo, por associação de ideias, a imagem de um Édipo: pois com este entra na literatura o sonho do incesto com a mãe. ${ }^{10}$ Será uma profecia post euentum: dada a cultura literária de César, podemos pensar que seja uma criação do próprio, para favorecer a sua aura mítica. ${ }^{11}$ Suetónio acata o episódio como pressago, mas não antecipa uma interpretação - como faz Plutarco, ao colocar o sonho na passagem do Rubicão - : prefere transmitir a explicação dos intérpretes: a mater subiecta seria a terra, o que lhe auguraria o governo do mundo (arbritrium terrarum). Mais tarde, o leitor ficará a saber que ele, já adulescentulus, escrevera umas Laudes Herculis e uma tragédia, Oedipus, de que Augusto proibiu a publicação. ${ }^{12} \mathrm{~A}$ associação repete-se: César é admirador de Hércules e émulo de Alexandre, mas tem comportamentos de um Édipo. Delineia-se o mito de uma personagem que vive acima do comum dos mortais, mas também se antevê a culpa de bybris que o há-de destruir.

Seguem-se cenas de acção, onde o tom se torna mais negro. Os seus feitos são apresentados como insolência de um aventureiro e demagogo ( Jul. 8-11). Sucessivos reveses, devidos à feroz oposição dos optimates, mostram a tenacidade de César e são seguidos de uma vitória estrondosa - à custa de um suborno bem generoso (profusissima largitio), como nota Suetónio - na corrida para o pontificado máximo, contra dois adversários poderosíssimos, que o excediam em muito na idade e na dignitas. ${ }^{13}$ Uma vitória em que apostara tudo: ao sair, pela manhã, dissera à mãe, pensando nas dívidas que contraíra, que não regressaria a casa senão como pontífice. A contrabalançar este sucesso, vem o agon a propósito da pena a aplicar aos cúmplices de Catilina, quando César já é pretor. De um lado, os defensores da pena capital; do outro, César, sozinho, a pedir a prisão e a confiscação dos bens. Mas o mais encarniçado opositor político, Catão, fez tombar o prato da balança para a pena capital. E César, que se continua a opor, corre o risco de ser morto por um grupo de cavaleiros: (...) ut sedentem una proximi deseruerint, uix pauci complexu togaque obiecta protexerint. Tunc plane deterritus non modo cessit, sed et in reliquum anni tempus curia abstinuit ${ }^{14}$ («... de tal modo que os que estavam próximos, todos à uma, o deixaram ali sentado sozinho; a custo, uns poucos o puderam proteger abraçando-o e interpondo as togas. Então, deveras aterrorizado, não só se

${ }_{10}$ Através de Sófocles, OT 981-982; e retomado em Heródoto, 6.107; Platão, R. 571c; Pausânias, 6.26.6. Para Artemidoro,1.79, o sonho significaria a tomada de poder; vide Della Corte, F.1989, 95-98. Segundo este autor, o pranto de César não exprimia inveja de Alexandre, mas de Pompeio, que submetera o Oriente e recebera o epíteto de Magnus.

${ }^{11}$ Vide Della Corte, F. 1967, 63.

${ }^{12}$ Jul. 56.7. Vide Cizen E. 1975a, 482: «Il est certes très caractéristique pour la pensée de César qu'il se soit penché sur un mythe, très populaire d'ailleurs, mais qui mettait en vedette le drame poignant d'un roi qui s'était fait tout seul. Pourtant Suétone n'en dit rien».

${ }^{13} \mathrm{Jul}$. 13. Servílio Isáurico e Quinto Cátulo, princeps senatus: cf. Plutarco, Caes. 7.1.

${ }^{14} \mathrm{Jul}$. 14.2. Suetónio não diz que, entre os pauci que o defenderam, estavam Curião e Cícero; cf. Plutarco, Caes. 8.2. Além disso, Plutarco, Caes. 8.5, diz que César voltou, dias mais tarde, ao senado, para se justificar. 
retirou, mas até se absteve de ir à Cúria na restante parte do ano»). Há um certo exagero na procura de maior dramatismo. Esta sessão do senado realizou-se já no final do ano, a 4 ou 5 de Dezembro. Por omissão, Suetónio parece querer sugerir que foi longa a ausência de César. Também o abandono dos lugares por parte dos senadores que o rodeavam é suspeito, como uma reminiscência do que aconteceu com Catilina. ${ }^{15}$

Continua a luta contra a aristocracia. Depois de mais um revés, ${ }^{16}$ César obtém uma grande vitória devido ao apoio da plebe. Referindo-se vagamente ao apoio a umas turbulentissimas leges, o biógrafo centra a narrativa na situação de César, suspenso do cargo de pretor pela ameaça da força das armas e refugiado na sua casa. César, contra o que era esperado, refreou uma turba, que se reunira espontaneamente para restabelecer a sua dignitas, o que lhe valeu o agradecimento do senado e a revogação do decreto que o suspendera. ${ }^{17}$ Manifesta-se já a característica magnanimidade, que torna César um ente superior aos seus inimigos e tem eco nos exemplos de clementia, apresentados mais tarde.

A argúcia de César continua a manifestar-se na forma como vira a seu favor a acusação de cumplicidade na conjura de Catilina, por apelo ao testemunho de Cícero. Suetónio, que não referiu a protecção do Arpinate quando César foi atacado pelos cavaleiros ( $\mathrm{Jul}$. 14.2), menciona agora o seu testemunho, porque a iniciativa de o interpelar é de César e demonstra a habilidade do acusado em usar em seu favor um opositor político de peso (Jul. 17). Os acusadores acabam desprovidos de crédito e castigados. A prova, confirmada por Cícero, de que César tinha dado ao então cônsul pormenores da conjura é apresentada como decisiva, mas sugere que César estava a par das manobras.

Suetónio, como é seu hábito, resume as campanhas na Hispânia à expressão «pacificada a província...», ${ }^{18}$ para se debruçar sobre a pressa de César em partir (por medo de um processo judicial enquanto priuatus, ou para ajudar aliados) e sobre a pressa em regressar a Roma, para pedir o triunfo e o consulado. Sofre novo revés quando pede uma excepção à lei que o obrigava a entrar na Urbe como priuatus para concorrer ao senado: como muitos se opuseram, teve de adiar o triunfo, para se apresentar às eleições.

A formação da aliança que ficou conhecida como primeiro triunvirato é tratada pelo biógrafo como a consequência de ter sido atribuída aos novos cônsules (César e Bíbulo) uma província sem importância, designada por siluae callesque.$^{19}$ Foi esta iniuria que o levou a procurar o apoio de Pompeio, com quem reconciliou também Crasso, e a dar início à societas com aqueles dois generais.

${ }^{15}$ Vide com. de Butler, H. E. \& CAry, M. 1927, 57-58.

${ }^{16}$ Em que se vê obrigado a retirar a acção contra Quinto Cátulo por oposição dos optimates (Jul. 15). César queria retirar-lhe a honra da restauração do Capitólio e transferir a tarefa in alium (para Pompeio).

${ }^{17}$ Jul. 16.2. Para este pormenor, Suetónio é a única autoridade. Vide com. Butler, H. E. \& CARY, M. 1927, 59-60.

${ }^{18}$ Jul. 18.1: Pacataque prouincia.... As campanhas são relatadas por Plutarco, Caes. 12.

${ }^{19}$ Jul 19.2. A designação é de interpretação obscura: há quem sugira que se trata da Córsega, mas parece pouco provável. 
Uma característica de César, e motivo da narrativa, é o desrespeito dos auspícios e dos direitos dos magistrados: expulsa, pelas armas, o colega Bíbulo do Foro, por este, quando da promulgação de uma lei agrária, protestar (segundo o seu direito de spectio) que os augúrios não eram favoráveis. E Bíbulo, comenta o biógrafo com espírito, limita-se a ficar em casa a emitir edictos em que afirma que os augúrios não são favoráveis. Suetónio sugere ainda o ridículo a que César expôs Bíbulo com os comentários anedóticos do povo (Jul. 20.1-2).

A narrativa torna-se ainda mais negra com a prática terrorista de César: expulsa da Cúria e prende Catão; intimida Lúcio Luculo; passa Clódio dos patrícios para a plebe, para alvejar Cícero; simula, para atingir os opositores, uma conspiração para assassinar Pompeio, mas, como o delator subornado se engana em alguns nomes, César trata de o envenenar (Jul. 20.3-5). Estas irregularidades são determinantes, porque constituirão uma das causas da guerra civil: César não poderá, mais tarde, apresentar-se como priuatus sem correr o perigo de ter de responder por elas.

Depois de conseguida, por intervenção do sogro e do genro, ${ }^{20}$ a província que desejava, a da Gália, que lhe proporcionaria matéria para um triunfo, César mostra-se insolente. A situação é de comédia:

Quo gaudio elatus non temperauit, quin paucos post dies frequenti curia iactaret, inuitis et gementibus adversaris adeptum se quae se concupisset, proinde ex eo insultaturum omnium capitibus'; ac negante quodam per contumeliam facile hoc ulli feminae fore, responderit quasi adludens: 'in Suria quoque regnasse Sameramin magnamque Asiae partem Amazonas tenuisse quondam' (Jul. 22.2).

«Arrebatado por esta alegria, não se conteve: poucos dias depois, com a Cúria apinhada, vangloriou-se de, 'contra a vontade e os lamentos dos opositores, ter conseguido o que desejava, e que por isso, a partir daí, iria abusar de todos eles'. A um indivíduo que, por afronta, lhe respondia que tal atrevimento não seria fácil para uma mulher, respondeu ele, como que a brincar: 'Também na Síria reinou Semíramis e outrora as Amazonas dominaram grande parte da Ásia’».

A ofensa parece pouco compatível com o carácter de César. ${ }^{21}$ No entanto, havia muitas testemunhas: foi pronunciada frequenti curia. ${ }^{22} \mathrm{~A}$ expressão insultaturum omnium capitibus tem um segundo sentido obsceno, ${ }^{23}$ que melhor

${ }^{20}$ Jul.22.1. Trata-se de Calpúrnio Pisão e Pompeio, que vinculara com alianças matrimoniais: casara com Calpúrnia, filha do primeiro, e dera a filha Júlia em casamento ao segundo. Cf. Plutarco Caes. 21.5-6.

${ }^{21}$ No seu com., Butler, H. E. \& CARY, M. 1927, 69, nota que a truculência não é uma característica de César.

${ }_{22}$ Por outro lado, juntamente com as palavras, também se pode inventar o contexto. Mas Suetónio encontraria estas frases célebres de César numa fonte segura: Asínio Polião; vide com. de Butler, H. E. \& Cary, M. 1927, 69; Canfora, L. 2000, 100-101.

${ }^{23}$ Semelhante a capitibus... illudere de Tib. 45. Caput é usado por os em sentido obsceno (Marcial, 14.74.2). Vide com. de Butler, H. E. \& Cary, M. 1927 (n. supl.de Townend, G. B. 1982), 158. 
explica a afronta do interlocutor, e que evoca a relação com Nicomedes e os costumes efeminados de César.

A partir daqui, a intriga política alterna com as acções militares. Feitas as alianças em Roma, para garantir que só seriam eleitos os magistrados que o defendessem (Jul. 23.2), e realizado o encontro, na cidade de Luca, com Pompeio e Crasso, para garantir que estes, e não Domício Aenobarbo, seriam cônsules no ano seguinte (55 a.C.), e the prolongariam o imperium por cinco anos, temos finalmente o general e o conquistador em acção, a recrutar e exercitar soldados na Gália e a fazer a guerra sob a suspeita e oposição do senado, que chega a pensar em entregá-lo aos inimigos. ${ }^{24} \mathrm{~A}$ narração de nove anos da campanha da Gália concentra-se num resumo das vitórias e das raras derrotas. ${ }^{25}$

De seguida, com uma indicação cronológica (Eodem temporis spatio), Suetónio introduz a notícia da morte da mãe, da filha e da neta (Jul.26.1) e a intriga política:liberalidades a expensas próprias e públicas (Jul.26.2-3); sistema de alianças internas ( $J u l .27)$ e externas (Jul.28.1). A mudança no decurso dos acontecimentos opera-se por intervenção do cônsul Marco Cláudio Marcelo, que propõe ao senado substituir César, antes do tempo, licenciar o exército, recusar o privilégio da sua candidatura a um segundo consulado in absentia, ${ }^{26}$ com a conivência de Pompeio, e retirar o direito de cidadania aos colonos de César (Jul. 28.3).

É reveladora a frase que César repete: difficilius se principem ciuitatis a primo ordine in secundum quam ex secundo in nouissimum detrudi $2^{27}$ («mais dificilmente o expulsariam do primeiro para o segundo lugar entre os cidadãos do que do segundo para o último»). Para atingir os fins, usa os seus agentes que estavam em Roma: um dos cônsules e os tribunos da plebe. Prepara-se o cenário da guerra civil. César, a princípio irredutível, acaba por mostrar alguma flexibilidade ao rogar ao senado que lhe mantenha o priuilegium que o povo the outorgara e ao fazer propostas de conciliação, ${ }^{28}$ cedências que contribuem para a construção da imagem de um clemente. Este braço de ferro levará César ao Rubicão e, a partir daí, ao poder supremo: o seu, e mais tarde, o dos outros Césares. Trata-se de uma ascensão movimentada, onde se destaca o espírito de iniciativa, uma ambição desmedida e a capacidade de arriscar. Outros Césares chegarão ao poder por azar, de forma passiva ou até contra a vontade. Mas César é o motor inicial que conduz ao Império.

\subsubsection{Octávio: o cruel vingador de César}

O biógrafo coloca especial cuidado na indicação da data e lugar do nascimento, mas, ao mesmo tempo, mostra-se geralmente sóbrio nesta parte. No entanto, em alguns casos, parece deixar-se impressionar pelas circunstâncias

\footnotetext{
${ }^{24}$ Jul. 24. Vide Luibheid, C. 1970 88-94.

${ }^{25} \mathrm{Jul}$. 25. Ao passo que Plutarco, Caes.15-28, apresenta um longo relato.

${ }^{26}$ Jul. 28.2. César tinha conseguido este privilégio (cf.Jul.26.1).

${ }^{27} \mathrm{Jul}$. 29.1. Palavras retiradas possivelmente de Asínio Polião, porque congruentes com as motivações de César, segundo a perspectiva deste autor: vide CANFORA, L. 2000, 145-146.

${ }^{28}$ Jul. 29.2; vide Canfora, L. 2000, 147.
} 
maravilhosas ou adversas que envolveram o evento e que parecem ter significado para um interpretação geral de cada Vida. O nascimento de Augusto é fortemente marcado pelo sagrado. Conta-se que Octávio nasceu paulo ante solis exortum («pouco antes do nascer do sol»), facto que adquirirá significado mais à frente. Um santuário foi erigido no local e um sentenciado, ao pedir clemência, apela ao facto de ser proprietário do lugar que o Diuus Augustus tocou ao nascer (Aug. 5). Do mesmo modo, a casa onde foi criado ganha uma atmosfera de íncubo, que se torna em fonte de escrúpulo religioso para quem entra, apesar de, paradoxalmente, o local ser modesto (permodicus et cellae penuariae instar). Está patente a concepção religiosa do temor perante a divindade, através do castigo de um culpado de hybris: um proprietário que - seu forte seu temptandi causa - tentou pernoitar na casa, foi expulso por uma subita uis et incerta e encontrado semiânime diante da porta, juntamente com a cama. ${ }^{29}$ Nenhum outro imperador merece tal tratamento no que respeita ao nascimento. Ora esta força oculta e o horror religioso estão continuamente presentes ao longo da Vida, nas crenças e nos temores de Augusto. O carácter divino e humano da personagem caminham a par, em dois planos. Isto equivale a dizer que a tarefa da elevação do principado não é meramente humana: é preparada pelos deuses, muito antes do nascimento de Augusto.

$\mathrm{Na}$ apresentação dos nomes que adoptou, há uma gradação do mais humano para o mais divino, o que corresponde também à ordem cronológica de assunção. Primeiro, o nome que lhe deram em criança, Turino, ${ }^{30}$ depois o de Gaio César e finalmente o de Augusto. Depois da hesitação entre este nome e o de Rómulo, prevaleceu o de Augusto pelo seu significado religioso e também por estar ligado à fundação de Roma, que segundo os Anais de Énio, se processou com um Augusto Augúrio. ${ }^{31}$

A perda do pai faz lembrar o início da Vida de César. Uma perda assim precoce (Octávio tinha apenas quatro anos) pode significar uma espécie de emancipação forçada. Acresce que esta informação é o primeiro elemento de uma narrativa rápida que resume toda a vida e vem seguida do elogio fúnebre da sua avó Júlia, e irmã de César - um paralelo com o que César faz para a sua tia Júlia. Podemos supor que o conteúdo seria semelhante: a ascendência divina e real. Esta função, que marca o primeiro aparecimento em público, antecede imediatamente a narrativa da assunção da toga viril e subsequente vida activa. $\mathrm{O}$ biógrafo faz ressaltar a morum indoles e a industria: nem a doença, nem os caminhos infestados de inimigos, nem um naufrágio - Neptuno é o seu deus oponente - o impedem de se reunir a César. ${ }^{32}$ São características que

${ }^{29}$ Aug. 6. Vide Picón García, V. 1984, 324-325.

${ }^{30}$ Aug. 7.1. Nome dado pelo lugar do seu nascimento ou porque o pai, Gaio Octávio, foi vencedor dos restos dos bandos de Espártaco e Catilina sitiados em Túrio: cf. Aug. 2.1. Vide VAsto, F. Di 1985, 39-40.

${ }^{31}$ Aug. 7.2. E Suetónio tem oportunidade de fazer considerações que dão voz ao grammaticus: explica a etimologia provável de Augusto.

32 Aug. 8.1. Segundo Magnino, D. 1986, 501-504, a proximidade semântica com Nicolau de Damasco (Vit.Caes. 24), por um lado, e a divergência na menção do naufrágio (omitido naquele biógrafo de Augusto), por outro, mostram que Suetónio utilizou, neste passo, uma fonte 
César aprecia vivamente naquele jovem e serão determinantes para o futuro imperador. Depois da morte de César, é a imediata reivindicação da herança que abre a Octávio o caminho para o poder, de que Suetónio faz agora um brevíssimo resumo (Aug. 8.3).

Suetónio inicia a exposição per species, ${ }^{33}$ com a descrição das guerras civis, onde os actos praticados revelam o homem. Vingar a morte de César é a causa inicial de todas as guerras em que então se envolve. ${ }^{34}$ Mas o biógrafo sugere que é tortuoso o caminho para atingir aquele objectivo. Um carácter calculista e pragmático se revela nas manobras políticas: como Marco António se mostra um oponente às suas ambições, Octávio transfere-se para o partido dos optimates; prepara um atentado contra a vida de António; vai em auxílio de Décimo Bruto, um dos assassinos de César, cercado em Mútina. Mostra-se covarde na primeira batalha, segundo António, e ousado na segunda (Aug. 10. 2-4). Fica também a forte suspeita da sua responsabilidade na morte dos cônsules Hírcio e Pansa, para aceder mais facilmente ao controlo da República (Aug. 11). Depois, com o pretexto de que os senadores o caluniavam e ameaçavam com um jogo de palavras - quasi alii se puerum, alii ornandum tollendumque iactassent $t^{35}$ ("por bradarem uns que era um rapazola e outros que se devia ataviá-lo e elevá-lo ao céu») -, abandona estrategicamente a causa dos optimates e, para ostentar a sua mudança, multa e desterra os cidadãos de Núrsia pelo facto de terem erigido uma estátua aos caídos em defesa da liberdade, isto é, na luta por Octávio e pelo senado, contra António (Aug. 12). Através de uma deslocação cronológica, ${ }^{36}$ Suetónio torna Octávio mais odioso, ao castigar os seus antigos apoiantes, só porque mudou de partido.

A constituição do segundo triunvirato (cum Antonio et Lepido societas) parece subordinar-se ao objectivo da vingança de César, que se completa depois da batalha de Filipos e sem moderação. Diz Suetónio que Octávio enviou a cabeça de Bruto para Roma, para ser lançada aos pés da estátua do tio-avô, e ultrajou prisioneiros de elevada estirpe.$^{37} \mathrm{O}$ pormenor da cabeça faz pensar no cumprimento de um voto macabro. Suetónio parece empenhado em oferecer a versão mais trágica. Plutarco diz que António concedeu funerais dignos a Bruto; ${ }^{38}$ e Díon Cássio, por sua vez, refere que António presidiu aos funerais e que a cabeça de Bruto foi enviada para Roma (onde nunca chegou, devido a

comum: a autobiografia de Augusto.

${ }^{33}$ Aug. 9.1: Proposita uitae eius uelut summa parte<s> singilatim neque per tempora, sed per species exequar.

${ }^{34}$ Aug. 10.1. Vide Baldwin, B. 1983, 248.

${ }_{35}$ Aug. 12. Suetónio envolve Cícero na designação genérica alii para designar aqueles que chamavam puer a Octávio: Att. 16.8.1; 16.11.6. De resto, a expressão é eco de laudandum adolescentem, ornandum, tollendum da autoria de Cícero, Fam. 11.20.1. MсDевмотт, W. C, 1972, 497, faz notar que Cícero nunca aparece em Suetónio, senão como autoridade final incontestada.

${ }^{36}$ Díon Cássio, 48.13.6, coloca o episódio no contexto da guerra de Perúsia, em que os habitantes de Núrsia seriam opositores, não aliados. Vide GAscou, J. 1984, 194-196.

${ }^{37}$ Aug. 13.1. Em contrapartida, não menciona o suicídio de Cássio no termo da primeira batalha [cf. Tito Lívio $(P e r)$ 124.], talvez porque tal facto descentrasse a acção.

${ }^{38}$ Plutarco, Ant. 22.7 e Brut. 53.3. Vide Gascou, J. 1984, 178. 
um naufrágio), sem referir a responsabilidade de Octávio. ${ }^{39}$ É também de notar a omissão do naufrágio por parte de Suetónio, que assim pretende sugerir que a vingança foi completa e a acção centralizada na pessoa de Octávio. As atitudes seguintes de Octávio são de clara impiedade, ilustrada com vários exemplos. ${ }^{40}$ A crueldade foi tal, que os restantes condenados, ao serem levados para a morte, o que é significativo, embora saudassem António como imperator, injuriaram Octávio (Aug. 13.2). O leitor começa a sentir que o herdeiro de César levava a vingança longe de mais. Esta fase da Vida é bastante negra. Mais à frente, no elenco das obras públicas, Suetónio nomeia em primeiro lugar o templo a Marte Vingador e esclarece que se tratava de um voto feito por altura da guerra de Filipos, desencadeada para vingar o pai adoptivo (Aug. 29.1-2).

$\mathrm{O}$ biógrafo torna presente a ameaça constante da morte, ao afirmar que muitos perigos estiveram a ponto de ditar o fim de Octávio, quer antes, quer durante a guerra de Perúsia: foi salvo por duas vezes em situação limite. Depois de mandar expulsar um soldado que se sentara nos lugares reservados aos cavaleiros no teatro, os inimigos de Octávio propagaram o rumor de que ele tinha mandado executar o soldado, o que provocou a indignação dos militares. E Suetónio, mais dramático que Apiano, ${ }^{41}$ diz que Octávio foi salvo no último momento, porque o soldado apareceu são e salvo. Outra vez, ao oferecer sacrifícios junto aos muros de Perúsia, quase foi apanhado por uma surtida de um grupo de gladiadores (Aug. 14). Mas nem esses perigos o fizeram moderar-se. A gradação atinge o auge:

Perusia capta in plurimos animaduertit, orare ueniam uel excusare se conantibus una uoce occurrens 'moriendum esse'. Scribunt quidam trecentos ex dediticiis electos utriusque ordinis ad aram Diuo Iulio extructam Idibus Martiis hostiarum more mactatos. ${ }^{42}$

«Depois da tomada de Perúsia, tomou duras providências contra muitos. A quem tentava pedir perdão ou desculpar-se replicava com uma única sentença: 'é preciso que morras'. Relatam alguns que escolheu trezentos dos que se renderam, de uma e outra ordem, e os imolou nos Idos de Março, junto ao altar erigido ao Divino Júlio, como é costume fazer com os animais dos sacrifícios».

${ }^{39}$ Díon Cássio, 47.49.2. Vide Gascou, J. 1984, 183.

${ }^{40}$ A um vencido que lhe suplicava a graça de ser enterrado, respondeu que «isso ficaria a cargo das aves»; a um pai e um filho que lhe pediam que lhes fossem poupadas as vidas, mandou-os tirar à sorte ou micare (jogo popular a que os italianos chamam a "morra"), para ver a qual dos dois concederia essa graça; depois assistiu à morte de ambos, pois que o filho se suicidou, ao ver que o pai dera a vida por ele. O episódio de tirar à sorte entre o pai e o filho é colocado por Díon Cássio, 51.2.5-6, depois da batalha de Áccio, em contexto que não é hostil a Octávio, com indicação do nome das vítimas, o que faz suspeitar que o erro de cronologia será de Suetónio; vide Gascou, J. 1984, 183-185.

${ }^{41}$ Apiano, $B C$ 5.2.15. Este autor pretende mostrar até onde foi a arrogância dos soldados, enquanto Suetónio quer mostrar a gravidade do perigo que Octávio correu: vide GAscou, J. 1984, 191-192.

${ }^{42}$ Aug. 15. Cf.Díon, 48.14.4. Suetónio é mais severo para Octávio: omite o perdão concedido a Lúcio António e acrescenta a nota moriendum esse que não vem em Díon; vide GAscou, J. 1984, 197. 
O deus poderia sentir-se apaziguado. Mas a Fúria está descontrolada. A ambição do jovem exacerba-se e deixa atrás de si um rasto de morte. Torna-se megalómano nas suas vitórias. Não poupa os oponentes: nem os homens, nem os deuses.

$\mathrm{Na}$ guerra da Sicília, vence Sexto Pompeio, entre Milas e Náuloco; mas, na hora de começar o combate, é acometido de um sono profundo. Por isso, António o acusa de falta de coragem (Aug. 16.2-3). Este sono seria realmente pouco dignificante, se não fosse decalcado de uma anedota semelhante que se conta a propósito de Alexandre Magno, na véspera da batalha de Gaugamelos. ${ }^{43}$ Suetónio deveria conhecê-la, mas omite o confronto. De resto, já Júlio César (como tantos outros generais) sonhava igualar Alexandre. São-lhe ainda imputadas palavras e atitudes ímpias: quando a tempestade destruiu a frota, Augusto disse que venceria, mesmo contra a vontade de Neptuno e retirou a imagem do deus da procissão dos jogos que se seguiram. Suetónio, para sublinhar o risco que Octávio correu nessa guerra, faz imediatamente saber que nunca, como então, ele se viu exposto a plura ac maiora pericula. Segue-se nova descrição de situações em que esteve muito perto de ser capturado e morto por um escravo. Mas, no fim, Octávio vence, e Lépido, que fizera exigências, é exilado depois de ter suplicado pela vida (Aug. 16.3-4). Descartado este colega, resta a incerta aliança com António (Aug. 17.1).

A ideia que se vai incutindo no leitor é de que Augusto perde batalhas, mas, no final, ganha a guerra. Os traços de falta de moderação e crueldade constrastam com a clemência do futuro príncipe.

\subsubsection{Galba: o destruidor da dinastia júlio-cláudia}

Os sucessores de Augusto (Tibério, Calígula, Cláudio e Nero) sobem ao poder por sucessão dinástica. $\mathrm{O}$ aparecimento de Galba justifica-se com a necessidade de destronar a família júlio-cláudia que se tinha tornado insustentável. À nobreza da família deste general juntam-se os presságios.

Depois de fornecer os dados relativos ao nascimento, por referência aos consules e ao lugar (Gal.4.1), Suetónio entra imeditamente na descrição dos presságios, que nesta Vida se multiplicam ${ }^{44}$ e que, desde cedo, fazem de Galba um predestinado para o império, mas em idade avançada. Um dia em que fora

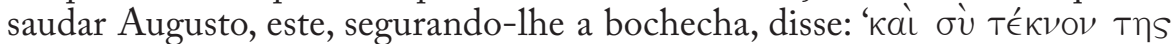

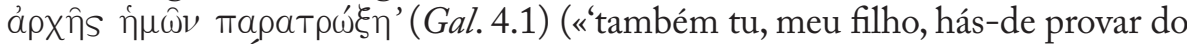
nosso poder'»). É significativo que Suetónio atribua ao fundador do principado um presságio que tanto Tácito como Díon Cássio atribuem a Tibério, ${ }^{45}$ mas mais espantoso é que ponha na boca de Augusto as últimas palavras de César

${ }^{43}$ Plutarco, Al. 32. Suetónio combina um relato da propaganda de Octávio com um da contrapropaganda do adversário: as insinuações de António acerca do alegado medo do seu rival. Vide Franco, C. 1989, 257-264.

${ }_{44}$ Dezasseis, entre os de elevação e de queda do príncipe, como nota Gascou, J. 1984, 447-450.

${ }^{45}$ Cf. Tácito, Ann. 6.20.2, e Díon Cássio, 57.19.4. 


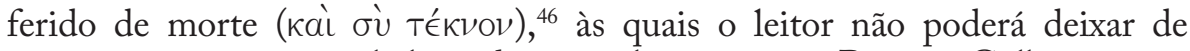
associar o vaticínio, estabelecendo assim ligação entre Bruto e Galba, entre o assassino de César e o principal agente do fim da dinastia júlio-cláudia. ${ }^{47} \mathrm{O}$ facto de ter sobrevivido sob Tibério fica a dever-se ao facto de este saber que Galba só em idade avançada seria imperador: 'uiuat sane', ait, 'quando id ad nos nibil pertinet"48 (“Que viva à vontade - diz ele -, já que isso a nós em nada nos afecta'»). Na preparação da revolta contra Nero, Galba toma como felicíssimo o facto de uma mula ter parido, fenómeno que outros esconjuravam como abominável, porque, certa vez, o seu avô, perante o vaticínio de que o poder soberano seria dado à sua família, mas numa época tardia, respondeu, incrédulo e a gracejar, com um provérbio: 'sane' inquit 'cum mula peperit' ("pela certa disse ele - quando uma mula tiver parido"»). ${ }^{49}$ Nesta perspectiva, a chegada de Galba ao império equivale à realização de um adynaton, tarefa que só os deuses podem levar a cabo. $\mathrm{O}$ destino de Galba cumpre-se entre o favor e desfavor da Fortuna. Depois de assumir a toga viril, a deusa aparece-lhe em sonhos a reclamar hospitalidade diante da sua porta. Ao despertar, Galba encontra uma estátua da deusa à entrada e consagra-lhe uma divisão da casa na propriedade de veraneio de Túsculo. ${ }^{50} \mathrm{~A}$ deusa irá abandoná-lo mais tarde (Gal.18.2).

Galba aparece como um homem íntegro e completo. É com admiração que Suetónio o apresenta atreito à observância dos antigos costumes ( Gal. 4.4) e culto (dedica-se aos estudos das humanidades e do direito). Cumpre o dever cívico do matrimónio, mas, ao perder a esposa, Lépida, permanece in caelibatu, apesar das solicitações de Agripina (Gal.5.1). À nobreza de família e aos sinais divinos junta-se agora a sua posição na corte, manifesta na veneração por Lívia Augusta (Gal.5.2), e a integridade de carácter, qualidades necessárias num príncipe. Suetónio, ao contrário do que é seu hábito, coloca estas rubricas na primeira parte da biografia, isto é, antes da tomada do poder: por um lado, Galba chegou ao império em idade avançada; mas, por outro, esta disposição

${ }^{46}$ Cf. Jul. 82.3. Arnaud, P. 1998, 57 61-71, diz que deveria tratar-se da adaptação, a julgar pela métrica atribulada de um verso grego então vulgarizado (mas que Díon não conhecia, visto que o traduz para grego a partir do latim presente nas fontes). $O$ verbo de fecho (que significa

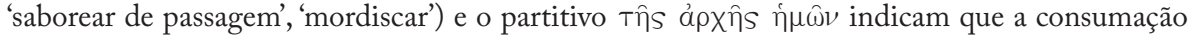
do poder será efémera.

${ }^{47}$ Vide Poulle, B. 1997, 248-249. Segundo este autor, «Par le jeu littéraire d'écho interne, il [Suétone] donne un bon reflet de la duplicité de la propagande de Galba, qui d'un côté se présentait comme l' héritier moral d'Auguste et de l'autre mettait en avant le thème de la libertas restituta.» $\mathrm{O}$ lema da libertas restituta figurava entre as legendas das moedas cunhadas por Galba, sem que isso, no entanto, faça dele um restaurador da República.

${ }^{48}$ Gal. 4.1. Cf. Díon Cássio, 57.19.4.

${ }^{49}$ Gal. 4.2. Cf. Díon Cássio, 54.1.3. Parece-nos uma elaboração da propaganda de Galba, para virar a favor do general um prodígio que, devido à superstição, poderia ameaçar o moral das tropas. Alguns militares hesitavam em aderir à sublevação. Já César procurava voltar os presságios a seu favor: cf. Jul. 59.

${ }^{50}$ Gal. 4.3. Díon Cássio, 54.1.2, coloca este sonho no período da revolta contra Nero. Será mais uma efabulação da propaganda na altura em que tentava conquistar o poder ou uma história posterior, elaborada a partir da devoção de Galba pela deusa Fortuna. Durante o principado, a Fortuna é, com a Vitória, um preeminente atributo da casa imperial; vide com. Murison, Ch. L. 1992, 35. 
permite ao biógrafo congregar estes aspectos favoráveis na primeira parte da vida, deixando os mais negros para o final.

O curriculum, favorecido pelo destino e pelas suas qualidades de carácter, é ilustrado com aspectos curiosos. $\mathrm{O}$ facto de atingir as honras antes do tempo legal ${ }^{51}$ contribui para o aproximar dos príncipes anteriores. Exerceu o consulado entre o do pai de Nero e o do pai de Otão, uelut praesagium insequentis $\operatorname{casus}^{52}$ («como um presságio do que aconteceria mais tarde»). Colocado por Calígula à frente do exército da Germânia, em lugar de Gétulico, restabeleceu imediatamente a disciplina, de tal modo que se difundiu pelo acampamento o verso: 'disce miles militare: Galba est, non Gaetulicus' (Gal. 6.2) («Aprende, tropa, a andar na tropa: este é Galba, não Getúlico»). O próprio Galba, modelo de general, dirige os exercícios militares e mantém a boa forma física: chega a correr ao lado do imperador durante uma distância de vinte mil passos. ${ }^{53}$ Abona seu favor o facto de se não mostrar ambicioso. Depois da morte de Gaio, recusa aceitar o poder, apesar de o exortarem, atitude que the valeu a gratidão de Cláudio. Este acolheu-o com tal estima, que inclusivamente adiou a expedição à Britânia devido a uma doença ligeira do general. ${ }^{54}$

Durante o seu consulado de África, Galba procedeu com seueritas e iustitia até nas mais pequenas coisas. ${ }^{55}$ Suetónio apresenta um exemplo para cada uma das qualidades. Quanto à seueritas, Galba proibiu que prestassem ajuda a um soldado que vendera a parte da ração que restava, e este acabou por morrer de fome. ${ }^{56}$ Tal severidade antecipa a futura crueldade. Quanto à iustitia, conta-se a história de um julgamento digno de Salomão para determinar a propriedade

${ }^{51}$ Gal. 6.1. Afirmação considerada estranha no com. de Murison, Ch. L. 1992, 40, pois havia uma idade mínima para ser candidato a cada magistratura. Esta idade mínima podia, ao abrigo da lex Papia Poppaea (9 d. C.), ser reduzida em tantos anos quantos os filhos. Se Galba obteve as magistraturas antes do tempo devido, foi graças aos filhos, que não sobreviveram; cf. Gal. 5.1.

${ }^{52}$ Como nota, no seu com., Murison, Ch. L. 1992, 42, a coincidência é ainda maior do que Suetónio afirma: Gneu Domício foi cônsul ordinário em 32; Galba em 33, Gneu Domício foi suffectus em 33 e a este sucedeu, como cônsul ordinário de 34, L. Vitélio, pai do sucessor de Otão. Cremos que tal omissão evidencia a técnica de Suetónio de centrar a narrativa no biografado. A coincidência de o pai de Vitélio suceder ao de Otão só poderia interessar às Vidas destes dois imperadores.

${ }^{53} \mathrm{Gal}$ 6.3. Não se diz que Galba foi obrigado a tal; o biógrafo só quer mostrar o vigor de Galba como legionário. Mas Suetónio dissera que Gaio (Cal. 26.2) obrigou os senadores a correrem atrás do seu carro como forma de humilhação. Do texto de Suetónio se depreende que Galba devia levar uma vida austera; vide Martin, R. 1991, 81 e 112.

${ }^{54} \mathrm{Gal}$. 7.1. Isto não quer dizer que Galba tenha participado na expedição à Britânia, como nota Barrett, A. A. 1983, 243-245. Mas, segundo Murison, C. L. 1985, 254-256, também já não estaria a comandar o exército da Germânia; teria acompanhado Cláudio de Roma até Gesoríaco, onde se sentiu doente.

${ }^{55}$ Se a iustitia é confirmada por Tácito, a afirmação da seueritas durante o proconsulado de África contrasta com o tacitiano moderate: Hist. 1.49.4. Vide com. de Venini, P. 1977, 30.

${ }^{56}$ Gal. 7.2. Segundo o com. de Murison, Ch. L. 1992, 47, esta história é absurda e revela completa ignorância do funcionamento do serviço de abastecimento do exército romano. $\mathrm{O}$ soldado pagava as suas rações e o dinheiro era descontado no salário. Logo, como legal possuidor, podia fazer o que quisesse das rações. 
de uma besta de carga: mandou levá-la com os olhos vendados ao seu habitual bebedouro e entregá-la ao litigante para cuja casa ela se dirigisse, depois de the retirarem a venda. ${ }^{57}$ Do conjunto, mais do que um justo, ressalta a imagem de um justiceiro. Depois dos êxitos na Germânia e em África, que lhe valeram a atribuição das insígnias triunfais e um triplo sacerdócio, passa a viver retirado. Mas aparece já implícito na narrativa um vício que o havia de marcar (a avidez do dinheiro): não empreendia qualquer viagem sem se fazer acompanhar de um carro carregado com um milhão de sestércios (Gal. 8.1).

Quando obteve governo da Hispânia Tarraconense, novos presságios lhe anunciaram o comando do Império. ${ }^{58}$ Mas a imagem, até agora positiva, começa a mudar à medida que Galba se vai aproximando do poder imperial. Se tivera até ao momento uma conduta quase irrepreensível, governa a província uarie et inaequabiliter. Mostra a sua tendência para a crueldade ao aplicar penas desproporcionadas. Paulatinamente, entrega-se à inércia, para não ter de prestar contas a Nero. ${ }^{59}$

\subsubsection{Vespasiano: o imperador que veio do Oriente}

Vespasiano representa a fundação de uma nova dinastia. Mas, ao contrário de César e Octávio, apresenta-se desprovido de ambição política, característica que, em certa medida, concorre a seu favor. Pelo nascimento, Vespasiano é conectado com o fundador do principado: além da indicação dos cônsules e do lugar modesto do nascimento, acrescenta-se que este ocorreu cinco anos antes da morte de Augusto. ${ }^{60} \mathrm{~A}$ indicação do biógrafo de que Vespasiano nasceu na região sabina sugere, à partida, valores positivos de frugalidade e bravura na guerra. $\mathrm{O}$ facto de não esconder as suas origens é posto, desde logo, em evidência, pela afirmação de que, já imperador, visitava frequentemente e preservava, imutável, o local onde foi criado, em casa da avó Tertula, em Cosa, na Etrúria (Vesp. 2.1). A pietas manifesta-se também na forma como conservou no coração a memória da avó ao ponto de (pormenor curioso do biógrafo), nos dias festivos, beber pela pequena taça que ela usara.

Além da origem, a carreira de Vespasiano é determinada também por total falta de ambição, o que contribui para tornar mais miraculosa a ascensão

${ }^{57} \mathrm{Da}$ brilhante carreira de Galba, Suetónio retém pormenores curiosos [elefantes funâmbulos ( Gal. 6.1); a corrida ao lado do carro de Calígula; o julgamento salomónico], que passam à frente da "grande história": vide Gascou, J. 1984, 422.

${ }_{58}$ Enquanto sacrificava, o cabelo do acólito que segurava o incenso tornou-se repentinamente todo branco, o que significava que um velho sucederia a um jovem. Um raio caiu num lago da Cantábria e foram descobertos doze machados, sinal evidente do poder supremo (Gal. 8.2).

${ }^{59} \mathrm{Gal}$ 9.1. Ao contrário de Suetónio, que fala de deterioração na actuação de Galba, as outras fontes apresentam uma visão unitária e mais favorável do comportamento do general nesta magistratura: Tácito, Hist. 1.49.4; Díon Cássio, 63.23; Plutarco, Gal. 4.1. Vide com. de Venini, P. 1977, 32.

${ }^{60}$ Vesp. 2.1. Vide com. de Cesa, M. 2000, 43. Nota, no seu com., Braithwaite, A. W. 1927, 23, que Suetónio indica habitualmente o ano do nascimento dos imperadores ou por referência aos cônsules ou a um facto histórico. Só no caso de Tibério e Vespasiano se mencionam ambos. 
ao império. Depois de assumir a toga viril, descura, durante muito tempo, envergar o laticlavo; e só os sarcasmos, os rogos ou a autoridade da mãe o convenceram a candidatar-se a tal honra. ${ }^{61}$ Apesar disso, a carreira da honras prossegue: é tribuno militar na Trácia; questor em Creta e Cirene. Candidato a edil, obtém o cargo, não à primeira vez, e, quando é eleito, não consegue melhor que o sexto lugar, isto é, o último; mas, candidato a pretor, obtém a honra à primeira e entre os primeiros. Tal sucesso parece sugerir um bom desempenho do primeiro cargo. ${ }^{62}$ Nesta altura, tentando ganhar as boas graças de Gaio, torna-se demasiado obsequioso, comportamento servil que deve ter sido alvo de muitas críticas, pois Calígula era um opositor do senado. ${ }^{63}$

Nem através do casamento Vespasiano ascende socialmente. Casa com Flávia Domitila, favorita de um cavaleiro, que depois, se tornou livre e cidadã romana a pedido de seu pai, escrivão de um questor. ${ }^{64}$ Depois da morte da mulher, retoma a antiga amante, Cénis, liberta e secretária de Antónia Menor e, quando imperador, trata-a quase como esposa legítima. ${ }^{65}$

Foi a influência do liberto Narciso que permitiu a Vespasiano, no principado de Cláudio, ser enviado, como comandante de uma legião, para a Germânia, de onde transitou para a Britânia. $\mathrm{O}$ valor do general começa a ser sustentado através da precisão numérica: participa em trinta combates; submete dois povos poderosos (e, para o biógrafo, importa mais salientar que se trata de duae ualidissimae gentes do que indicar os nomes da tribos ${ }^{66} \mathrm{e}$ mais de vinte praças-fortes. A culminar os sucessos, conquista a ilha de Véctis, contígua à Britânia.$^{67}$ Fica patente a parcialidade do biógrafo, se compararmos o tom usado neste passo com o correspondente da vida de Cláudio. Então Suetónio integrara a campanha e o sucessivo triunfo no processo de ridiculização daquele imperador: ${ }^{68}$ agora relata o mesmo empreendimento de forma a engrandecer os

${ }^{61}$ Vesp. 2.2. Sobre a interpretação controversa deste passo, vide Rossi, R. F. 1971, 166-167, Chastagnol, A. 1976, 253-256; Levick, B. 1991, 239-244; Jones, B. \& Milns, R. 2002, 44.

${ }^{62}$ Ves. 2.3. Rossi, R. F. 1971, 167-168, prefere ver neste êxito uma reacção do senado à abusiva intervenção de Calígula, quando Vespasiano era edil (cf. Ves. 5.3): o imperador, irritado com a deficiente limpeza das ruas, mandara encher de lama as vestes do magistrado.

${ }^{63}$ Rossi, R. F. 1971, 171 n. 1, sugere que, se Vespasiano tinha efectivamente o carácter que Suetónio lhe atribui, é provável que o exagero das propostas traduzisse uma subtil ironia.

${ }^{64}$ Ves. 3. Pelo nome da esposa, poderá tratar-se de um casamento entre parentes, em que, antes do prestígio, está o intuito de conservar o património familiar, como sugere LEvick, B. 1999b, 12, na sua monografia sobre Vespasiano.

${ }^{65}$ Provavelmente, pela influência de Cénis junto de Antónia, Vespasiano pôde avançar na carreira das honras. $\mathrm{O}$ retomar da ligação à liberta deve ter permitido o acesso de Vespasiano ao grupo dos cortesãos de Calígula por volta de 38 d. C., como sugere Levick, B. 1999b, 11.

${ }^{66}$ Os Belgas e os Atrébates ou os Durotriges; vide com. Braithwaite, A. W. 1927, 28, e Levick, B. 1999b, 18 e 214 n.12. Suetónio é o único autor a apresentar números para as empresas britânicas de Vespasiano.

${ }^{67}$ Ves. 4.1. Ora, ao contrário do que sugere Suetónio, a tomada da ilha, hoje com o nome de Wight, deve ter acontecido muito cedo na ordem das conquistas, segundo afirma LEvick, B. $1999 \mathrm{~b}, 18$.

${ }^{68}$ Cl. 17.1-2. Vide Gascou, J. 1984, 382-383 e 427-428. Agora (Ves. 4.1) que Suetónio não está preocupado em ridiculizar Cláudio, já pode admitir que os feitos de Vespasiano aconteceram partim Auli Plauti legati consularis partim Claudi [i] ipsius ductu. 
dotes militares de Vespasiano. Por isso, este recebeu os triumphalia ornamenta, seguidos de dois sacerdócios, e o consulado, que exerceu nos últimos dois meses do ano. ${ }^{69}$ Mas a influência de Narciso acaba por ser prejudicial, porque provoca o ódio de Agripina; e Vespasiano acha prudente afastar-se da corte. ${ }^{70}$ Com esta informação, o biógrafo diminui a influência do favor do liberto na ascensão do futuro imperador e coloca a tónica, exclusivamente, nos méritos do próprio.

Logo a seguir se salienta a exemplar integridade que demonstrou e grande apreço que colheu no seu proconsulado de África. Mas o bom governo não o impediu de ser agredido com rábanos em Hadrumeto (situação farsesca consonante com a feição jocosa do futuro imperador). ${ }^{71}$ Abona a sua honradez a afirmação de que não regressou mais rico, como era hábito dos governadores, tanto que teve de hipotecar ao irmão todos os bens e dedicar-se ao tráfico ( ad mangonicos quaestus) de animais, como sugere a alcunha de mulio, para poder manter a quantia que exigia o censo senatório; e consta que fez pagar cara a sua influência para obter o laticlavo para um jovem, contra a vontade do pai dele. ${ }^{72}$ Tal atitude, reprovável em si, é desculpável pela necessidade, e o facto de ser apresentada como um rumor - dicitur - contribuirá para lhe atenuar o efeito. ${ }^{73}$ Subtilmente, o biógrafo, sugerindo uma relação de causa-efeito entre o proconsulado e estas atitudes, apresenta uma virtude (a incorruptibilidade no exercício dos cargos) como causa primeira do principal e único vício, que será tratado mais à frente: a avareza.

Dado o conceito em que Nero era tido pelas suas actividades histriónicas, contribui para o favorecimento de Vespasiano o episódio cómico de que ele ofendeu aquele imperador por, na viagem pela Acaia, se ausentar dos espectáculos ou adormecer enquanto Nero se exibia. ${ }^{74} \mathrm{~A}$ uis comica, ao contrário do que acontecia com Cláudio, está ao serviço da criação, na mente do leitor,

${ }^{69}$ Ves. 4.2. Provavelmente em 51. Vespasiano teria 42 anos, idade normal para a ascensão de um homo nouus a esta honra: vide com. de Cesa, M. 2000, 52. Segundo Levick, B. 1999b, 19, os últimos dois meses do ano eram os menos prestigiados; e Vespasiano, dados os seus feitos, esperaria melhor.

${ }^{70}$ Deve também ter contribuído para o ódio de Agripina a proposta obsequiosa de deixar os insepultos os que conspiraram contra Calígula (Ves. 2.3), como nota Rossi, R. F. 1971, 171 n. 1. Vide Jones, B. W. 1984, 581-583. O afastamento da corte pode também ter acontecido por influência dos conselheiros de Nero, Séneca e Afrânio Burro, segundo Levick, B. 1999b, 20-21. Mas Suetónio parece exagerar no âmbito do retiro de Vespasiano, como notam, no seu com., Jones, B. \& Milns, R. 2002, 49: Tito continua a ser educado em companhia de Britânico, e Vespasiano continua a desempenhar as funções senatoriais e sacerdotais em Roma.

${ }^{71}$ Ves. 4.3: Exim sortitus Africam integerrime nec sine magna dignatione administrauit, nisi quod Hadrumeti seditione quadam rapa in eum iacta sunt. GAscou, J. 1984, 422 n. 156, considera a ruptura operada por nisi quod um efeito cómico de Suetónio.

72 Elemento encontrado talvez num panfleto de propaganda antiflaviana, como sugere dicitur; vide com. de CESA, M. 2000, 54-55.

${ }^{73}$ Como afirma Cizek, E. 1977, 142-143.

${ }^{74}$ Ves. 4.4. Tal atitude leva à proibição do acesso de Vespasiano ao palácio (cf. Ves. 14). Suetónio conta aqui uma parte do relato da censura de Febo a Vespasiano, segundo lemos em Díon, 63.10.1 a e 66.11.2. Também Tácito, Ann. 16.5.3, diz que Febo censurou Vespasiano por fechar os olhos durante o recital, mas, ao contrário de Suetónio e Díon, situa o episódio em Itália. 
de uma imagem positiva do general. De qualquer modo, Vespasiano tem de se afastar de Roma e, inclusive, teme pela sua vida. Mas, quando tudo parece perdido, eis que lhe é oferecida uma província com um exército. ${ }^{75}$

A partir daqui, a ascensão de Vespasiano integra-se na perspectiva messiânica. Os oráculos orientais têm peso nesta vida. Uma antiga profecia in fatis atribuía o poder a chefes vindos da Judeia; e Suetónio interpreta a profecia a favor dos Romanos. ${ }^{76}$ Ao ser enviado para a província, Vespasiano vai, sem o saber, ao encontro do seu destino. Suetónio salienta as razões pelas quais a escolha de Nero recaiu sobre Vespasiano: como as circunstâncias exigiam um exército muito numeroso e um general enérgico, ele era o ideal, porque, por um lado, possuía comprovada capacidade (industria experta), e, por outro, dada a sua origem humilde (bumilitas generis ac nominis), não o receava Nero como hipotético rival. Uma característica adversa à partida, a origem humilde (reiterada desde o início da Vida), revela-se determinante. Também na origem humilde parece residir a perspectiva messiânica. Em seguida, Suetónio reforça o retrato tipificado de um bom general, com um resumo da actividade militar de dois anos. ${ }^{77}$

A spes imperii é reforçada, como habitualmente, pelos ostenta, cuja lista, apresentada cronologicamente, é substancial. ${ }^{78}$ São apresentados vários prodígios de significado evidente para um romano: os rebentos de um carvalho consagrado a Marte, associados a cada parto da mãe de Vespasiano, e cujo diverso florescimento é sinal do futuro fatum de cada um dos irmãos; a confirmação do presságio pelos harúspices; a terra lançada, por ordem de Calígula, no regaço de Vespasiano, logo interpretada como sinal da futura proteç̧ão que haveria de dar ao Estado, depois da guerra civil; $;^{79}$ a mão humana que um cão deposita junto de Vespasiano, quando estava a almoçar; ${ }^{80}$

75 Ves. 4.4: (...) grauissimam contraxit offensam, probibitusque non contubernio modo sed etiam publica salutatione secessit in paruam ac deuiam ciuitatem, quoad latenti etiamque extrema metuenti prouincia cum exercitu oblata est.

${ }^{76}$ Vesp. 4.5: Percrebruerat Oriente toto uetus et constans opinio esse in factis ut eo tempore Iudaea profecti rerum potirentur. Id de imperatore Romano, quantum postea euentu paruit, praedictum Iudaei ad se trahentes rebellarunt. Também Tácito interpreta esta profecia como concernente a Vespasiano e Tito (Hist. 5.13.2). Griffiths, J. G. 1970, 363-368, diz que Tácito e Suetónio referem uma profecia antiga próxima do texto veterotestamentário do Livro de Daniel, 2.44.

77 Ves. 4.6. Vide com. de Cesa, M. 2000, 58.

${ }^{78}$ Ves. 5. A lista de presságios só é excedida pela que se refere a Augusto. Ora tanto Augusto como Vespasiano são fundadores de dinastias, como nota, no seu com., CEsA, M. 2000, 6-7.

${ }^{79}$ Ves 5.3. Díon Cássio, 59.12.3, conta a mesma anedota, mas acrescenta que ninguém, na altura, atribuiu qualquer significado especial ao acontecimento e que só quando Vespasiano restaurou a ordem passou a dar-se ao facto um significado premonitório. Segundo Rossi, R. F. 1971, 164-171, terá motivado a reacção do senado e o êxito de Vespasiano na eleição para a pretura (Ves. 2.3). Para GAscou, J. 1984, 359, este castigo explicaria o desejo de Vespasiano de procurar as boas graças de Calígula (Ves. 2.3), pelo medo que o imperador lhe inspirou. $\mathrm{O}$ biógrafo fraccionou as informações respeitantes à relação de Vespasiano com Calígula, reservando umas para a narrativa cronológica e outras para a species dos ostenta.

80 Ves. 5.4. A mão é o símbolo natural do poder: aparecia desenhada nas insígnias dos manípulos; vide com. de Braithwaite, A. W. 1927, 33, e a nota a este passo na ed. de Bassols de Climent, M. 1970. 
um boi que se liberta do jugo e se vem prostrar aos pés do futuro imperador, quando estava a jantar; ${ }^{81}$ um cipreste que tomba sem motivo e se ergue de novo no dia seguinte mais verde e mais vigoroso; ${ }^{82}$ um sonho de Vespasiano em que alcançaria a felicitas, depois de arrancado um dente a Nero, facto que se verificou no dia seguinte. ${ }^{83}$

A novidade está nos prodígios de influência oriental, que tornam Vespasiano aceite também naquela parte do mundo: o oráculo do deus do Carmelo, na Judeia, prometia-lhe a realização de todos os seus desejos, por grandiosos que fossem; ${ }^{84}$ e um cativo judeu, de nome Josefo, asseverou que seria libertado pelo mesmo Vespasiano, já imperador. ${ }^{85}$ Todos sabemos a força que, nessa época, tinha, na Judeia, a esperança em um messias libertador. Estava em curso uma revolta contra o domínio romano, que teve como baluarte o rochedo de Massada e que levou à destruição de Jerusalém, em 70.

O biógrafo volta aos ostenta tipicamente romanos e, no cúmulo, coloca sinais especialmente fortes de significado: um sonho de Nero, nos seus últimos dias, em que era advertido de que deveria levar o carro sagrado de Júpiter Óptimo Máximo do santuário para casa de Vespasiano e daí para o circo. ${ }^{86} \mathrm{O}$ facto de o sonho vir do próprio Nero afasta a suspeita, uma vez que ele não tinha qualquer interesse na ascensão de Vespasiano. A estátua do divino Júlio vira-se para o oriente ${ }^{87}$ duas águias lutam no campo de Betríaco, e a vencedora é superada por uma terceira, vinda do Oriente. ${ }^{88}$ Também os dois últimos reforçam a importância do Oriente na aclamação de Vespasiano.

${ }^{81}$ Cf. (para o presságio do cão e do boi) Díon Cássio, 66.1.2. O boi simboliza o Estado que se submete a Vespasiano, depois de se ter libertado do tirano. O facto de, nos dois ostenta, Vespasiano se encontrar à mesa é significativo, dada a importância dos banquetes assimilados às refeições sacrificiais: vide com. CESA, M. 2000, 60.

${ }^{82}$ Ao contrário de Tácito, Hist. 2.78.2, e Suetónio, Ves. 5.4, em Díon Cássio, 66.1.3, lê-se que a árvore caiu devido à violência do vento. $\mathrm{O}$ cipreste é símbolo da vida no mundo antigo, ligado às divindades procriadoras e consagrado a Apolo: vide com. de CESA, M. 2000, 60. O abatimento desta árvore há-de significar o fim da dinastia dos Flávios (Dom. 15.2).

${ }^{83}$ Ves. 5.5. Cf. Díon Cássio, 66.1.3.

${ }^{84}$ Ves. 5.6. Cf. Tácito, Hist. 2.78.3, que afirma que o nome do sacerdote era Basílides. Vide Morgan, M. G. 1996, 41-55.

${ }^{85}$ Cf. Díon Cássio, 66.1, e o próprio Flávio Josefo, BJ 3.8.2. Como nota Cesa, M. 2000, 60-61, é muito provável que Suetónio tenha aqui alterado a cronologia: Josefo foi capturado em 67, enquanto a profecia do Carmelo deve ser posterior, numa altura em que Vespasiano já acalentava spes ocultae, como diz Tácito (Hist. 2.78.3). Josefo refere simplesmente que, sem mencionar a própria libertação, profetizara a ascensão de Vespasiano ao trono. Vide intr. ao com. de Braithwaite, A. W. 1927, xv n.2 e 34; Gascou, J. 1984, 282-283.

${ }^{86}$ Ves. 5.7. Cf. Díon Cássio, 66.1.3. O sonho significava que Vespasiano gozava do especial favor do deus supremo: vide com. de Braithwaite, A. W. 1927, 34.

${ }^{87}$ Cf. Tácito, Hist. 1.86.1; Plutarco, Oth. 4.8. O fenómeno simboliza a passagem de uma casa à outra, uma vez que Júlio César é o fundador da dinastia júlio-cláudia; vide com. de Cesa, M. 2000, 62. Se Suetónio data este episódio do principado de Galba, Tácito e Plutarco colocam-no no de Otão. Mas a indicação de Suetónio é demasiado precisa para ser inventada: non multo post comitia secundi consulatus ineunte Galba.

${ }^{88}$ Só Suetónio relata o primeiro e o último prodígio desta lista. Tácito, Hist. 2.50.2, fala de um estranho pássaro, em Betríaco, que desaparece depois da morte de Otão. 


\subsubsection{Tito: amor e delícias do género bumano}

A $V i d a$ de Tito (superada a rubrica dos antepassados, assunto já desenvolvido no início da Vida de Vespasiano) inicia-se directamente com uma súmula dos tópicos a tratar durante a vida: «amor e delícias do género humano»; ${ }^{89}$ a quem não faltou quer o ingenium, quer a ars, quer a fortuna de granjear a simpatia de todos quando atinge o poder $;{ }^{90}$ mas que, quer como privado, quer durante o reinado do pai, não esteve livre do ódio e da uituperatio pública. A Vida desenrola-se como uma espécie de desenvolvimento deste enunciado. Desde o princípio se põem em evidência os méritos do príncipe e o papel da Fortuna, ${ }^{91}$ cuja menção é um tanto ambígua: ${ }^{92}$ note-se que, a par da boa Fortuna, também a má, da morte ante diem, inspirou simpatia e compaixão.

O filho mais velho de Vespasiano aparece associado na data do nascimento a um dos piores imperadores. Diz o biógrafo que Tito nasceu três dias antes das calendas de Janeiro do ano em que Gaio foi morto. Trata-se de uma aproximação inesperada, que parece sugerir, pela evocação de Calígula, o contraste entre os dois. ${ }^{93}$ Assim o monstrum é substituído pelo amor ac deliciae generis humani.

Ao descrever sumariamente o lugar do nascimento, o biógrafo insiste também naorigem humilde,comprovada por um pormenor de gosto antiquário. ${ }^{94}$ A educação in aula, na companhia de Britânico, e a grata recordação, que permanecerá em Tito, do filho de Cláudio, sugere também que, da linha oposta a Nero, nascerá o futuro imperador - já Vespasiano perdera o favor do último dos Júlio-Cláudios. A familiaridade com Britânico permite a Tito conhecer, desde cedo, o futuro: um fisiognomonista (metoposcopus), ao analisar os traços de Britânico, conclui que este não seria imperador, mas que Tito, que estava ao lado, o seria certamente. Mas, por outro lado, tal familiaridade quase lhe custa a vida, pois corre o rumor de que Tito chegou a provar levemente da bebida envenenada, preparada para Britânico, e ficou longo tempo doente. O carácter

89 Tit. 1: amor ac deliciae generis humani. Bajoni, M. G. 1983, 189-194, interpreta esta definição de Tito à luz do topos da figura do príncipe bom (p. 189), também presente no De clementia de Séneca.

${ }_{90}$ (...) quod difficillimum est, in imperio. BALdwin, B. 1983, 512, considera a expressão uma manifestação do sentido de humor de Suetónio: uma reflexão cínica sobre o impacto que o poder exerce nas relações.

${ }^{91}$ Em relação a Tito e Domiciano, Suetónio formula uma apreciação global desde o início das biografias, condicionando assim o juízo do leitor: vide Gascou, J. 1984, 694.

92 No seu com., Grassi, C. 1972, 155, interroga-se se se trata da ideia, difundida na antiguidade, de que as acções humanas só podem ter sucesso com uma fortuna favorável, ou da opinião, referida por Díon Cássio, 66.18.3-5, de que Tito deve a boa fama mais à eutychia que à arete, pois a brevidade do principado impediu que degenerasse.

${ }_{93}$ A coincidência parece falsa: Calígula foi morto a 24 de Janeiro de 41 d.C. e Tito nascera a 30 de Dezembro, mas de 39 (como sugere a informação de Tit.11). Vide com. de Martinet, H. C. 1981, 6-7. Para Levi, M. A. 1954, 288-289, esta artificiosa coincidência (imputada à fonte de Suetónio) e a aproximação a Britânico, no capítulo seguinte, sugerem uma linha de actuação política oposta à de Calígula e à de Nero.

${ }^{94}$ Tit.1: prope Septizonium sordidis aedibus, cubiculo uero perparuo et obscuro, nam manet adhuc et ostenditur. 
dramático da cena decorre da proximidade (muito ao gosto de Suetónio) da tragédia que poderia ter acontecido: tão bom imperador esteve bem perto de ser eliminado na juventude, num crime que tinha outro destinatário. A memória do amigo morto perdura na pietas de Tito que lhe eleva estátuas (Tit. 2). A aura favorável que Britânico granjeou, pelo seu destino, engrandece a imagem do devotado amigo, para mais, num ambiente hostil, dominado pela tirania de Nero. Tito aparece, de certo modo, na continuidade do amigo morto ante diem. Suetónio parece querer deixar claro, desde logo, que não há motivos para que alguns o considerem um segundo Nero.

$\mathrm{O}$ tom elogioso continua: In puero statim corporis animique dotes explenduerunt, magisque ac magis deinceps per aetatis gradus ${ }^{55}$ («logo em criança resplandeceram os dotes do corpo e do espírito, e ainda mais depois, pelas várias fases da vida»). Neste contexto se inclui o breve retrato físico e psíquico, que, contrariamente ao habitual, Suetónio coloca no início da biografia. Pelos dotes do corpo (forma egregia et cui non minus auctoritatis inesset quam gratiae) e do espírito (memoria singularis; docilitas ad omnis fere tum belli tum pacis artes), Tito incarna o príncipe belo e bom, a que se junta a componente da cultura - a concretização do que Germânico poderia ter sido: o retrato de Tito, de tipo encomiástico, lembra o do famoso general (Cal.3.1-2). Tal como o malogrado filho adoptivo de Tibério, Tito é apresentado como o homem completo, tanto pelas artes da guerra, ${ }^{96}$ como da paz, pois se mostra apto a fazer discursos e versos em latim e em grego, mesmo de improviso, ${ }^{97}$ a cantar e tocar lira com encanto e destreza. A capacidade de estenografar velozmente e imitar a letra de qualquer pessoa leva o próprio a confessar frequentemente que «poderia ser o rei dos falsificadores». ${ }^{98}$ Esta nota humorística pode deixar no leitor alguma suspeita, quando Domiciano acusa Tito de ter alterado o testamento do pai (Dom. 2.3), mas o biógrafo não sugere qualquer ligação entre as duas afirmações.

As artes da guerra e da paz constituem uma ideia reiterada e aparecem alternadas. Suetónio, como já fizera para Vespasiano, fundamenta as afirmações favoráveis com provas da antiquária. ${ }^{99}$ Depois do serviço militar, dedica-se ao

${ }^{95}$ Tit. 3.1. Cf. Aug. 79.1: forma fuit eximia et per omnes aetatis gradus uenustissima.

${ }^{96}$ (...) armorum et equitandi peritissimus. Veja-se a proximidade com Júlio César; cf. Jul. 57: armorum et equitandi peritissimus.

97 (...) facilis ad extemporalitatem usque. Vide Garuti, G. 1983, 307-312. A extemporalitas, capacidade de improvisar, é tradicionalmente considerada indispensável para a oratória prática. $\mathrm{O}$ estilo de Tito continha procedimentos retóricos e reflectia a influência dos neociceronianos que beneficiariam então de grande sucesso: vide MARTin, R. 1991, 239.

${ }^{98}$ Tit. 3.2: 'maximum falsarium esse potuisse'.

${ }^{99}$ Tal como a casa do nascimento e a estátua de Britânico, também a summa[e] industriae fama nec minor modestiae fama, que Tito granjeou, como tribuno militar na Germânia e na Britânia, se comprova com a multitudo de estátuas e imagines e respectivos tituli (Tit. 4.1). Exemplos que testemunham um état d'esprit de epigrafista e arqueólogo, mas que nos levam a pensar que Suetónio faz uma utilização pessoal deste tipo de documentos, como sugere GAscou, J. 1984, 519-520. Este autor não considera necessário inferir uma viagem de Suetónio à Britânia, como faz Syme, B. 1981, 111-112. 
foro, ${ }^{100} \mathrm{e}$, já à testa de uma legião, brilham a virtudes militares na tomada das ualidissimae urbes de Tariqueia e Gamala, na Judeia, onde Tito se comporta como um verdadeiro herói, sem hesitar em se expor ao perigo, ao ponto de, morto o seu cavalo, montar o de um soldado caído. ${ }^{101}$

Suetónio associa Tito à imagem tipificada do príncipe guerreiro e culto. Enviado a saudar Galba, todos o olham como se viesse para ser adoptado pelo imperador. ${ }^{102}$ Também os presságios divinos continuam a favorecê-lo. Depois da revolta de Otão contra Galba, consulta o oráculo de Vénus em Pafo e vê confirmada a imperii spes. ${ }^{103}$ Quando lhe é confiada a missão de subjugar completamente a Judeia, o acto heróico de abater doze defensores de Jerusalém com igual número de flechas ${ }^{104}$ parece simbólico: sugere-nos a vitória total sobre as doze tribos de Israel. Depois de tomar a cidade, no dia do aniversário da filha, recebe o favor dos soldados e por eles é aclamado imperator.

A suspeita de que quereria usurpar o poder ao próprio pai e tornar-se rei do Oriente - agravada com o facto de, ao venerar o boi Ápis em Mênfis, se cingir com o diadema - é virada a favor da imagem de Tito, quando este se apressa a regressar, para desmentir os rumores, demonstrando pietas e moderação: 'Veni', inquit, 'pater, ueni'105 ("Cheguei, meu pai - anunciou ele -, cheguei!»). Também a actuação posterior desmente tais pretensões: neque ex eo destitit participem atque etiam tutorem imperii agere («e, desde então, não deixou de agir como co-regente e até como defensor do poder»). Torna-se um verdadeiro collega do pai: com ele partilha a censura, a tribunicia potestas e sete consulados. Mas o facto de se manter na sombra de Vespasiano prova a sua falta de ambição. ${ }^{106} \mathrm{Um}$ excesso de zelo, ao exercer o cargo de prefeito do pretório, parece ser a causa da conduta demasiado despótica (inciuilius et uiolentius). Suetónio, em vez de descrever os pormenores da alegada conjura de Aulo Cecina, ${ }^{107}$ centra-se no excesso da reacção de Tito, que o mandou apunhalar à saída do triclínio. O biógrafo tem o cuidado de notar que o perigo exigia uma actuação rápida (sane urgente discrimine), uma vez que Tito havia interceptado um manuscrito com um discurso que o sedicioso

100 Tit. 4.2: Post stipendia foro operam dedit honestam magis quam assiduam.

${ }^{101}$ Tit. 4.3. Jones, B. W. 1989, 126-134, denuncia o exagero de Suetónio, que reflecte a ideia oficial do imperador guerreiro a quem se atribuem façanhas sobrevalorizadas: daí o aparecimento teatral de Tito naquelas cidades, como se fosse um deus ex machina. Antes do ano 70, as tarefas de Tito eram essencialmente diplomáticas, não militares, e o seu papel nos assédios das cidades foi secundário. Quanto à morte do cavalo, já sabemos que Suetónio se compraz em apresentar os perigos a que os Césares se vêem expostos e a que escapam como que por milagre. Vide Gascou, J. 1984, 419, n. 148.

${ }^{102}$ Cf. Tácito, Hist. 2.1.1.

${ }^{103}$ Tit. 5.1. Cf. Tácito, Hist. 2.4.1-2.

${ }^{104}$ Tit. 5.2: Cf. Flávio Josefo, BJ 5.288.

${ }^{105}$ Tit. 5.3. O comportamento de Tito no Egipto insere-se na perspectiva da imitação de Alexandre Magno por parte dos Flávios. Também ele visitou Mênfis, venerou o Boi sagrado e terá sido investido como rei do Egipto: vide Henrichs, A. 1968, 60.

${ }^{106}$ Tit. 6.1. Vide Martin, R. 1991, 232.

107 Aulo Cécina foi partidário de Galba; depois, de Vitélio; e, finalmente, de Vespasiano. Vide com. de Jones, B. \& Milns, R. 2002, 89 e 104. 
se preparava para fazer aos soldados. ${ }^{108}$ Suetónio nota igualmente que tal actuação lhe garantia a securitas futura, mas, naquele momento, gerava a ódio, de tal modo que ninguém chegou ao poder com fama tão má e tão contra a vontade de todos. ${ }^{109}$ À excepção da saeuitia, atenuada pela necessidade, todos os outros vícios são apresentados como suspeições (suspecta in eo etiam luxuria erat... nec minus libido... suspecta rapacitas). Cada um dos vícios é ilustrado com um exemplo. $\mathrm{O}$ resultado é que tais suspeitas fazem com que vejam nele «um outro Nero». ${ }^{110}$ Mas, ao contrário do que sucede no caso dos imperadores maus, o biógrafo refere os aspectos negativos de Tito imediatamente antes da chegada ao trono, para assim realçar a mudança na conduta.

Destes Césares ressalta a caminhada progressiva para o poder supremo. Embora as carreiras de César e de Octávio sejam mais marcadas pela ambição e a de Galba e de Vespasiano tenham em vista a restauração da ordem, Suetónio sublinha a presença da vontade dos deuses, que se manifesta em presságios diversos. Por vezes, o biógrafo parece aproximar as figuras históricas de joguetes. As acções humanas são apresentadas como reflexo do carácter, mas assinala-se a vantagem da convergência entre os planos humanos e divinos.

\subsection{Ascensão controversa}

\subsubsection{Tibério: um herdeiro de segunda escolha}

Depois da referência ao nascimento de Tibério - neste caso, o biógrafo preocupa-se em apresentar as posições opostas sobre o lugar e a data (Tib.5) sem lhes atribuir nenhum significado especial -, Suetónio entra na descrição da infância e puerícia, acentuando o facto de ser uma fase laboriosa ac exercitata (Tib. 6.1). Tibério tem uma entrada aparatosa em cena a acompanhar os pais na fuga; e quase a traí-los com o choro e a causar assim a sua própria perda. $\mathrm{Na}$ Lacedemónia, apanhado no meio de um incêndio florestal, esteve a ponto de ser pasto das chamas que atingiram as roupas e os cabelos de Lívia, facto que evidencia os desígnios do destino que o preserva. ${ }^{111}$

${ }_{108}$ Os traços aparentes de Tito (neste caso, a crueldade) revelam-se sob o efeito de circunstâncias particulares; vide GAscou, J. 1984, 431 n. 173.

${ }^{109}$ Tit. 6.2: (...) ut non temere quis tam aduerso rumore magisque inuitis omnibus transierit ad principatum. Vide Della Corte, F. 1967, 80.

${ }_{110}$ Tit. 7.1. Vide Martin, R. 1991, 118. Tito assemelha-se a Nero na perícia em compor versos, em tocar cítara e em cantar, pela gordura e pelos sumptuosos banquetes nocturnos, pelos eunucos e favoritos: vide Baldwin, B. 1983, 293. Nota Marastoni, A. 1983, 110-111, que Nero é um topos caro ao contexto cultural da época de Trajano; e Tito é apresentado como um Nero às avessas, que evolui da má fama para a admiração unânime. Para Levi, M. A. 1954, 291-292, o passado militar de Tito, certas emissões monetárias enquanto herdeiro designado do império, bem como a ligação a Berenice, princesa judia filha de Herodes Agripa I, faziam suspeitar de que iria seguir uma política orientalizante: daí a designação de alius Nero.

${ }^{111}$ Tib. 6.2. Tácito só refere de passagem que Tibério acompanha os pais no exílio: Ann. 6.51.1. 
Tibério teima em permanecer um Cláudio, pois, adoptado por Marco Gálio, aceita a herança, mas, por motivos políticos, renuncia ao nome. ${ }^{112} \mathrm{~A}$ subsequente informação da perda do pai, aos nove anos de idade, acompanhada da indicação de que fez o elogio fúnebre, parece reforçar a ligação ao pai biológico. ${ }^{113}$

A nota da presença de Tibério no triunfo de Augusto, do lado esquerdo, enquanto Marcelo ocupa o lado direito, coloca, desde já, o biografado no lugar de segunda escolha, como sucessor, posição que ocupará longo tempo. Pelo contrário, a sua participação como comandante de um esquadrão no jogo denominado "Tróia", parece definir já as suas reconhecidas capacidades de chefe militar (Tib. 6.4).

Depois de referir o acto de assunção da toga viril, Suetónio propõe-se tratar os feitos de Tibério até ao início do principado (Tib. 7.1). As virtudes e os vícios estão já presentes em germe, embora o biógrafo o não diga explicitamente. A pessoa do pai surge de novo nos jogos que Tibério dá em sua honra, e do avô Druso, o que revela uma virtude, a pietas. Mas essa é logo ensombrada por dois vícios que Suetónio há-de explorar largamente: um é a falta de ciuilitas organiza uns jogos, mas não está presente - e já sabemos a importância política que o biógrafo dá aos jogos; outro, a auaritia, infere-se pelo humor com que o biógrafo encerra a informação: cuncta magnifice, inpensa matris ac uitrici («todos com magnificência, a expensas da mãe e do padrasto»).

Mas também se faz presente a especial vivência do sofrimento que parece ensombrar toda a vida de Tibério e ajudará a explicar o seu carácter taciturno. O biógrafo, que resume os grandes factos político-militares, alarga-se a sugerir o drama de duas perdas dolorosas que marcaram Tibério:

Agrippinam, Marco Agrippa genitam, neptem Caecili Attici equitis R., ad quem sunt Ciceronis epistulae, duxit uxorem; sublatoque ex ea filio Druso, quanquam bene conuenientem rursusque grauidam dimittere ac Iuliam Augusti filiam confestim coactus est ducere non sine magno angore animi, cum et Agrippinae consuetudine teneretur et Iuliae mores improbaret, ut quam sensisset sui quoque sub priore marito appetentem, quod sane etiam uulgo existimabatur. Sed Agrippinam et abegisse post diuortium doluit et semel omnino ex occursu uisam adeo contentis et umentibus ${ }^{114}$ oculis prosecutus est, ut custoditum sit ne unquam in conspectum ei posthac ueniret. Cum Iulia primo concorditer et amore mutuo uixit, mox dissedit et aliquanto grauius, ut etiam perpetuo secubaret, intercepto communis fili pignore, qui Aquileiae natus infans extinctus est. Drusum fratrem in Germania amisit, cuius corpus pedibus toto itinere praegrediens Romam usque peruexit. ${ }^{115}$

${ }_{112}^{12}$ Tib. 6.3. M. Gálio era um opositor de Augusto: estivera ao serviço de António em Mútina e talvez fosse irmão de Quinto Gálio, executado por Augusto, a pretexto de atentar contra a vida do príncipe (Aug. 27.4).

${ }^{113}$ Suetónio não dá pormenores sobre a educação do puer, acaso influenciada, nos princípios, por aquele defensor dos ideais republicanos, segundo pensa SAlles, C. 1985, 29-33.

114 Por coerência de sentido, colocamos umentibus, em vez de [t]umentibus da ed. teubneriana.

115 Tib. 7.2-3. No seu com., Lindsay, H., 1995, 75, assinala o exagero de Suetónio ao dizer que o casamento com Júlia se realizou imediatamente. 
«Casou com Agripina, filha de Marco Agripa, neta do cavaleiro romano Cecílio Ático, destinatário de cartas de Cícero, e teve dela um filho, Druso. Embora vivesse com ela em boa harmonia, foi obrigado a repudiá-la, já grávida, e casar imediatamente com Júlia, filha de Augusto. Não o fez sem grande amargura de alma, porque, além do grande afecto que nutria por Agripina, ainda por cima desaprovava os costumes de Júlia, porquanto percebera que ela, mesmo na posse do primeiro marido, já o desejava, facto que era do conhecimento público. Mas doeu-lhe a separação de Agripina, depois do divórcio, e, ao vê-la, uma só vez, num encontro fortuito, seguiu-a com tal olhar feliz e húmido, que se tratou de velar para que ela nunca mais lhe aparecesse diante da vista. Com Júlia, primeiro viveu em concórdia e com mútuo amor; depois desentendeu-se, e tanto mais gravemente, que até passaram a dormir separados em definitivo, quando se cortou o liame garantido por um filho dos dois, que, tendo nascido em Aquileia, morreu ainda menino. Na Germânia, perdeu o irmão Druso, cujo corpo transportou até Roma, seguindo à frente, todo o caminho, a pé».

Poderá estranhar-se que Suetónio, centrado unicamente na dor de Tibério, nada diga sobre o filho de que Vipsânia Agripina estava grávida no momento da separação, nada diga sobre as segundas núpcias da ex-mulher e nada diga sobre o motivo da morte de Druso: a queda do cavalo. Talvez partisse do princípio de que eram factos conhecidos. Também nada diz sobre as repercussões que estes acontecimentos tiveram no comportamento do futuro imperador; poderão constituir uma explicação tácita para o azedume e mesmo para as suas alegadas perversões sexuais. ${ }^{116}$

Ao iniciar a resenha da carreira política de Tibério (Tib. 8), Suetónio refere a eficiência do jovem no processo de lesa-majestade contra Fânio Cepião, que conspirara com Murena. $\mathrm{O}$ afinco de Tibério, depois levado ao exagero, irá manchar os últimos anos do seu futuro governo. Por outro lado, tanto a condenação de Fânio, como a inspecção dos ergástulos (cujos donos eram suspeitos de escravizarem viajantes e refractários ao serviço militar), como ainda o estabelecimento de Tigranes no trono da Arménia, a devolução dos estandartes tomados pelos Partos a Crasso e a António e grande parte da obra militar de Augusto (Tib. 9.1-2), actividades atribuídas, na Vida anterior, ao antecessor, são agora retomadas, com pormenores suplementares, para serem atribuídas a Tibério. ${ }^{117}$ Suetónio, como é sabido, refere em cada vida o que diz respeito ao biografado.

Ao seu jeito habitual, no tratamento de questões político-militares, Suetónio resume rapidamente (Tib.9) as campanhas em que Tibério participou - e que lhe granjearam a fama de bom general - e a carreira das honras, com a

${ }_{116}$ Para Martin, R. 1991,131-132, os problemas conjugais de Tibério explicam boa parte dos seus comportamentos estranhos. Southern, P. 1998, 139, acha que, se Tibério tivesse continuado naquela situação feliz do casamento com Vipsânia, a história do principado teria sido também mais feliz.

${ }^{117}$ Não se trata de contradição, mas apenas especificação, uma vez que Tibério agia sob os auspícios de Augusto. O processo de Fânio é retomado de Aug. 19.1, e a inspecção dos ergastula de Aug. 32.1; a solução arménia e a devolução dos estandartes, de. Aug. 21.3; e as campanhas militares, de Aug. 21.1. Vide Gascou, J. 1984, 374-376. 
atribuição da tribunicia potestas por cinco anos. Mas, atingido o cume, Tibério parece tomado pela atracção do abismo. O biógrafo mostra-se seduzido por este afastamento enigmático da vida política e da família, na altura em que menos era de esperar. Ao contrário da brevidade com que tratou a longa carreira militar, alonga-se agora em explicações psicológicas e políticas: por não suportar Júlia; ${ }^{118}$ para evitar o cansaço da presença contínua e fazer sentir a sua falta em Roma; para deixar o caminho livre a Gaio e Lúcio Césares (motivo oficial que o próprio Tibério deu mais tarde). A inflexibilidade, a obstinação e o silêncio de Tibério são descritos com contornos dramáticos:

Tunc autem honorum satietatem ac requiem laborum praetendens comeatum petit; neque aut matri suppliciter precanti aut uitrico deseri se etiam in senatu conquerenti ueniam dedit. Quin et pertinacius retinentibus, cibo per quadriduum abstinuit. Facta tandem abeundi potestate, relictis Romae uxore et filio confestim Ostiam descendit, ne uerbo quidem cuiquam prosequentium reddito paucosque admodum in degressu exsosculatus (Tib. 10.2).

«Então alegando como pretexto o cansaço da carreira das honras e o desejo de descansar dos trabalhos, pediu licença para uma viagem. E não cedeu nem à mãe que, suplicante, lhe implorava, nem ao padrasto que se queixava no senado de ser abandonado. E mais, como se obstinavam em retê-lo, absteve-se de alimento durante quatro dias. Conseguida, enfim, a autorização para partir, deixando em Roma esposa e filho, desceu imediatamente até Óstia e, sem trocar uma palavra sequer com aqueles que o acompanhavam, limitou-se a beijar uns poucos no momento da partida».

A viagem para Rodes prefigura o futuro afastamento para Cápreas. Está já presente a dificuldade de comunicação e a misantropia que levará à criação de tantos boatos. $\mathrm{O}$ mau humor desaparece com a vida de simples particular na ilha, cuja beleza e salubridade é o refrigério para o espírito. Suetónio descreve um momento de apaziguamento interior, contrastante com as atitudes futuras de Tibério. É digno de nota, para o biógrafo, que se passeie desprotegido, numa prova de sociabilidade (ciuilitas), sem escolta, e trate os Graeculi de igual para igual, ${ }^{119}$ coisa impensável mais tarde. A narrativa alarga-se com duas anedotas, que o comprovam. Por má interpretação dos seus acompanhantes, Tibério, cuja intenção era visitar doentes, fez com que todos fossem reunidos num pórtico, e ele próprio se visse numa situação constrangedora: Perculsus ergo inopinata re diuque quid ageret incertus, tandem singulos circuit excusans factum etiam tenuissimo cuique et ignoto ${ }^{120}$ ( Então ficou abalado pelo inesperado da situação

${ }^{118}$ Tib. 10.1. Tácito, Ann. 1.53.1, diz que a razão foi Júlia o considerar inferior.

119 Tib.11.1. O diminutivo étnico representará o desprezo dos Romanos pelos seus contemporâneos Gregos, atestado em Juvenal, 3.86-108, como nota, no seu com., Lindsay, H., 1995, 85, e BALDWIN, B. 1983, 252. Mas, neste contexto, serve sobretudo para acentuar a ciuilitas de Tibério, através da diminuição da categoria dos interlocutores gregos.

${ }^{120}$ Tib. 11.2. Salles, C. 1985, 86, afirma que o que Tibério quereria visitar eram os asclepeia, dispensários, escolas de medicina e santuários de Esculápio, que eram curiosidades desta ilha, como da de Cós. Em consonância, Levick, B. 1999a, 122, pensa que o interesse de Tibério 
e longo tempo sem saber o que fazer, até que finalmente se acercou de cada um, por mais humilde e desconhecido que fosse, para se desculpar do equívoco»). Paralelamente, Suetónio revela outra característica de Tibério: a sua falta de presença de espírito para reagir a situações inesperadas. Mas, por ora, Tibério reage como se esperaria e a sua ciuilitas fica salva.

A outra anedota denuncia igualmente a incapacidade de responder de improviso. Num debate de sofistas, Tibério, injuriado por um altercador, vai a casa buscar os lictores, acusa-o e manda-o encarcerar (Tib. 11.3). O uso da força parece exagerado, mas o propósito desta anedota é mostrar que Tibério usou a tribunicia potestas apenas uma vez. A imagem que se transmite é positiva e o leitor é levado a sentir simpatia por este Tibério. Ao saber da notícia da condenação e do divórcio de Júlia, ordenados pelo imperador, Tibério chega a interceder por ela (Tib.11.4).

Expirada a tribunicia potestas, Tibério pede para regressar a Roma, pois Gaio e Lúcio eram maiores e tinham os direitos garantidos. Suetónio transmite a resposta irónica de Augusto: 'dimitteret omne curam suorum, quos tam cupide reliquisset' (Tib.11.5) («deixasse de se preocupar com os seus, já que tão prontamente os abandonara”). A situação de Tibério passa a uma nova fase: agora fica em Rodes contra a sua vontade (Tib.12) e, sob a capa de legado de Augusto, vive amedrontado, oculto no interior da ilha e avesso a visitantes. $O$ perigo e o medo, que o hão-de paralisar tantas vezes no futuro, torna-se real com as mostras de antipatia de Gaio, destacado em Samos, e os boatos que o tornam suspeito a Augusto. Suetónio faz agora o retrato de um perseguido, vestido à grega, cada vez mais desprezado e mais odiado (contemptior in dies et inuisior), caído em desgraça (já se derrubavam as estátuas em Nemauso), ameaçado de morte (um adulador de Gaio oferece-se para ir a Rodes buscar a cabeça do exilado), obrigado a suplicar pelo regresso, não já por medo, mas pelo perigo real, e, finalmente, a ser salvo por um acaso do destino (casus): Gaio, ofendido com o conselheiro Lólio, que o instigava contra Tibério, deu-lhe permissão para regressar a Roma, com a condição de não participar na vida política. ${ }^{121}$

A partir do regresso a Roma, o biógrafo centra-se na caminhada para o trono imperial (a magna nec incerta spes futurorum). Nesta altura, em que já se desenha a sucessão a favor de Tibério, Suetónio introduz a habitual série de presságios indicadores do poder supremo (Tib. 14.1), apresentados cronologicamente pelo recurso a uma analepse, cujo alcance recua até à gravidez de Lívia e cuja amplitude vai até aos últimos dias em Rodes. Entretanto, Tibério dedica-se a assuntos privados (Tib. 15.1), mas novo casus vai mudar a situação. A morte de Gaio e Lúcio, e consequente adopção de Tibério e Agripa Póstumo por

deveria ser mais científico do que humanitário.

${ }^{121}$ Tib. 13.2. Engenhosa é a teoria de Southern, P. 1998, 173-176: Tibério teria sido enviado para Rodes, por esta ilha se encontrar numa posição estratégica, numa espécie de missão secreta para controlar a questão arménia, em que tinha experiência. Augusto pode não ter deixado Tibério regressar até ter a certeza de que a questão estava resolvida e restabelecido o equilíbrio entre Roma e a Pártia. 
Augusto, ${ }^{122}$ marcam o retorno à vida pública. Suetónio apresenta-o agora apostado em aumentar o seu poder e a abdicatio de Agripa traz-lhe a esperança da sucessão. Depois de receber de novo a tribunicia potestas, Tibério engrandece a sua fama de general na Germânia e na Ilíria (Tib. 16-18). Sobressai nesta parte o retrato do comandante ideal e um exemplo para as suas tropas (Tib. 19). Apesar de deixar margem mínima à fortuna e ao casus, tinha como bom presságio para as batalhas, segundo a experiência dos seus antepassados, o facto de a sua lâmpada se apagar fortuitamente, sem que alguém lhe tocasse (Tib. 19). Mas, mesmo depois de uma vitória, é por pouco que escapa à morte por acção de inimigo infiltrado: de novo a providência a favorecê-lo; ou mais um feliz acaso. A gradação da actividade guerreira culmina com a celebração do triunfo que adiara (Tib.20). Vemos, coisa rara depois, Tibério a fazer donativos ao povo e a dedicar templos à Concórdia e aos Dioscuros.

\subsubsection{Calígula: o filho de Germânico}

Depois de breve referência à linhagem da esposa de Germânico, Agripina, e aos filhos do casal, o leitor fica a saber que o destino trágico dos irmãos determinou a herança de Gaio. ${ }^{123}$ Suetónio entra então na já referida discussão académica do lugar do nascimento ( $\mathrm{Cal}$. 8), que serve para provar a tese do biógrafo, de que este imperador nasceu em Âncio e não na Germânia como defendem outros autores. A este propósito, cita e rebate uns versos, em forma de charada, oriundos dos campos militares. ${ }^{124}$ Apesar de Suetónio negar que Calígula tinha nascido em campanha, aduzindo provas de carácter cronológico, o facto de aqueles versos correrem, denota a esperança depositada no facto de Calígula ser filho de Germânico.

Desde muito cedo Gaio começa a travestir-se. O cognomen de Caligula resulta do facto de andar vestido de soldado. ${ }^{125}$ Torna-se objecto do amor et gratia dos soldados, e somente a sua presença os acalma durante os motins que se seguiram à morte de Augusto. Com efeito, ao darem conta de que o pequeno era afastado do acampamento, os soldados arrependem-se, retêm o veículo que o transporta e suplicam que não os exponham à desconsideração (inuidia). ${ }^{126}$

${ }^{122}$ Tib. 15.2. Depois de Germânico ser adoptado por Tibério. Porque legalmente, depois da sua adopção, Tibério não podia adoptar mais ninguém; vide Levick, B. 1999 a, 50 e 240 n. 7.

${ }^{123}$ Cal. 7. A referência à morte de Nero e Druso às mãos de Tibério, apresentada antes de começar a Vida de Gaio, serve o propósito de clarificar a razão pela qual Gaio se torna imperador: vide intr. ao com. de WARDLE, D. 1994, 28.

${ }^{124}$ Cal. 8.1: In castris natus, patriis nutritus in armis / iam designati principis omen erat .

125 Cal. 9. A popularidade resultava do facto de usar uma miniatura de farda de baixa patente, pelo que os soldados mais simples se identificavam com ele. A caliga era o calçado do miles gregarius.

${ }^{126}$ Suetónio afirma que é Calígula (solus haud dubie) a refrear os soldados, enquanto Tácito, Ann. 1.40-44, fala de Gaio e Agripina em conjunto; e em Ann. 1.41 centra-se essencialmente em Agripina. Para Hurley, D. W. 1989, 316-325, é tentador pensar que, ao dizer solus haud dubie ex suo conspectu flexit, Suetónio se esforça por defender o protagonismo do pequeno soldado contra uma distorção da fonte por parte de Tácito. 
Faz-se depois um sumário da vida do jovem, onde se torna claro que teve uma infância e juventude irregulares, entregue aos cuidados de sucessivas pessoas, tão diversas entre si, que vão morrendo ou são condenadas: acompanha o pai na expedição à Síria; fica depois entregue à mãe, entretanto exilada por ser opositora de Tibério; depois à bisavó Lívia, esposa de Augusto; depois à avó Antónia, filha de Marco António, e finalmente a Tibério (Cal. 10.1). Adivinha-se a luta interior do jovem ao receber influências tão opostas. Se Augusto e Marco António continuam, de algum modo, em guerra nos seus descendentes, Gaio reúne em si os dois lados inimigos. A batalha de Áccio perpetua-se no seu íntimo e ele poderá errar entre um e outro campo.

O segredo da sobrevivência residia na forma como se furtava às insídias que lhe armavam, sem se prestar a queixas sobre a sorte dos seus. Mas sobretudo parece ter aprendido a lição de Tibério: adquiriu uma incredibilis dissimulatio na forma como suportava os reveses. Mostrava-se tão obsequioso com o velho de Cápreas e o seu entourage, que já corria o dito - non immerito, assegura o biógrafo - 'nec seruum, meliorem ullum nec deteriorem dominum fuisse "127 ('nunca existira melhor servo nem pior senhor'»). A arte de dissimulação aqui introduzida é a chave para entender os capítulos seguintes. ${ }^{128}$ Mas logo Suetónio faz saber que, mesmo então, Calígula não era capaz de dominar a natureza cruel e infame (natura saeua atque probrosa). A natura saeua é logo concretizada no prazer com que assistia ao castigo e às execuções dos condenados; e a natura probrosa, no giro nocturno por tabernas e prostíbulos, disfarçado com uma peruca e uma veste longa, e no gosto pelo teatro, pela dança e pelo canto, atracções consideradas degradantes, mas toleradas por Tibério, na esperança de que suavizassem a sua índole feroz (ferum ingenium). Por enquanto, acentua-se o disfarce, mas abre-se já, por antecipação, como acontece em outras biografias, um vislumbre da conduta futura do imperador. E a comprová-lo vem a opinião pressaga de Tibério de que Gaio vivia para sua perdição e de todos; e de que ele próprio (Tibério) estava a educar uma Hidra (natrix) para o povo romano, um Faetonte de todo o orbe (Cal.11). Como em casos semelhantes (relembrem-se as palavras do mestre de retórica de Tibério e do próprio Augusto sobre o seu sucessor), a previsão colocada na boca do sagacissimus senex (feita certamente por retrospectiva, depois de conhecido o desastre de Calígula) assume na biografia o valor de verdadeira profecia. A evocação de Faetonte, paradigma do jovem inexperiente que assume uma tarefa para a qual não está preparado, é pressaga também pelo fim trágico com que pagou a sua audácia. ${ }^{129}$

${ }^{127}$ Cal. 10.2. Também Tácito, Ann. 6.20.1, diz que ele encobriu o immanens animus com uma subdola modestia. No entanto, Colın, J. 1954, 13 400, afirma que a escolha que Calígula fará mais tarde dos seus cônsules mostra que ele não esqueceu nem a condenação da mãe, nem dos irmãos, nem o desejo de vingança, nem as vontades políticas e religiosas dos seus antepassados.

${ }^{128}$ Particularmente os caps 15-21; vide intr. ao com. de WARDLE, D. 1994, 90-91.

${ }^{129}$ Vide com. de Guastella, G. 1992, 114; e com. de Hurley, D. W. 1993, 32. Um jovem inexperiente que nunca fora preparado para ser o sucessor de Tibério, segundo Antonelli, G. 2001. 


\subsubsection{Nero: o filho de Agripina}

O nascimento de Nero, nove meses depois da morte de Tibério, em Âncio, como Calígula, acontece sob bons auspícios: tantum quod exoriente sole, paene ut radiis prius quam terra contingeretur ${ }^{130}$ («mesmo ao nascer do sol, tanto que quase foi tocado pelos raios, antes que pela terra»). Um privilégio que o aproxima de Augusto, associado repetidamente ao solis exortus ${ }^{131}$ e a Apolo. Mas tal presságio de fortuna é imediatamente anulado pelas palavras do pai, ao responder às felicitações dos amigos: dele e de Agripina só poderia nascer algo de detestável e destinado à calamidade pública. Manifestam-se já os sinais da futura infelicitas: ${ }^{132}$ assim é interpretado o iocus de Calígula ao propor-lhe o nome do tio Cláudio, apelido que o destino se encarregaria de lhe atribuir mais tarde. Transparece uma certa ironia do biógrafo na afirmação de que Agripina rejeitou esse nome, por Cláudio ser nessa altura alvo de troça. ${ }^{133} \mathrm{~A}$ condição de carência (paene inops atque egens) em casa da tia Lépida parece exagero do biógrafo, para acentuar a infelicitas. ${ }^{134}$ É de notar que, depois do exílio da mãe, foi educado em casa da tia por dois pedagogos: um bailarino e um barbeiro, ${ }^{135}$ gente de ínfima condição, que podem ter exercido influência sobre os pendores naturais da criança.

É com o advento de Cláudio que a sorte muda: recupera o património e recebe a herança do padrasto Passieno Crispo. Mas com a fortuna vêm os perigos e intrigas de corte. Dada a influência da mãe, filha de Germânico, Nero começa a ser um perigoso rival de Britânico, filho de Cláudio, e corre o rumor de um atentado por obra de Messalina, que teria mandado estrangular o concorrente do filho. Os assassinos são assustados por uma serpente que emergia da almofada: mais um elemento em comum com Augusto. ${ }^{136}$ Suetónio adianta uma explicação natural para esta fabula:

Quae fabula exorta est deprensis in lecto eius circum ceruicalia serpentis exuniis; quas tamen aureae armillae ex uoluntate matris inclusas dextro bracbio gestauit

${ }^{130}$ Nero 6.1. Cf. Díon Cássio, 61.2.1. Usamos a tradução defendida por Gallivan, P. A. 1974a, 386, e pelo com. de Warmington, B. H. 1999, 26. Trata-se de uma referência ao costume de depositar o recém-nascido no chão aos pés do pai para este o reconhecer.

${ }^{131}$ Cf. Aug. 5: paulo ante solis exortum; Aug. 94.4: Somniauit et pater Octauius uero Atiae iubar solis exortum; Aug. 94.6: repertus est iacens contra solis exortum.

${ }^{132}$ Nero 6.2. A infelicitas parece ser uma das chaves à volta da qual Suetónio constrói a biografia; vide com. de Bradley, K. R. 1978, 15 e 46; Lounsbury, R. C. 1991, 3756.

${ }^{133}$ Vide com. de Warmington, B. H. 1999, 26-27. A anedota da consulta a Calígula é juridicamente inconsistente, segundo Scarcia, R. 1991, 251-252, pois Domício Aenobarbo só morre depois de reconhecer o filho. Parece tratar-se de um omen imperii, que, retirado do contexto apropriado, servirá ao biógrafo para exemplificar os paradoxos da história e para sugerir o mau augúrio implícito nos defeitos de Cláudio.

${ }^{134}$ Lépida dificilmente seria pobre: vide Gallivan, P. A. 1974a, 390.

${ }^{135}$ Nero 6.3. Insinuação claramente maliciosa de Suetónio, segundo Gallivan, P. A. 1974a, 392: os ofícios de saltator e tonsor seriam exercidos apenas em part-time pelos libertos Berilo e Aniceto (nomes prováveis dos pedagogos a que Suetónio se refere).

${ }^{136} \mathrm{Cf}$. Aug. 94.4. Tácito, Ann. 11.11.3, fala das lendas fabricadas à volta de Nero sobre várias serpentes que o protegiam e diz que o próprio Nero afirmava que tinha visto apenas uma. 
aliquamdiu ac taedio tandem maternae memoriae abiecit rursusque extremis suis rebus frustra requisiit. ${ }^{137}$

«Esta lenda teve origem no facto de ter sido encontrada na cama dele, junto ao travesseiro, a pele de uma serpente, que, inserida por vontade da mãe numa bracelete de ouro, ele usou durante muito tempo no braço direito, mas que depois, por causa do mal-estar da recordação materna, enjeitou, e que procurou de novo, em vão, nas derradeiras tribulações».

Com esta explicação, o biógrafo integra a fabula no contexto da superstição de Nero e dos remorsos que o hão-de acometer. A rejeição da mãe surge, assim, aos olhos do leitor, como uma causa da desgraça final, que desde já se prenuncia.

A participação de Lúcio Domício nos jogos começa cedo (necdum matura pueritia): participou no jogo denominado Tróia com empenho e êxito. ${ }^{138}$ O favor popular começa já a manifestar-se. Esta busca de popularidade aproxima-o de Calígula. Com efeito, depois de nomeado preceptor de Nero, Séneca sonhou que educava Gaio. A aproximação entre os dois príncipes, corrente já na antiguidade, ${ }^{139}$ é aqui explicitamente sublinhada por Suetónio. Como fundamento de tal comparação alega-se a monstruosidade de carácter (immanitas naturae), que o leva a tentar provar que Britânico não era filho de Cláudio e a acusar a tia Lépida. ${ }^{140} \mathrm{O}$ biógrafo introduz claramente, nesta parte da $V i d a$, elementos que permitem antecipar a conduta futura do imperador.

\subsubsection{Otão: um companheiro de Nero}

Nesta breve $V i d a$, a rubrica do nascimento faz apenas referência ao tempo, sem menção de lugar (Otho 2.1). Otão surge, de início, em total oposição à disciplina do pai. A presença e a influência de Nero é acentuada em vários momentos da sua vida. No ano do nascimento, um dos cônsules era Domício Aenobarbo, pai de Nero. Também os costumes de Otão são semelhantes aos de Nero: A prima adulescentia prodigus ac procax, adeo ut saepe flagris obiurgaretur a patre, ferebatur et uagari noctibus solitus atque inualidum quemque obuiorum uel potulentum corripere ac distento sago impositum in sublime iactare ${ }^{141}$ («Desde o início da sua juventude foi de tal modo pródigo e licencioso, que muitas vezes

${ }^{137}$ Nero 6.4. A aurea armilla constitui a primeira de muitas vezes em que o elemento ouro aparece nesta $V i d a$, de modo que pode ser considerado um motivo recorrente, organizado em quiasmo à volta da Domus Aurea, segundo pretende Lounsbury, R. C. 1991, 3757-3758.

${ }^{138}$ Nero 7.1. Suetónio omite a presença de Britânico, que na realidade foi ofuscado pelo êxito de Lúcio (Nero): cf. Tácito, Ann. 11.11.2.

${ }^{139} \mathrm{E}$ não só entre os autores cristãos, embora as semelhanças sejam apenas aparentes; vide Martin R. 1991, 109-110.

${ }^{140}$ Tácito, ao referir o processo de Lépida, não menciona a participação de Nero na acusação: cf. Ann. 12.64.2-65.1. Para Wankenne, J.1981, 151, Suetónio, aparentemente mais objectivo, não poupa Nero, mesmo onde Tácito se cala.

${ }_{141}$ Otho 2.1. Cf. Nero 26.1-2. 
foi castigado pelo pai a golpes de chicote, e dizia-se que costumava deambular de noite e agarrar alguns fracos ou ébrios com que deparava: colocava-os num saio esticado e atirava-os ao ar»).

Morto o pai, pode dar largas aos seus instintos de libertino. Para se insinuar junto de Nero, finge-se apaixonado por uma liberta, velha e decrépita, mas influente na corte. Consegue facilmente o primeiro lugar entre os amigos daquele imperador: congruentia morum, ut quidam tradunt, et consuetudine mutui stupri ${ }^{142}$ («pela compatibilidade de hábitos, e ainda, como alguns dizem, pelas recíprocas relações carnais»). Deste modo, torna-se cúmplice dos planos de Nero (Otho 3.1), quer no que respeita à morte de Agripina (convoca mãe e filho para um banquete, no dia em que o imperador planeava assassiná-la, a fim de evitar suspeitas) ${ }_{1}^{143}$ quer no que toca ao estratagema para efectuar o casamento com Popeia Sabina. Mas um drama amoroso irá precipitar o fim da amizade e os acontecimentos seguintes. Gera-se um triângulo erótico em que Otão, com o imperador por concorrente, está em desvantagem. A cena assume o enredo que permite classificá-la como um verdadeiro mimo:

Item Poppaeam Sabinam tunc adbuc amicam eius, abductam marito demandatamque interim sibi, nuptiarum specie recepit nec corrupisse contentus adeo dilexit, ut ne riualem quidem Neronem aequo tulerit animo creditur certe non modo missos ad arcessendam non recepisse, sed ipsum etiam exclusisse quondam pro foribus astantem miscentemque frustra minas et preces ac depositum reposcentem. Quare diducto matrimonio sepositus est per causam legationis in Lusitaniam. Et satis uisum, ne poena acrior mimum omnem diuulgaret, qui tamen sic quoque hoc disticho enotuit: 'Cur Otho mentito sit, quaeritis, exul honore?/ Vxoris moechus coeperat esse suae.' ${ }^{144}$

«Também Popeia Sabina, até então amante de Nero, depois de retirada ao marido foi confiada temporariamente a Otão. Este recebeu-a com um simulacro de núpcias e, não satisfeito com seduzi-la, a tal ponto a amou que nem sequer suportava de boa mente a rivalidade de Nero. Conta-se como certo que, não só não recebeu os emissários que a vinham buscar, mas também que, certa vez, não deixou entrar nem o próprio imperador, que, de pé diante da porta, misturava, em vão, ameaças e rogos e exigia a devolução de quem the confiara. Por isso, anulado o casamento, foi afastado para a Lusitânia, a pretexto do cargo de legado. E pareceu-lhe suficiente, não fosse

142 Otho 2.2. Díon Cássio, 64.8.3, confirma a homossexualidade de Otão, mas com os favoritos de Nero; vide Martin, R. 1991, 166.

${ }^{143}$ Suetónio sugere que Otão estava presente na altura da morte de Agripina, mas, de facto, fora "exilado" para a Lusitânia em 58 e Agripina foi morta em 59. O biógrafo acaba por se contradizer, ao afirmar que Otão governou a Lusitânia durante dez anos; vide com. de MURIson, Ch. L. 1992, 99-102.

${ }_{144}$ Otho 3.1-2. Em Plutarco, Gal. 19.3-8, é Nero quem encarrega Otão de seduzir Popeia e a iniciativa de fechar as portas ao imperador é de Popeia. Tácito, Ann. 13.45-46, diz que Otão louva ostensivamente os dotes da esposa; mas, em Hist. 1.13.3, já afirma que foi Nero quem a confiou a Otão, enquanto resolvia a questão de Octávia, e que depois, suspeitando que ele fosse amante dela, o afastou para a Lusitânia. Díon Cássio, 61.11.2, fala de um verdadeiro ménage à trois.Vide Martin, R. 1991, 141; Townend, G. B. 1961, 227-248 ; Venini, P. 1974, 993. 
um castigo mais duro divulgar toda a farsa, a qual, no entanto, foi posta a nu neste dístico: 'Querem saber a razão por que está no exílio Otão com uma honra fingida? / Tinha-se tornado amante da sua mulher'».

Como o próprio biógrafo parece sugerir (ne poena acrior mimum omnem diuulgaret), o tema da disputa, o ciúme, faz lembrar uma trama de mimo. Através de uma inversão na cronologia, em que dá preferência a uma ordem "intensiva" ${ }^{145}$ Suetónio sugere que o trio amoroso, com o subsequente "exílio" de Otão, acontece depois da morte de Agripina; ${ }^{146}$ e faz do romance, infeliz para Otão, um ponto de viragem na vida do ex-amigo de Nero. ${ }^{147} \mathrm{Na}$ verdade, o biógrafo nota que ele administrou a província durante dez anos com exemplar moderatio atque abstinentia. ${ }^{148}$ Mas, em vez de se deter com questões políticas, Suetónio prefere acentuar que se tratou de uma longa e paciente espera do momento da vingança, a principal motivação da revolta: ut tandem occasio ultionis data est, conatibus Galbae primus accessit (Otho 4.1) («quando finalmente lhe foi dada a oportunidade de se vingar, foi o primeiro a aderir às tentativas de Galba»). À vingança junta-se a ambição pessoal e o curso do destino: eodemque momento et ipse spem imperii cepit magnam quidem et ex condicione temporum, sed aliquanto maiorem ex affirmatione Seleuci mathematici ${ }^{149}$ («e, naquele preciso momento, ele próprio acalentou esperanças grandes de obter o Império: grandes pelas circunstâncias dos tempos, mas, sem dúvida, maiores por uma declaração do astrólogo Seleuco»).

A diferença em relação à actuação de Galba é evidente. Otão prima pela generosidade. Após saber que lhe estava destinado o império, distribui moedas de ouro à coorte pretoriana da guarda e procura, por todos os meios, o favor dos outros corpos militares, com efeito favorável junto dos soldados: ut iam uix ullus esset, qui non et sentiret et praedicaret solum successione imperii dignum ${ }^{150}$ («de modo que seria difícil encontrar algum que não achasse e não proclamasse que ele era o único digno de suceder no império»). Desejo de vingança contra Nero, um destino favorável e a vontade dos soldados são, pois, os móveis apresentados por Suetónio para a adesão de Otão à revolta e sua ascensão ao trono imperial.

${ }^{145}$ Como lhe chama Gascou, J. 1984, 414.

${ }^{146}$ Mas Tácito, Ann. 14.1-2, relata a oposição de Agripina à ligação de Nero com Popeia, chegando ao ponto de, segundo Clúvio Rufo, se mostrar pronta a cometer incesto com o filho para segurar o seu poder (cf. Díon Cássio, 61.11). Vide com. de Murison, Ch. L. 1992, 99-100.

${ }_{147}$ Vide Martin, R. 1991, 147-148.

${ }^{148}$ Cf. ideia semelhante em Tácito, Hist. 1.13.4 e Ann. 13.46.3 e Plutarco, Gal. 20.2. Em Suetónio, o romance de amor eclipsa totalmente a carreira política de Otão; vide Gascou, J. 1984, 423, e n. 157.

${ }^{149}$ Tanto Tácito, Hist. 1.22.2, como Plutarco, Gal. 23.7, dizem que o astrólogo se chama Ptolemeu. Suetónio pode ter feito confusão com o astrólogo Seleuco da corte de Vespasiano; cf. Tácito, Hist. 2.78.1.

${ }^{150}$ Otho 4.2. Vide Martin, R. 1991, 226. 


\subsection{Ascensão inglória}

\subsubsection{Cláudio: uma carreira sem dignidade}

A vida de Cláudio aparece desde o primeiro momento marcada pelo contraste entre aspectos positivos e negativos. Ao nascimento em dia importante (o da dedicação do altar de Augusto em Lugduno ${ }^{151}$ e nobreza familiar do nome de Tiberius Claudius Drusus, acrescido do cognome de Germanicus, opõe-se a doença e a rejeição. Dentro desta visão negativa, duas ideias se conjugam à partida no retrato apresentado. Por um lado, a fraqueza física e mental (animo simul et corpore hebetato), o que lhe impedia o exercício de qualquer cargo público, e por outro, a submissão a pessoas de baixa categoria social. Ele próprio se queixará mais tarde de um preceptor bárbaro e cruel, que o castigava severamente ao mínimo pretexto. A consequência das deficiências é o afastamento dos olhares: preside aos jogos encapuchado (palliolatus) e, para assumir a toga viril, dirige-se ao Capitólio - manifesto exagero da parte de Suetónio - por volta da meia noite. ${ }^{152}$ Claúdio parece criado para o olvido.

$\mathrm{O}$ contraste (assinalado por tamen e por uerum ne sic quidem) manifesta-se também entre a dedicação às disciplinas liberais e a falta de dignitas com que é tratado, como provam as palavras e acções de repúdio por parte de pessoas de quem se esperaria afecto; e, para mais, figuras gradas. É escarnecido pela mãe Antónia, que o qualifica de «aberração» (portentum hominis), ${ }^{153}$ «obra inacabada da natureza, mas tão-somente começada» (nec absolutus a natura, sed tantum incohatus) e «tolo» (stultus); é tratado com desprezo pela avó Lívia. A irmã Livila lamenta a sorte do povo romano, se ele vier a ser imperador. ${ }^{154}$ Finalmente, transcrevem-se, em longo parágrafo ( $C l$. 4), as opiniões de Augusto, expressas em cartas: sobressai o julgamento negativo e a constante preocupação em esconder as deformidades deste neto de Lívia, mas regista-se também a ideia positiva de que, quando o ânimo de Cláudio se não extravia, a sua eugeneia se manifesta; e, apesar das dificuldades, a capacidade de se exprimir com correcção em público chega a provocar a surpresa de Augusto (Cl. 4.5-6.). Acresce, depois, o desprezo por parte de Tibério, que o trata como uma criança: Cláudio pede-lhe honras e Tibério dá-lhe moedas de ouro para as Saturnais (Cl. 5). E a vida de Cláudio transforma-se em contínuas Saturnais, com a

${ }^{151}$ Cl. 2.1. (Em 10 a.C.) Os eruditos rejeitam geralmente a informação de Suetónio, tomando por base a cronologia de Tito Lívio (Per.139) que situa claramente a dedicação do altar em 12 a. C. Vide Simpson, C. J. 1987, 586-592. Suetónio costuma ser rigoroso no tratamento dos nascimentos, mas também força a data de nascimento de Tito (Tit. 1), acaso para acentuar uma coincidência dramática.

${ }^{152}$ Cl. 2.2. O com. de Mottershead, J. 1986, 35, sublinha que o o pallium (sic) se destinava a esconder os sinais menos atraentes da aparência de Cláudio. Já Sterckx, C. 1969, 477-478, com base em textos da época sobre o uso do palliolum, diz que a motivação residia nas febres continuadas a que Cláudio estava sujeito.

${ }^{153}$ Cal. 3.1-2. Para Reenmans, T. 1992, 189-232, trata-se de um exemplo de humor pelo recurso à similitudo adhibita palam.

${ }^{154}$ Tal observação parece ser resposta a uma intenção do senado em apresentar Cláudio como pretendente à sucessão, pelo menos a par de Druso, filho de Tibério. Livila teria boas razões para o lamento, já que estava casada com Druso: vide Levick, B. 1990, 24. 
inversão social que este período festivo evoca. ${ }^{155}$ Cláudio perde a esperança de fazer carreira (spes dignitatis) e entrega-se ao ócio, na companhia de pessoas vis (sordidissimi homines), à ebriedade e ao jogo dos dados, embora não deixe de receber sinais de respeito particulares e públicos, ${ }^{156}$ dos quais dá notícia o biógrafo como casos de excepção ( $C l$. 6). Suetónio introduz assim, além da já referida tendência para submissão a pessoas de categoria inferior, mais dois aspectos determinantes no carácter de Cláudio e característicos das Saturnais: a bebida e o jogo.

Com o advento de Calígula, no período em que este busca a popularidade, aumenta a dignidade de Cláudio. Com efeito, é escolhido como colega de consulado de Gaio e dá-se um prodígio auspicioso: uma águia vem pousar no ombro direito do novo cônsul. Em uns jogos, é aclamado em coro pelo povo, como tio do imperador e irmão de Germânico. ${ }^{157}$ Perante sinais tão inesperados e relevantes, o leitor é levado a pensar que a sorte de Cláudio mudou e que o biógrafo abandonou a descrição negativa. Mas o que se diz a seguir apaga o efeito favorável que se gerara (o contraste é sublinhado por nec eo minus). Anedotas de sabor farsesco ridiculizam a personagem e representam um golpe na dignitas do filho de Druso Germânico:

Nec eo minus contumeliis obnoxius uixit. Nam et si paulo serius ad praedictam cenae horam occurrisset, non nisi aegre et circuito demum triclinio recipiebatur, et quotiens post cibum addormisceret, quod ei fere accidebat, olearum aut palmularum ossibus incessebatur, interdum ferula flagroue uelut per ludum excitabatur a copreis. Solebant et manibus stertentis socci induci, ut repente expergefactus faciem sibimet confricaret. ${ }^{158}$

«Nem por isso estava menos exposto a afrontas. De facto, se chegava um pouco mais tarde do que a hora prevista para o jantar, não era sem custo que, depois de dar a volta ao triclínio, se instalava e, cada vez que adormecia depois de comer, facto que quase sempre acontecia, atiravam-lhe caroços de azeitonas e de tâmaras. Por vezes, era acordado pelos bobos a golpes de palmatória ou azorrague, como se faz na escola. Enquanto ressonava, costumavam calçar-lhe socas nas mãos, para que, ao despertar de repente, esfregasse a cara com elas».

Cláudio é ultrajado na sua posição social, visto que lhe não reservam um lugar de honra, nem sequer um lugar comum. É ultrajado pelos convivas e pelos 'bobos', cujo nome (do grego koprias, ligado a kopros, 'excremento') revela seres de condição vil. Em dois pequenos capítulos sucessivos (Cl. 7-8), Suetónio

${ }^{155}$ A apresentação de Cláudio como Saturnalicius princeps é recorrente na literatura: vide Dickison, S. K. 1977, 634-647; HaArberg, J. M. 1982, 109-114; com. de Guastella, G. 1999, 21-22.

156 Cl. 5: cum interim, quanquam hoc modo agenti, numquam aut officium hominum aut reuerentia publice defuit. Esta é a disposição adoptada na ed. de IHм; Aılloud inicia com este período o capítulo 6 .

${ }^{157} \mathrm{Cl}$. 7. O facto de a águia pousar no ombro direito é sinal de bom agouro: cf. Vit. 9. Análogas predições em Aug. 94.7; 97.1; Tib. 14.4; Gal.1; 4.2; Ves. 5.7; Dom. 6.2.

${ }_{158}$ Cl. 8. Vide Guastella, G. 1999, 36. 
faz o biografado passar da glória ao vilipêndio. Este contraste tem um efeito demolidor sobre a imagem do futuro dono do mundo.

Além disso, o biógrafo retira o valor das honras que mencionou atrás: Cláudio é quase destituído do consulado, devido à sua incúria (segnitia); e, a propósito da delegação à Germânia, que Cláudio encabeça, para felicitar o sobrinho por ter sobrevivido à conjura de Lépido e Getúlico, Suetónio acrescenta um boato de gosto farsesco, com o fim de ridiculizar o seu biografado. Irritado com o uso que o senado fizera do estatuto de Cláudio (como se este fosse enviado para o controlar), Calígula atirou-o ao rio, vestido, tal como chegara. Suetónio refere que Cláudio é enviado inter legatos, mas circunscreve a reacção violenta de Calígula à figura do tio. ${ }^{159}$ Assim o efeito é maior: Cláudio aparece como vítima solitária. Para provar a humilhação que Cláudio sofria da parte do sobrinho, Suetónio acrescenta que ele era o último dos ex-cônsules a expressar a opinião e o último a ser consultado. ${ }^{160}$ Consequentemente, seria o último que se esperaria que fosse o sucessor de Calígula. Mas os desígnios da Fortuna são imprevisíveis. Desde o princípio se vai consolidando o retrato de uma personagem de comédia.

\subsubsection{Vitélio: a carreira de um glutão}

Tanto o nascimento como a morte de Vitélio são marcados por presságios negativos. Vitélio nasce sob uma estrela funesta. A indicação do dia do nascimento fica subordinada aos maus augúrios que o momento representa. $\mathrm{O}$ horóscopo do recém-nascido causa tanto horror, que o pai se opõe a que lhe confiem uma província, e a mãe, ao saber que ele tinha sido enviado às legiões e proclamado imperador, lamenta-o como perdido (Vit.3.2). Suetónio apresenta uma figura odiosa e empenha-se em mostrar que a ignomínia a marca desde cedo: diz que Vitélio passou a meninice e a primeira adolescência entre os prostitutos de Tibério em Cápreas ${ }^{161}$ e que o pai teria subido na carreira «graças ao corpo» do filho. ${ }^{162}$ Tal estatuto é agravado a seguir pelas palavras do biógrafo: sequenti quoque aetate omnibus probris contaminatus («também na idade seguinte foi conspurcado por todo o género de opróbrios»). Conforma-se aos vícios dos imperadores: teve o favor de Gaio pela comum paixão pelas corridas do circo;

${ }^{159}$ Cl. 9.1. Díon Cássio, 59.23.2-5, apresenta a reacção de Calígula dirigida contra toda a delegação; vide com. de Guastella, G. 1999, 150. Vide Simpson C. J. 1979, 347-366.

${ }_{160} \mathrm{Cl}$. 9.2. Mas Suetónio mais uma vez distorce os factos para obter o efeito que pretende. Díon Cássio, 59.8.6, diz que Calígula decretara, em 37, que os cônsules deviam expressar a opinião em conformidade com a ordem cronológica segundo a qual tinham exercido o cargo: naturalmente Cláudio seria dos últimos. Vide com. de Guastella, G. 1999, 150.

${ }^{161}$ Vit. 3.2. Esta informação é suspeita, como todos os rumores sobre a devassidão de Tibério em Cápreas. Se Vitélio (porque morreu com 59 anos: Vit. 18) nasceu em 12 d. C (e não em 15, como Suetónio indica, talvez erradamente, por referência aos cônsules), já tinha dezanove anos em 31, ano a partir do qual datam as histórias escabrosas sobre Tibério, o que se não conforma exactamente com pueritiam primamque adulescentiam Capreis egit; como observa Murison, Ch. L. 1987, 97-99. Vide Também com. Murison, Ch. L. 1992, 141-142.

${ }^{162}$ Tácito, Hist. 3.86.1, diz , pelo contrário, que Vitélio devia toda a sua ascensão aos méritos do pai. 
o favor de Cláudio, pela paixão pelo jogo dos dados; o favor de Nero, pelos mesmos gostos e porque, ao presidir aos jogos Neronianos, juntara os seus rogos aos do povo para que o imperador participasse no concurso dos citaredos - o que Nero desejava, mas se não atrevia a fazer (Vit. 4). Com efeito, o Vitélio de Suetónio parece ser uma caricatura daqueles três imperadores, sobretudo do último.

Quanto aos cargos públicos, o comportamento de Vitélio é variável. O biógrafo introduz um dado positivo, para o anular de seguida. Se, na província de Africa, mostra singularis innocentia, pelo contrário, no cargo urbano, subtraiu dos templos oferendas e ornamentos de ouro e prata, como já antes fizera Nero, e substituiu-os por outros de estanho e latão. Vitélio torna-se assim ímpio e suspeito aos olhos dos deuses. ${ }^{163}$ Cai ainda sobre Vitélio a suspeita da morte do filho Petroniano, pouco depois de o emancipar. Acusa-o posteriormente de parricídio, como se o jovem, levado pelo remorso, tivesse bebido o veneno que preparara para o crime. ${ }^{164}$

A gula é o seu principal defeito. Contra todas as expectativas, Galba envia-o para a Germânia Inferior, porque acha que os homens menos perigosos são os que só pensam em comer; e com a abundância da província podia satisfazer a sua gula insaciável. A nomeação é mais por desprezo que por favor (Vit. 7.1). Como outros agitadores e campeões da magnificência, está submergido em dívidas: nem sequer tem dinheiro para a viagem. Foi recebido com entusiasmo por um exército desejoso de revolta. Precede-o a reputação de ter «carácter benévolo e munificente» (facilis ac prodigus animus): durante a viagem, tratara os soldados com amabilidade e familiaridade, ao ponto de arrotar para mostrar que já tinha almoçado (Vit. 7.3) - um elemento de grosseria ligado à sua gula. A ânsia de agradar leva-o a, ao entrar no campo, não recusar os pedidos e retirar certos castigos.

\subsubsection{Domiciano: um irmão menor}

Como no caso de Tito, a imagem geral de Domiciano é sugerida logo no primeiro capítulo. Referidas as habituais indicações sobre o nascimento (a data e o lugar que depois se transformou no templo dos Flávios), o biógrafo passa a fazer um resumo da vida com informações bastante negativas: faz saber que este filho mais novo de Vespasiano passou a prima adulescentia na inopia e na infamia. A inopia é ilustrada com o facto de não possuir nem um vaso de prata, e a infamia, com o rumor da promessa de uma noite a Clódio Polião e da prostituição a Nerva, seu imediato sucessor. ${ }^{165}$ A sugestão de passividade

163 Vit. 5: In prouincia singularem innocentiam praestitit biennio continuato... at in urbano officio dona atque ornamenta templorum subripuisse et commutasse quaedam ferebatur proque auro et argento stagnum et aurichalcum supposuisse. Como nota CizeK, E. 1975b, 125-130, a conjunção at contribui para diminuir e quase anular o mérito precedente. Cf. Nero 32.4 e Jul.54.2.

${ }^{164}$ Vit. 6. Com efeito, a esposa Petrónia, depois do divórcio, faria do filho seu herdeiro, com a condição de ser emancipado do poder paterno. Como o filho morreu pouco depois, línguas malévolas acusaram Vitélio de ser o autor de tal morte. Vide Martin, R. 1991, 148.

${ }^{165}$ Dom. 1.1. Sobre a homossexualidade de Domiciano, vide Martin, R. 1991, 168. 
(expressa em corruptum Domitianum et a Nerua) contribui para o denegrir. ${ }^{166}$ Também a atitude de se esconder no Capitólio, depois do ataque dos Vitelianos e do incêndio, e depois fugir disfarçado de sacerdote de Ísis, sugere covardia e habilidade para a dissimulação. Com efeito, esconde-se tão bem em casa da mãe de um condiscípulo que não puderam dar com ele. As expressões insistem na ocultação (clam pernoctauit... Isiaci celatus habitu... ita latuit). ${ }^{167}$

O biógrafo mostra claramente que procura, na juventude de Domiciano, traços do carácter do futuro imperador: já então se servia do poder com tal licentia, que mostrou, desde logo, o modo futuro de agir. ${ }^{168}$ As tendências tirânicas manifestam-se, também, no domínio sexual - abusa de muitas mulheres casadas e desposa Domícia Longina, depois de a arrebatar ao marido ${ }^{169}$ - e na forma arbitrária como distribui os cargos, segundo parece, à revelia do pai imperador: 'mirari se' Vespasiano dictitante, 'quod successorem non et sibi mitteret” ('admirava-se - repetia continuamente Vespasiano - que lhe não enviasse também a ele um sucessor'»).

Outro traço é o sentimento de inferioridade em relação a Tito e consequente inveja ${ }^{170}$ que leva Domiciano a empreender uma campanha militar, considerada desnecessária, contra a Gália e a Germânia, com o único objectivo de igualar os feitos do irmão. Tal iniciativa valeu-lhe uma reprimenda e o ser colocado no lugar que competia à sua idade e condição, isto é, numa posição subalterna; ${ }^{171}$ e, dos seis consulados que exerceu, só um foi ordinário e, mesmo este, cedido pelo irmão. No meio destas contrariedades para Domiciano, o biógrafo refere a sua hábil simulação de modéstia e a dedicação à poesia, antes não cultivada e mais tarde abandonada com desprezo. ${ }^{172}$ Mas logo volta ao tema da hostilidade mortal em relação a Tito.

Esta é a situação dos vários Césares antes de atingirem o governo do Império. O biógrafo procura analisar as razões que fizeram destes homens

${ }^{166}$ Vide com. de Jones, B. W. 1996, 14; com. de Jones, B. \& Milns, R. 2002, 122.

${ }^{167}$ Dom. 1.2. Suetónio demonstra mais uma vez o gosto em sublinhar os perigos a que os imperadores escaparam por milagre: vide Gascou, J. 1984, 419 n. 148.

${ }^{168}$ Dom 1.3: ceterum omnem uim dominationis tam licenter exercuit, ut iam tum qualis futurus esset ostenderet. Mediante esta apreciação global, feita no início da biografia, a natureza de Domiciano fica definida antes da exposição dos factos que a caracterizam, como afirma GAscou, J. 1984, 694-695.

169 Segundo Martin, R. 1991, 152, o comportamento sexual de Domiciano reflecte a instabilidade e falta de moderação do décimo segundo César, mas esta conduta choca sobretudo pelo contraste com a política da restauração dos costumes antigos, da repressão do adultério e da castração.

${ }_{170}$ Como sugere Martin, R. 1991, 233. Este autor diz que Domiciano tem condutas de tipo infantil que revelam um rancor exacerbado de Domiciano contra o irmão e o pai.

${ }^{171}$ Dom. 2.1. Viu-se obrigado a viver sob o mesmo tecto que Vespasiano; a seguir, de liteira, o pai e o irmão, estes transportados numa sella; a acompanhá-los, montado num cavalo branco, no triunfo judaico. Mas estas situações são honrosas e dignas de um príncipe imperial. $\mathrm{O}$ facto de, durante o triunfo, seguir a cavalo pode ser colocado em paralelo com a participação de Tibério no triunfo de Augusto (Tib. 6.4).

${ }^{172}$ Dom. 2.2. Cf. Tácito, Hist. 4.86.2. 
imperadores: para além da nobreza (tratada na rubrica inicial de cada Vida), os méritos, as circunstâncias, o destino. Há carreiras gloriosas, que desde logo auguravam um futuro grandioso, carreiras dúbias, em que os aspectos negativos são intercalados com aspectos positivos e carreiras ignominiosas, que não faziam antever uma subida ao trono imperial. Mas Claúdio é empurrado pelos soldados pretorianos, Vitélio pelos soldados da Germânia, Domiciano pela lógica dinástica, apressada pela morte precoce de Tito. Por outro lado, através de referências caracterológicas, mais ou menos explícitas, ficam patentes as características gerais que hão-de nortear as condutas destes futuros príncipes. 
(Página deixada propositadamente em branco) 


\section{CONQUista E RECEPÇÃo Do PODER SUPREMO}

O acto de assumir o poder apresenta-se muitas vezes espectacular. A chegada de um novo César é pretexto para golpes de teatro: manipulação de massas, ostentação de liberalidade, de poder, de falsa modéstia, ou até motivo de cómico. Há casos em que o biógrafo, por influência da actuação posterior de determinados príncipes, torna a ascensão ao poder imperial numa usurpação antecedida de um crime.

\subsection{A vitória da ambição de uma família}

Um momento determinante na Vida de César é a passagem do Rubicão, um pequeno rio que deve a sua fama ao drama que o general viveu nas suas margens. Perante os ataques dos adversários, César passa à Gália Citerior, «para vingar pela guerra qualquer medida mais grave tomada pelo senado sobre os tribunos da plebe que intercediam a seu favor». ${ }^{1}$ Este praetextum de César serve de estímulo para um acumular de vozes sobre outras causas, e, assim, apresenta Suetónio o elenco das possíveis razões da guerra civil, sob o ponto de vista dos dilemas e das aspirações de César²: para Pompeio, a impossibilidade de César acabar as obras e cumprir as promessas que tinha feito, que o levava a querer baralhar e reformular tudo; ${ }^{3}$ para alii, anónimos, o medo de ter de responder pelas ilegalidades do seu consulado, em que violara leis, auspícios e a oposição dos adversários. Corrobora esta suspeita uma frase de César, ao ver os inimigos desbaratados, após a batalha de Farsalo, segundo o testemunho de Asínio Polião. ${ }^{4}$ Para uns quidam é o acalentado desejo de poder absoluto, opinião confirmada por uns versos de Eurípides que, segundo Cícero, repetia continuamente. ${ }^{5}$ Parece significativo que Suetónio termine a

${ }^{1} J u l .30 .1:$ (...) bello uindicaturus siquid de tribunis plebis intercedentibus pro se grauius a senatum constitutum esset.

${ }^{2}$ De modo diferente da narrativa mais completa e precisa de Díon Cássio, 41.1-3. Como afirma Gascou, J. 984, 12, «Suétone ne prétend pas faire une chronique détaillée de la guerre civile et il n'a pas la même visée qu'un historien comme Dion qui s'astreint à un récit aussi complet et aussi cohérent que possible: il met l'accent sur certains faits qui lui paraissent nécessaires à la compréhension de la personnalité de César et fait un choix dans la masse des informations qu'il avait à sa disposition». Também é diferente da longa narração contínua de Plutarco, Caes. 28-31, apesar de este, como Suetónio, se interessar mais pelos factos que desenham uma personalidade do que pelos grandes acontecimentos históricos.

${ }^{3}$ Jul. 30.2. Observação registada apenas em Suetónio. Tal opinião tornava César um conspirador a necessitar desesperadamente de dinheiro, à semelhança de Catilina: vide CANFORA, L. 2000, 152.

${ }^{4}$ Jul. 30.4: Hoc uoluerunt; tantis rebus gestis Gaius Caesar condemnatus essem, nisi ab exercitu auxilium petissem. Palavras que Plutarco prefere colocar no momento próprio, depois da batalha de Farsalo (Caes. 46.1).

${ }^{5} \mathrm{Jul}$. 30.5. Trata-se de uma parte do discurso de Etéocles (Ph. 524). Cícero dá a versão latina: Nam si uiolandum est ius, <regnandi> gratia / uiolandum est: aliis rebus pietatem colas. Em conformidade com o léxico político republicano, traduz tupavvís por regnum e exprime a noção de $\epsilon \dot{v} \sigma e ́ \beta \in \iota$ la por pietas. Vide CANFora, L. 2000, 153. 
discussão das causas com uma tirada em que o próprio César se revela através de um modelo trágico. Há uma transposição da realidade dramática da fala de Etéocles de Eurípides para a personagem de Júlio César, para quem a ambição de poder passa à frente da justiça e do respeito pelos deuses. ${ }^{6}$ Seguidamente (Jul. 31.1), Suetónio volta ao pretexto que antes (Jul. 30.1) apresentara como uma condição (si quid de tribunis plebis.... constitutum esset) e retoma-o agora como facto real: foi retirado o direito de veto aos tribunos e estes abandonaram a cidade. César tem o motivo que esperava para agir. Agora o conquistador procede com secretismo e per dissimulationem:

Cum ergo sublatam tribunorum intercessionem ipsosque urbe cessisse nuntiatum esset, praemissis confestim clam cohortibus, ne qua suspicio moueretur, et spectaculo publico per dissimulationem interfuit et formam, qua ludum gladiatorium erat aedificaturus, considerauit et ex consuetudine conuinio se frequenti dedit (Jul. 31.1).

«Depois de chegar a notícia de que fora retirado aos tribunos o direito de veto e que eles próprios tinham abandonado a Urbe, imediatamente enviou umas coortes em segredo, para não levantar suspeitas; e assistiu a um espectáculo público, para disfarçar, e examinou a maqueta, segundo a qual pensava construir uma escola de gladiadores; e, como habitualmente, tomou parte num banquete em numerosa companhia».

César é agora apresentado como um convincente actor. ${ }^{7}$ Acentua-se o secretismo e o perigo da acção do general. Depois do pôr-do-sol, César parte disfarçado num carro de mulas de um moinho das redondezas, por um caminho secretíssimo, com uma modesta escolta. Facto relevante, tanto que não é mencionado por Plutarco, é que, apagadas as tochas, se perdeu, andou, errante, até à madrugada e só então, com a ajuda de um guia, conseguiu encontrar o caminho a pé, através de sendas muito apertadas. As indicações temporais e cénicas (Post solis occasum; luminibus extinctis; diu, ad lucem) e a adjectivação (occultissimum iter; errabundus; per angustissimos tramites) acentuam o dramatismo. Por momentos o resultado esteve suspenso, devido a um simples desvio no caminho que poderia ter alterado o curso da história. ${ }^{8}$ Como nota Canfora, a narrativa tem aspectos surrealistas: o procônsul da Gália, que preparava a revolta contra a República, entregue a um guia desconhecido, abandona o carro e prossegue a pé até ao Rubicão, onde os seus soldados o esperavam há muito tempo, certamente desmoralizados por esta inquietante demora. ${ }^{9}$ De resto, Suetónio mostra repetidamente uma concepção de história enquanto resultado de situações simples e fortuitas, mas susceptíveis de alterar

\footnotetext{
${ }^{6}$ Sobre o significado desta fala de Etéocles, vide Romilly, J. 1969, 183-184 e 186-187.

${ }^{7}$ Plutarco transmite no essencial os mesmos pormenores (Caes. $32.3 \mathrm{ss}$ ), sem insistir no secretismo e na dissimulação.

${ }^{8}$ Gascou, J. 984, 17, pensa que Plutarco teria incluído na sua biografia este episódio dramático e um pouco romanesco, se o tivesse encontrado nas fontes. Pelo que deduz que Suetónio se serviu de uma fonte diferente.

${ }^{9}$ Vide Canfora, L. 2000, 159-160.
} 
todo o decurso dos grandes acontecimentos. O imprevisto descrito explica, de certo modo, a hesitação de César:

Consecutusque cohortis ad Rubiconem flumen, qui prouinciae eius finis erat, paulum constitit, ac reputans quantum molietur, conuersus ad proximos: 'etiam nunc', inquit, 'regredi possumus; quod si ponticulum transierimus, omnia armis agenda erunt' (Jul. 31.2).

«Alcançadas as suas coortes junto ao rio Rubicão, que marcava a fronteira à sua província, parou por momentos, e, reflectindo na magnitude da empresa, voltou-se para os que estavam próximos e exclamou: 'Até agora, ainda podemos tornar para trás, porque, se atravessarmos esta pequena ponte, tudo terá de ser resolvido pelas armas'».

Suetónio deixa, assim, patente a luta interior de quem se prepara para tomar uma opção grave e da qual não pode prever o desfecho. ${ }^{10}$ Poderá ser a hesitação de quem está algo perturbado, devido a um projecto que começou mal. Mas parece também uma sondagem de aparato, para pôr à prova o moral dos mais directos seguidores. O dilema é resolvido por uma espécie de deus ex machina, que, de certo modo, retira a César a responsabilidade plena da decisão: uma entidade de aspecto divino atravessa o Rubicão e dá um forte sinal de marcha com a tuba. $\mathrm{O}$ quadro termina com as palavras determinadas do general: Tunc Caesar: 'Eatur', inquit, 'quo deorum ostenta et inimicorum iniquitas uocat. Iacta alea est' inquit (Jul. 32) («Disse então César : 'Avante para onde os prodígios dos deuses e a iniquidade dos nossos inimigos nos chamam. $\mathrm{O}$ dado está lançado', acrescentou»). Suetónio é o único a apresentar a personagem sobrenatural. Não esqueçamos o relevo que o biógrafo dá aos fenómenos de carácter religioso e que o Diuus Iulius, apesar do seu cepticismo, aparece como alguém ligado ao divino. Assim, a acção parece desenrolar-se no plano divino e no plano humano: à iniciativa divina vem juntar-se a iniciativa de César expressa em Iacta alea est. ${ }^{11}$ Vista por esta perspectiva, a contaminação de duas tradições diferentes, apontada por Hohl, ${ }^{12}$ não implica incompatibilidade, ${ }^{13} \mathrm{e}$ parece mesmo justificar-se (para uma mente religiosa) como uma coincidência

${ }^{10}$ Plutarco, Caes. 32.7 centra-se na consciência dos males que, com a travessia do rio, advirão para a humanidade, mas que serão compensados com a glória futura; Apiano, $B C$ 2.5.35, faz o balanço entre a infelicidade de César e a da humanidade e faz César preferir a felicidade pessoal à do resto dos homens. GAscou, J. 984, 17, 21-22, pensa que utilizaram a mesma fonte, simplesmente Suetónio preferiu atenuar o cinismo de César.

11 Expressão de Menandro e que também figura em Plutarco, Caes. 32.8. César terá

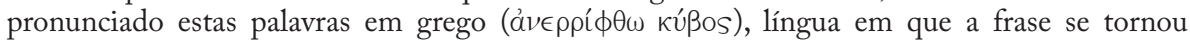
proverbial. Em latim, o termo alea é usado em sentido figurado, com o significado de "risco", mas a expressão no seu conjunto é raríssima neste idioma, pelo que aponta para uma tradução directa do grego por parte da fonte de Suetónio, Asínio Polião: vide Bickel, E. 1952, 269-273; Townend, G. B. 1960, 99; Dubuisson, M., 885-886.

${ }^{12}$ Hohl, E.1952,246-249. Gascou,J.1984,17,22-24, não pensa que Suetónio inventasse um ostentum para embelezar a história, mas que aproveitou uma fonte da propaganda cesariana.

${ }^{13}$ Ao contrário da opinião de GAscou, J. 1984, 24. 
da vontade divina e humana. Ao apresentar este ostentum, Suetónio manifesta o seu gosto pelo maravilhoso e pelo romanesco e aproxima a sua narrativa do mundo da tragédia e da épica. Este prodígio, um sinal oportuno da fortuna para restaurar o moral das tropas, poderá ter sido arquitectado pelo próprio César, ${ }^{14}$ na linha da sua actuação em Ravena. Se Suetónio percebeu que era uma encenação, mais uma vez pactuou com o artifício em proveito do romanesco, pois, se tal fenómeno não aconteceu, para a mentalidade da época, poderia ter acontecido. ${ }^{15}$ Este é um momento decisivo na vida de César: não admira, por isso, o relevo dramático que Suetónio lhe dá.

Na cena seguinte (Jul.33), são explorados os dotes teatrais do orador: vemos César, já acompanhado dos tribunos da plebe, expulsos de Roma, a chorar e a rasgar as vestes sobre o peito numa patética arenga às tropas. Suetónio não cria discursos, mas relata-nos as impressões que a alocução provocou. César mostra repetidamente o anel de cavaleiro na mão esquerda e os soldados das últimas filas - que já não ouvem nada do que ele diz - afirmam que o general está a prometer o censo equestre a cada um deles: e assim se gera o boato. $\mathrm{O}$ que César queria realmente dizer era que se despojaria até do anel para satisfazer os que o ajudassem a defender a sua dignitas. ${ }^{16}$

O biógrafo sugere, ao longo destes capítulos, o agudizar do conflito com os optimates até ao ponto culminante que foi a declaração de guerra. Mas, depois destes episódios, como anteriormente para a guerra da Gália, segue-se uma narrativa rápida: ordo et summa rerum (Jul. 34-36) da guerra civil, de que ressalta a velocidade de César (avança até Brundísio, volta a Roma, dirige-se à Hispânia, no caminho ataca Massília que lhe fechava as portas, regressa a Roma, transfere-se para a Macedónia); a sua intrepidez (que supera todos os obstáculos, ${ }^{17}$ até vencer Pompeio em Farsalo - Jul. 35.1); a superação da fama do opositor (com a derrota, fácil, de Fárnaces, filho de Mitridates, que Pompeio vencera e lhe valera o cognome de Magnus). ${ }^{18}$ No final, brilha o general vitorioso (Jul. 37), que destaca, com orgulho, a vitória do Ponto (sobre Fárnaces) com um cartaz (ueni, uidi, uici); faz dádivas aos soldados e ao povo (Jul. 38) e oferece espectáculos vários (Jul. 39), entre os quais, representações teatrais em todas as línguas, com a participação de Décimo Labério, cavaleiro romano e autor de mimos. ${ }^{19}$ Esta ocasião serve a César para alardear liberalitas e fausto.

${ }^{14}$ Pisístrato simulara algo de semelhante: uma aparição de Atena (Heródoto, 1.6; Aristóteles, Ath. 14.4.); vide Canfora, L. 2000, 160-161; Della Corte, F. (1967), 64; com. de Butler, H. E. \& M. Cary $1927,85$.

${ }^{15}$ Como diz Aristóteles, Poet. 1451 b, ao distinguir a poesia da história.

${ }^{16}$ O pormenor realista deste equívoco ocorre apenas em Suetónio. Vide Canfora, L. 2000, 163-164. Gascou, J. 1984, 26-27.

${ }^{17}$ Como é explicito em Jul.34.2: breui tamen omnia subegit.

${ }^{18} \mathrm{Jul}$. 35.2: crebro commemorans Pompei felicitatem, cui praecipua militiae laus de tam inbelli genere hostium contigisset.

${ }^{19}$ Jul. 39.2. Desta violência se queixará Labério no prólogo da sua peça, conservado em Macróbio, 2.7.3. Vide Schwartz, J. 1948b, 264-271. 
Também o herdeiro de César é movido pela ambição. A sua chegada ao poder é aparatosa e manchada de sangue. A ruptura definitiva com António abre a Octávio o caminho para o poder absoluto. A crueldade do jovem alterna com atitudes de condescendência: embora declare António hostis, permite que se lhe reúnam os familiares e amigos e dispensa os habitantes de Bonónia, clientes dos Antónios, de pegarem em armas contra o seu patrono (Aug. 17.2). A batalha de Áccio - que Suetónio, como habitualmente, não descreve: isso é matéria para a historiografia - é referida, não como derrota das forças egípcias, mas como a vitória decisiva sobre o triúnviro (Aug. 17.3). Depois de resumir os sucessos entre a batalha e a queda de Alexandria, a tempestuosa viagem de Augusto a Itália para responder às reclamações dos soldados (Aug. 17.1-3), Suetónio alonga-se a descrever os esforços de Augusto para conservar a rainha viva e a sequência final de atitudes antagónicas deste desenlace trágico:

Et Antonium quidem seras condiciones pacis temptantem ad mortem adegit uiditque mortuum. Cleopatrae, quam seruatam triumpho magno opere cupiebat, etiam psyllos admouit, qui uenenum ac uirus exugerent, quod perisse morsu aspidis putabatur. Ambobus communem sepulturae honorem tribuit ac tumulum ab ipsis incohatum perfici iussit. Antonium iuuenem, maiorem de duobus Fuluia genitis, simulacro Diui Iuli, ad quod post multas et irritas preces confugerat, abreptum interemit. Item Caesarionem, quem ex Caesare patre Cleopatra concepisse praedicabat, retractum e fuga supplicio adfecit. Reliquos Antoni[i] reginaeque communes liberos non secus ac necessitudine iunctos sibi et conseruauit et mox pro condicione cuiusque sustinuit ac fouit (Aug. 17.4-5).

«E a António, que pedia, já tarde, condições de paz, empurrou-o para a morte e viu-o morto. Quanto a Cleópatra, que ele desejava com grande empenho preservar para o seu triunfo, recorreu aos Psilos, para que the sugassem o veneno e a peçonha, já que se julgava que ela perecera devido à mordedura de uma áspide. A ambos honrou com sepultura comum e mandou acabar o túmulo por eles mesmos começado. Ao jovem António, o mais velho de dois filhos que António tivera de Fúlvia, arrebatou-o à estátua do Divino Júlio, junto da qual, depois de muitas e vãs preces, se refugiara, e matou-o. Do mesmo modo, a Cesarião, que Cleópatra proclamava ter concebido de César, depois de o apanhar na fuga, entregou-o ao suplício. Quanto aos restantes filhos comuns de António e da rainha, sem qualquer diferença em relação aos que a si estavam unidos pelo parentesco, não só os poupou, como depois, segundo a situação de cada um, os tomou a seu cargo e favoreceu».

Octávio procura assegurar que Áccio não se repetirá. Mas, ao mesmo tempo, procura dar algumas mostras de clemência. Tem finalmente o seu poder consolidado. E Suetónio vai, a partir daqui, reunir sinais de mudança na descrição do carácter da personagem. Segue-se a homenagem ao corpo de Alexandre Magno, numa clara alusão ao modelo, a fundação de Nicópolis, a celebrar a vitória de Áccio, a ampliação do templo de Apolo e a consagração 
a Neptuno e a Marte do lugar do acampamento. ${ }^{20}$ Octávio, sem rivais, está agora em condições de assumir o poder absoluto. Do fim das lutas civis nasce o principado.

\subsection{A pretexto da salvação do estado}

A chegada de Galba ao poder começa por ser uma atitude patriótica, para, no final, descambar para a arrogância. A sublevação das Gálias contra Nero vem apelar à consciência cívica do general: a um pedido de ajuda do legado da Aquitânia, segue-se uma carta de Víndex que o exorta a tomar a seu cargo o papel de assertor e dux do género humano. Suetónio conta, do ponto de vista da acção de Galba, esta rebelião que já relatara no que dizia respeito aos efeitos em Nero (Nero $40 \mathrm{ss).} \mathrm{Galba} \mathrm{não} \mathrm{hesita} \mathrm{muito} \mathrm{tempo} \mathrm{e} \mathrm{aceita}$ a proposta, movido, em parte, pelo medo e, em parte, pela esperança. Por medo, porque interceptara cartas secretas de Nero com ordem de o liquidar; pela esperança, porque se sente apoiado por secundissima auspicia e pelos omina. ${ }^{21} \mathrm{Na}$ sequência da solicitação humana e divina, Galba apresenta-se, teatralmente, como um libertador. Para isso, estadeia com exemplos concretos os crimes de Nero contra a liberdade. Simbolicamente, vai proceder a uma libertação (manumissio) universal:

Igitur cum quasi manumissioni uacaturus conscendisset tribunal, propositis ante se damnatorum occisorumque a Nerone quam plurimis imaginibus et astante nobili puero, quem exulantem e proxima Baliari insula ob id ipsum acciuerat, deplorauit temporum statum consalutatusque imperator legatum se senatus ac populi $R$. professus est. ${ }^{22}$

«Então, como se fosse tratar de uma manumissão, subiu ao tribunal. Diante dele, foi colocado o maior número possível de retratos de condenados e executados de Nero; e ao seu lado, de pé, estava um jovem nobre que, expressamente para este acto, mandara vir da mais próxima das ilhas Baleares, onde estava exilado. Deplorou a situação dos tempos e, depois de ser saudado como imperador, declarou-se legado do senado e do povo romano».

Pela ligação às instituições republicanas fica patente a preocupação de legalidade. Galba torna-se senhor da situação e entrega-se a grande actividade,

${ }^{20}$ Aug. 18.1-2. Suetónio diz que Augusto usou como sinete a imagem de Alexandre Magno (Aug. 50).

${ }^{21}$ Gal. 9.2. Uma virgem nobre confirmava um oráculo pronunciado no santuário de Clúnia há duzentos anos a anunciar o aparecimento, na Hispânia, de um príncipe e senhor do mundo. Trata-se de uma profecia local, semelhante às que, a leste, serão creditadas a favor de Vespasiano.

${ }_{22}$ Gal. 10.1. Em Plutarco, Gal. 5.1, mal ele sobe ao pódio, a multidão reunida proclama-o imperador. Segundo Venini, P. 1974, 996-997, a uma linha dupla apresentada por Plutarco (iniciativa de Galba e iniciativa dos soldados e do povo), Suetónio contrapõe uma única linha, dependente dos factos anteriores e em coerência com eles, que aponta para a iniciativa de Galba. 
que contrasta com a anterior inércia (desidia e segnitia): organização logística da revolta e busca de apoios ( Gal.10.2-3). O motivo dos presságios volta. Se a rebelião já é favorecida pelos deuses, uma vez em marcha, é secundada por prodígios favoráveis ${ }^{23}$ que vêm sancionar com o direito divino o levantamento de Galba: ut nemini dubium esset iustum piumque et fauentibus diis bellum suscipi ("de tal sorte que ninguém duvidava que se empreendia um guerra justa, santa e favorecida pelos deuses»). Reclamar o conceito de "guerra santa" aparece assim importante para a propaganda de Galba, no momento de dar início a uma campanha fratricida, o que constituiria ipso facto uma afronta à pietas.

Mas neste culminar de sucessos humanos e divinos, quando tudo parece correr pelo melhor, eis que, de repente, se dá uma reviravolta que quase faz perigar o empreendimento. ${ }^{24}$ Uma das alas de cavalaria arrepende-se de ter violado o juramento e a custo se consegue mantê-la in officio; e Galba é quase vítima de um atentado, descoberto por acaso (Gal. 10.5). A tão grandes perigos junta-se a morte de Víndex, que deixa Galba completamente desmoralizado e inclinado ao suicídio. O problema resolve-se inesperadamente com a chegada de mensageiros com a notícia do suicídio de Nero (Gal. 11).

$\mathrm{Na}$ caminhada para de Roma Galba mostra-se demasiado ostensivo. Perante a notícia da morte de Nero e o facto de que todos lhe juravam fidelidade, Galba abandona o título de legado e toma o de Caesar; ${ }^{25}$ e põe-se a caminho de Roma, vestido com o manto do general e um punhal, pendurado ostensivamente ao pescoço e pendente sobre o peito. ${ }^{26}$ Suetónio acentua a excessiva rapidez do processo e a atitude simbólica de Galba: ao ostentar o punhal, apresenta-se como um vingador e um libertador da tirania. ${ }^{27}$ Mas o punhal representa também a morte. Não retoma a toga, trajo civil, antes de esmagar os revoltosos: o prefeito do pretório Ninfídio

${ }^{23} \mathrm{Gal}$. 10.4. A descoberta de um anel, em cuja gema estava esculpida a imagem da Vitória com um troféu e a chegada de um navio alexandrino, carregado de armas, sem piloto, nem tripulantes, nem passageiros.

${ }^{24} \mathrm{Gal}$. 10.4. ... cum repente ex inopinato prope cuncta turbata sunt.

${ }_{25}$ Díon Cássio, 63.29.6, diz que Galba não adoptou o título de César até à chegada da delegação do senado. Vide VEnini, P. 1974, 995-996.

${ }_{26}$ Gal. 11. Através da narrativa centrada na personagem de Galba, Suetónio deixa de fora a acção de Virgínio Rufo, que derrotou Víndex, facto que levou ao suicídio deste (Plutarco, Gal. 6), o anúncio da morte de Nero, pela boca de Ícelo, e a chegada dos mensageiros oficiais, comandados por Tito Vínio (Plutarco, Gal. 7). Vide Venini, P. 1974, 1012-1013.

${ }^{27}$ Em Díon Cássio, 64.3.4, o grande punhal, em contraste com a velhice e a debilidade física de Galba, torna-se motivo de ridículo. Segundo Poulle, B. 1997, 243-252, Galba estaria a lembrar que o seu bisavô estivera entre os conjurados dos idos de Março (Galba 3.2). O punhal tornou-se emblemático: Bruto e Cássio cunharam moedas com um pileus circundado de dois punhais. Galba retoma a propaganda monetária dos assassinos de César, com a legenda libertas restituta. Mas não há razão para fazer de Galba um restaurador da República. O conceito de libertas perdera, com o principado, o significado político que tinha sob a República, e reduziu-se a liberdade de expressão: poucos pensariam já o restabelecimento da velha instituição. Vide Raoss, M. 1958, 52-54; com. de Venini, P. 1977, 35-36 e 38. 
Sabino ${ }^{28}$ e os legados da Germânia, Fonteio Capitão, ${ }^{29}$ e de África, Clódio Macro. ${ }^{30}$

Como habitualmente, a assunção do poder é teatral. Operou-se a transformação de um general austero e fiel, conformado à legalidade e à tradição, em um político arrogante e impiedoso que acabará por desencadear novos descontentamentos.

Apesar de os presságios se apresentarem favoráveis, a acção de Vespasiano é pautada pela moderação e prudência: Nec tamen quicquam ante temptauit, promptissimis atque etiam instantibus suis, quam sollicitatus quorundam et ignotorum et absentium fortuito fauor ${ }^{31}$ («Todavia nada tentou, apesar da grande determinação e da insistência dos seus, antes de receber testemunhos fortuitos de apreço de certos soldados desconhecidos e distantes»). O biógrafo considera fortuitus e, como tal, encarecedor da figura de Vespasiano, o fauor que seria certamente resultado de uma activa propaganda flaviana. ${ }^{32}$ Este imperador é de algum modo ligado por Suetónio a Otão, o único dos três efémeros imperadores anteriores por quem o biógrafo manifesta simpatia. As legiões da Mésia que iam em socorro de Otão, ao saberem da morte deste, escrevem, depois de longa avaliação dos vários legados, o nome de Vespasiano nos estandartes. ${ }^{33}$ Embora estes soldados tenham sido reconduzidos ad officium, o feito teve repercussões: primeiro, o prefeito do Egipto, Tibério Alexandre, levou as suas legiões a prestarem juramento nas calendas de Julho, data que ficou a marcar o principatus dies. Seguiu-se-lhe o exército da Judeia. ${ }^{34}$ Por seu turno, Vespasiano apresenta-se como um vingador de Otão. Exerceu grande influência uma carta do defunto imperador, verdadeira ou falsa (como nota o biógrafo), a confiar a Vespasiano a sua vingança e o auxílio à res publica. ${ }^{35}$ Ajudou ainda o rumor, que se dissipara, de que Vitélio pretendia mudar os acampamentos de inverno das legiões da Germânia para a Síria, onde teriam um serviço militar mais seguro e

${ }^{28}$ Segundo Plutarco, Gal. 14-15, Ninfídio foi morto pelos soldados no campo pretoriano e Galba limitou-se a ordenar a execução dos cúmplices que não morreram com ele.

${ }^{29}$ Tácito, Hist. 1.7.1, diz que ele foi morto por Cornélio Aquino e Fábio Valente, sem que estes tivessem recebido instruções para tal, e que corria o rumor de que o assassinaram por não conseguirem persuadi-lo a revoltar-se.

${ }^{30}$ Este sim, condenado por ordem directa de Galba; cf. Tácito, Hist.1.7.1. Tanto Tácito, Hist. 1.37.3, como Plutarco, Gal. 15.8, acentuam o terror da entrada de Galba em Roma.

${ }^{31}$ Ves. 6.1. Tácito apresenta uma imagem de amedrontado: his pauoribus nutantem et alii legati amicique firmabant (Hist. 2.76.1).

${ }^{32}$ Vide com. de Cesa, M. 2000, 63.

${ }^{33}$ Ves. 6.2-3. Cf. Tácito, Hist. 2.85; Flávio Josefo, BJ 4.10.4.

${ }^{34}$ Cf. Tácito, Hist. 2.79. A versão de Josefo, BJ 4.601, segundo a qual Vespasiano foi aclamado na Judeia, é rejeitada pelos autores modernos como tendenciosa; vide com. de CEsA, M. 2000, 64.

${ }^{35}$ Ves. 6.4. Suetónio é o único a falar deste documento. Seria uma acção da propaganda flaviana para conquistar as tropas fiéis a Otão; vide com. de CEsA, M. 2000, 65. GAscou, J. 1984,384 , nota a contradição deste passo com a referência, na Vida de Otão (10.2), a duas cartas apenas. A inconsequência fica a dever-se ao método do biógrafo: tratar cada Vida como um todo autónomo. 
mais suave. Foi oportuno o apoio do governador de provícia, Licínio Muciano, antigo rival de Vespasiano, que, pondo de lado o ressentimento, lhe garantiu o apoio do exército da Síria, ${ }^{36}$ e de Vologeso, rei dos Partos, que prometeu auxílio militar. ${ }^{37}$

Tal como acontecera na vida de Galba, uma vez a revolta em marcha, a confirmação divina necessária à nova empresa opera-se através de um prodígio sobrenatural e dois milagres de Vespasiano. Este envia as tropas para Itália, enquanto ele próprio se dirige para Alexandria, onde pretende consultar Serápis sobre o grau de certeza do seu poder (de firmitate imperii). Depois de permanecer algum tempo sozinho no santuário, ao regressar, encontra o liberto Basílides (cujo nome só por si já evoca a ideia de realeza) que lhe oferece, segundo o costume local, verbena, coroas e bolos. Ora Basílides, enfermo e impossibilitado de andar, só por milagre podia estar ali naquele momento. ${ }^{38}$ Salienta-se o simbolismo da consulta a um deus da saúde, num momento em que Roma enferma de guerra civil. Mas também é significativo que a missão "redentora" seja confirmada por uma divindade oriental e que se opere uma coroação segundo um ritual egípcio: mais um sinal do reconhecimento de Vespasiano no mundo oriental. O biógrafo acrescenta, com exagero, que chegaram imediatamente (ac statim) cartas a anunciar a derrota das tropas de Vitélio e a morte do próprio em Roma. ${ }^{39}$ Como forma de suprir a auctoritas e a maiestas, que faltavam a Vespasiano, dada a sua recente e inopinada aclamação, ${ }^{40}$ apresentam-se dois acontecimentos taumatúrgicos, forjados, certamente, pela propaganda flaviana. Dois homens da plebe, um cego e outro coxo, avisados em sonhos por Serápis, vêm pedir a Vespasiano que os cure, a um, cuspindo-lhe nos olhos, a outro, tocando-lhe com o pé na perna defeituosa. Depois de hesitar,

${ }^{36}$ Ves. 6.4. Suetónio, pela sua concisão, torna-se um tanto obscuro: o rumor sobre as intenções de Vitélio em transferir as tropas, integrado por Tácito no hábil discurso de Muciano ao exército (Hist. 2.80.3), pressupunha, em troca, a transferência das legiões da Síria para a Germânia. Vide com. de Cesa, M. 2000, 65. Também sabemos por Tácito que Muciano era muito favorável a Tito (Hist. 2.74.1). Segundo Martin, R. 1991, 231-232, Vespasiano, tal como Galba, não chegou ao poder por ambição, mas por força das circunstâncias e dos homens, que o forçaram, em nome dos seus ideais.

${ }^{37}$ Tácito, Hist. 4.51, coloca a chegada dos embaixadores, com a oferta dos archeiros, depois da batalha de Cremona; e regista a ironia de Vespasiano por receber tão magnífica e auspiciosa ajuda dos aliados e não ter necessidade dela. $\mathrm{O}$ envio dos archeiros seria a resposta a um pedido feito pelos embaixadores de Vespasiano (Hist. 2.82).

${ }^{38}$ Ves. 7.1. Tácito, Hist. 4.82, diz que Basílides é um dos ilustres do Egipto. Herrmann, L. 1953, 312-315, põe a hipótese de se tratar do mesmo Basílides do monte Carmelo, referido por Tácito em Hist. 2.78.3. Segundo Derchain, Ph. 1953, 261-279, os elementos apresentados (verbena, coroas e bolos) fazem parte do ritual de coroação dos monarcas egípcios. Vide também Derchain, Ph. et J. Hubaux 1953, 38-52.

${ }^{39}$ Estas notícias não teriam chegado ao mesmo tempo a Vespasiano, uma vez que decorreram dois meses entre a vitória de Cremona e a morte de Vitélio. Segundo Tácito, Hist. 3.48.3, Vespasiano recebe a notícia da vitória de Cremona antes de chegar a Alexandria; vide com. de Braithwaite, A. W. 1927, 38-39.

${ }^{40}$ Ves. 7.2: Auctoritas et quasi maiestas ut scilicet inopinato et adhuc nouo principi deerat; haec quoque accessit. Vide BALdwin, B. 1983, 287. 
o imperador acede e os milagres acontecem. ${ }^{41}$ Tais prodígios denunciam a influência do messianismo judaico. ${ }^{42}$ Junta-se uma descoberta maravilhosa na Arcádia: um vaso com uma figura muito semelhante a Vespasiano. ${ }^{43}$ Vindo do outro extremo do Império, a simetria com Galba é manifesta, mas a tendência é para a superação. Favorece a ambos uma profecia antiga de que da província que governa sairá um chefe; tal profecia é confirmada por oráculos locais (cf. Gal.9.2) e pelo achado de uma antiguidade: o anel com a imagem da Vitória, que favorece Galba (cf. Gal. 10.4), é superado, em Vespasiano, pelo seu próprio retrato. Além disso, entra em Roma precedido, ao contrário de Galba, pela boa fama com que os feitos maravilhosos o favoreceram. ${ }^{44} \mathrm{Com}$ Galba as intenções iniciais são boas, mas o resultado é mau; com Vespasiano são boas quer as intenções, quer o resultado. $\mathrm{O}$ Estado, libertado da tirania de Nero, caiu no caos. Vespasiano vem trazer de novo a estabilidade.

\subsection{A "farsa" de Tibério}

Ao chegar o momento de Tibério assumir o império, o discurso de Suetónio torna-se hostil. A caminho da Ilíria, é chamado à presença de Augusto, moribundo, com quem passa todo o dia em segredo. Suetónio serve-se da força que o momento dá à palavra para fazer a caracterização de Tibério, através de um lamento atribuído a Augusto: 'miserum populum $R$., qui sub tam lentis maxillis erit' ('desgraçado povo romano, que vai cair sob maxilas tão lentas'»). De seguida, dispõe-se a apresentar as razões da escolha do sucessor através do dilema de Augusto que, conhecedor e pouco apreciador do carácter de Tibério, acaba vencido pelas súplicas da esposa ou pela ambição de garantir que, por confronto com o sucessor, seria lembrado com saudade. ${ }^{45} \mathrm{O}$ próprio biógrafo intervém no texto (adduci tamen nequeo quin existimem) para ilibar o circumspectissimus et prudentissimus princeps da escolha: avaliados os prós e os contras, prevaleceu o peso das qualidades militares de Tibério (Tib. 21.3), como provam várias cartas, nas quais é manifesta a preocupação de Augusto com a saúde do enteado, que se tornara questão de Estado (Tib. 21.4-7).

Antes de Tibério tornar pública a morte de Augusto, outra tragédia obscura aconteceu. O jovem Agripa Póstumo foi morto, sem que o autor da

${ }^{41}$ Vesp. 7.2-3. Cf. Tácito, Hist. 4.81 e Díon Cássio, 66.8.1. Tácito fala da actividade taumatúrgica de Vespasiano antes da visita ao Serapeu. A alteração da ordem permite intensificar o significado; vide com. CEsA, M. 2000, 6-7; 69. Tácito fala também da consulta de médicos que asseguram não se tratar de doenças incuráveis. Muitas curas são atribuídas a Serápis, por isso estes milagres podiam sugerir a assimilação, procurada pela propaganda flaviana, de Vespasiano com aquele deus ou que o favor divino lhe conferia dons miraculosos: vide Henrichs, A. 1968, 51-80.

${ }^{42}$ A cura das doenças dos olhos com saliva é bem conhecida no mundo oriental, e também documentada nos evangelhos de Marcos (8.23) e João (9.6).

${ }^{43} \mathrm{~A}$ antiguidade dos objectos conferia-lhes uma espécie de santidade religiosa, como acontece com a placa de bronze que pressagia a morte de César: Jul. 81.1.

${ }^{44}$ Vesp. 8.1: Talis tantaque cum fama in urbem reuersus. Cf., por oposição, Gal.12.1: Praecesserat de eo fama saeuitiae simul atque auaritiae.

${ }^{45}$ Tib. 21.2. A mesma ideia apresenta Tácito, Ann. 1.10.7. 
ordem fosse conhecido: Augusto? Lívia, com ou sem a cumplicidade do filho? O conselheiro Salústio Crispo? A atitude de Tibério é ambígua: Tiberius renuntianti tribuno, factum esse quod imperasset, neque imperasse se et redditurum eum senatui rationem' respondit, inuidiam scilicet in praesentia uitans. Nam mox silentio rem obliterauit ${ }^{46}$ («Tibério, ao tribuno que lhe anunciava que estava feito o que ordenara, respondeu que 'ele não tinha ordenado nada e que o outro teria de prestar contas ao senado, evidentemente para, no momento, evitar a indignação. $\mathrm{O}$ certo é que logo fez esquecer o assunto com o seu silêncio»). Suetónio parece sugerir que ele, se não deu a ordem, como diz, pelo menos teria conhecimento dela. ${ }^{47}$ Insinua a culpa ao organizar o discurso entre a dissimulação e o silêncio. ${ }^{48} \mathrm{~A}$ hipocrisia domina a narrativa da entronização. Provavelmente a hesitação seria sincera: a sucessão no principado era uma realidade sem precedentes. Mas Suetónio opta pela acusação de duplicidade. Para o biógrafo, Tibério reúne a audiência, os senadores, para o grande teatro da sua vida: Iure autem tribuniciae potestatis coacto senatu incohataque adlocutione derepente uelut impari dolori congemuit, utque non solum uox sed et spiritus deficeret optauit ac praelegendum librum Druso filio tradidit ${ }^{49}$ ( Depois de convocar o senado pelo direito que lhe conferia o poder tribunício, começou o discurso. Subitamente, como se a dor lhe fosse insuportável, desatou a soluçar e desejou que, não só a voz, mas também o espírito lhe desfalecesse e entregou os papéis a seu filho Druso, para que os lesse até ao fim»). Parece existir uma certa ironia do biógrafo (ou da sua fonte hostil) em uelut impar dolori. Tibério estará a precaver-se quanto às revelações que trará a leitura do testamento de Augusto. Procura, com as suas lágrimas, atenuar o efeito. A situação do filho de Lívia era incómoda, pois tratava-se, como vimos, do herdeiro possível. Na verdade, o preâmbulo do testamento vem revelar que foi a atrox fortuna que, ao arrebatar os filhos de Júlia, Gaio e Lúcio, provocou a escolha de Tibério como herdeiro. $\mathrm{E}$ a voz corrente, referida a seguir, de que a escolha se deve à necessitas, dá ao advento de Tibério uma aura trágica, que o próprio Augusto não foi capaz de evitar e que faz esperar o pior. $^{50}$

De seguida, temos uma manifestação típica da indecisão hipócrita, atitude que Suetónio conota claramente como uma farsa (Tib. 24): Principatum, quamuis neque occupare confestim neque agere dubitasset, et statione militum, hoc est ui et specie dominationis assumpta, diu tamen recusauit impudentissimo mimo... («Ao principado, embora não hesitasse em ocupá-lo imediatamente e em exercê-lo - tomou até para si uma guarnição de soldados, o que lhe conferia

${ }^{46}$ Tib. 22. Dada a semelhança do texto, parece haver aqui influência de Tácito, ou de fontes comuns: Ann. 1.6.3: nuntianti centurioni, ut mos militiae, factum esse quod imperasset...; vide intr. ao com. de Lindsay, H., 1995, 10 e com. 106.

${ }^{47}$ Este foi, para Tácito, Ann. 1.6.1, primum facinus noui principatus. O assunto é complexo. Vide Detweiler, R.1970, 289-295; Paladini, M. L. 1954, 313-329; Jameson, S. 1975, 287-314; Levick, B. M. 1972, 674-697.

${ }^{48}$ Como sugere Gascou, J. 1984, 251-259.

${ }^{49}$ Tib. 23. Esta alocução não é conhecida de Tácito: vide GAscou, J. 1984, $260-261$.

${ }^{50}$ Objectivamente, contudo, Augusto só estava a justificar legalmente a adopção de Tibério: vide Wiedemann, T. 1989, 19. 
poder e uma forma de soberania - recusou-o longo tempo com um mimo francamente descarado...»). $\mathrm{O}$ uso de guarda-costas prova que Tibério deseja o poder ${ }^{51}$ mas recusa-o. Segundo o biógrafo, os actos desmentem as palavras: trata-se de um impudentissimus mimus, ${ }^{52}$ que Suetónio procura reproduzir. A tónica é colocada na longa recusa de Tibério (diu tamen recusauit). O confronto gera-se entre a insistência dos amigos e as evasivas de Tibério; entre o tom obsequioso dos senadores e o calculado suspense. ${ }^{53} \mathrm{O}$ passo coloca em relevo a falsa modéstia, o fingimento da recusa, exagerado pelos queixumes de Tibério, e a artificialidade da condescendência, expressa na citação final: ${ }^{54}$

Tandem quasi coactus et querens miseram et onerosam iniungi sibi seruitutem, recepit imperium; nec tam aliter, quam ut depositurum se quandoque spem faceret. Ipsius uerba sunt: 'dum ueniam ad id tempus, quo uobis aequum possit uideri dare nos aliquam senectuti meae requiem. ${ }^{55}$

«Finalmente, como que forçado e queixando-se da infeliz e pesada servidão que lhe era imposta, aceitou o império, desde que não deixasse de poder acalentar a esperança de um dia o abandonar. São estas as palavras do próprio: 'até eu chegar à idade em que vos possa parecer justo dar algum repouso à minha velhice'».

Mas, logo a seguir, Suetónio introduz outro factor: o medo, que persegue Tibério:56 Cunctandi causa erat metus undique imminentium discriminum, ut saepe 'lupum se auribus tenere' diceret. ${ }^{57}$ ( A causa da hesitação era o medo e os iminentes perigos que espreitavam de todas as partes, que o levavam a dizer frequentemente que 'segurava um lobo pelas orelhas'»). O discurso iterativo (saepe... diceret) realça a natureza do imperador. Para mostrar que os perigos

${ }^{51}$ A presença de guarda-costas era associada a tirania, em Atenas, desde Pisístrato; vide com. de Lindsay, H., 1995, 109. É seguida aqui uma tradição hostil transmitida por muitos historiadores, entre os quais poderiam estar Aufídio Basso, Servílio Noniano e Séneca, o retor: vide Gascou, J. 1984, 264-265.

${ }^{52}$ Mimus é uma conjectura de Gronouius por comparação com Cal. 45.2; Otho 3.2; os manuscritos apresentam animo.

${ }^{53}$ Para Levick, B. 1999a, 76, Tibério tentava definir o significado do seu poder. Não era só a posse do imperium que importava, mas o que fazer com ele. Esta interpretação parece confirmada em Nero 37.3: negauit quemquam principum scisse quid sibi liceret.

${ }^{54}$ Seager, R. 1972, 56-57, entende que é perverso negar a sinceridade de Tibério. A passagem do poder a um novo príncipe não tinha precedentes; além disso, ele tinha 54 anos e não podia ter pretensões de emular Augusto. Não há dúvidas de que ele preferiria rejeitar o principado. A farsa da discussão está em que Tibério sabia que, no fim, não podia recusar o que era da vontade de Augusto: mas o senado não compreende a sua situação. Vide Syme, R 1974, 485-486. Para Timonen, A.1993, 133-148, Suetónio lança uma sombra sobre Tibério, logo no início do seu reinado, que se torna em tirania no final. Assim, em comparação com Tácito, Ann. 4.9.1, exagera a hesitação na mira de vituperar o principado de Tibério no seu todo.

${ }^{55}$ Tib. 24.

${ }^{56}$ BALDwin, B. 1983, 253, considera flagrante a contradição interna entre o impudentissimus mimus e o medo como causa da hesitação. Mas parece-nos que o medo não exclui a dissimulação: os dois traços de carácter aparecem associados ao longo da Vida.

${ }^{57}$ Tib. 25.1. Trata-se de um provérbio ocorrente em Terêncio, $P h .506$. 
têm rosto, Suetónio, como é seu hábito, sacrifica a ordem cronológica à ordem lógica, referindo factos que ocorreram em tempos e circunstâncias díspares. ${ }^{58}$ Refere, resumidamente, a conjura de Clemente, um escravo que decidira vingar o seu antigo amo, Agripa Póstumo; ${ }^{59}$ a conspiração de Libão; ${ }^{60}$ as revoltas das legiões na Germânia e Panónia; ${ }^{61}$ o perigo da popularidade de Germânico, aclamado pelas legiões. ${ }^{62}$ Suetónio põe de novo em evidência o principal estratagema de Tibério, a simulação (Tib. 25.3): simulou doença para que Germânico fosse levado a esperar e não agisse de imediato. $\mathrm{O}$ próprio Clemente é subjugado através do dolo. $\mathrm{O}$ medo está também figurado nas precauções que toma contra Libão: no sacrifício, em vez da faca ritual, dá-lhe uma de chumbo e, ao recebê-lo, além da presença do filho Druso, segura-lhe o braço direito, enquanto finge apoiar-se. Ora parece atitude normal tomar o braço de uma pessoa, enquanto se conversa passeando: Suetónio quererá exagerar a paranóia de Tibério. Medo, dissimulação e desconfiança vêm de mãos dadas na caracterização do principado nascente. Tais comportamentos são apanágio dos tiranos.

\subsection{Sucessão e crime}

Em alguns casos, Suetónio faz assentar abusivamente a entronização de alguns imperadores na eliminação activa do antecessor, sem que a restante tradição histórica aponte claramente nesse sentido. Calígula começa a preparar activamente a sua sucessão sem olhar a meios: seduz a esposa de Mácron, para conseguir o favor deste prefeito do pretório e afastar Tibério do caminho. Diferentemente do que aconteceu na biografia de Tibério, a responsabilidade de Gaio no suposto envenenamento do antecessor aparece agravada e junta-se-lhe a cumplicidade (ou acção executora) de Mácron. Além disso, Suetónio parece querer fazer uma amálgama de várias versões que circulavam sobre a morte de Tibério, em que o elemento que as une é o próprio Gaio. Para concluir, apresenta a anedota da eliminação de uma testemunha: um liberto que Calígula manda crucificar. ${ }^{63} \mathrm{Na}$ busca de coerência com a caracterização

${ }^{58}$ Vide intr. à ed. de H. Ailloud, 1931-32, xxxviII.

59 Só dois anos depois é que esta aventura se desenrola publicamente; vide Mogenet, J. 1954, 321-330; Paladini, M. L. 1954, 313-329; Levick, B. 1999a, 150-151; Seager, R. 1972, 93.

${ }^{60}$ Esta só ocorreu em 16: vide Levick, B. 1999a, 150; SeAger, R. 1972, 89-92.

${ }^{61}$ Perigos reais, de facto, na sequência da morte de Augusto; vide Seager, R. 1972, 58-63.

${ }^{62}$ Tib. 25.3. Cf. Tácito Ann. 1.52 e 2.5; Díon Cássio 57.6.2ss. Na realidade, nada tinha a temer: a lealdade de Germânico ficou provada na forma como resolveu o motim correndo riscos; vide Seager, R. 1972, 63-66; Salles, C. 1985, 144-152. Não havia razão para Germânico tentar, pela sorte, o que a ascendência, a adopção, a experiência e os seus poderes lhe reservavam, como demonstra Levick, B. 1999a, 148.

${ }^{63}$ Cal. 12.2. Cf. Tib. 73.2. O facto de autores como Fílon de Alexandria e Flávio Josefo não atribuírem a Calígula responsabilidade na morte de Tibério deve ser tomado a favor da inocência do sucessor. Tácito, Ann. 6.50.4-5, atribui a Mácron a iniciativa de apressar a morte do velho imperador, e Díon Cássio, 58.28.3, sustenta que a ordem partiu de Calígula, mas nenhum fala da participação directa no acto de sufocar o imperador. O pormenor do liberto é 
global da personagem, Suetónio, de forma tendenciosa, transforma a narrativa da sucessão na de uma espécie de usurpação criminosa, elevando à categoria de facto histórico rumores que se levantaram na altura em que Calígula perdeu o estado de graça.

Para mostrar que não destoa da verdade, ${ }^{64}$ Suetónio sugere que vai apresentar uma prova concludente: a da aptidão psicológica para levar a cabo tal crime. Se Calígula se gabava muitas vezes de ter tido a intenção de matar Tibério (embora dissesse que, movido pela misericordia, o não efectuara) pode muito bem ter sido o assassino. Mas o argumento é ambíguo e poderia ser usado para provar justamente o contrário. ${ }^{65}$ Há distorção no emprego das anedotas, com o fim de reforçar uma imagem que se quer transmitir, mediante uma aparência de objectividade. Como aconteceu com Tibério, no momento da ascensão ao trono, o leitor fica preparado para o pior.

Ao assinalar que esta foi a forma de conseguir o império (Sic imperium adeptus), Suetónio parece acentuar a ideia do crime dinástico. Mas a mudança no tom é imediata: começa-se por relatar as boas acções do príncipe, para mais tarde se destacarem as más. Calígula é acolhido como um desejado do povo e do género humano, sobretudo devido à memória do pai e da sua família destruída. A acção centra-se no contraste de dois grupos de pessoas: de Miseno, Calígula avança vestido de luto (podemos imaginá-lo com a toga pulla e talvez com os cabelos e a barba em desalinho) e acompanha o funeral de Tibério por entre altares, tochas e sacrifícios. Ao seu encontro vem uma multidão cheia de alegria, que o aclama com um coro de nomes carinhosos (Cal. 13). Trata-se de pietas, virtude que é bem vista num novo príncipe.

Nero é aclamado imperador aos dezassete anos nos degraus do palácio. Suetónio parece acentuar a infelicitas do novo príncipe ao sugerir o carácter infausto do dia $^{66}$ e deixa ainda a nota negativa de que, na Cúria, o novo imperador não rejeitou nenhum dos honores, qualificados como immensi, à excepção do título de patris patriae, que recusou por causa da idade. ${ }^{67} \mathrm{~A}$ falta de moderação na aceitação de honras é uma característica dos tiranos, a começar por César (Jul. 76.1).

Mas, mais à frente, no elenco dos crimes de Nero, o biógrafo introduz um elemento inesperado na história desta sucessão, operada, segundo o relato incluído na Vida de Cláudio, pela acção criminosa de Agripina (Cl.44). Da Vida de Cláudio para a de Nero, há um crescendo da responsabilidade do segundo

desconhecido de outras fontes; serve de ilustração à crueldade brutal de Calígula. A crucificação de um liberto era pouco comum, e Calígula, a rigor, ainda não teria poder para tal.

${ }^{64}$ Cal. 12.3: nec abhorret a ueritate. Suetónio serve-se de expressões deste tipo para dar a sua aquiescência a rumores: nec abhorret a uero (Tib. 62.3); non abhorrentia a natura sua (Nero 43.1).

${ }^{65}$ Vide com. de Guastella, G. 1992, 119.

${ }^{66}$ (...) cum ob totius diei diritatem non aliud auspicandi tempus accomodatius uideretur.

${ }^{67}$ Nero 8. Como afirma, no seu com., Warmington, B. H. 1999, 31, votaram-se em bloco todos os poderes do princeps acumulados por Augusto e, desde então acrescentados, especialmente por Cláudio; e não há razão para crer, apesar do adjectivo immensi de Suetónio, que fossem acrescentadas novas honras. Vide Lesuisse, L. 1961, 383-390. 
na morte do pai adoptivo, de modo muito semelhante ao que acontecera com a alegada intervenção de Calígula na morte de Tibério. Na biografia de Cláudio, não fora mencionada a acção do sucessor, mas agora a culpa é evidente: se Nero não foi o auctor desta morte, pelo menos foi cúmplice (conscius), pela forma como, longe de dissimular, louvava, recorrendo a um provérbio grego, os cogumelos como «alimento dos deuses». Também as contumeliae contra Cláudio constituem, para o biógrafo, provas da culpa de Nero: dizia que ele deixara de «morar» entre os homens (alongando a sílaba inicial da palavra morari, o que alterava o sentido para o que em grego significa 'fazer disparates'); anulou decreta et constituta e negligenciou o seu túmulo. ${ }^{68}$ Esta acusação reforça a imagem de Nero conotada com a do modelo trágico de Édipo, papel que o imperador representou em palco, juntando assim o parricídio ao incesto, crime este que o biógrafo considera provado, como veremos mais à frente.

A ascensão de Domiciano ao governo do Império é marcada pela hostilidade em relação a Tito, que aumentara com a morte do pai. $\mathrm{O}$ atrevimento é sugerido numa gradação:

Patre defuncto diu cunctatus an duplum donatiuum militi offerret, numquam iactare dubitauit 'relictum se participem imperii, sed fraudem testamento adhibitam'; neque cessauit ex eo insidias struere fratri clam palam<que>, quoad correptum graui ualitudine, prius quam plane efflaret animam, pro mortuo deseri iussit; defunctumque nullo praeterquam consecrationis honore designatus, saepe etiam carpsit obliquis orationibus et edictis(Dom. 2.3).

«Depois da morte do pai, Domiciano, longo tempo indeciso sobre se devia ou não oferecer aos soldados o dobro do donativo, nunca hesitou em proclamar que 'The fora legada a comparticipação no poder, mas que o testamento fora objecto de fraude'; e, desde então, não deixou de armar ciladas ao irmão, de esconso e às claras, de tal sorte que, quando este foi atacado por doença grave, antes que ele exalasse o último suspiro, o mandou abandonar como se já estivesse morto; e, depois de ele morrer, lhe não atribuiu honra alguma, além da apoteose; e amiúde o criticou com alusões indirectas e edictos».

Ao contrário da prática adoptada para com Tito, o biógrafo procura potenciar a malvadez de carácter de Domiciano, que acusa injustamente o irmão - entre os dois, toma o partido de Tito. ${ }^{69} \mathrm{O}$ biógrafo quer sugerir ao

${ }^{68}$ Nero 33.1. A responsabilidade de Nero não é atestada em nenhum outro lugar. O uso do provérbio grego nada prova: vide com. de BrADley, K. R. 1978, 195; WANkENnE, J.1981, 151.

${ }^{69} \mathrm{Na}$ opinião de Amвrosio, F. G. D’1980 [1982], 234-235, sugere que Suetónio apresenta de forma inconsequente e separada a nota sobre a capacidade falsificadora de Tito e a acusação que lhe é movida, de ter forjado o testamento - informação que talvez circulasse em conjunto. Assim biógrafo manipula o material de que dispõe de modo a torná-lo hostil a Domiciano. Provavelmente tem razão em relação ao testamento: se Vespasiano quisesse realmente legar o império aos dois filhos em simultâneo, não estabeleceria, publicamente, distinção entre eles, como acontece em Dom. 2.1. Plínio, Pan. 8.6, assevera que Vespasiano só legou o poder a Tito; vide com. de Jones, B. W. 1996, 27. 
leitor a injustiça da acusação de Domiciano, uma vez que atrás dissera que Tito the continuara a chamar consors e successor (Tit. 9.3). Além disso, como acontecera com a culpa de Calígula na morte de Tibério e de Nero na morte de Cláudio, há um crescendo na culpa do sucessor em relação ao que se afirmara na biografia de Tito. Naquela $V i d a$, a morte de Tito era apenas devida à doença; na Vida de Domiciano, é apressada, parece sugerir-se, pela atitude deste, que abandona o irmão na agonia. ${ }^{70}$ Ao ser deslocada para aqui, esta informação tem o efeito de potenciar, no momento oportuno, um delito oculto que de repente se descobre. Por ser revelado agora, e agravado pela negação de honras ${ }^{71}$ concentra a indignação e revolta do leitor no momento chave em que Domiciano assume o império. Além disso, a ausência de presságios indicativos do futuro poder revela que, de modo semelhante a Vitélio, o acesso de Domiciano ao poder não é favorecido pela anuência dos deuses. ${ }^{72}$ Para o biógrafo, este imperador, tal como Calígula e Nero, assume o papel de um tirano criminoso, para quem o desejo de dominar se sobrepõe a todos os valores morais e legais, pelo que não manifesta qualquer respeito pela pietas mesmo em relação aos familiares.

\subsection{Aclamação farsesca}

Suetónio, que provara a ineptidão de Cláudio para altos cargos, pela sua segnitia e pela falta de dignitas, acentua a estranheza da sua ascensão ao trono imperial: decorrida a maior parte dos anos de vida, alcança o poder por um acaso extraordinário (mirabilis casus). A cena da aclamação é dramática e, ao mesmo tempo, farsesca: nela figura constantemente o topos da inversão do mundo. Não se trata, como no caso dos antecessores, de dissimulação. Muito pelo contrário: Cláudio é igual a si mesmo. É um imperador sem máscara, mas um imperador às avessas. A sua personalidade revela-se nas suas características mais vis. A falta de dignidade, a que se fora habituando desde criança, é exibida sem pudor, quer por parte de Cláudio, quer por parte do biógrafo, que não perde a oportunidade de sublinhar os pormenores mais caricatos:

Exclusus inter ceteros ab insidiatoribus Gai, cum quasi secretum eo desiderante turbam submouerent, in diaetam, cui nomen est Hermaeum, recesserat; neque multo post rumore caedis exterritus prorepsit ad solarium proximum interque praetenta foribus uela se abdidit. Latentem discurrens forte gregarius miles, animaduersis

${ }^{70}$ Esta ideia é secundada por Díon Cássio, 66.26.2: quando ainda havia possibilidade de recuperação, Domiciano, para apressar o fim, colocou Tito num cofre com gelo, sob o pretexto de que necessitava de refrigeração. Segundo Aurélio Victor, Caes. 10.5, Tito foi envenenado por Domiciano. Vide Martin, R. 1991, 196. Para Gascou, J. 1984, 385-386, esta revelação, ao figurar na Vida de Domiciano, tem a função de denunciar a impietas do último Flávio, ao passo que, se figurasse na $V i d a$ de Tito, ensombraria a perfeição deste príncipe com uma morte menos digna, que o assimilava à morte dos maus imperadores, como veremos mais à frente.

${ }^{71}$ Suetónio dá informações incorrectas; Domiciano honrou o irmão de várias formas: cunhagens; inscrições; construção do arco de Tito; o templo de Vespasiano e de Tito. O ódio fraterno é um antigo topos que tem de ser visto com reservas; vide com. de Jones, B. W. 1996, 28; com. de Jones, B. \& Milns, R. 2002, 126.

72 Vide Vidal Sánchez, J. M. 1989, 332-333. 
pedibus, [e] studio sciscitandi quisnam esset, ad[co]gnouit extractumque et prae metu ad genua sibi adcidentem imperatorem salutauit. Hinc ad alios commilitones fluctuantis nec quicquam adbuc quam frementis perduxit. Ab bis lecticae impositus et, quia sui diffugerant uicissim succollantibus in castra delatus est tristis ac trepidus, miserante obuia turba quasi ad poenam reperetur insons. Receptus intra uallum inter excubias militum pernoctauit, aliquanto minore spe quam fiducia. Nam consules cum senatu et cohortibus urbanis forum Capitoliumque occupauerant asserturi communem libertatem; accitusque et ipse per tr. pl. in curiam ad suadenda quae uiderentur, 'ui se et necessitate teneri' respondit. Verum postero die et senatu segniore in exequendis conatibus per taedium ac dissensionem diuersa censentium et multitudine, quae circumstabat, unum rectorem iam et nominatim exposcente, armatos pro contione iurare in nomen suum passus est promisitque singulis quina dena sestertia, primus Caesarum fidem militis etiam praemio pigneratus. ${ }^{73}$

«Arredado, juntamente com outros, pelos agressores de Gaio, que, a pretexto de que o próprio queria ficar sozinho, fizeram afastar a multidão, retirara-se para um aposento a que chamavam Hermeu. E, não muito depois, aterrado pelo boato do assassínio, arrastou-se para um terraço próximo e escondeu-se atrás do reposteiro que tapava a porta. Enquanto estava escondido, um soldado raso, que por acaso corria de um lado para o outro, ao reparar nos pés, movido pela vontade de investigar quem seria, reconheceu-o e retirou-o do esconderijo; e, enquanto ele, por medo, se lhe lançava aos joelhos, saudou-o como imperador. Daqui, conduziu-o até junto dos camaradas de armas, que estavam indecisos, e que, até então, não faziam outra coisa senão gritar. Foi por estes colocado numa liteira e eles próprios o carregaram, porque os escravos dele debandaram cada qual para seu lado; assim foi levado para o acampamento, cabisbaixo e temeroso. E a turba que passava tinha pena dele, julgando que arrastavam um inocente para o suplício. Recebido no interior da trincheira, passou a noite entre as sentinelas, muito menos esperançado do que confiante. Efectivamente, os cônsules, com o senado e as coortes urbanas, tinham ocupado o Foro e o Capitólio, com a intenção de assegurar a liberdade pública [i.é, restabelecer a República]. E ele, chamado à Cúria pelos tribunos da plebe para aconselhar o que lhe parecesse melhor, respondeu que 'estava retido pela força e pela necessidade'. Mas no dia seguinte, como o senado se mostrava mais hesitante em levar a cabo os seus intentos, por cansaço e por desacordo dos diversos pareceres, e como a multidão, que envolvia a área, clamava por um chefe e o designava a ele próprio, lá consentiu que os soldados, armados em parada, lhe prestassem juramento e prometeu a cada um quinze mil sestércios. Tornou-se, deste modo, no primeiro dos Césares a garantir a fidelidade dos soldados mediante um donativo».

Há uma clara intenção de apoucar e ridiculizar a personagem na indicação de certos pormenores. O medo, já proverbial, de Cláudio é explorado ao máximo em expressões como exterritus; prae metu, tristis ac trepidus; minor spe quam fiducia. Esta covardia provoca reacções ridículas para um futuro imperador: arrasta-se, esconde-se atrás de um reposteiro e fica com os pés de fora, o que desperta a atenção do soldado. Mas sobretudo (pormenor que só figura em Suetónio) lança-se aos joelhos do soldado - gesto tradicional de súplica. E Suetónio tivera

\footnotetext{
${ }^{73}$ Cl. 10. Cf. Díon Cássio, 60.1.3-4, e Flávio Josefo, AJ. 19.212-225.
} 
o cuidado de dizer que era um soldado raso, o que acentua a inversão de papéis. Com esta técnica, o biógrafo pretende mostrar que Cláudio é, desde o primeiro momento, totalmente inapto para o papel que dele se espera. ${ }^{74}$

Suetónio acentua o papel central, mas totalmente passivo, de Cláudio, como mostram as formas verbais usadas: exclusus; extractum; impositus; delatus; receptus; rapereretur; accitus; se teneri. A ascensão é levada a cabo pela influência de factores externos: por um lado, um miles gregarius; por outro, três forças colectivas - os cônsules e o senado, que querem restaurar a República, os soldados, que raptam literalmente Cláudio e o levam contra a sua vontade, e a multidão do povo (turba; multitudo), cuja acção tem dois momentos onde impera a emotividade. Primeiro a compaixão, perante o espectáculo de um inocente levado para a morte; depois a acção: contra os senadores que querem restaurar a República, a multidão cerca a Cúria, exige um rector e nomeia Cláudio. A passividade e a irresolução deste torna-se patente na resignação expressa em passus est, que marca o acto de assumir como um fardo o cargo para que era solicitado. Mas novo factor assegura o poder: o propósito de acentuar o carácter negativo desta assunção do império manifesta-se na forma tendenciosa como se qualifica o donativo às tropas, como medida inédita. ${ }^{75}$ Trata-se, pois, de uma concepção irracional da história, cujo motor central é a sorte: o mirabilis casus, manifesto no facto de ser um miles gregarius a encontrar Cláudio por um simples acaso (forte). Ao mesmo tempo, há manipulação cómica dos factos históricos: além da inversão de papéis, o motivo da personagem escondida e descoberta por ter os pés à vista é uma situação de comédia ${ }^{76}$ (expressa pelo nosso dito popular "gato escondido com o rabo de fora"). A honra da aclamação do imperador fica assim a dever-se àquele pormenor ridículo.

Também a aclamação de Vitélio é descrita como desorganizada, fortuita e farsesca, e, de algum modo, lembra a de Cláudio pela passividade da personagem: ${ }^{77}$

Quare uixdum mense transacto, neque diei neque temporis ratione habita, ac iam uespere, subito a militibus e cubiculo raptus, ita ut erat in ueste domestica, imperator est consalutatus circumlatusque per celeberrimos uicos, strictum Diui Iuli [i] gladium tenens detractum delubro Martis atque in prima gratulatione porrectum sibi a quodam. ${ }^{78}$

${ }^{74}$ Vide com. de Guastella, G. 1999, 37-38; Gascou, J. 1984, 428-430. O autor francês afirma: «L'insignificance de la cause de l'élévation de Claude correspond à l'insignifiance du personnage (aux yeux de son biographe) et cette façon de présenter les choses relève moins d'une conviction profonde sur le rôle du hasard en histoire que de la technique du pamphlétaire» (p. 430).

${ }^{75} \mathrm{Na}$ realidade, havia diversos precedentes (cf. Díon Cássio, 59.2.1) e o apoio dos soldados pretorianos nunca esteve em dúvida. Vide coms. de Guastella, G. 1999, 150-153, e de Mottershead, J. 1986, 46-50.

${ }^{76}$ Como afirma o prof. Philippe Moreau, da universidade de Caen, a quem agradecemos os escritos não editados que nos facultou com o comentário deste passo.

77 Vide Martin, R. 1991, 229-230.

${ }^{78}$ Vit. 8.1. Suetónio, ao desmembrar a narrativa entre as biografias de Galba (cf. Gal. 16.2). O biógrafo acentua a espontaneidade da aclamação de Vitélio e condensa os vários passos da 
«Pelo que, mal passou um mês, sem se ter em conta nem o dia nem o momento, e já ao anoitecer, foi subitamente arrebatado do quarto pelos soldados, assim mesmo como estava, em roupa de trazer por casa, foi saudado imperador e levado pelas ruas mais concorridas, empunhando a espada do divino Júlio, subtraída ao santuário de Marte e que um deles lhe tinha apresentado às primeiras felicitações».

Poulle sugere que, simbolicamente, contra o punhal de Galba, descendente de um cesaricida, Vitélio levanta agora a espada vingadora do próprio Júlio César. ${ }^{79}$ Como o ditador, também Vitélio procura voltar os presságios a seu favor. De regresso ao pretório, ao ver o triclínio em chamas, como todos ficaram ansiosos perante o presságio adverso, Vitélio dá a sua própria interpretação: 'Bono', inquit, 'animo estote! Nobis adluxit' (Vit. 8.2) («'Animem-se! - exclamou ele - Fez-se luz para nós!'»). Apesar destas semelhanças com o ditador, o biógrafo diz que ele aceitou o cognome de Germânico, oferecido por todos, adiou o de Augusto e recusou para sempre o de César: tal parece afastar de Vitélio a fortuna e o carácter de predestinação conectados com este nome. ${ }^{80}$ Vitélio não atrai o favor dos deuses. Os presságios são mais uma vez indicadores da sorte que o espera. Perante a notícia da morte de Galba, ${ }^{81} \mathrm{Vitélio} \mathrm{divide} \mathrm{as}$ suas tropas em dois grupos: um iria à frente para combater Otão; outro seria conduzido por ele. Enquanto o primeiro obtém um presságio favorável - uma águia apareceu da direita, voou à volta dos estandartes e precedeu a coluna ao colocar-se em marcha ${ }^{82}$, quando o grupo que Vitélio comandava se pôs a

revolta presentes em Tácito, Hist. 1.55-57 e Plutarco, Gal. 22. Venini, P. 1974, 997-2000, nota que, enquanto em Tácito e Plutarco há duas directrizes, uma do exército e outra de Vitélio (em Tácito, a aclamação é precedida da acção de Vitélio que envia mensagens revolucionárias às legiões, e, em Plutarco, Vitélio considera a possibilidade de assumir o poder antes da iniciativa de Valente, que o vem saudar como imperador), em Suetónio há apenas uma directriz, que, ao contrário do caso de Galba, parte de baixo (do exército) para cima. Vide com. de Venini, P. 1977, 118-119.

${ }^{79}$ Vide Poulle, B. 1997, 248. Segundo este autor, os partidários de Vitélio compreenderam a alusão de Galba ao colocar o punhal ao peito ( $G a l$. 11). Os legionários faziam alusão à vingança exercida sobre Cássio e Bruto e à conquista da Gália, pois foram estas legiões da Germânia que, como as de César, venceram os Gauleses e Víndex.

${ }^{80}$ Tácito confirma em Hist. 1.62.3 e 2.62.2. Mas, em Hist. 3.58.3, diz que Vitélio, mais tarde, quando as coisas corriam mal, apesar de ter desdenhado o título, quis ser chamado César, pela superstição ligada ao nome.

${ }^{81}$ Em Tácito, Hist. 1.64.1, a notícia da morte de Galba surge já depois da divisão e da partida das tropas, quando Valente já vai a caminho de Itália in ciuitate Leucorum. Para Venini, P. 1974, 995-956, com esta ligeira antecipação, Suetónio cumpre a obrigação de dar este pormenor sem interferir na linearidade da sequência seguinte. Mas também é verdade que Suetónio, ao antecipar a chegada da notícia da morte de Galba, volta implicitamente toda a acção de Vitélio contra Otão, que admira, tornando assim mais odiosa a acção de Vitélio.

${ }^{82}$ Tácito, Hist. 1.61, fala de tripartição: um grupo comandado por Valente, outro por Cecina e outro pelo próprio Vitélio; e o prodígio da águia manifesta-se a Valente ( Hist. 1.62.3). Dado que Suetónio guarda silêncio sobre Valente e Cecina, a divisão das tropas entre os dois legados não é pertinente. A extensão do prodígio da águia, de um só contingente ao grosso das tropas que não dependem directamente de Vitélio, torna mais clara e significativa a antítese entre 
caminho, as suas estátuas equestres ruíram, a coroa, que colocara religiosissime, caiu em um regato e, mais tarde, em Viena, quando exercia a justiça, um galo pormenor ridículo - saltou-lhe para o ombro e depois para a cabeça, presságio que ficará por explicar até ao final da biografia. Tais augúrios são confirmados pelos efeitos: Quibus ostentis par respondit exitus; nam confirmatum per legatos suos imperium per se retinere non potuit ${ }^{83}$ («a estes sinais ominosos respondem iguais resultados: de facto, o império, que the foi garantido pelos legados, por si próprio não foi capaz de o manter»). Apesar disso, actuação posterior de Vitélio é marcada pela insolência. O seu avanço pelas cidades, a caminho de Roma, tem um aspecto triunfal. Permite que escravos e soldados se entreguem à pilhagem e ao assassínio (Vit. 10.2). A pietas de Otão, que morre para evitar a guerra, assalta a mente do leitor por contraste com a atitude ímpia de Vitélio:

Vtque campos, in quibus pugnatum est, adit, abhorrentis quosdam cadauerum tabem detestabili uoce confirmare ausus est, 'optime olere occisum hostem et melius ciuem'. Nec eo setius ad leniendam grauitatem odoris plurimum meri propalam hausit passimque diuisit. Pari uanitate atque insolentia lapidem memoriae Othonis inscriptum intuens 'dignum eo Mausoleo' ait, pugionemque, quo is se occiderat, in Agrippinensem coloniam misit Marti dedicandum. In Appennini quidem iugis etiam peruigilium egit. ${ }^{84}$

"Quando chegou aos campos onde se travara o combate, ousou encorajar os que se afastavam dos cadáveres em decomposição com estas palavras execráveis: 'Muito bem cheira um inimigo morto, e ainda melhor se for um concidadão'. $\mathrm{E}$, facto não menos grave, para abrandar a violência do odor, bebeu bastante vinho puro, à vista de todos, e distribuiu-o em redor. Com a mesma jactância e insolência, ao olhar a lápide escrita à memória de Otão, disse que 'ele era digno de tal mausoléu'; e o punhal, com que o antecessor se tinha matado, enviou-o para Colónia Agripinense, para ser dedicado a Marte. E no cume dos Apeninos celebrou mesmo uma vigília».

As palavras ímpias de Vitélio são agravadas pelo acto de beber na presença dos cadáveres: já Nero fora censurado por fazer algo semelhante junto ao cadáver da mãe (Nero 34.4). Além disso, perante a morte do adversário e, para mais, numa guerra civil, em vez de proceder a ritos de expiação, como procurara fazer Otão para aplacar os Manes de Galba, Vitélio faz ritos de aç̧ão de graças. Vitélio quer transformar o suicídio altruísta de Otão numa vingança pessoal e dos deuses, ao consagrar o punhal ao santuário de Marte, de onde tinha retirado a espada de Júlio César. ${ }^{85}$

os prodígios favoráveis do primeiro grupo e os desfavoráveis de Vitélio: vide VEnini, P. 1974, 1005.

${ }^{83}$ Vit. 9. Para Tácito, Hist. 3.56.2, o principal presságio era o próprio Vitélio, que, ignorante na arte militar e desprovido de capacidade de decisão, mostrava o medo e deixava-se ver ébrio.

${ }^{84}$ Vit. 10.3. Tácito, Hist. 2.70, descreve a cena macabra sem mencionar as palavras ímpias, o gesto de beber ou a dedicação do punhal, embora note o contraste entre atitude dos que choravam e a atitude prazenteira do imperador.

${ }^{85}$ Vide Poulle, B. 1997, 251-52. 
A vaidade preside também à entrada triunfal de Vitélio em Roma, ao som da trombeta, com o manto de general, de espada cingida e rodeado de estandartes; os acompanhantes envergam traje militar (sagulati) e trazem as armas à vista. ${ }^{86}$ Suetónio acentua a ilegalidade deste comportamento. ${ }^{87} \mathrm{~A}$ gradação na insolência ímpia é sublinhada por magis deinde ac magis omni diuino bumanoque iure neglecto («desprezando cada vez mais todas as leis divinas e humanas»): assunção do pontificado máximo no dia do desastre do Ália (dia da derrota dos Romanos pelos Gauleses, junto a este rio, em 390 a. C.); nomeação plurianual dos cônsules; nomeação do próprio como cônsul perpétuo. ${ }^{88}$

A aclamação de Otão, embora não tão passiva como a de Cláudio e Vitélio, têm algo em comum com estas pelo facto de serem os soldados a tomar a iniciativa, quando ele parecia hesitar; e também por alguns pormenores farsescos. De qualquer modo, a imagem de Otão é mais positiva, dado o seu acto heróico na morte. Há nesta Vida uma oscilação entre atitudes censuráveis e louváveis, mas a tender para as segundas. A divergência em relação a Galba acontece por ter sido preterido na adopção. Ao saber que fora adoptado Pisão, decide-se pelo uso da força (Otho 5.1). Um segundo móbil são as dívidas: prometera cargos a troco de dinheiro; paga elevadas quantias aos soldados da guarda. ${ }^{89}$ O golpe toma também o aspecto de um acto desesperado e suicida ${ }^{90}-$ tanto se lhe dava morrer na batalha, como no Foro, perseguido pelos credores -, um jogo semelhante ao de César ao atravessar o Rubicão. O biógrafo mostra-se tendencioso, pois à contenção de Galba chama avareza, e à atitude de Otão não chama corrupção. As razões que Suetónio dá para o adiamento do golpe (uma vez que tinha decidido ocupar o campo pretoriano imediatamente a seguir à adopção de Pisão e atacar Galba durante um banquete) acentuam respeito pelos soldados: não queria tornar odiada a coorte, pois era a mesma que estava de serviço quando Gaio Calígula fora morto e Nero abandonado. ${ }^{91} \mathrm{~A}$ adiar

${ }^{86}$ Vit. 11.1. Vide Martin, R. 1991, 312.

${ }^{87}$ Uma versão mais próxima da legalidade é apresentada em Tácito, Hist. 2.89.1: Vitélio, que se dispunha a entrar na cidade paludatus accintusque, deixa-se convencer pelos amigos a vestir a praetexta, e os oficiais levam uma veste branca, enquanto, segundo Suetónio, envergam o sagum, hábito de guerra contraposto à toga. Vide com. de Venini, P. 1977, 125-126.

${ }^{88}$ Vit. 11.2. Cf. Tácito, Hist. 2.91.1 Vide Venini, P. 1974, 1003-1004. Coale, A. J. 1971, 49-58, comparando os textos de Suetónio e Tácito, conclui que Vitélio já era pontífice máximo, antes de 18 de Julho, dia do referido desastre. Tácito, Hist. 3.55.2, coloca a nomeação plurianual dos cônsules no último período do império de Vitélio, depois do desastre de Betríaco (medida anulada depois por Vespasiano: Hist. 4.47); a antecipação operada por Suetónio explica-se pela técnica de composição, porque esta medida é colocada sob a designação de omni diuino humanoque iure neglecto. Vide com. de Venini, P. 1977, 126-127.

${ }^{89}$ Otho 5.2. Suetónio, centrando-se na personagem principal, não menciona aqui as razões dos pretorianos: a falta do donativo aquando da adopção de Pisão (Gal. 17); vide Venini, P. 1974, 1001-1002.

${ }^{90}$ Vide Martin, R. 1991, 227-228.

${ }^{91}$ Otho 6.1. Tácito, Hist. 1.26, apresenta uma razão diversa: Otão temeu levar a cabo uma acção à noite, porque, como havia na cidade diversos efectivos de tropas que não o conheciam pessoalmente, corria-se o risco de os soldados ébrios, na penumbra, tomarem a pessoa errada e a proclamarem imperador. Suetónio deve ter seguido uma fonte militar, talvez o testemunho de 
aconselhava também a religio e o astrólogo; mas, no dia fixado, Otão ouve as predições do harúspice, que, como se diz na Vida anterior, são desfavoráveis a Galba. ${ }^{22}$ Conjugam-se assim os requisitos humanos e divinos para o sucesso da empresa. O texto suetoniano da aclamação de Otão, embora semelhante aos relatos de Plutarco e Tácito, tem, no entanto, pormenores curiosos que não figuram naquelas fontes:

Tunc abditus propere muliebri sella in castra contendit ac deficientibus lecticaris cum descendisset cursumque cepisset, laxato calceo restitit, donec omissa mora succollatus et a praesente comitatu imperator consalutatus inter faustas adclamationes strictosque gladios ad principia deuenit, obuio quoque non aliter ac si conscius et particeps foret adhaerente. ${ }^{93}$

«Então, escondendo-se à pressa numa liteira de mulher, dirigiu-se apressadamente para o acampamento. Mas, como os carregadores já estavam exaustos, desceu e começou a correr. Porque se desapertou um sapato, parou; até que, prescindindo de mais demoras, foi levado em ombros e saudado imperador pelo séquito presente e, entre alegres aclamações e espadas desembainhadas, chegou ao quartel-general. Pelo caminho, iam aderindo também outros, como se não fossem outra coisa senão cúmplices e participantes».

Suetónio realça pormenores não mencionados nos outros relatos: o disfarce numa liteira de mulher, o cansaço dos escravos, o facto de Otão ter de descer da liteira e começar a correr e ter de parar porque um sapato se desapertou. São situações que evidenciam, em crescendo, a pressa do grupo em chegar ao acampamento e o tempo psicológico. A referência ao pormenor do sapato acentua a ansiedade resultante do contraste entre a escassez do tempo e a demora da acção. A expressão do afã do pequeno grupo culmina em donec omissa mora, no momento em que a necessidade torna a decisão inadiável. Assim consegue o biógrafo um relato vivo do momento da aclamação. Nesta altura há uma subtil transferência da iniciativa de Otão para os soldados, expressa pela introdução da voz passiva (succollatus et a praesente comitatu imperator consalutatus). O pormenor da liteira de mulher ${ }^{94}$ parece remeter para os costumes efeminados, referidos no final da Vida por contraste com a coragem na morte.

Como habitualmente, o discurso transmitido pelo biógrafo é breve: ad conciliandos pollicitationibus militum animos nibil magis pro contione testatus est, quam id demum se habiturum, quod sibi illi reliquissent ("para cativar com promessas o coração dos soldados, nada mais proclamou diante da parada, a não ser que assumiria unicamente o que eles lhe deixassem»). Com esta insistência na brevidade do discurso e das promessas e na cedência à vontade dos apoiantes se apresenta um Otão não demagogo. ${ }^{95}$ Ao mesmo tempo reforçam-se os seus

seu pai: vide com. de Murison, Ch. L. 1992, 104.

${ }_{92}$ Otho 6.2; Cf. Gal. 19.1

${ }^{93}$ Otho 6.3. Cf. Tácito, Hist. 1.27.2; Plutarco, Gal. 25.1-4.

${ }^{94}$ Tácito, Hist. 1.27.2, diz apenas: et sella festinanter impositum.

95 Otho 6.3. Nibil magis pro contione testatus est, quam id demum parece contrastar 
laços às tropas com as razões que levam os soldados a amá-lo até ao ponto de darem a vida por ele, e não só no campo de batalha. Também a alocução ao senado é descrita como uma breuis oratio: Otão diz que foi como que raptado na rua e forçado a assumir o imperium, mas que o governaria de acordo com o arbítrio de todos. ${ }^{96}$ Torna-se mais perceptível a razão que levou os soldados a perderem a paciência e a saudarem-no: Otão estaria irresoluto, como sugerem as outras fontes.

\subsection{A mudança radical de comportamento}

Tito era já co-regente com o pai. A transição do título de imperador faz-se naturalmente, mas acompanhada de uma transformação inesperada na forma de actuar. $\mathrm{O}$ verdadeiro carácter manifesta-se na forma como consegue subverter a má fama: At illi ea fama pro bono cessit conuersaque est in maximas laudes neque uitio ullo reperto et contra uirtutibus summis ${ }^{97}$ («mas esta má reputação cedeu lugar à boa e foi transformada nos maiores elogios, já que se não lhe descobria nenhum vício e, pelo contrário, as maiores virtudes»). Uma dupla faceta - uma aparente e outra real - se descortina, de modo semelhante a Otão. Ao contrário dos imperadores dissimulados, que inicialmente aparentam virtudes (Tibério, Calígula, Nero, Domiciano), Tito aparenta vícios. Mas em Tito a revelação do verdadeiro carácter não ocorre no momento da morte, como aconteceu com Otão, mas na assunção do poder. Também, ao contrário dos imperadores maus, o poder não o corrompe: ao mau particeps imperii sucede o bom princeps. A partir daqui Suetónio caracteriza o imperador em consonância com o juízo com que inicia esta Vida: "amor e delícias do género humano".

propositadamente com o longo discurso citado por Tácito, Hist. 1.37.1-38.2, e provavelmente construído pelo historiador. A imagem de Otão deixada por Tácito é assaz negativa: o efémero imperador tem uma actuação vergonhosa que pode resumir-se com omnia seruiliter pro dominatione (Hist. 1.36.3).

${ }^{96}$ Otho 7.1. Cf. Plutarco, Gal. 28.1; Tácito, Hist. 1.47.1. Em Díon Cássio, 64.8, Otão diz, no seu discurso ao senado, que correria perigo de vida, se se opusesse aos soldados.

${ }^{97}$ Tit. 7.1. Vide Wardle, D. 2001, 64-69. 
(Página deixada propositadamente em branco) 


\section{Teatro e Poder}

\subsection{O culto do espectáculo: do conveniente ao escandaloso}

Os espectáculos constituem, como é sabido, uma preocupação para os imperadores. É uma forma de propaganda e um meio eficaz de aplacar a plebe, de modo a prevenir revoltas sociais. Oferecer espectáculos é sinónimo de liberalidade. Mas, além do patrocínio, a presença pessoal do imperador durante estes eventos é bem vista. É através dos jogos que os imperadores promovem o contacto com as classes mais baixas. Augusto, demonstra a sua habilidade política, ao primar pela assiduidade, variedade e magnificência dos espectáculos. Tal como já antes Júlio César, o fundador do principado apresentou espectáculos de teatro com actores de todas as línguas. ${ }^{1} \mathrm{E}$ também, como nos de César, participaram, nos jogos cénicos e nos de gladiadores, cavaleiros romanos, antes de tal ser proibido por um senato-consulto (Aug. 43). Suetónio salienta através de uma série de factos anedóticos a importância que Augusto atribuía aos jogos (Aug. 43.5). A consideração pelos espectadores é revelada pela forma como o imperador procura não se ocupar de mais nada durante os jogos, para evitar a censura movida a César, que aproveitava esse tempo para ler e responder a cartas (Aug. 45.1).

A longa abordagem demonstra o relevo deste aspecto administrativo para Augusto e para o próprio Suetónio, que, de resto, é autor de uma monografia sobre os jogos. Com efeito, o biógrafo inclui a oferta de espectáculos na parte positiva dos principados de Calígula e de Nero (Cal. 18-20; Nero 11-12). A descrição dos aspectos positivos do governo de Domiciano começa com os spectacula magnifica et sumptuosa no anfiteatro e no circo, longamente descritos pelo biógrafo (Dom. 4), ${ }^{2}$ o que pressupõe o grande relevo que os jogos assumem neste principado. Da mesma forma, Suetónio faz um longa e viva exposição (intercalada de anedotas) dos variados e magníficos espectáculos oferecidos por Cláudio (Cl. 21). Diz que Tito supera todos os outros em munificência no espectáculo de inauguração do anfiteatro flávio, onde num só dia morreram cinco mil feras de toda a espécie (Tit. 7.3). Pelo contrário, o biógrafo censura Tibério porque, de acordo com a sua avareza (Tib. 46), não promoveu nenhum espectáculo (Tib. 47). ${ }^{3}$ Nesse sentido se acrescenta que

${ }^{1}$ Aug. 43.1: per omnium linguarum histriones. A expressão é a mesma de Jul. 39.1.

${ }^{2}$ Os jogos aparecem na biografia de Domiciano mais como um produto das virtutes que dos uitia, como afirma Della Corte, F. 1967, 109. Mas, no seu com., Jones, B. W. 1996, 35, nota a hostilidade presente em sumptuosa.

${ }^{3}$ Segundo M. Antonietta Giva, M. A. 1978, 338-339, Suetónio contradiz-se em relação ao que disse atrás, quando colocou a contenção nas despesas dos jogos entre os méritos do imperador (Tib. 34). Mas a contradição será apenas aparente, se nos lembrarmos de que o biógrafo, depois de afirmar que os uitia tinham sido diu dissimulata (Tib. 42), está a reinterpretar estas atitudes à luz de um novo dado: a auaritia. Economicamente, tinha um lado bom: poupava o dinheiro público (que era o que estava em questão em Tib.34); eticamente, tinha o lado mau: era resultado da avareza de Tibério. De outra forma, seria estranho que o próprio biógrafo não desse conta da contradição, a tão poucos capítulos de distância. 
rarissime interfuit, ne quid exposceretur («assistiu muito raramente, para que lhe não fizessem pedidos»).

Mas, demasiada afeição aos jogos por parte do príncipe também é moralmente reprovável. Tal parece sintomático da alegada loucura de Calígula. No cume das suas extravagâncias, figura o exagerado interesse pelos espectáculos. Diz-se que praticava (e aqui é que reside a censura, por serem artes menos nobres) as artes do gladiador trácio, do auriga, do cantor e do dançarino. Mas, dentro destas actividades lúdicas, a gradação continua até à ânsia de cantar e dançar, que o leva a acompanhar a recitação do actor trágico e imitar os gestos do mimo (Cal. 54.1). Consta que, para a noite do dia em que pereceu, tinha planeado o seu primeiro aparecimento em cena. E, certa vez, três ex-cônsules, apavorados, por terem sido convocados ao palácio a meio da noite, são brindados com uma dança de Calígula em trajes de teatro. ${ }^{4}$

Naturalmente a paixão desmesurada pelos jogos levava a exageros, como favorecer ad insaniam os que partilhavam tal paixão, como o pantomimo Mnester (chegava a beijá-lo publicamente e punia com severidade quem fizesse barulho enquanto ele dançava) (Cal. 55.1), os gladiadores trácios e os aurigas da facção dos verdes (Cal. 55.2). A opinião pública, no esforço para compreender a imprevisível psicologia do imperador, começa a tentar estabelecer a relação de causa-efeito entre os seus gostos e consequências desproporcionadas. A paixão pelas corridas do circo (favorecia a facção dos verdes e o auriga Eutico $)^{5}$ e o desvelo com o cavalo Incitatus poderá estar na origem do rumor de que Calígula pretendia nomeá-lo cônsul. ${ }^{6}$ A inclusão, no final desta $V i d a$, das explicações sobre o gosto pelos espectáculos em geral, e pelo teatro em particular, parece constituir mais uma chave de leitura para os comportamentos estranhos de Calígula. É outra manifestação do distúrbio mental que o levava a trabalhar em frente ao espelho o rosto, natura horridus ac taeter, de forma a provocar terror ac formido. ${ }^{7}$ Esta nota parece sugerir os gostos teatrais do imperador, que também na prática da eloquência, parece assumir uma postura teatral. ${ }^{8}$

${ }^{4}$ Cal. 54.2. Trata-se da palla e da tunica talaris. A primeira era uma peça de vestuário feminina usada por homens no palco; a segunda, uma peça de roupa masculina não romana, mas talvez normal no palco, pois talarius significa espectáculo licencioso: vide com. de WARDLE, D. 1994, 347.

${ }^{5}$ Cal. 55.2. Esta paixão terá inspirado ao conjurado Quérea o desprezo da multidão, que, depois da morte de Calígula, pedia um novo César, e uma crítica aos costumes imperiais que substituem as vitórias militares pelas vitórias no circo (cf. Flávio Josefo, AJ 19.4 ): vide GAGÉ, J. 1969, 275-283.

${ }^{6}$ Cal. 55.3. Vide Lugand, R. 1930, 10-11; e, dentro do que se diz da dedicação ao cavalo, este rumor é cume da gradação: vide Gascou, J. 1984, 705.

${ }^{7}$ Cal. 50.1; efeito que Camus aproveita repetidamente como lugar aonde Calígula retorna para descobrir todas as caras que pode assumir: Caligula , I,3; I,11; III,5; IV,14. Antes de morrer, o Calígula de Camus parte o espelho - para significar o fim da experiência de absurdo: vide Gillis, J. 1974, 402-403.

8 Cal. 53.1. Afasta-se dos cânones pelo excesso de movimento (cf. Cícero, Orat. 59; Quintiliano, Inst. 11.3.126ss); vide com. WARdLE, D. 1994, 342. 
Um dos erros de Calígula, como mais tarde de Nero, parece ser a confusão da ficção com a realidade, ao trazer para a vida os mitos. Tal ideia parece estar presente na descrição do vestuário de Calígula (Cal. 52). O aspecto visual, determinante na caracterização da personagem, impera nesta parte da Vida. $\mathrm{O}$ interesse pelo calçado está de acordo com a alcunha deste imperador (pequena "bota" militar). Calígula, como mais tarde Nero, tenderá para uma osmose entre a sua vida e a cena (o canto e a dança) de que tanto gostava. Sugerem-se, pela lista de roupas apresentada, papéis femininos, trágicos, cómicos e divinos. A megalomania e a autodivinização são acentuadas pela sua tendência cénica. Tal propensão colide com a moralidade defendida pelo senado, ainda guardião dos ideais republicanos. Para os pragmáticos Romanos, os dramas têm um local e profissionais próprios: o teatro e os histriões.

A rubrica dos espectáculos assume uma importância especial na biografia de Nero (Nero 11-13). O teatro abarca a maior parte dos espectáculos. ${ }^{9}$ Embora Suetónio aprove geralmente os ludi, ${ }^{10}$ acrescenta-se que Nero permitiu que actuassem como actores velhos ex-cônsules e matronas idosas: já um seu antepassado fora censurado por proceder de modo semelhante. ${ }^{11} \mathrm{~A}$ arte cénica ocupa grande parte desta Vida e está presente nos principais momentos. Nero apresenta-se antes de mais como um verdadeiro encenador. É de notar que, entre as representações que promove, figura uma togata de Afrânio, intitulada incendium, em que é permitido aos actores saquearem a casa que ardia e ficarem com os bens. ${ }^{12}$ Tais efeitos revelam a tendência para o sensacional e para a piromania, que culminará com o incêndio de Roma, ao mesmo tempo que sugere o vício da pilhagem.

O biógrafo procura sugerir esta atmosfera exibicionista e acentuar o aparato da busca de popularidade protagonizada por Nero: a distribuição de bens é descrita numa notável gradação:

Sparsa et populo missilia omnium rerum per omnes dies: singula cotidie milia auium cuiusque generis, multiplex penus, tesserae frumentariae, uestis, aurum, argentum, gemmae, margaritae, tabulae pictae, mancipia, iumenta atque etiam mansuetae ferae, nouissime naues, insulae, agri (Nero 11.2).

${ }^{9}$ Como era pratica dos ludi e que se prolongou pelo Império: vide Pimentel, M. C. 2001, 329-348.

${ }^{10}$ Como sublinha, no seu com., Bradley, K. R. 1978, 81.

${ }_{11}$ Nero 11.1; cf. Nero 4. No com., Bradley, K. R. 1978, não parece ter totalmente razão quando, a propósito de Nero 11.2, afirma, generalizando (p. 84), que Suetónio, ao contrário de Tácito e Díon Cássio, se não opõe à apresentação de membros das classes elevadas sobre o palco. Tal afirmação deveria ser restringida a este passo: porque a tónica não está nesses factos nem em questões de moral, mas na quantidade e diversidade dos espectáculos que Nero deu, como se anuncia no início da rubrica: Spectaculorum plurima et uaria genera edidit. Suetónio não parece escandalizar-se tanto quanto Tácito (Ann. 14.15), mas tal não quer dizer que aprove declaradamente. A participação de aristocratas nos jogos insere-se no processo de helenização que constitui uma constante deste principado: vide CizeK, E. 1982, 123-127.

${ }^{12}$ Nero 11.2. 
«Todos os dias se atiravam ao povo brindes de todo o género: por dia, um milhar de aves de cada espécie, muitas provisões, senhas de trigo, roupas, ouro, prata, gemas, pérolas, quadros, escravos, bestas de carga e até feras amestradas; por último, navios, blocos de apartamentos, terras».

A dedicação ao espectáculo leva-o a deixar a sua marca com um novo concurso quinquenal à moda grega, a que chama Neronia, e que reúne provas musicais, gímnicas e equestres. $\mathrm{O}$ júri é composto por consulares (e não por especialistas). $\mathrm{O}$ próprio Nero recebe a coroa da eloquência e da poesia latina. Mas a que tem para ele maior significado é a coroa da cítara, que lhe é atribuída por consenso do júri: ajoelha-se e manda depositá-la junto à estátua de Augusto. ${ }^{13}$

O fundamento das acções perversas deste imperador (probra ac scelera) reside, conforme sugere Suetónio, no seu carácter histriónico. Em primeiro lugar, o biógrafo faz o historial da dedicação de Nero à música (o canto e a execução musical) a fonte da futura tragédia. O biógrafo começa a exposição deste gosto pelo princípio (pueritiae tempore), com um imediato salto temporal para o início do império, altura em que Nero chama o citaredo Terpno para o palácio (Nero 20.1). Os exercícios a que Nero se aplica para fortalecer a voz, que é exigua et fusca, têm como objectivo satisfazer o desejo de se apresentar cena, porque, como ele próprio repete, «a música escondida não é apreciada». Estreia-se em Neápolis, em ambiente grego, ${ }^{14}$ e cria mesmo uma claque de jovens, inspirada nos aplausos de uns marinheiros alexandrinos. ${ }^{15}$

O desejo de actuar no centro do Império (Cum magni aestimaret cantare etiam Romae) implica uma afronta aos costumes romanos. Parece haver ironia de Suetónio quando diz que todos reclamavam a sua caelestis uox. Nero faz-se um pouco rogado, prometendo uma actuação nos jardins do palácio; depois, como também os soldados juntavam o seu pedido ao do povo, promete que repraesentaturum se e acaba por se inscrever no concurso de citaredos. Entra acompanhado pelos prefeitos do pretório, que lhe levavam a lira, pelos tribunos militares e pelos amigos (Nero 21.1). Quis prolongar o concurso para o ano seguinte, para ter mais oportunidades de cantar. ${ }^{16}$ Pensou mesmo em apresentar-se a concurso inter scaenicos, em espectáculos particulares. Usa máscaras de heróis e deuses, de heroínas e deusas com os seus próprios

${ }^{13}$ Nero 12.3. Como nota, no seu com., Warmington, B. H.1999, 39, neste festival, instituído em 60, Nero não participou pessoalmente nas provas de retórica e poesia latina (Tácito, Ann. 14.21.4) nem de lira (Díon Cássio, 61.21.2), mas, apesar disso, os prémios foram-lhe atribuídos. Na repetição dos Neronia, em 65, o senado oferece-lhe antecipadamente os prémios, para evitar o escândalo de um imperador vestido de histrião (Tácito, Ann. 16.4), mas Nero insiste em participar. Vide Cizen 1982, 126-127. Para Griffin, M. T. 1984, 114, a impaciência de Nero impediu-o de vencer as resistências dos conservadores à helenização.

${ }^{14}$ Nero 20.2. Há neste capítulo e no seguinte uma iteratio do verbo cantare, como nota LorenZo, E. Di 1981, 529.

${ }^{15}$ Nero 20.3. Vide Martin, R. 1991, 310.

${ }^{16}$ Nero 21.2. Provavelmente Suetónio é tendencioso: há quem sugira que a razão para o adiamento do festival poderia ser a pressa que Nero tinha em partir para Alexandria: vide com. de Bradley, K. R. 1978, 133-134. 
traços ou os de mulheres que têm o seu favor, neutralizando assim o fosso entre representação e realidade. ${ }^{17}$ Além de Niobe, argumento proclamado por Clúvio Rufo (Nero 21.2), interpretou Cânace em trabalho de parto, Orestes matricida, Édipo cego, Hércules furioso. Ao seleccionar estes papéis, o biógrafo parece sugerir que tais mitos poderão estar na base de comportamentos reais de Nero, mencionados mais à frente. ${ }^{18} \mathrm{~A}$ propensão de Nero para encenar temas mitológicos de forma realista é visível nos argumentos das danças pírricas: o amor de Pasífae, supostamente encerrada dentro de uma vaca de madeira que um touro cobre, e o voo de Ícaro, que, ao cair, salpica de sangue o próprio Nero. ${ }^{19}$ Do ambiente de confusão entre mito e realidade dá prova o rumor que se levantou no momento da representação do Hércules furioso: um soldado novato, ao ver Nero carregado de cadeias e amarrado, de acordo com o argumento da peça, vem em seu socorro. ${ }^{20}$ Tal equívoco, se não foi preparado de antemão, é o melhor reconhecimento do trabalho do actor.

Sinal da facilidade com que Nero assimilava a realidade aos mitos é também o facto de, apanhado pelo pedagogo a lamentar-se de que um auriga da facção dos verdes fora arrastado pelos cavalos, disse que falava de Heitor (Nero 22.1). A paixão pelos cavalos (equorum studium), contrariada em vão, é mais uma característica que Nero partilhava com Calígula. Tratava-se de outro meio de satisfazer o seu desejo de popularidade: apoiava a facção dos verdes, favorita do povo; ${ }^{21}$ queria ele próprio dar espectáculo (spectari); treinava-se nos jardins inter seruitia et sordidam plebem; ofereceu-se à vista de todos no Circo Máximo (Nero 22.2).

Mas as preferências do imperador vão para os prazeres estéticos. ${ }^{22} \mathrm{O}$ palco de Roma torna-se pequeno para a sua ars. ${ }^{23} \mathrm{O}$ motivo da viagem à Acaia passa a ser principalmente a forma como esta região alimenta a vaidade de Nero: as cidades em que se realizavam concursos musicais enviam todas as coroas dos cantores de cítara e os legados aplaudem tão efusivamente o seu canto que

${ }^{17}$ Segundo Bartsch, S. 1994, 46 e 51-52, Nero representa o papel de si mesmo.

${ }^{18}$ Nero 21.3. Lounsbury, R. C. 1991, 3775, sugere que cada um destes papéis é uma máscara do próprio Nero: enquanto desflorado por Doríforo (Nero 29), assassino da mãe (Nero 34.1-4), incestuoso com a mãe (Nero 28.2); assassino de amigos e esposas (Nero 35.2-3, 5).Vide Martin, R. 1991, 264.

${ }^{19}$ Nero 12.2. Vide Bartsch, S. 1994, 57. Ser salpicado com sangue poderá considerado de mau agoiro pelo leitor que ainda tenha presentes os presságios da morte de Calígula (Cal. 57.4): este foi salpicado com o sangue de um flamingo durante o sacrifício, no próprio dia da morte, pouco antes de ser assassinado. Cf. Gal. 18.1: Galba é manchado com o sangue de um touro imolado.

${ }^{20}$ Nero 21.3. Hércules, depois de matar a mulher e os filhos, é amarrado a um poste. Para a interpretação do passo, vide BiLlerbeck, M. 1981, 54-57.

${ }^{21}$ Nero 22.1. A facção dos verdes foi apoiada por outros tiranos de má memória: Calígula e Domiciano.

${ }^{22}$ Como sublinha Martin, R. 1991,264: «en fait, Néron était porté vers les jeux du cirque par son goût de la popularité, mais son tempérament lui faisait préférer les plaisirs esthétiques».

${ }_{23}$ Nero 22.3: Nec contentus harum artium experimenta Romae dedisse, Achaiam, ut diximus, petit binc maxime motus. 
ele exclama 'solos scire audire Graecos solosque se et studiis suis dignos ${ }^{24}$ ("só os Gregos sabem ouvir e só eles são dignos de si e da sua arte'»). Uma frase que denuncia, por um lado, a reserva dos romanos perante o comportamento do imperador e, por outro, o filelenismo entusiástico de Nero. ${ }^{25}$

A preferência por este tipo de espectáculos leva-o a organizar em Olímpia, contrariamente ao uso, um concurso musical. E, de facto, nas prioridades de Nero, a música está não só à frente dos mores, mas também das questões políticas mais prementes (Nero 23.1). Da primazia da música rapidamente se passa para a tirania do canto. Por ser um imperador-actor, é no recinto do teatro e sobre a audiência que começa a exercer a tirania, em primeiro lugar sobre a assistência: é absolutamente proibido sair enquanto ele canta, pelo que consta que mulheres dão à luz durante os espectáculos e que alguns, saturados de ouvir e aplaudir, saltam furtivamente do alto dos muros ou se fingem mortos, para, assim, serem retirados do recinto (Nero 23.2). Os sentimentos que Nero experimenta durante os concursos correspondem aos de qualquer actor: tremor de ansiedade, inveja dos rivais e medo dos juízes. Suetónio lança a suspeita de que se trate de fingimento. ${ }^{26}$ Nero mostra reuerentia para com os juízes (Nero 23.3) e obedece rigorosamente ao regulamento. Ele próprio se anuncia como vencedor e, por isso, assume também as funções de arauto (Nero 24.1).

O triunfo, organizado pelo seu regresso, não é o tradicional desfile militar, mas a apoteose do actor. ${ }^{27}$ Os despojos são as coroas dos concursos de canto ou de peças teatrais e o cortejo termina não no templo de Júpiter Máximo, mas no templo de Apolo, patrono das artes. A teatralidade do momento é evidente:

\begin{abstract}
Reuersus e Graecia Neapolim, quod in ea primum artem protulerat, albis equis introiit disiecta parte muri, ut mos hieronicarum est; simili modo Antium, inde Albanum, inde Romam; sed et Romam eo curru, quo Augustus olim triumphauerat, et in ueste purpurea distinctaque stellis aureis chlamyde coronamque capite gerens Olympiacam, dextra manu Pythiam, praeeunte pompa ceterarum cum titulis, ubi et quos quo cantionum quoue fabularum argumento uicisset; sequentibus currum ouantium ritu plausoribus, 'Augustianos militesque se triumphi eius' clamitantibus. Dehinc diruto circi maximi arcu per Velabrum forumque Palatium et Apollinem petit. Incedenti passim uictimae caesae sparso per vias identidem croco ingestaeque aues ac lemnisciet bellaria. Sacras coronas in cubiculis circum lectos posuit, item statuas suas citharoedico habitu, qua nota etiam nummum percussit. ${ }^{28}$
\end{abstract}

${ }^{24}$ Nero 22.3. A viagem à Acaia, que antes fora referida como uma empresa louvável, sobretudo devido às obras de abertura de um canal no istmo de Corinto (Nero 19.2), aparece agora como objecto de censura, devido aos motivos que a determinaram: vide Gascou, J. 1984, 369-370.

${ }_{25}$ Para André, J.- M. 1995, 168-182, a viagem à Grécia revela o filelenismo de Nero, mas também a intromissão da tradição trágica (pelos papéis trágicos interpretados por Nero) e da tradição épica (pelo hipismo nobre) numa alma atormentada.

${ }^{26}$ Nero 23.2: Quam autem trepide anxieque certauerit, quanta aduersariorum aemulatione, quo metu iudicum, uix credi potest. Tácito, Ann. 16.4.4, fala de medo fingido. Vide BARTsch, S. 1994, 27.

${ }^{27}$ Vide Pimentel, M. C. 2001,336 n. 26.

${ }^{28}$ Nero 25.1-2. Uma descrição semelhante figura em Díon Cássio, 63.20.1ss. 
«Regressado da Grécia, fez uma entrada, com cavalos brancos, em Neápolis porque ali tinha pela primeira vez revelado a sua arte -, depois de abatida parte das muralhas, como é costume para os vencedores dos jogos sagrados. Entrou de modo semelhante em Âncio, depois no território do monte Albano, depois em Roma. Mas, em Roma, usou o mesmo carro de que Augusto outrora se servira no seu triunfo e uma veste de púrpura e uma clâmide adornada com estrelas de ouro e uma coroa olímpica na cabeça e a pítia na mão direita. Precedia-o o cortejo solene das restantes coroas, com inscrições a indicar onde, a quem e com que argumento de canto ou de peças teatrais vencera. Seguia o carro a claque a gritar, segundo o ritual das ovações, que eram 'os augustianos e os soldados do seu triunfo'. Em seguida, demolido que fora um arco do Circo Máximo, dirigiu-se, através do Velabro e do Foro, para o Palatino e para o templo de Apolo. À sua passagem, imolavam-lhe vítimas por toda parte, espalhavam continuamente açafrão pelas ruas e ofereciam-lhe aves e fitas e guloseimas. Dispôs as coroas sagradas pelos quartos, à volta dos leitos, e ainda estátuas suas em traje de citaredo, imagem com a qual fez ainda cunhar moedas».

Através desta paródia de triunfo, Nero revela a sua concepção de vitória e as suas prioridades políticas. Suetónio termina o assunto com a observação de que, para o imperador, o critério de amizade ou inimizade era o pródigo ou o parco louvor que faziam do seu talento (Nero 25.3). Tal encómio diz respeito às capacidades histriónico-canoras de Nero, pelo que se trata do elogio da sua própria degradação, dos seus probra. Na parte negra desta Vida (Nero 20-39) dá-se uma subversão: o poder fica subordinado ao teatro. Se o teatro ao serviço do poder é proveitoso, quando toma as rédeas do poder transforma-o numa tirania, pois as convenções cénicas não são morais nem sociais. Suetónio sublinha esta ideia ao iniciar e terminar esta fase da Vita, com referências explícitas à actividade teatral.

Depois da narrativa da morte, Suetónio, ao compor o retrato do biografado, retoma o assunto para tentar explicar a afeição à cena: um desejo enorme de popularidade, ${ }^{29}$ de conquistar o favor do uulgus pela sua participação activa nos jogos. A vaidade do imperador fazia-o conceber ainda novos projectos. Ao saber que era igualado a Apolo pelo canto, ao Sol na arte de auriga, ${ }^{30}$ planeava imitar também os trabalhos de Hércules: aparecer todo nu na arena e abater um leão praeparatus a golpes de maça e sufocá-lo com os braços. Se tivesse sobrevivido, o comportamento não teria mudado: pouco antes da morte (sub exitu) prometera que, se não fosse destronado, participaria nos jogos como tocador de órgão hidráulico, de flauta e de gaita de foles e como histrio, dançando o 'Turno de Virgílio'. Há quem afirme que o histrião Páris foi morto porque Nero o considerava um rival perigoso (Nero 54).

O impacto foi tal que, morto Nero, a sua sombra continua presente. Outros tiveram a tentação de lhe seguir os passos, o que demonstra que continuava a impressionar. Vitélio, para que não houvesse dúvidas sobre o modelo do seu

${ }^{29}$ Nero 53: Maxime autem popularitate efferebatur.

${ }^{30} \mathrm{~A}$ assimilação liga-se à ideia de uma teocracia à maneira oriental: vide com. de BRADLEY, K. R. 1978, 288-290. 
governo, além de oferecer no campo de Marte um sacrifício aos Manes de Nero, ${ }^{31}$ pediu a um citaredo que, num banquete solene, cantasse uma composição da autoria daquele imperador. Com esta atitude, Vitélio demonstra que era genuíno o seu entusiasmo quando instigava Nero a participar no concurso de citaredos (Vit. 4). Afinidade com Calígula e Nero manifesta-se também no facto de administrar o Império segundo a vontade dos mais vis histriões e aurigas (Vit. 12). À semelhança dos Neronia, também Domiciano instituiu um quinquennale certamen, à moda grega, em honra de Júpiter Capitolino, que incluía provas musicais, equestres e gímnicas (Dom. 4.4).

\subsection{Política e espectáculo}

Os imperadores actuam por vezes como verdadeiros actores tendo em vista determinados objectivos políticos. Augusto mostra-se um político hábil. A intenção, depois abandonada, de restaurar a República (manifestada, segundo o biógrafo, em duas ocasiões) inspira a Suetónio um comentário que, embora seja um tanto elíptico, parece sugerir aprovação: «é duvidoso se foi melhor o resultado ou a intenção». ${ }^{32} \mathrm{O}$ biógrafo dá a palavra a Augusto, através de um edicto, onde este se apresenta como o autor de um novo estado de coisas e como tal deseja ser lembrado à hora da morte:

Ita mibi saluam ac sospitem rem p. sistere in sua sede liceat atque eius rei fructum percipere, quem peto, ut optimi status auctor dicar et moriens ut feram mecum spem, mansura in uestigio suo fundamenta rei p. quae iecero.' Fecitque ipse se compotem uoti nisus omni modo, ne quem noui status paeniteret (Aug. 28.2).

«Assim me seja permitido consolidar o Estado são e salvo nos seus fundamentos e daí recolher o fruto que almejo, de ser proclamado autor do melhor regime e de levar comigo, ao morrer, a esperança de que permanecerão no seu lugar os alicerces do Estado que eu tiver lançado.' Ele mesmo se encarregou a si próprio do voto, esforçando-se de todos os modos para que ninguém ficasse insatisfeito com o novo regime».

E assim introduz Suetónio, nas Vidas dos Césares, a ideia do principado. A propaganda destinada a afastar a ideia de que era um tirano está implícita na actuação. Mas a preocupação de Augusto com a estabilidade do Estado é apresentada pelo biógrafo como genuína. Contornos dramáticos adquire a narrativa dos lamentos pela derrota de Varo na Germânia (que pertence já a uma fase muito avançada da vida de Augusto: 9 d. C.): Adeo denique consternatum ferunt, ut per continuos menses barba capilloque summisso caput

${ }^{31} \mathrm{O}$ mesmo diz Tácito, Hist. 2.95.1.

${ }^{32}$ Aug. 28.1. Foram igualmente bons a intenção de Augusto de renunciar à República e os efeitos do novo regime - segundo a interpretação apresentada na ed. de RoLFE, J. C. 1913, 164, n.b, e seguida por Gascou, J. 1984, 224-226; 719. Mas Suetónio exagera quando fala em duas tentativas, porque, na altura da doença, não estava em questão a restauração da República. Tal fora equacionado apenas em 27 a. C. 
interdum foribus illideret uociferans: 'Quintili Vare, legiones redde!' diemque cladis quotannis maestum habuerit ac lugubrem. ${ }^{33}$ ( Fez até um voto de dedicar grandes jogos a Júpiter Óptimo Máximo, se mudasse para melhor a situação do Estado, como tinha acontecido nas guerras com os Cimbros e com os Marsos. Em suma, diz-se que ficou tão transtornado que, durante meses a fio, deixando crescer a barba e o cabelo, batia de quando em quando com a cabeça nas portas e bradava: 'Quintílio Varo, devolve as legiões!' E o dia da derrota todos os anos o considerou de tristeza e de luto»).

No cúmulo das honras atribuídas a Augusto pelos seus méritos figura o título de Pai da Pátria, que corresponde, paralelamente, ao fastígio da consolidação do poder de Augusto:

Patris Patriae cognomen uniuersi repentino maximoque consensum detulerunt ei: prima plebs legatione Antium missa; dein, quia non recipiebat, ineunti Romae spectacula frequens et laureata; mox in curia senatus, neque decreto neque adclamatione, sed per Valerium Messalam is mandantibus cunctis: 'Quod bonum', inquit, 'faustumque sit tibi domuique tuae, Caesar Auguste! Sic enim nos perpetuam felicitatem rei p. et laeta huic precari existimamus: senatus te consentiens cum populo $R$. consalutat patriae patrem. Cui lacrimans respondit Augustus his uerbis - ipsa enim, sicut Messalae, posui - : 'Compos factus uotorum meorum, p. c., quid babeo aliud deos immortales precari, quam ut hunc consensum uestrum ad ultimum finem uitae mibi perferre liceat? ${ }^{34}$

«Ofereceram-lhe o cognome de Pai da Pátria, por espontâneo e supremo acordo universal. A plebe ofereceu-lho, primeiro, através de uma delegação enviada a Âncio, depois, como ele não aceitava, em peso e coroada de louros, no momento em que ele entrava para uns espectáculos em Roma; em seguida foi o senado, na Cúria, não por decreto ou por aclamação, mas por intermédio de Valério Messala. Este, em nome de todos, disse: 'Seja isto bom e propício para ti e para a tua casa, César Augusto! Assim, de facto, nós julgamos que estamos a pedir a eterna felicidade para o Estado, bem como a sua prosperidade: o senado, em consonância com o povo romano, te saúda como Pai da Pátria.' Respondeu-lhe Augusto, de lágrimas nos olhos, com estas palavras - transcrevi-as literalmente, como fiz para Messala - : 'Dado que obtive o cumprimento dos meus votos, patres conscripti, que outra coisa hei-de pedir aos deuses imortais, a não ser que me seja permitido manter este vosso acordo até ao derradeiro momento da vida?'»

O biógrafo insiste no facto de transcrever as palavras dos interlocutores: sugere o máximo de mimese e finge anular o narrador. Para esta narração

\footnotetext{
${ }^{33}$ Aug. 23.2.

${ }^{34}$ Aug. 58. Timonen, A.1993, 135-136, faz notar que « Suetonius succeeds in reconstructing a "glory effect" by the use of direct oration and by emphasis on consensus». Segundo GAscou, J. 1984, 215-220, Suetónio teria usado a autobiografia de Corvino Messala, cuja toada sentimental e lírica estava mais de acordo com a intenção do biógrafo de sublinhar a espontaneidade da estima geral para com Augusto. Vide também Southern, P. 1998, 179-180
} 
terá consultado os acta senatus, mas não os nomeia, como prometera atrás, ${ }^{35}$ procurando recriar o dramatismo do momento. A partir de uma acção, que deveria ser um acto calculado e concertado no final de um longo processo, Suetónio cria uma cena espontânea, quase comovente.

Calígula é aparatoso, como prova a simulação da queima dos processos relativos à mãe e aos irmãos, para tranquilizar os delatores (Cal. 15.4). Entre os espectáculos oferecidos por este imperador conta-se uma novidade: ${ }^{36}$ uma ponte formada com barcas entre Baias e Putéolos:

Per hunc pontem ultro citro commeauit biduo continenti, primo die phalerato equo insignisque quercea corona et caetra et gladio aureaque chlamyde, postridie quadrigario habitu curriculoque biiugi famosorum equorum, prae se ferens Dareum puerum ex Parthorum obsidibus, comitante praetorianorum agmine et in essedis cohorte amicorum. ${ }^{37}$

Por esta ponte atravessou, num sentido e no outro, dois dias sucessivos. No primeiro dia, montado num cavalo ornamentado, levava uma coroa de folhas de carvalho, um pequeno escudo e um gládio, bem como uma clâmide de ouro. No dia seguinte, ia em trajo de cocheiro de quadriga, numa biga de corrida puxada por cavalos de renome, precedido por Dario, um rapaz de entre os reféns partos, acompanhado de uma coluna de pretorianos e, em carros de guerra, uma coorte de amigos.

Pelo aparato assemelha-se a um triunfo. Calígula fora educado entre soldados. Parece ser uma forma de impressionar monarcas estrangeiros e, de modo especial, sugere o desejo de rivalizar com monarcas orientais. Uma das explicações aduzidas pelo biógrafo patenteia o desejo de emulação da ponte que Xerxes lançou sobre o Helesponto (Cal. 19.3) ${ }^{38}$. Tanto mais que, no desfile, o príncipe ostentava (prae se ferens) o pequeno Dario, um refém parto, filho de Artábano III. Por outro lado, simbolizará a vitória sobre o destino. Suetónio parece sublinhar esta última ideia, ao arredar as outras explicações para o espectáculo. Descarta as opiniões de que o propósito fora impressionar povos estrangeiros em favor da explicação que ouvira ao avô: Calígula quer superar o vaticínio de Trasilo, astrólogo de Tibério, de que «Gaio seria tanto imperador

${ }^{35}$ Aug. 57.1: Pro quibus meritis quanto opere dilectus sit, facile est aestimare. Omitto senatus consulta, quia possunt uideri uel necessitate expressa uel uerecundia. Vide BALDwIN, B. 1983, 128; Gascou, J. 1984, 217.

${ }^{36}$ Cal. 19.1: Nouum praeterea atque inauditum genus spectaculi excogitauit.

${ }^{37}$ Cal. 19.2. Para Lugand, R. 1930, 9-13, especialmente 11-12, a presença do jovem parto é a chave para entender a mensagem deste cortejo apoteótico. Os Partos imolam cavalos ao Sol. Sobre esta ponte, Calígula identifica-se com o Sol, cuja quadriga atravessa diariamente os céus. Esta cavalgada é a antecipação da apoteose a que está destinado depois da morte, em que acompanhará a viagem do Sol imortal. A hipótese não é inverosímil, dadas as tendências do jovem para se assimilar aos deuses. Mas a explicação parece mais simples: as tendências megalómanas de Calígula, como sugere Martin. R. 1991, 309. Vide com. de WardLe, D. 1994, 194-196. Para Antonelli, G. 2001, 120-125, é uma forma de demonstrar o poder ilimitado do príncipe, em confronto com o poder dos órgãos constitucionais da República.

${ }^{38}$ Cf. Heródoto, 4.83 ss. 
como atravessaria o golfo de Baias a cavalo». Suetónio apresenta-nos assim um Calígula que procura dobrar o destino à sua vontade. ${ }^{39}$

Da mesma forma, em consonância com o carácter teatral de Nero, o biógrafo coloca entre os espectáculos a recepção ao rei da Arménia, Tiridates:

Non immerito inter spectacula ab eo edita et Tiridatis in urbem introitum ret<t>ulerim. Quem Armeniae regem magnis pollicitationibus sollicitatum, cum destinato per edictum die ostensurus populo propter nubilum distulisset, produxit quo oportunissime potuit, dispositis circa fori templa armatis cohortibus, curuli residens apud rostra triumphantis habitu inter signa militaria atque uexilla. Et primo per deuexum pulpitum subeuntem admisit ad genua adleuatumque dextra exosculatus est, dein precanti tiara $[\mathrm{m}]$ deducta $[\mathrm{m}]$ diadema inposuit, uerba supplicis interpretata praetorio uiro multitudini pronuntiante; perductum inde in theatrum ac rursus supplicantem iuxta se latere dextro conlocauit. Ob quae imperator consalutatus, laurea in Capitolium lata, Ianum geminum clausit, tamquam nullo residuo bello. ${ }^{40}$

Não é sem fundamento que contarei entre os espectáculos a entrada de Tiridates na Urbe. Depois de convidar este rei da Arménia com grandes promessas, viu-se obrigado a adiar o dia que, através um edicto, destinara para o exibir ao povo, visto o tempo estar nublado, mas apresentou-o no momento mais oportuno que pôde. Dispostas as coortes armadas à volta dos templos do Foro, sentou-se numa cadeira curul, junto dos rostra, com vestes triunfais entre insígnias militares e estandartes. Primeiro recebeu o rei, que subiu uma plataforma inclinada e se ajoelhou, e, depois de o ajudar a levantar com a mão direita, beijou-o. Em seguida, a pedido dele, tirou-lhe a tiara e colocou-lhe o diadema, enquanto as palavras do suplicante, traduzidas, eram proclamadas à multidão por um antigo pretor. Conduziram-no dali para o teatro e, renovadas as súplicas, colocou-o junto de si, ao seu lado direito. Saudado imperador por este facto, depois de levar uma coroa de louro ao Capitólio, fechou o templo de Jano bifronte, para significar que não havia mais guerras em suspenso.

Trata-se de uma verdadeira produção sobre a cena, uma das acepções (segundo $O L D$ ) do verbo usado, producere. Nero apresenta-se no centro do palco: depois da frase introdutória, passa ser o sujeito dos verbos conjugados principais e subordinados, enquanto o rei Tiridates é descrito com particípios em acusativo e um deles em dativo. ${ }^{41}$ Ao apresentar este acto como um mero espectáculo, Suetónio desvaloriza o que foi um sucesso político e diplomático de Nero, ${ }^{42}$ preferindo associá-lo ao seu carácter histriónico. Mais à frente o

${ }^{39} \mathrm{Na}$ intr. ao com., WARDLE, D. 1994, 70, nota que esta escolha evidencia a preferência de Suetónio pelas versões mais romanescas e bizarras. Por outro lado, facilmente o leitor compreende que a refutação da profecia era desnecessária, uma vez que Calígula já era imperador há dois anos (vide p. 91).

${ }^{40}$ Nero 13.1-2. Esta recepção ocorreu no verão de 66. O encerramento do templo de Jano, não mencionado por Tácito é confirmado por inscrições; vide Nelson, N. 1941, 285-286; Townend, G. B. 1980, 233-242.

${ }^{41}$ Lounsbury, R. C. 1991, 3776-3777, depois de analisar as cláusulas métricas do passo, destaca a elegância e a riqueza rítmica.

${ }^{42}$ A vitória diplomática, que resultou na resolução da complicada questão arménio-parta e 
biógrafo retoma o episódio para o analisar pelo lado negativo: mostrar que a recepção foi particularmente ruinosa pelo desbaratamento da riqueza. ${ }^{43}$

Os actos públicos de Nero são teatrais: é no meio de uma hecatombe que corta pela primeira vez a barba, coloca-a numa píxide de ouro, adornada com pedras preciosas, e consagra-a ao Capitólio. ${ }^{44} \mathrm{Da}$ viagem à Acaia, Suetónio realça a inauguração das obras para abertura do canal do istmo de Corinto. Nero faz uma alocução à parada dos soldados pretorianos e, ao sinal da trombeta, dá o primeiro golpe de picareta e transporta um pedaço de terra num cesto ao ombro. ${ }^{45}$ Também Vespasiano dá o exemplo, com o gesto teatral de meter mãos ao trabalho, na reconstrução do Capitólio, destruído por um incêndio. ${ }^{46}$

$\mathrm{O}$ culto da imagem estende-se mesmo à preocupação com o aspecto exterior. Augusto usa solas altas para elevar a sua estatura (Aug. 73). Para esconder a calvície, Calígula não permite que o olhem de cima (Cal. 51.1), Otão usa peruca (Otho 12.1), e César usa uma coroa de louro (jul. 45.2). A importância destes pormenores é comprovada pelo relevo que o biógrafo dá ao aspecto físico e aos cuidados com a aparência na caracterização geral, como veremos na terceira parte deste trabalho.

Uma das formas de propaganda de qualquer regime autoritário é a política de grandes construções. Trata-se, no fundo, da criação do cenário condizente com a sua representação. A Urbe era a imagem visível de Roma divinizada. Os bons imperadores são restauradores, tanto quanto possível sóbrios e preocupados com o bem público. Os maus imperadores levam a cabo projectos megalómanos e ruinosos para o Estado. No caso de Augusto e Vespasiano, essa tarefa insere-se no programa de restauração da Urbe, depois das guerrras civis. Nota Suetónio que a principal preocupação de Augusto é o embelezamento e segurança da cidade (Aug. 28.3) e a elevação de várias obras arquitectónicas. Também Vespasiano é um restaurador, que, além da consolidação (stabilire) se preocupa com o ornare. Na perspectiva do adorno da cidade inclui Suetónio a construção de edifícios novos: o templo da paz, o do divino Cláudio e, a culminar, o amphitheatrum no centro da Urbe, com base numa pesquisa sobre um antigo projecto de Augusto. ${ }^{47}$ Também são aprovadas as construções grandiosas de Domiciano, entre as quais figura o templo da gens Flávia, ${ }^{48}$ se

na pacificação das fronteiras do Império: vide Cizek, E. 1982, 145-146; Griffin, M. T. 1984, 232-233; Fini, M. 1993, 73-78; Shotter, D. 1997,31-33.

${ }^{43}$ Nero 30.2; cf. Nero 13. Vide Baldwin, B. 1983, 273.

${ }^{44}$ Nero 12.4. Também Trimalquião (Petrónio, 29.8) guardava a sua primeira barba em uma pyxis aurea non pusilla.

${ }^{45}$ Nero 19.2. Suetónio refere o facto, sem explicar o interesse da obra nem o seu significado aos olhos de Nero: limita-se a fazer a reportagem jornalística, como se se tratasse de um ministro que vai colocar a primeira pedra de uma construção, como sublinha GAScou, J. 1984, 424-425.

${ }^{46}$ Ves. 8.5. Cf. Vit. 15.3 e Tácito, Hist. 3.71.4. Quanto à interpretação do gesto de Vespasiano como exemplar e encorajador, vide Keaveney, A. 1987, 213-216.

${ }^{47}$ Ves. 9.1. O argumento de que era um projecto de Augusto deve ter origem na propaganda flávia; vide com. de CESA, M. 2000, 78. Nota esta autora, com estranheza, que Suetónio não fala das vastas e grandiosas obras públicas fora de Roma. Mas o biógrafo centra-se na preocupação com stabilire e ornare a res publica (Ves. 8.1), no que concerne à deformis urbis (Ves. 8.5).

${ }^{48}$ Dom. 5. Suetónio, neste aspecto mais completo que os outros historiadores, deixa uma 
bem que, na parte negativa da vida, se diga que foram ruinosos os gastos com construções e espectáculos (Dom.12.1).

Quanto a Calígula, Suetónio termina a fase positiva da biografia com o elenco das construções feitas e projectadas. Mas, nos projectos apontados, parece sugerir-se uma tendência megalómana (Cal. 21). A coroar o elenco, figura o projecto de abertura do canal de Corinto, um sinal de mau augúrio, ao tempo de Suetónio, para quantos o tentaram. ${ }^{49}$

No que respeita a Nero, já referimos o começo aparatoso da perfuração do referido canal, projecto colocado na parte positiva da Vida (Nero 19.2). Muito mais negativa, porque dispendiosa, é a construção da famosa Domus aurea, com uma estátua colossal no vestíbulo, pórticos imensos, um lago central, campos cultivados e bosques, com requintadas salas de jantar, em que sobressaía a cenatio rotunda, cujo tecto simulava a abóbada celeste. É uma obra de arte à medida de Nero, a concretização arquitectónica da harmonia universal, da qual busca a perfeição através da música. A um músico culto não seriam alheios os conceitos pitagóricos. Depois de terminada a obra, Nero afirma que 'quasi hominem tandem habitare coepisse $e^{50}$ ("finalmente começava a habitar como uma pessoa'»). Mas, aos olhos do biógrafo, o mimetismo do universo presente na Domus Aurea é mais um sinal de megalomania, como o é também a construção de uma piscina desde o Miseno ao Averno, ou o canal navegável do Averno a Óstia, empreendimentos a que Nero deu início (Nero 31.3).

\subsection{Teatro e moralidade}

Uma das obrigações dos imperadores é a defesa da moral tradicional, função inerente ao estatuto de censor. Sobretudo depois de épocas de crise e perda de princípios, há que restabelecer a ordem moral e social, o que implica preservar a tradicional dignidade das classes elevadas e defender a cidadania romana de possíveis abusos.

Augusto empenha-se na moralização de costumes, corrompidos pela licentia das guerras civis (Aug. 32.1), através de uma reforma da justiça e

imagem de Domiciano grande construtor; vide Gascou, J. 1984, 668. Pelo contrário, o com. de Jones, B. W. 1996, 49-50, mostra que tanto Suetónio como outros autores são pouco generosos em relação à obra de Domiciano.

${ }^{49}$ Cf. Jul. 44.3; Nero 19.2. Vide intr. ao com. de Guastella, G. 1992, 52.

${ }^{50}$ Nero 31.2. Para Grimal, P. 1955, 15-20, estas palavras não são de desprezo pelas outras habitações, mas a expressão de um estoicismo místico. A casa com o colosso do imperador, representado sob o aspecto de Hélio, é a casa do Sol. Toda a descrição de Suetónio é a de um microcosmo. Na sua morada cósmica, Nero eleva-se à condição humana mais pura. Já para Campanille, D. 1990,186-191, e com. de Warmington, B. H. 1999, 57, não há razão para ver na cenatio rotunda referências cosmológicas e teológicas: Nero gosta deste tipo de engenhos. $\mathrm{Na}$ mesma linha, BLAIson, M. 1998, 617-624, sustenta que a cenatio rotunda se inscreve na tradição da arquitectura romana, de modo especial, a das salas de banquetes. Morford, M. P. O. 1968, 158-179, vê nas descrições da Domus Aurea (em Suetónio e Tácito, Ann. 15.42-43) distorções resultantes da retórica contra a luxuria e da acção dos opositores políticos de Nero, a classe senatorial. Blaison, M. 1998, 617-624, diz que se trata de um género literário com muitos paralelos na literatura: a ekphrasis de uma morada sumptuosa. 
da promulgação de leis para combater a sumptuosidade e o adultério e regulamentar o casamento (Aug. 34.1). Outra preocupação do príncipe é o rigor na atribuição do direito de cidadania, para não haver contaminação com sangue estrangeiro e servil. Neste particular, o biógrafo atribui ao imperador algumas reacções que parecem alardear um purismo exagerado, como a parcimónia ostensiva em conceder a cidadania. ${ }^{51}$ Também o esforço em revitalizar o trajo nacional fica patente na indignação que estadeia, quando vê, numa assembleia, muita gente vestida de negro: 'en Romanos, rerum dominos, gentemque togatam!'52 ("Ora vejam estes Romanos, senhores do universo, o povo vestido de toga!'»). Também Cláudio se preocupa com a dignidade das ordens sociais (Cl.24.1-2) e reprime a usurpação da cidadania romana (Cl. 25.3). Tibério usa de severa repressão para moralizar costumes degradados e defender a dignitas das classes senatorial e equestre, ameaçadas pela perversão sexual, pelos jogos cénicos e da arena e pelo desejo de lucro, pois os senadores deviam manter-se afastados de actividades comerciais (Tib.35). Para mostrar até onde ia a devassidão, Suetónio parece generalizar: fala no colectivo das feminae famosae que se declaravam prostitutas, para escaparem a sanções legais contra o adultério, quando este facto só terá acontecido com Vistília. ${ }^{33}$ Mesmo Calígula, ao chegar ao poder, desterrou de Roma os spintriae (homossexuais que exibiam posições eróticas requintadas, acolhidos na corte de Tibério em Cápreas: Tib.43.1), e até ameaçou lançá-los ao mar (Cal.16.1). Também Vespasiano se mostra um restaurador das ordens senatorial e equestre ${ }^{54}$ e se aplica a restaurar a moral, pois a libido e a luxuria tinham crescido sem peias (Ves. 11). Entre as inovações de Domiciano no campo dos costumes integra Suetónio (na parte positiva da $V i d a$ ) a proibição da castração e a contenção do preço dos eunucos, medida que Díon Cássio não vê com olhos tão benévolos. ${ }^{55}$ Também a condenação dos adultérios, que, em Suetónio, se subordina à correctio morum, figura em Díon em contexto negativo. ${ }^{56}$

${ }^{51}$ Aug. 40.3 : 'facilius se passurum fisco detrabi aliquid, quam ciuitatis Romanae unlgari honorem'. Segundo tompson, L. A. 1981, 35-46, tanto os critérios de Augusto como a interpretação do biógrafo não são racistas, mas culturais e morais. Opinião contrária tem GAscou, J. 1984, 744.

${ }_{52}$ Aug. 40.5. À parte o en introdutório, Augusto repete um verso de Virgílio, A. 1.282.

${ }^{53}$ Tib.35.2. Cf. Tácito, Ann. 2.85.2-3; vide Baldwin, B. 1983, 257.

${ }^{54}$ Ves. 9.2. A distinção entre as ordens faz-se com base na dignitas mais que na libertas. Vide Della Corte, F. 1967, 179-180.

${ }^{55}$ Dom.7.1. Díon Cássio, 67.2.3, integra a proibição da castração (referida entre os primeiros actos do príncipe) na polémica de Domiciano com Tito: visava insultar a memória do irmão, que tinha paixão por eunucos. Suetónio apresenta as ofensas ao irmão defunto em contexto diverso (Dom. 2.3). Para demonstrar a hipocrisia da lei imitida, Díon apresenta a paixão de Domiciano por Eárino, que Suetónio ignora (cf. Marcial, 9.11; 9.12; 9.13; 9.16; 9.17; 9.36; Estácio, Silv. 3.4). Vide Grelle, F. 1980, 340-345

${ }^{56}$ Dom. 8.3. Trata-se da restauração da lex Iulia de adulteriis, celebrada por Marcial, liv. vi dos epigramas: 6.2; 6.7; 6.22; 6.91. Segundo Díon Cássio, 67.12.1, Domiciano condenou muitos homens e mulheres por adultério, mas acrescenta-se que com algumas destas mulheres o próprio Domiciano tivera relações ilícitas. Vide Grelle, F. 1980, 345-346; com. de Jones, B. W. 1996, 75; com. de Jones, B. \& Milns, R. 2002, 141. 
No que se refere aos espectáculos, a preocupação de Augusto manifesta-se na regulamentação, ${ }^{57}$ através de criteriosa distribuição dos lugares por categorias sociais, idade, sexo, vestuário, proveniência, estado civil (Aug. 44). Aumenta os privilégios aos atletas, gladiadores e actores, sem diminuir a disciplina nas corridas e nos combates (Aug. 45.3-4). Tibério castiga certos jovens das duas classes superiores que procuravam que lhes impusessem uma pena de carácter infamante para não serem impedidos (por uma disposição do senado) de participarem nos jogos teatrais e circenses, actividades que lhes estavam vedadas desde o tempo de Augusto. ${ }^{58}$ Com Domiciano, os pantomimos, símbolos de licenciosidade, ficam confinados a palcos privados (Dom. 7.1); e um questor é expulso do senado por excessiva afeição aos pantomimos e à dança (Dom. 8.3). Ser actor, para Suetónio e para a mentalidade romana tradicional, significa degradação: não apenas social, mas sobretudo moral, pois facilmente se transpunha para a vida civil a licentia do palco, com o consequente quebrar das barreiras morais e sociais. Os actores estão frequentemente associados a diversos crimes, como a perturbação da paz pública (Cf. Nero 16.2 e 26.2) e a devassidão. $\mathrm{O}$ prestígio de que gozavam facilitava envolvimentos de natureza sexual com mulheres da alta-roda, crime que alguns pagaram com a vida. ${ }^{59}$ Para Suetónio, o bom princeps, como Augusto, castiga a licentia dos histriones (Aug. 45.4). Entre as boas medidas de Nero, figura a preocupação de pôr fim ao costume dos condutores de quadriga de andarem pela cidade a enganar e a roubar, por simples divertimento, bem como a expulsão da cidade dos pantomimos e das suas facções (Nero 16.2). Ora quando o governante se torna histrião, deve-se esperar o pior também dos restantes aspectos da governação. Muitas das determinações entram em conflito com a actuação do príncipe. No domínio sexual, a vida privada de alguns imperadores transforma-se numa paródia da sua própria legislação.

Outras virtudes, de cariz mais político, são salientadas como características do bom príncipe: a clemência (clementia), a modéstia (ciuilitas), a generosidade (liberalitas), a dedicação aos deuses, à pátria e aos familiares (pietas). Sobretudo os maus imperadores são acusados de ostentarem aquelas virtudes ou dissimularem os vícios, até ao momento em que tiram a máscara e se entregam abertamente ao vício.

\subsubsection{Ostentação de virtudes}

Enquanto patronos, os imperadores devem demonstrar superioridade moral. Suetónio, ao referir as virtudes dos Césares, ilustradas com diversas anedotas, procura deixar pistas ao leitor, de modo a sugerir sinceridade ou simulação. A questão reside na diferença entre o ser e o parecer. São apresentadas como genuínas as virtudes de César, que, colocadas no fim de

${ }^{57}$ Aug. 44.1: Spectandi confussissimum ac solutissimum morem correxit.

${ }^{58}$ Tib. 35.2. Cf. Aug. 43.3. Embora esta proibição fosse por vezes levantada.

${ }^{59}$ Páris foi morto por Domiciano por ser amado da esposa do imperador, e um discípulo daquele pantomimo teve o mesmo fim, só porque se assemelhava ao mestre (cf. Dom. $3.1 ; 10.1$ ). Vide Pimentel, M. C. 2001, 344-345. 
uma lista de traços de carácter e imeditamente antes do relato dos factos que levaram à morte, deixam uma imagem moderadamente positiva do ditador. São relatados exemplos extremos de dedicação e fidelidade aos amigos ( Jul. 71), afabilidade para com eles (Jul.72), prontidão a perdoar (Jul.73), suavidade na vingança (Jul.74), moderação e clemência para com os derrotados (Jul. 75). Mas a pública recusa e consagração a Júpiter Óptimo Máximo da coroa que António faz menção de lhe colocar na cabeça soa a um acto preparado para alardear ciuilitas, na mira de contrariar a suspeita corrente de que César desejava ser rei, ${ }^{60} \mathrm{em}$ contraste com a longa lista de actos e palavras com os quais ele próprio patenteia a ambição de poder absoluto: dominatio (Jul.76-79.2).

Os relatos sobre a clementia (Aug. 51) e a ciuilitas (Aug. 52-56) de Augusto contrastam de modo flagrante com o comportamento do jovem cruel. O leitor interroga-se se não será apenas uma máscara, ${ }^{61}$ mas o biógrafo prefere compor um processo de mudança. Aprova implicitamente a atitude, para nós teatral e suspeita, do imperador, caído de joelhos e com o peito desnudo, a suplicar ao povo que lhe não ofereça a ditadura (Aug. 52); a mostrar-se horrorizado com o título de dominus e a censurar por um edicto a saudação aplaudida 'O dominum aequum et bonum' (Aug. 53.1). Esta aclamação foi pronunciada durante um mimo; mais adiante se verificará que também Augusto representa o seu mimo da vida (Aug. 99.1). A exibição de liberalitas, ${ }^{62}$ que podia tornar teatral e insincera a atitude de Augusto para com as classes, perde o carácter negativo com a transcrição de vários ditos do próprio que reflectem uma maior preocupação com a salvação do Estado do que com a popularidade (Aug. 42.1).

No início do seu principado, Tibério dá mostras de querer evitar qualquer conexão com regimes autocráticos. ${ }^{63}$ Como exemplos de ciuilitas, Suetónio aponta a recusa de várias honras, como culto divino, a atribuição do seu nome ao mês de Setembro, o praenomen de imperator, o cognomen de Pater Patriae, a coroa cívica e até o nomen de Augusto, que lhe pertencia por herança ${ }^{64}$ A imagem de moderação é reforçada com a recusa da bajulação (Tib. 27) (exemplificada com uma anedota em que Tibério, para evitar que um cônsul lhe abraçasse os joelhos, cai de costas) ${ }^{65}$ com a renúncia explícita ao título de dominus e outras designações conotadas com autocracia (Tib. 27) e com

${ }^{60}$ Jul. 79.2. Vide Timonen, A. 1993, 133-148; Bell, A. 2004, 24 ss. Liberanome M. 1968 407-418, é de opinião que César pretendia assim conquistar o apoio dos moderados.

${ }^{61}$ Séneca, Cl. 3.7.1. e 9.1-2, não acredita nesta clemência. Vide Néraudau, J.-P. 1996, 17.

${ }^{62}$ Aug. 41.1: Liberalitatem omnibus per occasiones frequenter exhibuit.

${ }^{63}$ Tib. 26.1: Verum liberatus metu ciuilem admodum inter initia paulo minus quam priuatus egit.

${ }^{64}$ Tib. 26.2. Esta recusa é falsa, como mostra Levick, B. 1999a, 247-248 n. 11. Se tal nome não era usado em privado, pelo menos era usado publicamente através do Império e mesmo em Roma: vide SEAger, R. 1972, 143.

${ }^{65} \mathrm{Na}$ verdade, Suetónio dá uma cor favorável a uma anedota que, para Tácito, Ann. 1.13.4 e 6, reforça o carácter vingativo de Tibério. O biógrafo omite o nome do senador e as circunstâncias. Trata-se do senador Q. Hatério, que censura Tibério no senado pela sua hesitação e provoca a reacção violenta do príncipe; vide GAscou, J. 1984, 270 e 396-397. 
a defesa da liberdade de expressão e de pensamento (Tib. 28), a culminar na instauração de uma species libertatis, conseguida pela conservação dos antigos poderes dos magistrados e do senado. ${ }^{66}$ Neste estado de graça, Tibério não se ofende com resoluções contrárias ao seu parecer, ${ }^{67}$ dá ostensivas mostras de respeito para com os senadores (Tib. 31.2); e revela bom humor na resposta a ofensas pessoais (Tib. 32.2). Para provar que Tibério tem uma política provincial moderada, Suetónio, como habitualmente, generaliza. Aos governadores de província, que aconselham a aumentar os impostos, Tibério responde que 'boni pastoris esse tondere pecus, non deglubere' ("é missão do bom pastor tosquiar as ovelhas, não esfolá-las'»). De facto, tal resposta só terá sido dada ao prefeito do Egipto, Emílio Recto. ${ }^{68}$ Perante exemplos tão elevados no uso do poder, o leitor, confrontado com o anterior relato da farsa de Tibério na aceitação do poder imperial, duvida. Integrados na análise global do carácter, os exemplos de moderação servem para acentuar a hipocrisia, sobretudo quando, mais à frente, se percebe que o imperador é perito na dissimulação (Tib. 42.1).

Cláudio apresenta, no início, uma imagem bastante positiva pela sua pietas (Cl.11) e ciuilitas (Cl.12). Mas enquanto a primeira não é contestada, a segunda é duvidosa: se, em 12.1, Suetónio apresenta o imperador como ciuilis, em 35.1, passa a apresentá-lo como «o que se gaba de ser modesto» (iactator ciuilitatis). ${ }^{69}$

$\mathrm{Na}$ Vida de Calígula, o processo é mais marcado. $\mathrm{O}$ início deste principado é assinalado com uma série de actos que fomentavam a dedicação do povo: exibição da sua pietas, para com Tibério (no elogio fúnebre feito em copiosas lágrimas), para com a mãe e o irmão. Destes últimos, transladou as cinzas das ilhas em que morreram, mesmo quando o tempo estava mau, quo magis pietas emineret ("para que mais sobressaísse a sua devoção»): talvez ironia do biógrafo sobre a sinceridade de Calígula. Suetónio realça explicitamente a flagrante teatralidade dos actos (nec minore scaena) que decorrem até à deposição no mausoléu (Cal. 15.1). Esta pietas estende-se ainda ao pai, à avó Antónia, ao primo Tibério, e às irmãs (Cal. 15.2-3). A reabilitação dos condenados e a queima aparatosa dos processos relativos à mãe e aos irmãos são outros meios para aumentar a benevolência do povo:

Paripopularitate damnatos relegatosque restituit; criminum, si quae residua ex priore tempore manebant, omnium gratiam fecit; commentarios ad matris fratrumque suorum causas pertinentis, ne cui postmodum delatori aut testi maneret ullus

${ }^{66}$ Tib. 30. Cf. Tácito, Ann. 1.77.3; 4.6.2.

67 Tib. 31.1. Os exemplos apresentados mostram que se trata de assuntos de menor importância: vide Gascou, J. 1984, 737.

${ }^{68}$ Como afirma Díon Cássio 57.10.5; vide Baldwin, B. 1983, 256. Veleio Patérculo, 2.126.4, considera positiva a política provincial de Tibério. Opinião contestada por AlföLdY, G. 1965, 824-844. Segundo este autor, Tibério desenvolveu uma política provincial de vistas curtas em relação à nova ideia do Império: promoveu uma política colonialista de cariz republicano, voltada para a exploração, sem compensação através da concessão do direito de cidadania, em nítido retrocesso em relação ao que tinham feito César e Augusto.

${ }^{69}$ Vide Gascou, J. 1984, 368 e 701. 
metus, conuectos in forum, et ante clare obtestatus deos neque legisse neque attigisse quicquam, concremauit; libellum de salute sua oblatum non recepit contendens 'nibil sibi admissum cur cuiquam inuisus esset', negauitque se delatoribus aures habere. ${ }^{70}$

«Com igual demagogia reabilitou os condenados e os exilados. Agraciou todas a acusações, se algum resquício havia do período anterior. Aos documentos respeitantes aos processos da mãe e dos seus irmãos, para que, de futuro, em nenhum delator ou testemunha restasse qualquer receio, mandou-os juntar no Foro e, depois de tomar os deuses por testemunhas em como não tinha lido nem tocado nenhum deles, mandou-os queimar. A um escrito que lhe apresentaram sobre a sua segurança pessoal, não o aceitou, com o argumento de que 'não tinha feito nenhum mal para merecer o ódio de quem quer que fosse'; e disse que não prestava ouvidos a delatores».

Suetónio apresenta, nesta fase, um príncipe embriagado pela popularidade que procura mostrar, através de acções teatrais, que corresponde ao que dele esperam. Com esse fim, no que se refere aos tais processos, Suetónio conta os factos por metade. De facto, seguindo uma focalização idêntica à dos espectadores de tais actos, só mais tarde mostrará que tudo não passara de simulação. ${ }^{71}$ Suetónio, por agora, enfatiza a teatralidade da acção, não o aspecto fraudulento. ${ }^{72}$ Só o leitor mais atento poderá suspeitar, se não tiver já esquecido que Calígula tende para a dissimulatio. E quanto maior for a presente simpatia do leitor maior será depois a desilusão.

Segue-se nova enumeração de acções em favor de todas as ordens ( $\mathrm{Cal}$. 16). Mas as liberalidades são, na sua maioria, voltadas para o povo: para prolongar os festejos, até aumenta um dia às Saturnais (Cal. 17.2). O relato da parte positiva do principado de Calígula culmina com a referência aos jogos oferecidos (Cal.18), nos quais se inclui a novidade da ponte de Baias (Cal.19), de modo a sugerir o cuidado que Calígula coloca no espectáculo visual.

Actor por natureza, Nero revela virtudes demasiado espectaculares para serem sinceras. A suspeita de dissimulação vem logo à mente do leitor, e o próprio biógrafo a sugere. No momento de se referir à pietas, Suetónio fala de ostentatio, materializada no apparatissimus funeral de Cláudio. A senha optima mater, dada ao tribuno no primeiro dia do principado, e o facto de se mostrar em público a partilhar com Agripina a liteira, ${ }^{73}$ são factos agora apresentados

${ }^{70}$ Cal. 15.4. O libelo pode indicar que houve uma conspiração desconhecida no início do seu reinado, referida por Aurélio Victor, Caes. 3.8. Há um paralelo com Júlio César que recusa um libelo no dia em que foi morto (Jul.84.4); vide com. de HurLey, D. W. 1993, 42-43.

${ }^{71}$ Cf. Cal.30.2. Ao passo que Díon Cássio, 59.6.3, diz que Gaio queimou só cópias e refere utilizações posteriores (59.10.8 e 59.16.3). Cláudio queima-os de vez (60.4.5).

72 Vide com. de Wardle, D. 1994, 167.

${ }^{73}$ Nero 9. Sobre a ostentatio uirtutum, vide Croisille, J. M. 1970, 82-83. Segundo o com. de Bradley, K. R. 1978, 15-16 n. 14, a ostentatio neste contexto não é necessariamente negativa. Parece-nos que este autor não tem totalmente razão na crítica que faz a CROISILLE, porque nesta parte nem tudo é positivo: a ostentatio revela hipocrisia e pode ser comparada à dissimulatio, que se apresenta como característica negativa de Tibério e de Calígula. Assaz obsequente à letra da divisão que Suetónio estabelece em Nero 19.3, BRADLEY parece ignorar, de modo radical, os 
favoravelmente pelo biógrafo, para mais tarde serem desacreditados. Custa a aceitar que Nero desista da ideia de retirar as tropas na Britânia simplesmente para não insultar a glória do pai. ${ }^{74} \mathrm{Com}$ efeito, o biógrafo há-de referir o desrespeito do imperador para com a memória de Cláudio (Cl.33.1) e revelar o boato de que os passeios com Agripina na liteira incluíam prática incesto. ${ }^{75} \mathrm{E}$ assim desacreditada a pietas de Nero para com Cláudio e para com a mãe. ${ }^{76} \mathrm{De}$ forma semelhante, é considerada como alarde a afirmação de que vai governar segundo as prescrições de Augusto; ${ }^{77}$ e como exibição a forma de mostrar liberalitas, clementia e comitas, virtudes ilustradas com vários exemplos. ${ }^{78} \mathrm{~A}$ tendência para a ostentação de clementia é notória quando, ao ser solicitado para assinar uma execução, responde de forma teatral: 'Quam uellem,' inquit, 'nescire litteras $^{79}$ (“Como eu desejaria - exclamou - não saber escrever!”); e o facto de saudar gente de todas as ordens pelo nome e de cor constitui uma prova de comitas suspeita. Ao senado que lhe agradece responde: 'Cum meruero' ("Quando eu o tiver merecido’»), expressão que nos parece retirada do contexto de uma recusa de honras que lhe são oferecidas. Ainda como exibição de comitas se refere o facto de permitir à plebe a assistência aos seus treinos e declamações (Nero 10.2), de forma congruente com a sua busca de aplauso (Nero $11 \mathrm{ss}$ ).

Pelo contraste com a crueldade e cupidez posterior de Domiciano, caem sob a suspeita de dissimulação - arte que este imperador dominava (Dom.2.2) - os actos que o biógrafo apresenta como ocorridos no início do principado (inter initia). Diz-se que tinha tanto horror a todo o género de mortes, que, recordado de um verso de Virgílio, decidiu, na ausência do pai, promulgar um edicto a proibir a imolação de bois. ${ }^{80}$ Igualmente se salienta que, como cidadão

factos menos positivos que o biógrafo deixa transparecer nesta primeira parte.

${ }^{74}$ Nero 18. A decisão inicial de Nero devia-se provavelmente a problemas resultantes da revolta da rainha Boudica em 60-61 d.C. O abandono da ideia deve ter-se ficado a dever às repercussões negativas que sobre a opinião pública teria a retirada de uma província que os Romanos ambicionavam desde César. Mas várias são as teorias: vide com. de Bradley, K. R. 1978, 110-113; com. de Warmington, B. H. 1999, 45-46; De Filippis Cappai, C. 1992, 137-145. Há quem veja nesta referência de Suetónio às ideias não expansionistas de Nero e ao projecto de uma retirada da Britânia uma crítica a Adriano: vide Townend, G. B. 1959, 292.

75 Nero 28.2. Vide Lounsbury, R. C. 1991, 59. Tácito, Ann. 14.2, rejeita a versão de Fábio Rústico, seguida por Suetónio, e segue a versão de Clúvio Rufo, que diz que a iniciativa foi de Agripina, para manter o ascendente sobre o filho. Para o evitar, Séneca tratou de lhe contrapor Acte. Vide Verdière, R. 1975, 5-22; Martin, R. 1991, 145; Baldwin, B. 1983, 178. Gascou, J. 1984, 441-442 n. 207, lança a hipótese de o rumor ter surgido de uma graça de mau gosto de Nero sobre a semelhança de uma meretriz com Agripina.

${ }^{76}$ Vide Gascou, J. 1984, 370.

${ }^{77}$ Nero 10.1: Atque ut certiorem adhuc indolem ostenderet, ex Augusti praescripto imperaturum se professus.

${ }_{78}$ Neque liberalitatis neque clementiae, ne comitatis quidem exhibendae ullam occasionem omisit.

${ }^{79}$ Nero 10.2. Cf. Séneca, Cl.2.1.1-2.

${ }^{80}$ Dom. 9.1: 'impia quam caesis gens est epulata iuuencis'(Virgílio, G. 2.536). Scotт, K. 1934, 225-226, considera a hipótese de as razões de Domiciano não serem religiosas ou sentimentais, mas económicas: protegeria assim os depauperados rebanhos de Itália, até que recuperassem das perdas da guerra civil e evitaria mais abates devidos ao cumprimento dos numerosos votos feitos 
privado ou como imperador, não deu azo a suspeitas de cobiça (cupiditas) e avareza (auaritia), mas antes provas de abstinentia e até liberalitas. Destas virtudes se apresentam numerosos exemplos culminantes no castigo dos delatores, com a expressiva sentença: 'princeps qui delatores non castigat, irritat ${ }^{\text {'1 }}$ («o príncipe que não castiga os delatores, incentiva-os'»). O rosto ruborizado deste imperador sugere pudor (uerecundia), traço que ele procura usar em seu benefício. ${ }^{82}$

Pelo contrário, Vespasiano mostra-se autêntico: a clementia e a ciuilitas mantêm-se constantes do início ao fim do principado (Ves. 12). A ciuilitas revela-se em não dissimular a origem humilde (favoravelmente classificada como mediocritas pristina), mas até em ostentá-la, na troça que faz dos que lhe tentam propor uma árvore genealógica a entroncar nos fundadores de Reate e num companheiro de Hércules; ${ }^{83}$ no menosprezo do triunfo, no adiamento da aceitação da tribunicia potestas e do título de Pai da Pátria e na abolição do costume de revistar os que o vinham saudar pela manhã.$^{84} \mathrm{~A}$ clementia é demonstrada pela forma como suportava a libertas dos amigos, as alusões ambíguas ${ }^{85}$ dos advogados e a renitência (contumacia) dos filósofos. Para cada caso é aduzido um exemplo que evidencia a brandura (lenitas) do imperador. Num crescendo, o biógrafo demonstra ainda que Vespasiano não guarda rancor aos antigos inimigos, pois que até arranja um bom casamento para a filha do inimigo Vitélio ${ }^{86}$ e, a um dos oficiais de Nero que outrora o despachara de modo ofensivo, limita-se a responder da mesma forma; ${ }^{87}$ torna cônsul Métio Pompusiano, cujo horóscopo lhe prognosticava o império,

durante a guerra.

${ }^{81}$ Dom. 9.3. Enquanto Díon não indica elementos favoráveis e desenvolve a tradição do tirano, Suetónio pinta algo do homem real; vide Southern, P. 1997, 119.

82 Dom. 18.2: Commendari se uerecundia oris adeo sentiebat, ut apud senatum sic quondam iactauerit: 'usque adhoc certe et animum meum probastis et uultum'.

${ }^{83}$ Tal atitude contribui para o diferenciar de Galba (Cf. Gal. 2); mas também de Otão e de Vitélio (cf. Otho 1.1 e Vit.1.1).

${ }^{84}$ Medida já adoptada por Cláudio, enquanto iactator ciuilitatis (Cl. 35.1).

${ }^{85}$ Figurae significa, neste caso, artifícios literários. Pelo contrário, Domiciano condena Hermógenes de Tarso por usar umas certas figurae na sua historia (Dom. 10.1). Vide com. de Cesa, M. 2000, 83.

${ }^{86}$ Ves. 14. Gascou, J. 1984, 322, põe a hipótese de, na origem desta anedota, estar uma tentativa de evitar a impressão desfavorável que causaram as execuções (como a do próprio filho de Vitélio), levadas a cabo em Roma pelos partidários dos Flávios (cf. Tácito, Hist. 4.11 e 4.80), enquanto Vespasiano se encontrava ainda no Oriente.

${ }^{87}$ Mandara-o abire Morbouiam. Pelas fontes paralelas (Díon Cássio 63.10.1 a e 66.11.2 e Tácito, Ann. 16.5.3) se vê que a resposta do lacaio de Nero (Febo) se relaciona com uma ofensa a Nero na viagem à Grécia (Ves. 4.4). Gascou, J. 1984, 323-326, afirma que se trata de um só acontecimento (ao contrário do com. de Braithwaite, A. W. 1927, 30) e que as versões de Ves. 14 e de Díon, 66.11.2, resultam de uma recolha de ditos célebres de Vespasiano. O biógrafo omite neste passo as informações que já deu. O fraccionamento do mesmo episódio acaba por tornar difícil a identificação do incidente. Vide com. de CESA, M. 2000, 55. A vingança de Vespasiano lembra a de Tibério no tocante a um gramático de Rodes que o ofendera (Tib. 32.2). 
assegurando que assim ele se lembraria do benefício. ${ }^{88}$ Mas, a terminar a rubrica da clementia, evocam-se os sentimentos de Vespasiano, com um visível exagero. Fica a suspeita de representação teatral: ceterum neque caede cuiusquam umquam ‘...... iustis suppliciis inlacrimauit etiam et ingemuit ${ }^{89}$ («de resto nunca [se mostrava alegre] com a morte de quem quer que fosse e até nas execuções justas derramava lágrimas e suspirava»).

Para contrariar a fama da avareza, Vespasiano é apresentado como liberalissimus (Ves. 17). A sua generosidade abrange todos os grupos sociais, cidades devastadas por cataclismos, protecção às artes e aos ofícios, jogos (Ves. 17-19). O compromisso entre o fomento da inovação tecnológica e a preocupação social é bem patente numa anedota, segundo a qual, o imperador premiou o autor de um invento, que permitia levar, a baixo custo, grandes colunas para o Capitólio, mas se recusou a usá-lo porque, dizia, queria «alimentar o povinho». ${ }^{90} \mathrm{Na}$ mesma política social se insere o facto de dar banquetes sumptuosos para ajudar os fornecedores de comestíveis (Ves.19.1).A munificentia de Tito é visível na inauguração do Anfiteatro Flávio e das termas e nos espectáculos (Tit.7.3). A bondade inata deste imperador (Natura autem beniuolentissimus ${ }^{91}$ é ilustrada pela resposta à advertência de que prometia mais do que poderia dar: 'non oportere' ait 'quemquam a sermone principis tristem discedere' («não convém - explicava - que ninguém saia cabisbaixo da entrevista com o príncipe'») - uma frase que poderia ser usada, com efeito inverso, para sugerir um carácter irresponsável e perdulário - e pela memorabilis nox, num dia em que não concedera nenhum favor, 'amici, diem perdidi" ("Meus amigos, perdi o dia!'»). A comitas para com o povo é ilustrada com a afirmação, proferida durante um espectáculo de gladiadores, de que «dava o espectáculo não segundo o seu arbítrio, mas segundo o dos espectadores», e da forma como acedia aos pedidos e, sem perder a maiestas e a aequitas, trocava gracejos com o povo, devido à sua preferência pelos gladiadores trácios (Tit. 8.2).

Este teatro político é apresentado em Augusto, Vespasiano e Tito como expressão sincera de virtudes que em outros imperadores eram simuladas. Para o biógrafo estas qualidades fazem parte da essência dos bons imperadores e não se apresentam como meras exibições.

${ }^{88}$ Pelo contrário, Domiciano manda executá-lo (Dom. 10.3): cf. Díon Cássio, 67.12.2-4. GAscou, J. 1984, 326-328, aventa a hipótese de que tanto a actuação de Vespasiano como a de Domiciano viriam relatadas juntas em fontes posteriores à morte de Domiciano: Suetónio terá separado a parte que interessava a cada uma das Vidas.

${ }^{89}$ É geralmente aceite laetatus (omitido nos manuscritos mais antigos) para suprir a lacuna. Gascou, J. 1984, 332, suspeita que se trate da habitual generalização de Suetónio a partir do caso de Helvídio Prisco. De facto, Díon Cássio, 66.12, fala das lágrimas a propósito da prisão daquele filósofo.

${ }^{90}$ Ves. 18. (...) operam remisit praefatus sineret se plebiculam pascere’. Sobre a interpretação do passo, vide Casson, L. 1978, 43-50; Brunt, P. A. 1980, 81-100; Cesa, M. 2000, 90-91.

${ }^{91}$ Tit. 8.1. Não se trata já de aparências, mas de realidade: Vide GAscou, J. 1984, 431, n. 173. Enquanto o mau imperador dissimula virtudes, Tito prova que é essencialmente bom, como nota WARdLe, D. 2001, 65.

92 Tit. 8.2. Vide Della Corte, F. 1967, 151-152. 


\subsubsection{Os vícios como espectáculo}

Este subcapítulo constitui o reverso da medalha do exposto no anterior: detém-se sobre a fase em que os imperadores deixam de fingir. No momento de retirar a máscara, os vícios, abertamente assumidos, transformam-se por vezes em verdadeiros espectáculos encenados pelos imperadores. Então a desfaçatez ultrapassa todas as fronteiras. Quanto mais aparatoso for o imperador, mais exuberante será a encenação. Alguns relatos, pelos pormenores que incluem, aproximam-se de cenas de mimos, género realista, representado sem máscara. Muitas vezes, torna-se patente a distorção da realidade por parte do biógrafo, ou das suas fontes, de forma consonante com caracterização dominante do imperador em causa: os vícios documentados inscrevem-se no discurso tradicional contra a tirania. É difícil determinar se muitos dos relatos são decalcados de topoi retóricos ou se correspondem a verdadeiras tentativas de imitação de modelos helenísticos. A aspiração à realeza, que César procura dissimular (Jul. 79.2), é em Calígula descarada e espectacular. Em vez de se apresentar apenas como o primeiro dos cidadãos, coloca-se ostensivamente num patamar muito superior. A pretensão monárquica é expressa no grito

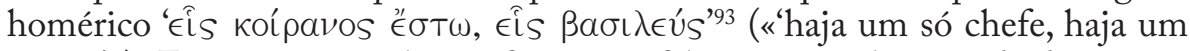
só rei!'»). E, acrescenta o biógrafo, pouco faltou para colocar o diadema, um tabu para os Romanos. Mas este imperador parece aspirar a uma monarquia teocrática, com usurpações de ritos orientais. Manda trazer da Grécia as estátuas mais veneradas dos deuses, entre elas a de Júpiter Olímpico, a famosa obra de Fídias, para lhes retirar a cabeça e substituí-la pela sua; transforma o templo de Castor e Pólux no vestíbulo do seu palácio e, colocado entre os Dioscuros, oferece-se à veneração dos que acorrem ao templo; e é invocado como Latiaris Iuppiter ${ }^{94}$ funda um templo ao seu numen, com sacerdotes e vítimas e uma estátua de ouro que todos os dias é vestida com roupa igual à do imperador. ${ }^{95}$ E, em noites de lua-cheia, Calígula convida a Lua para vir dormir com ele. ${ }^{96}$ Este passo de difícil interpretação ${ }^{97}$ parece sugerir uma assimilação a Pã, que seduz a Lua nas Geórgicas de Virgílio (3.392-393), o que está de acordo com o aspecto caprino, sublinhado no retrato físico deste imperador (Cal. 50.1).

${ }^{93}$ Cal. 22.1. As palavras são de Ulisses (Il. 2.204). Calígula abandona o modelo augustano e volta-se para o cesariano: vide com. Hurley, D. W. 1993, 85.

${ }^{94}$ Cal. 22.2. Os Dioscuros estão ligados ao culto de Ísis e Serápis e à dinastia dos Ptolemeus: vide BALsdon, J. P. 1964, 91-92.

${ }^{95}$ Cal. 22.2-3. Honras já oferecidas aos antecessores, mas que estes tinham recusado; cf. Aug. 52 e Tib. 26.1. Camus, Caligula III, 2, faz a exploração dramática destes dados: On ne comprend pas le destin et c'est pourquoi je me suis fait destin. J'ai pris le visage bête et incompréhensible des dieux. C'est cela que tes compagnons de tout à l'heure ont appris à adorer.

${ }^{96} \mathrm{Cal}$. 22.4; motivo que Camus encarece e repete, dando-lhe o valor simbólico do impossível a que Calígula aspira. Vide Strauss, W. A. 1951, 165; Gillis, J. 1974, 401.

${ }^{97}$ Várias são as tentativas de explicação. Talvez se trate de um rito (mal interpretado por fontes hostis), ligado ao culto de Ísis; vide Ceausescu, P. 1973, 277. Ísis aparece associada à lua em Apuleio, Met. 11.3-6. Calígula, nas suas aspirações a uma monarquia teocrática de tipo egípcio, poderia estar a identificar-se com Osíris. Vide Martin, R. 1991, 331-332; com. de WARdLE, D. 1994, 214-215. 
Mas a gradação continua. Calígula chega mesmo a conversar com Júpiter e a

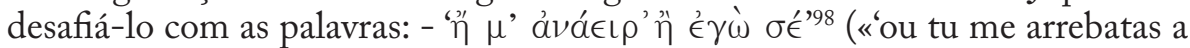
mim ou eu a ti!'»); ou a dizer que o deus o convida para o seu contubernium, palavras que denunciam hybris. E o fim de Calígula será relacionado com uma vingança deste deus. Também na descrição das roupas, Suetónio salienta a inciuilitas, ${ }^{99} \mathrm{sem}$ apontar o contexto em que os adornos referidos foram usados. $\mathrm{O}$ travestismo denota a versatilidade das facetas que o imperador assumia, entre a tendência orientalizante e o seu comportamento teatral. Faz-se alusão a roupas efeminadas; sandálias gregas (crepidae); ${ }^{100}$ calçado dos reis helenísticos e do actor trágico (coturnus); calçado dos correios militares e talvez de Hércules (speculatoria caliga); calçado de mulher e dos actores cómicos (soccus muliebris); roupas triunfais e até a couraça de Alexandre Magno, que faz suspeitar de um desejo de emulação; ${ }^{101}$ atributos divinos: barba de ouro, raio, tridente, caduceu; ${ }^{102}$ ou roupas de Vénus.

O filho mais novo de Vespasiano, também vai denunciar a inciuilitas com actos ostensivamente arrogantes: mostra indignação por o genro do irmão ter servidores vestidos de branco (cor da túnica dos servos imperiais) e expressa a desaprovação através de um verso homérico. ${ }^{103} \mathrm{~A}$ jactância torna-se intolerável: depois de se tornar imperador, dizia que tinha dado o império ao pai e ao irmão e que estes lho devolveram (Dom. 13.1). Reclama a majestade divina ao dizer que recebeu de novo a mulher no leito sagrado (puluinar). Se para um romano já é grave que aceite o tratamento de dominus, como aconteceu certa vez no anfiteatro, ${ }^{104}$ mais arrogante se torna por se atribuir, ao ditar uma carta, o título de dominus et deus, inaugurando o hábito de assim o apelidarem oficialmente. ${ }^{105}$ Domiciano manifesta total falta de moderação também pelo facto de consentir que lhe erigissem estátuas no Capitólio somente em ouro e prata e de um peso determinado; pelo exagero no número de consulados (dezassete); por, depois

${ }^{98}$ Cal. 22.4. Trata-se de uma expressão homérica, Il. 23.724: palavras de desafio que Ájax dirige Ulisses durante a luta. Séneca, Dial. 3.20.8, diz que Gaio respondia assim aos trovões que interrompiam um espectáculo de um pantomimo. Díon Cássio, 59.28.6, apresenta uma reacção mais teatral em que Calígula responde ao Tonante produzindo ele próprio o som do trovão com um aparelho (mechane) usado para o efeito.

${ }_{99} \mathrm{Cal}$. 52: Vestitu calciatuque et cetero habitu neque patrio neque ciuili, ac ne uirili quidem ac denique humano semper usus est.

${ }^{100} \mathrm{O}$ tipo de calçado que Tibério usava em Rodes; Tib 13.1.

101 Por Díon Cássio, 59.17.3, sabemos que usou a couraça de Alexandre na travessia da ponte de Baias. Sobre o vestuário deste imperador, vide os coms. de WARDLE, D. 1994, 336-341; Hurley, D. W. 1993, 186-189; Guastella, G. 1992, 272-273.

${ }^{102}$ A barba de ouro era atributo dos deuses: cf. Cícero, N.D. 3.83; Varrão, R. 1.1.4. Já Augusto se mascarara de Apolo (Aug. 70). Calígula persiste onde Augusto hesitou: vide com. de WardLE, D. 1994,340 .

${ }^{103}$ Il. 2.204. Trata-se da primeira parte do verso já referido em Cal. 22.1. Vide Berthet, J. F. $1978,325$.

${ }^{104}$ Dom. 13.1. Augusto e Tibério recusaram o título de dominus; cf. Aug. 53.1 e Tib. 27.

105 Dom. 13.2. Díon Cássio, 67.13.3-4, conta o caso de Juvêncio Celso que, acusado de conspiração, salva a vida por tratar Domiciano por senhor e deus. Par arrogantia é aproximada do multo arrogantius factum que qualifica as aspirações monárquicas de César: Jul. 79.1. Vide Gascou, J. 1984, 724 n.41. 
de adoptar o cognome de Germânico, dar este nome ao mês de Setembro e o de Domiciano ao de Outubro (Dom. 13.2-3).

O certo é que estes três Césares, Júlio César, Calígula e Domiciano tem um final sangrento semelhante. No primeiro e no último os actos de arrogância aparecem associados, pela proximidade, ao relato da morte. Na Vida de Calígula, estes relatos dão início à descrição do monstrum, por oposição ao princeps.

A crueldade é o traço mais marcante dos tiranos. Políbio (7.7) diz que alguns autores descreveram em termos trágicos a crueldade e impiedade de Jerónimo, tirano de Siracusa. Ao exemplificar a crueldade atroz de alguns imperadores, o biógrafo introduz várias cenas de horror. O carácter espectacular de algumas execuções visa certamente acentuar o exemplo para demover futuros prevaricadores. No cúmulo das crueldades de Octávio durante o triunvirato, Suetónio apresenta a morte do pretor Quinto Gálio. Há algo de trágico nesta morte, resultante de um erro de juízo de Augusto que, na sequência de uma suspeita infundada de atentado, incapaz de reconhecer o erro, mandou matar o magistrado, depois de lhe ter arrancado os olhos com as próprias mãos (Aug. 27.4). Se episódios deste género pertencem a uma fase inicial da Vida de Augusto, em outros imperadores aparecem mais tarde, sobretudo quando o mal reside na natura. A crueldade é inerente à natureza de Tibério: apesar de a tentar dissimular, a natureza cruel (saeua ac lenta natura), latente a princípio (Tib. 57.1), acaba por se manifestar, acompanhada de um humor negro (Tib. 57.2) que pode ter sido a causa da atribuição de tantas atrocidades a este imperador.

Ao falar dos espectáculos dados por Calígula fora de Roma, Suetónio transmite uma anedota sobre o original concurso de eloquência greco-latina, em Lugduno, em que os vencidos são obrigados a premiar os vencedores e a comporem o elogio destes. Os que obtêm piores resultados são obrigados a apagar os seus escritos com uma esponja ou com a língua, se não querem levar palmatoadas ou serem lançados ao rio. ${ }^{106} \mathrm{~A}$ presença da palmatória e do apagador sugere a paródia de uma lição escolar. Este episódio é ainda relatado na parte positiva da biografia, mas revela-se já consonante com a natureza cruel e histriónica do imperador. ${ }^{107}$ Calígula, como mais tarde Nero, tende a associar a crueldade ao seu pendor para o espectáculo. Nero começa por praticar os vícios de forma discreta, mas ninguém nega que se trata de naturae uitia ${ }^{108}$ quando ele, à noite, envergava um pileus $^{109}$ ou uma cabeleira para se

106 Cal. 20; Camus, Caligula IV,12, aproveita, de modo original, esta anedota: transforma o concurso de eloquência num concurso de poesia e dá-lhe considerável desenvolvimento dramático, escolhendo para tema do concurso "a morte". Vide Strauss, W. A. 1951, 165; Gillis, J. 1974, 398; intr. ao com. de Guastella, G. 1992, 53-54.

${ }^{107}$ Cal. 11: Naturam tamen saeuam atque probrosam ne tunc quidam inbibere poterat. Na natura probrosa se incluem as scaenicae saltandi canendi artes (mencionadas a seguir) desonrosas para um cidadão romano. A mesma distinção se opera na Vida de Nero (19.3), entre probra (actos desonrosos, à cabeça dos quais figuram as actividades cénicas) e scelera (os crimes).

${ }^{108}$ Nero 26.1: Sed ut tunc quoque dubium nemini foret naturae illa uitia, non aetatis.

${ }^{109}$ Nero 26.1. Cf. Tácito, Ann. 13.25.1. O pileus ou pileum era o barrete dos sálios, dos escravos libertos e usava-se nas Saturnais: era um sinal de alegria; vide Mastellone, E. 1990, 365-374. 
divertir a atacar as pessoas e a destruir e pilhar as lojas, com sérios riscos para si próprio. ${ }^{110}$ É ainda secretamente que se faz transportar ao teatro, para aí fomentar desordens, provocando confrontos entre as facções dos pantomimos e participando nas acções de violência dos espectadores. ${ }^{111}$

No requinte das torturas se manifesta o humor negro dos tiranos, de que é exemplo o facto de Tibério (post longa et exquisita tormenta) fazer precipitar os condenados do alto de um rochedo em Cápreas (local que se tornou turístico, como mostra o biógrafo), ou a invenção de um novo tipo de suplício, que consistia em mandar ligar os órgãos genitais das vítimas depois de as ter feito beber grande quantidade de vinho. ${ }^{112} \mathrm{~A}$ anedota do pescador de Cápreas é reveladora da crueldade associada ao medo: o esforçado homem, depois de subir as altíssimas escarpas para oferecer a Tibério o melhor peixe que pescara ${ }^{113}$, é fustigado na cara com a dádiva e também com uma lagosta enorme que tinha capturado, por ter demonstrado a forma de chegar junto do tirano.

Os espectáculos punitivos são muito do agrado de Calígula. É significativa a referência ao hábito de, durante banquetes, assistir à tortura ou à decapitação de condenados (Cal. 32.1); ou ao facto de só se dar por satisfeito ao ver os membros e as entranhas de um senador depostos a seus pés. ${ }^{114}$ Como prova do grau da crueldade de Gaio é narrado o facto de obrigar os próprios pais a assistirem à morte dos filhos ou de mandar cortar a língua a um cavaleiro para que, lançado às feras, não proclamasse a sua inocência. ${ }^{115}$ Este imperador transforma alguns actos repressivos numa espécie de sacrifício ritual. Obriga o fulano que prometera combater na arena pela saúde do imperador ao cumprimento do voto e faz questão de assistir ao combate - talvez uma forma de dissuadir votos bajulatórios e ímpios. Outro, que oferecera a vida, será ataviado como as vítimas dos sacrifícios, conduzido pelas ruas e lançado do alto das antigas muralhas (agger). ${ }^{116}$ Uma condenação semelhante, mas

As deambulações nocturnas de Lúcio Vero (HA, Verus, 4.4-6) são comparadas às de Calígula, Nero e Vitélio.

${ }^{110}$ Nero 26.2. Um senador agride Nero violentamente, por este lhe ter agarrado a esposa, e deixa-o em estado crítico. O senador é Júlio Montano, segundo informa, sem referir a esposa, Tácito, Ann.13.25.2. Este autor não diz que Nero ficou prope ad necem caesus, mas antes que o senador foi coagido a suicidar-se.

${ }^{111}$ Nero 26.2. Suetónio divide esta anedota: em 16.2 referira a medida positiva da expulsão das facções dos pantomimos. Cf. Tácito, Ann. 13.25.4. O historiador diz que Nero assiste às desordens, que ele próprio incentiva, mas não refere a sua participação activa nas rixas.

112 Tib. 62.2: Carnificinae eius ostenditur locus Capreis. Também Domiciano inventa um tipo de tortura que consistia em chegar fogo aos órgãos sexuais (Dom. 10.5).

${ }^{113}$ Tib. 60. Tratava-se de um enorme mullus. Sobre a predilecção de Tibério por este peixe, vide com. de Lindsay, H., 1995, 125. De resto, era um peixe apreciado nos banquetes requintados, como se vê em Marcial, 2.37.4; 2.40.4; 2.44 .9 etc. Mas há quem veja no episódio reflexo de uma guerra astrológica em que os Peixes são humilhados pelo Escorpião, signo de Tibério: Vide Dupont, F. et Eloi, T. 2001, 307-308.

${ }_{114}$ Cal. 28. Trata-se provavelmente de Escribónio Próculo identificado em Díon Cássio, 59.26.2: Suetónio conclui com detalhes de horror ausentes de Díon; vide com. de Wardee, D. 1994, 252.

${ }^{115}$ Cal. 27.4. Factos que Camus aproveitará e amplificará em Caligula II,.5 e II,12.

116 Cal. 27.2; cf. Cal. 14.2. Segundo Néraudau, J. P. 1988, 324-341, e Veyne, P. 1983, 
atribuída à inveja de Calígula, é o ritual que envolve a morte do Colósseros, assim chamado pela sua imponência e pela sua beleza. ${ }^{117} \mathrm{~A}$ ideia de substituir o animal por um humano aparece expressa na anedota, pouco credível para nós, de que, certa vez, imolou o sacrificador em vez da vítima. ${ }^{118}$ Quando descrevera a construção da ponte de Baias, Suetónio só falara do espectáculo apoteótico; mas, na parte em que descreve o monstro, diz que mandou precipitar no mar uma multidão que estava na margem. ${ }^{119}$ Este imperador parece tirar um prazer especial em castigar as pessoas, lançando-as ao rio: além deste passo, o castigo dos vencidos do concurso de Lugduno (Cal.20) e uma reacção colérica contra o tio Cláudio, como se lê na Vida deste imperador (Cl.9.1).

$\mathrm{Na}$ Vida de Nero, o aparecimento de um cometa é apresentado como causa última de uma chacina. Como, segundo o astrólogo Balbilo, era costume os reis imolarem uma vítima ilustre, para desviarem sobre outrem o presságio funesto, Nero projecta a morte de todos os mais nobres cidadãos. O exagero do biógrafo parece evidente. As duas conjuras, a de Pisão ${ }^{120}$ e de Vinício, não são, em si, a razão das mortes, mas dão-lhes aparência de legalidade (quasi per iustam causam). As mortes dos conjurados são, assim, transformadas por Suetónio em sacrifícios expiatórios realizados por Nero. Entre os condenados, diz o biógrafo, o feito é considerado heróico e justo: Nonnulli etiam imputarent, tamquam 'aliter illi non possent nisi morte succurrere dedecorato flagitiis omnibus' («não faltava quem considerasse o acto meritório, como se 'lhe não pudessem prestar outro socorro senão com a morte a quem como ele estava desonrado por todas as ignomínias'»), numa provável alusão, pelo paralelo com outras fontes, ao efeito das actividades histriónicas de Nero. ${ }^{121} \mathrm{E}$ o episódio é encerrado

18-25, todo o ritual que envolve esta morte (trata-se, segundo Díon Cássio, 59.8.3, de P. Afrânio Potito), bem como o vocabulário técnico que a descreve, parece denotar a restauração de um rito de expulsão arcaico, que indicia uma concepção de monarquia sacra por parte de Calígula. Vide Lugand R. 1930, 9-10. Camus aproveita estes votos (Caligula IV. 8), com a diferença de que não coloca a morte em cena.Vide interpretação psicanalítica de LucAs, J.1967,173-174. ANTONELLI, G 2001, 110, põe em dúvida o real derramamento de sangue no final da encenação.

117 Cal. 35.2. Tratar-se-ia de um antigo ritual de justiça colectiva restaurado por Calígula; vide Veyne, P. 1983, 18-25. Nesta perspectiva folclorista se pode também entender o facto, relatado a seguir por Suetónio (Cal.35.3), sobre a intervenção abusiva de Calígula no caso do rex nemorensis, um sacerdote de Diana cuja sucessão estava ligada a um rito arcaico: o sucessor (um escravo fugitivo) devia matar o actual rex. O interesse de Calígula, segundo BERnARdi, A. 1953, 273-287, pode enquadrar-se na obra de repristinação e de restauro dos ritos e da religião antiga, como fundamento para a monarquia teocrática que subjaz ao seu programa de governo.

118 Cal. 32.3. Segundo Lucas, J. 1967, 184, como em Calígula existe um "mélange" indiferenciado do consciente e do inconsciente, uma fantasia franqueou sem entraves a barreira do inconsciente e realizou-se.

${ }^{119}$ Cal. 32.1; cf.Cal. 19. VEYNe, P. 1983, 18-19, integra o facto na restauração de tradições de um passado rude, pois Calígula era um folclorista. Antonelli, G. 2001, 124, pensa que seriam apenas brincadeiras de hóspedes mais atrevidos e os afogamentos seriam exagero dos autores antigos.

${ }^{120}$ Nero 36.1. Suetónio é extremamente breve ao referir a conspiração de Pisão, em contraste com o longo relato de Tácito, Ann. 15.48-74. Vide Baldwin, B. 1983, 178.

${ }^{121}$ Nero 36.2: Ao dizer nonnulli etiam imputarent, Suetónio estará, como habitualmente, a generalizar: aquelas palavras, segundo Tácito, Ann. 15.68.1, foram pronunciadas somente por 
com uma crueldade, ainda mais revoltante, por envolver a morte de inocentes: Damnatorum liberi urbe pulsi enectique ueneno aut fame; constat quosdam cum paedagogis et capsaris uno prandio pariter necatos, alios diurnum uictum probibitos quaerere («Quanto aos filhos dos condenados, foram expulsos da Urbe e mortos com veneno ou à fome. Consta que alguns foram mortos, durante um almoço, juntamente com os pedagogos e os escravos porta-livros; outros foram proibidos de procurar a alimentação diária»). Suetónio, como é seu hábito, apresenta acontecimentos histórico-políticos à luz da caracterização global da personagem: neste caso, o carácter histriónico, cruel e supersticioso de Nero. A tendência de Nero para transformar a crueldade em espectáculo manifesta-se também no facto de correr o boato de que quereria dar homens vivos a comer a um polyphagus egípcio, habituado a comer de tudo o que se lhe dava. ${ }^{122}$

A impietas da crueldade contra os familiares resulta em verdadeiros argumentos de tragédia. No caso de Tibério, o brutal tratamento dado à viúva de Germânico - desterrada, com um olho arrancado ${ }^{123}$ e em greve de fome termina com a lembrança do humor negro do Imperador, a que Suetónio junta os seus comentários irónicos sobre a especial clemência do imperador por não a ter estrangulado e lançado às Gemónias (Tib. 53.2). Semelhante desenlace tem a vida dos filhos da condenada: Nero forçado ao suicídio e Druso a tentar, com a fome, devorar o seu próprio colchão. Os restos mortais de ambos são tão dispersos que a custo podem ser reunidos: ${ }^{124}$ uma vaga associação a Medeia a disjuntar os membros do irmão, se considerarmos que Tibério é um especialista em lendas. ${ }^{125} \mathrm{O}$ rumor, que o biógrafo assume como verosímil (nec abhorret a uero), de que queria eliminar todos os descendentes, é comprovado através da inversão de um modelo épico da autoria do imperador: namque identidem 'felicem Priamum' uocabat, 'quod superstes omnium suorum extitisset' («com efeito, repetidas vezes dizia que 'Príamo era feliz, porque tinha sobrevivido a todos os seus'»). ${ }^{126}$

As acções de Calígula monstrum (Cal.22.1 ss) viram-se, como no caso de Tibério, contra os seus próprios familiares, os que deviam ser objecto da sua devoção ou protecção. Nesta fase se encontram relatos que desmentem a pietas, anteriormente alardeada. Calígula nega que fosse neto de Agripa, por este ser de origem humilde: prefere afirmar que Agripina (a esposa de Germânico)

Sulpício Áspero. Díon Cássio, 62.24.2, diz que outro conjurado, Súbrio Flavo, acrescenta que não podia ser escravo de um citaredo e de um auriga.

${ }^{122}$ Nero 37.2. Littman, R. J. 1976, 369, sugere que polyphagus seja um hapax legomenon e que, em latim, designa 'crocodilo'. Tal hipótese é contestada por Baldwin, B. 1977, 406-409. Segundo este autor, há várias referências ao termo, uma delas, do cronógrafo do ano 354, que, na entrada 'Nero', se refere a um glutão humano e indica o nome: Arpocras. Poderia tratar-se de uma espécie de artista de circo.

${ }^{123}$ Notícia que só se encontra em Suetónio.

${ }^{124}$ Tib. 54.2. Suetónio omite o papel pérfido de Sejano apontado por Tácito, Ann. 4.59 ss.

${ }^{125} \mathrm{Cf}$. Tib. 70.3: Maxime tamen curauit notitiam historiae fabularis usque ad ineptias atque derisum.

${ }^{126}$ Tib. 62.3. É a inversão jocosa de uma máxima famosa de Calímaco (presente em Cícero, Tusc. 1.93), segundo a qual a longa vida de Príamo o torna infeliz, porque chora muitas mais desventuras do que quem morre jovem; vide LA Penna, A. 1987, 181-185. 
nasceu do incesto de Augusto com a filha Júlia. ${ }^{127}$ A ofensa a Augusto aumenta com a proibição de festejar as vitórias de Áccio e da Sicília. ${ }^{128}$ Nega também a nobreza da linhagem de Lívia ${ }^{129}$ e trata com desprezo a avó Antónia; corre o rumor de que a envenena e não lhe presta honras nem depois de morta (Cal. 23.2). A negação do tributo aos mortos é impiedade própria dos tiranos trágicos.

A longa narração da morte de Agripina é espectacular pelo significado do matricídio, pelos meios usados, pela dissimulação de Nero, pelo contraste entre expressões de crueldade e de afecto (Nero 34) e pela inevitável associação a modelos mitológicos. Depois da degradação no relacionamento entre mãe e filho, vem a decisão de a matar. Falhadas as três tentativas com veneno, os atentados passam a ser mais engenhosos e teatrais: um mecanismo (machina) que faria abater sobre ela o tecto do quarto e um barco preparado, em que ela morreria ou pelo desabamento do camarote ou pelo naufrágio.

Atque ita reconciliatione simulata iucundissimis litteris Baias euocauit ad sollemnia Quinquatruum simul celebranda; datoque negotio trierarchis, qui liburnicam qua aduecta erat uelut fortuito concursu confringerent, protraxit conuinium repetentique Baulos in locum corrupti nanigii macbinosum illud optulit, bilare prosecutus atque in digressu papillas quoque exosculatus reliquum temporis cum magna trepidatione uigilauit opperiens coeptorum exitum. Sed ut diuersa omnia nandoque euasisse eam comperit, inops consilii L. Agermum libertum eius saluam et incolumem cum gaudio nuntiantem, abiecto clam iuxta pugione ut percussorem sibi subornatum arripi constringique iussit, matrem occidi, quasi deprehensum crimen uoluntaria morte uitasset. ${ }^{130}$

«E, simulando assim uma reconciliação, convidou-a para Baias, com uma carta cheia de afecto, para vir celebrar juntamente com ele as Quinquátrias. Tinha dado previamente aos capitães o encargo de abalroarem, como que por choque fortuito, a trirreme libúrnica na qual ela tinha sido para ali transportada. Prolongou o banquete e, para ela regressar a Baulos, ofereceu-1he o navio do truque em substituição do estragado. Acompanhou-a alegremente e, à despedida,

${ }^{127}$ Cal.23.1. Os testemunhos epigráficos parecem desmentir a informação de Suetónio. Vide Rosborough, R. R. 1920, 25-26 e 36. De qualquer modo, não pode concluir-se forçosamente que Suetónio minta: uma coisa são as inscrições oficiais, outra as observações pessoais. O incesto é tolerado no quadro de uma realeza de tipo oriental a que Calígula, segundo alguns críticos, aspiraria, como veremos a propósito de Drusila.

${ }^{128}$ Segundo Lambrechts, P. 1953, 219-232, Calígula tem uma política oposta a Augusto. Gaio acompanhara o pai ao Oriente e fora educado pela avó Antónia, filha do triúnviro: é natural que realce a descendência de António e siga a sua ideologia egipcizante. Segundo Colın, J. 1954, 394-416, a herança de Germânico, a má recordação de Áccio, e a relação com o culto de Ísis condicionam a escolha dos cônsules do "césar-pharaon Caligula".

${ }^{129}$ Segundo Suetónio, Calígula diz que Lívia é descendente de um decurião de Fundos. Como prova da injustiça, o biógrafo afirma que documentos públicos deixam claro que Aufídio Lurcão desempenhou importantes cargos em Roma. As inscrições provam que Suetónio se enganou: Lívia era neta de M. Alfídio e não de Aufídio Lurcão. Vide Rosborough, R. R. 1920, 36-37; Liderski, J. 1974, 463-480; Barret, A. A. 1989 (2000), 219.

${ }^{130}$ Nero 34.2-3. Vide Lounsbury, R. C. 1991, 3768-3770. 
até lhe beijou os seios. O resto do tempo ficou acordado em grande agitação, a aguardar o resultado do plano. Mas quando descobriu que tudo correra de forma diferente e que ela se salvara a nado, na falta de outro plano, lançou, de forma dissimulada, um punhal para junto de L. Agermo, liberto dela, que lhe vinha anunciar alegremente que ela estava salva e incólume; e, como se o mensageiro tivesse sido subornado para o matar, mandou detê-lo e agrilhoá-lo e à mãe mandou matá-la, como se ela, perante a descoberta do crime, evitasse a acusação com a morte voluntária».

O carácter artístico de Nero aparece associado ao carácter criminoso. ${ }^{131}$ Ao estratagema do barco preparado, junta-se agora o truque para acusar e prender o mensageiro que (julgava o infeliz) iria trazer boas notícias. Se já é ímpio prender um arauto, é impensável atacar o que traz boas notícias. Se aceitarmos a versão papillas quoque exosculatus, ${ }^{132}$ Suetónio faz uma amálgama de dois crimes em relação à mãe, um explícito e outro sugerido: o matricídio e o incesto, ambos largamente explorados pela tradição trágica. Parece haver uma assimilação dos crimes de Nero a modelos mitológicos que ele próprio incarnava no palco. Nero assumia, entre outros, os papéis de Orestes matricida e o de Édipo cego. O biógrafo acentua a suspeita de incesto ao acrescentar, de imediato, factos que declara mais atrozes: que Nero acorreu a contemplar o cadáver da mãe, que palpou os membros, censurou uns, louvou outros e, como entretanto sentiu sede, bebeu. ${ }^{133}$ Há uma preocupação de acentuar ao máximo a impietas do ultraje ao corpo de Agripina até atingir os limites do suportável, pelo despudor e insensibilidade de Nero, que nem se coíbe de beber, acto

${ }^{131} \mathrm{O}$ termo machina que designa o expediente (depois não usado) para o desabamento do tecto do quarto e machinosum referido ao nauigium destinado a naufragar pertencem ao universo do teatro; machinamentum em Tácito, Ann. 14.6.1. Vide Foucher, A. 2000, 793-794. Díon Cássio, 61.12.2, refere que Nero teve esta ideia a partir de um barco que viu no teatro; e Tácito, Ann. 14.7.6 diz explicitamente que Nero, ao saber que o mensageiro Agermo se aproximava, ipse... scaenam ultro criminis parat. Vide Frazer R. M. 1966, 17-20.

${ }^{132}$ Verdière, R. 1960, 774-776, propõe a correcção de papillas por pupillas, a partir do confronto com oculi de Tácito, Ann. 14.4.4, e com ő $\mu \mu a \tau a$ de Díon Cássio, 61.13.2: pelo que o beijo de Nero seria apenas um beijo filial, vide ID. 1975, 14. Tal emenda é contestada por Benediktson, D. Th. 1992, 161-163, que, procurando reconstituir a fonte seguida pelos três autores, provavelmente Clúvio Rufo (Tácito diz oculis et pectori haerens; e Díon, фı

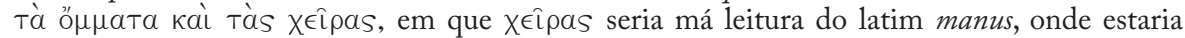
mammas), conclui que Suetónio reteve somente o pormenor que despertou a sua atenção. Lounsbury, R. C. 1991, 3760, coloca exosculatus, com que Suetónio termina o período, em paralelo com exosculans (Nero 28.2), caracterizador do comportamento de Nero para com Esporo.

${ }^{133}$ Nero 34.4. Tácito não é tão assertivo, como se pode ler em Ann. 14.9.1: Aspexeritne matrem exanimem Nero et formam corporis eius laudauerit, sunt qui tradiderint, sunt qui abnuant. Em Díon 61.14.2, Nero, depois de mandar desnudar o cadáver e observar as feridas, diz que não sabia que a mãe era tão bela. Vide Verdière, R. 1975, 13. Para Baldwin, B. 1979, 380-381, este passo denota os gostos histriónicos de Nero: o toque nos membros de um corpo real seria uma inversão da cena de Agave e Penteu nas Bacchae de Eurípides. Acresce que Díon, 61.20.2, diz que, depois da morte da mãe, Nero faz a sua estreia no palco com a peça Atthis ou as Bacchae. Vide Martin, R. 1991,264. Bartsch, S. 1994, 61-62, contesta a teoria de Baldwin e conclui que os papéis de Nero provocaram nas fontes um efeito retroactivo sobre a sua vida. 
que, mais do que uma vez, causa a repulsa de Suetónio. ${ }^{134} \mathrm{Na}$ explanação da crudelitas, Nero parece ser também assimilado a Hércules furioso, assassinando os que lhe estão próximos. Quanto à morte das esposas: Octávia é acusada impiamente de adultério, contra o testemunho de todos; ${ }^{135}$ Popeia, apesar de Nero a amar intensamente, teria sido alvo de um pontapé mortal, quando se encontrava grávida. ${ }^{136}$ Ao enteado, Rúfrio Crispino, filho de Popeia, manda-o afogar quando o jovem pescava. ${ }^{137}$

Além da narração das acções, a transcrição de ditos célebres tem um papel relevante na medida em que comprova, acentua ou torna mais realista o traço de carácter que se pretende ilustrar. A fim de tornar mais viva a expressão dos vícios dos biografados, Suetónio concede-lhes muitas vezes a palavra: uma forma dramática de reforçar a conexão entre comportamento e carácter. Tal método é particularmente visível no que respeita à crueldade. A dureza de coração de Tibério aparece associada ao humor negro na anedota dos cidadãos de Ílion que lhe vêm apresentar, tarde, condolências pela morte de Druso: em resposta, recebem os pêsames pela morte de Heitor. Trata-se, provavelmente de um exagero de Suetónio, para provar a tese da falta de patria caritas: quasi obliterata iam doloris memoria (Tib. 52.2) («como se a memória da dor estivesse já esquecida»). Uma censura irónica e a inconveniência do dito (dadas as circunstâncias) favoreceu o arranjo da tradição hostil. ${ }^{138}$ É possível que Tibério não primasse por um sentido apurado das conveniências.

As palavras em discurso directo servem sobretudo para sugerir a atrocidade de Tibério na aplicação da justiça: Mori uolentibus uis adbibita uiuendi. Nam mortem adeo leue supplicium putabat, ut cum audisset unum e reis, Carnulum nomine, anticipasse eam, exclamauerit: 'Carnulus me euasit'. Et in recognoscendis

${ }^{134}$ Nem Tácito nem Díon Cássio referem tal acto. Beber junto dos cadáveres é atitude que Suetónio vê como insolente e ímpia: cf. Vit. 10.3.

${ }^{135}$ Nero 35.2; pernegantibus cunctis é um exagero. Tácito, Ann. 14.60.3, diz que alguns, vencidos pela tortura, confessaram as falsas acusações. Octávia torna-se a heroína da tragédia homónima, atribuída, em uma parte dos códices, a Séneca. Mas há quem veja uma alusão burlesca a Octávia na Quartila do romance de Petrónio, 17-18; vide LEÃo, D. F. 1998, 81-82.

${ }^{136}$ Nero 35.3. O paralelo com Tácito, Ann. 16.6 e com Díon Cássio, 62.27, mostra que a morte de Popeia deve ter resultado de acidente. A paixão que Nero tinha por ela faz pensar num rumor mal-intencionado. Vide com. Bradley, K. R. 1978, 212; Verdière, R. 1975, 15; Cizek, E. 1982, 180; Martin R. 1991, 142. Mayer, R. 1982, 248-249 nota que este episódio pode fundar-se na tentativa conotar Nero com um típico tirano. Periandro, que apresenta semelhanças com Nero (como o incesto e o projecto de abertura de um canal no istmo de Corinto), matou, segundo Diógenes Laércio (1.94), a esposa grávida num momento de cólera, talvez com um pontapé.

${ }^{137}$ Nero 35.5. Para Frazer R. M. 1966,19, este assassínio tem um modelo mitológico. Tal incidente vem associado à censura feita por um filósofo cínico (Nero 39.3) de que Nero, que sabia cantar as desgraças de Náuplio, dispunha mal dos seus bens. A grande desgraça de Náuplio é o assassínio do seu filho Palamedes, descrito primeiramente nos Cypria, epopeia perdida. Palamedes seria afogado por Diomedes e Ulisses, quando saía para pescar. Também no incêndio de Roma, Nero revive as desgraças de Príamo. BARTsch, S. 1994, 61, critica esta tese e alerta para a perniciosa tentação de usar o drama para reconstituir a vida imperial.

${ }^{138}$ Vattuone, R. 1983-1984, 213-235, pensa que se trate de uma tirada irónica de desprezo pela antiquitatis gloria dos Troianos. 
custodiis precanti cuidam poenae maturitatem respondit: 'nondum tecum in gratiam redii'(Tib. 61.5) («Aos que queriam morrer obrigava-os a viver. É que ele considerava a morte um suplício tão leve que, ao ouvir dizer que um dos réus, de nome Cárnulo, a tinha antecipado, teria exclamado: 'Cárnulo escapou-me'. $\mathrm{E}$ quando passava revista às prisões, a um tal que lhe pedia que apressasse a condenação, respondeu: 'ainda não fiz as pazes contigo'»).

Também em Domiciano, a crueldade aparece associada à hipocrisia e ao humor negro pela forma como, na véspera de mandar crucificar o seu tesoureiro, o convida para o seu quarto, o faz sentar ao seu lado e o despede confiante e ainda lhe envia parte do seu jantar (como oferta honrosa). Quando decide condenar o seu familiar Arrecino Clemente, redobra o favor para com ele, até que um dia, quando iam juntos na mesma liteira, ao avistar o delator: 'uis,' inquit, 'bunc nequissimum seruum cras audiamus?'39 ("Queres - disse ele - que dêmos audiência amanhã a este miserável escravo?'»). Como se trata de expor o cinismo do Imperador, o biógrafo nem refere a causa destas condenações e centra a atenção no modo como o imperador dita as sentenças. Uma sentença, por mais terrível que fosse, era antecedida de um preâmbulo onde aludia à sua clemência quo contemptius abuteretur patientiam hominum (Dom. 11.2) («para, da forma mais detestável, abusar do sofrimento das pessoas»). A hipocrisia do imperador é ainda exemplificada com a transcrição, um tanto suspeita, das suas próprias palavras ao senado. Fez comparecer na Cúria uns acusados de lesa-majestade e, com a declaração introdutória de que 'experturum se illa die quam carus senatui esset' ("'naquele dia teria a prova de quanta estima lhe devotava o senado'»), facilmente conseguiu que fossem condenados a sofrer o castigo, e segundo o uso antigo. Depois, temeroso do rigor da pena, para suavizar o ódio que tal medida lançaria sobre a sua pessoa, disse: 'Permittite, patres conscripti, a pietate uestra impetrari, quod scio me difficulter impetraturum, ut damnatis liberum mortis arbitrium indulgeatis; nam et parcetis oculis uestris et intellegent me omnes senatui interfuisse ${ }^{140}$ ("Permiti-me, senadores, obter da vossa piedade o que sei que dificilmente obterei, que concedais aos condenados a liberdade da escolha do género de morte: assim não só poupareis os vossos olhos, mas também todos compreenderão que eu estive presente na sessão do senado'»). Tais palavras, só por si, seriam favoráveis a Domiciano, mas o contexto em que Suetónio as cita acentua a cruel e arbitrária manipulação do senado por parte do imperador. ${ }^{141}$ Certo é que, entre as palavras introdutórias ('experturum se illa die quam carus senatui esset') e as palavras finais, não parece haver a contradição nem a mudança de atitude que Suetónio sugere. Pelo contrário, este excerto poderia ser usado, se fosse esse o caso, para provar quer

${ }^{139}$ Jones, B. W. 1972, 320-321, aventa uma conjectura para explicar a desgraça de Arrecino Clemente: este, como era irmão da mulher de Tito, tio de Júlia e amigo de Domiciano, terá censurado a relação de Domiciano com a sobrinha, o que provocou o conflito. Clemente foi talvez exilado e não executado (V. n.11 do referido estudo).

${ }^{140}$ Dom. 11.3. Suetónio não descreve aqui o castigo more maiorum; com efeito, já o fizera em Nero 49.2: nudi hominis ceruicem inseri furcae, corpus uirgis ad necem caedi.

${ }^{141}$ Como nota Murphy, J. P.1991, 3788. 
a clementia de Domiciano, que intercede pelos condenados, quer a sua ciuilitas, por não usar o seu estatuto para impor uma decisão ao senado. Mas Suetónio adapta os exemplos à imagem que do imperador quer transmitir: assim, tudo não passa de uma farsa.

Os actos de crueldade de Calígula são agravados com ditos célebres, em que o protagonista alardeia o seu poder ilimitado sobre a vida e sobre a morte. Responde a uma repreensão da avó Antónia: 'memento', ait, 'omnia mibi et <in> omnis licere' ("lembra-te de que posso tudo o que eu quiser e contra todos'»); e, pouco antes de mandar assasinar o primo Gemelo, suspeitando de que ele tomava um contraveneno para se precaver: 'Antidotum', inquit, 'aduersus Caesarem?’142 (“Um antídoto, reagiu ele, contra César?’); ameaça as irmãs relegadas de que não dispunha só de ilhas, mas também de espadas. A crueldade é expressa na frase 'ita feri ut se mori sentiat' ("proceda-se de modo que ele sinta a morte'») e num verso trágico típico de um carácter tirânico: 'oderint, dum metuant ${ }^{143}$ («tenham ódio, desde que tenham medo»). Certo dia, durante um banquete, aos cônsules que lhe perguntavam educadamente de que estava a rir, responde: 'Quid', inquit, 'nisi uno meo nutu iugulari utrumque uestrum statim posse?"144 («De que há-de ser, disse ele, senão de que me bastaria um só aceno para vos fazer degolar aos dois imediatamente?’»). E sempre que beijava o pescoço da mulher ou da amante dizia: 'Tam bona ceruix simul ac iussero demetur' (“Tão bela cerviz tombará, mal eu o ordenar'»). E repetia que recorreria à tortura para saber porque é que amava tanto Cesónia. ${ }^{145}$ Tais ditos consagram a imagem de um tirano que procura incutir o terror nos súbditos. O efeito é tal que, no final (Cal. 60), muitos não acreditam que Calígula tenha perecido e pensam que se trata de mais um golpe de teatro para descobrir os sentimentos das pessoas.

As acções de rapina de Nero são agravadas com as palavras, ao delegar cargos (Nero 32.4): 'Scis quid mibi opus sit' ("Já sabes do que eu preciso'») e 'Hoc agamus, ne quis quicquam habeat' ('Façamos de modo que ninguém fique com nada'»). A crueldade e o humor negro de Nero estão bem patentes na morte da tia Domícia. Por ocasião de uma visita, quando ela, doente, lhe acariciou a barba dizendo: 'simul hanc excepero, mori uolo' ("Logo que a receber, morrerei de boa vontade'»), Nero responde a rir que 'confestim se positurum' («imediatamente se desfaria dela'»). Depois de ordenar aos médicos a morte, nem esperou que ela exalasse o último suspiro para se apoderar dos bens. ${ }^{146}$ Depois de violar e

${ }^{142}$ Cal. 29.1. Cf. Cal. 23.3. O jovem tomava um medicamento para a tosse persistente de que sofria.

${ }^{143}$ Cal. 30.1. Frase do Atreu de Ácio. Cf. Tib 59.2: oderint, dum probent.

${ }^{144}$ Cal. 32.3. Anedota não atestada em outra fonte.

145 Cal. 33. Afirmar que dizia 'sempre' (quotiens), em relação ao pescoço das esposas e amantes, parece exagero de Suetónio na mira de apresentar um imperador obcecado pela ideia da decapitação; cf. 30.2: "Vtinam p. R. unam ceruicem haberet! Aqui se inspira Camus para a cena do estrangulamento de Cesónia.

${ }^{146}$ Nero 34.5. Provavelmente só quereria ser agradável à moribunda, mas, como ela faleceu logo de seguida, os detractores de Nero transformaram as palavras amigáveis em projecto criminoso. 
matar Aulo Pláucio exclama: 'Eat nunc', inquit 'mater mea et successorem meum osculetur', iactans dilectum ab ea et ad spem imperii impulsum ${ }^{147}$ ("Venha agora a minha mãe - disse ele - e beije o meu sucessor', referindo-se ao amor que ela sentira por ele e ao facto que o levara a acalentar esperança de reinar»). Com um cruel sentido de humor, aos que demoravam tempo a por termo à vida mandava-lhes médicos qui cunctantes continuo 'curarent"148 («para, sem mais delongas, 'tratarem da saúde' aos hesitantes») e, ufano de tais sucessos, negauit 'quemquam principum scisse quid sibi liceret' (Nero 37.3) («disse que nenhum dos príncipes fazia ideia do que lhe era permitido») - dito que põe em evidência o carácter ilimitado dos poderes imperiais.

No cúmulo dos parricidia de Nero figura o incêndio dos muros da pátria. Neste episódio, além da impietas, são integradas no espectáculo a petulantia, a luxuria, a crudelitas e auaritia (vícios atribuídos a Nero:26.1).Já Calígula desejava calamidades (Cal 31), e, segundo o biógrafo, terá promulgado a fome pública com encerramento dos celeiros (Cal.26.5). Nero, mais aparatoso, é apresentado como quem reclama para si uma espécie de conflagração universal. A ideia de uma ekpyrosis da pátria poderá ter origem em algumas palavras de Nero, acaso influenciadas pela filosofia estóica de Séneca. Com efeito, em resposta à citação

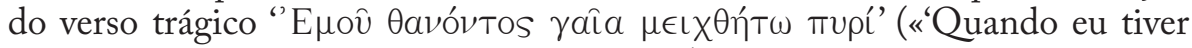

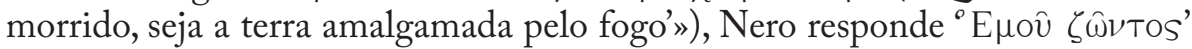
(«Enquanto eu estiver vivo!"). Para o biógrafo, o objectivo do imperador é criar uma cidade nova e os critérios são estéticos: quasi offensus deformitate ueterum aedificiorum et angustiis flexurisque uicorum ("como que agredido pela fealdade dos antigos edifícios e pela estreiteza e sinuosidade dos quarteirões»). Para Suetónio, Nero, artista e criminoso, é claramente o autor. ${ }^{149}$ As provas de tão grave culpa são um suspeito flagrante delito: diversos cônsules (plural vago da classe que era opositora de Nero) surpreenderam escravos de quarto do imperador, nas suas propriedades, com estopa e tochas; e um manifesto anacronismo: uns celeiros de pedra, num apetecido espaço junto à Domus Aurea (que só seria construída depois do incêndio), ${ }^{150}$ foram destruídos por máquinas

${ }^{147}$ Nero 35.4. É difícil determinar de quem se trata.

${ }^{148}$ Nero 37.2. Refere-se naturalmente àqueles a quem era concedido cometer suicídio.

149 (...) incendit urbem tam palam.... O dolus principis é apenas uma das versões que corria em pé de igualdade com a de um acidente fortuito; cf. Tácito, Ann. 15.38.1. Os boatos sobre a culpa de Nero poderão ter surgido posteriormente, a partir do cuidado posto na reconstrução e na qualidade dos edifícios, como se pode deduzir das palavras de Tácito, Ann. 15.40.2. Pelo contrário, Nero parece ter feito esforços para combater o fogo ou atenuar os seus efeitos, como sublinha Holson, P. 1976, 37-44. Não se entende em que é que Nero beneficiaria com este incêndio e é pouco provável que Nero quisesse destruir a Domus Transitoria, que estava em construção. Vide com. Bradley, K. R. 1978, 231.

${ }^{150}$ Nero 38.1. De certo modo, para a técnica de Suetónio não é um anacronismo, uma vez que o biógrafo não segue a cronologia e já relatou a construção da Domus Aurea (Nero 31): do ponto de vista seguido nesta biografia já pertence ao passado. Assim, Nero, que fora elogiado pela forma como construiu pórticos para facilitar o combate aos incêndios (Nero 16.1), é agora acusado de atear o incêndio. Mas a noua forma urbis, atrás louvada, é posterior ao incêndio. Esta inversão cronológica mostra que a uma apresentação histórica dos factos Suetónio prefere uma "exposição puramente impressionista”, como lhe chama GAscou, J. 1984, 371. 
de guerra e pelo fogo. O crime é agravado pela extensão da calamidade, que dura seis dias e sete noites, pelo sofrimento da plebe, empurrada para os monumentos e para os túmulos, ${ }^{151}$ pela extensão e importância dos monumentos destruídos, pela perda para a cultura antiquária. ${ }^{152} \mathrm{~A}$ culpa de Nero no crime, que para Suetónio é efectiva, também se justifica nos gostos histriónicos do imperador e é ilustrada com mais uma representação teatral, em que a realidade se mescla com o mito: Hoc incendium e turre Maecenatiana prospectans laetusque 'flammae', ut aiebat, 'pulchritudine' Halosin Ilii in illo suo scaenico habitu decantauit ${ }^{153}$ ("Ao contemplar este incêndio da torre de Mecenas e entusiasmado com a "beleza das chamas", como ele dizia, cantou, no seu traje de cena, "a tomada de Ílion"»). É escandaloso o contraste entre a calamidade pública e a laetitia do soberano, a cantar a destruição que ele próprio causara. Nero veste-se para a aç̧ão mais que para a representação. Não se trata de simples mimesis, mas antes de poiesis. $\mathrm{O}$ cenário apocalíptico é a fonte de inspiração para o tema cantado. $\mathrm{O}$ mito combina-se com a realidade pelas mãos e pela voz do artifex Nero, que pode agora experimentar os sentimentos de Príamo, ao ver arder Tróia. Mais uma razão, portanto, para o biógrafo atribuir a Nero a responsabilidade do incêndio: o autor do poema será também o autor da matéria cantada, pois, na sua megalomania, precisava de criar um cenário realista, grandioso e terrível, à medida da sua obra. O espectáculo inspirará um horror real e é esse o objectivo do biógrafo. De resto, Nero lembra-nos a figura lendária de Anfíon, mas ao inverso: Anfíon com a música da sua lira fez alinhar as pedras nos muros de Tebas ${ }^{154}$; Nero canta enquanto destrói os muros da pátria.

O carácter teatral de Calígula e de Nero e o seu desejo de protagonismo leva-os a terem atitudes exageradas devidas à inveja. Calígula manda abater as estátuas de varões ilustres (Cal.34.1) e concebe o projecto de destruir os poemas homéricos, com a justificação de que Platão banira Homero da República, e de retirar das bibliotecas os retratos de Virgílio e Tito Lívio. ${ }^{155}$ À inveja se atribui

${ }^{151}$ Nero 38.2. Esta indicação pode coincidir com a abertura do Campo de Marte e dos monumenta Agrippae: medidas tomadas por Nero para acolher a população, como diz Tácito, Ann. 15.39.2. É que Nero, apesar de estar em Âncio, preocupa-se em vir imediatamente em socorro das vítimas. Suetónio prefere enfatizar o sofrimento das pessoas e omite as providências de Nero. Vide Wankenne, J.1981, 145-146 ; com. de Bradley, K. R. 1978, 227 e 232-233.

${ }^{152}$ Suetónio é, como habitualmente, vago: está mais preocupado em dar a ideia da enormidade dos estragos do que em ser preciso: Tunc praeter immensum numerum insularum domus priscorum ducum arserunt hostilibus adhuc spoliis adornatae deorumque aedes ab regibus ac deinde Punicis et Gallicis bellis uotae dedicataeque. Tácito, em Ann. 15.40.2, indica as regiões afectadas, e em 15.41.1, apresenta uma lista dos edifícios destruídos. Vide Bradley, K. R. 1978, 234.

${ }^{153}$ Nero 38.2. Suetónio, cedendo à versão mais romanesca. Tácito, Ann. 15.39.3, apresenta o episódio como um rumor. Além disso, o historiador fala de um palco particular; e Díon Cássio, 62.18.1, coloca-o no telhado do palácio. Ora os três locais mencionados parecem ter sido pasto das chamas. Vide Holson, P. 1976, 43; Gascou, J. 1984, 442-443. Petrónio, 88, faz Eumolpo cantar um poema com o mesmo título - talvez uma paródia do de Nero: vide LEÃo, D. F. 1998, 50 .

${ }^{154}$ Cf. Apolodoro, 3.5.5-6; Horácio, Carm. 3.11.2.

155 Cal. 34.2. Segundo Lambrechts, P. 1953, 219-232, o afastamento das obras e retratos de Vírgílio e Tito Lívio entende-se à luz de uma política contrária a Augusto, visto que Calígula se assumia mais como descendente de Marco António e era avesso à celebração da vitória de 
a remoção das insígnias das famílias nobres de Roma e a morte de Ptolemeu, parente do imperador, porque o fulgor da púrpura do seu manto tinha atraído todos os olhares durante um espectáculo. ${ }^{156}$ Mais uma vez, Suetónio deixa de lado as motivações políticas, para seguir as razões éticas. A culminar estes exempla, recria uma cena particularmente viva, onde a inveja leva o imperador a tornar-se ridículo:

Cum quodam die muneris essedario Porio post prosperam pugnam serum suum manummittenti studiosius plausum esset, ita proripuit se spectaculis, ut calcata lacinia togae praeceps per gradus iret, indignabundus et clamitans 'dominum gentium populum ex re leuissima plus honoris gladiatori tribuentem quam consecratis principibus aut praesenti sibi' (Cal. 35.3).

Uma vez, em dia de jogos, como o gladiador de carro Pório foi calorosamente aplaudido por ter libertado o seu escravo depois de um glorioso combate, saiu do espectáculo tão bruscamente que calcou a orla da toga e se precipitou de cabeça pelos degraus abaixo, a ferver de indignação e a gritar que 'o povo dominador do mundo, por uma futilidade, concede mais honras a um gladiador do que aos divinos príncipes ou a ele próprio ali presente'.

Como no caso de Calígula, a inveja de Nero vira-se contra os outros heróis: manda abater as estátuas de todos os vencedores dos jogos sagrados, arrastá-las e lançá-las às latrinas. ${ }^{157}$ De modo semelhante, para a morte de Britânico, Suetónio apresenta, em primeiro lugar, a inveja que Nero tinha da voz dele, a par do medo de perder a popularidade em favor do filho de Cláudio (Nero 33.2). Suetónio alonga-se a descrever todo o cuidado que Nero põe em controlar a actividade de Locusta, na preparação de venenos sucessivamente mais fortes, capazes de dar morte instantânea ao rival. Por contraste, acentua-se o pouco cuidado posto no

Áccio. Com base numa pintura existente no Iseu do Palatino, que representará o desembarque de Helena e Páris no Egipto, Segundo Lambrechts deduz que Calígula preferiria a versão do mito apresentada por Estesícoro à de Homero. Vide WARdLE, D. 1994, 266. O próprio Suetónio transmite citações de Homero e Virgílio feitas por Calígula. Barretr, A. A. 1989 (2000), 48, vê no passo em análise algo da convenção que atribui aos imperadores visões literárias perversas, como acontece com Adriano; cf. Díon Cássio, 69.4.6.

${ }^{156}$ Cal. 35.1. Ao contrário do que afirma Gascou, J. 1984, 421, n. 153, não parece haver contradição em Suetónio em relação ao que tinha dito em Cal. 26.1: então apresentava um exemplo de impietas familiar; agora fala da causa da morte: a inveja. Esta não exclui a impietas, antes a agrava. Vide com. de Wardle, D. 1994, 270-271. Mas esta morte levanta questões políticas que Suetónio não aborda. Para FAur, J.-C. 1973, 55 248-271, Ptolemeu foi morto porque se envolvera na conjura de Getúlico e, dado ser descendente de Marco António, era um potencial rival de Calígula. Esta hipótese é contestada por Gascou, J. 1984, 420 n.152, que a considera inverosímil. Para Barrett, A. A. 1989 (2000), 116-118, e Antonelli, G 2001, 140-142, dado o contexto em que ocorreu a morte de Ptolemeu, este deve ter estado envolvido numa conjura, talvez com a promessa de um reino independente.

${ }^{157}$ Nero 24.1. Deve tratar-se de uma generalização e exagero de Suetónio, a partir do caso da estátua do citaredo Pâmedes, mutilada devido à inveja de Nero (como diz Díon Cássio, 63.8.5); ou de uma grosseira acusação, baseada no facto de que Nero removeu numerosas estátuas da Grécia para o adorno da Domus Aurea. Vide com. de Bradley, K. R. 1978, 143; com. de Warmington, B. H. 1999, 52. 
funeral, realizado num cenário desolador de chuva torrencial. ${ }^{158}$

Vitélio mostra a sua espectacularidade no seu vício principal: a gula. Os banquetes de Vitélio são uma caricatura dos de Nero. Ele próprio consegue ter capacidade para tantas refeições, graças ao recurso ao vómito (Vit. 13.1). Tais banquetes implicam enormes gastos, com pratos enormes e requintados, de que se destaca o denominado «escudo de Minerva protectora da cidade». A gula incontrolável expõe este imperador a atitudes ridículas e indignas. ${ }^{159}$ Este vício aparece também associado à saeuitia na expressão que usa quando manda executar um condenado à sua frente porque «queria dar alimento aos olhos» (Vit. 14.2).

Os tiranos exercem também o seu poder no domínio sexual. A impudicitia e a as libidines de César são expostas, como já vimos, nos versos dos soldados no triunfo da Gália (Jul. 49.4; 51). Motivo de muitos comentários foi o chamado "banquete dos doze deuses" no palácio de Augusto, em que o próprio imperador se disfarçou de Apolo. No segredo de Cápreas, Tibério pode entregar-se ao vício. $\mathrm{O}$ abandono da máscara - a característica dissimulação de Tibério - é concretizado com uma luxuriosa mise-en-scène:

Secessu uero Caprensi etiam sellaria excogitauit, sedem arcanarum libidinum, in quam undique conquisiti puellarum et exoletorum greges monstrosique concubitus repertores, quos spintrias appellabat, triplici serie conexi, in uicem incestarent coram ipso, ut aspectu deficientis libidines excitaret. Cubicula plurifariam disposita tabellis ac sigillis lasciuissimarum picturarum et figurarum adornauit librisque Elephantidis instruxit, ne cui in opera edenda exemplar impetratae schemae deesset. In siluis quoque ac nemoribus passim Venerios locos commentus est prostantisque per antra et cauas rupes ex utriusque sexus pube Paniscorum et Nympharum babitu, quae palam iam et uulgo nomine insulae abutentes Caprineum dictitabant. ${ }^{160}$

«No seu retiro em Cápreas, inventou também um quarto com divãs, sede das suas lascívias secretas, no qual, bandos de moças e rapazes pervertidos, recolhidos de toda a parte, e os inventores de monstruosas uniões, aos quais chamava spintriae, encadeados em grupos de três, se pudessem prostituir alternadamente à sua frente, para que, ao olhar, ele excitasse os seus desejos em declínio. Adornou alcovas, dispostas em vários sítios, de quadros e estatuetas com pinturas e esculturas de extrema devassidão e guarneceu-os de livros de Elefântis, para que a ninguém faltasse, ao executar o serviço, o modelo da atitude exigida. Também, nas matas e nos bosques, teve a ideia de distribuir, por aqui e por ali, sítios para os prazeres de Vénus e, por antros e grutas, os que se prostituíam, de entre a juventude de um e outro sexo, em traje de pequenos Pãs e Ninfas. Por esta razão, às claras e jogando publicamente com o nome da ilha, repetidas vezes lhe chamavam 'capríneo'».

Embora diga que tudo se passa no segredo da ilha, o biógrafo descreve

${ }^{158}$ Nero 33.2-3. Tácito, Ann. 13.17.1, diz que o vulgo viu nesta tempestade uma manifestação da ira divina por causa do crime. Fini, M. 1993, 125-129, rejeita a culpa de Nero na morte de Britânico.

${ }^{159}$ Vit. 13.3. Vide Martin, R. 1991, 115.

${ }^{160}$ Tib. 43. Grandes semelhanças verbais com Tácito, Ann. 6.1. 
toda esta cena, servindo-se do perfeito do indicativo, como se a ela tivesse assistido. A trama mitológica é evidente. A referência aos Pãs e ninfas bem como à alcunha de capríneo sugere que a sexualidade de Tibério é inspirada na dos Sátiros. Tibério cria à sua volta um teatro pornográfico e mitológico, consonante com o gosto da época, - encenações que, para o biógrafo, são apenas motivadas pelo voyeurismo do velho depravado. Mas o apetite pelo escândalo faz Suetónio ceder às versões mais romanescas resultantes da calúnia. $\mathrm{O}$ erotismo na piscina, que o biógrafo considera mais grave (maiore adhuc turpiore) - pois meninos de tenra idade, a quem o imperador chamava pisciculi, nadavam à sua volta para lhe excitarem os sentidos (Tib. 44.1) -, inscreve-se num topos da poesia epigramática e na diatribe contra os tiranos. ${ }^{161}$ Corre o boato de que Domiciano também depila as concubinas e nada no meio das mais vis cortesãs; e designa, cinicamente, o coito como "combate de cama". ${ }^{162}$ Como é típico dos tiranos, o último dos Flávios apresenta um apetite sexual desmedido e amoral, que se manifesta na forma como, apesar de ter recusado o casamento com Júlia, filha do irmão, a seduz depois de casada, ao ponto de, mais tarde, lhe causar a morte, ao obrigá-la a abortar. ${ }^{163}$

Por vezes os imperadores tornam-se protagonistas de actos que se transformam em verdadeiros espectáculos de tragicomédia ou de mimo. $\mathrm{O}$ rumor da violação do jovem ministro do sacrifício e do irmão, com o requinte do quebrar das pernas a ambos, quod mutuo flagitium exprobrarant («porque tinham censurado um ao outro aquela vergonha»), alia a lascívia de Tibério à crueldade, à profanação e ao humor negro. Tal crueldade manifesta-se também em relação às mulheres nobres. $\mathrm{O}$ caso de Malónia representa o abuso do tirano para com as mulheres da aristocracia:

Feminarum quoque, et quidem illustrium, capitibus quanto opere solitus sit inludere, euidentissime apparuit Malloniae cuiusdam exitu, quam perductam nec quicquam amplius pati constantissime recusantem delatoribus obiecit ac ne ream quidem interpellare desiit, 'ecquid paeniteret'; donec ea relicto iudicio domum se abripuit ferroque transegit, obscaenitate [m] oris hirsuto atque olido seni clare exprobrata. Vnde mora in Atellanico exhodio proximis ludis adsensu maximo excepta percrebuit, 'bircum uetulum capreis naturam ligurire' (Tib. 45).

Também o empenho com que costumava infamar a honra das mulheres, e

${ }^{161}$ Vide Gascou, J. 1984, 438; Martin, R. 1991, 153-157; Dupont, F. et ÉLoi, T. 2001, 293-306 ; BRANDÃo, J. L. 2005c, 92-94..

162 Dom. 22: Libidinis nimiae, assiduitatem concubitus uelut exercitationis genus 'clinopalen' uocabat. Díon Cássio, 67.6.3-4, diz que ele gostava de ter comércio com mulheres e rapazes. Domiciano, também no campo sexual, terá sido vítima, como Tibério, Calígula e Nero, de uma tradição desfavorável, que atribuía ao tirano todos os vícios, também na vida privada: vide Martin, R. 1991, 161.

${ }^{163}$ Ideia semelhante se encontra em Juvenal, 2.29-33; Plínio, Ep. 4.11.6; Díon Cássio, 67.3.1. No seu com. Jones, B. W. 1996, 151 (e, mais tarde, Jones, B. \& Milns, R. 2002, 167), duvida de que o relacionamento de Domiciano com Júlia fosse o descrito pela tradição, tendo em conta o que se diz em Marcial, 6.3.5. 
mesmo das ilustres, manifesta-se muito claramente na morte de uma certa Malónia, que, depois de possuída, como ela se recusava com muita firmeza a deixá-lo ir mais além, lançou-a aos delatores e não deixou de perguntar à acusada se 'se arrependia'. Até que ela, abandonando o tribunal, se refugiou em casa e se trespassou com um punhal, depois de ter censurado sem rodeios a obscenidade oral do velho rude e malcheiroso. Daí que, por altura dos jogos seguintes, um exódio de atelana se divulgou com a aprovação geral: 'o velho bode lambe o sexo às cabras'.

Trata-se de um momento trágico: Malónia é a nova Lucrécia, vítima de tirania sexual. ${ }^{164} \mathrm{O}$ suicídio torna mais dramáticas e mais credíveis as censuras que a mulher faz a Tibério. Ao mesmo tempo, tem um desfecho burlesco, pela apropriação a um verso de atelana, género conhecido pelo assunto escabroso. A transição entre o primeiro e o segundo momento parece demasiado apressada e desconcertante. A nobreza de Malónia não se acomoda ao plebeísmo de caprea. Mas é comum em Suetónio encontrar o trágico e o burlesco associados: uma espécie de humor negro que era também apanágio de Tibério. O carácter teatral da narrativa é acentuado pela selecção dos acontecimentos: Suetónio é o único autor que conta este caso. O exódio da Atelana vem, mais uma vez, reforçar a ideia da associação de Tibério às figuras de Pã que povoavam a ilha.

Quanto a Calígula, Suetónio parte da conviç̧ão de que cometeu incesto com todas as irmãs, para se centrar na relação privilegiada com Drusila, a quem violentara na juventude e tratava mais tarde publicamente como esposa. ${ }^{165}$ Quando Drusila morre, o imperador, incapaz de suportar a dor, retira-se para a Campânia e, dali, para Siracusa, e depois volta com os cabelos e a barba compridos. ${ }^{166}$ Calígula manifesta necessidade de fazer da sua vida pessoal um espectáculo constante. Depois de arrebatar Orestila ao marido, Gaio Pisão, disse que procurara um matrimónio segundo o exemplo de Rómulo e de Augusto, evocando assim o modelo matrimonial dos fundadores de Roma e do principado. Pretende associar o seu acto ao mítico rapto das Sabinas e à consagrada união de Augusto e Lívia, ao tomar para si outra Lívia. ${ }^{167} \mathrm{O}$ facto de amar ardentemente Cesónia, parece ser o motivo de a ostentar aos soldados, ataviada de clâmide, escudo e elmo, a cavalgar ao lado dele - paródia do general triunfador ou imagem de amazona -, e de a exibir nua aos amigos. ${ }^{168}$

${ }^{164}$ Vide Martin, R. 1991, 133.

${ }^{165}$ Cal. 24.1. A identificação com os príncipes Lágidas, com quem Calígula (segundo Fílon, Leg. 162) mantém boas relações e que casam com as irmãs, pode explicar a relação com Drusila e as honras que lhe concede depois da morte. Vide Martin, R. 1991, 331; Colin, J. 1954, 408; LAmbrechts, P. 1953, 226-228 e n. 2.

${ }^{166}$ Cal. 24. 2. É este o momento que Camus escolherá para começar a sua peça. Para Lucas, J. 1967, 175, trata-se de uma acto impulsivo, uma de regressão afectiva a um estádio infantil.

${ }^{167}$ Cal.25.1. Suetónio diz que também se chama Lívia, quando Díon Cássio, 59.8.7, fala de Cornélia Orestila (ou Orestina). Quer se trate de uma justificação do imperador para o seu acto, quer seja uma marca de humor negro, Suetónio situa o dito, como toda a rubrica dos casamentos, sob o estigma da impietas: matrimonia contraxerit turpius an dimiserit an tenuerit, non est facile discernere.

${ }^{168}$ Este facto só é transmitido por Suetónio, Cal. 25.3. Também Nero vestia as concubinas 
Destaca-se também o episódio, certamente generalização (o uso do imperfeito sustém um discurso iterativo), da avaliação das mulheres mercantium more (como ironicamente nota o biógrafo) à frente dos maridos, para escolher uma e no fim comentar o seu corpo e a sua "performance" na cama. ${ }^{169}$

Nero, ainda mais aparatoso que o seu tio, quando se entrega abertamente ao vício, promove a prostituição de matronas ao longo das margens do Tibre, nas viagens para Óstia, e ao longo da costa, nas viagens para Baias, e impõe orgias sumptuosas aos amigos. ${ }^{170} \mathrm{O}$ seu carácter histriónico manifesta-se na paródia do ritual do casamento com o eunuco Esporo, com dote e flammeum e cortejo nupcial, ao ponto de o tratar, em público, como legítima esposa, ${ }^{171} \mathrm{e}$ nos jogos de devassidão que inventa:

Suam quidem pudicitiam usque adeo prostituit ut contaminatis paene omnibus membris nouissime quasi genus lusus excogitaret, quo ferae pelle contectus emitteretur e cauea uirorumque ac feminarum ad stipitem deligatorum inguina inuaderet et, cum affatim desaeuisset, conficeretur a Doryphoro liberto; cui etiam sicut ipsi Sporus, ita ipse denupsit, uoces quoque et heiulatus uim patientium uirginum imitatus. ${ }^{172}$

«Prostituiu a tal ponto o seu pudor que, depois de contaminar quase todos os membros, inventou como que um jogo completamente novo, segundo o qual, coberto com uma pele de animal selvagem, se lançava de uma jaula e atacava os órgãos sexuais de homens e mulheres atados a um poste e, depois de se fartar de tais sevícias, era possuído pelo seu liberto Doríforo, a quem serviu de noiva, como Esporo a ele próprio, e chegou mesmo a imitar os gritos de sofrimento das virgens ao serem forçadas».

O biógrafo apresenta, assim, sob a perspectiva da degradação moral, duas representações miméticas do imperador: uma que recria a sorte dos condenados às feras, mas em que Nero se transforma na fera executora do

de amazonas (Nero 44.1).

${ }^{169}$ Cal. 36.2. Cf. Aug. 69.1.

170 Nero 27.3. Estes episódios relatados em Nero 27, fazem suspeitar de generalização de Suetónio a partir do banquete de Tigelino (descrito em Tácito, Ann. 15.37), que não seria meramente um banquete de devassidão, mas uma celebração dos Floralia, o festival das prostitutas; vide Allen, W. 1962, 99-109; com. de Bradley, K. R. 1978, 158-160; Higgins, J. M. 1985, 116-118.

${ }^{171}$ Nero 29.1. Díon Cássio, 63.13.1, fala da semelhança de Esporo com Popeia Sabina. O ritual tem sido visto por alguns autores como uma cerimónia de iniciação numa religião mistérica: Esporo teria sido castrado, porque era servidor de Cíbele. O Alammeum é também o véu do iniciado. Vide Verdière, R. 1975,21-22; com. de Bradley, K. R.1978, 161-162; CizeK, E. 1982, 41; Martin, R. 1991, 171; Fernández Uriel P. 1994, 111-124.

${ }^{172}$ Nero 29. Crê-se que este Doríforo e o Pitágoras que figura no relato de Tácito, Ann. 15.37.4, e Díon Cássio, 63.13.2, sejam a mesma pessoa e que se trataria, como no caso de Esporo, de um casamento místico, em que Nero seria o iniciado. Doríforo não era o nome próprio, mas a função de ministro do culto de Cíbele ou da deusa Ma-Belona; vide Verdière, R. 1975, 19-20; com. de Bradley, K. R. 1978, 164-165; Cizek, E. 1982, 41-42; Martin, R. 1991, 160 e 169-171; Fernández URiel P. 1994, 111-124. Pelo contrário, Dupont, F. et Éloi, T. 2001,322, criticam estas hipóteses e consideram mais prudente confinarmo-nos aos textos. 
castigo (nouissime quasi genus lusus); ${ }^{173}$ outra em que mimetiza uma situação que, pela obscenidade e pela procura de realismo, nos faz lembrar uma cena de mimo (como sugere imitatus).

Tais exemplos representam o ponto de vista biográfico da fase final dos piores imperadores. Quanto mais cruel e arrogante se mostra um imperador, mais dramático se torna o sacrifício do tirano, explorado na narrativa da morte. A morte transforma-se numa necessidade e, em certos casos, assemelha-se a um ritual de expiação, como veremos à frente. Constatamos que a ilustração destes caracteres remete por vezes para a evocação de modelos trágicos, mas, nestes casos, o conceito de culpa é acima de tudo moral. Nero só é um Édipo pela metade, uma vez que é consciente quer a morte do pai (de que Suetónio o culpa) quer o incesto com a mãe. Apesar de Agripina ser responsabilizada pela morte de Cláudio, Nero não é propriamente um Orestes: o assassínio da mãe não tem o objectivo de vingar a morte do pai. O objectivo principal do biógrafo é demonstrar que Nero é parricida e incestuoso e que por isso merece $o$ castigo que o acomete no final.

${ }^{173}$ Há quem se interrogue sobre se esta anedota, descrita em Suetónio e Díon (63.13.2), não será uma referência deformada às punições sofridas pelos cristãos em $64 \mathrm{~d}$.C, que, segundo Tácito, Ann. 15.44.4, foram cobertos de peles de animais e dilacerados pelos cães. Vide com. de Bradley, K. R. 1978, 164. 


\section{VIDAS E DRAMA}

Aludimos agora ao teatro do próprio biógrafo. Neste capítulo, veremos como Suetónio utiliza elementos dramáticos, trágicos ou cómicos, sobretudo no que diz respeito à caracterização do período de governação de cada imperador, a parte central das Vidas. Através da distorção, o biógrafo afasta-se frequentemente do âmbito dos factos e entra no domínio da ficção. Contribui para isso o facto de seguir as versões mais romanescas: assim acontece com a sua versão do incêndio de 64 d C., do alegado incesto de Nero, das depravações de Tibério em Cápreas, etc. Por outro lado, as Vidas reflectem por vezes assimilação de elementos pertencentes aos géneros dramáticos.

Há uma certa insistência do biógrafo nos logros da fortuna. $\mathrm{O}$ destino pode ser conhecido por meio de sinais mais ou menos cifrados. Daí que sonhos e prodígios apareçam ao lado de factos históricos. Além disso, a progressão que se gera na maior parte das Vidas organiza-se em função de um desenlace, que parece ter um efeito catártico. A progressão gera-se com base na gradação das características do ethos. Assim, a catarse irá resultar do prémio ou castigo do imperador, de acordo com o seu carácter. Outro elemento presente é a deformação cómica. Usados com intuitos éticos, os recursos próprios da comédia permitem desautorizar ou ridiculizar um imperador ou, pelo contrário, simplesmente atenuar um vício.

\subsection{As voltas da Fortuna e suas consequências biográficas}

Um dos elementos que remete para o ambiente dramático é a presença constante do destino, que se manifesta de diversas maneiras. Os próprios Césares são avaliados também pela forma como prestam ou não atenção aos sinais divinos. $\mathrm{Na}$ busca das versões mais romanescas, Suetónio coloca a par de factos históricos grande quantidade de presságios. Tal insistência poderá dever-se à própria crença do biógrafo ${ }^{1}$ e à mentalidade da época, mas parece também explicar-se por critérios biográficos. A biografia ocupa-se de homens excepcionais, aos quais foram concedidos grandes destinos. Neste sentido, a biografia afasta-se do domínio da história, para se aproximar do mundo da tragédia.

Dado que se trata de descrever figuras e acontecimentos históricos, o papel que é dado à Fortuna implica um visão fatalista da progressão dos tempos. A queda de Galba é directamente associada à perda do favor da Fortuna, que se manifesta através de um sonho pressago (Gal. 18.2.). Também Augusto, afortunado na vida pública, foi, na vida familiar, uma vítima da Fortuna, que lhe defraudou a alegria e a esperança na descendência e na disciplina da casa, ${ }^{2}$

${ }^{1}$ Uma "credulidade" que contrasta com o cepticismo de Tácito, como procura demonstrar Gascou, J. 1984, 444-450.

${ }^{2}$ Aug. 65.1: Sed laetum eum atque fidentem et subole et diciplina domus Fortuna destituit. A mesma ideia em Tácito, Ann. 3.24.2. 
com o opróbrio da filha e da neta, as duas Júlias, a quem se viu obrigado a exilar, e a morte dos netos. As leis moralizadoras que promulgara (Aug. 34) são infringidas na sua própria família. Mas, ao referir os desmandos de Júlia, Suetónio não explora a questão política da desobediência a leis, que Augusto impusera com grande oposição: ${ }^{3}$ prefere colocar a tónica no carácter dramático do sofrimento de um pai incapaz de suportar a desonra dos filhos:

Aliquando autem patientius mortem quam dedecora suorum tulit. Nam C. Lucique casu non adeo fractus, de flia absens ac libello per quaestorem recitato notum senatui fecit abstinuitque congressu hominum diu prae pudore, etiam de necanda deliberauit. Certe cum sub idem tempus una ex consciis liberta Phoebe suspendio uitam finisset, 'maluisse se' ait 'Phoebes patrem fuisse.'

«Suportava bem melhor a morte dos seus do que o opróbrio. De facto, a tragédia de Gaio e de Lúcio não o quebrou tanto; sobre a filha, informou o senado sem comparecer e serviu-se de um libelo lido por um questor e longo tempo se absteve, por vergonha, do convívio dos homens; e chegou mesmo a ponderar a morte dela. Certo é que, pela mesma altura, como uma das cúmplices, a liberta Febe, pôs termo à vida por enforcamento, ele declarou que 'teria preferido ser o pai de Febe'».

O mesmo acontece com a abdicatio e exílio de Agripa, filho póstumo de Agripa e de Júlia, pouco tempo antes adoptado por Augusto, juntamente com Tibério. ${ }^{5} \mathrm{O}$ biógrafo acentua as sanções de carácter moralizante: a Júlia, no desterro, Augusto proibiu-lhe o vinho, as roupas elegantes e o contacto, sem autorização, com qualquer homem; e nunca mais levantou totalmente $o$ desterro; perante os pedidos insistentes do povo, que a amava, respondeu que «lhes desejava tais filhas e tais esposas» (Aug. 65.3). Se, nas suas motivações, o exílio da filha não fica esclarecido, muito menos o da neta, que, inclusive, se vê impedida de reconhecer e educar o filho que lhe nasceu depois da condenação: ${ }^{6}$ permanece o mistério desta tripla tragédia. O facto de Suetónio,

${ }^{3}$ Cf. Aug. 34.1. Quanto a uma possível teoria da conspiração, Southern, P. 1998, 179, não acredita que Júlia fosse castigada por estar envolvida, juntamente com os amantes, numa conjura contra Augusto, mas pela questão moral. De opinião contrária se mostra NÉrAudAu, 1996, 227-231, pois Júlia reunia à sua volta um grupo de potenciais agitadores, entre os quais, Julo António, filho sobrevivente de António e Fúlvia, que foi depois condenado à morte.

${ }^{4}$ Aug. 65.2. Suetónio não presta atenção às acções das mulheres em si mesmas, não discute a veracidade das afirmações nem condena os comportamentos; neste caso, está simplesmente interessado nas reacções de Augusto; vide VIDÉn, G. 1993, 85.

${ }^{5}$ Aug. 65.1 e 65.4. Sobre o âmbito jurídico da abdicatio, vide Levick, B. M. 1972, 674-697. O exílio de Agripa e a excessiva segurança com que foi guardado ficaram envoltos em mistério. Se houve conspiração, não ficou provada: nenhum dos contemporâneos de Augusto parece conhecer a verdade, como refere Southern, P. 1998, 186 (e n. 7 p. 253-254). Mas Lúcio Audásio e Asínio Epicado tinham um plano para a evasão de Agripa e Júlia e para os apresentar aos exércitos (Aug. 19.2): uma possível intentona a que talvez Escribónia não fosse alheia, segundo NÉrAudAu, J.-P. 1996, 250.

${ }^{6}$ Aug. 65.4. Graves seriam as acusações para suportar os rigores do exílio durante os vinte anos que refere Tácito, Ann. 4.71.4. O marido, Lúcio Emílio Paulo, foi acusado de conspiração 
por força da exposição per species, tratar em conjunto os três destinos contribui para aumentar o pathos. E, ao terminar o quadro, o biógrafo coloca, perante os olhos do leitor, a infelicidade de um pai, que expressa, por meio de um verso de Homero habilmente modificado, ${ }^{7}$ o desgosto de ter tais descendentes (as duas Júlias e Agripa), cruamente aplidados de 'pústulas' e 'cancros'. Estes infortúnios ganham mais relevo na medida em que têm consequências no decurso da história: interferem com as intenções dinásticas de Augusto; vão levar à escolha de Tibério como sucessor - uma partida da Fortuna patente no próprio testamento do fundador do principado. ${ }^{8}$

No que respeita a Tibério, também duas tragédias - a morte de Germânico e a de Druso - são apontadas como possível causa da sua retirada para a Campânia: ${ }^{9}$ acaso uma tentativa de explicar o pendor taciturno do sucessor de Augusto. De resto, o carácter parece ser a causa do infortúnio que marca Tibério (Tib. 67). No final desta Vida, o biógrafo, pela selecção que faz das palavras do próprio, apresenta um imperador amargurado consigo mesmo. Um excerto transcrito de uma carta ao senado revela um espírito perturbado: 'Quid scribam uobis, p. c., aut quo modo scribam, aut quid omnino non scribam hoc tempore, dii me deaeque peius perdant quam cotidie perire sentio, si scio" ("Que vos hei-de escrever, senadores, ou como vos hei-de escrever, ou o que é que de modo nenhum vos hei-de escrever nesta altura, se eu faço alguma ideia, deuses e deusas me destruam mais do que dia a dia me sinto morrer'»).

$\mathrm{O}$ infortúnio manifesta-se também em grandes calamidades. Aos desmandos de Nero juntam-se catástrofes apresentadas como fortuitas, mas que subtilmente são dispostas de modo a acentuar o descrédito do imperador: uma peste, uma derrota na Britânia e uma ignominia no Oriente, com a submissão das legiões ao jugo, e quase a perda da Síria. ${ }^{11}$ São obra da mala fortuna, resultado

(Aug. 19.1) e não se lhe conhece o destino; a filha dela, Emília Lépida, casada com Cláudio, foi repudiada ainda virgem, quod parentes eius Augustum offenderant (Cl. 26. 1), mas não se especifica o tipo de ofensa.

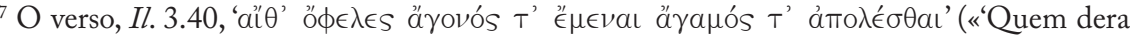
que não tivesses nascido ou tivesses morrido sem tomar mulher'») - palavras de Heitor a Páris

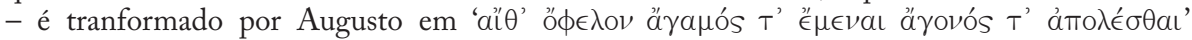
(“'Quem dera que eu tivesse permanecido solteiro ou tivesse morrido sem ter gerado filhos!»). Vide Berthet, J. F. 1978, 317-318.

${ }^{8}$ Tib. 23: Testamenti initium fuit' 'quoniam atrox fortuna Gaium et Lucium filios mibi eripuit, Tiberius Caesar mibi ex parte dimidia et sextante heres esto'. Quo et ipso aucta suspicio est opinantium successorem ascitum eum necessitate magis quam iudicio, quando ita praefari non abstinuerit.

${ }^{9}$ Tib. 39. É pouco provável que fosse esta a causa, uma vez que Germânico morreu em 19 e Druso em 23. Ora esta partida para a Campânia acontece em 26. Nesta fase Suetónio ainda apresenta Tibério a uma luz favorável; mais tarde (Tib. 51.1) apresentará outra razão para a partida; vide Gascou, J. 1984, 362-364.

${ }_{10}$ Tib. 67.1; cf. Tácito, Ann. 6.6. Trata-se de uma carta para dissuadir o senado de condenar Cota Messalino (cf. Ann. 6.5.2). Mas Tibério gostava de brincar com o senado, como sugere Levick, B. 1999a, 201-202. Uma comparação estilística do texto de Suetónio com o de Tácito pode ler-se em Monti, S. 1953, 141-144.

${ }^{11} \mathrm{~A}$ ordem de apresentação dos desastres é outra que, não a cronológica: o primeiro ocorreu em 65; o segundo provavelmente em 60 e o terceiro em 62. A passagem das legiões sob o jugo é apresentada como um rumor em Tácito, Ann.15.15.2, e a referência à ameaça de perda da Síria 
da infelicitas que marca Nero desde o nascimento. ${ }^{12} \mathrm{E}$ a infelicitas do príncipe cai também sobre os súbditos. Mas a desventura é também consequência de comportamentos criminosos. O topos das Fúrias vingadores parece estar presente. Os tiranos de Suetónio sofrem pesadelos. ${ }^{13}$ A experiência onírica, da tradição épica e trágica, assume um papel de relevo em Suetónio, que, numa carta ao amigo Plínio, se mostra crente nos sonhos (Ep. 1.18.1). Depois de tantas atrocidades, Calígula tinha de ser perseguido pelos fantasmas da sua própria loucura. Coloca-se em cena o sofrimento de quem se sente enlouquecer, sem perder completamente a consciência do seu estado:

Incitabatur insomnio maxime; neque enim plus quam tribus nocturnis horis quiescebat ac ne iis quidem placida quiete, sed pauida miris rerum imaginibus, ut qui inter ceteras pelagi quondam speciem conloquentem secum uidere uisus sit. Ideoque magna parte noctis uigiliae cubandique taedio nunc toro residens, nunc per longissimas porticus uagus inuocare identidem atque expectare lucem consuerat. ${ }^{14}$

«Era atormentado ao máximo pela insónia; e não conseguia dormir mais de três horas por noite. Mesmo durante esse tempo, o repouso não era tranquilo, antes aterrado por estranhas visões, ao ponto de, entre outras, lhe parecer, certa vez, que via o espectro do mar a falar com ele. Assim, grande parte da noite, farto de estar acordado e de estar deitado, ora sentado na cama, ora vagueando por intermináveis pórticos, costumava continuamente invocar e esperar o dia».

O texto é expressivo devido à riqueza da adjectivação e ao jogo de contrastes, que consegue transmitir a angústia de um espírito agitado que anseia pela aurora. Este contraste começa por ser sugerido, logo no início, pelas formas verbais e depois, em quiasmo, pelos adjectivos: Incitabatur ... quiescebat / placida ... pauida. Há um jogo de contrastes em insomnio... quiete; uigiliae cubandique; residens... uagus; toro... porticus. A ansiedade da espera é sugerida por taedio... inuocare... expectare, mas também pelo superlativo longissimas, que, embora se ligue a porticus, é mentalmente associado à magna pars noctis, expressando assim perfeitamente a extensão do tempo psicológico de quem está ansiosamente à espera.

A conexão trágica é mais nítida no que se refere ao matricídio de Nero. Este é um ser contaminado. Como Orestes e Alcméon, Nero será perseguido pelas Erínias vingadoras. É ele próprio a reconhecer a transposição dos fantasmas da peça para a sua vida: ${ }^{15}$

é infundada. Vide com. de Bradley, K. R. 1978, 237; com. de Warmington, B. H. 1999, 74.

${ }^{12}$ Como afirma, no seu com., Bradley, K. R. 1978, 15, 46, 236 e 248.

${ }^{13}$ Cf. Jul. 45.1; Nero 46.1; Gal. 18.2; Dom. 15.3; exceptua-se Vitélio. Vide intr. ao com. de WARdLE, D. 1994, 73 e com. 332. Mas Vitélio insere-se num período de transição e não terá igual tratamento da parte do biógrafo.

${ }^{14}$ Cal. 50.3. Camus, Caligula I, 11. Martin, R. 1991, 104-105, fala de um desregramento na vida de Calígula que o leva a confundir a noite com o dia, como acontece quando convoca os senadores a meio da noite para assistirem à sua dança (Cal. 54.2). Para Ceausescu, P. 1973, 277, este passo reflecte a ligação de Calígula ao culto de Ísis.

${ }^{15}$ Vide Martin, R. 1991, 264. 
Nec tamen conscientiam sceleris, quanquam et militum et senatus populique gratulationibus confirmaretur, aut statim aut umquam postea ferre potuit, saepe confessus exagitari se materna specie uerberibusque Furiarum ac taedis ardentibus. Quin et facto per Magos sacro euocare Manes et exorare temptauit. Peregrinatione quidem Graeciae et Eleusinis sacris, quorum initiatione impii et scelerati noce praeconis summouentur, interesse non ausus est (Nero 34.4).

«Mas verdade é que o remorso do crime, apesar de aprovado pelas felicitações dos soldados, do senado e do povo, Nero não o pôde suportar, nem nos tempos mais próximos, nem alguma vez mais tarde. Confessou repetidas vezes que era atormentado pelo fantasma da mãe e pelas vergastadas e tochas ardentes das Fúrias. Tentou mesmo, recorrendo ao ritual sagrado de uns magos, evocar os Manes e aplacá-los. Durante a viagem à Grécia, não ousou assistir aos mistérios de Elêusis, de cuja iniciação eram excluídos, pela voz do arauto, os ímpios e os criminosos».

A menção do fantasma e das Fúrias afigura-se-nos simulada por Nero ou ampliada pelo biógrafo, como mais uma forma de assimilar ao imperador histrião os papéis que representa. $\mathrm{O}$ carácter permanente do assombramento conjugado com a vã tentativa de aplacar Manes, facto que nem Tácito nem Díon Cássio referem, ${ }^{16}$ adensa ainda mais a atmosfera trágica pela necessidade de expiar o crime e pela incapacidade de Nero em se purificar. De uma maneira ou de outra, a castradora mãe, que este jovem imperador procurou suprimir, continua presente, mesmo depois de morta, o que contribui para transformar a vida dele numa existência trágica. $\mathrm{O}$ seu destino é ainda marcado por datas funestas que acentuam a expiação dos crimes. Se o biógrafo começara a narrativa da desgraça com a nota de que Nero recebera a notícia da revolta da Gália no mesmo dia em que matara a mãe, sublinha no final que morreu no mesmo dia em que matara a esposa Octávia: os verbos na activa parecem acentuar a culpa. ${ }^{17} \mathrm{O}$ destino tem, de facto, um peso grande nesta vida: a morte é uma necessidade, já marcada pela consciência de uma próxima fatalis hora (Nero 49.2). De facto, antes de morrer, Nero consulta as entranhas das vítimas sem conseguir resultados favoráveis. ${ }^{18}$

Com Otão acontece algo de semelhante. A morte de Galba lança sobre ele uma mancha que exige expurgação:

Dicitur ea nocte per quietem pauefactus gemitus maximos edidisse repertusque a concursantibus bumi ante lectum iacens per omnia piaculorum genera Manes Galbae, a quo deturbari expellique se uiderat, propitiare temptasse; postridie quoque in augurando tempestate orta grauiter prolapsum identidem obmurmurasse: "Tí rá $\rho$

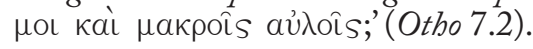

${ }^{16}$ Plínio-o-Velho, Nat. 30.14, diz que Nero foi iniciado na religião dos magos por Tiridates que, na sua visita a Roma, viria acompanhado de alguns.

${ }_{17}$ Nero 57.1: die quo quondam Octauiam interemerat. Cf. Nero 40.4: die ipso quo matrem occiderat. Vide Lounsbury, R. C. 1991, 3756.

${ }^{18}$ Nero 56. 
«Diz-se que naquela noite, durante o sono, lançou enormes gemidos e, depois de ter sido descoberto, pelos que acorreram, caído no solo diante do leito, tentou propiciar, com todo o género de ritos expiatórios, os Manes de Galba, por quem se vira ser precipitado e expulso; que, no dia seguinte, quando tomava os augúrios, como se levantou uma tempestade, ele, caindo pesadamente por terra, murmurava sem cessar: 'para que queria eu grandes flautas?'».

A referência proverbial às grandes flautas sugere que se trata de uma tarefa para a qual Otão não estava capacitado. A actividade bélica de Otão começara sob uma má estrela. $\mathrm{O}$ biógrafo nota que expeditionem autem inpigre atque etiam praepropere incohauit, nulla ne religionum quidem cura $^{19}$ («a expedição começou de modo diligente e até demasiado apressado, e mesmo sem nenhuma preocupação religiosa»), num crescendo de gravidade. A tónica é colocada no desrespeito pela religião, nos auspícios desfavoráveis e nos sinais ominosos: nos exemplos que ilustram estes três aspectos ressaltam as ideias de interdição (os escudos de Marte estavam ainda fora do seu sítio; as cheias do Tibre impediam a passagem) e morte (lamentos pela morte de Átis, amado de Cíbele; auspícios favoráveis de Plutão).$^{20} \mathrm{~A}$ sentença é clara para quem toma uma iniciativa que lhe foi interdita. O desrespeito pela religio marcara já a entrada de Júlio César na reunião do senado nos Idos de Março (Jul. 81.4).

Suetónio, segundo o seu habitual gosto, fundamenta numa explicação romanesca o insucesso do golpe militar de Fúrio Camilo Escriboniano contra Cláudio. Os soldados são dominados por um medo supersticioso, por terem mudado o juramento de fidelidade (sacramentum): é que no momento de começarem a marcha não foram capazes de ornar uma águia nem de arrancar do lugar as insígnias. ${ }^{21} \mathrm{O}$ biógrafo sugere que se tratou de um acaso e da vontade divina (casu quodam ac diuinitus). A entronização de Cláudio ficou a dever-se a um acaso - mirabilis casus - (Cl.10.1) e a sua manutenção no poder fica a dever-se a outro acaso. Isto pode tornar-se providência. ${ }^{22}$

Tibério, que recorria aos conselhos do astrólogo Trasilo, estava convencido de tudo era governado pelo destino (Tib.69). Este fatalismo está presente na constatação que encerra a vida de Calígula: todos os Césares, cujo primeiro nome fosse Gaio, morreram assassinados. ${ }^{23}$ Também Tito advertirá uns

${ }^{19}$ Otho 8.3. Cf. Tácito, Hist. 1.89.3.

${ }^{20}$ Otho 8.3 (...) sed et motis necdum conditis ancilibus, quod antiquitus infaustum habetur, et die, quo cultores deum Matris lamentari et plangere incipiunt, praeterea aduersissimis auspiciis. Nam et Diti patri caesa litauit, cum tali sacrificio contraria exta potiora sint, et primo egressu inundationibus Tiberis retardatus ad uicensimum etiam lapidem ruina aedificiorum praeclusam uiam offendit.

${ }^{21}$ Cl. 13.2. Segundo Díon Cássio, 60.15.1ss, a resistência dos soldados nada teve que ver com o prodígio, antes se ficou a dever ao facto de Camilo pretender restaurar a República. É de salientar o silêncio de Suetónio em relação ao acto heróico de Árria que se suicida para incentivar o marido, Cecina Peto, implicado na conjura, quando tal suicídio foi celebrado por vários autores: Marcial, 1.13; Plínio, Ep. 3.16.7ss; Díon Cássio, 60.16.5ss. Suetónio segue a sua técnica de se centrar na figura principal, rejeitanto os factos que não digam directamente respeito ao seu biografado e possam desviar a atenção do leitor.

${ }_{22}$ É o que pensa Vigourt, A. 1993, 140-141.

${ }^{23}$ Exagero: Júlio César pai morreu naturalmente, tal como Augusto, e o irmão mais velho de 
conspiradores de que é ao fatum que cabe a tarefa de conceder o principado (Tit. 9.1). A noção do fatum como determinante da chegada ao Império era comprovada pelo advento dos Flávios, família humilde e sem ambição.

O essencial é conhecer antecipadamente o seu destino, como acontecia com Augusto. Mas para isso é preciso estar atento aos sinais e acreditar neles. Mesmo em relação a Nero, considerado religionum contemptor (Nero 56), se refere, na parte positiva da Vida, a obediência a presságios: cancela uma viagem a Alexandria porque ficou preso pela orla da toga no templo de Vesta e porque a seguir se formou uma bruma densa. ${ }^{24} \mathrm{O}$ fundador do principado manifesta crença nos sonhos (é salvo por um em Filipos), nos auspícios e nos prodígios (Aug. 91-92), característica que lhe confere uma sabedoria oracular.Mostra uma confiança tal no seu destino, que faz publicar o seu horóscopo e cunha moedas de prata com o signo de Capricórnio, sob o qual nascera. Facto estranho para quem nasceu em Setembro, mas o biógrafo não o questiona. ${ }^{25}$ Vários prodígios anunciaram a Augusto o desenlace de todas as guerras (Aug. 96.1) - na batalha de Filipos é o próprio fantasma de César a anunciar a vitória a um tessálio; ${ }^{26}$ em Perúsia, os inimigos roubaram as vítimas dos sacrifícios e, com elas, os presságios desfavoráveis; nas vésperas da batalha da Sicília, um peixe saltou do mar e lançou-se aos pés de Octávio; em Áccio, apareceu-lhe no caminho um burriqueiro chamado Êutico ('afortunado') com um burro de nome Nícon ('vencedor'), pelo que lhes erigiu uma estátua, depois da vitória. ${ }^{27} \mathrm{Da}$ mesma forma, conhece antecipadamente a sua morte e divinização ${ }^{28}$ - fica a saber que viveria mais cem dias. Pressagas são também as suas próprias palavras: 'non, si omnia morarentur, amplius se posthac Romae futurum' (Aug. 97.3) ("ainda que tudo o atrasasse, não ficaria, de seguida, mais tempo em Roma'»).

O próprio Domiciano, na fase positiva da Vida, tem notícia, através de presságios, da vitória sobre o ciuile motum, comandado por Lúcio António Saturnino, antes da chegada dos mensageiros a Roma (a revolta é sufocada in

Gaio Calígula; vide Wardee, D. 1994, 372; Hurley, D. W. 1993, 217.

${ }^{24}$ Nero 19.1. Tácito, Ann. 15.36.2, dá uma versão diferente, com Nero trémulo devido à presença da divindade ou à lembrança dos seus crimes. A superstição de Nero provirá da mãe, que consultava os astrólogos em momentos decisivos: vide Martin, R. 1991, 339.

${ }_{25}$ Aug. 94.12. Segundo Néraudau, J.-P. 1996, 20-21, o facto de Augusto não querer renunciar a nenhum dos signos - o Capricórnio, signo comum de Rómulo e de Roma e sob o qual Augusto fora concebido (em Dezembro) e a Balança, signo sob o qual nasceu e símbolo da justiça -, leva Suetónio a colocar o signo de Capricórnio em Setembro.

${ }^{26}$ Aug. 96.1. Em Díon Cássio, 47.41.2, o fantasma não anunciou a vitória, mas que a batalha se travaria no dia seguinte. Parece que Suetónio transformou em presságio de vitória a visão do tessálio, a fim de provar a tese com que inicia o parágrafo: Quin et bellorum omnium euentus ante praesensit. Vide Gascou, J. 1984, 181-182.

${ }^{27}$ Aug. 96.2. Admira-se menos a subtileza dos deuses do que a argúcia de Augusto em perceber a mensagem de um presságio como o do burriqueiro, observa NéraUdAu, J.-P, 1996, 138. O texto de Plutarco, Ant. 65.5, vem, em alguns códices, acompanhado de um escólio que identifica este grupo escultórico com o existente no hipódromo de Bizâncio, para onde teria sido transferido de Nicópolis. Esta notícia é confirmada por fontes bizantinas: vide MaNfRedini, M. 1986, 481-483.

${ }^{28}$ Aug. 97.1: Mors quoque eius, de qua dehinc dicam, diuinitasque post mortem euidentissimis ostentis praecognita est. 
loco por um imprevisto degelo, que faz subir o Reno e assim impede os reforços bárbaros de se reunirem ao revoltoso): uma águia enorme abraçou uma estátua de Domiciano com as asas e lançou gritos de grande alegria (Dom. 6.2).

O biógrafo refere a opinião de alguns de que Tibério conhecia antecipadamente toda a sua acerbitas et infamia ${ }^{29}$ e que daí resultava recusa do título de Pai da Pátria e do juramento pelos seus actos. Desta opinião se apropria o biógrafo ao juntar-lhe, como provas documentais, as próprias palavras do imperador, onde este expressava o receio de, contra a sua vontade, poder vir a mudar os mores, se um acaso afectasse a sua sanidade mental. ${ }^{30}$ Trata-se de uma manifestação de modéstia de circunstância lida à luz do que depois se passou. Está presente no discurso uma noção de destino, como um determinismo do casus ${ }^{31}$ e a preocupação de Tibério de que se mantenha o bom conceito do si. Suetónio, para acentuar a mudança no comportamento do príncipe, sugere que aqueles votos eram, então, sentidos, mas apresenta-os numa altura da Vida em que já se sabe que houve realmente mudança: o desenvolvimento dado ao carácter permite verificar que os receios do imperador se concretizaram; mas já nada se pode fazer. Fica ainda a interrogação sobre se tais palavras não seriam mais um sinal do sarcasmo de Tibério, conhecedor da opinião que já dele teriam os senadores.

O conhecimento prévio do destino está também patente nas últimas palavras da biografia de Cláudio, em que as suas afirmações assumem uma toada trágica, contrastante com o resto da Vida: afinal o imperador, que passava por tonto, mostra-se perfeitamente consciente da proximidade do fim da sua vida mortal (Cl. 46).

Podemos perguntar a razão por que coloca Suetónio tais presságios depois da morte e em final absoluto (só em quatro Vidas figuram depois da morte e só em três em final absoluto). O certo é que, deslocando para aqui esta rubrica, o biógrafo obtém um efeito que obriga o leitor a repensar a imagem de Cláudio. O maior presságio - destacado dos anteriores com sed - são as suas palavras e o facto de ser ele próprio a profetizar o seu fim: o que torna patente o seu sofrimento. ${ }^{32}$ No final desta Vida, o biógrafo concede a Cláudio a dignidade que the negara ao longo dos capítulos anteriores.

Os grandes acontecimentos são precedidos de sinais, reconhecidos no momento em que se cumprem. Fenómenos indicadores de boa ou má fortuna são inseridos nos momentos fulcrais da vida, em que a cronologia tem algum peso para o biógrafo: sobretudo o nascimento, a chegada ao trono imperial e a

${ }^{29}$ Tib. 67.2: Existimant quidam praescisse haec eum peritia futurorum ac multo ante, quanta se quandoque acerbitas et infamia maneret.

30 Tib. 67.4: 'Si quando autem, inquit, de moribus meis deuotoque uobis animo dubitaueritis, quod prius quam eueniat, opto ut me supremus dies huic mutatae uestrae de me opinioni eripiat-, nibil honoris adiciet mihi patria appellatio, nobis autem exprobrabit aut temeritatem delati mibi eius cognominis aut inconstantiam contrarii de me iudicii'.

${ }^{31}$ Tib. 67.3: 'quia aliquo casu mutari posset'.

${ }^{32}$ Martin, R. 1991, 357-361, fala de morte por desgosto da vida e agravamento do estado de saúde. 
morte, mas também o momento da assunção da toga viril, do primerio consulado ou outros marcos que se afigurem relevantes para cada Vida. Suetónio interpreta como sinal de prosperidade um círculo em volta do sol, em dia de céu limpo, como um arco-íris, à chegada de Octávio de Apolónia. ${ }^{33} \mathrm{E}$, como Augusto é o novo Rómulo, o novo fundador mítico, no seu consulado, durante a consulta aos augúrios, doze abutres se mostraram, como outrora a Rómulo. ${ }^{34}$

Os imperadores são seres situados no tempo e integram-se numa sucessão previamente determinada, por vezes há séculos. As listas de prodígios tem em vista sobretudo a ascensão ao governo do Império e a perda do poder ${ }^{35}$. Imperadores como Augusto, Galba ou Vespasiano, segundo os presságios apresentados, ${ }^{36}$ estão há muito tempo fadados para a sua missão. Estes representam o início de três ciclos diferentes na história de Roma Imperial. A chegada de tais imperadores aparece como a realização daqueles presságios, indicando que o tempo se cumpriu. A repetição de fenómenos reforça a ideia de predeterminação de um acontecimento. Os presságios preanunciam o facto e o facto confirma os presságios. Depois de se realizarem, presságios e facto são interpretados em conjunto. ${ }^{37}$

O exemplo mais notável é o de Augusto. A mitificação de que foi alvo projecta-se retroactivamente no tempo. ${ }^{38}$ A species, apresentada já perto do final da $V i d a$, adquire o aspecto de uma longa analepse (Aug. 94-97), em que Suetónio retoma elementos desde o início da vida e mesmo antes de esta ter início. O fundador do principado é integrado numa perspectiva messiânica, como um esperado. A sua vinda foi profetizada desde tempos antigos, a partir de um raio que caiu em Velitras, o que se pode relacionar com o seu medo dos trovões e a preocupação em erigir um templo ao Tonante. Júlio Márato fala de um prodígio ocorrido em Roma que pressagiava um rex, facto que serve implicitamente o propósito de apresentar Augusto como sobrevivente de um massacre dos inocentes (num paralelo com o próprio Jesus Cristo), uma vez que o senado determinara que nenhum menino naquele ano fosse criado (Aug. 94.2-3). A concepção de Augusto é explicada teologicamente e ligada a Apolo através de uma serpente que se introduzira na liteira de Ácia, quando esta praticipava numa cerimónia nocturna no templo do deus. A natureza divina do imperador é ainda reforçada por um sonho de Ácia grávida, em que via as suas entranhas serem elevadas aos astros e estenderem-se a toda a volta da terra e do céu, e outro do pai Octávio, em que do ventre da esposa saía a luz do sol. ${ }^{39}$

${ }^{33}$ Aug. 95. Ao passo que Díon Cássio, 45.4.4, o considera sinal de problemas para os Romanos; vide Gascou, J. 1984, 356.

${ }^{34}$ Aug. 95. Provavelmente uma encenação de Augusto; vide Southern, P. 1998, 50 e n. 6, p. 214-215.

${ }^{35}$ Vide Wallace-Hadrill, A. 1984, 191-192.

${ }^{36}$ Aug. 93.1ss; Gal. 9.2; Ves. 4.5.

${ }^{37}$ Vide Vigourt, A. 1993, 135-136.

${ }^{38}$ Aug. 94.1: Et quoniam haec uentum est, non ab re fuerit subtexere, quae ei prius quam nasceretur et ipso natali die ac deinceps euenerint, quibus futura magnitudo eius et perpetua felicitas sperari animaduertique posset.

39 Aug. 94.4. Cf. Díon Cássio 45.1. Apolo é o oposto de Dioniso, a quem António está 
Esta lenda segue o topos da concepção divina de vários heróis, entre os quais Alexandre Magno, cuja mãe teria também sido visitada por uma serpente durante a ausência do marido. ${ }^{40}$ Também os prodígios que Suetónio relata a seguir têm como destinatário o pai, Octávio: pelas palavras do senador P. Nigídio, adepto do pitagorismo e especialista em astrologia, fica a saber que Augusto, dada a hora do parto, é o predestinado dominus terrarum; pelos sacerdotes trácios tem a confirmação, quando ao derramar vinho sobre o altar, as chamas subiram tão altas, como só acontecera com Alexandre. ${ }^{41}$

Augusto é ainda associado a Júpiter Óptimo Máximo, num sonho do pai, e ao Sol, na anedota de que, quando menino, desaparecera uma noite do berço e que foi no dia seguinte encontrado, numa alta torre, de rosto voltado para o sol nascente. Com esta assimilação ao astro rei ganha significado a informação dada no início da Vida: nasceu pouco antes do nascer do sol. ${ }^{42} \mathrm{O}$ seu poder manifesta-se sobre a natureza: a força da sua palavra - cum primum fari coepisset - faz calar as rãs; e uma águia, símbolo de Júpiter, devolve-lhe o pão que lhe arrebatara (Aug. 94.7). São ainda referidos os sonhos de Q. Cátulo e Cícero sobre o favorecimento de Júpiter a um menino e o reconhecimento deste na pessoa de Octávio, ${ }^{43}$ e outros sinais reveladores da futura glória. Os acontecimentos mais salientes da vida de Augusto, a começar pela tomada da toga viril, são retomados numa óptica sobrenatural, acompanhados dos respectivos prodígios (Aug. $94.10 \mathrm{ss}$ ).

Os presságios do império, numerosos na Vida de Galba, ${ }^{44}$ incluem palavras do próprio fundador do principado ${ }^{45}$ (o que é irónico, se considerarmos que Galba é o principal agente do fim da dinastia júlio-cláudia) e de Tibério, ${ }^{46}$ que o dá como imperador numa idade avançada. Algo de semelhante se passa com Vespasiano, fundador da dinastia flávia (Ves.5). A luta pelo poder é sancionada por uma actividade taumatúrgica (Ves. 7.2-3) que confere a Vespasiano uma aura messiânica.

ligado; vide Néraudau, J.-P. 1996, 121.

${ }^{40}$ Cf. Plutarco, Alex. 2.6-3.2. Para outros heróis foi usado o mesmo topos: do lado grego, Aristómenes e Arato (Pausânias, 4.14.4-7); do lado romano, Cipião, o Africano (Tito Lívio, 29.19.6; Sílio Itálico, 13.634-644; Aulo Gélio, 6.1-5).Vide Martin, R. 1991, 329-330; Lorsch, R. S. 1997, 790-799.

${ }^{41}$ Aug. 94.5. Vide Néraudau, J.-P. 1996, 39-43.

${ }^{42}$ Aug. 94.6: (...) repertus est iacens contra solis exortum; cf. Aug. 5: Natus est... paulo ante solis exortum. Segundo Grimal, P. 1986, 737, há uma aplicação a Augusto da união ao disco solar, praticada pelos faraós, que anuncia a predestinação divina do imperador e, portanto, esta lenda só poderia ter aparecido depois da integração do Egipto no Império.

${ }^{43}$ Aug. 94.8-9. Na opinião de NÉRAUdAu, J.-P. 1996, 69-70, o inventor desta história mostra atrevimento e cinismo, ao fazer aparecer o poder de Augusto no imaginário onírico de Cícero, que, na República aconselha a colocar os destinos da República romana sob os desígnios de um princeps, título que Augusto assumirá mais tarde, mas em concepção do poder oposta à do orador. Se é que Cícero não evitou esta palavra: vide Rocha Pereira, M. H.2002, 149.

${ }^{44}$ Vide Gascou, J. 1984, 447-450.

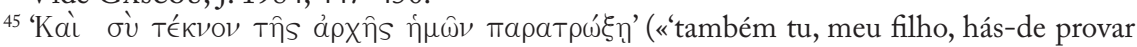
do nosso poder’») (Gal. 4.1). Tácito, Ann. 6.20.2, e Díon Cássio, 57.19.4, atribuem a frase a Tibério.

${ }^{46}$ Sed et Tiberius, cum comperisset imperaturum eum uerum in senecta: 'uiuat sane', ait, 'quando id ad nos nibil pertinet (Gal. 4.1). Cf. Díon Cássio, 57.19.4. 
Augusto, Galba e Vespasiano apresentam-se como fundadores de dinastias, embora Galba tenha falhado. Mas também Tibério (Tib. 14), Cláudio (Cl. 7), Otão (Otho 4.1) e Tito (Tit. 5.1-2) são favorecidos por presságios que lhes asseguram o império.

Parece pouco provável que Suetónio, até pela proveniência dos relatos de que dispunha, se não apercebesse do carácter fabricado destes elementos. O sacrílego festim dos deuses, em que Augusto se travestiu de Apolo (Aug. 70.1), deixa a suspeita de que a sua crença não seria sincera; e Vespasiano troça da sua futura apoteose (Ves. 23.4). Os prodígios são mitificação operada pela propaganda política. Mas Suetónio, longe de mostrar cepticismo, transpõe, do plano da história para o da narrativa a ilusão criada. Se esta imagem de Augusto não é real historicamente, é-o na narrativa de Suetónio: uma narrativa marcadamente "religiosa", que religa o plano divino e o humano, como na tradição épica e trágica.

Outra série importante de presságios anuncia a morte dos imperadores e está presente em todos sem excepção. ${ }^{47}$ Mas onde a contagem decrescente do tempo, marcada por presságios, se torna mais dramática é nos relatos das mortes violentas, como veremos à frente.

Os sinais do destino ultrapassam as Vidas individuais. A prosperidade e queda da dinastia júlio-cláudia é indicada por signa euidentissima. O biógrafo recua ao momento da fusão dos Júlios com os Cláudios, pelo casamento de Augusto e Lívia. ${ }^{48}$ Nessa altura, uma águia - ave associada amiúde por Suetónio ao poder supremo ${ }^{49}$ - deixou cair no regaço de Lívia uma galinha branca com um ramo de louro no bico. Lívia alimentou a galinha, que se tornou a matriarca de uma longa prole, e plantou o ramo de louro, que se expandiu e se tornou a fonte dos louros para o triunfo dos Césares. ${ }^{50}$ Observou-se que, por altura da morte de cada um, murchavam as pernadas que tinha plantado e, no ano da morte de Nero, todo o bosque secou e todas as galinhas morreram. Suetónio parece exagerar, na procura de maior efeito. ${ }^{51}$ Além disso, o templo dos Césares

${ }^{47}$ Jul. 81; Aug. 97; Tib. 74; Cal. 57; Cl. 46; Nero 46; Gal. 18; Otho 8.3; Vit. 9 e18; Ves. 23.4; Tit. 10.1; Dom. 15.2-3, 16.1; 23.2.

${ }^{48}$ Vide com. de Murison, Ch. L. 1992, 26.

${ }^{49}$ Cf. Aug. 94.7; 96.1; 97.1; Tib. 14.4; Cl. 7; Gal.4.2; Vit. 9; Ves. 5.7.

${ }^{50}$ Plínio, Nat. 15.136-137, diz que são os harúspices que aconselham Lívia a preservar a galinha e a sua descendência e a cuidar religiosamente do ramo. Para FLORY, M. B. 1988-1989, 343-356, trata-se de uma manobra da propaganda de Augusto para fazer face à hostilidade pública. Segundo Díon Cássio, 41.39.2, também na altura em que Júlio César se preparava para a campanha contra Pompeio, no final de 49 a. C., um milhafre deixou cair um ramo de louro sobre um dos homens que estavam com ele no Foro. O prodígio teria inspirado Octávio a imitá-lo uma década mais tarde, quando estava em guerra com Sexto Pompeio: um conflito que tinha tornado o herdeiro de César impopular pelo embargo no fornecimento de trigo. Além disso, era uma forma de legitimar o casamento com Lívia, que seria escandaloso (Lívia era casada e estava grávida de seis meses) e levantaria rumores, como prova o facto de António encontrar no facto motivo para a sua propaganda.

${ }^{51}$ Segundo o com. de Murison, Ch. L. 1992,27, Suetónio entra aqui no domínio da fantasia, uma vez que tal afirmação é desautorizada por Plínio, Nat. 15.137: ... traditusque mos est ramos quos tenuerant serendi et durant siluae nominibus suis discretae. 
foi atingido por um raio (tacta de caelo), tombaram as cabeças das estátuas e o ceptro foi arrebatado das mãos da de Augusto. $\mathrm{O}$ simbolismo é evidente.

A Vida de Vitélio termina com a revelação do significado do presságio occorido em Viena: o facto de um galo ter saltado para o ombro e para a cabeça do imperador (Vit. 9), significava que este cairia às mãos de um gaulês. Com efeito, foi derrotado por António Primo, que nascera em Tolosa e tivera na infância a alcunha de Beccus ('bico de galo'). ${ }^{52}$ Como no caso de Cláudio, pelo facto de se deslocarem para final absoluto, os presságios de morte parecem adquirir um relevo especial. Ao apresentar, no final, a chave de leitura do presságio, Suetónio dá maior unidade à biografia e aumenta a influência do fatum sobre a vida e morte de Vitélio. Este sétimo livro (constituído pelas Vidas de Galba, Otão e Vitélio) começa e termina com presságios onde as aves (galináceos) têm papel relevante, o que revela a importância destes auspícios na história romana. Neste caso, delimitam um período de guerras civis de 68-69 d.C.

A Vida de Vespasiano termina com a referência à intenção dinástica deste imperador e ao papel do fatum nessa iniciativa. Tal é a crença nas predições astrológicas, que Vespasiano parece não temer as constantes conspirações ${ }^{53}$ ao ponto de ter a ousadia de afirmar no senado que 'aut filios sibi successuros aut neminem $^{54}$ («'ou os filhos lhe sucederiam ou ninguém'»). Por último, narra-se um sonho do imperador, em que este via no seu átrio uma balança: num dos pratos, Cláudio e Nero, e no outro, Vespasiano e os filhos. Tal sonho revela-se verdadeiro, uma vez que uns e outros governaram por igual tempo. ${ }^{55} \mathrm{~A}$ Vida de Vespasiano conclui-se assim com um sonho do próprio sobre a sua dinastia, mas fica já implícito o fim desta, uma vez que o tempo de governo dos descendentes é bem delimitado. A conjugação do fatum e do tempo contribui para a tensão que se adensa no final deste ciclo de Vidas. Tal pressão cronológica do fatum irá intensificar-se, como é natural, com a aproximação do fim do tempo do último dos Flávios: Domiciano. Tal como a Vida de Vespasiano, também a de Domiciano termina com um sonho. Mas se o sonho do primeiro delimitava o tempo de governação dos filhos, o de Domiciano promete, sem limitações de tempo, um futuro próspero: uma espécie de idade de ouro. ${ }^{56}$

Com a referência, algo adulatória e vaga, aos príncipes seguintes, o biógrafo termina, de forma optimista, três ciclos de vidas sangrentas, apontando para um recomeço: como que a dizer que, depois destas doze Vidas, se não

${ }^{52}$ Vit. 18.... id ualet gallinacei rostrum - explica o biógrafo, para quem é mais importante este pormenor do que a batalha de Cremona (não mencionada), onde António Primo foi vencedor. Vide Gascou, J. 1984, 358-359.

${ }^{53}$ Vide Martin, R. 1991, 341. Assiduas in se coniurationes parece exagero do biógrafo. A única que conhecemos é a de 79, protagonizada por A. Cecina Alieno e Éprio Marcelo.

${ }^{54}$ Cf. Díon Cássio, 66.12.1. Para Murphy,J.P.1991, 3784, Vespasiano é uma pessoa directa, que diz o que pensa. Díon fala de um só filho, pelo que é possível que o plural filios sibi successuros, em Suetónio, seja uma alteração da época de Domiciano, não acolhida pelo historiador grego; vide com. de CESA, M. 2000, 98.

${ }_{55}$ Ves. 25: Nec res fefellit, quando totidem annis parique temporis spatio utrique imperauerunt.

${ }^{56}$ Dom. 23.2. Vide Baldwin, B. 1983, 491. 
repetiram os mesmos erros. A profecia de Domiciano cumpre-se na actuação dos Antoninos. Mas este optimismo final não arreda um conceito determinista da história e da vida dos homens. O destino parece determinar a o carácter do imperador, com consequências morais. Tibério está, desde logo, acorrentado à sua saeua ac lenta natura (Tib. 57.1), Calígula à natura saeua atque probrosa (Cal. 11), Nero à infelicitas (Nero 6.2), Vitélio a um mau horóscopo (Vit. 3.2). Os imperadores parecem em última análise ser joguetes dos deuses. Embora os tiranos possam ser, no final castigados pelos seus vícios,${ }^{57}$ fica a ideia de que dificilmente poderiam agir de outro modo. Se tentam fugir ao destino, a natura acaba por falar mais alto e o período incial de felicidade é substituído por um regime de terror.

\subsection{Carácter e progressão dramática}

As Vidas não estão organizadas por simples acumulação de materiais exemplificativos das rubricas. O biógrafo manifesta claramente o intuito de criar uma imagem que só se apresenta completa no final. $\mathrm{Na}$ fase do governo dos imperadores, vamos encontrar características que já se apresentavam em germe no relato das actividades que antecederam a chegada ao poder e que serão completadas (confirmadas ou postas em causa) na narrativa da morte. O biógrafo procura fazer análise o mais completa possível do biografado. $\mathrm{O}$ carácter dos imperadores é avaliado quer pela sua actividade governativa, quer pela vida privada. A descrição dos feitos do governante vai submeter-se não tanto a critérios cronológicos, mas sobretudo éticos. Uma vez que se trata de ilustração de vícios e virtudes, a progressão procurada tem a ver com a intensidade de determinado traço moral.

\subsubsection{Construção da imagem de um tirano}

Assegurado o poder de César, sem rivais, Suetónio passa a descrever a tarefa administrativa ( $J u l .40-44)$ e sugere o carácter imediato do empreendimento. ${ }^{58}$ Entre a magnitude dos projectos (que incluem a abertura do istmo de Corinto e a guerra aos Partos, sintomáticos do carácter de César ${ }^{59}$ e sonho de outros tiranos posteriores), surge a primeira referência à morte, como desaire que vem cercear tais planos. ${ }^{60}$ Mas, cumprido o curso da vida, muito há ainda para dizer. Entramos na parte organizada por rubricas: ${ }^{61}$ descrição física e cuidados corporais ( $\mathrm{Jul} .45 .1-2)$, vestuário ( $\mathrm{Jul}$. 45.3), tendência para o fausto e desbaratamento (Jul. 46-47), disciplina doméstica (Jul. 48), impudicitia (Jul.

${ }^{57}$ Situação claramente difinida no que respeita a Domiciano (Ves. 1.1: ... licet Domitianum cupiditatis ac saeuitia merito poenas luisse), mas igualmente sugerida em outros passos: Jul 76.1; Cal. 56.1; Nero 40.1; Galba 16.1; Vit.17.2; Dom.14.1.

${ }^{58}$ Jul. 40.1: Conuersus binc ad ordinandum reipublicae statum...

${ }^{59}$ Jul. 44.3. Vide McDermotт, W. C. 1982-1983, 223-231.

${ }^{60} \mathrm{Jul}$. 44.4: Talia agentem atque meditantem mors praeuenit.

${ }^{61} \mathrm{Jul}$. 44.4: De qua prius quam dicam, ea quae ad formam et habitum et cultum et mores, nec minus quae ad ciuilia et bellica eius studia pertineant, non alienum erit summatim exponere. 
49), adultérios (Jul. 50-52), moderação no vinho e na comida (Jul. 53), falta de abstinentia nos cargos civis e militares (Jul.54), eloquência e actividade militar (respectivamente, Jul. 55-56 e 57-70), dedicação e fidelidade para com os clientes (Jul.71), afabilidade para com os amigos (Jul. 72), prontidão a perdoar as ofensas (Jul. 73), suavidade na vingança (Jul. 74), moderação e clemência (Jul.75). Nesta imagem de cambiantes há aspectos bastante positivos que distinguem nitidamente César dos outros tiranos: as qualidades da fides ('fidelidade'), da facilitas ('bondade'), do perdão e, no clímax, uma extraordinária clemência, ${ }^{62}$ comprovada com vários exemplos. No que respeita à descrição física e aos cuidados com o corpo e com o vestuário, destaca-se o carácter efeminado, consonante com a já analisada narrativa da ligação com Nicomedes (Jul. 49). O abuso das matronas, característico dos tiranos, inicia a descrição dos adultérios, ${ }^{63}$ aos quais se associa a sumptuosidade, pelos donativos à amante Servília (Jul.50.2), pelos gastos com as mulheres das províncias, como entoam os soldados no triunfo, ${ }^{64}$ pelos donativos à rainha Ênoe e pela vida faustosa em companhia de Cleópatra (Jul.52.1). A consequência normal do fausto é a falta de abstinentia (Jul. 54.1), que culmina em rapina e sacrilégio (Jul. 54.2). Entre as características dos tiranos figuram, como se verá melhor nos casos de Tibério, Calígula e Nero, a prepotência no domínio sexual, materializada no abuso de mulheres e homens livres, e comportamentos homossexuais passivos (impudicitia).

Mas César é apresentado acima de tudo como um homem de acção. $\mathrm{Na}$ rubrica do manejo das armas e equitação, a descrição ganha movimento acentuam-se as virtudes do soldado e do general numa cinemática gradação de façanhas que ilustram a resistência e velocidade no avanço (Jul. 57), cautela e a audácia (Jul.58.1-2), desafio aos deuses e aos presságios desfavoráveis (Jul. 59), temeridade e coragem (Jul. 60; 62-64). Apesar de se tratar de rubricas, os exemplos apresentados transformam a descrição em narrativa dinâmica que sugere o carácter de excepção da personalidade de César. Suetónio procura mostrar que César é um bom general que mantém a disciplina (Jul. 65), que é tolerante nas faltas e rigoroso com desertores e revoltosos (Jul. 67.1), pelo que gera soldados devotados e fortíssimos (Jul. 68). Mas um bom general não será necessariamente um bom governante. Intercalada, surge a descrição do cavalo (Jul. 61): um animal de pés quase humanos, que não tolera outro cavaleiro, complementa a imagem de um general. Mas o facto de César o criar com cuidado, porque os harúspices tinham prognosticado para o seu dono o imperium orbis terrae, diz muito do carácter de César. Parece haver aqui uma imitação de Alexandre, que César admirava. Há uma reminiscênica do famoso cavalo do macedónio: Bucéfalo. ${ }^{65}$

${ }^{62} \mathrm{Jul}$. 75.1: Moderationem uero clementiamque cum in administratione tum in uictoria belli ciuilis admirabilem exbibuit.

${ }^{63} \mathrm{Jul}$. 50.1: Pronum et sumptuosum in libidines constans opinio est, plurimasque et illustres feminas corrupisse.

${ }^{64}$ Jul. 51: Aurum in Gallia effutuisti, bic sumpsisti mutuum.

${ }^{65}$ Cf. Plutarco, Alex. 61. 
A ausência de temor religioso, ao ponto de subordinar a religião aos seus objectivos (Jul. 59), sugere insolência. Mas a alternância de traços de carácter muito negativos com outros muito positivos fazem de César, em parte um tirano, em parte um bom governante. Se partilha com os tiranos a inciuilitas, que lhe causará a morte ( $u$ ul. 76 ss), a sumptuosidade, a irreligiosidade, a homossexualidade e o abuso de matronas, distingue-se, além da clementia, pela moderação na comida e na bebida - traço que o afasta da moleza decadente dos tiranos nédios e é consonante com a austeridade do general.

No caso dos maus imperadores, observa-se uma progressão para o vício e em último lugar tendem a aparecer os comportamentos mais horrendos. Os piores tiranos são aqueles em que se observa uma progressão mais marcada. No caso de Tibério, a progressão para a tirania é inequívoca. As gradações presentes nesta Vida sugerem um protótipo da criação da imagem do tirano detestado e temido, cruel e temeroso de revoltas. Depois do começo feliz do principado, o biógrafo introduz uma mudança, assinalada por paulatim, no comportamento do imperador. Começa a manifestar-se o princeps (aqui entendido no sentido de tendência para a tirania), embora de modo variado e ainda inclinado sobretudo para o bem público; e nota-se já o aumento de rigor na aplicação da lei. $O$ déspota começa a crescer: ${ }^{66}$ passa a governar com maior firmeza e determinação, como revelam as medidas de contenção das despesas (Tib.34), que seriam impopulares. A repressão mostra já plena força com a proibição dos ritos egípcios e judaicos e recrutamento e envio dos jovens judeus para regiões de pior clima, bem como expulsão dos astrólogos. ${ }^{67}$ Atinge-se o auge desta fase com as medidas para a restauração da ordem, ilustrada com vários acontecimentos. Exemplar é a repressão da exploração, por parte da plebe de Polência, do evergetismo dos herdeiros de um primipilo, mediante a retenção do seu funeral no foro. ${ }^{68}$ Suetónio, ao querer mostrar a desproporção do uso da força (duas coortes entram na cidade de espada em riste e ao som de clarins), parece exagerar, quando diz que Tibério «lançou na prisão, para o resto da vida, a maior parte da plebe e dos decuriões».

Entramos numa fase de visível transição (Tib. 38-40). Suetónio, acaso para acentuar a inconsequência do príncipe (de futuro, a ausência de Roma será perpétua), lembra que ele, durante dois anos, não se ausentou de Roma, embora anunciasse e preparasse contínuas viagens: de modo que já lhe chamavam «Calípides», nome porque era designado, num provérbio grego, alguém que corria sem sair do sítio (Tib. 38). Mas, quando se ausenta para a Campânia (Tib.39), surgem os rumores de que nem voltaria a Roma nem viveria muito mais. Suetónio, além de acentuar que o primeiro presságio se cumpriu, centra-se na forma milagrosa (praeter spem) como o imperador evitou por pouco o segundo, ao escapar ileso de uma derrocada na gruta de Spelunca.

${ }_{66}^{6}$ Tib. 33. Vide Giua, M. A. 1978, 331; ID. 1991, 3736.

${ }^{67}$ Tib. 36. A razão da expulsão dos judeus seria a desaprovação do proselitismo, segundo pensa Smallwood, E. M. 1956, 314-329.

${ }^{68}$ Tib. 37.3. Vide Sartori, A. 1990, 687-697. 
Suetónio gosta de explorar estes acasos que por pouco não mudaram o decurso da história, mas não retira as ilações políticas de tal evento. ${ }^{69}$

O biógrafo procura acentuar a crescente misantropia do imperador. Consagrar um templo a Júpiter Capitolino em Cápua e outro a Augusto em Nola,${ }^{70}$ era apenas o pretexto oficial da viagem, pois Tibério rumou a Cápreas. O motivo que o biógrafo apresenta para a predilecção de Tibério por esta ilha está ligado ao carácter do próprio. Não se tratava da inegável beleza da ilha, como acontecera com Rodes, mas da sua inacessibilidade ${ }^{71}$ : motivo denunciador do medo que atormenta o tirano. $\mathrm{O}$ facto de ele se deslocar ao continente (na sequência da derrocada de um anfiteatro que custou a morte de vinte mil pessoas) ${ }^{72}$ e de permitir a aproximação de todos é apresentado como uma grande concessão: Tanto magis, quod urbe egrediens ne quis se interpellaret edixerat ac toto itinere adeuntis submouerat («Tanto mais que, ao sair da Urbe, publicara um edicto para que ninguém o importunasse, e, em todo o trajecto, mandara afastar os que se aproximavam»). Ao acentuar-se o carácter de excepção de tal facto, o biógrafo cria a imagem de um imperador desconfiado e misantropo. Como outrora em Rodes, Tibério impõe de novo um exílio a si próprio.

A instalação definitiva na ilha é o ponto de charneira na evolução do principado de Tibério. Se já atrás (Tib. 33) houve sinais de afirmação do déspota, agora a viragem é completa: entramos na fase negativa do governo. A negligência ou demissão de Tibério em relação às questões políticas é tratada, como faz habitualmente Suetónio nestes assuntos, num breve resumo, ${ }^{73} \mathrm{a}$ narrativa centra-se no estudo do carácter e degradação dos comportamentos: Ceterum secreti licentiam nanctus et quasi ciuitatis oculis remotis, cuncta simul uitia male diu dissimulata tandem profudit: de quibus singillatim ab exordio referam ${ }^{74}$ («Mas, dado que encontrara a conivência do retiro, e como os olhares da cidade estavam, por assim dizer, afastados, deu largas, de uma assentada, a todos os

${ }^{69}$ Para Tácito, Ann. 4.59, o acidente não têm imporância em si, mas pelas suas consequências políticas: Tibério foi salvo por Sejano, que se torna assim digno de total confiança e todo poderoso, com consequências nefastas na evolução deste principado; vide GAscou, J. 1984, 419-420. Na gruta, descoberta em 1957, os quatro maiores grupos escultóricos encontrados têm como protagonista Ulisses em situações que ilustram as diversas facetas do seu carácter. Tendo em conta gostos estético-literários de Tibério (Tib. 70) e as semelhanças entre o carácter de Tibério e Ulisses ambos propensos à dissimulação, Stewart, A. F. 1977, 76-90, sugere a possibilidade de as esculturas serem da iniciativa de Tibério, quando da sua retirada para a Campânia.

${ }^{70}$ Tib. 40. Cf. Tácito, Ann. 4.57.1; 4.67.1.

${ }^{71}$ Ao passo que Tácito, Ann. 4.67.2, junta à inacessibilidade o clima temperado e a beleza do lugar.

${ }^{72}$ Contra as 50000 referidas por Tácito, Ann. 4.63.

${ }^{73}$ Tib. 41. Além disso, ao dizer que não mudava os cargos, parece generalizar, a partir de uma opção política de Tibério: deixava os governadores de província nos seus postos até ao final da vida, como afirma Tácito, Ann. 1.80.1; Flávio Josefo, AJ 18.170. Vide Levick, B. 1999a, 127-128. A negligência em relação às incursões dos Partos, dos Dácios e dos Sármatas e dos Germanos, se confrontado com o relato de Tácito, Ann. 6.31-44, parece ser uma calúnia.

${ }^{74}$ Tib. 42.1. A ideia da mudança na conduta é como que um cliché na tradição sobre os imperadores da dinastia júlio-cláudia; vide GiUA, M. A. 1975, 353ss. 
vícios há longo tempo mal dissimulados. Desses vícios vou eu agora tratar, um por um, desde o início»). Este é o momento do tirar da máscara: frustração definitiva das expectativas que os primeiros anos de governo geraram no leitor. Com a afirmação de uitia male diu dissimulata, o biógrafo sugere que toda a vida anterior tem de ser vista a uma nova luz: os vícios já existiam, mas eram dissimulados pela hipocrisia de Tibério. Para realçar a dissimulação do imperador, o biógrafo procede ao ocultamento provisório da informação. Impõe-se por isso uma analepse completiva (ou uma série de analepses, para os vários vícios), introduzida pela expressão ab exordium referam, que aqui não pode entender-se senão em sentido temporal. ${ }^{75}$ Trata-se de uma anacronia significativa, que, além de depender da organização per species, visa uma reinterpretação do carácter da personagem. Começa pela avidez de vinho, que se manifestava já no início da carreira militar. Com um postea, introduz-nos bruscamente no período do principado (Tib. 42.1), e transita da ebriedade para a luxúria (Tib. 42.2).

O biógrafo, como é seu hábito, usa rumores com valor de prova das depravações ocorridas no secretismo da ilha. $\mathrm{O}$ exílio de Cápreas favorece a criação de um fantasma que se cristaliza particularmente em torno da sexualidade do imperador. ${ }^{76}$ Perante a monstruosidade dos factos, o biógrafo parece manifestar alguma incredulidade. ${ }^{77}$ As anedotas são apresentados em gradação, mesmo quando não passam de rumores; os actos de pedofilia a que se entregava pela natura e pela idade; o escandaloso quadro de Parrásio, colocado no quarto de dormir, revelador dos seus gostos; ${ }^{78}$ a violação de um minister de um sacrifício no final da cerimónia; o abuso de matronas, de que é exemplo paradigmático o caso de Malónia (Tib. 45). Não deixa de ser interessante verificar as associações do biógrafo: começa pela paixão pelo vinho, que logo se associa a devassidão; faz a transição para as atitudes de perversão sexual e, ligada a estas, a sádica crueldade, própria da tirania.

Depois passa a outro item: a avareza (pecuniae parcus ac tenax) (Tib. 46). Novo vício exige nova analepse (Tib. 47), uma vez que disse atrás que os trataria ab exordio (Tib. 42). O condicionamento da análise moralista ao vício da avareza manifesta-se também na forma como diminui acções positivas, ao atribuir carácter de excepção (bis omnino) à ajuda que Tibério dá ao povo, através de um crédito e do reembolso de proprietários de insulae destruídas pelo

${ }^{75}$ Vide Giua, M. A. 1978, 331. Sobre o topos da hipocrisia em Suetónio e Tácito, vide intr. ao com. de Lindsay, H., 1995, 14; Giva, M. A. 1975, 53 352-363.

${ }^{76}$ Como sugerem Dupont, F. et Éloi, T. 2001, 295.

${ }^{77}$ Tib. 44.1: : Maiore adhuc ac turpiore infamia flagrauit, uix ut referri audiriue, nedum credi fas sit.

${ }^{78}$ Tib. 44.2: in qua Meleagro Atalanta ore morigeratur - «no qual Atlante e Meleagro se satisfaziam sexualmente com a boca um ao outro», se aceitarmos a tradução de morigerari no seu sentido médio-passivo de 'estimulação mútua', como propõe Hallet, J.P. 1978, 196-200. Pode bem acontecer que o interesse de Tibério por arte erótica, aliada à especulação sobre as suas actividades em Cápreas, gerasse a tradição hostil que o representa como um pervertido sexual; vide intr. ao com. de LindSaY, H., 1995, 14; e com. 142. 
fogo (Tib. 48.1), e às cidades da Ásia destruídas por um terramoto. ${ }^{79}$ Actos que, em si, seriam louváveis tornam-se inexpressivos, ou mesmo negativos, porque “a excepção confirma a regra”: revelam avareza.

A gradação continua: procedente mox in tempore etiam ad rapinas conuertit animum (Tib. 49.1) («com o decorrer do tempo, voltou também o seu espírito para a rapina»). Nesta perspectiva se aduz uma série de exemplos, apresentados não pela odem cronológica, mas segundo uma gradação de intensidade: forçou ao suicídio o abastado Gneu Lêntulo; ${ }^{80} \mathrm{fez}$ condenar Lépida para agradar a Quirínio, homem rico e sem herdeiros; ${ }^{81}$ explorou particulares e cidades nas províncias; e, no cúmulo da gradação, espoliou e matou Vonones, rei dos Partos, refugiado, com grandes riquezas, em Antioquia. Se este facto é anterior aos outros, é colocado no cúmulo da gradação, devido ao escândalo: era um rei e estava quasi fidem p. $R$. e foi objecto de perfidia. ${ }^{82}$ Como habitualmente, Suetónio força a ordem dos factos de modo a sugerir a ligação entre a gradação do ponto de vista moral e cronológico.

A seguir, introduz outra rubrica, para tratar diacronicamente o odium aduersum necessitudines (Tib. 50.1). Começa pela denúncia do irmão Druso a propósito de uma carta conspiratória contra Augusto, ${ }^{83}$ passa pelo agravamento da situação de Júlia, para se centrar no relacionamento com a mãe, através de uma longa lista de focos de conflito, que culmina na total falta de pietas. ${ }^{84}$ Sugere-se inclusivamente que o facto de ela, irritada, exibir umas cartas de Augusto sobre a dureza e insolência (acerbitas et intolerantia) do carácter de Tibério, seria, em contradição com o que se disse atrás (Tib.39), uma das razões, senão a principal, que o levaram a afastar-se de Roma. Suetónio alheia-se, dizendo que se trata da opinião de alguns e uma consequência deduzida do modo violento como Tibério reagiu à ofensa, ${ }^{85}$ mas reconhece que os factos seguintes o sugerem: em três anos, só a viu uma vez, não a visitou quando doente, não foi às exéquias, negou-lhe honras divinas, e perseguiu-a, mesmo depois da morte, nas pessoas dos amigos dela (Tib.51.2). Sob a autoridade da pesquisa nos documentos, Suetónio coloca a própria mãe, desprezada, a apontar, através das palavras de Augusto, os defeitos do filho.

79 Tib. 48.2: Ne prouincias quidem liberalitate ulla subleuauit, excepta Asia, disiectis terrae motu ciuitatibus. Vide GiuA, M. A. 1978, 341; Alföldy, G. 1965, 830-831.

${ }^{80}$ Morto em 25 d. C.; cf. Tácito, Ann. 4.44.1.

${ }^{81}$ Condenada em 20 d. C., segundo Tácito, Ann. 3.23.1. É um processo complexo; vide Townend, G. B. 1962, 484-493.

${ }^{82}$ Tib. 49.2. Segundo Tácito, Ann. 2.68, ele foi assassinado em 19 d. C., na fuga para a Arménia, por um praefectus equitum, sem responsabilização de Tibério. Vide Gascou, J. 1984, 408-410.

${ }^{83}$ (...) de cogendo ad restituendam libertatem Augusto agebat. Povavelmente em 10 a. C. Esta carta pode ter origem nas Memórias de Agripina; vide Levick, B. 1999a, 32 e 237 n.8.

${ }^{84} \mathrm{Tib}$. 50.2-51.2. A recusa de honras, interpretada pela tradição hostil como desentendimento, seria uma política oficial de moderação que Tibério também aplicava à sua pessoa. Vide com. de Lindsay, H., 1995, 151.

${ }^{85}$ Tib. 51.1: tam infeste adeo grauiter tulit, ut quidam putent inter causas secessus hanc ei uel praecipuam fuisse. Segundo Gascou, J. 1984, 363, as duas explicações resultam do ponto de vista em que Suetónio se coloca para julgar Tibério: no primeiro caso numa perspectiva favorável (Tib.39), no segundo, desfavorável. 
Depois de mostrar que Tibério não é bom filho, Suetónio vai provar que não é bom pai: não tem patria caritas (Tib. 52.1), nem para com o filho biológico, Druso, nem com o adoptivo, Germânico. Está definitivamente arredada a hipótese de estas mortes serem a causa do afastamento para Cápreas. ${ }^{86}$ Vão sendo sistematicamente eliminados aos olhos do leitor os melhores traços do retrato de Tibério. Persegue-o a fama de ter invenenado Germânico, por intermédio do legado da Síria. A suspeita de crime, presente na voz coral do povo - Redde Germanicum! - , é confirmada pela forma como Tibério perseguiu até à morte a viúva, Agripina (Tib. 53), e os filhos, Nero e Druso (Tib. 54). O âmbito alarga-se: Finalmente vem o ódio contra os antigos amigos e íntimos. Por motivos fúteis, a sede de sangue faz perecer quase todo o seu consilium (Tib.55) e os comensais gregos (Tib. 56).

Neste momento, Suetónio, com uma nova rubrica, introduz mais uma análise retrospectiva para tentar explicar a origem e a evolução da natura cruel e fria que, já na infância, o preceptor de retórica reconhecia em Tibério e, por isso, lhe chamava "barro amassado em sangue". Suetónio, como era norma no seu tempo, mostra conceber o carácter como algo inato, embora os vícios se acentuem com a idade. A gradação não se refere ao vício em si, mas à sua manifestação, que corresponde ao progressivo abandono da dissimulação: Sed aliquanto magis in principe eluxit, etiam inter initia cum adbuc fauorem hominum moderationis simulatione captaret (Tib. 57.1) («Mas, uma vez príncipe, manifestou-se muito mais o seu carácter, e mesmo nos começos, quando ainda granjeava o favor das pessoas simulando moderação»). A seguir, com sub id tempus, remete para o mesmo período de inter initia (do capítulo anterior: Tib. 57.1) e introduz a aplicação da lex maiestatis, levada até ao ridículo. ${ }^{87}$

A apregoada tolerância de Tibério em relação aos versos satíricos (Tib. 28) parece ser agora posta em causa. ${ }^{88} \mathrm{Diz}$ o biógrafo que Tibério, numa primeira fase, os atribuía aos descontentes e repetia: 'Oderint, dum probent!' («'Odeiem-me, desde que me aprovem!»). Mas depois acrescenta: dein uera plane certaque esse ipse fecit fidem («depois ele próprio tratou de garantir que eram verdadeiros e completamente acertados»). O biógrafo, com estas palavras, não parece referir-se só ao castigo dos autores dos versos (apesar de, em Tácito, Ann 6.39.1, haver condenações devido a escritos contra o imperador). Trata-se antes de um remate espirituoso de Suetónio: Tibério, pelo seu procedimento, fez com que o conteúdo dos versos - que era azedo e terrível (asper et immitis); que era um governante da idade do ferro; que era sedento de sangue - se tornasse bem real. Os versos são, pois, introduzidos com intenção caracterológica. O contexto em que esta afirmação é inserida é o da crueldade (como se vê pelos capítulos anteriores e seguintes) e não da falta de libertas. Suetónio não dá,

${ }^{86}$ Causa apresentada em Tib. 39. Vide Gascou, J. 1984, 363.

${ }^{87}$ Tib. 58. Tácito, Ann.1.72.3, remete a orientação de Tibério para a aplicação da lex maiestatis ao ano 15. Vide GiUA, M. A. 1978, 332.; ID. 1991, 3737.

${ }^{88}$ Tib. 59.2. Giva, M. A. 1978, 342-344, aponta várias contradições que ocorrem em Tácito e Suetónio, mas são mais visíveis no segundo, devido à estrutura da biografia: pertenceriam a uma tradição anterior. 
a seguir, exemplos de repressão sobre poetas, mas transita para a já referida história do pescador de Cápreas (Tib. 60), como mais um exemplo do humor cruel de Tibério. Sem o imaginar, o pescador tinha posto em causa a razão pela qual o imperador apreciava esta ilha: a segurança. A razão do suplício foi o choque sofrido: territus quo is a tergo insulae per aspera et deuia erepsisset ad se («aterrorizado porque ele escalara, desde a parte de trás da ilha, por escarpas inacessíveis, até junto dele»). ${ }^{89} \mathrm{E}$ a reacção do imperador é desproporcionada.

Chegámos à parte mais cruenta da Vida. As várias analepses, feitas para historiar os vários vícios de Tibério (iniciadas no capítulo 42), confluem para aqui: ${ }^{90}$ mox in omne genus crudelitatis erupit («em breve irrompeu em todo o género de crueldades»). Contra a tese da funesta influência de Sejano, Suetónio quer provar que a responsabilidade dos crimes contra os filhos de Germânico recai sobre Tibério, uma vez que ele próprio mandara matar um, quando Sejano já era suspeito, outro, somente depois do temível prefeito ter sido executado. ${ }^{91}$

A seguir o biógrafo, preocupado com a extensão, adverte o leitor de que vai fazer um sumário: Singillatim crudeliter facta eius exequi longum est; genera uelut, exemplaria saeuitiae, enumerare sat erit (Tib. 61.2.) («seguir uma a uma as acções cruéis tornar-se-ia longo, basta enumerar, a título de exemplo, os tipos de crueldades»). A partir daqui, Suetónio, generalizando, transforma casos particulares em procedimentos habituais: sentenciados no primeiro dia do ano (só se conhece o caso de Tício Sabino, através de Tácito, Ann. 4.70.1); acusados e condenados juntamente com os seus filhos, e outros até acusados pelos próprios filhos; ${ }^{92}$ a proibição do luto à família dos condenados; ${ }^{93}$ a condenação de um poeta e de um historiador, e destruição das respectivas obras, apesar de aprovadas outrora em presença de Augusto; ${ }^{94}$ os condenados que, sem esperança, se apunhalavam em casa, ou bebiam veneno no senado, e

${ }^{89}$ Como já vimos, a razão para a escolha da ilha por parte de Tibério é, para Suetónio, a inacessibilidade do lugar: Tib. 40. Cf. Tácito, Ann.4.67.2.

90 Segundo Giua, M. A. 1991, 3737, só no capítulo 60 se chega verdadeiramente ao período de vícios que fora anunciado no cap. 42, e contraposto a toda uma fase precedente de moderação, e se entra na descrição da louca desumanidade de Tibério, desencadeada sem freios no isolamento de Cápreas.

${ }^{91}$ Tib. 61.1. A acção de Sejano provocou actos e palavras de hostilidade por parte das vítimas que não foram obliterados depois da morte, como afirma Levick, B. 1999a, 173. Vide SeAger, R. 1972, 214-215.

${ }_{92}$ De filhos que acusaram os pais, só se conhece o caso de Víbio Sereno: cf. Tácito, Ann. 4.28.1.

${ }^{93}$ Generalizado provavelmente a partir do caso de Vícia, condenada à morte por chorar o filho; cf. Tácito, Ann. 6.10.1. O problema é que chorar um condenado do crime de maiestas pode assumir uma dimensão política, como nota Seager, R. 1972, 228-229. Tácito, Ann. 6.19.3, a propósito da exposição dos cadáveres dos cúmplices de Sejano, diz: neque propinquis aut amicis adsistere, inlacrimare, ne uisere quidem diutius dabatur.

${ }^{94}$ Tib. 61.3. O poeta é, como já se disse atrás, Mamerco Escauro, autor de um Atreu que se tornou ofensivo para Tibério, oficialmente acusado de adultério com Lívia Júlia e magia: cf. Tácito, Ann. 6.29.3-4, e Díon Cássio, 58.24.3-5. O segundo é Cremúcio Cordo, defensor da libertas, que, acusado de ter louvado Cássio e Bruto, se suicidou. Se as obras dos dois foram queimadas só a do segundo era conhecida de Augusto. 
eram, depois de lhes ligarem as feridas, arrastados, agonizantes, para a prisão; ${ }^{95}$ todos os condenados arrastados e lançados às Gemónias; ${ }^{96}$ a violação de virgens antes de as estrangular, porque a lei proibia estrangular donzelas. ${ }^{97} \mathrm{O}$ clima de terror é acentuado pelas frases, naturalmente exageradas: nemini delatorum fides abrogata. Omne crimen pro capitali receptum (Tib. 61.3) («não se pôs em dúvida a palavra de nenhum delator. Toda a acusação era considerada capital»). E a gradação continua: Auxit intenditque saeuitiam exacerbatus indicio de morti filii Drusi (Tib. 62.1) («aumentou e estendeu a sua crueldade exasperado pela denúncia sobre a morte do seu filho Druso»). Trata-se agora da aplicação da tortura a que submete, por engano, até um hóspede.

A imagem do tirano cruel e misantropo (apresentada em gradação) conflui para o consequente estado de odiado por todos e aterrorizado, ${ }^{98}$ que o leva a exageradas precauções com os oráculos e com os homens: assim se interpreta a retenção em Roma de governadores de província nomeados (Tib. 63.2). Assim se explica também o cuidado com que faz transportar a nora e os netos depois de condenados: presos com cadeias, dentro de uma liteira fechada, sem contacto visual com os transeuntes (Tib. 64). E até a narrativa da desgraça de Sejano é subordinada ao tema do medo de Tibério. O prefeito aparece mais como uma vítima do dolo do imperador (Tib.65) do que como um conspirador. Os procedimentos de Tibério são os de uma fera acossada: finge-se vítima indefesa, através da pudenda miserandaque oratio ao senado, prenhe de autocomiseração, ${ }^{99} \mathrm{e}$, receando um tumulto, prepara navios para o caso de ser necessário fugir. Nem depois de sufocada a conjura se sente mais seguro: não sai da Villa Iouis durante nove meses. Com um insuper ('ainda por cima') a assinalar a gradação, Suetónio apresenta-nos uma alma ansiosa (anxia mens), fustigada por toda a espécie de injúrias: o exagero do biógrafo chega ao ponto de afirmar que o rei dos Partos, Artábano, através de uma carta, na qual inumera os vícios de Tibério (parricidia, caedes, ignauia, luxuria), lhe aconselha o suicídio como forma de satisfazer o ódio mais que justo dos cidadãos (Tib. 66). E, no clímax dos clímaces, indicado por postremo, aparece um Tibério desgostoso consigo próprio (semet ipse taesus) (Tib.67).

Chegamos ao momento culminante da Vida, marcado, a seguir, por uma quebra na linha da narrativa, ${ }^{100}$ para se fazer a descrição geral do biografado.

95 Tib. 61.4.Trata-se de uma mistura de factos: os cúmplices de Sejano suicidaram-se em 31, mas não foram impedidos de morrer (Díon, 58.15.1-2.), nem arrastados para a prisão. Quanto aos suicídios no senado, Vibuleno Agripa bebeu veneno em plena Cúria, em 36, foi conduzido à prisão, e o suplício foi ainda infligido ao cadáver (Tácito, Ann. 6.40.1; Díon Cássio, 58.21.4); Albucila feriu-se ligeiramente e foi conduzida à prisão (Tácito $A n n$. 6.48.4) - só a esta convém a nota conligatis uulneribus. Os dois últimos são factos únicos que Suetónio generaliza.

${ }^{96}$ Generalizado a partir de circunstâncias específicas: o caso de Tício Sabino, em 28, exposto nas Gemónias, antes de ser lançado ao Tibre (Díon Cássio, 58.1.3; Plínio, Nat. 8.145) e a exposição de cadáveres que seguiu a queda de Sejano (Tácito, Ann. 6.19.2).

${ }_{97}$ Tib. 61.5. Trata-se do caso único da filha de Sejano (Tácito, Ann. 5.9.2; Díon Cássio, 58.11.5). Vide, para estes casos de generalização, GAscou, J. 1984, 452-456.

${ }_{98}^{9}$ Tib. 63.1: de inuisus ac detestabilis; praetrepidus; contumeliis obnoxius.

${ }^{99}$ Vide Levick, B. 1999a, 201.

${ }^{100}$ Para a progressão gradativa até ao clímax, vide Cizek, E. 1977, 124-125. Segundo este 
Mas os traços principais continuam presentes nas rubricas do retrato físico, religião, e estudos literários. No que respeita à descrição física (Tib. 68), Suetónio apresenta Tibério com os traços dos Cláudios, coerentes com a herança genética que recebe quer da mãe, quer do pai, com consequências morais evidentes. A transição para a descrição psicológica é feita através da rigidez do caminhar, o porte arrogante, o ar sombrio, o jeito taciturno. Com a avisada opinião de Augusto, confirma-se o determinismo biológico: são vícios da natureza, ${ }^{101}$ o que, de certo modo, absolve Tibério, mas por outro lado o deixa inexoravelmente impossibilitado de regeneração. A natura é, como vimos cruel e fria: é "barro amassado em sangue". Quando se manifesta a natura, os actos são cruentos. Por isso, Suetónio constrói um período de dissimulação: de atitudes não naturais. A partir de determinada altura, a natureza tinha de se manifestar; e revela-se progressivamente, até atingir a plenitude. Este determinismo pessimista é, de certo modo, agravado pela convicção de Tibério, derivada do cultivo da astrologia, de que tudo depende do fatum, e, por outro lado, pela negligência em relação aos deuses e práticas religiosas (Tib. 69) uma característica dos piores tiranos. Mesmo no cultivo das artes liberais, em si um dado positivo, se manifesta o ethos: sed adfectatione et morositate nimia obscurabat stilum (Tib. 70.1) («mas obscurecia o estilo pela afectação e excessivo rigor»). Pelo seu carácter, Tibério obriga o senado a substituir, num decreto, o termo emblema, nem que fosse por uma perífrase. ${ }^{102}$

O relato da governação de Calígula começa com factos muito positivos que, ainda que de forma aparatosa, revelam um governante justo. A preocupação do biógrafo, nesta fase, é assinalar uma imagem positiva do imperador, confirmada pelas honras concedidas. Mais ainda, o biógrafo parece empreender mesmo uma desculpabilização de certos actos que possam parecer desonrosos. Diz-se que Calígula assume sozinho o terceiro consulado em Lugduno, mas non ut quidam opinantur superbia neglegentiaue («não, como alguns julgam, por arrogância ou negligência»). O facto é que o afastamento de Roma o impedira de saber que o colega tinha falecido pouco antes do início do novo ano. ${ }^{103}$ No entanto, no final da parte positiva desta Vida, as manifestações de poder de Calígula através do espectáculo tomam uma coloração negativa, ou pelo menos

autor, tal climax aproxima Tibério, sem o colocar ao mesmo nível, de Calígula e de Nero.

${ }^{101}$ Tib. 68.3: naturae uitia esse, non animi. Vide Martin, R. 1991, 59-64.

${ }^{102}$ Tib. 71. Trata-se de um termo técnico dificilmente substituível por um latino: são placas em relevo colocadas no fundo dos vasos, em geral em metal mais rico que o vaso e delícia dos coleccionadores de arte. Estes pruridos linguísticos seriam exagerados para Suetónio, que usa o grego sempre que necessário. Díon Cássio, 57.15.1, situa esta anedota no contexto das leis sumptuárias. Segundo Dubuisson, M. 1986, 109-120, trata-se da arte de deformação histórica (definida por Cizek, 1977), na mira de criar uma impressão: Suetónio silencia a política de contenção do uso do grego em situações oficiais e, ao isolar os dados das circunstâncias históricas, insere-os no quadro psicológico de um carácter mesquinho, marcado pela adfectatio e pela morositas.

${ }^{103}$ Cal.17.1. Semelhante julgamento aparece em Díon Cássio 59.24.2. Ou se trata da influência de uma fonte comum, ou Díon foi aqui influenciado por Suetónio. 
suspeita. A violência contra os derrotados do concurso de Lugduno (Cal. 20) prenuncia uma iminente deterioração no comportamento do príncipe. À parte a divisão entre espectáculos celebrados em Itália e oferecidos em outras paragens (peregre), a gradação caminha para os mais inventivos e mais estranhos.

Se, na narrativa destas acções, o biógrafo diz que tratou quasi de principe, ${ }^{104}$ propõe-se, de seguida, dissertar de monstro. A técnica usada é sugerir fortemente ao leitor a transformação radical no comportamento do imperador, mesmo que para isso seja preciso forçar os dados históricos. ${ }^{105}$ Tudo o que para trás se disse de bom se transforma agora num prelúdio ilusório. Se já antes (Cal.10.2) se registara que Gaio dominava a arte da dissimulatio, agora Suetónio propõe-se desvelar o verdadeiro carácter de Calígula. E obviamente os episódios são mais coloridos. A parte boa do reinado fica, assim, sob suspeita da referida dissimulatio. $\mathrm{O}$ termo monstrum sugere uma extraordinária enormidade, estranha às normas naturais, que provoca maravilha ou horror e que pode conter em si o sentido religioso de um presságio. ${ }^{106}$ Suetónio começa esta parte com as aspirações a usurpação de prerrogativas monárquicas e divinas (Cal. 22). À impietas para com os deuses segue-se a impietas para com os antepassados e para com os familiares, a culminar no incesto com Drusila e prostituição das irmãs (Cal. 24). Suetónio, na mira de obter o efeito desejado - acumular actos do Calígula monstro -, não só desloca a morte da avó (ocorrida a 1 de Maio 37 d.C.) para a fase negativa do principado (Cal.23.2), mas entra mesmo em contradição com o que dissera sobre as honras a ela concedidas. É que antes tratava de pietas, mas agora é de impietas. ${ }^{107}$ Apresenta-se também o reverso da medalha em relação ao que se afirmou atrás (Cal.15.2-3) no tratamento dado também ao primo Tibério, em breve morto sob um pretexto fútil (Cal. 23.3), e às irmãs.

O carácter de Calígula manifesta-se também na forma torpe como faz e desfaz os seus casamentos: o espírito tirânico está patente no arrebatamento

${ }^{104}$ E este quasi (Cal. 22.1), muitas vezes ignorado por tradutores e comentadores, parece sugerir que Suetónio questiona a sinceridade e o mérito das acções de Calígula, como nota, na intr. ao seu com., WardLE, D. 1994, 92.

${ }^{105}$ Esta divisão da narrativa em princeps e monstrum é mais o resultado da técnica biográfica (repetida na biografia de Nero, 19.3) de Suetónio do que um dado histórico, uma evolução cronológica. Na primeira fase da biografia, narram-se também acontecimentos que pertencem já a uma fase avançada do governo: a ponte de Baias (Cal. 19) data do ano 39; o concurso de Lugduno (Cal. 20) acontece dois anos depois da doença de Calígula em 37; ao passo que a morte de Antónia, narrada na segunda parte (Cal. 23.2), ocorre apenas mês e meio depois da proclamação de Calígula como imperador (18 de Março de 37); vide intr. ao com. de Guastella, G. 1992, 18-19, e com. 156-157; com. de WARdLe, D. 1994, 202. Em todo o caso, geralmente se aceita que houve uma mudança: a um período inicial bom, segue-se depois um mau. Fílon, Leg. 13, faz coincidir a mudança com a doença de 37; Díon Cássio, 59.2.6-3.1, diz que a mudança ocorre em 38; Josefo, $A J$ 18.256, sustém que a mudança ocorre depois de dois anos de bom governo. Vide com. Hurley, D. W. 1993, 83 e n.41.

106 Como acontece em Gal. 18.1: magna et assidua monstra iam inde a principio exitum ei, qualis euenit, portenderant. Monstrum associa-se etimologicamente a moneo. Vide com. de Guastella, G. 1992, 157.

107 Cf. Cal. 15.2: Post haec Antoniae auiae, quidquid umquam Liuia Augusta honorum cepisset, uno senatus consulto congessit. Vide Gascou, J. 1984, 365. Só Suetónio fala no boato de envenenamento. 
das esposas aos maridos (Cal. 25.1). A propósito desta rubrica, ao referir-se à filha que Calígula tivera de Cesónia, e ao indício que ele evocava como prova de que a criança que Cesónia dera à luz era sua filha, Suetónio afasta a dimensão política para se cingir à dimensão ética. Com efeito, não se refere à preocupação do imperador em ter herdeiro, mas centra-se no facto de a prova evocada para a paternidade ser a feritas que a levava a procurar ferir os olhos das outras crianças (Cal. 25.4). Calígula não só tem consciência da sua natureza selvagem, como parece manifestar orgulho neste seu carácter. Como no caso de Tibério, esta ferocidade manifesta-se na sua leviandade e frieza em relação a próximos e amigos (Cal.26), como o seu parente Ptolemeu, neto de Marco António, o prefeito Mácron e a esposa. A seguir, extravasa a esfera da vida familiar pelo desrespeito para com os senadores, os cônsules e pela superbia uiolentiaque com que trata as restantes ordens. A Hidra para o povo romano, anunciada por Tibério (Cal. 11), manifesta-se. Suetónio faz o sumário destes actos, a culminar numa fome pública, que Calígula promove com a ordem de encerrar os celeiros. ${ }^{108}$

Chegado a este ponto, provada que foi toda a ausência de escrúpulos, o biógrafo trata as demonstrações da saeuitia ingenii no seu mais elevado grau. ${ }^{109}$ Nota-se também uma gradatio em relação ao que acontecia com Tibério. Neste, a crueldade estava na natura, o que, de algum modo, era uma atenuante, ${ }^{110} \mathrm{em}$ Calígula é intrínseca à natura (Cal.11) e ao ingenium. E, para acentuar a crueldade dos factos, Suetónio faz uma analepse. Atrás, Suetónio dissera apenas que muitos fizeram votos de combater na arena e de oferecer a própria vida pela saúde do imperador. O que omitira (porque apresentava então um imperador querido dos súbditos), e que vem dizer agora, é que Calígula exige o cumprimento dos votos. O retardamento desta informação é uma consequência da divisão por species; mas também é verdade que a anterior omissão, resultante do tratamento por rubricas, permite aumentar agora o efeito. Uma das características do monstrum é a sua imprevisibilidade: age inesperadamente (repente), ${ }^{111}$ deixando os circunstantes e o leitor desconcertados e estupefactos. Sem evitar os pormenores mais cruéis, Suetónio continua a gradatio ${ }^{112}$ e passa a referir os actos acompanhados de palavras (Cal. 29-31). Como Tibério, Calígula parece manifestar consciência da sua psicologia, mas, longe de sentir pesar, mostra-se orgulhoso dos seus defeitos: Nibil magis in natura sua laudare se ac probare dicebat quam, ut ipsius uerbo

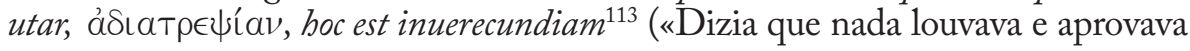

${ }^{108}$ Cal. 26.5. Em Camus, Caligula, II.9, a decisão da fome é um meio de Calígula provar a sua liberdade de ser autor de uma calamidade e a liberdade de lhe pôr fim quando quiser. Vide Gillis, J. 1974, 396.

${ }^{109}$ Cal. 27.1: Saeuitiam ingenii per haec maxime ostendit. Em Cal.11, fala-se de natura saeua atque probrosa.

${ }^{110}$ Cf. Tib. 57.1: saeua ac lenta natura. Em Tib. 68.3, Augusto desculpa-o afirmando naturae uitia esse, non animi.

${ }^{111}$ Cal. 32.1: cum multos e litore inuitasset ad se, repente omnis praecipitauit; Cal. 45.2: deserto repente conuiuio...; Cal. 46: repente ut conchas legerent galeasque et sinus replerent imperauit.

${ }^{112}$ Cal. 29.1: immanissima facta augebat atrocitate uerborum.

${ }^{113}$ Suetónio dá um sentido ético (ligado ao carácter de Calígula) a uma palavra que talvez 
mais na sua natureza do que, para usar as palavras do próprio, a adiatrepsia, isto é, a sua desvergonha»). A sua desfaçatez é expressa em frases onde impera a crueldade e o humor negro, características que já vinham associadas em Tibério. A seguir refere-se a violência contra as classes sociais, do estrato mais elevado ao mais humilde. O leitor que vira Calígula queimar os processos relativos à mãe e aos irmãos de Gaio, com a garantia de que não os tinha lido,é agora surpreendido com Calígula a exibir os documentos, pois apenas simulara queimá-los. A correcção permite potencializar no momento próprio o efeito sobre o leitor. Além da já característica dissimulatio, Calígula aparece agora aos olhos do leitor como um ímpio perjuro, pois jurara pelos deuses em como não os lera nem lhes tocara. ${ }^{114}$ É com eles em punho que ameaça agora os senadores. E se antes não dava ouvidos a delatores, justifica agora a saeuitia de Tibério como necessária, pois não havia outra solução, salvo acreditar em tantos acusadores. Aos cavaleiros insulta-os pela excessiva afeição aos jogos cénicos e de gladiadores e, quanto ao povo, lamenta que este não tenha uma só cerviz. Sobre todos paira a ameaça da decapitação (Cal. 30.2-3). Sucedem-se outros ditos, célebres pela crueldade e pelo humor negro, e que culminam no lamento de que nenhuma catástrofe acontecia no seu principado. ${ }^{115}$ Suetónio acrescenta ainda uma rubrica sobre a saeuitia de acções e palavras especificamente em momentos de lazer (Cal.32-33) ilustrada com outros exemplos, todos terríveis. Alguns são atrozes e incutem o terror resultante do facto de se poder esperar tudo desta mente que se apresenta cada vez mais desvairada. Assim uma espada de Dâmocles paira sobre quem o rodeia. A gradação continua e os alvos são agora homens de todos os tempos (Cal.34-35). Além disso, faz-se a transição da superbia e saeuitia para o liuor ac malignitas.

Outra característica usual do tirano é a impudicitia e abuso de matronas e de homens livres. Além do comércio carnal com o pantomimo Mnester e com homens nobres, do incesto com as irmãs e do amor pela cortesã Pirális, Calígula não respeitou, à semelhança de Tibério (Tib. 45), nenhuma mulher, por mais ilustre que fosse (Cal.36.1). Tal juízo soa a generalização; o mesmo se diga do envio de ordens de divórcio a algumas mulheres em nome dos maridos ausentes de Roma. ${ }^{116}$

fosse usada em sentido meramente político. Com efeito, Dubuisson, M. 1998, 589-594, pensa que o hápax em questão (que expressa a qualidade do que não se desvia) é um neologismo da autoria de Calígula (como acontece em Cal. 47) para descrever, sem conotações morais, a frieza do seu poder absoluto e neutro, uma vez que não havia uma palavra latina adequada (inuerecundia é considerado glosa desde a ed. de Egnatius, 1516).

${ }^{114}$ Cal. 30.2; cf. 15.4. Não é de crer que Suetónio, que tanto cuidado coloca na recolha e análise, se mostre descuidado ou esquecido do que atrás dissera sobre a queima dos processos, como sublinha, na intr. ao seu com., WardLE, D. 1994, 86. Suetónio parece querer colocar diante do leitor a progressiva revelação do carácter de Calígula.

115 Cal. 31. Esta marca de humor macabro torna-se para o Calígula de Camus mais uma razão de agir: Caligula, IV,9. Vide GiLlis, J. 1974, 396-397. Calígula parece ter uma completa falta de tacto e o seu talento para o insulto é um desastre; vide intr. ao com. de HurLEy, D. 1993, xiii.

${ }^{116}$ Cal. 36.2. Deve tratar-se do caso de Lólia Paulina, esposa de Mémio; cf. Díon Cássio, 59.12.1. Vide Gascou,J. 1984, 488 n. 145. A abordagem de erotica tem em Suetónio uma função 
A dissipação com sumptuosidades (Cal.37) é outro traço habitual no tirano e tem como consequência a rapina mascarada sob as mais diversas formas, para fazer face aos gastos (Cal. 38-42): calúnias, leilões, impostos inauditos, exploração, contribuições para o imperador.

A seguir o biógrafo entra na descrição das actividades militares de Calígula (Cal. 43ss), para, no final, retomar o topos da crueldade gratuita - a nefanda atrocitas que o leva a planear dizimar as legiões que se tinham revoltado depois da morte de Augusto, por terem cercado o pai Germânico e ele próprio. ${ }^{117}$ Mais uma vez não consegue levar avante o seu projecto; e lança a sua fúria contra o senado. Uma consequência da tirania em contexto romano é o desrespeito por esta grandiosa classe. De regresso a Roma, o monstro vem de péssimo humor. A uma delegação do senado que lhe vem pedir que apresse o regresso responde, apontando para o gládio: 'Veniam', inquit, 'ueniam, et hic mecum' ("hei-de chegar, disse ele, hei-de chegar: e este vai comigo"») e ainda edixit 'et reuerti se, sed iis tantum qui optarent, equestri ordini et populo; nam se neque ciuem neque principem senatui amplius fore' (Cal. 49.1) («Disse por um edicto que 'regressaria, mas somente para os que o desejavam: a ordem equestre e o povo. Pois, para o senado, não seria mais nem príncipe nem cidadão'»). As ofensas ao senado pagam-se caras. Júlio César fora disso exemplo. Augusto conhecia o risco e procurava uma solução de compromisso. O biógrafo diz que Calígula pereceu quatro meses mais tarde, quando projectava crimes ainda maiores, como mudar a corte para Âncio e depois para Alexandria e eliminar os membros mais ilustres da ordem senatorial e dos cavaleiros. ${ }^{118}$ Como evidência destes crimes (quod ne cui dubium uideatur) Suetónio apresenta a descoberta de duas listas negras com nomes sugestivos, "o gládio" e "o punhal", e um cofre de venenos (Cal. 49.3).

Mas antes de encetar a narrativa da morte, o biógrafo introduz, como se fez para Júlio César e Tibério, as habituais rubricas sobre o aspecto, o carácter e os interesses de Calígula. Além de constituir informação suplementar, contribui para o suspense. Estas rubricas funcionam, assim, como momento de síntese: os traços do carácter do monstro recebem agora um rosto e um corpo que os incarna e os torna personagem concreta e histórica, da qual se pode elaborar um retrato-robot. Nota-se uma intenção caricatural. ${ }^{119} \mathrm{~A}$ desproporcionalidade

crucial: demonstrar que Calígula viola todas as normas sexuais através da homossexualidade, incesto, adultérios e travestismo. O seu relacionamento sexual prova a sua monstrositas; vide com. de Wardle, D. 1994, 275; Martin, R. 1991, 157-158.

117 Cal. 48.1. A história soa a exagero de Suetónio: poucos ou nenhuns dos soldados envolvidos no motim de 14 estariam ainda ao serviço em 40 . O facto de se dizer que era um projecto levanta a suspeita de que se trataria de um rumor hostil.

${ }^{118}$ Cal. 49.2. A referência antecipada à morte, oito capítulos antes da narração, faz lembrar Jul. 44.4. Também o projecto da mudança da capital para Alexandria, referido no contexto da narrativa da morte, cria um paralelo com Júlio César (Jul. 79.3) e com Nero (Nero 47.2).

${ }^{119}$ Cal. 50.1. Vide com. de Guastella, G. 1992, 263-264; Gascou, J. 1984, 607-610. Há quem proponha a influência da tradição fisiognomónica (que Suetónio conheceria) na descrição de Calígula, como pretendem Evans, E. C. 1950, 277-282; Couissin, J. 1953, 234-256; Sток, F. 1995, 109-135. Colocam sérias reservas à aplicação dos princípios destas teorias às Vidas dos Césares Baldwin, B. 1983, 500 e Gascou, J. 1984, 592-598. Vide com. Wardle, D. 1994, 
e o excesso são comuns ao carácter e ao aspecto físico (de que falaremos mais à frente) que o tornam num monstrum. Do retrato físico, Suetónio rapidamente transita para o psicológico, de que o primeiro é um reflexo: Valitudo ei neque corporis neque animi constitit ("nem tinha firme a saúde do corpo nem a da alma”). E a situação torna-se mais dramática quando o biógrafo faz saber que Calígula tinha consciência do seu estado mental e parecia sofrer com isso: por várias vezes pensou retirar-se para purgar o cérebro. $\mathrm{E}$ para tal loucura procuram-se explicações. Corre o boato de que Cesónia lhe propinara um filtro de amor. ${ }^{120}$ Numa tentativa de interpretação das contradições de Calígula, Suetónio introduz a sua opinião pessoal, para atribuir a causa do distúrbio mental à conjugação de um atrevimento extremo com um medo exagerado. ${ }^{121}$ A rubrica da religio, é introduzida no contexto das incoerências do imperador, que, por um lado, despreza os deuses e, por outro, aos mínimos trovões fecha os olhos e cobre a cabeça; e, quando são mais fortes, esconde-se debaixo do leito. $\mathrm{O}$ biógrafo alonga-se a relatar vários exemplos do extremo medo, quer dos fenómenos naturais quer de possíveis ataques de inimigos (Cal. 51.2). A perturbação mental manifesta-se também na indumentária e no calçado. Note-se a construção em clímax, do mais digno para o mais escandaloso: Vestitu calciatuque et cetero habitu neque patrio neque ciuili, ac ne uirili quidem ac denique bumano semper usus est (Cal. 52) («Nas roupas e no calçado e no restante trajar não usou o tradicional do seu país, nem o habitual dos cidadãos, nem sequer masculino - e, em suma, nem humano»). A indumentária, consonante com a descrição do monstrum, revela o carácter imoral e inumano do imperador, e sugere as suas tendências histriónicas.

Suetónio mostra claramente, através de uma gradatio, para onde tendem os interesses de Calígula: desprezo pela disciplinas tradicionais, dedicação à eloquência e, sobretudo, a outras artes ${ }^{122}$. A progressão do gosto de Calígula pelas artes cénicas e circenses culmina com o favorecimento ad insaniam (Cal. 55.1) do pantomimo Mnéster, dos gladiadores trácios e dos aurigas da equipa dos verdes e sobretudo as prodigalidades concedidas ao seu cavalo, o

323-327. De qualquer modo, é obvio que Suetónio concebia a deformidade física como reflexo da desordem psíquica; vide MARTin, R. 1991, 67-70.

${ }^{120}$ Cal. 50.2. Várias são as hipóteses modernas que apontam para uma doença do foro psíquico ou neurológico: vide Lucas, J. 1967, 159-189; Katz, R. S. 1972, 223-225; Massaro, V. \&. Montgomery, I. 1978, 894-909 e id. 1979, 699-700. Contra, Morgan, M. G. 1973, 327-329. Nem Suetónio nem Díon, 59.8.1-3, consideram a doença significativa para o comportamento do imperador. De resto Fílon ( Leg. 16 e 19) afirma sem hesitar que a doença era estritamente física e que o imperador recuperou completamente. Benediktson, D. Th. 1988, 370-375, defende que Calígula sabia que tinha problemas e que o boato do filtro de Cesónia poderia ter provindo da boca dele próprio. Quando dizia que recorreria à tortura para saber por que razão a amava tanto (Cal. 33), Calígula queria dizer que pensara recorrer à tortura (de escravos, certamente) para apurar se ela lhe tinha dado de facto qualquer afrodisíaco. Vide também Barrett , A. A. 1989 (2000), 73.

${ }^{121}$ Cal. 51.1. Vide Baldwin, B. 1983, 516.

${ }^{122}$ Ex disciplinis liberalibus minimum eruditioni, eloquentiae plurimum attendit... (Cal. 53.1); sed et aliorum generum artes studiosissime (Cal. 54.1). Trata-se de estabelecer a conexão entre educação e carácter: julgava-se que as disciplinae liberales formavam um carácter virtuoso. 
qual, segundo o rumor, pretendia elevar à categoria de cônsul (Cal. 55.3). A partir daqui entramos na narrativa da morte. Assim se estabelece a relação de causa-efeito entre os comportamentos anteriores e o assassínio de que Calígula foi vítima (Cal. $56 \mathrm{ss}$ ).

$\mathrm{Na}$ teoria da degeneração, Calígula representa a fase seguinte em relação a Tibério: parece que herdou os defeitos de Tibério e os potenciou, ao passo que perdeu a principal virtude (reconhecida por Augusto) do seu antecessor: as qualidades militares. Por outro lado, a vida de Calígula decorre numa espécie de delírio báquico (bacchans); em um estado intermédio entre a loucura e a realidade.

Nero retoma e amplia os vícios de Calígula. O biógrafo começa por descrever a parte boa da governação: o tom não é de censura, mas também não é totalmente elogioso, devido à cambiante que denuncia o carácter teatral de tais manifestações. Como Calígula, Nero inicia a sua actividade pela ostentação de virtudes, declarando que seguia o modelo de Augusto (Nero 10.1): antes de mais, a pietas (Nero 9); depois, liberalitas, clementia, comitas (Nero 10.1). Depois da rubrica relativa aos jogos (Nero 11-13), cuja extensão e género de espectáculos descritos é reveladora das tendências deste imperador, o biógrafo insere a enumeração dos consulados (Nero 14) e uma espécie de catálogo de medidas justas que contribuem para uma imagem mais positiva: exercício da justiça (Nero 15), onde se vislumbra a correcção de alguns erros do pai adoptivo; medidas políticas e administrativas (Nero 16-17), como criar pórticos a suas expensas para combater os fogos (Nero 16.1); regulamentação dos gastos sumptuários. São medidas que contradizem o veredicto posterior. ${ }^{123}$ Inclusivamente, Nero é louvado, por um lado, por não desejar expandir o Império, e, por outro, por não retirar da Britânia, demonstrando pietas para com Cláudio (Nero 18).

Subitamente, Suetónio introduz na biografia uma divisão semelhante à que estabelecera na Vida de Calígula. Aos factos que acabara de apresentar, "em parte, não merecedores de repreensão e, em parte, merecedores de um louvor não regateado", opõem-se infâmias e crimes (probra ac scelera) ${ }^{124}$ relatados a seguir. Os vícios de Nero parecem ser uma consequência do facto de o imperador se tornar actor. Aos probra, as desonrosas actividades histriónicas, longamente historiadas (Nero 20-25), Suetónio acrescenta os scelera (conforme anunciara em Nero 19.3): uma série de características enunciados em epígrafe, petulantia, libido, luxuria, auaritia, crudelitas, considerados naturae uitia e não próprios da idade. A progressão é acentuada com a informação de que tais vícios eram exercidos, a princípio, de modo discreto. ${ }^{125}$ Assim se verifica com

${ }^{123}$ Nero 16.2. A perseguição aos cristãos é colocada aqui entre as medidas boas de Nero e sem qualquer conexão com o incêndio de 64 , cuja responsabilidade será mais à frente totalmente imputada ao imperador.

${ }^{124}$ Nero 19.3. Uma fractura na Vida que traz consigo a fractura de alguns episódios entre aspectos positivos e negativos; vide Gascou, J. 1984, 369-373.

125 Sensim... et occulte (Nero 26.1). Vide Lounsbury, R. C. 1991, 3752. 
as saídas nocturnas, à semelhança do que fizera Calígula, e na forma como, durante o dia, se fazia transportar secretamente ao teatro (Nero 26.2). Como Tibério e como Calígula, Nero cultiva a dissimulatio. A gradatio na descrição dos vícios implica o retirar da máscara, que acompanha o crescendo: Paulatim uero inualescentibus uitiis iocularia et latebras omisit nullaque dissimulandi cura ad maiora palam erupit (Nero 27.1) («Mas, gradualmente, com o recrudescimento dos vícios, deixou-se de brincadeiras e de mistérios e, sem nenhuma preocupação de dissimular, irrompeu às claras nos maiores excessos»). Entre estes abusos, figuram banquetes fora de horas e orgias (Nero 27.2-3).

Suetónio transita assim para a exploração da libido. A nota do desafio às regras e da propensão de Nero para quebrar limites proibidos, é assinalada pela justaposição de opostos: tem comércio carnal com rapazes, mas de nascimento livre (ingenuorum paedagogia); tem concubinas, mas casadas (nuptarum concubinatus); viola a vestal Rúbria (Vestali uirgini Rubriae uim intulit); ${ }^{126}$ pensa em casar com a liberta Acte e trata de arranjar quem declare que é de linhagem real; castra Esporo para o transformar em mulher; deseja o incesto com Agripina (Nero 28.2). A gradação no tratamento da libido atinge o máximo com a prostituição da pudicitia, através de um jogo, em que o imperador se entrega sexualmente a um liberto (Nero 29). Por preferir o que Gascou chama a ordem "intensiva” à ordem cronológica, ${ }^{127}$ Suetónio coloca, no cúmulo da gradação, a prostituição da pudicitia. ${ }^{28} \mathrm{~A}$ homossexualidade passiva, agravada por se tratar, neste caso, de submissão sexual a uma pessoa de estatuto social inferior, implicava, como é sabido, maior degradação. Em relação a este comportamento extremo, Suetónio acrescenta o testemunho de alguns autores sobre o pessimismo moral de Nero: estava convencido de que 'neminem hominem pudicum aut ulla corporis parte purum esse, uerum plerosque dissimulare uitium et callide optegere' («nenhum homem era casto ou tinha pura alguma parte do corpo, mas que a maior parte dissimulava o vício e o ocultava habilmente'»). Tal constatação levava o imperador a ser condescendente com os que se confessavam culpados de impudor.

A seguir Suetónio entra na descrição da luxuria. No esbanjamento, Nero aproxima-se de Calígula, a quem admira. ${ }^{129}$ As exibições do artista são dispendiosas. Tal como Calígula, promove favorecimentos indevidos: atribui ao citaredo Menécrates e ao gladiador Espículo o património que se oferece a um general pelo seu triunfo (Nero 30.2). A comitiva das suas deslocações é

${ }^{126}$ Nero 28.1. O episódio da vestal Rúbria não aparece em outras fontes, à excepção de Aurélio Victor, Caes. 5.11. Sobretudo o silêncio de Díon Cássio, que também é coleccionador de mexericos, torna lícita a dúvida de Verdière, R. 1975, 7. Vide Martin, R. 1991, 144; com. de Warmington, B. H. 1999, 54.

${ }^{127}$ Vide Gascou, J. 1984, 414.

128 Quando, segundo Verdière, R. 1975, 17-19, o suposto casamento com Doríforo / Pitágoras, em que Nero faz de mulher, teria ocorrido em 64, na altura em que Popeia dá uma filha a Nero, e o casamento com Esporo, em que este coloca o véu, aconteceria entre a morte de Popeia e a viagem de Nero à Grécia (65-66). Vide a análise cronológica de Gallivan, P. A. $1974 \mathrm{c}, 309$.

${ }^{129}$ Nero 30.1, cf. Cal.37. Vide Lounsbury, R. C. 1991, 3755; Gascou, J. 1984, 370-371. 
aparatosa (Nero 30.3). O cúmulo da luxuria e extravagância é a construção da Domus Aurea. ${ }^{130}$ A ligação entre luxuria a auaritia é feita através de um episódio romanesco: Nero é impulsionado nos gastos pela esperança de encontrar um tesouro de Dido. ${ }^{131}$ Mais uma vez o imperador baseia a sua acção num mito. A realidade é bem diferente. A esperança no tesouro rapidamente se revela vã (Nero 32.1). Nero vê-se forçado a adiar o pagamento dos soldados e as pensões dos veteranos, o que obviamente gera riscos e mal-estar. Como Calígula, depois de arruinado, Nero volta-se para a calúnia e para a rapina. ${ }^{132}$ Dos muitos exemplos ressalta o seguinte, introduzido por quin no cúmulo de uma gradação: enquanto cantava, reparou que na assistência estava uma matrona vestida de púrpura, contra a lei; prontamente a mandou despojar do vestido e dos bens. ${ }^{133}$ Como já acontecera com César, nem os deuses escapam: também os templos são despojados (Nero 32.4. Cf. Jul. 54.3).

Os parricidia et caedes de Nero começam com o pater adoptivo (Nero 33.1) e terminam na patria (Nero 38) ${ }^{134}$ Primeiro os familiares mais próximos: Cláudio (Nero 33.1), Britânico (Nero 33.2-3), a mãe (Nero 34.1-4), a tia (Nero 34.5), as esposas (Nero 35.1-3). O círculo alarga-se, e os condenados mais diversos transformam-se em meras vítimas do tirano. Da morte das esposas Suetónio transita para a morte de outros familiares ${ }^{135}$ e pessoas ligadas por algum laço de proximidade. ${ }^{136}$ Entre estas mortes são colocadas a do seu ex-preceptor, Séneca, e a do prefeito do pretório, Burro, seus conselheiros. ${ }^{137}$ Nesta gradação, passa-se aos crimes contra pessoas de fora da casa imperial e estrangeiros, ${ }^{138} \mathrm{em}$ que se incluem os conspiradores. E a progressão continua ainda com o alargamento do leque das vítimas e das causas do castigo: quem

${ }_{130}$ Nero 31.1: Non in alia re tamen damnosior quam in aedificando domum...

${ }^{131}$ Nero 31.4. Segundo Tácito, Ann. 16.1-3, o autor do sonho foi Cesélio Basso. A este acontecimento parece aludir-se em Petrónio, 128.6; vide LEÃo, D. F. 1998, 21.

${ }^{132}$ Nero 32.1: ... calumniis rapinisque intendit animum. Cf. Cal. 38.1; Dom. 12. Esta é uma característica dos tiranos, já manifesta em Júlio César: Jul.54.3.

${ }^{133}$ Nero 32.3: Quin etiam inter canendum animaduersam matronam in spectaculis uestita purpura cultam demonstrasse procuratoribus suis dicitur detractamque ilico non ueste modo, sed et bonis exuit. Gascou, J. 1984, 706, faz notar, neste exemplo, a passagem sub-reptícia do rumor, indicado por dicitur, ao facto indiscutível (começa por usar o infinitivo demonstrasse, para terminar com o perfeito do indicativo exuit).

${ }^{134}$ Vide Lounsbury, R. C. 1991, 3753.

${ }^{135}$ Nero 35.4: Nullum adeo necessitudinis genus est, quod non scelere perculerit. Antónia é morta porque recusara uma proposta de casamento e porque se mostrava revolucionária. Tácito, Ann. 15.53.3, transmite, com dúvida, o testemunho de Plínio, que atesta que ela estaria implicada na conjura de Pisão. Bradley, K. R. 1977, 79-82, assevera que, sendo ela a única sobrevivente da família imperial, era a candidata preferida, por nascimento, a Estatília Messalina. A atitude de recusa era considerada traição.

${ }^{136}$ Nero 35.4: (...) similiter [inter] ceteros aut affinitate aliqua aut propinquitate coniunctos; in quibus Aulum Plautium iuuenem, quem cum ante mortem per uim conspurcasset.

${ }^{137}$ Nero 35.5. O assassínio de Burro é confirmado por Díon (62.13.3), enquanto Tácito (Ann. 14.51.1) hesita entre doença e envenenamento. Provavelmente nunca se saberá se esta morte teve causas naturais ou se a doença forneceu uma conveniente camuflagem para o assassínio: vide com. de Bradley, K. R. 1978, 218.

${ }_{138}$ Nero 36.1: Nec minore saeuitia foris et in exteros grassatus est. 
lhe apetecesse e a qualquer pretexto. ${ }^{139}$ Mas as pessoas apresentadas - Suetónio escusa-se de referir os restantes (Sed ne de pluribus referam) - são figuras gradas, acusadas por motivos políticos. Os pretextos apresentados por Suetónio parecem pouco importantes para serem os verdadeiros: Salvidieno Órfito (cônsul de 51) é acusado de arrendar três tabernae da sua casa perto do Foro aos delegados das cidades; o jurista Cássio Longino, de conservar na sua árvore genealógica a efígie de Cássio, assassino de César ${ }^{140}$; o célebre estóico Trásea Peto de ter simplesmente um tristior et paedagogi uultus. ${ }^{141} \mathrm{~A}$ culminar, figura o rumor de que dava a comer homens vivos a um polyphagus egípcio (Nero 37.2). Seguem-se exclamações em que Nero, como já antes Calígula, se mostra ébrio do poder ilimitado que possui: ${ }^{142}$ o poder de destruidor, de quem tudo se pode esperar. Prometia inclusive acabar com a mais nobre instituição do Estado, os senadores, e entregar as províncias a cavaleiros e libertos (Nero 37.3).

No cúmulo da gradação da crudelitas, aparece o atentado contra o povo e contra os muros da patria. ${ }^{143}$ Como vimos atrás, a narração, voluntariamente tendenciosa, não só apresenta como inquestionável a culpabilidade do imperador no incêndio de 64, suspeita que Tácito põe em dúvida (Ann. 15.38.1), como procura ainda acentuar o horror com o histrionismo de Nero (Nero 38.2) e rumores infundados de pilhagem. ${ }^{144}$ Além das catástrofes por obra do príncipe ocorreram outras fortuitas que concorrem para a perda de popularidade do imperador.

Suetónio salienta com admiração a notável tolerância de Nero em relação aos ditos e poemas difamatórios (Nero 39.1). Na verdade, os exemplos seleccionados dizem respeito aos dotes artísticos do imperador. Apesar de satíricos, os versos assimilam Nero a grandes personagens mitológicas - aos matricidas Orestes e Alcméon; ao pio Eneias, por antífrase, - e a personagens divinas - Apolo Péan, tocador de cítara - e acentuam a dimensão da Domus

139 Nero 37.1: Nullus posthac adhibitus dilectus aut modus interimendi quoscumque libuisset quacumque de causa. Segundo BALdwin, B. 1967, 425-439, não há razão para crer que tenha havido um período de terror no principado de Nero.

${ }^{140}$ Terá sido apenas exilado na Sardenha (cf. Tácito, Ann. 16.9.1) e chamado de novo para Roma por Vespasiano (cf. Dig. 12.5.52)..

${ }^{141}$ Suetónio transforma a morte num simples exemplum da crueldade de Nero, deixando de lado toda a perspectiva histórico-política, sublinhada longamente por Tácito, Ann. 16.21-22; vide Gascou, J. 1984, 436.

${ }^{142}$ Nero 37.3: negauit quemquam principum scisse quid sibi liceret. Cf. Cal. 29.1: 'memento' ait 'omnia mibi et <in> omnis licere.'

${ }^{143}$ Nero 38.1: Sed nec populo aut moenibus patriae pepercit. É interessante o uso do termo patria (raro em Suetónio) que enfatiza a solenidade do momento; a abordagem subjectiva remete para a noção de parricida; vide com. de Bradley, K. R. 1978, 227-228; com. de Warmington, B. H. $1999,72$.

${ }^{144}$ Nero 38.3: Ac ne non binc quoque quantum posset praedae et manubiarum inuaderet, pollicitus cadauerum et ruderum gratuitam egestionem nemini ad reliquias rerum suarum adire permisit. Tácito, Ann. 15.43.2, coloca a promessa de remover escombros e cadáveres entre as medidas louváveis de Nero, o que sugere que tanto Tácito como Suetónio usaram a mesma fonte, que era favorável, mas que Suetónio terá manipulado. Vide com. de Bradley, K. R. 1978, 235; com. de Warmington, B. H. 1999, 73. A proibição de as pessoas se aproximarem dos escombros é uma medida compreensível, dado o perigo de derrocadas. 
Aurea, a obra arquitectónica suprema de Nero. ${ }^{145}$ Mesmo em casos mais graves, em que a ofensa é feita em público, o castigo não é tão severo como em outras sítuações. O cínico Isidoro diz que ele canta bem os males de Náuplio, e administra mal os seus bens. Mas o que Nero suporta mal são as censuras à sua arte, ${ }^{146} \mathrm{e}$, neste caso, trata-se de elogio. Mas nos versos é visível a perda do apoio popular, que Nero conseguira manter através do espectáculo. Sugere-se que, a partir do incêndio, o principado se desagrega: passa-se a narrar o castigo do tirano (Nero 40ss), apesar de, historicamente, Nero ainda governar vários anos.

Quanto a Domiciano, cria-se progressivamente a imagem de um tirano misantropo e cruel: sublinha-se a continuidade entre a natureza, as vicissitudes da vida e a evolução negativa na condução do Império: circa administrationem autem imperii aliquamdiu se uarium praestitit, mixtura quoque aequabili uitiorum atque uirtutum, donec uirtutes quoque in uitia deflexit: quantum coniectare licet, super ingenii naturam inopia, rapax, metu saeuus (Dom. 3.2.) («Ora no que respeita à administração do Império, mostrou-se longo tempo variável, com uma mistura igualmente equilibrada de vícios e virtudes, até que fez mesmo descambar as virtudes em vícios: quanto se pode conjecturar, na sequência das suas inclinações naturais, a carência tornou-o rapace, o medo cruel»).

Fica assim sugerida a ideia da correspondência entre uma evolução cronológica e uma evolução psicológica e moral, em que os vícios naturais do imperador se manifestam gradualmente, impulsionados por uma característica psicológica (o medo) e por força das circunstâncias (carência). ${ }^{147}$ Estes dois factores irão, em última análise, precipitar a tragédia de Domiciano, enquanto potenciadores dos vícios que o tornarão odiado (Dom. 14.1).

Uma série de traços fazem pensar em Tibério: a frustração na juventude por ocupar um lugar subalterno, a tendência para o isolamento, a infelicidade no amor (Dom.3.1), a rapacidade, o medo associado à crueldade. Mas também há diferenças notáveis: Tibério é censurado por não ter construído nenhum monumento importante nem ter dado nenhum espectáculo (Tib. 47). Ora entre os aspectos positivos do principado de Domiciano figura o evergetismo. Além dos jogos, contam-se as distribuições ao povo e os banquetes públicos (Dom.4) e uma política de grandes construções (Dom. 5). Igualmente positivas se consideram as expedições militares contra os Catos, contra os Sármatas e contra os Dacos, relatadas em síntese, como é hábito do biógrafo. ${ }^{148} \mathrm{Na}$ parte positiva deste reinado, figuram as medidas administrativas, apresentadas em longo catálogo (Dom. 7-9). Mas, ao acentuar uma evolução cronológica de

145 Nero 39.2. Assim se poderá entender melhor a aparente contradição com a afirmação de Nero 32.2: tunc ut lege maiestatis facta dictaque omnia, quibus modo delator non deesset, tenerentur. Tratava-se, nessa altura, de oposição política, e não era anónima, como no caso dos versos.

${ }^{146}$ Nero 39.3. Sobre a dor que lhe causam as críticas de que era mau citaredo, cf. Nero 41.1.

147 Vide Gascou, J. 1984, 398; 431 e 684; Baldwin, B. 1983, 298.

${ }^{148}$ Dom. 6.1. Uma lista incompleta: vide com. de Jones, B. W. 1996, 53; com. de Jones, B. \& Milns, R. 2002, 134-135. 
bom para mau, o biógrafo leva o leitor a pensar que todas as medidas positivas acontecem na primeira fase do governo, o que não corresponde à verdade histórica: por exemplo, Suetónio sugere indevidamente que a punição da vestal Cornélia e seus cúmplices se situa na fase inicial. ${ }^{149}$

Suetónio é impreciso sobre a duração desta fase positiva. ${ }^{150}$ Mas o facto de repetir que este estado de graça acontecia inter initia («nos começos») e aliquamdiu («por algum tempo»), prepara, desde logo, o leitor para a mudança. Com efeito, logo a seguir (Dom. 10), o biógrafo pode constatar: Sed neque in clementiae neque in abstinentiae tenore permansit, et tamen aliquanto celerius ad saeuitiam desciuit quam ad cupiditatem («mas não perseverou nem na clemência nem no respeito pelo alheio, e, no entanto, degenerou muito mais rapidamente para a crueldade que para a cobiça»). A ideia é, como se disse, a de uma progressão cronológica. ${ }^{151}$ Os casos apresentados falam por si: fez executar um discípulo do pantomimo Páris, pelo simples facto de se assemelhar ao mestre na arte e na beleza; ${ }^{152}$ Hermógenes de Tarso, devido a umas alusões (f gurae) na sua história, pelo que mandou também crucificar os amanuenses que a copiaram; um pater familias por ter apoiado os gladiadores trácios. ${ }^{153}$ Segue-se uma lista de execuções de senadores e mesmo antigos cônsules em que, para provar que Domiciano é um tirano cruel, se acentua expressamente a futilidade dos pretextos ${ }^{154} \mathrm{e}$ a forma excessiva como reage com base em simples desconfiança. ${ }^{155}$ É a suspeita de conjura que motiva a execução de Cívica Cereal, então procônsul da Síria, ${ }^{156}$

${ }^{149}$ Dom. 8.4. Segundo Galli, F. 1991, 78, o suplício de Cornélia teria acontecido em 89. Grelle, F. 1980, 347, coloca este processo, com base na cronografia de Eusébio, em fins de 90 ou decurso de 91. Gascou, J. 1984, 400, parece situá-lo um ano mais tarde e acentua que aconteceu na parte final do principado de Domiciano: no décimo primeiro dos quinze anos que durou este principado. Também a uma fase adiantada deste governo pertence uma medida louvada por Marcial no livro nono [9.5 (6); 9.7 (8)], publicado por volta de 94 ou 95: a repressão da prostituição dos meninos; vide Grelle, F. 1980, 347, n. 29. Além disso, Suetónio não liga o incestum de Cornélia ao de Domiciano com a sobrinha Júlia (como faz Plínio, Ep. 4.11), cuja morte, alegadamente, em consequência de um aborto forçado pelo imperador (Dom. 22), ocorreu pela mesma altura da execução da vestal: vide com. de Jones, B. W. 1996, 78; com. de Jones, B. \& Milns, R. 2002, 142-143.

${ }^{150}$ Vide Baldwin, B. 1983, 298.

${ }^{151}$ Dom. 10.1. Vide Gascou, J. 1984, 696. Segundo Baldwin, B. 1983, 487, com esta transição pretende-se salientar a imagem de Domiciano como um segundo Tibério (cf. Tib. 42.1).

${ }^{152}$ Se o discípulo foi morto, tem de se pressupor - Suetónio não o diz - que Páris, por quem a esposa imperial se apaixonara, foi suprimido por ter sido alvo deste amor. Segundo Díon Cássio, 67.3.1, foi morto no meio da rua.

${ }^{153}$ Dom. 10.1. Domiciano apoiava os mirmilões. Iguais manifestações de partidarismo tirânico em Cal.32.2 e Vit.14.3.

154 leuissima quemque de causa... uerum et ueteres et innoxios iocos (Dom. 10.2). O uso de quod com imperfeito do conjuntivo desvaloriza as razões do imperador: quod ... circumferret quodque indidisset; quod... passus esset; quod... edidisset appellassetque (Dom. 10.3); quod... pronuntiasset (Dom. 10.4).

${ }^{155}$ Como sugerem as expressões: quasi molitores rerum nouarum (Dom.10.2); quasi... diuortium suum cum uxore taxasset (Dom.10.4).

${ }^{156}$ C. Vetuleno Cívica Cereal pode ter estado associado ao levantamento do falso Nero no Oriente em 88-89; ou pelo menos Domiciano não acreditou que ele não estivesse: vide 
de Salvidieno Órfito ${ }^{157}$ e de Acílio Glabrião, ${ }^{158}$ que estavam no exílio. As várias anedotas mostram um agravamento da hipersensibilidade de Domiciano, que, ao contrário de Vespasiano, não suporta alusões hostis à sua pessoa. ${ }^{159}$ Elio Lâmia, a quem Domiciano arrebatara a esposa, é morto por uns ditos de espírito inocentes: a um amigo, que lhe elogiava a voz, disse que praticava a castidade; e a Tito, que o exortava a contrair novo matrimónio, perguntou se também ele se queria casar. ${ }^{160}$

A técnica adoptada é a inversa da empregada para Vespasiano (no caso de Helvídio Prisco) e para Tito (repressão da conjura de Aulo Cecina Alieno): acentua-se a culpa de Domiciano, considerando leves, menores ou até fúteis os crimes dos condenados. Mas os crimes não seriam tão veniais como Suetónio quer fazer crer: a morte de Sálvio Otão Coceiano não se ficaria a dever à celebração pura e simples do aniverdário de Otão; ${ }^{161}$ Salústio Luculo não seria certamente morto só por permitir que chamassem "luculiano" a certo tipo de lança; ${ }^{162}$ Flávio Sabino dificilmente terá sido executado apenas pelo erro do arauto que o proclamou imperator, em vez de consul. ${ }^{163}$ Além do mais, existe, em uma das anedotas, amálgama de informação e omissão de um nome: diz-se que Júnio Rústico foi morto por ter escrito as laudes de Trásea Peto e de Helvídio Prisco e os ter apelidado sanctissimi uiri. Ora não consta que Júnio Rústico, autor da laus de Trásea, tenha escrito também uma laus de Prisco - esta seria da autoria de Herénio Senecião, omisso em Suetónio. ${ }^{164}$ Entre as vítimas aparece uma figura que Vespasiano poupara:

Southern, P. 1997, 104 e 112.

${ }^{157}$ Este foi desterrado em consequência de um processo que envolvia Nerva e Apolónio de Tíanos, como nota Filóstrato, VA 7.8; 7.33; 8.7.10. Foi executado mais tarde, talvez por envolvimento em algum tipo de conjura. $\mathrm{O}$ facto de o pai dele ter sido executado por Nero, deixaria ressentimento suficiente na família para encorajar uma vingança na pessoa do imperador reinante: vide Southern, P. 1997, 116.

${ }^{158}$ Segundo Díon Cássio, 67.14, Acílio Glabrião foi morto, acusado de ateísmo e muitos outros crimes, entre os quais, de combater, como gladiador, com bestas ferozes. Os feitos na arena provocaram a inveja do imperador. Há quem tente provar que ele era cristão: vide Southern, P. 1997,15 .

${ }^{159}$ Como diz Martin, R. 1991, 295.

${ }^{160}$ Dom.10.2. O ressentimento deve ter atirado Élio Lâmia para a oposição, mas Domiciano, desconfiado, devia temer uma reacção violenta e procurou suprimi-lo: vide Southern, P. 1997, 116.

${ }^{161}$ Dom. 10.3. Tratava-se da subversiva veneração da memória de um homem que fora imperador: assim se lembraria que o familiar vivo podia aspirar ao principado; vide GALLI, F. 1991, 81-82; Southern, P. 1997, 116.

${ }^{162}$ Dom. 10.3. Provavelmente teria aderido à revolta de Lúcio António Saturnino em 89, ou poderia ter caído em desgraça pela sua oposição à política não expansionista de Domiciano na Britânia, o que o tornava um potencial traidor aos olhos do imperador, que se mostrava mais consciente dos perigos depois da revolta de Saturnino: vide Jones, B. W. 1983, 629-633; GaLli, F. 1991, 82; com. de Jones, B. W. 1996, 91; com. de Jones, B. \& Milns, R. 2002, 147.

${ }^{163}$ Dom. 10.4. É suspeita a ligação da morte ao equívoco do praeco, uma vez que T. Flávio Sabino foi designado como colega de consulado de Domiciano para o ano de 82 e viveu o suficiente para ocupar o cargo. Existiria certamente a suspeita de adesão a uma conjura: vide Galli, F. 1991, 84; Southern, P. 1997, 43.

${ }^{164}$ Dom. 10.3. Cf. Díon Cássio, 67.13.2; Tácito, Ag. 2; Plínio, Ep. 1.5. Segundo Díon, o 
Métio Pompusiano, a quem um horóscopo anunciava o império. A morte desta personagem acentua o contraste entre a clementia de Vespasiano e a saeuitia de Domiciano. ${ }^{165} \mathrm{O}$ confronto entre a morte de Helvídio Prisco, no principado de Vespasiano, e a de Helvídio filho, morto por supostamente ter censurado a separação de Domiciano e Domícia, sob o nome de Páris e Enone, em um scaenicum exodium (peça cómica representada depois de peças sérias), lança sobre o biógrafo a suspeita de parcialidade. ${ }^{166}$ Por outro lado, revela que Domiciano, ao contrário do pai, não tem sentido de humor: é a negação da comitas de Vespasiano (cf. Ves. 22). As mortes apresentadas não pertencerão todas a uma fase adiantada do governo, como o biógrafo pretende fazer crer, ao propor uma evolução cronológica na crueldade do príncipe: a morte de Flávio Sabino, primo de Domiciano, poderá ser anterior. ${ }^{167}$ Mas esta morte é a acme do furor assassino de Domiciano, dada a parentela e o absurdo da causa. ${ }^{168}$

A gradação na saeuitia é marcada cronologicamente por referência à guerra civil movida por Lúcio António: Verum aliquanto post ciuilis belli uictoriam saeuior $^{169}$ ( (Mas tornou-se muito mais cruel depois de sair vitorioso da guerra civil»). A verdade é que, para conseguir a impressão desejada, Suetónio sugere, mais uma vez, uma falsa cronologia: a maioria das mortes acima referidas são certamente posteriores a este acontecimento. ${ }^{170} \mathrm{O}$ biógrafo selecciona os factos pela sua intensidade: refere atrocidades, como a invenção de um novo tipo de tortura que consistia em lançar fogo aos órgãos genitais e acrescenta que o imperador chegara a cortar as mãos a alguns. ${ }^{171}$ Consta que só dois de apelido de santo é apenas atribuído a Trásea (por Aruleno Rústico). Vide Della Corte, F. 1967, 96-98.

165 Dom. 10.3. Cf. Ves. 14; Díon, 67.12.3. Vide análise das divergências dos relatos em Gascou, J. 1984, 326-328. Tal como a apresenta Díon Cássio, 67.12.2-4, esta informação devia circular conjuntamente em fontes posteriores à morte de Domiciano.

${ }^{166}$ Mas a verdade é que Helvídio pertence a um grupo, unido por laços familiares e de amizade com um longo historial de oposição estóica: Cecina Peto, Trásea Peto; Helvídio Prisco; Aruleno Rústico; Herénio Senecião; os dois últimos executados por Domiciano e talvez em conjunto com Helvídio filho. No grupo se incluem mulheres como Árria, a heróica esposa de Cecina Peto, e Fânia, filha de Trásea Peto e esposa de Helvídio Prisco filho. Vide Southern, P. 1997, 113-114.

${ }^{167}$ Dom. 10.4. Terá sido executado entre 82 e 89, uma vez que a mulher, a filha de Tito, lhe sobreviveu (Dom. 22) e morreu, o mais tardar, em 89: vide Galli, F. 1991, 84; Gascou, J. 1984, 412. Mais provavelmente a execução terá ocorrido, juntamente com a de outros senadores, entre Outubro de 82 e Setembro de 83: vide Southern, P. 1997, 43.

${ }^{168}$ Como se lê em Gascou, J. 1984, 413, e Southern, P. 1997, 43.

${ }^{169}$ Dom. 10.5. A guerra civil aconteceu em Janeiro de 89.

${ }^{170}$ Se tomarmos como referência as datas adoptadas por GAscou, J. 1984, 411-413 (e 691), Cívica Cerial morre por volta de 89; Salvidieno Orfito, por volta de 93; Acílio Glabrião, cônsul com Trajano em 91 (cf. Díon 67.14.3), foi morto em 95; Élio Lâmia em 93 (ou em 85, segundo Galli, F. 1991, 59); Métio Pompusiano, talvez em 91; a desgraça de Salústio Luculo é colocada entre 86 e 96 (ou entre 89 e 90, segundo GALLI); Júnio Rústico em 93; a expulsão dos filósofos de Itália poderá ter acontecido em 93 (vide Galli, F. 1991, 82).

${ }^{171} \mathrm{O}$ facto de o biógrafo não mencionar os nomes destas vítimas pode explicar-se com uma providência de Domiciano que, para abafar o escândalo, proibiu a menção dos nomes nos registos: cf. Díon Cássio, 67.11.3. 
entre os mais ilustres - um tribuno laticlavo e um centurião - obtiveram o perdão, pois provaram serem homossexuais passivos (impudici), pelo que não eram dignos de crédito junto dos soldados ou do general. ${ }^{172} \mathrm{O}$ grau seguinte nesta progressão é o cinismo com que aplicava as penas: Erat autem non solum magnae, sed etiam callidae inopinataeque saeuitia (Dom.11.1) («Era pois de uma crueldade, não só brutal, mas também astuta e imprevisível»). Já vimos que o humor negro é apanágio dos grandes tiranos. ${ }^{173}$

O biógrafo passa ao tema da rapina, já anunciado atrás. A causa é, como em Calígula e em Nero, a carência das finanças, devido aos gastos com construções, espectáculos e aumento do soldo: ${ }^{174}$ é o reverso da medalha do evergetismo imperial. ${ }^{175}$ A anterior abstinentia (Dom. 9.1), a recusa das heranças da parte de quem tinha filhos vivos (Dom. 9.2), a repressão das fiscales calumniae e o castigo dos delatores, pomposamente ostentado (Dom. 9.3), são suprimidos da memória do leitor pela constatação de que bona uiuorum ac mortuorum usquequaque quolibet et accusatore et crimine corripiebantur ${ }^{176}$ («confiscavam-se os bens dos vivos e dos mortos onde quer que fosse, qualquer que fosse o acusador ou o crime»). Para os vivos, bastava qualquer facto ou dito contra a maiestas do imperador; para os mortos, bastava que alguém afirmasse que o defunto, em vida, referira o imperador como herdeiro. ${ }^{177} \mathrm{O}$ facto de se não apresentarem exemplos faz pensar na habitual generalização por parte do biógrafo. Como ponto culminante desta prática de extorsão, Suetónio refere o excesso de rigor posto na colecta do Iudaicus fiscus aos prosélitos não declarados e judeus natos que disfarçavam a origem. O biógrafo atesta a veracidade do facto com o testemunho pessoal (interfuisse me adulescentulum memini): a impressão que lhe causara a

${ }^{172}$ Dom. 10.5. O tribuno seria Júlio Calváster, como se depreende das palavras de Díon, 66.11.4. Os acusados terão argumentado que a sua ligação a António Saturnino era de natureza sexual e não política; vide com. de Jones, B. \& Milns, R. 2002,149.

${ }^{173}$ Cf. Cal. 29.1: Immanissima facta augebat atrocitate uerborum.

${ }_{174}$ Dom. 12.1: Exhaustus operum ac munerum inpensis stipendioque, quod adiecerat. Cf. Cal. 38.1: Exhaustus igitur atque egens ad rapinas conuertit animum; Nero 32.1: iam exhaustus et egens... calumniis rapinisque intendit animum. Vide Gascou, J. 1984, 749 n. 261. Exhaustus é exagero do biógrafo, como notam, no seu com., Jones, B. \& Milns, R. 2002, 150-151: Domiciano teria recursos suficientes, mas quereria mais (cf. Plínio, Pan. 50.5) para o seu programa de construções monumentais.

${ }^{175}$ Ficam assim ensombradas pelo exagero nos gastos medidas anteriormente apresentadas como positivas (Dom. 4-5). Então sublinhou apenas a generosidade do imperador: só agora aborda as consequências nefastas; vide GAscou, J. 1984, 372.

${ }^{176}$ Dom. 12.1. Esta atitude contrasta com a de Tito, que desencoraja e castiga os delatores (Tit. 8.5), e faz lembrar a de Nero, pela repressão indiscriminada: Nullus posthac adbibitus dilectus aut modus interimendi quoscumque libuisset quacumque de causa (Nero 37.1).

${ }^{177}$ Dom.12.1-2.Esta restauração da lex maiestatis, abolida depois da queda de Nero, explica-se, segundo Martin, R. 1991, 342-343, por um comportamento patológico de desconfiança, misantropia e dissimulação: uma verdadeira fobia que o leva a suprimir sistematicamente todas as pessoas susceptíveis de subirem ao governo do Império ou de atentarem contra a sua vida. Southern, P. 1997, 119ss, tenta explicar o carácter desconfiado de Domiciano, com base em estudos de psicologia, no facto de ter perdido a mãe muito cedo. Seria essa a razão que levaria Domiciano a declarar-se filho de Minerva, numa tentativa para criar uma mãe substituta. 
inspecção de um nonagenário, na presença de largo conselho, para averiguar se era circunciso. ${ }^{178}$

A seguir, faz-se a apresentação diacrónica da inciuilitas de Domiciano, que, desde a juventude, se mostra arrogante e sem moderação nas palavras e nos actos, ${ }^{179}$ a começar pela atitude arrogante para com Cénis, concubina de Vespasiano (limita-se a estender-lhe a mão, quando ela, ao chegar de uma viagem, lhe oferecia o rosto para ser beijado). Os exemplos seguintes lembram de perto os descritos ao longo do capítulo 76 da Vida de Júlio César: facta e dicta e falta de comedimento na aceitação de honras que tornaram justificada a morte do ditador. Assim se constrói a gradação na actividade de Domiciano como imperador ${ }^{180}$, até se tornar no tirano odiado de todos (Dom.14.1), altura em que se inicia o relato da morte.

Só depois da narrativa da morte e do funeral aparecem as rubricas descritivas: o retrato físico (Dom. 18), os gostos desportivos (Dom. 19), os estudos liberais (Dom. 20), os hábitos (Dom.21) e a libido (Dom. 22), com nítido paralelismo estrutural com Nero (Nero 51ss.). É como se o biógrafo não quisesse que a interposição destes elementos descritivos, que, em outros casos, antecedem a narrativa da morte ${ }^{181}$ prejudicasse a ligação entre a culpa e o castigo e diminuísse a tensão que se gerou com a descrição das enormidades. Com o físico amolecido, Domiciano é apresentado como um decadente e preguiçoso, incapaz de fazer qualquer tipo de esforço. ${ }^{182}$ Não se aplicava ao manejo das armas, mas praticava com perícia o tiro ao arco, que não pertencia ao equipamento de uma legião. Também Tito mostrara destreza no uso do arco, mas usara-o para fins militares, com bons resultados (Tit. 5.2.). Censura-se a negligência revelada nos liberalia studia, embora, em outros passos, se lhe atribuam uma citação de Virgílio e duas de Homero (Dom 9.1; 12.3; 18.2). Parece sintomático que Domiciano só leia os commentarii de Tibério; ${ }^{183}$ e o facto de recorrer ao engenho alheio para compor cartas, discursos e edictos aproxima-o de Nero. ${ }^{184}$ A tendência para o isolamento é confirmada pelo hábito

${ }^{178}$ Dom. 12.2. Suetónio faz referência à taxa da didracma, que os Judeus já pagavam para o templo de Jerusalém e, que, depois da destruição deste, no ano 70, passaram a pagar para o templo de Júpiter Capitolino, o que lhes dava o direito de praticarem livremente a sua religião: cf. Josefo, BJ 7.6.6; Díon Cássio, 66.7.2. Muitos dos acusados poderiam ser cristãos, mas a destrinça não contava para o governo imperial. Vide Keresztes, P. 1973, 1-7; Galli, F. 1991, 86-88.

${ }^{179}$ Dom.12.3: Ab iuuenta minime ciuilis animi confidens etiam et cum uerbis tum rebus immodicus. Vide Martin, R. 1991, 312-313.

${ }^{180}$ Cize K, E. 1977, 120, não concorda que haja gradações na Vida de Domiciano. Segundo este autor, o biógrafo prefere apresentar uma imagem de matizes.

${ }^{181}$ Cf. Jul. 44.4; Aug. 72ss; Tib. 68ss; Cal. 50ss; Cl. 30ss. Ves. 20ss.

${ }_{182}$ Dom. 19. A mesma ideia em Tácito, Agr. 40; Plínio, Pan. 14; Díon Cássio, 67.6.3.

${ }^{183}$ Dom. 20. As críticas de Suetónio parecem injustas. Coleman, K. M. 1986, 3087-3095, sustenta que Domiciano teria talento literário, mas, ao chegar ao poder, terá revelado uma conscienciosa preocupação com o governo e legislação, facto que o levou a abandonar a actividade literária.

${ }^{184}$ Tácito, ao comparar os dotes oratórios de Nero com os dos príncipes anteriores, afirma que este foi o primeiro imperador a recorrer à aliena facundia (Ann. 13.3). Suetónio talvez esteja 
de passear sozinho entre a hora de jantar e a de ir dormir. O rosto ruborizado sugere uerecundia (Dom.18.2), o que está de acordo com a sua tendência para a dissimulação. Como é habitual nos tiranos, tem um apetite sexual desmedido. A tirania sexual manifesta-se na forma como recusa o casamento com Júlia, filha do irmão, mas não hesita em seduzi-la, depois de casada, ainda em vida de Tito. E, mais tarde, causa-lhe a morte ao obrigá-la a abortar. ${ }^{185}$ Domiciano fica, deste modo, associado aos piores príncipes Júlio-Cláudios: Tibério, Calígula e Nero.

No que diz respeito aos efémeros imperadores de 68-69 d.C., como o período de governação é muito curto, a gradação não tem a mesma amplitude. Mas, nos casos de Galba e Vitélio, é visível a progressão até um estádio de degradação moral que terá como consequência a morte. A imagem positiva de que Galba gozava antes da chegada ao poder supremo, e que lhe garantira a posse do império, esfuma-se. A explicação deste insucesso encontra-a Suetónio no carácter de Galba. Dois vícios se salientam e que, afinal, já eram conhecidos: Praecesserat de eo fama saeuitiae simul atque auaritiae ("Tinham-no precedido a fama, que sobre ele corria, ao mesmo tempo de crueldade e avareza»). Tal informação, embora respeitante à actividade anterior de Galba, foi deslocada para esta secção, onde permite verificar o efeito sobre a actividade governativa e confere maior unidade à narrativa. Apresentam-se exemplos de atitudes anteriores de falta de moderação no tocante a cidades da Hispânia e da Gália e, concretamente, Tarragona. ${ }^{186}$ Como habitualmente, os traços negativos do carácter tendem a agravar-se com a ascensão ao poder; e o que era fama torna-se triste realidade: Ea fama et confirmata et aucta est, ut primum urbem introiit (Gal. 12.2) («Essa fama foi confirmada e agravada, mal entrou na Urbe»). Seguem-se exemplos dos excessos de zelo: despromoveu e dizimou os classiarii, que Nero elevara de remadores a soldados de pleno direito (iusti milites); desmobilizou a coorte da guarda germânica e enviou-a sem recompensa para a sua pátria. O biógrafo transita, então, dos actos iniciais para a descrição do governo, propriamente dito, de Galba (Gal. 14-16). O balanço pende claramente, logo à partida, para o lado negativo. É manifesta a frustração das expectativas: Maiore adeo fauore et auctoritate adeptus est quam gessit imperium, quanquam multa documenta egregii principis daret; sed

a generalizar, pois anteriormente apresentara Domiciano a ditar um documento oficial (Dom. 13.2). Vide Martin, R. 1991, 240.

${ }^{185}$ Ideia semelhante se encontra em Juvenal, 2.29-33; Plínio, Ep. 4.11.6; Díon Cássio, 67.3.1. No seu com. Jones, B. W. 1996, 151 (e, mais tarde, Jones, B. \& Milns, R. 2002, 167), duvida de que o relacionamento de Domiciano com Júlia fosse o descrito pela tradição: os rumores sobre a morte de Júlia devem ter-se levantado depois da morte de Domiciano; caso contrário, dificilmente Marcial, 6.3.5, se referiria a Júlia como divina protectora de um futuro filho de Domiciano, que Roma esperava, humilhando assim publicamente Domícia; para mais, com a referência a um filho cujo nome (Iulius) perpetuaria a lembrança da amante do marido.

${ }^{186}$ Gal. 12.1. Para Le Roux, P. 1984,113-124, Suetónio mostra-se dividido entre a aprovação da revolta de Galba e a condenação dos excessos que provocou por culpa do carácter de Galba e do contexto de guerra civil. 
nequaquam tam grata erant, quam inuisa quae secus fierent ${ }^{187}$ ( Gozou de maior apoio e prestígio ao assumir o império do que ao governá-lo. Embora desse muitas provas dignas de um príncipe distinto, todavia de modo algum tão gratas como odiosas se tornaram as más acções»). Ora Suetónio não apresenta nenhuma boa acção, ${ }^{188}$ como que a sugerir que os actos bons não contaram ou foram esquecidos perante a impressão fortemente negativa que se gerou. Em contrapartida, uma nova linha surge na narrativa: ${ }^{189}$ a submissão do imperador a três homens, que o vulgo já apelidava de "pedagogos" - Tito Vínio, Cornélio Lacão e o liberto Ícelo - , e as inconsequências que daí resultavam na expressão da sua avareza. Ao abandonar-se aos vícios, diferentes entre si, dos três, Galba, como já antes Cláudio, acaba por agir de forma incoerente: modo acerbior parciorque, modo remissior ac neglegentior quam conueniret principi electo atque illud aetatis ${ }^{190}$ («ora mais rígido e poupado, ora mais brando e perdulário do que era conveniente para a um príncipe eleito e para a sua idade»). Por um lado, é grande a severidade e as condenações aparecem em catadupa: quosdam claros ex utroque ordine uiros suspicione minima inauditos condemnauit ("condenou alguns ilustres varões de uma e outra ordem, à mínima suspeita, sem os ouvir») - cinco expressões (quosdam - claros - ex utroque ordine - suspicione minima inauditos) apresentadas em gradação emotiva, que sugerem a imagem de um tirano sedento de sangue. ${ }^{191}$ Segue uma política de exagerada contenção, ${ }^{192}$ na qual se vislumbra um esforço para fazer face à dilapidação dos cofres do Estado operada por Nero; mas o biógrafo retém o aspecto negativo do excesso das medidas. Os Romanos já não estavam habituados a viver sob a austeridade arcaica do velho general. Em flagrante oposição (sublinhada por at contra) a esta política grassa a corrupção, o que acentua a incoerência do governo. Verifica -se a coexistência de dois pesos e duas medidas: Galba tolera que os amigos e libertos concedam, por dinheiro ou por favor, vários privilégios: rendimentos, isenção de impostos, castigo de inocentes, impunidade aos culpados. Chega até a poupar a vida, contra o pedido do povo romano, a Haloto e a Tigelino. Mais grave ainda: acaba por conceder a Haloto um cargo importante; e, num edicto em defesa de Tigelino, censura ao povo a sua crueldade. ${ }^{193}$

As rubricas descritivas do físico e dos costumes são, também nesta Vida, apresentadas depois da morte. Quanto aos hábitos, fica-se a saber que era

${ }^{187}$ Gal. 14.1. Cf. Tácito, Hist. 1.7.2. A ideia de que era um bom cidadão privado e um mau imperador também vem expressa em Tácito, Hist. 1.49.4: et omnium consensu capax imperii, nisi imperasset.

${ }^{188}$ Tácito, Hist. 49.1, e Díon, 64.2.1-3.4, expõem as boas acções.

${ }^{189}$ Sobre a análise das linhas condutoras da narrativa do governo de Galba, vide Venini, P. 1974, 1006-1008.

${ }^{190}$ Gal. 14.2. Cf. Tácito, Hist. 1.13.1. Vide Martin, R. 1991, 286-287.

${ }^{191}$ Gal. 14.3. Como salienta, no seu com., Murison, Ch. L. 1992, 68, o propósito desta enumeração não é restringir a referência através de uma definição cuidadosa, mas criar a impressão de tirania crescente e sangrenta.

${ }_{192}$ Gal. 15.1. Cf. Plutarco, Gal. 16. 3-4; Tácito, Hist. 1.20.

${ }^{193}$ Gal.15.2. Mas Suetónio silencia a eliminação, com o aplauso do povo, de vários agentes de Nero, como se vê pelo confronto com Plutarco, Gal. 17.2-3, e Díon Cássio, 63.3.4. 
homem de apetite voraz ${ }^{194}$ e, quanto a preferências sexuais, tendia para os jovens vigorosos. ${ }^{195}$ Não escondia o seu relacionamento com Ícelo (Gal. 22). Tais preferências anulam as notas favoráveis de que se não voltou casar e de que resistiu aos intentos de Agripina. ${ }^{196}$

A actuação de Vitélio como imperador é iniciada com duas medidas consideradas louváveis. Licenciou as coortes pretorianas, pelo seu péssimo exemplo (subentende-se a traição a Nero e a Galba) e condenou à morte os que pediram a Otão uma recompensa por terem participado na morte de Galba. O biógrafo comenta: egregie prorsus atque magnifice et ut summi principis spem ostenderet, nisi cetera magis ex natura et priore uita sua quam ex imperii maiestate gessisset (Vit. 10.1) («procedia com nobreza, no fim de contas, e com grandeza, ao ponto de criar até a esperança num eminente príncipe, se, quanto ao resto, não agisse mais segundo a natureza e a vida anterior que segundo a majestade do império»). As expectativas saem frustradas. Logo no campo de batalha de Betríaco tem reacções que o biógrafo qualifica de uanitas e insolentia (Vit. 10.3). A semelhança com Nero, cujo modelo Vitélio pretenderia seguir (Vit. 11.2), diz respeito ao que aquele tinha de mais negativo e processa-se não só no plano da actuação política, mas também no moral. Para mais, Vitélio tinha encorajado as ambições artísticas do último dos Júlio-Cláudios (Vit. 4). Como vícios principais, a luxuria e a saeuitia (Vit. 13.1) fazem de Vitélio uma caricatura de Nero. A luxúria concretiza-se na gula, vício no qual ele manifesta a sua desmesura e que também era superlativado em Cláudio (Cl. 33.1). O cúmulo deste vício é expresso por homo non profundae modo, sed intempestiuae quoque ac sordidae gulae (Vit. 13.3) («homem não só de uma gula sem fundo, mas também despropositada e abjecta»).

A saeuitia é tal que, pelas semelhanças verbais, corresponde ao grau mais elevado de Nero: é exercida contra quem quer que seja e a qualquer pretexto. ${ }^{197}$ Suetónio parece desdobrar informações retiradas de uma mesma história, distribuídas em gradação ao longo da rubrica, com se se tratasse de pessoas diferentes. Conta que, a um doente que, durante um acesso de febre, lhe pedia água, o próprio Vitélio lhe deu veneno num copo de água fria (Vit. 14.1); a outra vítima, depois de a condenar, mandou reconduzi-la de novo à sua presença e, quando todos celebravam já a sua clemência, ordenou que a matassem à sua frente (Vit. 14.2). Ora a comparação com Tácito parece indicar a utilização

${ }^{194}$ O que poderá ser a causa da gota de que sofria; vide Martin, R. 1991, 113.

195 Uma característica atribuída por Suetónio aos tiranos, segundo CARney, T.F.1968,11-12: os bons imperadores não tendem para a homossexualidade (Augusto desmentiu os hábitos da juventude com a conduta posterior).

${ }^{196}$ Para Martin, R. 1991, 146-147, a vida nas campanhas militares poderá explicar o facto de se não voltar a casar, mas há que ter em conta a sua preferência por homens, mencionada unicamente por Suetónio (vide p. 165-166).

${ }^{197}$ Vit. 14.1: Pronus uero ad cuiuscumque et quacumque de causa necem atque supplicium; cf. Nero 37.1: Nullus posthac adbibitus dilectus aut modus interimendi quoscumque libuisset quacumque de causa. Contrasta com esta afirmação de Suetónio a notícia, dada por Díon Cássio, 66.6.2, de que suprimiu reduzido número de otonianos. 
de elementos da narrativa da morte de Júnio Bleso. ${ }^{198}$ A tirania manifesta-se também nos jogos, à maneira de Calígula, com quem Vitélio partilhava o gosto pelas corridas: manda executar uns homens da plebe por terem caluniado a facção azul. ${ }^{199}$ Mas o seu maior ódio era aos bufões e astrólogos. ${ }^{200}$

A semelhança com Nero vai até à acusação de matricídio. Cai sobre Vitélio a suspeição de responsabilidade na morte da mãe, a quem teria negado alimento durante uma enfermidade, movido por um oráculo que the prognosticava um longo reinado, se ele sobrevivesse aos pais. Outros dizem que a mãe, desgostosa da situação do momento e temerosa do que se seguiria, pediu veneno ao filho e que este lho deu sem se fazer rogado. Este crime marca o auge da sua saenitia. ${ }^{201}$

A construção da imagem destes imperadores segue as linhas gerais do discurso sobre a tirania. O biógrafo procura ilustrar a progressiva manifestação das qualidades próprias dos tiranos e o grau da sua ocorrência. Seria errado acreditar em tudo o que se diz, mas também não seria correcto rejeitá-lo sem mais. As características apontadas correspondem a uma descrição verosímil para os contemporâneos do biógrafo. ${ }^{202}$ Do ponto de vista doutrinal, tomando como exemplo os monarcas helenísticos, todo o tirano evidenciaria à partida inciuilitas, saeuitia ou crudelitas, luxuria, rapacitas, libido exagerada (que inclui abuso de matronas e homens livres, impudicitia e incesto) e impietas contra os deuses, contra a pátria e contra a família (parricídios, matricídios, morte de familiares). E, se não apresentava estas características, conclui-se que as dissimulava: é uma forma cómoda de explicar, sem entrar em contradição, o tradicional período bom de príncipes como Calígula ou Nero. Ora Suetónio, ao escolher das fontes as versões mais romanescas, apresenta narrativas, baseadas muitas vezes em rumores, que correspondem precisamente ao desenvolvimento daquelas características. Combinando estas versões com a técnica da gradação, o biógrafo confere às Vidas um efeito que se aproxima dos textos dramáticos.

\subsubsection{A Construção da imagem de um bom principe}

No caso dos bons imperadores, a estratégia é deixar para o final as virtudes. Procura-se, por vários modos, justificar, desculpabilizar ou minimizar os vícios. A tónica é colocada nas boas acções, de modo a que os piores comportamentos sejam relegados para uma fase inicial ou para um plano secundário. Suetónio começa a narrativa da actividade de Augusto como detentor único do poder com um resumo das conspirações que se formaram (Aug. 19). A contrastar com a larga narrativa das guerras civis aparece o sumário das guerras externas: parte

${ }^{198}$ Tácito, Hist. 3.39.1. Vide com. de Murison, Ch. L. 1992, 162-163.

199 Vit. 14.3. Também Calígula se ofende por a plebe apoiar outra equipa: Cal. 30.2. Domiciano condena um indivíduo que apoia os gladiadores Trácios (Dom. 10.1).

${ }^{200}$ Vit. 14.4: Nullis tamen infensior quam uernaculis et mathematicis.

201 Vit. 14.5. Tácito, Hist. 3.67.2, dá notícia de uma opportuna mors, ocorrida poucos dias antes da de Vitélio. Sobre a organização em clímax (Vit. 12-14), vide CizeK, E. 1977, 132-133.

${ }^{202}$ Vide Dupont, F. et ÉLoI, T. 2001, 263-323. 
da constatação de que dirigiu pessoalmente apenas duas guerras, mas acentua os riscos e as feridas de guerra (Aug. 20); faz o elenco dos povos submetidos e rechaçados, para se centrar na justiça das guerras, na política não expansionista e no trato com os vencidos (Aug. 21.1-2). Emerge uma imagem de uirtus e moderatio que favorece as relações diplomáticas com os povos estrangeiros, de que se destaca a fácil devolução dos estandartes tomados pelos Partos a Crasso e a António (Aug. 21.3), e a política de paz, simbolizada pelo encerramento do templo de Jano (Aug. 22). Ao tratar as derrotas, Suetónio introduz já a imagem do princeps preocupado com o bem público e a sofrer com as calamidades (Aug. 23). Da res militaris destaca Suetónio o rigor e a restauração de costumes (Aug. 24). Depois das guerras civis, Octávio distingue-se do pai adoptivo pelo distanciamento que cria na relação com os soldados, que trata por milites, em vez de commilitones, com vista a restabelecer uma forte disciplina. Tal como Júlio César, também Augusto citava versos das Fenícias de Eurípides, mas, neste caso, a propósito da prudência do general (Aug. 25.4).

No tratamento diacrónico das magistraturas e as honras (Aug. 26-28), a imagem negativa é retomada através da descrição da atitude de Augusto durante o triunvirato e as proscrições. O biógrafo introduz agora elementos que havia omitido quando da referência à formação do triunvirato (Aug. 13.1). Diz o biógrafo que Augusto, embora se opusesse inicialmente às proscrições, as aplicou depois com maior rigor e que foi o único que se esforçou para que ninguém fosse poupado (Aug. 27.1). Esta posição é interessante, porque contrasta com a generalidade dos outros testemunhos. ${ }^{203}$ Suetónio acrescenta que Octávio proscreveu mesmo o seu tutor e colega de seu pai, C. Torânio. E acrescenta, em gradação, outros actos cruéis, passados durante o triunvirato, que lhe granjeariam a inuidia (Aug. 27.2-4). Mas nada diz sobre o mais famoso dos proscritos: Cícero. Suetónio usa-o como fonte, mas tem tendência para omitir algumas das suas intervenções. ${ }^{204}$ Talvez, neste caso, tivesse relutância em lembrar as indignas circunstâncias do fim do grande orador. Não que este tipo de descrições desagradasse ao biógrafo, mas, neste caso, a execução não era da responsabilidade directa de Octávio, em quem a biografia se centra, mas de António.

A partir deste cúmulo de crueldades a Vida deixa de apresentar marcas tão negativas, de tal sorte que o leitor verifica uma notável mudança no carácter de Octávio, que se faz coincidir com a decisão de implantar o principado. Atingido o objectivo da sua ambição, Octávio torna-se mais moderado nas suas acções. $O$ jovem ambicioso e cruel, que não olha a meios para atingir os fins, transforma-se no "monarca" magnânimo. ${ }^{205}$ Depois da decisão de não

${ }^{203}$ Veleio Patérculo, 2.66, e Plutarco, Ant. 20-21, Brut. 27-28, Cic. 46-49, censuram António e Lépido pelo excesso das proscrições; Díon Cássio, 47.3-13, desculpa Octávio e diz que salvou muita gente.

${ }^{204}$ Sobre a responsabilidade nas proscrições e sobre a omissão de Cícero, vide Southern, P. 1998, 55-59 e n. 14 (p. 217); McDermotт, W. C., 1972, 495-499. Suetónio já omitira Cícero em 12, ao designar genericamente por alii os que chamavam puer a Octávio.

${ }^{205}$ Suetónio parece estar a seguir um topos, que se impôs talvez por influência de Séneca, que opunha a crueldade de Octávio à clemência de Augusto: vide Gascou, J. 1984, 201-205. 
restaurar a república (Aug. 28), a qualidade do governante afere-se pelas suas realizações. Estas tornam-se, a partir de agora, definidoras da personalidade do imperador. Suetónio passa a descrever a política civil e militar (Aug. 29-60). ${ }^{206}$ Esta é uma parte essencial da Vida de Augusto, dada a extensão e a natureza do seu governo, mas também se torna uma parte monótona. A narrativa da actividade governativa é longa, como o foi o governo de Augusto, mas contribui também para afastar da memória do leitor os cruéis actos do jovem ambicioso e substituí-los pelo novo retrato, formado a partir das inúmeras acções do bom governante.

Suetónio apresenta a nota curiosa de que Augusto começa por usar como sinete uma esfinge, depois a imagem de Alexandre Magno e finalmente a sua própria (Aug. 50). Este parágrafo denota uma processo de busca de identidade: a busca de um modelo e a posterior caminhada para a auto-afirmação. Augusto agora é o princeps: já não sente necessidade de fundamentar o seu poder em símbolos e heróis do passado. Esfuma-se a tutela de César e o modelo de Alexandre. E, como afirma Néraudau, «dá o seu rosto à sua função». ${ }^{207}$ Este processo de maturação é imediatamente seguido da descrição das virtudes da clementia (Aug. 51) e da ciuilitas (Aug. 52-56), que o afastam da imagem dos tiranos, méritos premiados com a estima geral (Aug. 57.1), cuja expressão máxima é a atribuição do título de Pai da Pátria (Aug. 58). Com este título, se mostra que foi cumprido o voto que fizera de ser o auctor do optimus status (Aug. 28.2). ${ }^{208}$

Depois de mostrar como o imperator atingiu o cume político, Suetónio passa ao tratamento da vida familiar e dos hábitos de Augusto até ao fim da sua existência: ${ }^{209}$ constatará que neste campo, à parte o amor por Lívia (Aug. 62.2), foi desafortunado pela morte dos netos, Gaio e Lúcio, e pela desonra da filha e da neta, e ainda de Agripa Póstumo (Aug. 65). A ironia da Fortuna traz-lhe também traições de amigos a quem se dedicara (Aug. 66). Nas suas funções de patrono e senhor é severo, mas também tolerante e clemente para com os escravos e libertos. São narrados factos que poderiam ser usados como exemplos de crueldade (como condenar à morte por imoralidade Pólo, um dos libertos mais queridos, ou mandar quebrar as pernas ao secretário Talo, por ter revelado o conteúdo de uma carta) (Aug. 67.29), mas Suetónio, ao acentuar o afecto de Augusto para com estes prevaricadores, transforma estas acções em sinais da tragédia do justo governante, que se vê obrigado a fazer cumprir a lei

${ }^{206}$ Vide Baldwin, B. 1983, 241-243.

${ }^{207}$ NÉraudau, J.-P. 1996, 19.

${ }^{208}$ A gradação dos méritos sugerida por Suetónio parece confirmar a opinião de SALmon, E. T.1956, 456-478. Segundo este autor, o título de Pater Patriae, atribuído em 2 a. C., normalmente visto como puramente honorífico, é, na realidade, o culminar da evolução do principado de Augusto (mais do que em 19 a. C. com a atribuição do que Díon Cássio, 54.10.5, chama 'poder dos cônsules'), pois o próprio Augusto termina as Res gestae com a sua citação como Pai da Pátria, o que deixa a impressão que é para ele o ponto máximo da sua carreira.

${ }^{209}$ Aug. 61.1: Quoniam qualis in imperis ac magistratibus regendaque per terrarum orbem pace belloque re p. fuerit, exposui, referam nunc interiorem ac familiarem eius uitam quibusque moribus atque domi et inter suos egerit iuuenta usque ad supremum uitae diem. 
na sua casa.

Quanto às acusações de ser efeminado (Aug. 68), de adultérios (Aug. 69) e de fausto (Aug. 70), Augusto refuta a primeira, com a castitas, e a última, com o desprendimento. Mas não pôde afastar a acusação de luxúria, pois diz-se que gostava de desflorar virgens que a própria esposa lhe forneceria, ${ }^{210}$ e ele mesmo confessava em cartas a Tibério e a Júlia que era apaixonado pelo jogo dos dados (Aug. 71. 2-3). Suetónio quer nitidamente desculpar Augusto: parece querer ignorar o facto bem conhecido de que uma das referidas amantes do imperador, Terência, é esposa do seu amigo Mecenas. ${ }^{211} \mathrm{O}$ abuso da mulher de um cônsul, em presença do marido (Aug. 69.1.), não é apresentado com a gravidade que assume quando atribuído ao monstrum Calígula. ${ }^{212} \mathrm{Na}$ enumeração dos vícios (sodomia, adultérios, sumptuosidade, vício do jogo) e na sua refutação (sodomia, sumptuosidade, adultérios, vício do jogo) há uma gradação descendente. A reordenação em quiasmo (adultérios, sumptuosidade / sumptuosidade, adultérios), visa uma desculpabilização que deixa para o final, como menores, os que não podem ser refutados: o adultério e o vício do jogo (Aug. 71.1). Suetónio apresenta-os mesmo, contraditoriamente, como boatos (ut ferunt ... aleae rumorem) que acaba por confirmar, na tentativa de os menorizar: a luxúria é desdramatizada com a complacência de Lívia; o vício dos dados, com a franqueza de Augusto em relação ao boato: nullo modo expauit lusitque simpliciter et palam oblectamenti causa («de nenhum modo o receou e jogou sinceramente e às claras para se distrair»). Pela estratégia da menorização, cria Suetónio um Augusto com vícios humanos toleráveis. Tais vícios são ainda desvalorizados face ao exemplo da vida: In ceteris partibus uitae continentissimum constat ac sine suspicione ullius uitii (Aug. 72.1) ( $\mathrm{Na}^{\mathrm{Na}}$ restante parte da vida, consta que foi muito sóbrio e sem suspeita de outro vício»). Tudo isto permite demonstrar que Suetónio modela a personagem. Nesta altura da Vida, o biógrafo já não quer acentuar demasiado os traços negativos. $\mathrm{O}$ retrato centra-se agora na parcimónia e frugalidade de Augusto, que, no entanto, não deixava de mostrar liberalidade para com os outros (Aug. 72-78).

A imagem idealizada é patente também no retrato físico, não só pela sua forma eximia, resistente ao tempo, mas sobretudo pela aura divina e pela autoridade do porte (Aug. 79.1-3), que remetem pra o seu deus tutelar, Apolo. Parece haver uma luta entre a mitificação da imagem, que já estava na tradição, ${ }^{213}$ e o realismo do biógrafo. As enfermidades (Aug. 80-82) explicam a sua troca dos exercícios de equitação e de manejo das armas por exercícios menos violentos (Aug. 83). Mas, nesta fase da narrativa, os defeitos físicos já

${ }^{210}$ Aug. 71.1. Díon Cássio, 58.2.5, diz que Lívia soube conservar o marido, porque teve a inteligência de tolerar as estroinices dele.

${ }^{211}$ Díon Cássio, 54.19.3, fala de uma violenta paixão de Augusto por Terência, ao ponto de fazer um concurso de beleza entre esta e Lívia, e sugere (54.19.6) que a amizade entre Augusto e Mecenas esmoreceu por causa daquela mulher. Vide Verdière, R. 1971, 623-648. Este autor indica os vários pontos histórico-poéticos de convergência, que, a despeito da dificuldade da métrica, permitiriam identificar Terência com a Corinna de Ovídio.

${ }^{212}$ Cal. 25.1 e 36.2. Vide Baldwin, B. 1983, 245.

${ }^{213}$ Vide Martin, R. 1991, 56, e Néraudau, J.-P. 1996, 23. 
não ensombram a imagem criada. É o momento de Suetónio introduzir, em tom laudatório, a actividade intelectual de Augusto: a eloquência e os estudos liberais (Aug. 84-89), onde mais uma vez se evoca Apolo. A este deus construiu Augusto no seu palácio um templo, com uma biblioteca grega e latina. No que respeita às religiones, Suetónio começa por apresentar um Augusto aterrorizado por relâmpagos e trovões, com reacções que revelam reverência religiosa. Uma breve analepse permite reinterpretar, como causa do pavor, o episódio da queda do raio, que antes (Aug. 29.3) fora indicado como sinal da protecção divina e motivara a construção de um templo a Júpiter (Aug. 90). Igualmente positiva é crença nos sonhos, nos omina e nos prodígios (Aug. 91-92). Em relação aos cultos estrangeiros, manifesta respeito reverente pelas práticas religiosas ueteres ac praeceptae, como os mistérios de Elêusis, e desprezo pelas restantes (boi Ápis, judaísmo) (Aug. 93). De resto, a reforma da religião vai ser uma das suas preocupações como Pontífice Máximo (Aug. 31).

A transformação do jovem cruel no príncipe magnânimo e bom governante tem, pelo notável contraste, um efeito positivo no leitor. Se, na primeira parte da $V i d a$, há momentos que geram no leitor um sentimento altamente desfavorável ao jovem Octávio, devido à sua crueldade, com o decorrer dos capítulos sobre uma governação eficaz e qualidades de carácter opostas às dos tiranos, o leitor vai esquecendo os erros e experimenta admiração pelo fundador do novo Estado. Depois de dar a sua adesão, o leitor é convidado a dar a sua simpatia: é levado a experimentar compaixão pelos numerosos infortúnios do imperador, também elencados por Plínio (Nat. 7.46). Ora dolor e furor são características psicológicas dos heróis da tragédia latina. ${ }^{214}$

Vespasiano entra na cidade precedido, ao contrário de Galba, pela boa fama que - segundo se sugere - lhe deram os feitos taumatúrgicos ocorridos no oriente. ${ }^{215} \mathrm{~A}$ imagem do bom governante reflecte-se na preocupação com a salvação do Estado: ac per totum inperii tempus nibil habuit antiquius quam prope affictam nutantemque rem $p$. stabilire primo, deinde et ornare (16 $^{21}$ (e por todo o tempo do seu império a nada deu mais importância do que proporcionar, antes de mais, estabilidade ao Estado, que estava quase abatido e vacilante, e depois, embelezá-lo»). Esta atitude aproxima Vespasiano de Augusto, que se preocupa em restaurar a beleza e a segurança da Urbe ${ }^{217}$ Está estabelecido um padrão de conduta que é exemplificado de seguida. A tarefa urgente do novo imperador é controlar os malefícios da guerra civil: a licentia e a audacia dos soldados, ${ }^{218}$ das províncias e das cidades livres e dos reinos. Desde logo se mostra parco nos gastos com gratificações, e apresenta-se como paladino da antiga austeridade,

${ }^{214}$ Assim pensa Néraudau, J.-P. 1996, 83.

${ }^{215}$ Vesp. 8.1: Talis tantaque cum fama in urbem reuersus. Cf., por oposição, Gal. 12.1.

${ }^{216}$ Vesp. 8.1. Vide Baldwin, B. 1983, 287.

217 Aug. 28.3: Vrbem neque pro maiestate imperii ornatam et inundationibus incendiisque obnoxiam excoluit adeo, ut iure sit gloriatus 'marmoream se relinquere, quam latericiam accepisset'. Tutam uero, quantum prouideri humana ratione potuit, etiam in posterum praestitit.

${ }^{218}$ Ves. 8.2. Também Augusto tomara providências quanto à situação dos soldados depois da guerra civil: Aug. 24-25. 
o que também o aproxima, moderadamente embora, de Galba.

Depois de descrever a actividade do imperador (Ves. 9-11), o biógrafo centra-se nas qualidades morais do homem. Faz o elogio da ciuilitas e da clementia e salienta a constância destas virtudes, que se mantiveram do início ao fim do seu governo (Ves. 12). Tal constância distingue-o de imperadores dissimulados, como Tibério, Calígula, Nero e Domiciano, nos quais se manifestaram virtudes paralelas que depois degeneraram em vícios, ${ }^{219} \mathrm{e}$ aproximam-no de Augusto, em quem se fortaleceram. ${ }^{220} \mathrm{O}$ biógrafo atinge o ponto mais elevado da decrição da clementia com o elogio: Non temere quis punitus insons reperi[r]etur nisi absente eo et ignaro aut certe inuito atque decepto (Ves. 15) («Não se encontraria facilmente um inocente que fosse castigado, a não ser na sua ausência e com o seu desconhecimento ou contra a sua vontade e enganado»). Mas, para ilustrar o alto grau da clemência de Vespasiano, Suetónio apresenta, paradoxalmente, a execução certamente mais escandalosa deste principado. Não parece credível que o senador Helvídio Prisco, célebre estóico, genro de Trásea Peto, fosse morto no exílio, sem o conhecimento do imperador. ${ }^{221}$ A estratégia do biógrafo é, por um lado, salientar a culpa de Prisco - num crescendo de superbia que culmina em altercationes insolentissimae ${ }^{222}-$ e por outro, diminuir a de Vespasiano - provar que o imperador agiu certe inuitus atque deceptus ("a contragosto ou enganado»). ${ }^{223} \mathrm{~A}$ culpa da morte é assim desviada para outrem. ${ }^{224} \mathrm{O}$ imperador tenta revogar a sentença de morte que assinara e tê-lo-ia salvo se não recebesse a notícia, falsa, de que Prisco já tinha morrido. Prisco teve a desdita de ser condenado por um imperador considerado bom: se não existe culpa no imperador, é porque existe no réu.

Semelhante estratégia se vislumbra no tratamento do vício da avareza, desde logo apresentado, de modo benévolo, como único: Sola est, in qua merito culpetur, pecuniae cupiditas (Ves. 16.1) («há só um vício, do qual é acusado com razão: a avidez de dinheiro»). De facto, Suetónio afirma que, além de retomar as contribuições suprimidas por Galba, ${ }^{225}$ de impor impostos novos e aumentar (em alguns casos para o dobro) o tributo das províncias, vendeu descaradamente

${ }^{219}$ Cf. Tib. 26.1; Cal. 15.4; Nero 10.1; Dom. 9.1.

${ }^{220}$ Ves. 12: Ceteris in rebus statim ab initio principatus usque ad exitum ciuilis et clemens. Cf. Aug.

51.1: Clementiae cuilitatisque eius multa et magna documenta sunt.

${ }^{221}$ Como sublinha, no seu com., CESA, M. 2000, 85-86.

${ }^{222}$ Vide Paratore, E. 1980, 17-18. Della Corte, F. 1967, 97-98, destaca a diferença de tratamento, por parte do biógrafo, para com membros da mesma família, réus da mesma culpa: considera Helvídio Prisco pai arrogante e Helvídio Prisco filho inocente (Dom. 10.4). Tácito, pelo contrário, faz o elogio de Helvídio Prisco (Hist. 4.5-6), pelo que se depreende que não aprovaria a sua condenação.

223 Ves. 15. Segundo o com. de Braithwaite, A. W. 1927, 57-58, e Gascou, J. 1984, 328-332, absente eo alude às execuções levadas a cabo por Muciano em Roma, em 70; ignaro poderá referir-se às crueldades imputadas a Tito, durante a sua pretura; e inuito atque decepto (sem ser obscuro, como pretende Braithwaite) dirá respeito ao caso de Helvídio Prisco.

${ }^{224}$ Talvez Muciano, uma vez que Díon Cássio, 66.13, o aponta como fomentador da perseguição aos filósofos.

${ }^{225}$ Provavelmente Galba concedeu benefícios fiscais às províncias que o proclamaram imperador - a Hispânia e a Gália: vide com. de Braithwaite, A. W. 1927, 60. 
cargos públicos e absolvições a réus, fossem eles inocentes ou culpados. ${ }^{226}$ Mas as afirmações seguintes perdem peso por serem apresentadas apenas como rumores: recorria aos procuradores (creditur) mais rapaces, como esponjas que depois espremia; era natura cupidissimus (tradunt). O terceiro rumor segue a via da argumentação contra o vício de natura (sunt contra qui opinentur): que ele cede às espoliações e rapina por necessidade, ${ }^{227}$ dada a penúria do erário e do fisco. Em abono desta opinião se apresenta o testemunho de Vespasiano, no início do seu principado, sobre a quantia necessária à sobrevivência do Estado. Este argumento recebe no fim o aval do biógrafo: Quod et ueri similius uidetur, quando et male partis optime usus est ${ }^{228}$ («opinião esta que parece mais de acordo com a verdade, porquanto o que adquiriu mal usou-o muito bem»). Aqui o biógrafo assume o papel de juiz para encerrar o assunto. $\mathrm{O}$ único vício, já minimizado com estas explicações, é depois praticamente anulado com a afirmação da virtude contraposta - liberalissimus para com todos. ${ }^{229} \mathrm{O}$ biógrafo vai sugerindo (por enquanto implicitamente) que a avidez de dinheiro correspondeu a uma fase passageira e justificada no início do principado e que depois mudou. A fama de avareza, embora imerecida, mostra-se arreigada: Et tamen nec sic quidem pristina cupiditatis infamia caruit («E todavia nem sequer assim se livrou da sua má reputação, antiga, de avidez»). Ao enfatizar a adversativa (Et tamen nec sic quidem) e ao classificar a cupiditatis infamia de pristina, Suetónio está a separar a actuação presente da anterior, a realidade da opinião, Vespasiano da sua fama. ${ }^{230}$

Uma característica largamente ilustrada nesta Vida é, sem dúvida, o sentido de humor, associado pelo biógrafo à afabilidade (comitas) de Vespasiano: erat enim dicacitatis plurimae, etsi scurrilis et sordidae, ut ne praetextatis quidem uerbis abstineret ${ }^{231}$ («era muito dado às facécias, se bem que a tender para o farsesco e para a vulgaridade, ao ponto de nem sequer omitir palavras obscenas»). A sua comitas e ciuilitas é o oposto do humor negro e da arrogância dos tiranos. Era

${ }^{226}$ Ves. 16.2. Tácito, Hist. 2.84, atribui venalidade da justiça antes de mais a Muciano, cujo mau exemplo é depois seguido por Vespasiano; e Díon Cássio, 66.14.3, diz que era Cénis quem vendia os cargos.

${ }^{227}$... necessitate compulsus - em contraposição a natura cupidissimus; vide com. de CESA, M. $2000,88$.

${ }^{228}$ Ves. 16.3. Tácito, pelo contrário, tende para a a opinião dos que consideram Vespasiano natura cupidissimus: Prorsus, si auaritia abesset, antiquis ducibus par (Hist. 2.5.1). Vide BALdwin, B. 1983, 290.

${ }^{229}$ Ves. 17. O bom príncipe é generoso com todas as ordens, tal como Augusto (cf. Aug. 41.1). Vide Martin, R. 1991, 300-301.

${ }^{230}$ Ves. 19.1. Segundo afirma, no com., CESA, M. 2000, 86, «l'impressione generale che si ricava dal suo ritratto è piuttosto negativa - anche perché, alla sezione sulla largitas, segue una ripresa del tema dell' avidità, che, anche a causa di questa posizione all' interno della biografia, è quello che colpisce maggiormente la fantasia dei lettori». Mas, neste caso, a posição na biografia (determinante em geral), não aumenta o vício, antes prova que ele já não existe e que a infamia é injusta. Como nota Gascou, J. 1984, 702-703, Suetónio renuncia a deixar falar os factos, mas interpreta-os e decide, de modo arbitrário e parcial, que uns são do domínio da aparência e outros da realidade.

${ }^{231}$ Ves. 22. Os ditos do imperador contribuem para revelar o carácter: vide Della Corte, F. 1967, 152 . 
sobretudo nos momentos de lazer que se mostrava mais acessível e indulgente (Ves.21).Vespasiano tinha sentido de humor em relação a si próprio e usava o riso como forma de atenuar a má fama de avaro: Maxime tamen dicacitatem adfectabat in deformibus lucris, ut inuidiam aliqua cauillatione dilueret transferretque ad sales (Ves. 23.1) («Mostrava-se sobremaneira escarninho a propósito dos ganhos indecentes, para, com um gracejo, atenuar a impopularidade e transformá-la em dito de espírito»). O riso gera no leitor um efeito positivo antes da narrativa da morte. O humor, associado ao carácter, contribui, assim, para favorecer a imagem do imperador.

Como no caso de Vespasiano, o processo usado para Tito é o da desculpabilização. ${ }^{232} \mathrm{O}$ biógrafo começa por contestar os vícios suspeitados através da contraposição de factos reais: contra a suspecta luxuria, por causa das orgias prolongadas na companhia dos amigos mais dissolutos ${ }^{233}$ apontam-se banquetes agradáveis mais que sumptuosos e amigos escolhidos que merecem a confiança dos imperadores seguintes por se mostrarem necessários ao estado; ${ }^{234}$ à libido de que fazem suspeitar os grupos de rapazinhos e eunucos, bem como o insignis amor por Berenice (Tit. 7.1), contrapõe-se a atitude racional que o leva a afastar de Roma a rainha ${ }^{235}$ contra a vontade dele próprio e contra a vontade dela (como traduz a feliz concentração expressiva do poliptoto inuitus inuitam) e a forma como põe fim ao favorecimento dos delicati e se abstém de assistir aos espectáculos deles em público (Tit. 7.2); em oposição à suspecta rapacitas, pelo que constava da forma venal e lucrativa como costumava actuar na instrução dos processos do pai (Tit. 7.1), afirma-se, pela negativa, que não lesou a nenhum dos cidadãos, respeitou, mais que ninguém, os bens alheios e nem sequer recebeu as habituais oferendas (denominadas conlationes); ${ }^{236}$ e, pela positiva, contrapõe-se a generosidade ímpar (et tamen nemine ante se munificentia minor) (Tit.7.3).

Os vícios atrás enumerados, que representam topoi da descrição dos tiranos na historiografia romana, ficam assim reduzidos a pecadilhos da juventude e,

${ }^{232}$ Como observa Cize K, E. 1977, 133-134, trata-se de uma organização em anticlímax: os vícios são apresentados dos mais graves aos menos prejudiciais. Nos bons príncipes, às species negativas sucedem-se as positivas; vide Gascou, J. 1984, 696 n. 52.

${ }^{233}$ Tit. 7.1. Contribui para desacreditar esta acusação o conjuntivo oblíquo: quod ad mediam noctem comissationes cum profusissimo quoque familiarium extenderet.

${ }^{234}$ Tit. 7.2. Aparentemente, Suetónio é contestado por Díon, 67.2.1, que diz que Domiciano se empenha em lançar a desgraça e a ruína sobre os amigos do pai e do irmão. Sobre a política de Tito na selecção dos amici, vide Jones, B. W. 1975, 454-462.

${ }^{235}$ Cf. Flávio Josefo, AJ 18.5.4; 19.5.1; 20.7.3; Tácito, Hist. 2.2.1; Díon Cássio, 66.15.3-4. Berenice regressará depois a Roma (cf. Díon, 66.18.1). Esta ruptura dramática teria motivações políticas. Acontece na altura da execução de Cecina e Marcelo, dois senadores que conspiraram contra Vespasiano, o que provocou atritos na relação com o senado. Tito foi provavelmente pressionado por Vespasiano para afastar Berenice, de modo a pacificar os senadores descontentes. Ele próprio perceberia o problema: esta ambiciosa rainha oriental fazia temer uma nova Cleópatra. Vide Rogers, P. 1980, 94; Martin, R. 1991, 150-151; 167-168.

${ }^{236}$ A abstinentia é, tal como a moderatio, inerente à definição do bom princeps, como se verá pela observação final das Vidas dos Césares: vide Gascou, J. 1984, 725-727. 
por isso, desculpáveis. ${ }^{237} \mathrm{~A}$ inciuilitas e a uiolentia, por onde o biógrafo começara a exposição dos vícios de Tito, é definitivamente anulada através da análise da sua natura: Natura autem beniuolentissimus (Tit. 8.1). Os ditos memoráveis são, neste caso, evocados em proveito da imagem positiva: afabilidade extrema para com os homens. Suetónio, na preocupação implícita de refutar a ideia de que Tito seja alius Nero (cf. Tit.7.1), apresenta o retrato de um príncipe perfeito. A acção política é um modelo de bondade: ao contrário da acção incendiária e saqueadora de Nero, ${ }^{238}$ Tito acode às catástrofes (fortuita et tristia) da erupção do Vesúvio, de um incêndio de Roma e de uma peste terrível, não só com o zelo de um príncipe, mas também com o incomparável amor de um pai; ${ }^{239}$ castiga e desencoraja os delatores (Tit. 8.5); confessa que aceita o pontificado máximo para conservar as mãos puras e - nota o biógrafo - mantém a palavra: não foi mais nem autor nem cúmplíce de nenhuma morte; apesar de lhe não faltarem motivos de vingança, ${ }^{240}$ jura que prefere morrer a matar. ${ }^{241}$ A clementia chega ao ponto de mostrar tolerância para com dois aspirantes ao império: limita-se a demovê-los com a sapiente máxima de que ao fatum cabia conceder o principado, trata-os com honra e, segundo o boato, ao conhecer o horóscopo de ambos, afirma que estava para cair sobre eles um perigo, mas proveniente de outro, como aconteceu. ${ }^{242}$ Esta descrição, na qual se descortina um encómio emotivo, prepara o comovente relato da morte deste imperador.

A brevidade do principado de Otão espelha-se na biografia. O biógrafo não faz propriamente uma análise do carácter na fase governativa e deixa essa tarefa para o relato de morte, onde se revela a sua coragem contrastante com a vida. Mas, mesmo nesta parte, a narrativa de Suetónio não é tão desfovorável como a de Tácito. A primeira associação é a Nero. A recordação do antigo amigo é retomada com a afirmação de que, entre as adulações que lhe foram prodigalizadas, a infima plebs o apelidou de Nero, sem que ele desse algum sinal de o recusar; antes pelo contrário, juntou, segundo alguns, ${ }^{243}$ tal cognome em alguns documentos (diplomata primaeque epistulae). A esta afirmação, de que parece duvidar, o biógrafo acrescenta, como certeza, que Otão permitiu a reposição dos retratos e estátuas de Nero, chamou os seus procuratores e libertos

${ }^{237}$ Também Augusto resgatou a impudicitia de outrora com o seu comportamento posterior; cf. Aug. 71.1: Ex quibus siue criminibus siue maledictis infamiam impudicitiae facillime refutauit et praesentis et posterae uitae castitate.

${ }^{238}$ Cf. Nero 38. As catástrofes naturais (fortuita) serviram para aumentar a impopularidade de Nero (Nero 39.1).

${ }^{239}$ Tit. 8.3: In iis tot aduersis ac talibus non modo principis sollicitudinem sed et parentis affectum unicum praestitit.

${ }^{240}$ Tit. 9.1 nec auctor posthac cuiusquam necis nec conscius. Cf. Díon Cássio, 66.19.1. Ao contrário de Nero que parricidia et caedes a Claudio exorsus est, cuius necis etsi non auctor, at conscius fuit (Nero 33.1).

${ }^{241}$ Tit. 9.1: sed 'periturum se potius quam perditurum' adiurans.

${ }^{242}$ Tit. 9.1-2. Também Aurélio Victor, Caes. 10.3, refere as pretensões dos dois patrícios; vide Martin, R. 1991, 342; com. de Jones, B. \& Milns, R. 2002, 116.

${ }^{243}$ Clúvio Rufo, segundo Plutarco, Oth. 3.2, acrescenta que Otão renunciou a esta prática ao ver o descontentamento que gerava. 
e a sua primeira disposição foi estabelecer um crédito para o acabamento da Domus Aurea. ${ }^{244} \mathrm{~A}$ referência à política filoneroniana aparece como ponto de viragem: a situação de Otão começa logo a degradar-se e sucedem-se os sinais de mau augúrio.

Após a notícia da aclamação de Vitélio pelos exércitos da Germânia, Otão propõe ao senado o envio de uma delegação a aconselhar a paz e a concórdia. ${ }^{245}$ Só Suetónio refere a oferta de Otão a Vitélio de uma aliança através de um casamento com a filha do rival. Mas a guerra era inevitável e os campos estremavam-se: de um lado, os generais de Vitélio já estavam em marcha; do outro, os pretorianos deram prova de fidelidade a Otão. Acentua-se a devoção deste último corpo militar ao imperador. Julgando que se desencadeava uma conjura, irromperam desordenadamente pelo palácio a reclamar a chacina do senado e só acalmaram depois de verem o imperador. ${ }^{246} \mathrm{~A}$ preparação da contra-ofensiva é pautada por uma falta de preocupação religiosa (Otho 8.3), o que só pode augurar um mau fim. O biógrafo considera ainda igual temeridade o facto de Otão decidir provocar imediatamente o confronto, quando todos lhe aconselhavam o contrário. Suetónio apresenta um Otão que começa a dar sinais de cansaço e inquietude (impatiens longioris sollicitudinis) e que parece mais preocupado em pôr fim ao "jogo" do que em obter bons resultados. Além disso, não conseguia conter o ardor dos soldados. Ele próprio, diz o biógrafo sem comentar, não participa em nenhuma batalha. ${ }^{247}$ A nulla religionum cura, acrescida de similis temeritas na estratégia militar, conduzem ao desastre de Betríaco. Mesmo assim, aponta-se a fraude como causa da derrota. ${ }^{248}$

Um novo motivo aparece nesta Vida: uma ansiedade de pôr fim ao conflito; o desejo da paz e de concórdia entre as facções, numa guerra que já tinha ceifado muitas vidas. Este ensejo irá servir de pano de fundo à narrativa da morte. Nesta fase da Vida de Otão, o biógrafo apenas prepara o caminho para a revelação que a morte trará. Ao contrário do que acontece com outros príncipes, a parte correspondente è governação não é a mais relevante da Vida; parece funcionar como um momento de transição para o cerne desta biografia: a inesperada manifestação de virtudes romanas presente na narrativa da morte.

Como se vê, a construção progressiva da imagem de um bom imperador assenta na conexão com as virtudes opostas às características dos tiranos. Nestes príncipes, os vícios são colocados numa fase inicial de imaturidade ou

${ }^{244}$ Otho 7.1. Mas Otão, durante o curto principado, adoptou um estilo de vida austero que o próprio Tácito, apesar de não ser benevolente com ele, reconhece (Hist. 1.71.1). Suetónio silencia os outros factos, mesmo os favoráveis a Otão, como o castigo de Tigelino (Hist. 1.72.3). Wellesley, K. 2000, 60, salienta que a conexão com Nero tornou Otão politicamente suspeito, apesar da moderação que adoptava de momento.

${ }^{245}$ Otho 8.1. Cf. Plutarco, Oth. 4.4-6; Tácito, Hist. 1.74.1; Díon Cássio, 64.10.1.

${ }^{246}$ Otho 8.2. Mais desenvolvidos são os relatos de Tácito, Hist.1.80-85 e Plutarco, Oth. 3.3-13.

${ }^{247}$ Otho 9.1. O facto de não participar na batalha é mais criticado pelas outras fontes: as tropas ficam desmoralizadas pela ausência de Otão e pela retirada de uma força considerável de infantaria e cavalaria; cf. Plutarco, Oth. 10.1; Tácito, Hist. 2.33.2-3.

${ }^{248}$ Otho 9.2. Cf. Plutarco, Oth. 12.1-2; Tácito, Hist. 2.42.1-2. 
são justificados pela necessidade. As actuações mais cruéis são integradas no drama do governante justo, que, como um pai, é coagido pelas circunstâncias a proceder severamente com os filhos.

\subsubsection{A construção da imagem de um imperador incapaz}

A biografia de Cláudio tem particularidades que a distinguem das restantes, pelos contrastes que ocorrem a cada passo. A imagem do início da sua actividade governativa é positiva. As demonstrações de pietas (Cl.11) e ciuilitas (Cl.12) fazem com que, em pouco tempo, goze de tão grande popularidade, que a simples suspeita de que fora morto provoca um tumulto. Mas ao favor popular logo se opõe o relato dos atentados, ${ }^{249}$ onde se representa, em gradação, a hostilidade de todas as ordens. Começa-se pelo ataque de um plebeu anónimo (de suspeita generalidade, tanto que não é referido em nenhuma outra fonte), passa-se, depois, aos ainda anónimos da classe equestre, para finalmente chegar aos da classe senatorial, nomeadamente Asínio Galo e Estatílio Corvino, e à guerra civil, movida por Fúrio Camilo Escriboniano (Cl. 13.2). Mesmo na apresentação de um dado positivo, o zelo com que aplicava a justiça, Suetónio coloca reservas: parece deformar os factos de forma a aparecer uma imagem negativa e satirizada. Com efeito, em tom de censura, anota-se que Cláudio aplicava a justiça etiam suis suorumque diebus sollemnibus, nonnumquam festis quoque antiquitus et religiosis ${ }^{250}$ («até nos dias solenes para si e para os seus, e algumas vezes em dias festivos, mesmo os que já vinham da antiguidade e até em dias consagrados pela religião»). De modo semelhante (ainda no mesmo capítulo), a inovação que demonstra em não se restringir sempre à letra da lei, mas modificar o rigor ou lenidade do código segundo o princípio, ditado pela lei natural, do que é bom e justo, é imediatamente ensombrada pela expressão perinde ut adficeretur («conforme a sua disposição»): um comentário do narrador que cala a originalidade de Cláudio, para colocar, desde logo, a tónica no humor variável com que este imperador aplica a justiça. ${ }^{251}$ Imediatamente a seguir, o biógrafo é bem explícito na caracterização de Cláudio enquanto juiz: In cognoscendo autem ac decernendo mira uarietate animi fuit, modo circumspectus et sagax, interdum inconsultus ac praeceps, nonnumquam friuolus amentique similis (Cl. 15.1) («Na instrução dos processos e nos julgamentos, foi de uma espantosa inconstância: ora se mostrava ponderado e arguto, outras vezes irreflectido e

${ }^{249} \mathrm{Cl}$. 13.1: Nec tamen expers insidiarum usque quaque permansit.

${ }^{250}$ Cl.14. Em relação aos dies sollemnes, Díon Cássio, 60.5.7, diz que ele exerceu a justiça no dia em que uma filha foi prometida em casamento e em que outra se casou. Mas tal comportamento é positivo para Díon Cássio: é sinal de moderação cívica, na medida em que Cláudio, ao contrário de Calígula, dava pouca importância à sua pessoa e à família imperial. Quanto aos festis quoque antiquitus et religiosis, não se trata, como explica Aulo Gélio, 4.9.5, de dies nefasti, nos quais estava proibida toda a actividade pública ou privada, mas de dias ligados a eventos de maus auspícios, pelo que se pensava que era melhor limitar as celebrações religiosas e o início de novas actividades. Além disso, uma vez que Cláudio, segundo Díon Cássio, 60.17.1, suprimiu muitos dias festivos, afirmar que ele exercia a justiça naqueles dias é deformação satírica, como acentua Gascou, J. 1984, 623-624. Vide com. de Guastella, G. 1999, 158-159.

${ }^{251}$ Vide com. de Guastella, G. 1999, 159. 
precipitado; nem faltaram ocasiões em que foi superficial e se portou como um mentecapto»). Aos exemplos de bom julgamento - alguns dignos de Salomão: perante o caso da mãe que não queria reconhecer o filho, à falta de outras provas, Cláudio arrancou-lhe a verdade obrigando-a a casar com o rapaz ( $\mathrm{Cl}$. 15.2) - , opõem-se julgamentos farsescos.

A ciuilitas do imperador acaba por ser transformada em falta de dignidade. Durante os jogos que oferece, a vontade de se mostrar communior aut remissior leva-o de novo à inversão de papéis, com gestos e palavras pouco dignas e ao invés do seu estatuto: provoca a hilaridade dos espectadores, ao tratá-los por domini (Cl. 21.5).

Suetónio, ao empreender a descrição das medidas administrativas $(C l$. 22-25), parece assumir um tom desafectado. A apresentação das medidas religiosas $(C l .22)$ e jurídicas $(C l .23)$ revela um juízo favorável do biógrafo. 252 Já na concessão de honras (Cl.24) se revela falta de moderação. Mas na relação entre as ordens e os estrangeiros (Cl. 25) não há tom negativo: o aspecto de catálogo parece pretender criar uma impressão favorável. Não deixa de tocar os sentimentos do leitor uma medida humanitária de Cláudio: determina que os escravos doentes, abandonados na ilha de Esculápio, se tornem livres; e que, se algum dono der morte a um escravo em vez de o expor, seja perseguido como assassino. ${ }^{253}$ Todas estas medidas positivas são, no entanto, condicionadas por uma restrição que obriga a reinterpretar as iniciativas tomadas: Sed et haec et cetera totumque adeo ex parte magna principatum non tam suo quam uxorum libertorumque arbitrio administrauit, talis ubique plerumque, qualem esse eum aut expediret illis aut liberet. 254 ("Mas tanto estes como os restantes assuntos, e mesmo tudo o que respeita a grande parte do seu principado, dirigiu-os não tanto segundo o seu arbítrio, mas segundo o das mulheres e dos libertos: na medida do interesse ou do capricho deles, em toda a parte e momento»).

Não há, como acontece com Tibério ou Calígula, dissimulação por parte de Cláudio, que nem domina essa arte característica de um tirano, mas apenas retardamento de informação por parte do biógrafo. A inversão de papéis torna-se, assim, mais explícita e mais flagrante. E outras personagens - caso pouco comum na biografia suetoniana - saltam quase para primeiro plano: as mulheres e os libertos. A ideia é retomada mais à frente. Cláudio, apresentado

${ }^{252}$ Vide Gascou, J. 1984, 625-629: Suetónio, mais que os outros historiadores, contribui, com os materiais abundantes que terá reunido, para nos dar uma ideia mais precisa de Cláudio como juiz e como legislador.

${ }^{253}$ Cl. 25.2. Fasciato, M. 1949, 454-464, não vê razão para grande optimismo: a medida de Cláudio representa uma evolução importante, mas discreta, do ponto de vista jurídico e os beneficiários são poucos.

${ }^{254}$ Cl. 25.5; cf. Vit. 2.5: Claudium uxoribus libertisque addictum. Segundo Baldwin, B. 1983, 281, trata-se de um cliché para o governo de Cláudio, partilhado por Tácito e Díon Cássio, com a diferença de que, para Suetónio, as mulheres e libertos controlam tanto o lado bom como o mau. Mais à frente, veremos que assim é. Mas o efeito imediato introduzido, neste passo, por sed é o de, nesta fase, privar o imperador da paternidade das acções louváveis que acabaram de ser enunciadas, como afirma Gascou, J. 1984, 702. 
como addictus ${ }^{255}$ perante as mulheres e os libertos, comporta-se, não como um princeps, mas como um minister; e segue, na distribuição das honras, o studium e a libido deles. Põem-se em evidência decisões tomadas por tais favoritos em nome de Cláudio. Depois de retirar a Cláudio a paternidade dos actos bons (Cl. 25.5), Suetónio agora retira-lhe a paternidade, também, dos maus. O que resta? Um não-imperador. ${ }^{256}$ Parece ser esta a tese que Suetónio pretende sustentar.

$\mathrm{Na}$ parte da vida privada e aspectos particulares da personalidade (Cl. 30 ss), Suetónio torna a descrição explicitamente negativa. Apesar de tudo, os contrastes continuam a verificar-se. A descrição física de Cláudio é consentânea com a imagem paradoxal que Suetónio dá da sua personalidade. A dignidade da sua figura em repouso é desfeita pelas suas acções, que o revelam inadaptado ao papel que desempenha (Cl. 30). Contribuem para a imagem indigna de Cláudio os excessos na comida e na bebida, nas mulheres e no jogo, caricaturados por recurso sistemático a superlativos (cibi uinique... appetentissimus, somni breuissimi, libidinis in feminas profusissimae; aleam studiosissime lusit). ${ }^{257}$

No que diz respeito à análise da personalidade de Cláudio (Cl. 34-39), Suetónio faz saber que saeuum ac sanguinarium natura fuisse («era cruel e sanguinário por natureza»), o que o aproxima da imagem dos tiranos. ${ }^{258}$ Tal característica manifesta-se no gosto por execuções e jogos mais cruéis. Introduz-se uma gradação: Sed nibil aeque quam timidus ac diffidens fuit (Cl. 35.1) («Mas a nada se comparava o medo e desconfiança»). Diz o biógrafo que Cláudio se mostra consciente da ira atque iracundia e desculpa-se dizendo que a primeira era breve e inócua e a segunda não era injusta (Cl.38.1). Mas alguns factos desmentem as suas afirmações e demonstram que guarda rancores desde antes do principado. Depois de tratar a stulticia (Cl. 38.3), a obliuio e inconsiderantia (Cl.39.1), a negligentia (Cl.40.1), o biógrafo põe em evidência o contraste com sua cultura (Cl.40.3). Assim, ao mesmo tempo que acentua os paradoxos de Cláudio, introduz Suetónio a oportuna transição para a rubrica seguinte: a vasta e erudita actividade literária. O catálogo das obras em latim e em grego (Cl.41-42) encerra esta parte da biografia. Os contrastes presentes na Vida parecem continuar na forma como redige o De uita sua: a que falta mais capacidade do que elegância de estilo (Cl. 41.3).

As qualidades do carácter de Cláudio são exemplificadas sobretudo com exemplos que nos transportam para o mundo da comédia, como veremos a seguir, e lançam sobre Cláudio a imagem, injusta, de um incompetente.

${ }^{255}$ Cl. 29.1. Addictus é, segundo Quintiliano, Inst. 7.3.26, aquele que deve continuar escravo até que salde a sua dívida. Logo o termo é adequado a Cláudio, escravo não por natureza, mas devido à sua fraqueza: vide com. de Guastella, G. 1999, 196.

${ }^{256}$ Vide Dickison, S. K. 1977, 642-643.

${ }^{257}$ Cl. 33. Destoa, pelo carácter positivo, a nota suetoniana de que Cláudio se abstém do comércio com homens: marum omnino expers. No que diz respeito ao gosto pelo jogo, a comparação com Aug. 71.1-3 mostra que Suetónio é tendencioso; vide com. de Guastella, G. 1999, 202-203.

${ }^{258}$ Cl. 34.1; cf. Tib. 57.1: saeua ac lenta natura. Já Calígula possui saeuitia ingenii, Cal. 27.1. 
A estrutura das vidas, organizada em função do carácter, sugere uma progressão que se efectiva na criação gradual de uma impressão na mente do leitor, tendo em vista um final catártico alcançado pela narrativa da morte. Trata-se de um tratamento ficcional de factos históricos cujo resultado é naturalmente moralizante. Este efeito é mais forte nas Vidas dos piores dos imperadores, onde a progressão para o vício ultrapassa os limites do suportável. Mas também nos bons governantes há um crescendo na revelação do carácter, organizada, neste caso, de modo a deixar no final uma imagem tanto quanto possível impoluta.

\subsection{Comédia e carácter}

Temos visto que se encontram nas Vidas diversos momentos trágicos. Fala-se de 'historiografia trágica' sobretudo a respeito de Tácito, mas tais elementos também estão presentes em Suetónio. ${ }^{259}$ No entanto, há também várias incursões no mundo da comédia, a que já acenámos na primeira parte deste trabalho. Por vezes, o cómico resulta da paródia da augusta função dos protagonistas. Neste sentido, chegam a transformar-se numa espécie de anti-imperadores. Particularmente fértil em cómico é a parte relativa à vida privada dos principes, pela matéria tratada e pela linguagem usada.

Se os capítulos relativos à vida sexual de Júlio César (Jul 49-52) provocam o riso, a parte correspondente da Vida de Augusto fazem-nos lembrar cenas de comédia. Esta Vida parece balançar entre a tragédia e a comédia. ${ }^{260}$ Augusto tentara escrever em tempos uma tragédia, Aiax, mas não foi bem sucedido com o estilo, e como ele próprio espirituosamente dizia, «o seu Ájax precipitara-se sobre uma esponja». ${ }^{261}$ De facto, a Vida do jovem Octávio, com todas as incertezas e perigos, desafios a uns deuses e protecção de outros, aproxima-se do ambiente de uma tragédia; sentido semelhante tem a insistência nos golpes da Fortuna sobre a casa de Augusto. Mas depois, os amores de Augusto, apresentados com sentido de humor, as observações do imperador, a culminar na cláusula com que encerra a vida, assimilam-na mais à comédia ou ao mimo. É um deus que faz lembrar Júpiter com os seus amores humanos - embora assistidos por uma Juno / Lívia complacente.

O cómico resulta também do facto de ser o próprio Augusto a quebrar as leis que propusera. Com a descrição da uariorum dedecorum infamia (má fama

${ }^{259}$ Vide Foucher, A. 2000,773-801. Diz este autor (p. 801): «Le théâtre romain a été avec la tragédie prétexte un des premiers modes de représentation de l'histoire. Quand le théâtre, pour différentes raisons, n'a plus été productif, la prose narrative a renoué ce lien, d'autant plus volontiers que la théâtralisation du récit historique a pu coïncider avec la recherche du sublime, seule esthétique compatible avec la grandeur morale».

${ }^{260}$ Vide NÉraudau, J.-P. 1996, 26-28.

${ }^{261}$ Aug. 85.2: Nam tragoediam magno impetuexorsus, non succedentistilo, aboleuit quaerentibusque amicis, quidnam Aiax ageret respondit 'Aiacem suum in spongiam incubuisse'. Imediatamente a seguir, Suetónio diz que Augusto compõe epigramas, e Marcial (11.20) transcreve um epigrama extremamente obsceno da autoria deste imperador, o que mostra que tem inclinação para o género cómico. Compõe versos de improviso em grego (Aug. 98.4) e versos fesceninos (Macróbio 2.4.21). Vide Bejarano, V. 1974 , 87-109. 
das diversas desvergonhas) de Augusto o leitor assiste a episódios burlescos. São topoi da invectiva política romana, mas Suetónio retira-os do contexto, para os integrar na construção do carácter da personagem. A acusação de efeminado, feita por Sexto Pompeio, é ampliada por Marco António, que o acusa de ter conseguido a adopção de César mediante o stuprum, e por Lúcio António, que lhe imputa a prostituição a Hírcio por dinheiro e o hábito de depilar as pernas com casca de noz a arder. Tais acusações tornam-se do domínio público e o povo entende como referido a Augusto o verso dito em cena a propósito de um sacerdote de Cíbele que tocava tambor frígio: 'Videsne, ut cinaedus orbem digito temperat?'262 («Estás a ver como um invertido rege o orbe com o dedo?'»). Do mesmo modo, os inegáveis adultérios de Augusto, comicamente justificados como meio eficaz de espionagem (talvez fosse deste modo que ele ficou a saber da inconfidência de Mecenas), ${ }^{263}$ são exemplificados com diversas acusações de cariz sexual, retiradas do contexto da luta política em que o antagonista as terá proferido. ${ }^{264} \mathrm{~A}$ terminar o assunto, Suetónio transcreve uma carta de António que visa a informação do leitor, no que diz respeito às amantes de Augusto, mas também o efeito cómico, resultante da franqueza da linguagem, com apelo a termos obscenos próprios do mimo:

Scribit etiam ad ipsum haec familiariter adhuc necdum plane inimicus aut hostis: 'quid te mutauit? quod reginam ineo? uxor mea est? nunc coepi an abbinc annos nouem? Tu deinde solam Drusillam inis? ita ualeas, uti tu, hanc epistulam cum leges, non inieris Tertullam aut Terentillam aut Rufillam aut Saluiam Titiseniam aut omnes. An refert, ubi et in qua arrigas? ${ }^{265}$

«Escreveu mesmo ao próprio Octávio estas palavras, na altura em que ainda não era declaradamente nem inimigo pessoal nem público: 'Que é que em ti mudou? Lá porque eu monto uma rainha? É minha mulher? Comecei agora ou há já nove anos? E depois, tu montas só a Drusila? Assim tenhas saúde, como tu, quando leres esta carta, não hás-de ter já montado a Tertula ou a Terentila ou a Rufila ou a Sálvia Titisénia ou todas! Tem alguma importância onde e com quem te entesas?'».

${ }^{262}$ Aug. 68. A graça resulta do equívoco de orbe, entendido como o "círculo do tambor" e o "globo da terra". A referência aos Galli, sacerdotes castrados de Cíbele, como cinaedi é um topos da comédia e da poesia epigramática.

${ }^{263}$ Aug. 69.1. Mecenas contou à esposa, Terência, pormenores secretos de uma conspiração descoberta (Aug. 66.3).

${ }^{264}$ Não está em causa, para o biógrafo, a motivação destas acusações - trata-se de um contra-ataque de António perante a acusação de imoralidade, devido à sua ligação a Cleópatra e repúdio de Octávia (Vide Southern, P. 1998, 92-93) -, mas o contributo que trazem para o conhecimento da vida sexual de Augusto.

265 Aug. 69.2. Adoptamos a correcção introduzida por KRAFt, K. 1967, 496-499, e confirmada, mediante confronto com Plutarco, por Moles, J. 1992, 245-247, no sentido de dar forma interrogativa a uxor mea est. António quer negar que Cleópatra seja sua mulher: trata-se apenas de uma relação extraconjugal como muitas de Octávio. 
Este motivo repete-se ao longo das Vidas, quando se trata a vida sexual dos imperadores. Bastará recordar os já referidos casamentos farsescos com Esporo e com Dorífero organizados por Nero (Nero 28-29). A relação de Vitélio com o liberto Asiático é uma ligação picaresca, digna do Satyricon, como nota Régis Martin, e que nos faria sorrir, se o liberto não fosse o principal conselheiro de Vitélio: ${ }^{266}$

Hunc adulescentulum mutua libidine constupratum, mox taedio profugum cum Puteolis poscam uendentem reprehendisset, coiecit in compedes statimque soluit et rursus in deliciis habuit; iterum deinde ob nimiam contumaciam et furacitatem grauatus circumforano lanistae uendidit dilatumque ad finem muneris repente subripuit et prouincia demum accepta manumisit ac primo imperii die aureis donauit anulis super cenam, cum mane rogantibus pro eo cunctis detestatus esset seuerissime talem equestris ordinis maculam (Vit. 12).

«Depois de o desonrar, ainda adolescente, pela mútua lascívia, o jovem fugiu, movido pela náusea. Ao apanhá-lo em Putéolos, onde vendia molho avinagrado, prendeu-o com grilhões e libertou-o logo a seguir e fez dele novamente seu amante. Mas depois, agastado pela sua teimosia e pendor para o furto, vendeu-o a um mestre de gladiadores ambulante. Como o rapaz tinha sido reservado para o fim dos jogos, arrebatou-o de repente e, quando recebeu o encargo da província, deu-lhe a liberdade. E, no primeiro dia como imperador, presenteou-o ao jantar com anéis de ouro, apesar de, pela manhã, perante todos os que intercediam por ele, se ter recusado com dureza a lançar tal mancha sobre a ordem equestre».

Além do mais, Vitélio, dada a sua extrema gula, parece aproximar-se do tipo cómico do parasita, mas o facto de estar à cabeça do Império gera um efeito que, como acontece com Cláudio, vai além do cómico.

O biógrafo começa a narrativa dos factos relativos ao principado de Domiciano (inter initia) por uma sugestiva anedota. Domiciano costumava fechar-se diariamente sozinho longo tempo, simplesmente a caçar moscas e a trespassá-las com um estilete; por isso, certa vez, a alguém que perguntava quem estaria com o imperador, Víbio Crispo respondeu: ne muscam quidam («nem sequer uma mosca»). ${ }^{267}$ Com esta anedota, Suetónio quererá sugerir algo de insano na atitude do imperador: uma tendência para a misantropia e para a crueldade. ${ }^{268}$ Desequilíbrio sugere também o relacionamento atribulado com a esposa, onde se explora o motivo do paradoxo amor/ódio. Depois de repudiar Domícia, por esta estar enamorada do histrião Páris, mostra-se incapaz de suportar a separação, e recebe-a de novo, alegando a insistência do povo. ${ }^{269}$

${ }^{266}$ Vide Martin, R. 1991, 167 e 288-289.

${ }^{267}$ Dom. 3.1. Cf. Díon Cássio, 66.9.4-5; Aurélio Victor, Caes. 11.5-6.

${ }^{268}$ Vide Martin, R. 1991, 120. Segundo o com. de Galli, F. 1991, 62, esta atitude de Domiciano escondia amargura e humilhações, unidas à ambição de poder e era indício de ressentimento contra o pai e inveja do irmão.

${ }^{269}$ Dom. 3.1. Díon Cássio 67.3.2, que associa o episódio ao romance de Domiciano com a sobrinha Júlia, não sugere uma paixão avassaladora de Domiciano pela esposa, nem põe em dúvida a insistência do povo. Segundo este historiador (67.3.1), Páris foi morto no meio da 
Por vezes, a farsa afecta as funções do imperador, e a dignidade imperial fica manchada. É o que acontece com a rubrica das actividades militares Calígula, que Suetónio, diferentemente do que sucede nas biografias anteriores, situa a concluir os actos públicos do monstrum. Na descrição da campanha militar (Cal. 43-49), nota-se o intuito de ridiculizar, sobretudo para o leitor que recorde o génio militar e os êxitos de Germânico, com que esta Vita se iniciara. Mais se acentua agora a diferença entre o pai e o filho. Também neste aspecto, Calígula se revela uma decepção para quem nele tem esperança. Mesmo o velho Tibério, de funesta lembrança, obtivera glórias militares sob os auspícios de Augusto. $\mathrm{O}$ acontecimento é tratado como um golpe de teatro de Calígula. Não é uma verdadeira campanha, é uma farsa: um mimus, como nota Suetónio. O biógrafo quer deixar claro que esta acção militar, desde a sua génese, não obedece a um plano estabelecido. É antes um capricho, uma ideia súbita que acometeu Calígula numa viagem de lazer. A própria marcha tem um ritmo absurdo: umas vezes excessivamente rápida, outras tão lenta, que inclui o varrimento das ruas para evitar a poeira. ${ }^{270}$ No fundo, a campanha é mais um dos divertimentos novos que este imperador tanto gosta de inventar. Parece o retorno às brincadeiras de infância do soldadinho Calígula, pois já no campo militar passara os primeiros tempos de vida:

Mox deficiente belli materia paucos de custodia Germanos traici occulique trans Rhenum iussit ac sibi post prandium quam tumultuosissime adesse hostem nuntiari. Quo facto proripuit se cum amicis et parte equitum praetorianorum in proximam siluam, truncatisque arboribus et in modum tropaeorum adornatis ad lumina reuersus, eorum quidem qui secuti non essent timiditatem et ignauiam corripuit, comites autem et participes uictoriae nouo genere ac nomine coronarum donauit, quas distinctas solis ac lunae siderumque specie exploratorias appellauit. Rursus obsides quosdam obductos e litterario ludo clamque praemissos deserto repente conuinio, cum equitatu insecutus ueluti profugos ac reprehensos in catenis reduxit, in hoc quoque mimo praeter modum intemperans. ${ }^{271}$

«De seguida, sem ter nada para combater, ordenou que levassem uns poucos germanos da escolta e os ocultassem para lá do Reno e que, depois de almoço, lhe viessem anunciar a presença do inimigo com o maior alarme possível. Perante tal facto, precipitou-se com os amigos e parte da cavalaria pretoriana para a floresta vizinha e, depois de cortar árvores e as ornar à maneira de troféus, regressou à luz de archotes e ainda zurziu o medo e a preguiça dos que o não seguiram. Mas aos acompanhantes e aos que participaram na

rua.

${ }^{270}$ Cal. 43: neque ex destinato, sed cum ad uisendum nemus flumenque Clitumni Meuaniam... expeditionis Germanicae impetum cepit. Parece exagero. $\mathrm{O}$ projecto seria anterior, como pode sugerir a ponte de Baias. Vide Barrett, A. A. 1989 (2000), 103-107; Antonelli, G. 2001, 138 e 144.

${ }^{271}$ Cal. 45.1-2. A ed. de Ailloud apresenta uma pontuação diferente, ligando intemperans à anedota seguinte, sobre os oficiais que manda 'deitar' à mesa armados. No novo tipo de coroas aparecem, mais uma vez, os símbolos do sol e da lua, ligados ao culto de Ísis, como se verifica em Apuleio, Met. 11.7. Vide com. de Hurley, D. W. 1993, 165. 
vitória presenteou-os com coroas de um novo tipo e uma nova designação, adornadas com o sol e com a lua, a que ele chamou coroas 'de batedor'. Em outra ocasião, depois de retirar uns reféns de uma escola elementar e de os enviar secretamente à frente, abandonou de súbito o banquete e perseguiu-os com a cavalaria, como se de fugitivos se tratasse, e, depois de os apanhar, trouxe-os de novo presos com cadeias, mostrando assim também nesta farsa uma total falta de moderação».

Pela forma como são preparados, pelo nome dado às condecorações, parece tratar-se de exercícios militares. ${ }^{272}$ Mas Suetónio, prefere ver apenas o mimus de um imperador, que está sempre a criar momentos espectaculares, semelhantes aos da scaena do retorno das cinzas da mãe e do irmão e dos novos spectacula da ponte de Baias. ${ }^{273}$ No contexto criado, o de uma campanha farsesca, tornam-se mais gravosas, pelo cinismo, as palavras com que Calígula censura o senado e o povo por meio de um grauissimus edictus: quod 'Caesare proeliante et tantis discriminibus obiecto tempestiua conuinia, circum et theatra et amoenos secessus celebrarent' (Cal.45.3.) ("porque 'enquanto César combatia e se expunha a tão grandes perigos, frequentavam banquetes que começavam cedo, o circo, o teatro e agradáveis locais de retiro'»). Tais palavras estão colocadas no momento em que geram maior indignação e assumem um tom de troça para com o senado e o povo de Roma.

Mais incrível ainda é outra encenação que Suetónio apresenta a culminar a campanha. Com a expressão quasi perpetraturus, Suetónio acentua a tendência de Calígula para brincar ao faz-de-conta:

\begin{abstract}
Postremo quasi perpetraturus bellum derecta acie in litore Oceani ac ballistis machinisque dispositis, nemine gnaro aut opinante quidam coepturus esset, repente ut conchas legerent galeasque et sinus replerent imperauit, 'spolia Oceani' uocans 'Capitolio Palatioque debita', et in indicium uictoriae altissimam turrem excitauit, ex qua Pharo noctibus ad regendos nauium cursus ignes emicarent; pronuntiatoque
\end{abstract}

272 Vide com. de Wardle, D. 1994, 297-311; Antonelli, G. 2001, 146-147. Além disso, pela mesma altura, nos finais de 39 , Galba, o novo comandante em substituição do malogrado Getúlico, estava a tentar restabelecer a disciplina, que fora descurada pelo seu antecessor, e a treinar as tropas e mesmo envolvido em combates (cf. Galb. 6.2: disce miles militare: Galba est, non Gaetulicus); vide Simpson C. J. 1979, 361-362, e Barrett, A. A. 1989 (2000), 130-131. Simpson C. J. 1979, 345-346, põe em dúvida a conspiração ocorrida nesta altura. Tal conjura seria invenção de Gaio para justificar, no relatório ao senado, as execuções de Lépido e Getúlico: o primeiro morto por adultério com Júlia Livila e Agripina (que depois, antes de partir para o exílio, é obrigada a trazer para Roma as cinzas do amante), o que era considerado crimen maiestatis; o segundo por incompetência como legado da Germânia Superior, pondo em causa a segurança do Império. Fundamenta a sua opinião no facto de a referência explícita à coniuratio figurar unicamente em Suetónio, Cl. 9.1. A falta de qualquer referência explícita ao facto na Vida de Calígula, Simpson considera as insidiae, referidas em Cal. 24.3, apenas conotadas com o comportamento adúltero das irmãs e de Lépido. Mas podemos perguntar se tais insidiae não poderão, em sentido lato, representar uma conjura. Pelo menos nesse sentido parece ser tomada a expressão de $C l .10 .1$, ab insidiatoribus Gai, numa clara referência aos executores da única conjura que teve êxito.

${ }^{273}$ Respectivamente, Cal. 15.1 e 19. Vide com. de Hurley, D. W. 1993, 165-166. 
militi donatiuo centenis uiritim denariis, quasi omne exemplum liberalitatis supergressus: 'abite', inquit, 'laeti, abite locupletes'. ${ }^{274}$

«Por fim, como fosse levar a cabo uma guerra, levou as tropas para a margem do Oceano e dispôs as balistas e máquinas de guerra, sem que alguém soubesse ou suspeitasse o que ele estava para empreender. De súbito, mandou apanhar conchas e encher delas os capacetes e as pregas das vestes, dizendo que eram 'despojos do Oceano devidos ao Capitólio e ao Palatino'. E, a assinalar a vitória, levantou uma torre muito alta, da qual brilhasse um fogo de noite, como a de Faros, para guiar a rota dos navios. E, tendo prometido aos soldados um donativo de cem denários por cabeça, como se tivesse superado qualquer modelo de generosidade, disse: 'ide embora, contentes; ide embora, ricos'».

A quantidade de teorias explicativas deste estranho episódio mostra que o biógrafo conseguiu intrigar o leitor e espevitar a sua curiosidade. ${ }^{275} \mathrm{Como}$ nos anteriores casos, provavelmente nem Suetónio suspeitaria: eram relatos que corriam. O biógrafo transcreve a anedota como mais uma farsa sem sentido, resultado da mente tortuosa e insondável de Calígula: nenhum dos acompanhantes percebe as suas reais intenções. E, a terminar o relato, vem mais um discurso de humor insultuoso, desta vez aos soldados. O contraste entre o carácter ridículo destes feitos e a empáfia posta na organização do triunfo (Cal. 47), acompanhada da desilusão por o senado não lho decretar (Cal. 48.2), faz pensar no topos cómico do soldado fanfarrão.

Suetónio, pela repetição da palavra mimo, associada ao comportamento de Calígula (Cal. 45.2) e a um presságio de morte (Cal. 57.4), parece denotar, consciente ou inconscientemente, a influência incontornável daquele parente popular da comédia. O género que Suetónio cultiva, com o tipo de linguagem

${ }^{274}$ Cal. 46. Cf. Díon Cássio 59.25.1-3. A torre, situada em Boulogne-sur-Mer, que teve ao longo do tempo várias designações (Pharus, Turris Ardens, Pharus Odrans e Le Vieil Homme), foi considerada uma maravilha da arquitectura e manteve-se de pé até ao séc. XVII: seria uma construção de estratégia militar de Calígula (e não de Júlio César, como antes se julgou), para preparar a invasão da Bretanha; vide D'ERCE, F. 1966, 89-96.

275 São especulações difíceis de provar; vide com. de WARdLE, D. 1994, 313-314; com. de Hurley, D. W. 1993, 168-169. Vitória sobre o mar inspirada por um rito celta: vide BickNELL P. J. 1962, 72-74; exercícios militares com o nome de código "invasão da Britânia" (uma noção demasiado moderna para WARDLE, D. 1994, 301) em que usariam as conchas como mísseis de treino: vide DAVIEs, R.W.1966,125-128; uma forma de humilhar os soldados por, sensatamente, se recusarem a embarcar: vide Antonelli, G. 2001, 151 (seguindo uma antiga hipótese de BALDSON); ou por terem mostrado covardia numa operação menor contra os Caninefates em que Calígula participou: vide Bicknell P. 1968, 496-505. Outros sugerem que houve corrupção na fonte histórica: conchas poderia referir-se aos genitais femininos e Calígula estaria a sugerir que concedia uma licença aos soldados para se divertirem nos bordéis da região; confusão com o termo militar musculus (arma de assédio destinada a proteger os assaltantes); nome pejorativo para barcos pequenos capturados no canal ao inimigo (provavelmente britânico) e levados para Roma para figurarem no triunfo: vide Woods, D. 2000, 80-87. Este autor, conhecedor embora das teorias modernas anteriores (que resume), parece querer descurar um pormenor de uma fonte antiga. Ao partir da narrativa de Díon Cássio (resumo de Xifilino), negligencia a informação de Suetónio de que Calígula mandou encher elmos e regaços: não podia ser de barcos nem de armas de assédio. 
que usa, o tipo de pormenores, sem ocultar os mais macabros - descrição de cenas de tortura, de sangue e de morte, como o cadáver do senador com as vísceras de fora (Cal. 28) - parecem aproximar do mimo esta Vida, que, tal como a cena final do mimo intitulado Laureolus, que pressagia a morte de Calígula (Cal. 57.4), termina de forma sangrenta. Outra influência possível será a pantomima, cultivada por Mnester e também por Calígula: o imperador parece estar a desenvolver o seu talento para a dança. Provável será a combinação de elementos vários: da tradição da comédia; da tradição da tragédia; do mimo e da pantomima.

A transformação da actividade imperial em farsa atinge o auge com Cláudio. A deformação cómica é evidente na descrição da forma de aplicar a justiça, ilustrada com exemplos de situações burlescas: na ausência de uma das partes ausente, favorece os presentes; ${ }^{276}$ como um litigante pedia que se cortassem as mãos a um falsário, exigiu a presença do carrasco com o sabre e a banca da decepação; para ostentar imparcialidade, compele um estrangeiro, acusado de usurpar a cidadania romana, a vestir alternadamente a toga ou o pálio, consoante se argumentava a favor ou contra o réu. Ainda mais ridículo se torna o contraste entre a seriedade de uma declaração por escrito (ex tabella) $)^{277}$ e a leviandade da sententia, por esse meio proferida: declara-se a favor dos que dizem a verdade. $\mathrm{O}$ resultado é que Cláudio se torna motivo de chacota (contemptui esset) e alvo do abuso dos advogados, que o chamavam em alta voz, o agarravam pela toga e pelo pé (Cl. 15.3). Com a expressão ac ne cui haec mira sint («e para que tais factos não causem admiração»), o biógrafo introduz o clímax. Um Graeculus chama-lhe velho e tonto, e um cavaleiro, acusado injustamente, atira-lhe mesmo as tabuinhas e o estilete e fere-o gravemente na face. ${ }^{278} \mathrm{~A}$ inversão de papéis, já presente na narrativa das actividades de Cláudio antes de chegar ao governo do Império, renova-se e perpetua-se no exercício do poder. Contudo, Suetónio leva a cabo este processo de ridiculizar o imperador com base em fontes orais (creditur; a maioribus natu audiebam) e anedóticas, apresentando factos não confirmados por outros autores.

Também no que respeita ao exercício da censura Cláudio se torna ridículo. Privou do direito de cidadania um grego ilustre, pelo simples facto de este não saber latim. ${ }^{279}$ Acrescentam-se exemplos, como erros crassos na instrução dos

${ }^{276}$ Cl. 15.2. Díon, 60.28.6, prefere ver aqui uma medida positiva, para evitar que os processos se arrastassem por falta de presença da parte que receava perder a demanda: vide GAScou, J. 1984, 624 n. 659. Mas era impensável para os juristas romanos que alguém fosse condenado sem apresentar a sua defesa: vide Segurado e Campos, J. A. 2001, 171-172.

277 O com. de Mottershead, J. 1986, 60, assinala, fundamentando-se em OLD, que tabella não se refere, neste caso, às tabuinhas usadas para registar o veredicto num julgamento, mas a uma página de notas.

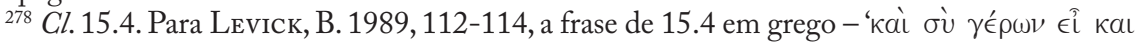
$\mu \omega \rho$ ś $^{\prime}$ - será a resposta a algo que Cláudio disse, provavelmente uma citação homérica (LEvick propõe $I l .1 .26$ ou 2.796).

${ }^{279}$ Cl. 16.2. A história vem desenvolvida em Díon Cássio, 60.17.4, o qual diz que o cidadão (lício, segundo o historiador) não foi capaz de entender o que Cláudio lhe disse, devido, na 
processos, sem paralelo em outras fontes, ou edictos sobre assuntos frívolos: a preparação dos tonéis para o vinho para a colheita que se previa abundante (que recorda, numa situação inoportuna, o seu vício da bebida) e as propriedades curativas do teixo na mordedura da víbora. ${ }^{280}$

No que se refere à actividade militar, Suetónio quer realçar o contraste entre a modéstia (exagerada) da anexação da Britânia (unam omnino suscepit eamque modicam... ac sine ullo proelio aut sanguine... intra paucissimos dies) e a magnificência do triunfo, que assim aparece desproporcionado e totalmente imerecido. Deixa também claro que a operação militar foi empreendida porque Cláudio se não contentara com as insígnias triunfais que o senado lhe oferecera, mas queria um verdadeiro triunfo. $\mathrm{E}$ a situação da ilha aparece apenas como um pretexto, não como uma motivação. Mais uma vez, o biógrafo menospreza as razões políticas, para se cingir aos motivos éticos: a vaidade, quase pueril, de Cláudio, desejoso de um triunfo, é apresentada como a causa única para a conquista da Britânia. ${ }^{281}$ Ainda mais que no caso de Calígula, parece haver aqui uma aproximação ao topos cómico do soldado fanfarrão.

Os motivos farsescos manifestam-se ainda a propósito da preocupação com a Urbe e com o aprovisionamento (Vrbis annonaeque cura). Ao acudir a um incêndio, coloca à sua frente cestos de dinheiro, como engodo para atrair a plebe a prestar ajuda (Cl. 18.1); e, durante uma carestia, foi atacado no Foro por uma multidão que lhe lançava injúrias e bocados de pão: só a custo conseguiu retirar-se para o palácio por uma porta das traseiras $(\mathrm{Cl}$. 18.2). Também na rubrica respeitante aos jogos, é verdadeiramente farsesca a reacção de Cláudio quando, numa naumaquia, os naumachiarii se recusam a combater: desata a correr com um disforme coxear (non sine foeda uacillatione discurrens) a ameaçá-los e a exortá-los ao combate (Cl. 21.6). Suetónio associa assim, desta forma, ao ridículo das acções, o grotesco do aspecto físico.

Mas Cláudio é sobretudo apresentado como servo das mulheres e dos

opinião de LEvick, B. 1989, 114-116, às dificuldades de articulação do imperador (resultantes, como propõem recentes investigações, da paralisia cerebral de que teria sofrido) agravadas pelas emoções: quando se zangava, o estado piorava (cf. Cl. 30). Também Séneca, Apoc. 5.3, diz que a linguagem de Cláudio era ininteligível (uox rauca et implicata). Como o lício não entendia as palavras do imperador, Cláudio perdeu a calma ao ver o homem evidenciar o seu defeito e foi o cidadão quem teve de arcar com a culpa.

${ }^{280}$ Cl. 16.4. Major, A. 1995, 101-104, diz que a ciência moderna vem vingar Cláudio do ridículo a que o expõe Suetónio. Esta é a primeira referência às qualidades homeopáticas da seiva do teixo. Em 1993 anunciou-se que o taxol, um alcalóide extraído da casca da Taxus breuifolia, foi aprovado como remédio contra o cancro. Portanto, Cláudio não era o fautor de disparates que as fontes apresentam.

${ }^{281}$ Cl. 17. 1-2. A expressão sine ullo proelio aut sanguine seria um slôgane (um fragmento de uma inscrição encontrada no Campo de Marte e que talvez pertencesse ao arco do triunfo de Cláudio) com o qual Cláudio se gabava de ter poupado as suas tropas e que as fontes hostis aproveitaram para demonstrar o carácter imerecido do triunfo. Em Ves. 4.1-2, a mesma campanha é apresentada em tom bem mais heróico: se na Vida de Cláudio não houve um só combate, Vespasiano participou em trinta batalhas, partim Claudi [i] ipsius ductu; vide Gascou, J. 1984, 382-383 e 427-428. Díon Cássio, 60.23.1, diz que Cláudio passou apenas dezasseis dias na Britânia e que no sexto mês, depois da partida, estava de regresso a Roma para celebrar o triunfo. 
libertos (Cl.25.5). Numa sequência de capítulos (Cl.26-29) o imperador é posto a ridículo, como um velho de comédia, vítima das maquinações de mulheres e de escravos, neste caso, libertos. ${ }^{282} \mathrm{~A}$ referência diacrónica às sponsae e uxores, a começar pelo tempo pelo tempo de adulescens, torna patente um crescendo na desventura dos casamentos, em que a simples evocação de Messalina logo cria a suspeição do leitor. Cláudio faz uma jura, em tom dramático, perante os soldados:

Post has Valeriam Messalinam, Barbati Messalae consobrini sui filiam, in matrimonium accepit. Quam cum comperisset super cetera flagitia atque dedecora $C$. Silio etiam nupsisse dote inter auspices consignata, supplicio adfecit confirmauitque pro contione apud praetorianos, 'quatenus sibi matrimonia male cederent, permansurum se in caelibatu, ac nisi permansisset, non recusaturum confodi manibus ipsorum. 283

«Depois destas, aceitou em casamento Valéria Messalina, filha do seu primo Messala Barbato. Ao descobrir que ela, além dos outros escândalos e faltas de decoro, casara ainda com Gaio Sílio, com dote autenticado na presença de testemunhas, mandou executá-la e garantiu frente a uma parada, no campo dos pretorianos, que, 'devido ao fracasso dos seus casamentos, tencionava manter-se celibatário, e, se não se mantivesse, não recusaria ser trespassado às mãos deles'».

Mas essa jura-imediatamente desacreditada por nec durare ualuit-torna-se motivo de cómico quando o próprio Cláudio a quebra, expondo a incoerência do seu carácter; e quando - facto mais grave ainda - celebra um casamento à época incestuoso ${ }^{284}$ e com uma mulher cuja influência se adivinha mais forte e mais perigosa que a anterior. A passividade de Cláudio, já maliciosamente sugerida pela expressão Messalinam in matrimonium accepit (em vez de duxit), é acentuada na cedência às artimanhas (inlecebrae) da sobrinha Agripina: per ius osculi et blanditiarum occasiones pellectus in amore ${ }^{285}$ («seduzido pelo direito

${ }^{282}$ Vide Croisille, J. M. 1970, 74-77. Sobre o tema da inversão e topoi da comédia em Tácito, vide Dickison, S. K. 1977, 634-647.

${ }^{283}$ Cl. 26.2. No juízo do tempo, Messalina era símbolo da ninfomania, consagrado pelos célebres versos 114-132 da Sátira VI, de Juvenal, mas também por Plínio-o-Velho, Nat. 10.83; Tácito, Ann. 11.32-38; Díon Cássio, 60.18.1 e (epítome) 60.31.1. Martin, R. 1991, 138-139, fala de uma verdadeira paixão de Cláudio por esta mulher. Messalina, por sua vez, poderá ter sido vítima de uma paixão avassaladora por Gaio Sílio, que a levaria a ultrapassar os limites do razoável: vide Guastella, G. 1999, 185. Além da referência vaga aos flagitia e dedecora, Suetónio não menciona o seu próprio veredicto sobre o comportamento de Messalina, pois, tal como no caso de Júlia, filha de Augusto, considera esse assunto bem conhecido dos seus leitores. O biógrafo está mais interessado em apresentar as reacções da personagem principal e a influência que sobre esta tem o comportamento das mulheres: vide VIDÉn, G. 1993, 86 e 89.

${ }^{284}$ E inaceitável para a lei romana: vide Segurado e Campos, J. A. 2001, 164.

${ }^{285}$ Cl. 26.3. O retrato de Agripina difere do das outras mulheres em Suetónio: enquanto estas são ornamentos na descrição de homens, Agripina aparece caracterizada em si mesma. Tal ficará a dever-se à imagem que deixara entre os Romanos: esta filha de Germânico era o símbolo da falta de moderação (impotentia), como Lucrécia da castidade e Tarpeia da traição, segundo pensa VIDÉn, G. 1993, 86-87. Tácito, Ann. 12.3.1, mais sóbrio na descrição do assédio 
ao beijo e pelas ocasiões que ela tinha de o acariciar»). Cláudio, homem fraco e ingénuo, torna-se presa fácil de uma mulher arguta que finge amor - situação de comédia. ${ }^{286} \mathrm{~A}$ matéria cómica continua quando o amante ensandecido quebra a ordem estabelecida: de modo a ultrapassar as dificuldades legais, suborna senadores para o coagirem a casar com Agripina. A pomposa justificação é indicada ironicamente pelo próprio biógrafo: quasi rei p. maxime interesset ${ }^{287}$ («como se fosse do máximo interesse para o Estado»). O que Suetónio faz é aligeirar manobras de política dinástica e cortesã, transformando-as em típicos enredos de comédia. Esta parece ser uma técnica muito presente nesta vida, como sugere Guastella, ${ }^{288}$ e com um efeito seguro: o riso é demolidor.

A própria morte do filho Druso e a rejeição da filha Cláudia têm contornos trágicos e cómicos. O primeiro morreu em circunstâncias tristemente burlescas: sufocado com uma pêra, quando se divertia a atirá-la ao ar e a apanhá-la na boca. E Suetónio insiste que se não tratou de um atentado de Sejano. Quanto a Cláudia, que na realidade era filha do liberto Bóter - como frisa com malícia o biógrafo -, o imperador, depois de a ter reconhecido, mandou lançá-la, nua, à porta da mãe, depois do divórcio, o que faz pensar numa descoberta tardia de adultério. ${ }^{289}$

Cláudio torna-se também servo de servos. As exageradas concessões aos libertos, de que se destacam Narciso e Palante, lembra a imagem de um senex de Plauto (como o Perífanes do Epidicus) explorado pelo escravo. Suetónio sugere a identificação com o humor dos que à volta se apercebem da inversão de papéis: Tantum praeterea adquirere et rapere, ut querente eo quondam de fisci exiguitate non absurde dictum sit, 'abundaturum, si a duobus libertis in consortium reciperetur ${ }^{290}$ («Tanto acumularam e rapinaram, que, quando uma vez ele

de Agripina, centra o discurso nas intenções políticas desta mulher: preparar a sucessão em favor do filho Domício; vide Segurado e Campos, J. A. 2001, 169-170.

${ }^{286}$ Por exemplo, o Pirgopolinices de Plauto cai nos ardis de quem o quer enganar (Plauto, Mil. 1216-1283): convence-se de que a suposta esposa do vizinho (papel desempenhado por Acrotelêucio) está perdida de amor por ele.

${ }^{287}$ Suetónio cala - propositadamente, parece - a necessidade dinástica deste casamento, que se adivinha por detrás do comentário. Agripina assegurava melhores vantagens que as suas rivais: era filha de Germânico e directa descendente de Augusto; o filho dela, Lúcio Domício, futuro imperador Nero, era neto de Germânico e devia ser unido à família imperial, e (como sustentava o liberto Palante em Tácito, Ann. 12.2.3) uma união com uma mulher de fora da família criava uma crise dinástica. Agripina e o filho eram muito populares, sobretudo depois do aparecimento de Lúcio Domício no lusus Troiae, ao lado do apagado Britânico, filho de Cláudio (cf. Nero 7.1 e Tácito, Ann. 11.11.2). Além do mais, Agripina era jovem e podia gerar descendência. Portanto, apesar dos impedimentos legais, era ela a escolha lógica como futura mulher do imperador. Vide com. de Mottershead, J. 1986, 110.

${ }^{288}$ Vide com. de Guastella, G. 1999, 33-45.

${ }^{289} \mathrm{Cl}$.27.1. Suetónio, que normalmente se não preocupa com nomes próprios de personagens secundárias, revela a identidade do pai de Cláudia, não por causa da gravidade do adultério, susceptível de corromper uma estirpe nobre, mas para sublinhar a condição de liberto; vide com. de Guastella, G. 1999, 190.

${ }^{290}$ Cl. 28. Trata-se, para Reekmans, T. 1992, 220, de um tipo de humor designado por subabsurda, pertencente aos géneros distinguidos por Cícero, de Orat. 2.289, no campo de ridicula in re et ipsa sententia. 
se queixava da indigência do tesouro, lhe disseram, não a despropósito, que 'poderia vê-lo prosperar se tomasse os dois libertos por sócios'»). Como estes ministros tomam decisões em nome do imperador, surge a situação caricata do imperador se não recordar de ter dado a ordem de execução de um ex-cônsul: os libertos elucidam-no e ele dá a sua aprovação. ${ }^{291}$ Mas, em jeito de clímax, aparece um caso digno de uma comédia e pouco credível na vida real, como sublinha o biógrafo, sem deixar de o referir:

Nam illud omnem fidem excesserit quod nuptiis, quas Messalina cum adultero Silio fecerat, tabellas dotis et ipse consignauerit, inductus, quasi de industria simularentur ad auertendum transferendumque periculum, quod imminere ipsi per quaedam ostenta portenderetur. ${ }^{292}$

«Na verdade, o caso seguinte terá excedido toda a credibilidade, pois nas núpcias, que Messalina celebrou com o amásio Sílio, terá sido induzido a assinar, por sua própria mão, as tabuinhas do dote, como se fossem propositadamente simuladas, para desviar e transferir para outrem o perigo que, pelo que alguns fenómenos pressagiavam, estava a ponto de cair sobre o imperador».

Mais uma vez, faz lembrar uma cena de palliata em que, mediante o conluio da mulher e do amante, a amada é subtraída ao detentor, com a perfeita anuência deste, convencido das vantagens que da cedência pode extrair. ${ }^{293} \mathrm{O}$ facto de se dizer que fidem excesserit serve para aliciar a curiosidade do leitor, assim levado a adoptar as posições do biógrafo. $\mathrm{O}$ motivo do consentimento do marido enganado era, naturalmente, também explorado pelo mimo. ${ }^{294}$

$\mathrm{O}$ ridículo alastra a todos os aspectos da personalidade de Cláudio: às características físicas e às psicológicas. No que respeita ao aspecto físico, a linhagem nobre não deixa de se manifestar, mas é suplantada pelos traços pessoais do portentum hominis, para usar a descrição que dele fizera a própria mãe (Cl.3.2). A caricatura é a técnica usada aqui pelo biógrafo numa gradação que começa no mais nobre e vai até ao repugnante (Cl. 30). Os contrastes da personalidade manifestam-se na aparência. Deveria manter-se inactivo, porque o seu agir é ridículo: é grotesco, como grotescas são as personagens da comédia. Também no que respeita aos hábitos pessoais e divertimentos, a

${ }^{291}$ Cl. 29.2. Situação já explorada por Séneca, Apoc. 13.4-6.

${ }^{292}$ Cl. 29.3. Tácito, Ann. 11.27, descreve um rito matrimonial segundo as regras, mas não fala do envolvimento de Cláudio na assinatura do contrato. Tudo chega depois ao conhecimento do imperador através de Narciso, que o aconselha a obrigar Sílio a rasgar o contrato e a restituir a mulher. Vide com. de Guastella, G. 1999, 199.

${ }^{293}$ Como a cena do miles gloriosus de Plauto em que Pirgopolinices, induzido por Palestrião (vv. 973-984 e 1094-1136), cede de boa vontade Filocomásio ao amante, com os seus haveres e o escravo (vv. 1311-1377), em vista da posse da esposa do vizinho (que na verdade era solteiro). A diferença é que, no texto de Suetónio, há adultério pelo meio e personagens moralmente reprováveis - o que, segundo o com. de GuAstella, G. 1999, 43-44, traz consigo um efeito que vai além do cómico.

${ }^{294}$ Segundo a Historia Augusta (M. Aur. 29), um mimo ridiculizava uma situação semelhante: a complacência de Marco Aurélio para com os amantes da imperatriz. 
imagem começa por ser positiva, mas rapidamente descamba para o caricato. É humorística, embora "pedagógica", a lição que dá a um suspeito de ter roubado um copo de ouro: convida-o no dia seguinte para a sua mesa e dá-lhe um de barro. Bem mais ridículo é o boato de que tinha em mente promulgar um edicto (dicitur etiam meditatus edictum) a dar licença para a libertação de gases à mesa. ${ }^{295}$ Estamos perante a referência a um recurso farsesco bem conhecido da comédia, já criticado por Aristófanes nas Nuvens, ${ }^{296}$ mas sempre eficaz.

Com esta anedota se introduziu o tom das informações seguintes. A ligação à comédia é acentuada agora pelo comportamento báquico. Situações cómicas ilustram os excessos de Cláudio na comida e na bebida: atraído pelo odor de uma refeição dos Sálios, abandona o tribunal; cheio de comida e encharcado em vinho (distentus ac madens), adormecia deitado de costas e de boca aberta, e tinham de lhe introduzir uma pena na boca para aliviar o estômago. ${ }^{297} \mathrm{Um}$ comportamento degradante que proporcionará o cenário para a sua morte.

O exagerado medo atribuído a este imperador é exemplificado com vários exemplos, entre os quais a seguinte anedota: quando Camilo, mentor de uma revolta civil, lhe ordena, com injúrias e ameaças, que renuncie ao império, Cláudio reúne um conselho para saber se não devia obedecer (Cl. 35.2). Pensa abdicar perante $\mathrm{o}$ anúncio de algumas conspirações e tem reacções espontâneas despropositadas. Quando descobriram no palácio um homem armado com um punhal (como se referira em 13), senatum per praecones propere conuocauit lacrimisque et uociferatione miseratus est condicionem suam, cui nibil tuti usquam esset («convocou imediatamente o senado pelos pregoeiros e, com lágrimas e gritos, lamentou a sua condição, própria de quem não encontrava segurança em nenhum lugar»). E o amor flagrantissimus por Messalina foi abandonado, afinal, mais por medo que pela indignidade dos ultrajes. Nessa altura, refugiou-se, a tremer, junto dos pretorianos, e, ao longo de todo o caminho, não parava de perguntar "se continuava imperador". ${ }^{298}$

$\mathrm{O}$ medo e a desconfiança aliam-se à já referida credulidade. Um simples sonho serve como prova para a pena capital. Citam-se dois episódios paralelos. Um litigator diz que sonhou com um atentado contra Cláudio; o autor do sonho diz reconhecer depois o assassino: é quanto basta para condenar o

${ }^{295}$ Cl. 32. Mais uma vez se trata de uma anedota colhida de fontes orais. Semelhante graça é também concedida aos convidados pelo petroniano Trimalquião: Petrónio, 47.5-6; vide Ferreira, P. S. 2000, 81, e 129-130. Séneca, Apoc. 4.3, explora este argumento: Vltima uox eius haec inter homines audita est, cum maiorem sonitum emisisset illa parte qua facilius loquebatur: 'Vae me, puto, concacaui me.'

${ }^{296}$ Vv. 293-296. Vide Silva, M. F. 1987, 87-89.

${ }^{297}$ Cl. 33.1. A pena será o meio usado no seu assassínio, para introduzir a segunda dose de veneno, segundo a versão de Tácito, Ann. 12.67.2.

${ }^{298}$ Cl. 36. Cf. 26.2 e 29.3. GAscou, J. 1984, 367-368, acha que, nas duas referências ao casamento de Sílio e Messalina, se inseriu uma incoerência involuntária, rara em Suetónio, que resultaria da tripartição do mesmo episódio e de um mau uso de fontes de proveniência diversa. Mas parece tratar-se antes de diferentes ângulos de abordagem do mesmo facto: em $\mathrm{Cl}$. 26.2, faz-se um resumo do acontecimento no que diz respeito aos casamentos de Cláudio; em Cl. 29.3, o ponto de vista é a subordinação e ingenuidade de Cláudio perante as mulheres e os libertos; e já está presente o medo do imperador. 
suspeito (Cl. 37.1). Mas, se os intervenientes nesta anedota são anónimos, os do episódio seguinte são figuras famosas:

Pari modo oppressum ferunt Appium Silanum: quem cum Messalina et Narcissus conspirassent perdere, diuisis partibus alter ante lucem similis attonito patroni cubiculum inrupit, affirmans somniasse se uim ei ab Appio inlatam; altera in admirationem formata sibi quoque eandem speciem aliquot iam noctibus obuersari rettulit; nec multo post ex composito inrumpere Appius nuntiatus, cui pridie ad id temporis ut adesset praeceptum erat, quasi plane repraesentaretur somnii fides, arcessi statim ac mori iussus est. Nec dubitauit postero die Claudius ordinem rei gestae perferre ad senatum ac liberto gratias agere, quod pro salute sua etiam dormiens excubaret. ${ }^{299}$

«Contam que assim foi morto Ápio Silano. Como Messalina e Narciso conspiravam para acabar com ele, dividiram os papéis: Narciso, com ar estupefacto, irrompeu antes da aurora pelo quarto do patrono a dizer que sonhara que Ápio usava da força contra ele; Messalina, fingindo admiração, contou que a mesma visão lhe surgia há já algumas noites. Não muito depois, conforme fora concertado, anunciaram-lhe que irrompia Ápio, a quem se recomendara no dia anterior que se apresentasse naquele momento. Como se a veracidade do sonho se tornasse totalmente evidente, Cláudio mandou acusá-lo e executá-lo. E não hesitou em relatar no dia seguinte ao senado o completo desenrolar dos acontecimentos e dar graças ao liberto que até a dormir velava pela sua segurança».

Além da inversão de papéis, a forma como o ingénuo Cláudio é enganado tem contornos de comédia e correspondência em enredos da palliata. ${ }^{300} \mathrm{E}$ ainda aumenta o cómico o facto de, no dia seguinte, contar a história do seu engano ao senado. Mas o cúmulo da farsa é agradecer publicamente a quem o enganou. Tal inversão tem paralelo na cena final do Epídico de Plauto. ${ }^{301}$ Mas, se o Perífanes de Plauto, embora fosse "uma coluna do senado", era uma

${ }^{299} \mathrm{Cl}$. 37.2. A anedota não está atestada por outras fontes e provirá de fontes orais, denunciadas pelo genérico ferunt. $\mathrm{O}$ facto de os dois episódios apresentarem uma mecânica absolutamente idêntica parece indicar que Suetónio queria tornar mais credível a inverosímil condenação de Ápio Silano, fazendo-a preceder de um episódio perfeitamente análogo, que demonstraria a propensão de Cláudio para acreditar nos sonhos como prova, conforme sugere, no seu com., Guastella, G. 1999, 207. Ora a forma como Suetónio começa (pari modo oppressum) parece-nos reforçar esta opinião.

${ }^{300}$ Como sublinha, no seu com., Guastella, G. 1999, 9-10 e 33-34, desenvolvendo estes ingredientes, facilmente se poderia elaborar uma cena teatral centrada no engano de um senex pelas artimanhas de um libertus fallax e uma matrona (ou uma meretrix, dado o conceito que Suetónio tem de Messalina). Além disso, há uma nítida semelhança com uma cena do miles gloriosus de Plauto, vv. 370-410: Palestrião, com base num suposto sonho de Filocomásio sobre o aparecimento de uma irmã gémea, convence o medroso Céledro de que não vira Filocomásio na casa do vizinho, mas a tal gémea.

${ }^{301}$ Dizer que Narciso até durante o sono velava, poderá ser uma forma hiperbólica de agradecimento pelos serviços do liberto, proferida em qualquer altura pelo imperador e transcontextualizada por fontes hostis. Sobre o triunfo do escravo na cena final do Epídico de Plauto, vide Medeiros,W. DE 1981, 379-394. 
personagem fictícia e um tipo, Cláudio é uma figura individual, histórica e, para mais, o imperador: a consequência do engano é a morte de um inocente. Os factos e figuras históricos são narrados como um enredo e personagens de comédia, mas o efeito tende para o trágico.

Depois de apresentar uma personagem grotesca, licenciosa, medrosa e crédula, Suetónio parece sugerir que Cláudio assume o papel de um verdadeiro senex iratus, pois introduz logo a seguir as rubricas da ira e comportamento colérico ( $\mathrm{Cl}$.38) do qual Cláudio se procura desculpar de forma caricata. Do mesmo modo, não tem o bom senso de calar a sua toleima (stultitia): antes tenta inverter o efeito, apresentando-a como simulada ex industria, para sobreviver no reinado de Gaio. Mas logo o biógrafo contrapõe um libelo, que apareceu na altura, a provar que ninguém pode fingir stultitia. ${ }^{302}$ Esta última característica é particularmente explorada como geradora de cómico. De facto, concretizações da stultitia, o esquecimento e a distracção são motivo de riso, pelas anedotas que o biógrafo reúne, sem evitar uma conveniente distorção:

Occisa Messalina, paulo post quam in triclinio decubuit, 'cur domina non ueniret' requisiit. Multos ex iis, quos capite damnauerat, postero statim die et in consilium et ad aleae lusum admoueri iussit et, quasi morarentur, ut somniculosos per nuntium increpuit. Ducturus contra fas Agrippinam uxorem, non cessauit omni oratione 'filiam et alumnam et in gremio suo natam atque educatam' praedicare. Adsciturus in nomen Neronem, quasi parum reprehenderetur, quod adulto iam filio privignum adoptaret, identidem diuulgauit neminem umquam per adoptionem familiae Claudiae insertum'(Cl. 39.1-2.).

«Executada Messalina, perguntou, pouco depois de se recostar no triclínio, 'porque é que a senhora não vinha'. Muitos dos que condenara à pena capital, mandava avisá-los, logo no dia seguinte, quer para virem a conselho, quer para jogarem aos dados e, como se estivessem a tardar, censurava-os, por um mensageiro, por serem dorminhocos. Quando estava para casar com Agripina, contra as leis divinas, não parava de lhe chamar em todos os discursos 'filha e pupila e nada e criada ao seu colo.' Quando estava para dar a Nero o seu nome de família, como se fizessem já poucas censuras por adoptar um enteado quando tinha um filho já crescido, a toda a hora tornava público que 'nunca ninguém entrara por adopção na família cláudia'».

Há neste passo sinais vários de distorção, na procura de um efeito em que a verdade histórica não é a prioridade. $\mathrm{O}$ esquecimento da morte de Messalina parece inspirado na ignorância de Cláudio acerca da morte de Popeia Sabina em que Messalina não foi a vítima, mas a mentora (poderá haver, por parte

302 Cl. 38.3. Ideia semelhante é expressa por Séneca, Apoc. 1.1: obiit ille, qui uerum prouerbium fecerat, aut regem aut fatuum nasci oportet. O fingimento da stultitia figura também em Díon Cássio, 59.23.5 e 60.2.4. O com. de Mottershead, J. 1986, 130, sugere que Cláudio, antiquário como era, se deve ter inspirado em Bruto, que, segundo Tito Lívio, 1.56.7, fingira stultitia durante o reinado de Tarquínio. Herrmann, L. 1951, 143-145, acha que a obra

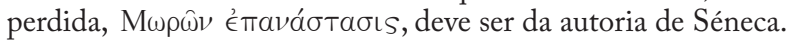


do biógrafo, confusão dos papéis, ou contaminatio dos dois episódios). ${ }^{303}$ Transpor tão anormal esquecimento para a morte da ex-imperatriz aumenta consideravelmente o caricato da situação. As expressões multos ex iis e omni oratione fazem suspeitar de amplificação, e adulto iam filio é exagero nítido. ${ }^{304}$ Além disso, a afirmação de que ninguém entrara por adopção na família cláudia, observação infeliz se pronunciada por Cláudio, perde o peso se for atribuída a outrem, como faz Tácito. ${ }^{305}$ Mas, verdade é que, com as deformações históricas de Suetónio, o cómico se torna mais flagrante.

Tal efeito resulta também da negligentia de Cláudio, pelo contraste entre as funções que desempenha e a sua linguagem, marcada pela vulgaridade e pelo ridículo, e a que falta todo o sentido da oportunidade. ${ }^{306} \mathrm{~A}$ propósito de uma discussão no senado sobre carniceiros e taberneiros, pergunta: rogo uos, quis potest sine offula uiuere?' Descripsit<que > abundantiam ueterum tabernarum, unde solitus esset uinum olim et ipse petere ${ }^{307}$ («digam-me, por favor, quem pode viver sem um niquito de pão?' e pôs-se a descrever a abundância das tabernas de outrora, onde ele próprio costumava então ir tomar um copo»). Tal comentário, além de despropositado, expõe, em acto oficial, um dos defeitos de Cláudio: a apetência pela bebida. Recomenda um candidato à questura 'quod pater eius frigidam aegro sibi tempestiue dedisset" ("porque o pai deste lhe tinha dado oportunamente água fresca durante uma doença'»), o que, além do ridículo, sugere um favorecimento com base em outros critérios que não o mérito pessoal. Sustenta a credibilidade do testemunho de uma mulher no senado, com o elogio: 'Haec', inquit, 'matris meae liberta et ornatrix fuit, sed me patronum semper existimauit; hoc ideo dixi, quod quidam sunt adhuc in domo mea, qui me patronum non putant ${ }^{308}$ («Esta - disse ele - era liberta e criada de quarto de minha mãe, mas sempre me considerou patrono; digo isto porque há alguns, até em minha casa, que patrono me não julgam'»). Com este desabafo, dito em tom de aparte cómico, Cláudio explicita a falta de dignitas a que se expõe na sua própria casa. Aos cidadãos de Óstia que vinham pedir um favor, 'nibil habere se' uociferatus est, 'quare cos demereatur; si quem alium, et se liberum esse'

${ }^{303}$ Os comentadores (Mottershead, J. 1986, 131; Guast Ella, G. 1999, 210-211) realçam a grande semelhança entre este passo de Suetónio e Tácito, Ann. 11.2.3, em que Cláudio, durante um banquete, ignorando a morte de Popeia Sabina, forçada ao suicídio por maquinação de Messalina, pergunta porque não está ela ao lado do marido. Quanto à morte de Messalina, Tácito conta as coisas de modo um pouco diferente: realça a responsabilidade de Narciso, que, receoso de um recuo do imperador, toma a seu cargo a morte da condenada (Ann. 11.37); descreve depois a absoluta apatia de Cláudio ao receber a notícia da morte da mulher (Ann. 11.38).

${ }^{304}$ Quando Nero, em 50, foi adoptado, Britânico tinha nove anos; e Nero era três anos mais velho; cf. Tácito, Ann. 12.25.1-2; vide Levick, B. 1989, 72.

305 Tácito, Ann. 12.25.2, dá-a como afirmação de periti, e não de Cláudio.

${ }^{306}$ De tais desconcertos de linguagem não ficou traço algum em outras fontes; vide com. de Guastella, G. 1999, 211-212.

${ }^{307} \mathrm{Cl}$. 40.1. Offula é termo do latim coloquial, inadequado em sessão do senado.

${ }^{308}$ Cl. 40.2. Suetónio já dissera, em Cl. 25.1, que Cláudio legislara para que os libertos ingratos voltassem à escravatura, mas deve tratar-se de generalização a partir de um caso particular, como sugere BaUmann R. 1982, 109, n.133, com base em Ulpiano, dig. 37.14.5. 
(«'não tinha qualquer razão - berrou ele - para os obsequiar, e se havia alguém livre, ele também o era'»). Tinha fórmulas que repetia continuamente: 'Quid,

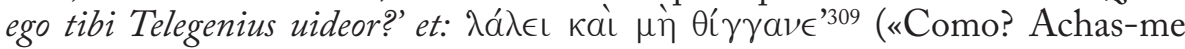
com cara de Telegénio?» e «Fala, mas não me toques»). E Suetónio termina com o comentário do biógrafo ao contraste entre tais ditos e o que seria de esperar de um príncipe, para mais culto : multaque talia etiam priuatis deformia, nedum principi, neque infacundo neque indocto, immo etiam pertinaciter liberalibus studiis dedito («e muitas outras saídas da mesma sorte, degradantes até para um particular, quanto mais para um príncipe a quem não faltava nem eloquência nem cultura, e que, bem pelo contrário, se entregava mesmo com afinco aos estudos liberais»).

Mesmo no tratamento da actividade literária, o biógrafo realça os aspectos mais caricatos, com episódios burlescos que, contra o que seria de esperar desta rubrica, nada dizem sobre a qualidade da obra de Cláudio. O momento da recitação da sua primeira obra torna-se hilariante: ${ }^{310}$

Et cum primum frequenti auditorio commisisset aegre perlegit refrigeratus saepe a semet ipso. Nam cum initio recitationis defractis compluribus subsellis obesitate cuiusdam risus exortus esset, ne sedato quidem tumultu temperare potuit, quin ex interuallo subinde facti reminisceretur cachinnosque reuocaret (Cl. 41.1).

«E, quando se atreveu pela primeira vez, frente a numeroso auditório, a custo terminou a leitura, arrefecida muitas vezes por ele próprio. Como, no início da recitação, por ter desabado uma série de bancos sob o peso de um gordo, se gerou o riso, nem sequer depois de acalmada a confusão foi capaz de o mitigar, já que de tempos a tempos o assaltava a lembrança do facto e retomava as gargalhadas».

Trata-se, pois, de uma biografia diferente das anteriores. A profusão de elementos cómicos aproxima da comédia esta biografia e os enredos da vida familiar lembram o mimo ${ }^{311}$ - mas o papel do protagonista e o epílogo transformam-na numa tragicomédia.

Efeito diverso têm os elementos cómicos da Vida de Vespasiano. O sentido de humor e franqueza contribuem para tornar simpática a imagem

${ }^{309}$ Cl. 40.3. Alguns manuscritos apresentam Telegonius. Herrmann, L. 1962, 860, propõe que se leia Pelagonius, latinização do nome de um eunuco de Cláudio, Pelagon (cf. Tácito, Ann. 14.59.2); pelo que tanto este nome como a fórmula grega que se segue teriam conotações sexuais. Qualquer que seja a forma do nome, deve tratar-se da referência a alguém de proverbial estupidez, afirma, no seu com., Mottershead, J. 1986, 134. Parece-nos que expressão

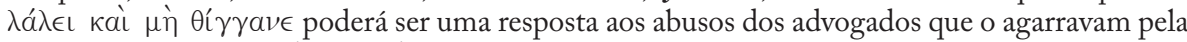
orla da toga e pelo pé ( $C l$. 15.3); ou palavras usadas quando afastava os importunos com a sua própria mão (Cl.38.2).

${ }^{310}$ Vide com. de Guastella, G. 1999, 213.

${ }^{311}$ Vide Dickison, S. K. 1977, 644: «The life of Claudius (his two wives and the poisoning at hands of the second) bears a marked resemblance to a mime plot that was familiar to the Roman audience». 
deste imperador. De entre os ditos de espírito sobreviventes (Ves. 22), destaca o biógrafo a conhecida anedota protagonizada por Méstrio Floro, que, depois de advertir o imperador de que não devia dizer plostra, mas sim plaustra, se vê saudado, na manhã seguinte, por Flaure; ${ }^{312}$ e a resposta de Vespasiano ao dispensator sobre a designação a dar à despesa pro concubitu com uma amante ocasional: 'Vespasiano,' inquit 'adamato' ("Por uma paixão - disse ele - que Vespasiano inspirou!'»). ${ }^{313}$ Outro exemplo do humor é a forma versátil e repentista como usa versos gregos (tempestiue satis). Cita um verso de Homero referido a Ájax (Il.7.213) e emprega a expressão "lança que projecta as sombras longe" metaforicamente em sentido obsceno de órgão sexual masculino desmesurado (Ves. 23.1).

O riso demove: as respostas humorísticas de Vespasiano atenuam a impressão negativa resultante do exagero no rigor. A propósito da correcção da disciplina, o imperador mostra a sua austeridade com humor. A um jovem que, todo perfumado, lhe vem agradecer uma prefeitura, lança-lhe em tom de censura: 'maluissem alium oboluisses' ("preferiria que cheirasses a alho'») e revogou a nomeação; e quando os marinheiros, que tinham de fazer a pé o percurso de Óstia e de Putéolos até Roma, lhe pedem um subsídio para o calçado, o imperador não só não acede, como ainda os manda percorrer o caminho descalços. E o biógrafo conclui, também com humor: ita ex eo ita cursitant $^{314}$ («e, desde então, assim o percorrem»).

A fama de avarento que perseguia este imperador leva os habitantes de Alexandria a apelidarem-no de Cybiosactes ("mercador de peixe salgado"), alcunha de um dos seus piores reis. ${ }^{315}$ Tal acusação persegue-o até à última

312 Assim Florus, derivado de flos ('flor'), passa a soar como o grego phlauros ('mau'; 'insignificante'; 'desagradável'). Segundo Reekmans, T. 1992, 189-232, trata-se de uma réplica com recurso a humor in uerbis e não in rebus. Vide com. de CESA, M. 2000, 94.

${ }^{313}$ Esta interpretação é contestada por ZINN, T. 1951, 10. Segundo este autor, pro deve traduzir-se por 'em vez de' e não 'em troca de'; e adamatus é um jogo de palavras com o grego adamatos 'não seduzido': daqui resulta que Vespasiano pagou à mulher, em vez de se deitar com ela, e depois mandou colocar a despesa sob o item "para preservação da castidade de Vespasiano". Reekmans, T. 1992, 210 n. 74, é de opinião que adamatos não deve ser explicado pela presunção de que o imperador se não deitou com a tal mulher, mas pelo facto de ele, depois da morte da esposa (Flávia Domitila), ter decidido não voltar a casar (e 'livre' é o significado de adamatos, quando aplicado a uma mulher). Grassi, C. 1972, 149, nota que o motivo da graça reside no inesperado: normalmente seria o inspirador do amor a exigir pagamento pelos seus serviços, mas Vespasiano faz o contrário, pois considera tal paixão fingida na mira de obter uma dádiva. De facto, a teoria de ZINN parece cair logo por terra com as palavras introdutórias da anedota, onde se afirma claramente que Vespasiano foi Expugnatus autem a quadam, quasi amore suo deperiret. Segundo Martin, R. 1991, 149, a sexualidade de Vespasiano foi à imagem do comportamento do general e do homem: plena de moderação.

${ }^{314}$ Ves. 8.3. Suetónio refere-se aos destacamentos da frota de Miseno que se encontravam em Óstia e Putéolos. Os classiarii exerciam também a função de correios: vide com. CEsA, M. $2000,73$.

${ }^{315}$ Ves. 19.2. Trata-se do nome com apelidaram um suposto selêucida, com quem casou Berenice IV, filha e sucessora de Ptolemeu XIII Auletes. Segundo Díon Cássio, 66.8, os alexandrinos sentiam-se desiludidos com Vespasiano: esperavam favores pelo facto de este imperador ter sido primeiramente aclamado em Alexandria, mas sofreram um agravamento de 
morada: o arquimimo Fávor, que, no funeral, imitava as palavras e os gestos do defunto, depois de interrogar os procuradores e de saber que a cerimónia custava dez milhões de sestércios, pede-lhes que lhe dêem cem mil e que o atirem mesmo ao Tibre (Ves.19.2). O facto de o biógrafo terminar com humor o tratamento desta pecha - considerada o único vício de Vespasiano (Ves. 16.1) - também contribui, afinal, para a suavizar.

Efeito diferente têm as anedotas, verdadeiras ou inventadas, contadas per ludibrium, sobre a avareza de Galba, e que o colocavam nos antípodas de Nero: lamentou-se de um jantar que lhe serviram, por ser assaz requintado; ofereceu um prato de legumes a um administrador, como recompensa pelo seu bom trabalho; deu, do seu bolso, cinco denários ao famoso flautista Cano. ${ }^{316}$ Suetónio dá um tom totalmente negativo a estes rumores.

Pelo contrário, o próprio Vespasiano usava o sentido de humor para atenuar o efeito da forma pouco ortodoxa de obter lucros (Ves. 23.1). O biógrafo transcreve dois exemplos, em que Vespasiano arranja forma de participar dos lucros que obtiveram os seus subordinados com a intercessão em favor de terceiros (Ves. 23.2); uma resposta irónica à reprovação de Tito ao imposto sobre a urina recolhida pelos pisoeiros (fullones) - apresenta-lhe o produto da primeira colecta e pergunta-lhe se cheira mal - ; e uma resposta a uma delegação que lhe vinha anunciar a elevação de uma estátua a um preço elevado - mostra o côncavo da mão, numa atitude de quem pede, e diz que já está preparada a base. ${ }^{317}$

Mesmo na rubrica do retrato físico, Suetónio introduz uma anedota que demonstra que Vespasiano não só aceita, de acordo com a sua bonomia (Ves. 13), um bom dito de espírito sobre si próprio, como até o incentiva. Certa vez que Vespasiano pedira a um espirituoso que dissesse uma graça acerca da sua pessoa, o interpelado, aludindo à característica contracção facial do imperador, respondeu: 'Dicam,' inquit, 'cum uentrem exonerare desieris' (Ves. 20) («Estou pronto a dizê-la - retorquiu ele - , quando acabares de aliviar a tripa») - palavras que estão a nível da dicacitas do imperador que nem evitava o calão (Ves. 22).

Vespasiano mantém o humor até aos últimos momentos de vida: Ac ne in metu quidem ac periculo mortis extremo abstinuit iocis («e nem sequer com o medo e o extremo risco de morte se absteve de gracejos»). Neste contexto integra o biógrafo uma seç̧ão que costuma ser séria: os presságios de morte. Suetónio

impostos. Apesar de ter sido aclamado e apoiado pelo Oriente, Vespasiano, ao chegar a Roma, optou por uma política ocidental de hostilização a tudo o que era exótico. Ainda estava bem viva, particularmente entre os senadores, a reacção às pretensões de Nero, que se apresentava como artista à moda grega e actuava como um déspota oriental. Vide com. de Grassi, C. 1972, 147.

${ }^{316}$ Gal. 12.3. Plutarco, Gal. 16.1-2, insere a recompensa a Cano numa política de contenção contraposta à prodigalidade de Nero. Diz que as moedas oferecidas são de ouro e acrescenta a afirmação, feita por Galba, de que o donativo não era era retirado dos cofres do estado. Vide com. Murison, Ch. L. 1992, 65. Também Tácito, Hist. 1.49.3, dá uma imagem positiva da avareza de Galba, num retrato de sabor salustiano: ...pecuniae alienae non adpetens, suae parcus, publicae auarus.

${ }^{317}$ Ves. 23.3. Vide Murphy, J. P. 1991, 3780-3782. 
transmite, assim, a perspectiva de Vespasiano, que não leva a sério os prodígios: quanto ao facto pressago de o mausoléu de Augusto se abrir, Vespasiano disse que tal prodígio se aplicava a Júnia Calvina, que era descendente (a última) de Augusto; quanto ao significado do aparecimento de um cometa, o imperador disse que se aplicava ao rei dos Partos, que tinha cabeleira. ${ }^{318}$ Se antes zombara da origem divina que lhe queriam atribuir (Ves. 12), no primeiro acesso da doença, que se manifesta em diarreia, zomba da futura divinização: 'Vae', inquit, "puto deus fio. ${ }^{319}$ («Ai! - exclamou ele - acho que me estou a tornar um deus!'»).

Esta observação serve para distanciar Vespasiano das pretensões teocráticas dos maus imperadores. Suetónio usa nesta biografia a técnica sugerida pelo próprio biografado ao diluir os vícios nos jogos espirituosos. Por aqui se pode verificar como elementos próprios da biografia são usados pelo biógrafo com objectivos e resultados completamente diferentes no que respeita à caracterização dos imperadores: por um lado, ridiculização da figura de Cláudio, e por outro, favorecimento da imagem de Vespasiano.

Os elementos dramáticos, de natureza trágica ou cómica, estão portanto ao serviço de um objectivo mais vasto na biografia: a caracterização moral dos imperadores, feita precisamente a partir das suas acções, as quais tendem a ser esteriotipadas de acordo com os topoi conhecidos. Daqui resulta que se terá de esperar no final uma espécie de catarse de tipo moralizador.

${ }^{318}$ O gracejo sobre o cometa assenta no facto de Vespasiano ser calvo.

${ }^{319}$ Ves. 23.4. Paródia das últimas palavras de Cláudio na Apocolocyntosis (4.13): uae me, puto, concacaui me. Fisнwicк, D. 1965, 155-157, acha que as palavras de Vespasiano não devem ser interpretadas como uma troça grosseira do fátuo ritual da apoteose. Há quem pense que se não trata de um gracejo de Vespasiano, mas de uma brincadeira hostil aos Flávios. Vide com. de CESA, M. 2000, 96. 


\section{ACTA EST FABVLA}

A narrativa da morte e os acontecimentos a ela ligados, como reaç̧ão das várias classes, permitem completar a imagem do biografado. Os elementos seleccionados pelo biógrafo, a partir das fontes, para integrar o desenlace reflectem o juízo do autor. Se quisermos procurar sinais de uma catarse nas Vidas, teremos de ter em conta esta parte. Com o género de morte e com a reacção das gentes serão purificados os sentimentos de medo ou de compaixão, de ódio ou de simpatia, gerados ao longo das Vidas.

\subsection{As boas mortes}

Os bons imperadores são premiados com mortes dignas. $\mathrm{O}$ facto de Augusto conhecer a data da morte com cem dias de antecedência (Aug. 97.2), além de conferir especial significado às acções e às palavras do imperador, não gera um clima de tensão (como em Domiciano), mas parece produzir um ambiente de espera tranquila. Augusto decide passar quatro dias de ócio em Cápreas, onde se entrega ao divertimento e ao improviso de versos espirituosos em grego, enquanto aguarda o fim. Num jogo de palavras, fala do fogo sobre a campa do fundador. Embora se refira a um favorito a quem, por graça, chamava fundador (ktistes) da ilha, a atmosfera de presságio que se gerou dos prodígios elencados (Aug. 97), a proximidade da morte e as várias associações de Augusto a Rómulo ao longo da Vida transformam o dito em profecia sobre a sua própria morte. Ao sentir-se pior, manda regressar Tibério, que ia em viagem. O longo secretus sermo com o herdeiro, ${ }^{1}$ a sua última actividade oficial, cria algum mistério na passagem do testemunho. E na narrativa do supremus dies, Suetónio transmite momentos de uma cena íntima centrada nas dúvidas de Augusto, na manifesta preocupação de saber se é amado e se agradou, na sua despedida da vida:

Supremo die identidem exquirens, an iam de se tumultus foris esset, petito speculo capillum sibi comi ac malas labantes corrigi praecepit et admissos amicos percontatus, 'ecquid iis uideretur mimum uitae commode transegisse', adiecit et clausulam:

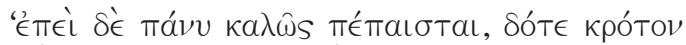

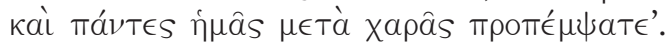

Omnibus deinde dimissis, dum aduenientes ab urbe de Drusi filia aegra interrogat, repente in osculis Liuiae et in hac uoce defecit: 'Liuia, nostri coniugii memor uiue ac uale!' Sortitus exitum facilem et qualem semper optauerat. ${ }^{2}$

«No derradeiro dia, enquanto perguntava sem cessar se havia agitação lá fora por

\footnotetext{
${ }^{1}$ Segundo Tácito, Ann. 1.5.4, quando Tibério chegou a Nola, Augusto já teria morrido há vários dias, mas Lívia mantivera a sua morte em segredo para assegurar a sucessão ao filho.

2 Aug. 99.1. Optamos aqui, por nos parecer que faz mais unidade de sentido com o subsequente, pela lição mi[ni]mum, $P^{2}$ (Beroaldus), em vez de mi[ni)mum da ed. de IHм, que temos vindo a seguir.
} 
causa dele, depois de pedir um espelho, mandou pentear os cabelos e compor as maçãs do rosto descaídas e perguntou aos amigos que recebera 'se por acaso lhes parecia que tinha representado bem o mimo da vida'; e acrescentou a fórmula de remate: Já que foi muito bem representado, dêem-me o vosso aplauso / e todos juntos, com alegria, me deixem partir à frente’. Em seguida, depois de os despedir a todos, enquanto interroga os que chegam sobre a doença da filha de Druso, desfalece subitamente, entre os beijos de Lívia, com estas palavras: «Lívia, vive na lembrança da nossa união, e adeus!» Teve sorte de ter um fim fácil, como sempre desejara».

A morte é o momento supremo da revelação do ethos. É nas manifestações das pessoas que se verificam os verdadeiros sentimentos: a reacção do povo tem importância para o biógrafo. Por outro lado, o cuidado com o cabelo e o rosto que Augusto manifesta no derradeiro momento, apesar de antes se ter dito que era negligente com a sua aparência, ${ }^{3}$ mostram o princeps a criar a sua "personagem” até ao fim. Depois da opinião geral, vem a opinião dos amigos. Suetónio não a transmite, mas o leitor sabe que, dadas as circunstâncias, não podia ser outra senão afirmativa. Então Augusto, com sentido de humor, pede o aplauso, servindo-se de uma fórmula de fecho da comédia, ou, mais provavelmente, do mimo. ${ }^{4}$ Augusto gostava de comédia, ${ }^{5}$ Suetónio já o dissera. A comparação da vida a um mimo faz todo o sentido: o mimo é a imitação da vida e está na moda. O cerimonial parece composto: Augusto mantém a mise-en-scène até ao último momento ${ }^{6}$ e Suetónio não a desmonta. A frase com que se despede de Lívia soa a composição dramática. O desfecho de paz, de euthanasia, a conversar com os amigos, corresponde a um ideal de morte que implica um juízo moral do biógrafo sobre os méritos do imperador. Associação da vida a um mimo, com a cláusula final, não sugere reprovação por parte de Suetónio, mas constatação de que a vida deste homem foi a representação realista - com aspectos bons e maus, mas onde o bem supera o mal -, que merece aplauso. ${ }^{7}$

Há, contudo, um indício de delírio (um apenas, insiste o biógrafo), que

${ }^{3}$ Aug. 79.1: ... et omnis lenocinii neglegens; in capite comendo tam incuriosus, ut raptim compluribus simul tonsoribus operam daret.

${ }^{4}$ A fórmula, segundo Monaco, G. 1970, 255-273, é retirada da comédia nea (na antiga não existia) e imitada pelos autores latinos da palliata. Para Kessissoglu, A. I. 1988, 385-388, será uma improvisação do próprio Augusto, que era capaz de improvisar versos em grego (cf. Aug. 58.4). Fornaro, P. 1988, 162, sugere que é mais significativo e coerente que se trate de uma clausula mimi, improvisada pelo próprio Augusto, como complemento irónico da pergunta sobre a sua vida associada a um mimo.

${ }^{5}$ Sobretudo a antiga: cf. Aug. 89.1. Sobre o sentido de humor de Augusto, vide Southern, P. 1998, 136.

${ }^{6}$ Vide Néraudau, J.-P. 1996, 8-9.

${ }^{7}$ Fornaro, P. 1988, 155-167, defende que a cláusula teatral é metáfora ética que expressa a consciência do dever cumprido e não tem, em Suetónio, o sentido pejorativo de hipócrita "farsa da vida", que lhe tem sido dada pelos intérpretes do biógrafo latino (e por Díon Cássio, 56.30.4), mas equivale a uma representação sem máscara. Segundo NéraudAu, J.-P. 1996, 42, o argumento do mimo é a mitificação que Augusto assumiu através de todas aquelas histórias prodigiosas. 
poderia ensombrar a alegada serenidade dos últimos momentos. O biografo não dá uma explicação convincente para a visão dos quarenta jovens que levavam Augusto pela força ${ }^{8}$ mas evita lançar qualquer mácula sobre esta morte grandiosa e apela às capacidades divinatórias de Augusto (magis praesagium quem mentis deminutio): talvez se tratasse de um presságio sobre o número de soldados pretorianos que haveriam de transportar o seu corpo. ${ }^{9}$ Pode ser apenas um forma subtil de o biógrafo satisfazer o escrúpulo em ser completo, sem estragar a encenação. Além disso, esta breve nota introduz um pouco de mistério na narrativa da morte. É significativo que Suetónio, apesar da propensão para as versões mais escandalosas, não sugira qualquer indício de assassínio, como faz Tácito. ${ }^{10}$ Veremos que, no caso dos maus imperadores, a atitude do biografo é bem diferente. A morte de Augusto, como prémio da vida, tem de ser o mais possível imaculada.

A narrativa da morte de Vespasiano é a de um imperador bom, que cumpriu o seu papel e encara o seu fim com naturalidade e boa disposição. Trata-se de um regresso ao lugar de origem: Reate. Sucumbe à febre e, apesar de súbita diarreia, não deixa de cumprir as obrigações do imperador e mantém a dignidade - 'imperatorem' ait 'stantem mori oportere' ("um imperador afirma ele - deve morrer de pé!') - e expira nos braços dos que o sustêm. ${ }^{11}$ Os pormenores realistas, menos decorosos (intestina uitiasset... ad defectionem soluta), não parecem diminuir a grandeza da personagem, antes lhe conferem uma feição mais humana. ${ }^{12}$ Se os ditos servem para iluminar o carácter, ${ }^{13}$ uma frase dita à hora da morte assume especial significado. ${ }^{14} \mathrm{~A}$ morte serena e a

${ }^{8}$ Aug. 99.2: Unum omnino ante efflatam animam signum alienatae mentis ostendit, quod subito pauefactus a quadraginta se iuuenibus abripi questus est.

${ }_{9}$ Para NÉraudAu, J.-P. 1996, 24-25, trata-se de uma interpretação confusa, pois mistura causa e efeito, e incoerente, pois apresenta Augusto terrificado por uma visão da manifestação solene de respeito e o verbo abripi da visão (recolhido a partir de um grito do enfermo) não se coaduna com extollere do funeral. Além disso, Augusto conheceria minuciosamente os pormenores do seu funeral.

${ }^{10}$ Com efeito, Tácito, Ann. 1.5.4, menciona o rumor da responsabilidade de Lívia na morte de Augusto; e Díon Cássio, 56.30.1-2, diz expressamente que Lívia o envenenou com um figo. Trata-se provavelmente de um decalque da morte de Cláudio por obra de Agripina: vide Martin, R. H. 1955, 350-352; Questa, C. 1959, 41-55.

${ }^{11}$ Ves. 24. Cf. Díon Cássio, 66.17.1-3. Martin, R. 1991, 193-195, aponta, como causa provável de morte, a tuberculose pulmonar: a diarreia súbita corresponde a uma das formas mais graves da evolução da doença e, em pessoa idosa, quando acompanhada de febre, anuncia uma morte iminente. Díon diz que alguns, entre os quais Adriano, espalharam o falso rumor de que Vespasiano fora envenenado por Tito durante um banquete. Suetónio exclui tal boato, o que, segundo BALDwin, B. 1983, 190, pode ter alguma relação com a crítica a Adriano de que alguns autores suspeitam nas Vidas dos Césares. Mas é mais provável que Suetónio não quisesse macular a boa morte reservada aos imperadores bons, como nota GAscou, J. 1984, 793. De resto, tal crime não se coadunaria com a apresentação de Tito, dois capítulos à frente.

${ }^{12}$ Como afirma, no seu com., Grassi, C. 1972, 153.

${ }^{13}$ Como observa Della Corte, F. 1967, 152.

${ }^{14} \mathrm{~A}$ última frase do imperador moribundo reflecte o respeito pela função que desempenhou e a ausência de angústia manifesta-se no humor, como sugere MARTin, R. 1991, 352-353, que 
consciência do dever cumprido aproxima-o de Augusto.

Toda a Vida de Tito parece estruturada de forma a salientar o carácter prematuro e injusto da morte daquele que fora apresentado, logo no início, como "amor e delícias do género humano". A narrativa mergulha numa atmosfera de melancolia evidente. ${ }^{15}$ Ao acentuar a elevação de carácter de Tito, Suetónio torna mais comovente o relato da sua morte e injusto o tratamento de que será vítima por parte do irmão. O contraste entre os dois é desde logo posto em evidência, em proveito de Tito. Com efeito, as insídias, que se esperariam de adversários políticos, vêm da parte de Domiciano, que procura, às claras, aliciar o exército. A reacção de Tito é comovedora: continua a proclamá-lo "sócio e sucessor" e chega a pedir-lhe, de lágrimas nos olhos, que se esforce por corresponder à sua afeição. ${ }^{16}$ Tito é o homem do afecto, ${ }^{17} \mathrm{e}$ ao acentuar o contraste entre o a benevolência de Tito e a má vontade de Domiciano, o biógrafo apela à compaixão e indignação do leitor. A magnanimidade, o clima de emoção, a morte prematura são ingredientes que elevam Tito à categoria de herói épico e trágico. Se a morte ante diem é sempre triste, o desaparecimento de Tito é considerado dano maior para a humanidade que para o próprio ${ }^{18}-\mathrm{o}$ que deixa, à partida, implícito, um juízo sobre o sucessor. $\mathrm{O}$ damnum suum é ilustrado com as reacções emotivas. Coloca-se a tónica na profunda tristeza: no final de um espectáculo, Tito chora copiosamente à frente do povo ${ }^{19} \mathrm{e}$ depois parte para o país dos Sabinos tristior, porque uma vítima tinha fugido durante um sacrifício ${ }^{20}$ e trovejara quando estava bom tempo. Busca-se a compaixão do leitor, e Tito aparece, segundo Baldwin, como a vítima desafortunada de uma tragédia grega: ${ }^{21}$

Deinde ad primam statim mansionem febrim nanctus, cum inde lectica transferretur, suspexisse dicitur dimotis pallulis caelum, multumque conquestus 'eripi sibi uitam immerenti, neque enim extare ullum suum factum paenitendum excepto dum taxat uno'. Id quale fuerit, neque ipse tunc prodidit neque cuiquam facile succurrat. ${ }^{22}$

aproxima a morte de Vespasiano da de Augusto. Vide Murphy, J. P.1991, 3784.

${ }^{15}$ Como nota Martin, R. 1991, 353-354.

${ }^{16}$ Tit. 9.3: ... non numquam secreto precibus et lacrimis orans, 'ut tandem mutuo erga se animo uellet esse’. Cf. Díon Cássio, 66.26.2; Aurélio Victor, Caes. 10.11. Jones, B. W. 1970, 346-347, a partir da comparação deste passo nos dois autores, admite que Aurélio Victor tenha copiado Suetónio de perto. A relação entre os dois irmãos seria pautada por mútua indiferença: vide com. de Jones, B. \& Milns, R. 2002, 117.

${ }^{17}$ Vide Marastoni, A. 1983, 120.

${ }^{18}$ Tit. 10.1: Inter haec morte praeuentus est maiore hominum damno quam suo.

${ }^{19}$ A mesma observação em Díon Cássio, 66.26.1.

${ }^{20}$ Um mau presságio, segundo Suetónio: Jul. 59; Gal.18.1; e segundo outros autores:Tácito, Hist. 3.56.1; Plínio, Nat. 8.183.

${ }^{21}$ Vide Baldwin, B. 1983, 517.

${ }^{22}$ Tit. 10.1-2. A causa da febre súbita poderia ser paludismo cerebral, e, segundo o Talmud, representaria um castigo de Deus pela destruição do templo de Jerusalém: vide MARTin, R. 1991, 197; com. de Jones, B. \& Milns, R. 2002, 118. 
«Depois, logo na primeira pousada, apanhou febre. Ao ser dali levado na liteira, diz-se que, arredando as cortinas, levantou os olhos ao céu e se queixou amargamente de que 'a vida lhe era arrebatada sem ele o merecer, pois nada fizera de que se arrependesse - a não ser, quando muito, um só acto'. O que quer que fosse, nem ele então o revelou, nem ninguém o descobrirá facilmente».

Sobre esta confissão perdura a incerteza: algumas vozes opinam que Tito estaria a recordar o adultério com a esposa do irmão. Mas o biógrafo, depois de apresentar o rumor como duvidoso, ${ }^{23}$ refuta-o com o testemunho da própria Domícia: jurava ela que, se tal relação tivesse existido, não teria razão para a esconder, antes se gloriaria, como prontamente fizera com todos os seus erros. $\mathrm{E}$ o mistério permanece. ${ }^{24} \mathrm{O}$ biógrafo afasta tal escândalo da responsabilidade de Tito, em consonância com o que dissera sobre a mudança na libido deste imperador, depois da sua chegada ao poder. ${ }^{25}$ Implicitamente, ao introduzir o juramento de Domícia, está a glorificar indirectamente Tito e a apoucar Domiciano. Significativo é que o biógrafo, sem apresentar uma solução, seja levado a expor mais este enigma pela dose de estímulo que resulta de o assunto ficar em aberto. Interessante é também o facto de não mencionar rumores da implicação de Domiciano na morte do irmão, quando na Vida daquele faz insinuações que apontam nesse sentido. ${ }^{26}$

A coincidência de morrer na mesma casa de seu pai salienta o regresso às origens humildes da família na terra dos Sabinos e a aproximação, na morte, de Tito e Vespasiano.

\subsection{Morte e castigo}

É interessante notar que, à excepção de Augusto, Vespasiano e Tito, não

${ }^{23}$ Como demonstra o uso do conjuntivo oblíquo: ... consuetudinem recordatum, quam cum fratris uxore habuerit.

${ }^{24} \mathrm{O}$ mesmo mistério se encontra em Díon, 66.26.3-4. Este historiador inclina-se para a hipótese de que Tito lamenta não ter executado Domiciano quando ele conspirou abertamente contra ele, em vez de entregar o império a uma pessoa com tal carácter. MARTin, R. 1991, 355, considera esta hipótese plausível e LEvi, M. A. 1954, 288-293, acentuando o caracter polémico da biografia, hostil a Domiciano, diz que o erro poderia ser o exercício da clementia em relação a Domiciano. Pelo contrário, Ambrosio, F. G. D’ 1980 [1982], 232-241 (especialmente 235), sugere que o motivo do arrependimento teria sido o facto de não ter associado Domiciano ao império, como era vontade de Vespasiano. Este autor imagina uma longa e bem planeada urdidura do senado, para a destruição desta família flávia, fomentando o desentendimento entre os irmãos. Outras hipóteses se aventaram: arrependimento por ter executado Cecina; por ter alterado o testamento de Vespasiano; por ter destruído Jerusalém; por ter entrado, contra a proibição, no Santo dos Santos do templo de Jerusalém: vide com. de Jones, B. \& Milns, R. 2002, 120 .

${ }^{25}$ Tito, depois de assumir o poder, procura manter-se irrepreensível, como diz Díon, 66.18.1. Vide Martin, R. 1991, 151.

${ }^{26}$ Segundo Aurélio Victor, Caes. 10.5, foi envenenado por Domiciano. Suetónio não faz qualquer referência a esse facto, embora na Vida de Domiciano sugira que este o abandonou à morte (Dom. 2.3). O biógrafo parece obedecer ao pressuposto de que a uma vida bela se sucede uma morte digna; daí que omita os pormenores que ensombrariam o final de Tito: vide Gascou, J. 1984, 385-386 e 793. 
há, para o biógrafo, mais mortes puramente naturais. Há sete assassínios, e dois suicídios. E Suetónio apresenta os relatos da queda em desgraça e morte de forma a sugerir uma consequência do modo de vida dos imperadores.

\subsubsection{O ferro: o sacrifício do tirano}

No caso das mortes violentas a narrativa é mais longa e mais complexa. $\mathrm{O}$ processo de aproximação é revelador das técnicas do biógrafo: na progressão dos acontecimentos evidencia-se as qualidades de carácter da personagem. $\mathrm{O}$ modelo de assassínio político é o de Júlio César. O processo é introduzido com um juízo de valor do biógrafo: Praegrauant tamen cetera facta dictaque eius, ut et abusus dominatione et iure caesus existimetur ${ }^{27}$ ( Thodavia assumem tal relevo outras acções e palavras dele que se considera que ele abusou da tirania e que mereceu a morte»). Esta referência à morte mostra ao leitor que a narrativa é retomada no ponto em que tinha sido interrompida pela introdução das rubricas descritivas (Jul. 44.4).

A gradação reforça os motivos do assassínio: honras desmedidas, que superam os limites humanos (Jul. 76.1), exemplificadas com prerrogativas de reis e de deuses; palavras arrogantes contra a República e contra os auspícios (Jul. 77); o ódio de morte que causou por se não ter levantado quando recebia, diante do templo de Venus Genetrix, os senadores que o vinham cumular de honras ( $J u l .78 .1$ ); e, finalmente, um acto de suprema arrogância (Jul. 79.1): ofendido porque uns tribunos prenderam um homem que coroara a sua estátua com uma faixa branca, símbolo da realeza, César exonerou-os do cargo. A desculpa de César é que lhe arrebataram a glória da recusa, mas não se livrou da fama da aspiração ao reino, apesar de responder a quem o aclama «Sou César, não um rei» e de recusar repetidamente a coroa que António fazia menção de lhe colocar na cabeça e de a consagrar a Júpiter Óptimo Máximo (Jul. 79.2). É mais um dos famosos golpes de teatro de César. Além disso, o biógrafo sabia que era premonitória a resposta do ditador aos que o aclamavam: por Césares, não por reis, serão conhecidos os sucessores de César e deste título tirará Suetónio a designação para as suas biografias.

No final da gradação fica no ar um boato (uaria fama). Suspeitava-se de que César pensava mudar-se para Alexandria ou para Tróia, com as riquezas do Império, e que lhe iria ser proposto no senado, o título de rex, uma vez que se afirmava nos livros sibilinos que só um rei poderia vencer os Partos (Jul. 79.3), tarefa que, como vimos, estava nos planos de César (Jul. 44.2). O rumor da proposta é apresentada pelo biógrafo como a causa próxima da organização da revolta. ${ }^{28}$

${ }^{27}$ Jul. 76.1. Gugel J.1970, 5-22, defende que a Vida de César está organizada de acordo com certos Leitmotiven, como a ambição de realeza, a hipertrofia da sua pessoa, o desrespeito pelas manifestações usuais do culto romano, que confluem no relato de morte e ajudam a reforçar o efeito teatral - uma interpretação pessoal da personagem de César que, diz GugeL, só poderia ser feita por «un vero scrittore».

${ }^{28}$ Jul. 80.1: Quae causa coniuratis maturandi fuit destinata negotia, ne assentiri necesse esset. 
Suetónio é preciso na narrativa da preparação das conjuras contra os tiranos: descreve as divergências sobre os executores, o lugar e o momento certos. ${ }^{29} \mathrm{O}$ leitor quase consegue adivinhar a discussão dos conspiradores até decidirem que fica marcado para os Idos de Março, data da reunião do senado, na Cúria de Pompeio, nome significativo (Jul. 80.4). Relevante é a sucessão de prodígios que se estendem no tempo até à hora do atentado. A gradação é sugerida com notações temporais cada vez mais precisas. Nos meses anteriores (Paucos ante menses), é descoberta uma tabula aenea, no túmulo do fundador de Cápua, com uma inscrição que previa a morte de César e o castigo dos assassinos à custa de grandes penas para a Itália. ${ }^{30}$ Uns dias antes (Proximis diebus), os cavalos que César consagrara ao rio Rubicão recusam alimento e choram copiosamente, ${ }^{31}$ e o harúspice Espurina previne César contra um perigo que não iria além dos idos de Março (Jul. 81.2). Na véspera (Pridie autem easdem Idus), várias aves perseguem até à Cúria de Pompeio e despedaçam uma carriça (cujo nome latino, regaliolus, evoca rex) que leva um ramo de louro no bico. Nessa noite (Ea nocte, cui inluxit dies caedis), César sonha que voa sobre as nuvens e aperta a mão de Júpiter ${ }^{32}$ e Calpúrnia, que desaba o tecto da casa e que o marido é apunhalado no seu regaço. Um pormenor estranho, introduzido por subito, adensa a atmosfera dramática causada pelos sonhos: as portas do quarto abrem-se espontaneamente. ${ }^{33} \mathrm{~A}$ partir daqui o relato assume contornos ainda mais dramáticos com a luta entre a sorte habitual que o tenta proteger e o fatum que, segundo tais presságios, se deve cumprir. Quando César está quase decidido a ficar em casa por causa dos presságios (ob haec) e de uma indisposição, Décimo Bruto, homem da sua confiança, exorta-o a prosseguir, e César sai fere hora quinta (última notação temporal); no caminho, alguém lhe entrega um bilhete a revelar a conjura, mas ele junta-o a outros papéis para ler mais tarde; ${ }^{34}$ imola diversas vítimas, sem conseguir presságios favoráveis, e entra na Cúria spreta religione; troça do harúspice Espurina, que o havia precavido contra os Idos de Março, e acusa-o de ser impostor, «pois os Idos de Março aí estavam sem nenhum perigo para ele»; ao que o adivinho lhe respondeu «que tinham realmente chegado, mas não tinham passado». ${ }^{35} \mathrm{~A}$

${ }^{29}$ Cf. Cal. 56.2; Dom. 17.1.

${ }^{30} \mathrm{Jul}$. 81.1: 'Quandoque ossa Capyis detecta essent, fore ut illo [ou Iulo, edd.] prognatus manu consanguineorum necaretur magnisque mox Italiae cladibus uindicaretur.'

${ }^{31}$ Esta é a única referência a estes animais.

${ }^{32}$ Também Calígula tem um sonho semelhante pridie quam periret (Cal. 57.3).

${ }^{33}$ Segundo Gugel, J. 1970, 10-11, os prodígios já vinham na tradição paralela, mas a ordenação é de Suetónio: a forma de apresentar o prodígio das portas do quarto, comparada com outras fontes (Plutarco, Caes. 63; Díon Cássio, 44.17), demonstra a vontade de surtir efeito teatral.

${ }^{34}$ Segundo Plutarco, Caes. 65, foi Artemidoro de Cnidos, mestre de Letras Gregas (embora diga também que, segundo alguns autores, se tratava de outra pessoa, pois Artemidoro fora impedido de se aproximar de César).

${ }_{35} \mathrm{Jul}$. 81.4: Dein pluribus hostiis caesis, cum litare non posset, introit curiam spreta religione Spurinnamque irridens et ut falsum arguens, quod sine ulla sua noxa Idus Martiae adessent: quamquam is uenisse quidem eas diceret, sed non praeterisse. 
arrogância e o desprezo dos presságios, que já antes manifestara, ${ }^{36}$ provocará o seu fim. Faz, de algum modo, lembrar um herói trágico que, sem se aperceber, vai ao encontro do seu destino. A contagem do tempo, cruzada com os vários sinais que se sucedem, a par da cegueira arrogante de César intensifica a ambiência dramática. A ignorância torna-se a expressão da finitude humana no herói: invicto em muitas batalhas, César comete o erro elementar de descurar avisos, repetidos e convergentes e encaminha-se, sem o saber, para a morte, às mãos daqueles que considera leais.

Segue-se o relato do assassínio ( $\mathrm{Jul}$. 82), no qual o carácter "teatral” de César é mantido até ao último sopro de vida. O protagonista está no centro: apercebe-se, tarde de mais, do perigo (Ista quidam uis est?); é ferido pouco abaixo do pescoço; reage com a única arma que tinha (um estilete); ${ }^{37}$ tenta escapar e é retido por outro golpe; resigna-se ao ver tantos punhais; cobre a cabeça com a toga e procura cair composto, ${ }^{38}$ sem proferir palavra alguma, à excepção

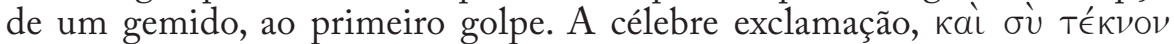
(«Também tu, meu filho!»), ao ver Marco Bruto, aparece como aditamento de outras fontes (etsi tradiderunt quidam) e vai ao encontro do gosto de Suetónio pelo romanesco. ${ }^{39}$ Por fim, há debandada geral, enquanto César, exânime, ali fica abandonado durante muito tempo, até que três escravos o levam numa liteira: e, pormenor realista, um braço do defunto vai pendente. ${ }^{40}$ Suetónio não diz que César caiu junto à base da estátua de Pompeio, como faz Plutarco (Caes. 66.12-13), talvez por não querer sugerir, como o biógrafo grego, que o Grande preside à vingança: para Suetónio, cavaleiro romano, a

${ }^{36} \mathrm{Jul}$. 59 . O facto de descurar os prodígios é uma linha estruturante da narração: vide GugEL J. 1970, 1-15.

${ }^{37} \mathrm{Jul}$. 82.2. Só Suetónio menciona este incidente. O grito de César, a meio da descrição do assassínio, revela o momento em que ele dá conta da real situação: vide Gugel, J. 1970, 16.

${ }^{38} \mathrm{O}$ decoro, consonante com o cuidado que tinha com o corpo (cf. Jul. 45), é, como nota Gugel J. 1970,17-18, outra linha estruturante explorada por Suetónio na cena de morte, e o gesto de compor a toga gera efeito teatral.

${ }^{39}$ Só Suetónio Jul. 82.3 e Díon Cássio 44.19.5, referem estas palavras. Não se aceita, geralmente, a apóstrofe como autêntica, por se basear na lenda de que Bruto era filho de César. Aponta-se como data provável para o nascimento de Bruto 85 a.C.: vide com. de Butler, H. E. \& M. Cary 1927, 110 e ns. supl. (de Townend, G. B. 1982) 159-160. Nessa época, César teria apenas 16 anos e a relação com Servília situa-se muito mais tarde. Ora o termo Tékvov, primariamente de uso trágico e épico, é empregado como afectuoso desde Homero (Il. 9.437; Od.4.611), o que não acontece com filius latino. Muitos jovens latinos aprendem o grego como primeira língua, e aprendem o latim mais tarde. Assim, o grego torna-se, para os jovens romanos das classes superiores, a língua da espontaneidade. Outras fontes referem palavras gregas pronunciadas naquele momento (Plutarco, Caes. 66.8). Com base nestes argumentos, Dubuisson, M. 1980, 881-890, conclui que estas palavras, inseridas num comportamento linguístico definido, devem ser autênticas; e se não são mencionadas pela maior parte dos historiadores é porque não têm interesse para a história política. Vide CANFora, L. 2000, 367. Mas, autênticas ou não, estas palavras aumentam o carácter romanesco da narrativa: a prova é o eco que obtiveram em autores posteriores, como o Et tu, Brute no Júlio César de Shakespeare (vide Lyons, M., \& Montgomery, H. C. 1968, 37-39), e o Et toi aussi, mon doux ami! em La nouvelle Heloïe de Rousseau (vide Scanlan, T. M. 1976, 60-61).

${ }^{40}$ Mais um exemplo da exploração do efeito teatral, segundo Gugel J. 1970, 21. 
culpa principal de César é a ambição da tirania.

Mas César é uma personagem de contrastes. No final, o biógrafo apresenta uma versão que dignifica o ditador e confere à Vida um desfecho trágico. Suetónio introduz aqui a suspeita de que César não queria viver mais tempo: ${ }^{41}$ repetia que a «sua segurança importava mais ao Estado do que a si próprio».É premonitória a afirmação atribuída ao defunto de que, se algo lhe acontecesse, o Estado não teria paz e cairia em guerras civis ainda mais sangrentas. ${ }^{42}$ Conclui-se que César teve, afinal, a morte que repetidamente desejara. Suetónio introduz confidências feitas em tempos diversos: quondam César rejeitara o tipo de morte lenta que Xenofonte atribui a Ciro; e precisamente pridie quam periret desejara uma morte rápida e inesperada. ${ }^{43}$ Visto por esta perspectiva, talvez César não fosse tão ignorante afinal da sorte que o esperava: fica a suspeita de que caminhara voluntariamente para o sacrifício. A personagem revela-se mais complexa do que parece à primeira vista. Em César, brilhava uma centelha de divino que provocava a admiração dos restantes mortais. De facto, foi contado in deorum numero: um cometa brilhou sete dias no céu (Jul. 88). Assim a uiolatio do deus exigia o castigo dos criminosos. A Vida termina com a já referida morte trágica dos assassinos: alguns com o mesmo punhal com que "profanaram" César. ${ }^{44}$

O resultado das prepotências de Calígula só podia ser a morte, mais cedo ou mais tarde: Ita bacchantem atque grassantem non defuit plerisque animus adoriri («perante tal delírio báquico e tal devastação não faltou a muitos a coragem de o atacar»), diz Suetónio, retomando a ideia que deixara atrás (Cal. 49.2), na altura em que, muito à semelhança do procedimento adoptado na $V i d a$ de César, dissera que ele morreu no momento em que projectava maiores enormidades. Assim inicia o biógrafo a narrativa da catástrofe..$^{45}$ Ao referir as conjuras, Suetónio introduz uma tirada dramática de Calígula suspeitoso dos libertos e dos prefeitos do pretório: Nam et statim seductis magna fecit inuidiam destricto gladio affirmans 'sponte se periturum, si et illis morte dignus uideretur' ${ }^{246}$ ( Com efeito, depois de os tomar imediatamente à parte, provocou-lhes o ódio,

${ }^{41}$ Jul. 86.1. Segundo McDermott, W. C. 1982-1983, 227-228, o desejo de morrer seria um rumor cultivado pelos inimigos políticos de César.

${ }^{42}$ Jul. 86.2: Solitum ferunt: 'non tam sua quam rei publica interesse, uti saluus esset: se iam pridem potentiae gloriaeque abunde adeptum; rem publicam, si quid sibi eueniret, neque quietam fore et aliquanto deteriore condicione ciuilia bella subituram'.

${ }^{43} \mathrm{Jul}$. 87. Xenofonte, Cyr. 8.7. Plutarco, Caes. 63.7. César preferiria a versão de Heródoto, 1.214, segundo o qual, Ciro morreu em combate.

${ }^{44} \mathrm{Jul}$. 89: Percussorum autem fere neque triennio quisquam amplius superuixit neque sua morte defunctus est. Damnati omnes alius alio casu periit, pars naufragio, pars proelio; nonnulli semet eodem illo pugione, quo Caesarem uiolauerant, interemerunt. Plutarco, Caes. 69.3, reporta a Cássio o suicídio com o mesmo punhal.

${ }^{45}$ Como a designa Croisille, J. M. 1970, 78 e n.5.

${ }^{46}$ Cal. 56.1. Segundo Díon Cássio, 59.25.7, a denúncia caluniosa, que incluía os dois prefeitos, o liberto Calisto e a própria Cesónia, foi feita por Betilieno Capitão, na tentativa desesperada de salvar a vida. Coagido a assistir à execução do filho, fora condenado por ter pedido para fechar os olhos; vide Antonelli, G. 2001, 166. 
ao afirmar, de gládio em punho, que 'se mataria voluntariamente, se até a eles lhes parecia que ele merecia a morte'»). Imediatamente se prepara a conjura e o leitor é posto ao corrente. Fica combinado o golpe para os jogos Palatinos, quando Calígula abandonasse o espectáculo, ao meio-dia. Cássio Quérea, tribuno de uma coorte pretoriana, reclama o papel principal, ofendido por o imperador o tratar como efeminado (Cal. 56.2).

No sumário dos prodígios que indiciam a morte, várias ideias unificadoras estão presentes: antes de mais, a hostilidade de Júpiter, cuja maiestas o imperador tanto quis usurpar, mas também o motivo recorrente do sacrifício, o simbolismo do nome de Cássio e dos Idos de Março. À cabeça da lista é referida a assustadora gargalhada da estátua de Júpiter Olímpico (Cal. 57.1), que Calígula quisera trazer para Roma, para lhe substituir a cabeça pela sua (Cal. 22.2). E um tal Cássio recebe em sonhos a ordem de imolar um touro a Júpiter. Nos Idos de Março, um raio atinge o capitólio de Cápua e outro o local da guarda do palácio imperial (cella atriensis): o segundo raio é interpretado como um perigo da parte dos guardas, o primeiro é considerado prenúncio de um importante assassínio, como o que fora perpetrado no mesmo dia. ${ }^{47}$ O imperador é avisado pelo astrólogo Sula e pelas Fortunae Antianae - local onde Suetónio insiste que Gaio nasceu (Cal. 8) - , que lhe anunciam que deve precaver-se contra um Cássio. Na procura de evitar o destino, Calígula é vítima de um equívoco: para contrariar a realização do oráculo (como outrora fizera com a ponte de Baias, para evitar o cumprimento da profecia de Trasilo), comete o erro involuntário de emitir a ordem de matar Cássio Longino, governador da Ásia, sem se lembrar de que Quérea também era Cássio.48

$\mathrm{Na}$ véspera da morte, sonha que Júpiter o empurra com os pés e o precipita na terra. Mas, para último lugar, o biógrafo reserva acontecimentos fortuitos, depois considerados pressagos, que envolvem a iminência de sangue e de morte. Durante um sacrifício, Calígula foi aspergido com o sangue de um flamingo, acidente que pressagiaria a assimilação do imperador à vítima. Os últimos prodígios relatados estão relacionados com o teatro. O pantomimo Mnester dançou a mesma tragédia que fora recitada nos jogos em que Filipe da Macedónia foi morto. Uma cena do mimo apelidado Laureolus, em que o protagonista se lança de um edifício arruinado, resultou excessivamente sangrenta devido ao empenho dos actores secundários. $\mathrm{O}$ facto de, no mimo Lauréolo, os actores secundários subressaírem (plures secundarum certatim experimentum artis darent, cruore scaena abundauit), mostra também, como argutamente nota Hurley, que personagens de segunda categoria podem assumir papéis de destaque: Quérea, um subordinado, quis as primas partes no assassinato de Calígula (Cal. 56.2). ${ }^{49}$

${ }^{47}$ Cal. 57.2. Na trad. de Ailloud, H. 1931-1932, identifica-se a cella Palatini atriensis com o «santuário de Apolo guardião do palácio» erigido por Augusto (cf. Aug. 29.3). Tal hipótese é contestada no com. de Guastella, G. 1992, 291-292. Ligado a Cápua estivera também um presságio da morte de César (Jul.81.1).

${ }^{48}$ Cal. 57.3. Cássio Longino era descendente do homónimo que se contava entre os assassinos de Júlio César; Cf. Díon Cássio 59.29.3.

${ }^{49}$ Vide Hurley, D. W. 1993, 206-207. 
Por último são referidas umas representações de assunto ligado ao mundo dos infernos, levadas a cabo por actores egípcios e etíopes, cujo negrume da pele acentuaria o carácter lúgubre do tema. ${ }^{50}$

Entretanto, Suetónio introduz algumas delongas geradoras de suspense. Calígula, no dia marcado, não tem pressa em se levantar. Está entre duas forças, sem ter consciência dessa situação: uma, exterior, que o impele para a morte e outra, interior, que se diria querer salvá-lo. Tal como Júlio César, parece hesitar em ir ao encontro do seu destino. Até ao último momento Calígula mostra-se preocupado com o teatro:

VIIII. Kal. Febr. hora fere setima cunctatus an ad prandium surgeret marcente adhuc stomacho pridiani cibi onere, tandem suadentibus amicis egressus est. Cum in crypta, per quam transeundum erat, pueri nobiles ex Asia edendas in scaena operas euocati praepararentur, ut eos inspiceret hortareturque restitit, ac nisi princeps gregis algere se diceret, redire ac repraesentare spectaculum uoluit. ${ }^{51}$

«Ao nono dia das calendas de Fevereiro, pela hora sétima, estava hesitante em se levantar do lugar para o almoço, com o estômago pesado da comida da véspera; por fim, a conselho dos amigos, lá saiu. Como na cripta, pela qual tinha de passar, estavam a ensaiar uns jovens nobres mandados vir da Ásia para levarem umas obras à cena, deteve-se a assistir e a encorajá-los e, se o chefe do grupo não dissesse que tinha frio, de bom grado teria regressado e feito representar o espectáculo».

O leitor, antecipadamente avisado da data da conjura, compreende e vive a ansiedade dos conjurados. Parece estranho que Calígula se não aperceba de que algo se tramava. Mas, como César, parece ter o discernimento embotado: está completamente absorvido pelos espectáculos. Por sinal, a imagem de Calígula que se colhe deste pequeno trecho não é a de um tirano implacável. Pelo contrário, mesmo contra a sua vontade, abandona o espectáculo e não obriga o chefe do grupo a actuar, a despeito do frio. E o leitor experimenta até uma certa simpatia pelo imperador que, por humanidade para com os actores e cedendo à vontade dos amigos, se deixa conduzir como vítima inocente.

Segue-se a cena da morte com as suas duas versões, nas quais se retoma o motivo do sacrifício, efectivado na imolação do tirano: a primeira versão sugere-o pelo golpe desferido por trás, no pescoço (a tergo Chaeream ceruicem gladio caesim grauiter percussisse), e pelas palavras rituais de Quérea: 'Hoc age!' ${ }^{2}$ A segunda sugere a oferta de uma vítima a Júpiter, presente na palavra de ordem dada por Calígula (o nome do deus) e na resposta de Quérea: Accipe

${ }^{50}$ Cal. 57.4. Vide Schmidt, V. 1983, 156-160.

${ }^{51}$ Cal. 58.1. Os jogos realizavam-se num teatro temporário, erigido em frente à residência imperial; vide BARRETt, A. A. 1989, 162-163.

${ }^{52}$ Cal. 58.2. Trata-se da metáfora do sacrifício. Hoc age era um grito com o qual o sacerdote, depois de fazer aos presentes a pergunta ritual agone?, era convidado a golpear a vítima para levar a cabo o sacrifício; vide os coms. de Guastella, G. 1992, 300; Hurley, D. W. 1993, 209-210; Wardle, D. 1994, 364; e ed. de Ailloud, H. 1931, n. ao passo citado. 
ratum!', provavelmente outra expressão formular que significa algo como «aceita o que calculaste» e que torna Calígula alvo da ira daquele deus. ${ }^{53}$ Já vimos que o imperador ofendera o pai dos deuses mais do que uma vez; e chegara a desafiá-lo (Cal. 22.4). Quando já está prostrado por terra, não pára de gritar que ainda está vivo. ${ }^{54} \mathrm{~A}$ fúria assassina dos conjurados é sugerida pelas trinta feridas ao som de 'repete' («outra vez») e pela nota de crueldade gratuita: quidam etiam per obscena ferrum adegerunt ${ }^{55}$ («alguns até lhe trespassaram com o ferro os órgãos genitais»). Extrema violência e sangue encerram esta Vida, porque, por um lado, nem todos o abandonam: fiéis, os lecticários vêm em seu socorro com os varais da liteira e a guarda germânica mata culpados e inocentes; por outro, porque o castigo do tirano se estende aos familiares mais directos: juntamente com ele morreu a esposa, Cesónia, à espada de um tribuno, e a filha, atirada contra um muro. ${ }^{56}$ Assim se destrói a semente do monstro, que, como se viu atrás (Cal. 25.4), perpetuava a sua feritas.

Há fortes conexões trágicas no final desta Vida. Como se trata da morte de um tirano, Calígula fica, a princípio, quase insepulto. Está também presente o motivo do aparecimento do fantasma do morto ao qual não foram prestadas as devidas honras fúnebres. Calígula só descansa quando as irmãs, regressadas do exílio, lhe fazem um funeral digno (Cal. 59). Pela segunda vez o mimo aparece associado à morte de um imperador. Augusto pergunta se representou bem o mimo da vida. Em Calígula, cuja vida foi um mimo constante, é o próprio mimo que pressagia a sua morte. Há demasiado sangue neste mimo, como houve na vida do imperador.

A caminhada de Galba para a morte ocorre de modo semelhante. Há uma gradação que atinge um cúmulo, sinal de um processo de abuso de poder: Per haec prope uniuersis ordinibus offensis uel praecipua flagrabat inuidia apud milites $^{57}$ ( Com estas acções provocou a hostilidade de quase todas as ordens, mas o rancor ardia principalmente entre os soldados»). Se antes condensou as ofensas às várias classes - a crueldade, a avareza, a complacência incoerente com o governo dos três diferentes satélites -, o biógrafo dispõe-se agora a narrar os factos que geraram a inuidia dos soldados e, consequentemente, provocaram a morte de Galba. O tema da avareza, principal traço deste imperador, regressa com a recusa do donativo que os seus oficiais tinham prometido, na sua ausência, aos soldados. Galba replica simplesmente que

53 Houve mesmo quem propusesse a correcção para accipe iratum; vide os coms de Guastella, G. 1992, 301; Hurley, D. W. 1993, 211; Wardle, D. 1994, 365; e ed. de Rolfe, J. C. 1913, 494 n. b.

${ }^{54}$ Cal. 58.3; grito que Camus valorizará ao transportá-lo para o estilo directo e fazer dele o último brado do seu herói: "Je suis encore vivant"; vide MARTin, R. 1991, 372-374.

${ }_{55}$ Díon Cássio, 59.29.7, acrescenta mesmo canibalismo.

${ }^{56}$ Cal. 59. A morte de Cesónia desmentirá o seu envolvimento na conjura.

${ }^{57} \mathrm{Gal}$. 16.1. Esta afirmação sugere que a queda de Galba é uma consequência directa da conduta anterior. Suetónio costuma colocar a supressão dos imperadores em explícita relação com a conduta precedente: cf. Jul. 76.1; Cal. 56.1; Nero 40.1; Dom.14.1. Vide Cizeк, E. 1977, 129-130. 
«costuma recrutar e não comprar os soldados». Tais palavras teriam revoltado todos os exércitos ${ }^{58}$ - uma afirmação que parece exagerada. ${ }^{59}$ Suetónio, sem mencionar a honestidade política destas palavras impopulares, como faz Tácito ${ }^{60}$ limita-se referir o ponto de vista negativo e hostil dos soldados; e apresenta Galba cada vez mais isolado, com a perda do apoio dos pretorianos. O ponto culminante é a irritação do exército da Germânia Superior, que, defraudado das recompensas merecidas pela campanha contra Víndex e os Gauleses, é o primeiro a sublevar-se e a rejeitar um imperador eleito na Hispânia: envia aos pretorianos uma delegação a exigir a escolha de um imperador capaz de reunir o consenso. ${ }^{61}$ Assim, é a avareza que, por fim, facilita o caminho a Otão, pois Galba, julgando que o problema residia no facto de ser velho e não ter filhos, adopta repentinamente Pisão, ${ }^{62}$ sem conceder às tropas o habitual donativo ${ }^{63}$ - erro que se revela fatal, pois permite a Otão alcançar os seus intentos nos seis dias que se seguiram ( Gal. 17). Dir-se-ia que Suetónio está a louvar o esbanjamento que criticou em Nero. Mas o biógrafo, seguindo a formação e a evolução da opinião pública adversa e dos soldados, acaba de demonstrar, de forma viva, como uma política de austeridade, aparentemente virtuosa, pode levar ao desastre, se não for aplicada com critério e bom senso e, sobretudo, com coerência.

A dialéctica do favor e desfavor dos deuses e dos homens organiza-se

${ }^{58}$ Gal. 16.1. Segundo o com. de Murison, Ch. L. 1992, 72-73, os soldados constituem, de momento, uma ideia unificadora da narrativa de Suetónio; e nos capítulos 17 e 18 vão sendo mencionados soldados, como para lembrar ao leitor a sua constante presença em plano de fundo.

59 Há pelo menos um destacamento da Germânia que permanece fiel, por ter sido especialmente bem tratado por Galba: cf. Gal. 20.1 e Tácito, Hist. 1.31.3.

${ }^{60}$ Hist. 1.5.2: Acessit Galbae uox pro republica honesta, ipsi anceps, legi a se militem, non emi. Esta afirmação, que merece, apesar de ser considerada ambígua, algum louvor a Tácito, é claramente louvada por Plutarco, Gal.18.4, e Díon Cássio, 64.3.3. Suetónio é o único a considerar totalmente negativa a atitude de Galba: vide Gascou, J. 1984, 752.

${ }^{61}$ Gal. 16.2. Segundo Tácito, Hist. 1.12.1, as legiões da Germânia Superior entregavam a eleição ao senado e ao povo romano, para atenuarem o carácter insurreccional do movimento. Suetónio desmembra a narração deste facto entre a Vida de Galba e a de Vitélio (cf. Vit. 8.1), pelo que, neste ponto, silencia os factos relativos ao último; vide Venini, P. 1974, 999-1000.

${ }_{62}$ Baldwin, B. 1983, 538, acha absurda a cena da adopção como Suetónio a transmite. Pelo contrário, no com., Murison, Ch. L. 1992, 79, considera-a preferível ao relato de Tácito, Hist. 1.14.1. Della Corte, F. 1967, 115-125, analisa o episódio do ponto de vista da polémica com Tácito que, como representante dos interesses da ordem senatorial, considerava a adopção (sistema que acabara de receber um rude golpe por intervenção de Plotina, ao entronizar um favorito, Adriano, como sucessor de Trajano) com entusiasmo (cf. Hist. 1.15.2). Enquanto o historiador senatorial aproveita o facto da adopção para colocar na boca de Galba um discurso que reflecte a «euforia senatorial» presente no panegyricus de Trajano da autoria de Plínio, o biógrafo e cavaleiro Suetónio retém apenas o gesto de Galba de apertar a mão ao adoptado e de the chamar filho.

${ }^{63}$ Tanto Plutarco, Gal.23.4, como Tácito, Hist. 1.18.2, referem a ausência do donativo. Mas enquanto para Tácito tal é motivo de louvor, para Suetónio é sinal de avareza, enfatizado por ne tunc quidem; vide Della Corte, F. 1967,118. Tácito, ao encerrar o assunto, acentua a facilidade com que Galba poderia ter segurado a situação e lastima que o rigor de outros tempos se tenha tornado impopular (Hist. 1.18.3). 
em quiasmo ao longo da biografia. Antes da tomada do poder, ao favor dos deuses seguiu-se o favor dos homens. Depois da ascensão, à perda do favor dos homens segue-se a perda do favor dos deuses: Magna et assidua monstra iam inde a principio exitum ei, qualis euenit, portenderant (Gal.18.1) ("Grandiosos e frequentes prodígios, já desde o início, lhe pressagiavam o fim que o esperava»). A lista é extensa e nenhuma outra fonte regista estes presságios. Estes reportam-se a vários momentos da vida. Podemos mesmo verificar, pelas notações temporais, que aconteceram logo após os últimos presságios que lhe confirmavam a justiça e a santidade da revolta (Gal. 10.4). Ainda mal os deuses lhe tinham concedido o poder e já lhe anunciavam a queda: uma explicação para tão curto principado. Com efeito, ainda durante o caminho para Roma, entre as inúmeras vítimas imoladas nas cidades de passagem, um touro, já ferido pelo machado, rompe as amarras e precipita-se sobre o carro de Galba e, empinando-se, inunda-o de sangue. ${ }^{64}$ Quando se vai a apear, um soldado, empurrado pela multidão, quase o fere com a lança. Ao entrar em Roma, e depois no Palácio, foi acolhido por um tremor de terra e um som semelhante a um mugido. E, mais importante, a Fortuna, que Galba, inspirado por um sonho, acolhera em sua casa ( Gal. 4.3), vem agora, defraudada, anunciar, através de outro sonho, que lhe retira a proteç̧ão. É de notar a incapacidade de Galba, que tenta, através de um sacrifício, remediar o erro, mas já não vai a tempo ( Gal. 18.2). E o biógrafo acrescenta ainda outros prodígios: a coroa cai-lhe da cabeça durante um sacrifício nas calendas de Janeiro; as aves fogem durante uns auspícios; os servos esquecem-se de colocar a cadeira castrense diante do tribunal, para Galba arengar aos soldados; a cadeira curul aparece colocada ao contrário no senado ( Gal. 18.3). Os sinais vão-se acumulando até ao último dia. Aos avisos dos harúspices sobre a proximidade dos assassinos (prius uero quam occideretur sacrificantem mane), segue-se o anúncio de que Otão se apossara do campo pretoriano. ${ }^{65}$

Em tais circunstâncias, Suetónio narra a morte de um imperador abandonado dos deuses e dos homens. Como é hábito do biógrafo, os factos estão concentrados na personagem principal e as intervenções dos circunstantes limitam-se a menções genéricas. Um momento de falta de determinação, em que decide ficar no palácio, revela-se fatal: apesar de muitos o aconselharem a dirigir-se ao campo, para se impor pela autoridade e presença, ${ }^{66}$ limita-se a reforçar a guarda, apelando aos destacamentos dispersos pela cidade, e a vestir uma couraça de linho, reconhecendo embora que serviria de pouco contra tantas espadas. ${ }^{67} \mathrm{O}$ fim é precipitado pela queda em uma armadilha preparada

${ }^{64}$ Já é considerado muito mau sinal se a vítima escapava meia morta (cf. Jul. 59): presságio semelhante leva Vitélio retroceder para Roma quando se dirigia para Mevânia (Tácito, Hist. 3.56.1-2). Ficar sujo do sangue da vítima era ainda pior. Basta recordar Calígula, salpicado com o sangue de um flamingo, durante o sacrifício, no próprio dia da morte (Cal. 57.4).

${ }^{65}$ Gal. 19.1. Vide Venini, P. 1974, 1001-1002. É significativo o silêncio de Suetónio sobre a presença de Otão no sacrifício: cf. Otho. 6.2; Tácito, Hist. 1.27.1; Plutarco, Gal. 24.5; Díon Cássio, 64.5.2.

${ }^{66}$ Havia conselhos contraditórios: vide Plutarco, Gal. 26.1; Tácito, Hist.1.32.2-33.

${ }^{67}$ Suetónio, para manter a atenção concentrada em Galba, omite o envio de Pisão com o 
pelos conjurados: para o fazerem sair, lançam rumores de que a revolta tinha fracassado e de que os cabecilhas estavam mortos. De novo confiante, Galba vai ao encontro da morte. Mostra ainda severidade e disciplina militar. A caminho do Foro, a um soldado que se gloria de ter matado Otão, pergunta 'Quo auctore? (“Quem deu a ordem?»), frase que, à falta de comentário do biógrafo, pode sugerir o descontentamento do imperador, pois sabia não ter dado tal ordem, ou o seu desconforto, por sentir que lhe fugia o controlo da situação, já que a ordem podia ter partido de um dos seus indesejáveis ministros. Mesmo assim, prosseguiu até ao Foro, onde o esperavam os cavaleiros encarregados de o matar. E Suetónio acentua o drama da solidão e abandono na morte (desertus a suis). ${ }^{69}$

O motivo do sacrifício repetidas vezes presente nos presságios de morte, manifesta-se de novo. Seguem-se duas versões da cena de morte, que, longe de se excluírem uma à outra, antes se completam. A primeira - Sunt qui tradant - sugere que ele apelara à sua condição de militar - 'Quid agitis, commilitones? Ego uester sum et uos mei' ('Que é lá isso, camaradas? Eu estou convosco e vós comigo!'») - e tentara corrigir o seu erro com a promessa de um donativo. A segunda, mais digna e autorizada por plures, reforça a dignidade e o orgulho do antigo general: estende o pescoço (como vítima voluntária) e incentiva os assassinos com uma fórmula ritual que dá um tom sacrificial ao gesto: 'ut hoc agerent ac ferirent, quando ita uideretur' hortatum ${ }^{70}$ («exortou-os a 'agir e a ferir, já que assim lhes parecia'»). Esta reacção parece a consequência do insucesso da tentativa narrada pela primeira versão: Galba ainda teria tentado impor-se, mas, ao ver-se desobedecido, oferece-se aos agressores como vítima para o sacrifício.

Há várias semelhanças com a morte de Calígula: ambos foram manchados pelo sangue das vítimas de sacrifícios; ambos ofenderam um deus, o admonitor dos presságios de morte (Calígula, Júpiter; Galba, a Fortuna); ambas as mortes são contadas em duas versões; há fórmulas que sugerem um sacrifício, acompanhadas de gestos rituais: golpe no pescoço e até desmembramento do cadáver. Mas há diferenças fundamentais: Galba mostra-se mais digno. Enquanto Calígula assume um papel apenas reactivo - Suetónio dá a palavra aos assassinos -, Galba tem um papel activo - ele é quem assume a palavra e nele se concentra a narrativa; enquanto Calígula é ajudado pelos carregadores

objectivo de testar os sentimentos da coorte pretoriana de guarda ao palácio (Plutarco, Gal. 25.8). Tácito, Hist. 1.29.2-30.3, desenvolve longamente a arenga de Pisão aos soldados. Vide com. de Murison, Ch. L. 1992, 83.

${ }^{68}$ Cf. Díon Cássio, 64.6.2; Plutarco, Gal. 26.2, e Tácito, Hist. 1.35.2. Este último interpreta o facto como resultado do carácter incorruptível do antigo general.

${ }^{69} \mathrm{Gal}$. 19.2. Outras fontes referem, com louvor, a ajuda de um homem, Semprónio Denso: cf. Plutarco, Gal. 26. 8-10; Díon Cássio, 64.6.4. Tácito, Hist. 1.43.1, refere-o como defensor de Pisão.

${ }^{70}$ Gal. 20.1. Versão semelhante em Tácito, Hist. 1.41, e Plutarco, Gal. 27.1. Martin, R. 1991,378-380, sublinha a dignidade de Galba nos últimos momentos. A lucidez e a serenidade manifestam-se no envergar da couraça; na interrogação / repreensão dirigida ao soldado que se vangloria de ter matado Otão; e sobretudo nas palavras enérgicas transmitidas pelas três fontes: uma atitude de vítima que se apresenta ao sacrificador. A expressão hoc agerent faz eco das palavras dos assassinos de Calígula (Cal. 58.2). 
e pela guarda, Galba morre abandonado. Com efeito, para o biógrafo, este abandono chega a ser surpreendente. ${ }^{71}$ Tem contornos dramáticos o facto de a ajuda, por um erro, chegar tarde de mais:

Illud mirum admodum fuerit, neque praesentium quemquam opem imperatori ferre conatum et omnes qui arcesserentur spreuisse nuntium excepta Germanici<an>orum uexillatione. Ii ob recens meritum, quod aegros et inualidos magno <o>pere fouisset, in auxilium aduolauerunt, sed serius itinere deuio per ignorantiam locorum retardati. $^{72}$

«O que terá sido verdadeiramente extraordinário é que nenhum dos presentes tentou prestar ajuda ao imperador e que todas as forças que foram mandadas chamar desprezaram a ordem, à excepção de um destacamento do exército da Germânia. Estes soldados, por um recente favor - pois, quando estavam doentes e incapacitados, Galba se não poupara a esforços para cuidar deles - voaram em seu auxílio, mas, tomando um caminho errado, por não conhecerem os lugares, chegaram tarde de mais».

A tragédia do abandono é acentuada pela ofensa feita ao cadáver ( Gal. 20.2). Suetónio apresenta um longo e horrífico quadro da peregrinação da cabeça, desde que é cortada até à sua inumação junto com o corpo. A indignidade por que passa é acentuada pela categoria dos protagonistas do ultraje: um miles gregarius que vinha de receber a ração, pousa o fardo e corta a cabeça. A dificuldade em pegar-lhe, devido à calvície, dá azo aos macabros pormenores do transporte no regaço e do acto de meter o polegar na boca para levar o sinistro troféu a Otão. Este entrega-a aos servos do exército (lixae e calones), que a passeiam na ponta de uma vara - episódio que, embora Suetónio não o diga, lembra a sorte de Penteu nas Bacantes de Eurípides (vv. 1139 ss) $)^{73}$ - e fazem troça do seu aspecto, repetindo 'Galba, Cupido, fruaris aetate tua' («'Galba, Amorzinho, goza a tua juventude’), por ele, dias antes, em resposta a um elogio à sua aparência, se ter vangloriado, citando um verso homérico, das suas forças. ${ }^{74}$ Tem ainda contornos trágicos, com impressionante paralelo

${ }^{71}$ Della CoRte, F. 1967, 127, diz que Illud mirum admodum fuerit é expressão de uma falsa admiração e de sarcasmo. Cize k, E. 1977, 151, diz que Suetónio não lamenta o facto, como faz Tácito, Hist. 1.40-44.

${ }^{72}$ Gal. 20.1. Feito o confronto com Tácito, Hist. 1.31.2-3, parece que Suetónio, para acentuar o drama do atraso, exagera no empenho do destacamento. A afirmação de Tácito - Germanica uexilla diu nutauere (Hist. 1.31.3) - é pouco compatível com in auxilium aduolauerunt de Suetónio. Segundo o com. de Murison, Ch. L. 1992, 84-85, como Galba favoreceu este corpo militar, devem-se ter levantado várias tentativas de explicação para o facto de esses soldados não terem aparecido, como seria de esperar. A solução apresentada por Suetónio não convence: se estavam acantonados, como diz Tácito, no Atrium Libertatis (que seria na área dos Fora) e, para mais, há seis meses, dificilmente não conheceriam o caminho.

${ }^{73}$ Plutarco, Gal. 27, conecta directamente este feito com o das Bacantes.

${ }^{74}$ Segundo Nutting, H. C. 1933, 45, trata-se de provável distorção: é possível que o imperador, perante tão descarada adulação (disseram que parecia novo e vigoroso), respondesse de modo sarcástico. Mas o biógrafo vê sinais de petulantia na vanglória (neste caso talvez associada a senilidade) que tende a tornar cego o imperador. 
em $O$ monge de Cister de Herculano, a macabra vingança post mortem de um liberto de Patróbio Neroniano (também liberto de Nero): compra a cabeça por cem moedas de ouro e atira-a simbolicamente para o lugar onde o seu patrono fora morto por ordem de Galba. Os errores da cabeça terminam finalmente com a sua reunião ao resto do corpo, na sepultura, por caridade do dispensator Argivo. ${ }^{75}$

Tal como acontecera com Nero, a descrição pessoal de Galba vem depois da morte, na sequência das referências à aparência durante os ultrajes dos soldados à cabeça de Galba, como que para explicar a razão da troça. Com efeito, o seu aspecto físico é o de um homem já idoso, a altura em que foi imperador. ${ }^{76} \mathrm{~A}$ decrepitude física pode sugerir, no campo mental, a senilidade, que explicaria as incongruências no governo de quem fora outrora um bom general.

No relato da morte de Vitélio continua a indignitas que dominara toda a Vida: o aviltamento é uma constante. A sua falta de coragem leva-o a actos covardes e ímpios. Perante a revolta dos exércitos, tenta conservar a dedicação e o favor com exageradas liberalidades (Vit. 15.1). Suetónio faz referências breves e genéricas às actividades militares, ultrapassando factos importantes, como a segunda batalha de Betríaco, ${ }^{77}$ para se centrar nas reacções de Vitélio, reveladoras do seu carácter. Derrotado em todas as frentes pelos partidários de Vespasiano, Vitélio procura salvar a vida e o dinheiro.

O biógrafo atribui a Vitélio três tentativas desesperadas de abdicar, sem que os soldados e o povo lho permitam. O imperador vê-se obrigado a arcar com as responsabilidades que quer rejeitar. Primeiro, nos degraus do palácio, proclama, diante de grande multidão de soldados, que cede o imperium que recebera contra a vontade. Perante os protestos dos soldados, adia a decisão e repete a declaração no dia seguinte nos rostra, sordidatus, em sinal de luto, e com abundantes lágrimas. ${ }^{78}$ Depois de novos protestos dos soldados e do povo, recobra a coragem, mas comete um acto covarde e outro ímpio, pelos quais Suetónio, ao contrário de Tácito, o responsabiliza totalmente: aproveita o clima de segurança de que gozavam os partidários dos Flávios (devido certamente às declarações de abdicação), ataca-os subitamente, como que à traição, empurra-os para o Capitólio e aniquila-os, depois de incendiar o templo de

${ }^{75}$ Gal. 20.2. O horror dos pormenores contrasta com a sobriedade de Tácito, Hist. $1.41 .3 \mathrm{e}$ 1.49.1, que não hesita em suprimir pormenores sórdidos. Plutarco, Gal. 27.3, fala da dificuldade de segurar a cabeça devido à calvície e do seu transporte no manto, mas só Suetónio refere a introdução do polegar na boca. Díon Cássio, 64.6.5 , alude genericamente à decapitação de várias vítimas. Vide intr. ao com. de Murison, Ch. L. 1992, xi

${ }^{76} \mathrm{Gal}$. 21. Facto que o torna objecto de troça e rejeição para os Romanos, habituados à juventude de Nero, e que o leva a adoptar Pisão; vide Martin, R. 1991, 81-82.

${ }^{77} \mathrm{Cf}$. Tácito, Hist. $3.55 \mathrm{ss}$. O biógrafo não menciona também a destruição de Cremona. Vide VENINI, P. 1974, 1012; com. ID. 1977, 5.

${ }^{78}$ Vit. 15.2. Tácito, Hist. 3.67.2ss, aqui só refere uma tentativa de abdicação. Sordidatus corresponde à pullus amictus indicada por Tácito. 
Júpiter Máximo. ${ }^{79}$ Para agravar a impiedade, contempla a refrega e o incêndio do palácio de Tibério, no meio de um banquete. Mais um motivo para a morte de Vitélio aparecer como um castigo dos deuses. ${ }^{80} \mathrm{~A}$ semelhança com Nero é manifesta, na autoria e na contemplação do incêndio. Mas diverge a atitude, coerente com as preferências de cada um: Nero canta e toca, Vitélio, de acordo com a sua gula, come. O biógrafo não só lhe imputa tal crime, como diz que ele lança a culpa sobre outros. A atitude de Vitélio, na sua terceira tentativa de abdicar, é verdadeiramente teatral, com sabor a hipocrisia. $\mathrm{O}$ motivo do punhal regressa:

Non multo post paenitens facti et in alios culpam conferens uocata contione iurauit coegitque iurare et ceteros nibil sibi antiquius quiete publica fore. Tunc solutum a latere pugionem consuli primum, deinde illo recusante magistratibus ac mox senatoribus singulis porrigens, nullo recipiente, quasi in aede Concordiae positurus abscessit. Sed quibusdam adclamantibus 'ipsum esse Concordiam', rediit nec solum retinere se ferrum affirmauit, uerum etiam Concordiae recipere cognomen (Vit. 15.3-4).

«Não muito depois, arrependido do acto e querendo lançar a culpa sobre outros, depois de convocar a assembleia, jurou e fez jurar também os presentes de que a nada dariam maior importância do que à tranquilidade pública. Então, retirou o punhal que the pendia do lado, estendeu-o primeiro ao cônsul, depois, perante a recusa deste, aos magistrados e logo a cada um dos senadores. Como nenhum o aceitava, retirou-se, como se estivesse disposto a colocá-lo no templo da Concórdia. Mas, como alguns se puseram a clamar que 'ele mesmo era a Concórdia', regressou e não só disse que mantinha em seu poder o ferro, mas que também tomava o cognome de Concórdia».

O acto de entregar o punhal, símbolo do poder de dar a morte, representa a tentativa de devolver o poder às instituições republicanas do Estado. ${ }^{81} \mathrm{O}$ facto de o reter - Tácito diz que ele saiu decidido a depositá-lo no templo

${ }^{79}$ Vit. 15.3. Em Flávio Josefo, BJ 4.645, a iniciativa parte dos flavianos. Também segundo Tácito, Hist. 3.69-71, são os pártidários dos Flávios, comandados por Sabino, irmão de Vespasiano, que decidem ocupar o Capitólio, como medida de segurança (3.69). O ataque ao Capitólio parece mais uma iniciativa acéfala dos soldados, da qual Vitélio se demarca, dizendo que já não era imperador; e chega mesmo a proteger o mensageiro, Cornélio Marcial, enviado por Flávio Sabino (3.70.4). Também para o incêndio, Tácito apresenta duas versões: uma que seriam os atacantes a incendiar os tecta, e outra, mais acreditada, que seriam os próprios sitiados (3.71.4). Os sitiados são mortos contra o parecer de Vitélio (3.74.2). Além da simpatia por Otão e consequente antipatia pelo sucessor e do possível efeito da propaganda flávia, o biógrafo segue a tendência habitual de concentração dos factos sobre o protagonista da biografia; vide VENINI, P. 1974, 993-994, e com. ID. 1977, 138.

${ }^{80}$ Como afirma Cizek, E. 1975, 128-129.

${ }^{81}$ A entrega do punhal significava abdicar do poder, como notam Tácito, Hist. 3.68.2 e Díon Cássio 65.16.6. Este punhal representa, no dizer de Tácito, uelut ius necis uitaeque ciuium. Vitélio quereria trazer a paz civil, abandonando o símbolo da libertas conquistado pela força; e o retorno à Concórdia marcaria o fim da legitimidade do assassínio de cidadãos. A resposta dos cidadãos, de que Vitélio era a Concórdia, tinha, segundo Poulle, B. 1997, 251, um duplo sentido: por um lado, era adulatória (Vitélio encarnava a paz civil); por outro, sugeria que o imperador devia depositar o punhal em si mesmo, isto é, suicidar-se. 
- aparece implicitamente como um erro: Vitélio retém, com ele, o perigo de ser morto. Se tivesse renunciado ao punhal, poderia ter evitado maior desastre para o Estado. Otão teve o mérito de o usar em si mesmo - coragem e nobreza que Vitélio não terá. Torna-se irónico que um imperador, como o biógrafo o apresenta, assuma o cognome de Concórdia - e só Suetónio refere este acto.

As atitudes indignas proliferam. Perante a aproximação do inimigo, foge para o Aventino, escondido numa liteira - fuga que parece ser uma paródia da de Nero para casa de Fáon. Vitélio tinha então por única e significativa companhia um padeiro e um cozinheiro (cuja presença nos recorda a sua gula) e oculta-se na casa paterna, de onde, depois, pensava fugir para a Campânia. Rumores de que se concertara a paz fazem-no regressar ao palácio. Ao encontrar o lugar deserto, cinge o corpo com um cinto de moedas de ouro e barrica-se, indignamente para um imperador, na pequena cela do porteiro, depois de prender um cão diante da entrada e de colocar um leito e um colchão contra a porta. ${ }^{82} \mathrm{O}$ opróbrio é mais grave quando, depois de descoberto, mente para ocultar a sua identidade. A cena do linchamento popular é aviltante:

Deinde agnitus rogare non destitit, quasi quaedam de salute Vespasiani dicturus, ut custodiretur interim uel in carcere, donec religatis post terga manibus, iniecto ceruicibus laqueo, ueste discissa seminudus in forum tractus est inter magna rerum uerborumque ludibria per totum uiae Sacrae spatium, reducto coma capite, ceu noxii solent, atque etiam mento mucrone gladii subrecto, ut uisendam praeberet faciem neue summitteret; quibusdam stercore et caeno incessentibus, aliis incendiarium et patinarium uociferantibus, parte unlgi etiam corporis uitia exprobrante. ${ }^{83}$

«Depois de o reconhecerem, não deixou de rogar, a pretexto de ter revelações a fazer sobre a segurança de Vespasiano, que o guardassem entretanto, nem que fosse no cárcere. Até que, de mãos atadas atrás das costas, com um laço apertado ao pescoço, com as roupas rasgadas, foi arrastado para o foro, no meio de grandes ultrajes por actos e palavras, ao longo de toda a Via Sacra: puxaram-lhe a cabeça para trás pelos cabelos, como se costuma fazer aos criminosos, e ainda lhe mantiveram o queixo levantado com a ponta de um gládio, para que deixasse ver a cara e não a baixasse, enquanto alguns the atiravam esterco e lama, outros the gritavam os apelidos de incendiário e alarve; parte do povo até the censurava os defeitos do corpo».

Trata-se de uma cena viva, na qual o biógrafo, para acentuar a degradação

${ }^{82}$ Vit. 16.1. Cf. Tácito, Hist. 3.84.4. Quanto à paterna domus do Aventino, Suetónio parece corrigir Tácito, que diz que se tratava da domus uxoris. Em relação ao sórdido refúgio, Díon Cássio, 65. 20.1, refere mesmo que foi mordido pelos cães. Pelo contrário, Tácito é mais vago: pudenda latebra; vide Della Corte, F. 1967,133. n. 85.

${ }^{83}$ Vit. 17.1-2. Cf. Tácito, Hist. 3.84.5-85. Suetónio não menciona a tentativa de um soldado da Germânia o tentar matar rapidamente (ou talvez atacar o tribuno), nem a última uox de Vitélio que lhe daria alguma dignidade: aos insultos de um tribuno responde que, apesar de tudo, fora seu imperator (cf. Díon Cássio, 65.21.2). Tácito censura a vileza da multidão: Et uolgus eadem prauitate insectabatur interfectum qua fouerat uiuentem. Vide MARTin, R. 1991, 380-385. 
de Vitélio, concentra grande quantidade de informação realista. Muito apropriadamente se introduz a descrição física, inserida na narrativa da morte a partir da menção dos insultos populares, que expõem defeitos humilhantes, ${ }^{84}$ resultado dos prazeres da mesa. ${ }^{85} \mathrm{E}$, como veremos à frente, um retrato mais grotesco do que o de Cláudio, o qual ainda apresentava aspectos positivos. Assim, a execução pública de Vitélio transforma-se também no castigo da sua gula. A perna aleijada recorda o seu gosto pelas corridas do circo e, através deste desporto, a associação a Calígula.

Depois da descrição física, segue-se a execução junto às Gemónias, o local destinado aos mais vis criminosos. Foi torturado até à morte (minutissimis ictibus excarnificatus) e, derradeira humilhação, foi arrastado com um gancho para o Tibre, o maior insulto que se podia fazer a um condenado morto: o castigo que o povo chegara a propor para o corpo de Tibério. Fica mais uma vez patente o gosto de Suetónio pelos pormenores mórbidos. O dramatismo da morte é ainda acentuado pelo facto de o biógrafo salientar que pereceu com o irmão e o filho, estabelecendo, para o caso do segundo, uma falsa coincidência. ${ }^{86}$

Esta é a morte mais humilhante das Vidas dos Césares, em oposição radical à dignidade do fim de Otão. $\mathrm{O}$ biógrafo parece sugerir que se trata de um castigo dos deuses. ${ }^{87}$ Se pensarmos nas impiedades apontadas por Suetónio a Vitélio - espoliou os templos durante os cargos administrativos, matou o filho, proferiu palavras ímpias e bebeu em presença de cadáveres de cidadãos, matou, segundo Suetónio, a própria mãe, assumiu o pontificado máximo num dia infausto, não resistia a retirar a comida do lume durante os sacrifícios, banqueteou-se ao contemplar o incêndio no templo de Júpiter Máximo, conservou o punhal que decidira depositar no templo da Concórdia - parece lógico que tal morte corresponda a uma punição divina. ${ }^{88} \mathrm{E}$, em final absoluto, figura a interpretação de um presságio conectado com a morte deste imperador (Vit. 18). Mas, ao passo que os presságios finais da Vida de Cláudio abonam em favor do retrato do biografado, o presságio do galo (Vit. 9;18) que salta para a cabeça de Vitélio, de modo algum compatível com a dignidade imperial, contribui para o efeito do ridículo. Segundo a leitura que foi feita, Vitélio pereceria às mãos de um natural da Gália (António Primo).

Com um castigo dos deuses põe o biógrafo termo a um ciclo atroz de guerra civil, em que as divindades tiveram um papel especial: os três imperadores (Galba, Otão, Vitélio) aparecem como joguetes oprimidos ao mesmo tempo pela culpa pessoal. O biógrafo expõe, assim, uma visão trágica deste período

${ }^{84}$ Vide Newbold, R. F. 1984, 120.

${ }^{85}$ Vide Martin, R. 1991, 215-216.

${ }^{86} \mathrm{Vit}$. 18. O filho de Vitélio não morreu ao mesmo tempo que o pai, mas mais tarde, como se lê em Tácito, Hist. 4.80. E mesmo o irmão terá perecido um ou dois dias depois. Vide Gascou, J. 1984, 322 n. 18.

${ }^{87}$ Assim pensa Cizek, E. 1975, 125-130. Tácito, pelo contrário, não associa a morte de Vitélio a nenhum presságio divino.

${ }^{88}$ Cize , E. 1975, 129, diz mesmo que a morte ignóbil de Vitélio é o ponto de partida para a descrição da vida odiosa que Suetónio nos oferece deste imperador: esta morte oferece ao biógrafo o meio, dir-se-ia a obrigação, de o incriminar constantemente e de o tornar desprezível. 
saturado de vinganças dos deuses e dos homens.

No que respeita a Domiciano, Suetónio inicia o relato da catástrofe de forma semelhante à parte correspondente das Vidas de Calígula e Nero: Per haec terribilis cunctis et inuisus, tandem oppressus est $\langle. .$.$\rangle amicorum libertorumque$ intimorum simul et uxoris ${ }^{89}$ ("Com tais atitudes, tornou-se objecto de terror e de ódio para todos e acabou por ser morto numa conjugação de esforços dos amigos e libertos mais chegados e até da mulher»). Como fizera com César, Calígula e Nero, Suetónio sublinha a noção de culpa-castigo na medida em que estabelece íntima relação entre os crimes do príncipe e a sua morte. ${ }^{90}$ Fica patente a solidão do tirano, odiado por todos - e, neste aspecto, evidencia-se o paralelismo com Tibério. ${ }^{91} \mathrm{Na}$ narrativa da morte de Domiciano gera-se um suspense dramático pela presença de um destino inexorável: "Um homem está só e sabe que vai morrer"..$^{92} \mathrm{~A}$ tragédia de Domiciano joga-se entre conhecimento (sob a forma de suspeita) e desconhecimento. Conhecimento, porque Annum diemque ultimum uitae iam pridem suspectum habebat, horam etiam nec non et genus mortis («Já muito antes suspeitava qual seria o ano e o dia e até a hora e não menos o tipo de morte»). Esta precognição provinha-lhe dos astrólogos (Chaldaei) e do próprio pai. Vespasiano troçara do facto de Domiciano se abster de cogumelos, quando devia temer antes o ferro. ${ }^{93}$ Por outro lado, desconhecimento, porque Domiciano não fazia ideia de onde e de quem viria a traição. Assim a tragédia desenrola-se também entre a aproximação inexorável do momento da morte e a tentativa, vã, de o evitar.

O topos do medo em que vive o tirano é elemento constante no desenrolar desta trama. $\mathrm{O}$ conhecimento da hora da morte gera terror, à medida que se aproxima o momento: Quare pauidus semper atque anxius minimis etiam

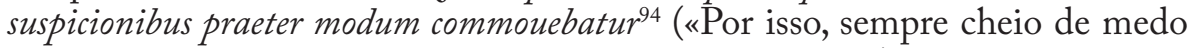
e ansioso, à mínima suspeita ficava sobremodo abalado»). Suetónio salienta, como no caso de Calígula (Cal.51.1), a explicação psicológica para os actos do imperador, que age e reage em função do medo e da superstição, pelo crédito dado aos astrólogos. ${ }^{95}$ É à luz do medo, causado pelos versos de um libelo

${ }^{89}$ Dom. 14.1. É notável o paralelismo com as Vidas de Calígula e de Nero: Ita bacchantem atque grassantem non defuit plerisque animus adoriri (Cal. 56.1); Talem principem paulo minus quattuordecim annos perpessus terrarum orbis tandem destituit (Nero 40.1). Vide CRoIsille, J. M. 1970, 78 n. 5. Díon Cássio, 67.15.1-2, refere os nomes dos implicados na conjura.

${ }^{90}$ Vide Gascou, J. 1984, 790.

${ }^{91}$ Cf. Tib. 63.1: Quam inter haec non modo inuisus ac detestabilis, sed praetrepidus quoque atque etiam contumeliis obnoxius uixerit, multa indicia sunt. MARTIN, R. 1991, 323, aproxima o ódio a Domiciano do ódio expresso nas reacções à morte de Tibério.

${ }_{92}$ Assim o define Pimentel, M. C. 1993, 94-102.

${ }^{3}$ Dom.14.1. O tema tradicional do tirano inquieto e desconfiado (cf. Plínio, Pan. 49; 82) recebe um novo tratamento: o fundamento desta apreensão doentia reside nas predições astrológicas, como afirma BRIND'Amour, P. 1981, 338-344.

${ }_{94}^{94}$ Dom. 14.2. Já atrás se disse que o medo o tornou cruel (Dom. 3.2).

${ }^{95} \mathrm{O}$ desprezo dos cultos pátrios, acompanhado do crédito dado a cultos estrangeiros e aos astrólogos, é apanágio dos maus imperadores. Vide Della Corte, F. 1967, 73; Martin, R. 1991, 342-343. 
(em que o imperador era associado ao bode imolado a Baco), que o biógrafo interpreta a não aplicação do edicto que ordenava o corte das vinhas, medida arrolada atrás entre as positivas, ${ }^{96}$ e a recusa (motivada, explicitamente, por Eadem formidine ...) de uma honra nova, oferecida pelo senado, que consistia em incluir, no habitual séquito dos lictores e dos apparitores, cavaleiros romanos vestidos com a trabea (toga ornada com bandas ou listras de púrpura) e armados de lança, sempre que exercesse o consulado embora desejasse muito tais distinções (Dom. 14.3).

Suetónio procura sugerir o aumento da ansiedade com o aproximar do dia fatídico: Tempore uero suspecti periculi appropinquante sollicitior in dies porticuum, in quibus spatiari consuerat, parietes phengite lapide distinxit, e cuius splendore per imagines quidquid a tergo fieret prouideret (Dom 14.4) («Mais inquieto de dia para dia, à medida que se aproximava a data do suspeitado perigo, ornou as paredes dos pórticos, pelos quais costumava passear, com placas de fengite, que lhe permitiam ver o que se passava atrás das costas»). Acossado pelo medo, torna-se extremamente desconfiado - interroga os prisioneiros a sós, em lugar secreto e segurando nas mãos as cadeias. ${ }^{97}$ É neste contexto que condena Epafrodito, suspeito de ter ajudado Nero a suicidar-se (Nero 49.3), para desencorajar tais ousadias.

O crime que precipitou o assassínio do imperador foi a execução, repentina e fundada numa suspeita assaz ligeira, do primo direito e cônsul em exercício Flávio Clemente, cujos dois filhos Domiciano tinha designado como sucessores. $\mathrm{O}$ imperador, querendo evitar o destino, contribui para o apressar. ${ }^{98} \mathrm{Na}$ sequência desta morte (continuis octo mensibus...), se narra uma série de prodígios, onde é manifesta a cólera dos deuses ${ }^{99}$ Domiciano, que não fora beneficiado com prodígios favoráveis anunciadores do império (afortunados foram somente os presságios do fracasso da revolta militar de Saturnino: Dom. 6.2), torna-se agora alvo de sinais funestos. Nesses oito meses seguintes, ocorreram tantos trovões que Domiciano exclamou: 'feriat iam, quem nolet ${ }^{100}$ («Pois que atinja lá a quem quiser!»). E a sugerir causa-efeito,

${ }^{96}$ Dom. 14.2; cf. Dom. 7.2. Vide Gascou, J. 1984, 373.

${ }^{97}$ Díon Cássio, 67.12.5, conta o mesmo facto e acrescenta que os interrogava sozinho para evitar que outros conhecessem o conteúdo da conversa.

${ }_{98}$ Quo maxime facto maturauit sibi exitium (Dom. 15.1). Cf. Díon Cássio 67.14.1. Flávio Clemente foi consul ordinarius nos primeiros quatro meses de 95. Dado que foi executado na última parte do ano, seria a rigor, ex-cônsul, como sugere, no seu com., GALLI, F. 1991, 92-93. Díon afirma que Flávio Clemente foi acusado de ateísmo, como muitos convertidos ao judaísmo e que a esposa, Flávia Domitila, sobrinha do imperador, foi exilada na ilha de Pandatária. Não é impossível que a contemptissima inertia, censurada por Suetónio, se refira à ausência de sacrifícios oficiais às divindades pagãs. KereszT Es, P.1973,1-28, procura demonstrar que Flávio Clemente e a esposa eram judeus prosélitos e não cristãos. Pelo contrário, Pergola, Ph. 1978, 407-423, procura evidenciar, com provas arqueológicas, a forte possibilidade de serem cristãos. Talvez a verdade nem mesmo dos contemporâneos dele fosse conhecida, como nota Southern, P. 1997, 115 .

${ }^{99}$ Vide Gascou, J. 1984, 790.

100 Também Calígula lança palavras de desafio a Júpiter (Cal. 22.4). Martin, R. 1991, 343-344, sugere que Domiciano manifestava, nos últimos tempos, sinais de paranóia delirante. 
o biógrafo acrescenta que foram atingidos pelo raio (tactum de caelo), como outrora o templo dos Césares (Gal.1), o Capitólio, o templo da gens Flávia, o palácio do Palatino e o próprio quarto do imperador; e uma tempestade violenta arrancou uma inscrição de uma estátua triunfal de Domiciano e lançou-a sobre um sepulcro próximo. Como o loureiro que secara pelo ocaso de Nero (Gal. 1), também o cipreste que se reerguera, quando Vespasiano era um cidadão privado (Ves. 5.4), abateu-se de novo subitamente: a queda de Domiciano representa, como a de Nero, a queda de uma dinastia. ${ }^{101}$ A Fortuna de Preneste, a quem Domiciano encomendava sortes cada novo ano e que sempre lhe fora favorável, dera no último ano um oráculo funesto, com menção de sangue. ${ }^{102}$ Como a Fortuna de Galba (Gal. 18.2), a divindade por quem Domiciano tinha grande veneração, Minerva, 103 aparece-lhe em sonhos a dizer que lhe não pode conceder mais protecção, porque Júpiter a desarmou. No auge dos prodígios, figura um relato impressionante, que sugere o conflito entre o esforço e a impotência de Domiciano para ludibriar o destino que sobre ele impende:

Nulla tamen re perinde commotus est quam responso casuque Ascletarionis mathematici. Hunc delatum nec infitiantem iactasse se quae prouidisset ex arte, sciscitatus est, quis ipsum maneret exitus; et affirmantem fore ut breui laceraretur a canibus, interfici quidem sine mora, sed ad coarguendam temeritatem artis sepeliri quoque accuratissime imperauit. Quod cum fieret, euenit ut repentina tempestate deiecto funere semiustum cadauer discerperent canes, idque ei cenanti a mimo Latino, qui praeteriens forte animaduerterat, inter ceteras diei fabulas referretur. ${ }^{104}$

«Nenhum facto o impressionou tanto como a resposta e a desgraça do astrólogo Ascletarião. Este, que, denunciado, não negara ter divulgado as previsões derivadas da sua arte, foi interrogado acerca do fim que estava reservado para ele próprio. E, como afirmou que seria em breve dilacerado pelos cães, Domiciano mandou-o matar sem demora, mas, para demonstrar a insipiência da arte, mandou também que lhe fizessem o funeral com todo o cuidado. Enquanto tal

${ }^{101}$ Vide Gascou, J. 1984, 778.

${ }^{102}$ Dom. 15.2. Também Tibério tivera problemas com este oráculo em contexto muito semelhante: Vicina uero urbi oracula etiam dis[s]icere conatus est, sed maiestate Praenestinarum sortium territus destitit... (Tib.63.1).

${ }^{103}$ Quam superstitiose colebat. Superstitio exprime habitualmente em Suetónio falsas crenças, religiões alheias, práticas de magia; mas, neste caso, sugere censura do exagero e demasiada exclusividade da veneração por uma divindade do panteão, Minerva: Vide GAscou, J. 1984, 729 n. 94. A ligação de Domiciano a Minerva (Pallas Caesariana) é recordada também por Marcial, 5.2.6-8; 6.10.9-12; 7.1.1-2; 8.1.4; 9.3.10. Díon Cássio, 67.16.1, dá uma versão ligeiramente diferente da de Suetónio. Segundo Girard, J-L, 1981, 233-245, nenhuma divindade poderia oferecer tantos traços próprios para ilustrar aspectos da personalidade e as ambições do principado de Domiciano como Minerva, terceira da tríade capitolina (como Domiciano era o terceiro dos Flávios), guerreira, vingadora implacável, terror dos inimigos, protectora das artes.

${ }^{104}$ Dom. 15.3. Díon Cássio, 67.16.3, diz que ele foi condenado a ser queimado vivo. Ascletarião pertenceria a um pequeno grupo de astrólogos egípcios que exercia esta actividade em Roma no primeiro século e cuja nomeada se estendia por todo o Império. Vide SijPesteijn, P. J. 1990, 164-165. 
se cumpria, aconteceu que uma violenta tempestade derrubou a pira e os cães despedaçaram o cadáver semicremado. E isto lhe contou ao jantar, entre outras histórias do dia, o mimo Latino que, ao passar, presenciara por acaso o facto».

O facto de a história ser colocada na boca de um mimo parece associá-la a um enredo do género teatral do mesmo nome. $\mathrm{O}$ tipo de peripécia parece apontar nesse sentido. Também o desfecho sangrento do mimo Lauréolo anunciara a morte de Calígula (Cal.57.4). Poderia sugerir ainda que, tal como o destino do astrólogo, a morte de Domiciano é um mimo trágico. A história é um prenúncio terrível para o imperador: nem com a morte se pode impedir que o destino se cumpra.

O dramatismo intensifica-se com a aproximação do dia e da hora fatal: tempus suspecti periculi (Dom. 14.4). O tempo é um factor fundamental na tragédia de Domiciano, uma vez que ele suspeitava do seu fatum. Na verdade, a contagem decrescente já começara muito antes: Suetónio concluíra a Vida de Vespasiano com a referência ao sonho do imperador sobre o tempo de governo da dinastia (Ves. 25). E, como fizera para César, o biógrafo sugere a aproximação da hora da morte de Domiciano com indicações cronológicas cada vez mais precisas: começa por se referir a uma duração de continuis octo mensibus (Dom. 15.2), para depois ir indicando espaços de tempo cada vez mais precisos: Pridie quam periret ...; at circa mediam noctem...; debinc mane (Dom. 16.1); horas requirenti pro quinta, quam metuebat, sexta ex industria nuntiata est (Dom.16.2). Com estas notações temporais regista as acções das últimas vinte e quatro horas do imperador. Chegado à véspera do dia fatal, o imperador, sentindo a proximidade do perigo, ao mandar guardar para o dia seguinte umas túberas que lhe ofereceram, acrescenta, com dúvida: 'si modo uti licuerit' («se me for permitido saboreá-las!'). A sua suspeita provém, como vimos, de conhecimentos de astrologia. Mas o biógrafo concretiza um pouco mais: coloca na boca do imperador a razão astrológica para temer aquele dia: ad proximos affirmauit 'fore ut sequenti die luna se in aquario cruentaret factumque aliquod existeret, de quo loquerentur homines per terrarum orbem. ${ }^{105}$ («asseverou aos que estavam próximos que 'aconteceria no dia seguinte que a lua se cobriria de sangue no signo de aquário e ocorreria algo de que todos os homens falariam por todo o mundo'»). Os dados da astrologia vêm assim enriquecer o enredo e aumentar a tensão, uma vez que o leitor fica a conhecer o fundamento da suspeita que provoca a angústia do imperador. A angústia é, como em casos semelhantes (Cf. Cal. 50.3; Otho 7.2), expressa pela perturbação do sono: at circa mediam noctem ita est exterritus, ut e strato prosiliret («e cerca da meia-noite foi de tal modo tomado pelo pavor, que saltou fora da cama»). Na manhã do fatídico dia,

${ }^{105}$ Dom. 16.1. Na opinião Brind'Amour, P. 1981, 338-344, trata-se de um registo póstumo da vida e da morte de Domiciano, segundo uma visão da astrologia (elaborada por uma fonte competente em matéria de astronomia) que se manifesta várias vezes ao longo da vida, pelo que, nesta biografia, há uma trama astrológica que pouco a pouco conduz o imperador ao seu destino. 
continua a sua luta contra o destino. O leitor, que já sabe que a traição virá dos que lhe são mais próximos, sente a angústia do imperador que desfere golpes às cegas: ouve e condena um harúspice enviado da Germânia que profetizava um golpe de estado. ${ }^{106} \mathrm{~A}$ tentativa de esconjurar o mal é expressa pelas palavras de Domiciano, ao fazer sair sangue de uma verruga da fronte: 'utinam', inquit 'bactenus' ("oxalá - disse ele - seja quanto baste!"). Mas é o dolo (ex industria) que vem ajudar a cumprir o destino: a traição parte de dentro de casa, dos que lhe são mais íntimos. $O$ suspense atinge o ponto culminante: ao chegar a temida hora quinta, Domiciano pergunta as horas e dizem-lhe que é a sexta. O perigo vem quando o imperador julga passado o momento crítico. No momento em que o imperador tem a sensação de alívio, Parténio (o camareiro-mor e que se revelará cúmplice) anuncia-lhe um visitante, portador de uma notícia que não admite adiamento. A figura do mensageiro transforma-se aqui numa personagem dolosa que traz a morte. Neste momento, o imperador afasta os presentes e, sem desconfiar, recebe sozinho o assassino e é morto no quarto (Dom. 16.2).

Chegado a este ponto, o biógrafo introduz uma breve analepse para tratar da preparação da conjura, e inclui, no seguimento da narrativa, o relato da morte. ${ }^{107}$ Se até aqui seguira o ponto de vista de Domiciano, que desconhecia os factos, Suetónio apresenta agora a perspectiva dos conjurados: a hesitação inicial sobre o momento e o género de morte (quando et quo modo); a identificação do até agora secreto mensageiro (Estéfano, procurator de Domitila); 108 a elaboração do plano, proposto pelo próprio (Estéfano fazia-se ver durante algum tempo com o braço esquerdo ligado, como se tivesse sofrido um acidente, e, chegado o momento, esconderia um punhal sob este aparelho); por último, o conteúdo da suposta notícia que serviria de engodo para introduzir o assassino junto do imperador (o pretexto seria a denúncia de uma conjura ${ }^{109}$ ): o plano resulta na perfeição, porque o isco se baseia, de modo astuto, nas fraquezas de Domiciano.

Depois de toda a tensão dos momentos que antecederam a morte, a narrativa do atentado propriamente dito parece mais débil: o fim natural e esperado de um longo processo. Suetónio assume mais o seu papel de historiador e inclui duas versões, como acontece em vários relatos de assassinatos anteriores (César, Calígula, Galba). Numa primeira versão, Domiciano, atingido no baixo-ventre enquanto lia, atónito, o libellus da falsa denúncia, luta, mas é morto por vários conjurados que acorrem. É só no último momento, como acontece a todas

${ }^{106}$ Dom. 16.1. Segundo Díon, 67.16.2, chamava-se Largino Próculo; e escapou, porque a sua execução foi adiada para poder ver que o imperador escapara à sua previsão. Foi recompensado por Nerva.

107 Dom. 17.1: De insidiarum caedisque genere haec fere diuulgata sunt. Cf. Díon Cássio, 67.17.1-2 e Filóstrato, VA 8.25. Vide Martin, R. 1991, 374-378.

${ }^{108}$ Esta Domitila era a sobrinha do imperador e esposa de Flávio Clemente, cuja execução precipitara a decisão de assassinar o imperador. Estéfano foi escolhido como executor, segundo Díon (loc. cit.), por ser mais forte que os outros.

${ }^{109}$ Segundo Filóstrato (loc. cit.), Estéfano sustentava que Flávio Clemente havia escapado à morte e se preparava para atacar o imperador. 
as vítimas de assassínio, que o imperador fica a saber toda a verdade: mas é tarde de mais. O biógrafo nomeia os agressores, evidenciando a proximidade deles em relação ao imperador através da menção das suas funções no interior do palácio: Clodiano, oficial subalterno (cornicularius); Máximo, liberto do camareiro Parténio; Sátur, chefe dos criados de quarto (decurio cubiculariorum) e alguns gladiadores. Uma segunda versão, mais dramática, baseia-se no relato de uma testemunha ocular: um puer, que cuidava dos Lares do quarto, refere que Domiciano the pedira o punhal que estava debaixo da almofada e lhe ordenara que chamasse os guardas, mas do punhal o escravo só encontrou o cabo ${ }^{110}$ e achou as portas todas fechadas. Conta ainda que o imperador, depois de agarrar e prostrar Estéfano por terra, lutou longo tempo, tentando ora tirar-lhe o punhal, ora furar-lhe os olhos com os dedos dilacerados. ${ }^{111} \mathrm{~A}$ sugestão do bode imolado a Baco - uma ameaça velada nuns versos contra o corte das vinhas, que infundiu medo no tirano (cf. Dom. 14.2) - contribui para aproximar esta morte do universo da tragédia.

Suetónio, ao contrário de Díon, ${ }^{112}$ omite qualquer ajuda; e faz de Domiciano uma personagem solitária na morte. Tal solidão é acentuada no funeral, ou quase ausência dele. O biógrafo não deixa de notar que, em lugar de um cortejo honroso, foi levado pelos uispillones e na indigna sandapila, o caixão dos pobres. ${ }^{113}$ Os últimos cuidados são prestados ao cadáver pela ama, Fílis. Como as amas e a amante, Acte, de Nero (Nero 50), Fílis parece a única pessoa que sentiu verdadeiro apego pelo defunto imperador. E é também Fílis que, às escondidas (clam), coloca os restos mortais no templo dos Flávios, junto às cinzas de Júlia (Dom. 17.3. Cf. Díon, 67.18.2). A angústia solitária da vida do tirano é expresso através das próprias palavras de Domiciano, transmitidas já depois do relato da morte - considerava muito infeliz a condição dos príncipes, pois ninguém acreditava que uma conspiração fora descoberta, a menos que fossem assassinados. ${ }^{114}$

O matança dos tiranos, em muitos casos acompanhada sugestões de partição do cadáver, parece aproximar-se de um ritual apotropaico colectivo, semelhante a sacrifícios de animais ou a ritos arcaicos de expulsão, em que o imperador, como vítima, expia o mal da comunidade que ele próprio representa. Além de Domiciano, outros tiranos são associados a um bode: Tibério (Tib. 45) e Calígula (Cal. 50).

${ }^{110}$ Segundo Díon, 67.17.1, foi Parténio quem retirou a lâmina do punhal.

${ }^{111}$ Dom. 17.2. Encontramos aqui, segundo Gascou, J. 1984, 308 e 796, o realismo mórbido e atroz, tão ao gosto de Suetónio, presente também nas mortes de Júlio César (o braço pendente: 82.3); Tibério (na versão de Séneca, o rétor; 73.2); Calígula (58.2-3); Cláudio (pormenores sórdidos: 44.2-3); Nero (49.2-4); Galba (particularmente os insultos à cabeça: 20.2); Vitélio (17).

${ }^{112} \mathrm{Na}$ versão de Díon e Filóstrato, o assassino é morto pelos que vieram em socorro de Domiciano.

${ }^{113}$ Vide com. de Jones, B. W. 1996, 136; com. de Jones, B. \& Milns, R. 2002, 162.

114 Dom. 21: 'Condicionem principum miserrima' aiebat, 'quibus de coniuratione comperta non crederetur nisi occisis'. Palavras que, para Southern, P. 1997, 124-125, são manifestação da paranóia de Domiciano. 


\subsubsection{O veneno: mortes suspeitas}

As linhas principais da Vida de Tibério - os traços de carácter do imperador - mantêm-se na narrativa da morte. Tibério manifesta uma espécie de fobia do regresso à Urbe e das multidões (Tib. 72). Coloca um cordão de soldados ao longo do Tibre, mas volta para trás, sem se saber porquê. Tenta de novo mais tarde, mas, ao avistar os muros de Roma, inverte a marcha, porque encontrara a sua cobra de estimação devorada pelas formigas, e é aconselhado a tomar cuidado com a turba. Mostra-se incapaz de regressar à Urbe: o medo e a desconfiança não o deixam ultrapassar a solidão. Para não confirmar a suspeita de doença, assiste e participa nuns jogos (Tib. 72.1-2). Piora, mas não altera os hábitos, nem se abstém dos prazeres (partim intemperantia, partim dissimulatione): a natureza viciosa e a capacidade de dissimular mantêm-se (Tib. 72.3). O mesmo acontece com a entranhada desconfiança: tem um lictor ao lado, para sua segurança, quando se despede dos hóspedes no triclínio. Porque non temere quicquam nisi ex tuto ausurus (Tib. 73.1) («não ousava arriscar o que quer que fosse senão em segurança»), pretende regressar de novo a Cápreas, fremens por se sentir desautorizado pelo senado; mas a morte sobrevém em condições não esclarecidas. À cabeça é mencionada a suspeita de que Gaio Calígula lhe teria dado um veneno lento e mortal. ${ }^{115}$ Mas seguem-se outras versões, todas atrozes: morte por inanição forçada, por sufocação com uma almofada, por abandono da parte dos que dele deviam cuidar. A última versão, autorizada por Séneca, ${ }^{116}$ desenha um imperador cioso do seu poder: depois de retirar o anel e fazer menção de o entregar, coloca-o de novo no dedo e segura-o avaramente apertando a mão esquerda (a sinistra agilior ac ualidior, como se diz em Tib. 68.1). Morre na solidão, como sempre viveu: ...subito uocatis ministris ac nemine respondente consurrexisse nec procul a lectulo deficientibus uiribus concedisse ${ }^{117}$ («Subitamente chamou os servos, mas, como ninguém lhe respondia, levantou-se e, devido ao desfalecimento das forças, morreu não longe do leito»). A morte de Tibério não careceria de grandes especulações dada a sua idade (78 anos), mas Suetónio, ao apresentar estas versões, parece manifestar algo mais do que o simples escrúpulo de historiador em ser completo (minúcia que em outros passos é negligenciada). Como nota Gascou, Suetónio procura dar a Tibério o fim terrível que ele mereceu e coloca, por isso, a versão de Séneca, em último lugar, por ser a mais impressionante e a mais simbólica: o imperador morre apartado de todos, na

115 Tib. 73.2; cf. Tácito, Ann. 6.50.4; Díon Cássio, 58.28.1-4. A suspeita sobre Calígula será fruto da sua impopularidade; a narrativa de Séneca, escrita menos de quatro anos depois da morte parece preferível: vide Seager, R. 1972, 244-245; Levick, B. 1999a, 218-219. Na respectiva Vida (Cal.12.2), Calígula assume um maior protagonismo na morte do antecessor.

116 Trata-se certamente do retor, da sua História das Guerras Civis. Suetónio não acha necessário precisar, pois que esta obra devia ser clássica para os historiadores, como afirma Grisart, A. 1961,303. Mas também se poderia tratar de uma obra perdida de Séneca o filósofo, autor no qual mais facilmente pensaria o leitor de Suetónio: vide GıUA, M. A. 1975, 357 n. 25.

${ }^{117}$ Tib. 73.2. Tibério tem um fim à semelhança da vida: o de um solitário desconfiado dos próximos: vide MARTin, R. 1991,355-357. 
angústia e na solidão. ${ }^{118}$

Três prodígios lhe anunciam a morte (Tib.74): um sonho profético e dois omina. Tibério, que já um dia tentara em vão trazer para Roma as Praenestinae sortes (Tib. 63.1), é alvo da vingança divina, desencadeada pelo acto de hybris de remover uma estátua de Apolo de Témeno (subúrbio de Siracusa). O deus anuncia-lhe em sonhos, no dia do aniversário, que a estátua já não seria dedicada por ele. ${ }^{119} \mathrm{Um}$ tremor de terra faz desabar o farol de Cápreas. Os carvões consumidos de uma braseira reacendem-se inesperadamente, o que é significativo para quem, pelo contrário, considera de bom agoiro uma luz apagar-se sem ninguém lhe tocar (Tib. 19).

A Vida de Tibério, como a de Augusto, termina, simplesmente, com a menção do testamento e distribuição dos bens (Tib. 76). A expressão dedit et legata plerisque remete, pelo flagrante contraste, para a fatuidade da alegada avareza de Tibério em vida.

Os elementos farsescos presentes na Vida de Cláudio têm continuidade no relato da morte. Cláudio mostra-se consciente da trama que o rodeia e manifesta vontade de agir. Começa a dar sinais de arrependimento do casamento com Agripina e da adopção de Nero e prepara uma mudança na política: lamenta-se dos seus omnia impudica, sed non impunita matrimonia; e ao mesmo tempo procura reforçar a posição do filho Britânico. ${ }^{120} \mathrm{~A}$ tragédia de Cláudio, que se lê nas entrelinhas, é que ele, acaso pela sua natural indolência (a segnitia antiga já no cap. 5, e que quase o faz ser destituído do consulado, em $C l$. 9.1), não age com a necessária energia e determinação, e, sobretudo, não age a tempo: prius igitur quam ultra progrederetur, praeuentus est ab Agrippina, quam praeter haec conscientia quoque nec minus delatores multorum criminum arguebant ${ }^{121}$ («antes que fosse mais longe, foi antecipado por Agripina, a quem, além disso, a sua consciência, e não menos os delatores, acusavam de muitos crimes»). A suspeita de assassínio faz correr rumores diversos. Suetónio recria esse ambiente com a narrativa de diferentes versões da morte: duas para o lugar e a pessoa do assassino e duas para os acontecimentos subsequentes. As características atribuídas a Cláudio parecem estar na base dos diferentes

${ }^{118}$ Vide Gascou, J. 1984, 795.

119 Há uma semelhança com a remoção da estátua de Zeus de Olímpia por parte de Calígula (Cal. 22.2; 57.1).

${ }^{120}$ Cl. 43. Segundo o com. de Mottershead, J. 1986, 139, Vespasiano - que fora apoiado pelo liberto Narciso, opositor de Agripina (Ves. 4.1-2; Tácito, Ann. 12.65; Díon Cássio, 60.34.4), e cujo filho Tito fora educado no palácio com Britânico (Tit. 2) -, terá contribuído para a divulgação da tradição segundo a qual Cláudio não pretendia ter Nero como sucessor. E uma hipótese que nos parece assaz razoável, pois em $C l .45$ há uma referência a Vespasiano em contexto favorável: restaura a honra da divindade de Cláudio, que Nero suspendera. Plínio-o-Velho era hostil a Nero e Suetónio deve ter-se fundamentado nele para a redacção desta secção.

${ }^{121}$ Cl. 44.1. Alguns editores preferem urguebant. Para Martin, R. 1991, 357-361, é possível vislumbrar na morte de Cláudio quer um último traço da sua natureza amorfa, quer uma espécie de suicídio indirecto, já que ele nada faz para reprimir as intrigas que sabia existirem ao seu redor. 
testemunhos, pelo que os tornam verosímeis. Os banquetes que Cláudio tanto apreciava facultam o meio, o envenenamento, e o momento oportuno para a morte (como para Calígula foram os jogos): ou junto dos sacerdotes, ou em casa. A sua subordinação aos libertos e às mulheres parece fomentar as duas versões sobre os executores: o veneno foi ministrado ou pelo eunuco Haloto, o provador oficial, ou pela própria Agripina, num cogumelo. A gula de Cláudio, superlativada (auidissimus ciborum talium) no que àquele alimento se refere, propicia a ingestão do boletus fatal. ${ }^{122} \mathrm{~A}$ última versão sobre os acontecimentos que se sucederam apresenta cruamente, na linha de outros momentos da vida, os aspectos menos dignos e mais caricatos até atingir o nível do sórdido: Cláudio adormece, como é seu hábito, depois a comida vem-lhe à boca e vomita; repete-se a dose de veneno em umas papas, com a desculpa de que precisava de se refazer com mais comida, ou num clister, por se encontrar obstipado e ter necessidade deste meio para evacuar ( $C l .44 .3)$. Através da insistência em pormenores indecorosos, Suetónio dá um fim repugnante a este imperador sem majestade. ${ }^{123}$ Além disso, mesmo morto, o imperador continua a ser um joguete da esposa - só poderá descansar em paz quando esta o decidir. Elementos ligados ao teatro sublinham o cómico da situação: a farsa de Agripina é sustentada com a presença real de comediantes: Mors eius celata est, donec circa successorem omnia ordinarentur. Itaque et quasi pro aegro adhuc uota suscepta sunt et induct $i$ per simulatione comoedi, qui uelut desiderantem oblectarent ${ }^{124}$ ( $(\mathrm{A}$ sua morte foi ocultada, até que se regularizasse tudo o que respeitava à sucessão. Por isso, como se estivesse doente, até se fizeram votos públicos e, em prol da farsa, se trouxeram comediantes, para, de acordo com um suposto desejo de Cláudio, o divertirem»).

O biógrafo introduz, mais uma vez no final da vida, uma referência ao teatro, concretamente a actores de comédia. Porque a morte representa o momento crucial da revelação do ethos, é significativo que seja este o meio usado para fazer crer que Cláudio ainda vive. Pode significar não só o gosto do imperador pela comédia (expresso em uelut desiderantem; o álibi só funcionaria, se correspondesse a um gosto reconhecido de Cláudio), mas também que toda a sua vida foi quasi comoedia. Afastado para sempre da cena, Cláudio deixa agora a Agripina o papel principal.

De qualquer modo, no final, ao referir o prévio conhecimento que o imperador tivera da morte ( $C l .46)$, Suetónio confere-lhe alguma dignidade. Há uma certa semelhança com César, que dava sinais de estar consciente da morte que o esperava e parecia até desejá-la.

${ }^{122} \mathrm{Cl}$. 44.2. A versão do envenenamento é quase universalmente aceite. Só Flávio Josefo, $A J$ 20.151, manifesta dúvidas. Para a comparação das várias fontes sobre a morte de Cláudio, vide Gascou, 1984, 281-293; Baldwin, B. 1983, 164-165; Questa, C. 1959, 46-48.

${ }^{123}$ Como nota Gascou, 1984, 795-796.

${ }^{124}$ Cl. 45. Vide Gascou, 1984, 290-291. Tácito, Ann. 12.68.2-3, desenvolve a comédia de Agripina, mas não refere o pormenor dos comoedi. Tal pormenor é ridiculizado por Séneca, Apoc. 4.2: Exspirauit autem dum comoedus audit. 


\subsubsection{Suicídio: a morte como necessidade}

As capacidades artísticas de Nero parecem influenciar Suetónio, sobretudo na redacção desta parte da Vida (Nero 40-50), que se apresenta como um desenlace trágico: talem principem paulo minus quattuordecim annos perpessus terrarum orbis tandem destituit ${ }^{125}$ («Após ter suportado tal príncipe pouco menos que catorze anos, o orbe da terra destituiu-o finalmente»). O princípio do fim foi a revolta dos Gauleses, sob o comando de Víndex. A tragédia de Nero joga-se entre a inércia do imperador artista e o perigo que o ameaça, entre conhecimento e desconhecimento, entre desespero e confiança, entre destino e amechania. Neste desenlace, cada passo é marcado pelo carácter de Nero, esteta e actor, ${ }^{126}$ que não sabe ou não quer ver como o seu carácter histriónico precipita o fim. Perante a predição dos astrólogos (mathematici) de que seria destituído, Nero afirmava, em grego, que a sua arte o alimentaria, para se desculpar do afinco com que cultivava a arte da cítara, principi sibi gratam, priuato necessaria («agradável para ele enquanto imperador, necessária enquanto particular»). Além disso, o biógrafo acentua a presunção de predestinado, que leva Nero a ser optimista. As promessas de que governaria o Oriente, de que recuperaria o seu poder, e a reconquista da Britânia e da Arménia fazem-no sentir-se liberto do infortúnio, a infelicitas que parece ser um dos condicionantes da leitura desta Vida ${ }^{127}$ : defunctum se fatalibus malis existimabat (Nero 40.2.) («julgava estar quite das fatalidades do destino»). Tal como Calígula, Nero erra a leitura de um presságio: interpreta favoravelmente um oráculo de Apolo que o aconselha a acautelar-se do ano setenta e três. Julga que será esta a idade da sua morte, quando, na verdade, o presságio se referia à idade actual de Galba. ${ }^{128} \mathrm{O}$ biógrafo transmite esta informação para sublinhar o engano em contraste com a confiança de Nero, excessiva para o momento: Tanta fiducia non modo senectam sed etiam perpetuam singularemque concepit felicitatem, ut amissis naufragio pretiosissimis rebus non dubitauerit inter suos dicere 'pisces eas sibi relaturos.' ${ }^{129}$ ( «Depositava tal confiança não só em chegar a velho, mas até numa perpétua e excepcional felicidade, que, depois de perder num naufrágio bens de grande valor, não hesitava em dizer diante dos seus que "os peixes lhos devolveriam"»). Mais uma vez Nero reclama a assimilação de um mito à sua pessoa: neste caso, a lenda de Polícrates, tirano de Samos (Heródoto, 3.39-43).

O ambiente dramático é conseguido pela oposição entre a consciência do leitor, que sabe do engano, e a inconsciência de Nero, perante os sinais funestos que lhe anunciam a catástrofe. Uma coincidência trágica, que só Suetónio

125 Nero 40.1. Cf Cal. 56.1: Ita bacchantem atque grassantem non defuit plerisque animus adoriri.

${ }^{126}$ Vide Lounsbury, R. C. 1991, 3755-3756; Martin, R. 1991, 265.

${ }^{127}$ Cf. Ner 6.2. Vide com. de Bradley, K. R. 1978, 15 e 46; Lounsbury, R. C. 1991, 3756.

${ }^{128}$ Cf. Cal. 57.3. Segundo Gallivan P. A. 1974c, 297-318, o cálculo da idade de Galba está errado: teria 71 anos em 68, pois este futuro imperador terá nascido em 3 a.C. e não em 5 a.C.

${ }^{129}$ Nero 40.3. Para Cize K, E.1977, 150, trata-se da expressão da megalomania de Nero. 
refere, é que recebe a notícia da revolta da Gália no mesmo dia em que, anos antes, matara a mãe (o uso da forma activa occiderat parece acentuar a culpa): fica sugerido um castigo divino. ${ }^{130}$ Mas Nero, cego às evidências, procede como se nada fosse (lente ac secure tulit): parece até alegrar-se com a possibilidade da pilhagem na contra-ofensiva. Prefere esconder a gravidade da situação sob a capa do silêncio (conatus rem silentio obli[t]erauit) e continua a dedicar-se às suas actividades habituais, como a ginástica e sobretudo a música. ${ }^{131}$

Abandona finalmente a apatia perante a propaganda ofensiva (edicta contumeliosa) de Víndex, mas nada lhe dói tanto como acusação de ser mau citaredo e de ser apelidado Aenobarbo em vez de Nero (Nero 41.1). Víndex percebera o ponto fraco do imperador. Nero, ferido no seu orgulho de artista, recusava-se a aceitar que o acusassem de ignorância em relação a uma arte que julgava ter levado à perfeição e perguntava continuamente a todos se conheciam melhor executante do que ele. A intriga sofre novo avanço com a chegada de novas urgentes, que deixam Nero aterrado (Nero 41.2). Mas prossegue a alternância entre o medo e a confiança. $\mathrm{O}$ biógrafo põe a nu a credulidade do imperador ao apelidar de friuolum um auspicium que Nero lê no relevo de um túmulo: um cavaleiro romano a arrastar um soldado gaulês pelos cabelos. Suetónio sugere a progressiva recuperação do ânimo (primeiro leuiterque modo... mente recreata, depois exiluit gaudio caelumque adorauit). ${ }^{132}$ Como sublinha o biógrafo (ac ne tunc quidem), apesar da gravidade dos acontecimentos, Nero não convoca o povo e o senado, mas um consilium dos primores. ${ }^{133}$ De facto está mais interessado em ter assistência para tratar aquilo que realmente o preocupa: a música. A ligeireza com que versa o assunto da reunião (transactaque raptim consultatione), contrasta com o tempo (reliqua diei pars) dedicado a mostrar as particularidades dos novos órgãos hidráulicos. Os projectos para depois da crise são evidentes pela afirmação de Nero: 'iam se etiam prolaturum omnia in theatrum' affirmauit, 'si per Vindicem liceat' («em breve iria apresentar mesmo tudo isto no teatro - asseverou ele - se, por acaso, Víndex lho permitisse»). O humor do dito sugere que ele não acreditava no êxito da revolta. Mas as notícias tornam-se alarmantes, e a reacção de Nero, que rapidamente passa da felicidade ao desespero, é aparatosa, com gestos típicos da cena trágica:

${ }^{130}$ Nero 40.4: Neapoli de motu Galliarum cognouit die ipso quo matrem occiderat. Como sublinha GAscou, J. 1984, 789-790, com esta nota se estabelece a relação entre o acontecimento que vai conduzir à desgraça de Nero e o matricídio que cometera.

${ }^{131}$ A atitude de Nero talvez não seja tão irracional como Suetónio sugere. A revolta deve ter parecido insignificante, dada a ausência de legiões na Gália; e Nero deve ter começado a tomar providências secretas para liquidar Galba (cf. Gal. 9.2): Vide Bessone, L. 1976-1977, 343-349; com. de Bradley, K. R. 1978, 251-252.

132 (...) leuiterque modo in itinere friuolo auspicio mente recreata, cum adnotasset insculptum monumento militem Gallum ab equite $R$. oppressum trabi crinibus, ad eam speciem exiluit gaudio caelumque adorauit. Segundo Lounsbury, R. C. 1991, 3767, a exagerada alegria do imperador é enfatizada pelo ritmo (uma invulgar sequência de três anapestos e dois créticos) do ponto central deste passo, ad eam speciem exiluit gaudio.

${ }^{133} \mathrm{O}$ que parece mais natural, dada a gravidade e urgência dos acontecimentos. 
Postquam deinde Galbam et Hispanias desciuisse cognouit, conlapsus animoque male facto diu sine noce et prope intermortuus iacuit, ut resipiit, ueste discissa, capite conuerberato, 'actum de se' pronuntiauit consulantique nutriculae et aliis quoque iam principibus similia accidisse memoranti, 'se uero praeter ceteros inaudita et incognita pati' respondit, 'qui summum imperium uiuus amitteret.' ${ }^{134}$

«A seguir, perante a nova de que Galba e as Hispânias se tinham juntado à revolta, tombou por terra e, em completo desânimo, longo tempo esteve deitado sem fala, bem perto da morte. Quando recobrou os sentidos, entre rasgar as vestes e golpear a cabeça, proclamou que 'chegara ao fim' e, à ama, que o consolava e lhe recordava que semelhantes infortúnios já tinham também atingido outros príncipes, respondeu que 'mais do que os outros, o sofrimento dele era inaudito e desconhecido, pois, em vida, perderia o poder supremo'».

Mas a urgência em agir contrasta com a inércia de Nero, que, em vez de tomar providências, se prefere abandonar, com estas tiradas de sabor trágico, à inevitabilidade do destino. $\mathrm{O}$ imperador-actor, habituado aos aplausos do teatro, não consegue suportar os desaires da vida. Mesmo nesta altura, continua com as suas actividades teatrais. Uma notícia favorável (talvez da morte de Víndex, mas Suetónio não especifica) é motivo para cantar e acompanhar de gestos os versos satíricos dirigidos contra os generais revoltosos. Além disso, continua a frequentar os espectáculos de teatro em segredo. Manifesta até inveja do sucesso de um actor e manda-lhe dizer que 'abuti eum occupationibus suis' (Nero 42.2) («'se estava a aproveitar do facto de ele próprio andar ocupado'»).

O biógrafo interrompe a narrativa cronológica para referir as reacções de Nero, que resultam inadequadas. Concebeu vários projectos que revelam a brutalidade da sua natura ${ }^{135}$ e se ligam ao carácter histriónico amoral: assassínios, extermínio do senado, incêndio de Roma, lançamento de feras contra o povo. ${ }^{136}$ Mas, depois de desesperar de realizar tais crimes, resta-lhe a esperança nas suas capacidades de actor:

Ac susceptis fascibus cum post epulas triclinio digrederetur, innixus umeris familiarium affirmauit, 'simul ac primum prouinciam attigisset, inermem se in conspectum exercituum proditurum nec quicquam aliud quam fleturum, reuocatisque ad paenitentiam defectoribus insequenti die laetum inter laetos cantaturum epinicia quae iam nunc sibi componi oporteret' (Nero 43.2).

${ }^{134}$ Nero 42.1. Segundo o com. de Bradley, K. R. 1978, 254-256, a histriónica reacção de Nero, descrita por Suetónio, mostra que a notícia da revolta de Galba marca o ponto de viragem na história da rebelião. Segundo Bessone, L. 1976-1977, 343-349, a reacção de desespero de Nero é provocada pelo inesperado da notícia: ele esperaria a notícia da morte de Galba, que ordenara em segredo (cf. Gal. 9.2).

${ }^{135}$ Nero 43.1: multa et inmania, uerum non abhorrentia a natura sua.

${ }^{136}$ Uma lista de rumores, surgidos antes e depois da revolta, sem prova histórica; vide com. de Bradley, K. R. 1978, 258; com. Warmington, B. H. 1999, 80. 
«E, tomados os fasces, ao abandonar o triclínio, depois de um banquete, apoiando-se nos ombros dos seus íntimos, afirmou que 'mal chegasse à província, se apresentaria, desarmado, à frente dos exércitos e não faria outra coisa senão derramar lágrimas e, depois de reconduzir os revoltosos ao arrependimento, cantaria, no dia seguinte, feliz entre felizes, epinícios, que tinha de compor desde já»».

Assim, a prima cura, ao preparar a expedição, é providenciar sobre os carros para o transporte dos scaenica organa e vestir as concubinas de amazonas, com um corte de cabelo masculino e armadas de machado e de escudo. ${ }^{137}$ Mas a anterior popularidade de Nero começa a soçobrar. Quando falta o pão, já não basta o circo. Durante a publica fames, chega inoportunamente um navio de Alexandria, carregado de areia para os lutadores do palácio. ${ }^{138} \mathrm{O}$ odium faz-se ouvir nas ofensas públicas dos graffiti. Uma inscrição aponta a arte do imperador como causa da revolta, ao dizer que o seu canto acordara os Galli, numa referência ambígua às aves e ao povo; durante a noite, ouvem-se vozes de pessoas que, fingindo altercar com os escravos, reclamam um Vindex (Nero 45.2). Finalmente, as reacções das divindades e dos mortos: sinais funestos que aterrorizavam Nero. A conexão da morte de Nero com o assassínio da mãe, da esposa Octávia e do pai é bem patente: com ela o biógrafo começa e termina a rubrica dos presságios. Depois da morte de Agripina, sonha que lhe arrancam o timão com que governava um navio e que Octávia o arrebata para as densas trevas (Nero 46.1). Depois de apresentados vários presságios, o biógrafo termina com o último verso da última

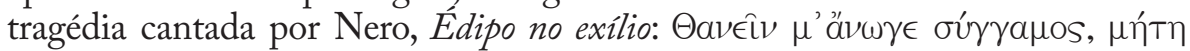
$\rho$, $\pi \alpha T n \rho^{139}$ ( Que eu morra me ordena a minha esposa, a minha mãe, o meu pai!»). Sublinha-se mais uma vez a ligação entre aquele papel trágico e a vida de Nero. Não esqueçamos que Suetónio o culpa também pelo assassínio de Cláudio, seu pai adoptivo (Nero 33.1). Os fios condutores da Vida juntam-se, assim, na narrativa da morte.

Depois, Suetónio retoma a narrativa cronológica, que entretanto abandonara. Novos sucessos vêm provocar reacções cada vez mais desesperadas. A notícia da adesão dos restantes exércitos à revolta provoca uma explosão de cólera (Nero 47.1). O biógrafo apresenta-nos a luta interior de Nero, hesitante entre várias saídas, a adiar as decisões. ${ }^{140}$ Ao ver-se abandonado de todos e sem encontrar quem lhe desse a morte, faz mais uma observação de carácter dramático: 'Ergo ego', inquit, 'nec amicum babeo nec inimicum?' («Então eu

${ }^{137}$ Nero 44.1. Cf. Cal. 25.3: Caesoniam... ut saepe chlamyde peltaque et galea ornatam ac iuxta adequitantem militibus ostenderit.

${ }^{138}$ Nero 45.1. O passo, retirado do contexto político, é uma forma tendenciosa de desacreditar Nero. O fornecimento de trigo terá sido interrompido devido às actividades de L. Clódio Macro, legado em África, que se insurgira, seguindo o exemplo de Víndex e Galba. A fome causada pela estratégia de Macro desempenha o seu papel, ajudada pela falta de iniciativa de Nero. A população, que antes o amava, retira-lhe o apoio, pois a urgência de pão era maior que a de circo. Vide BRADLEY K. R. 1972, 451-458.

${ }^{139}$ Nero 46.3. Díon Cássio, 63.28.3-5, não identifica a peça e liga este verso ao próprio destino de Nero. Vide Bartsch, S. 1994, 43-46.

140 Nero 47.3: Sic cogitatione in posterum diem dilata. 
- bradou ele - nem tenho amigos nem inimigos?'») e corre, como quem vai precipitar-se no Tibre.

Segue-se o relato próximo da morte. A descrição do caminho nocturno para a casa de Fáon é aterrador, pela sucessão dos vários elementos que compõem o cenário: ${ }^{141}$ um tremor de terra, um raio, o clamor no vizinho campo pretoriano, as conversas dos viandantes, o odor do cadáver que faz empinar o cavalo, o cair do véu e o reconhecimento do imperador por parte de um antigo pretoriano, a aproximação da casa de Fáon por entre arbustos e silvas, a entrada sub-reptícia no interior. Nero, descalço, por este caminho tortuoso, depois de gatas, torturado pela fome e pela sede, a beber água de um charco, é a imagem de miséria que contrasta com a anterior opulência. $\mathrm{O}$ acolhimento na casa de Fáon constitui a antítese do conforto da Domus Aurea e a total humilhação da púrpura. Um jogo de sinestesias permite ao leitor experimentar as sensações de Nero caído em desgraça, como vimos no capítulo relativo ao estilo de Suetónio.

De seguida, as ordens para a abertura de uma fossa à medida do corpo, e a preparação das homenagens fúnebres, acompanhadas do choro de Nero e da célebre exclamação 'Qualis artifex pereo!'; ${ }^{142}$ a chegada da notícia (trazida por um cursor, introduzido no momento certo) de que tinha sido declarado inimigo do senado; a descrição do castigo; a verificação do gume dos punhais - são fases de um processo gradativo, quebrado pela falta de coragem de Nero, que volta a guardar os punhais, com o pretexto de que ainda não chegara a fatalis hora (Nero 49.2). Há então um pequeno retardamento em que Nero exterioriza o terror da morte: ora exorta a começar os lamentos, ora pede que alguém se suicide para lhe infundir coragem, ora censura a sua própria fraqueza. $\mathrm{O}$ aumento da tensão é de novo retomado com o barulho dos cascos dos cavalos, que leva Nero, no seu constante gosto de transpor as situações míticas para a realidade, a recitar um verso da Ilíada apropriado à ocasião. Nero vê-se progressivamente empurrado para a morte: esta chega com a ajuda de Epafrodito, ${ }^{143}$ como o culminar de um já longo caminho que começara com a notícia da revolta de Víndex (Nero 40.1). Neste momento, irrompe um centurião que simula prestar auxílio e coloca a veste sobre a ferida. Nero limita-se a dizer 'Sero'(«Tarde de mais!'») e 'Haec est fides' («Esta é que se chama lealdade!'») - forma irónica de acentuar, pela derradeira vez, a sua tragédia pessoal: o contraste entre o alto conceito que tem de si e o abandono a que se vê votado. Depois de expirar, o

${ }^{141}$ Nero 48. Narrativa muito semelhante se encontra em Díon Cássio, 63.27.3-29.2.

${ }^{142}$ Nero 49.1. Segundo Grimal, P.1955,15-20,é o estoicismo místico, presente na concepção da Domus Aurea, que explica esta afirmação. Nero, vivo, julga encarnar o artista supremo, o cosmocrátor, pela perfeição a que eleva a sua música. Para Lorenzo, E. Di 1981, 523-535,

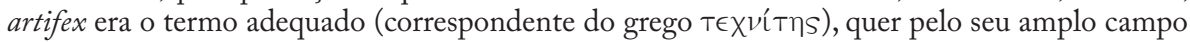
semântico (nenhum outro termo para actor designava tão bem a polivalência de Nero), quer pelo seu valor expressivo no contexto rico de dramaticidade em que foi pronunciado: Nero queria recordar a si e aos outros não só que fora poeta, auriga, artista, mas sobretudo um actor completo, que na cena e na vida soube recitar bem a sua parte.

${ }^{143}$ Nero 49.3. Esta será a razão apontada para Domiciano o condenar à morte: cf. Dom 14.4: ne bonum quidam exemplo aud[i]endam esse patroni necem, Epaphroditum a libellis capitali poena condemnauit. 
olhar rígido de Nero incute horror e espanto nos presentes: é o olhar de um monstro. ${ }^{144}$ Fica ainda a nota de que pedira insistentemente que a sua cabeça não fosse separada do corpo e que fosse cremado inteiro, o que lhe é concedido por Ícelo, liberto de Galba. ${ }^{145}$

Também na morte de Nero se acentua a ligação entre teatro e vida: esta é a última representação de Nero. Ao dizer que morre como artifex, Nero afirma a superação da mimesis pela poiesis: assume que cria arte. Só que desta vez não tem um condenado substituto (como no caso de Ícaro): o seu papel é insubstituível, porque representa a sua própria tragédia real. Paradoxalmente, o artifex não parece estar na posse de todos os dados: o seu infortúnio deriva de uma absurda necessidade da morte, a que não pode fugir, ${ }^{146}$ mas também do desconhecimento de vários fios da trama que se desenrola à sua volta e que precipita o seu fim. Com efeito, ele nem sequer sabe qual é o castigo destinado pelo mos maiorum a um inimigo público. Mas fica também sem resposta uma série de questões levantadas por Townend. ${ }^{147}$ Porque é que o grupo se aproximou da casa de modo furtivo? Porque não entraram na casa por uma porta, ainda que lateral? Se era para ocultar a entrada aos servos de Fáon, como se poderia esperar que eles não vissem o túnel aberto na divisão? Porque não poderia Fáon oferecer comida e bebida mais agradáveis? Porque é que, de repente, se decide que não era possível manter o segredo e era urgente que Nero se suicidasse? Nero pretende ser enterrado ou cremado? Porque é que, depois de todas as precauções, a cavalaria pretoriana se dirige para a casa e descobre imediatamente o imperador moribundo? Tudo aponta para uma traição não explícita. Será que o pretoriano na reserva, que reconheceu Nero no caminho, deduziu, pelos acompanhantes, o local para onde ele se dirigia? $\mathrm{O}$ cursor que trouxe a notícia de que Nero fora declarado inimigo público estaria a par dos acontecimentos e revelaria o paradeiro de Nero? Não sabemos. Há uma série de circunstâncias de que não conhecemos as causas. O biógrafo está mais preocupado com os efeitos sobre a personagem do que com os motivos que os geram. Através da focalização interna na personagem de Nero, o leitor tem acesso às percepções do imperador em fuga e não mais. Assim poderá sentir melhor o drama do imperador, pela insuficiência da informação que ele possuía.

O funeral é dispendioso, como o fora a vida. É de notar a presença das amas e sobretudo da concubina Acte, que depositam os restos mortais no sepulcro dos

144 Nero 49.4: Atque in ea uoce defecit, extantibus rigentibusque oculis usque ad horrorem formidinemque uisentium.

${ }^{145}$ Nero 49.4. Ironicamente, tal mercê não será concedida a Galba: cf. Gal. 22.

${ }^{146}$ Lounsbury, R. C. 1991, 3756, sublinha o facto de Suetónio compor o texto de modo que Nero é levado do trono à morte sem uma forte razão, cativo de uma necessidade à qual não pode escapar.

${ }^{147}$ Vide Townend, G. B. 1967, 95; Baldwin, B. 1983, 510. 
Domícios. ${ }^{148}$ Acte retribui assim o verdadeiro amor que Nero tinha por ela. ${ }^{149}$

Nero é o primeiro imperador cujo retrato Suetónio coloca depois da morte. A razão poderá ser o desejo não de interromper, com um capítulo descritivo, a ligação da narrativa da morte ao resto da vida, sublinhada atrás por Talem principem (Nero 40.1). Deslocados para aqui, estes elementos assumem o papel de uma avaliação póstuma e ajudarão a explicar as paradoxais reacções à morte, apresentadas em final absoluto. É neste momento que Suetónio dá os habituais apontamentos sobre a estatura e o aspecto do rosto, o cabelo e o vestuário (Nero 51), bem como a inclinação para as artes: poesia, escultura e pintura (Nero 52). Todo o afã de Nero se parece subordinar ao desejo de glória eterna. O problema é que se trata de uma ambição imponderada (inconsulta), que o leva a chamar neroniano ao mês de Abril, e a querer rebaptizar Roma com o nome de Nerópolis. ${ }^{150}$ Este retrato de tirano completa-se com a impiedade para com os deuses (Nero 56). Nero mostra-se desrespeito pelos cultos religiosos e sacrílego até para com a Deusa Síria, ao passo que cede a superstições menos dignas (alia superstitione captus). Parece assim justo que caia vítima de um destino adverso.

\subsection{Morte e redenção}

Quanto a Otão, Suetónio descura, como é seu hábito, os grandes acontecimentos históricos, que perdem o valor próprio e passam a ser considerados em função do biografado: a batalha de Betríaco é referida de passagem e perde impacto perante a narrativa da morte deste imperador. ${ }^{151}$ Galba, desmoralizado, chegara a pensar no suicídio, mas uma viragem nos acontecimentos deixou de o exigir ( Gal.11).A morte de Otão é um acto corajoso, voluntário e altruísta, ${ }^{152}$ numa altura em que (todas as fontes concordam) nem tudo estava perdido: estavam a chegar reforços da Dalmácia, da Panónia e da Mésia e os soldados vencidos em Betríaco ansiavam por uma desforra. O suicídio de Otão não é, como fora o de Nero, determinado pela necessidade. Suetónio acentua a firmeza da decisão: Ac statim moriendi impetum cepit, ut multi nec frustra opinantur, magis pudore, ne tanto rerum hominumque periculo dominationem sibi asserere perseueraret, quam desperatione ulla aut diffidentia copiarum $^{153}$ ( «Tomou imediatamente a resolução impulsiva de morrer, segundo muitos pensam, e não em vão, mais por escrúpulo, para não persistir em

${ }^{148}$ Nero 50. Segundo o com. de Warmington, B. H. 1999, 85, a sepultura no túmulo dos Domícios remove simbolicamente Nero da família júlio-cláudia, pelo que Suetónio complementa assim a ênfase que coloca no facto de Nero ser um Domício, tónica presente logo no começo da Vida.

${ }^{149}$ Vide Verdière, R. 1975, 8.

${ }^{150}$ Nero 55. Vide Martin R. 1991, 326-327; Cizek, E. 1977, 150.

${ }^{151}$ A descrição da primeira batalha de Betríaco é dividida entre duas referências vagas: Otho 9.2 e Vit. 10.1. Vide intr. ao com. de Venini, P. 1977, 5.

${ }^{152}$ Cf. relatos muito semelhantes em Plutarco, Oth. 15-18; Tácito, Hist. 2.46-50; Díon Cássio, 64.11-15. As várias fontes estão de acordo sobre a nobreza da morte; vide MARTin, R. 1991, 364-367; Harris, B. F. 1962-63, 73-77; Gascou, J. 1984, 295-316.

${ }^{153}$ Otho 9.3. A mesma constatação em Marcial, 6.32. 
assegurar para si o poder à custa de tão grande risco para o Estado e para os homens, do que por desespero ou qualquer falta de confiança nas tropas»).

O biógrafo introduz o testemunho do seu próprio pai, Suetónio Leto, que participara na campanha como tribuno angusticlavo. A afirmação do horror que Otão tinha a guerras civis (detestatum ciuilia arma) e de que se não revoltaria contra Galba, se não confiasse que o golpe se podia resolver sem guerra, torna a morte de Otão coerente com as suas convicções e reduz a sua culpa na morte de Galba. ${ }^{154}$ A inspiração do suicídio parte do exemplo de um simples soldado raso (manipularis) que, ao trazer a notícia da derrota de Betríaco, se mata à sua frente para provar que falava verdade. Perante tal exemplo, Otão afirma que 'non amplius se in periculum talis tamque bene meritos coniecturum "155 ("não mais exporia ao perigo homens daquela envergadura e que tão bem o serviram'»). Otão mostra-se, deste modo, consciente da necessidade do seu sangue para pôr fim à guerra civil e aceita voluntariamente o papel de vítima expiatória, tornando-se um herói da pietas.

Os últimos momentos de Otão são de serenidade e de preocupação com os outros: neles procura infundir a sua tranquilidade. Inquieta-o a sorte daqueles que lhe são próximos: exorta o irmão, o sobrinho e os amigos a porem-se a salvo. Envia cartas à irmã, para a consolar, e à viúva de Nero, Estatília Messalina, com quem projectara casar-se, ${ }^{156}$ para lhe recomendar os seus restos e a sua memória. A ligação a Nero continua a ser acentuada: dir-se-ia que Suetónio pretende evocar, de modo subtil, a lembrança daquele imperador e suscitar a comparação entre os dois suicídios. Otão destrói ainda cartas comprometedoras, para proteger terceiros, e distribui os haveres de que dispunha pelos da sua casa (Otho 10.2). Quanto já está preparado para morrer, tumultos que se geraram, levam-no a adiar a morte: 'Adiciamus', inquit, 'uitae et hanc noctem' (Otho 11.1) («'Acrescentemos - exclama ele - ainda esta noite à nossa vida”). Tal frase, só referida por Suetónio, mostra que a morte de Otão não é uma fuga: o imperador continua a assumir as suas responsabilidades, concretamente com o exercício da sua autoridade, e proíbe que se use de violência contra quem quer que seja (porque alguns queriam partir). Depois de, como Nero, beber água e experimentar a ponta de dois punhais, ${ }^{157}$ coloca um sob a almofada e cai num

${ }^{154}$ Só Suetónio fala do ódio de Otão às guerras civis antes da ascensão ao império. As outras fontes referem a mesma aversão, mas como uma virtude tardia (Tácito, Hist. 2.47.2; Plutarco, Oth. 15.7; Díon Cássio 64.13.2). A visível simpatia do biógrafo por Otão parece levá-lo a minimizar a infâmia da morte de Galba, considerada facinus flagitiosissimum por Tácito, Hist. 2.50.1. A utilização de uma fonte oral é uma forma de defender a memória de Otão contra uma tradição demasiado severa, como afirma GAscou, J. 1984, 301-302.

${ }^{155}$ Otho 10.1. Díon Cássio, 64.11, diz que se trata de um cavaleiro. Plutarco, Oth. 15.3, fala também do suicídio de um simples soldado, mas por razões diferentes: para exortar Otão a retomar coragem e lhe mostrar até que ponto todos estavam dispostos a ir.

${ }^{156}$ Só Suetónio fala destas duas cartas e da intenção de se casar com a viúva de Nero. Plutarco, Gal. 21.1, e Tácito, Hist. 1.13.2, falam do plano de casamento com a filha de Vínio, no tempo em que Otão estava para ser adoptado por Galba.

157 Poulle, B. 1997, 250, põe em evidência o simbolismo dos dois punhais, numa alusão à dualidade tradicional dos tiranicidas e semelhança, também linguística, entre o gesto de Nero e de Otão. 
sono profundo, revelador da sua serenidade de espírito, bem diferente da de Nero. Se, depois da morte de Galba, Otão tinha o sono perturbado (Otho 7.2), quando decide sacrificar-se, atinge a pacificação interior. Também diferente de Nero é a forma como se suicida: enquanto este, acolitado por Epafrodito, trespassa o pescoço (Nero 49.3) - os tiranos são degolados - Otão trespassa o peito de um só golpe, o que confere dignidade ao gesto, e morre ora ocultando ora desvelando a ferida aos que acorreram ao seu primeiro gemido. ${ }^{158} \mathrm{O}$ funeral é feito à pressa, como tinha recomendado. ${ }^{159}$

O retrato físico de Otão, como já anteriormente os de Nero e de Galba,vem apresentado a seguir à narrativa da morte. No caso de Galba, vimos que o retrato vinha em contiguidade com as referências feitas ao seu aspecto, intercaladas no relato de morte, técnica que, no caso de Vitélio, será mais evidente. Por um lado, a morte é o lugar da revelação do ethos e, por outro, a descrição física é vista em continuidade com os traços de carácter, como veremos mais adiante. Ora, em Otão, o retrato físico é feito em ligação à narrativa da morte, mas por contraste com a atitude tomada: tanto Othonis animo nequaquam corpus aut habitus competit ${ }^{160}$ («a tão grande coragem não correspondia de modo algum nem o físico nem os modos»). A nobreza e virilidade do carácter demonstrada contrasta com os traços físicos e hábitos que o tornam muito diferente de um estóico. O biógrafo parece defender Otão, ao reduzir subtilmente o lado negro da sua vida aos costumes efeminados, isto é, ao domínio da aparência, não da essência: sugere que foi este habitus a causa do juízo comum que considera a vida de Otão indigna, e a morte, por oposição à vida, surpreendente: per quae factum putem, ut mors eius minime congruens uitae maiore miraculo fuerit ${ }^{161}$ («é por este facto que julgo que a morte dele, de modo algum consonante com a vida, causou maior espanto»). A morte de Otão representa, para Suetónio, o momento da revelação do verdadeiro carácter do imperador e a oportunidade de este redimir in extremis a sua vida. Desta forma se transforma em bom um imperador que faria esperar o pior, como se vê pelas reacções à morte.

158 Otho 11. 2. Só Suetónio diz que se feriu infra laeuam papillam e que expirou modo celans, modo tegens plagam. São exemplos do sentido do concreto e do gosto de Suetónio pelo horror e pelos pormenores mórbidos, como diz Gascou, J. 1984, 307-308.

159 Tácito, Hist. 2.49.2, acrescenta que Otão assim o desejara para evitar que lhe cortassem a cabeça e a expusessem ultrajes. GAscou, J. 1984, 309, pensa que, se esta informação estava na fonte comum, Suetónio a terá calado por simpatia para com Otão. Recorde-se que o biógrafo não calara a informação no que se refere a Nero (Nero 49.4).

160 Otho 12.1. Cf. Tácito, Hist. 1.22.3: Non erat Othonis mollis et corpori similis animus.

${ }^{161}$ Enquanto Suetónio opõe o modo de vida efeminado a uma morte viril, os outros autores estabelecem um contraste de natureza diferente, como nota GAscou, J. 1984, 311-312. Tácito, Hist. 2.50.1, opõe a morte digna de Otão (facinum egregium) ao infame assassínio de Galba. Plutarco, Oth. 18.3, compara-o com Nero: não viveu mais "honestamente", mas morreu mais "nobremente". Díon Cássio, 64.15.2, opõe a morte à impiedade e perversidade de Otão, uma morte óptima a uma vida péssima. Portanto, Suetónio não partilha a severidade destes três autores em relação à vida de Otão, porque lhe parece que os costumes efeminados (característica partilhada com César) são menos graves que a saeuitia. Segundo Cizer, E. 1977, 130-132, o clímax de uma gradação é este miraculum que Otão incarna pela sua existência e morte. 


\subsection{Aplauso e pateada}

O povo tinha muitas formas de aplaudir ou patear a actuação dos imperadores. Suetónio dá notícia de panfletos e grafitos ou reacções espontâneas da multidão. Quando César perde o apoio do povo, que protestava contra a dominatio, ${ }^{162}$ aparece um libellus de versos; levanta-se vozearia contra os novos senadores gauleses (Jul. 80.2); gravam-se inscrições contra o novo rex, com apelo à memória do libertador Lúcio Bruto. ${ }^{163}$ No que respeita à vida privada de Augusto, o "coro" da voz do povo entra em cena para reprovar, com versos cómicos, o sacrílego festim secreto, em que o imperador se vestiu de Apolo, a sua grande apetência por vasos coríntios e o vício do jogo dos dados. ${ }^{164}$ No caso de Tibério, com o episódio de Malónia, Suetónio oferece a desforra do povo que censura a perversidade do seu morosus governante num verso de Atelana (Tib. 45). E o queixume público, devido ao excesso de crueldade deste imperador, é expresso por uma série de versos difamatórios (Tib. 59). Também a perda do apoio popular de Nero se torna manifesta nos epigramas escritos pelas paredes e em versos de Atelana (Nero 39.2-3). No que respeita a Domiciano, surgem palavras de duplo sentido nos pórticos que mandara construir (Dom.14.2) e difunde-se um libelo em que se preanuncia a imolação expiatória do tirano, assimilando-o a um bode (Dom. 13.2). Vitélio ofendeu os astrólogos. Depois de ordenar, em um edicto, que aquele grupo deixasse Roma e Itália antes das calendas de Outubro, apareceu afixado um libelo em que os astrólogos decretavam que, pela mesma altura, Vitélio não estivesse em parte alguma. ${ }^{165}$ O efeito da fama da avareza de Galba sobre os Romanos, habituados ao luxo e profusão de Nero, é imediato - Quare aduentus eius non perinde gratus fuit («por isso, a sua chegada também não foi grata») - e o espírito mordaz manifesta-se no verso da atelana que os espectadores glosaram: Veni $[t]$ Onesimus a uilla ${ }^{166}$ ("Chega o Onésimo da quinta"). Também Vespasiano é alvo de observações sarcásticas pela sua fama de avarento (Ves. 19.2).

Dada a estrutura bipartida da Vida de Calígula, entre acções do princeps e do monstrum, no início do principado, sucedem-se manifestações de alegria, e, quando Calígula cai doente, fazem-se, pela saúde do novo imperador, votos

162 Jul. 80.1: ne populo quidem iam praesenti statu laeto, sed clam palamque detrectante dominationem atque assertores flagitante.

163 Jul. 80.2-3: Brutus, quia reges eiecit, consul primus factus est: / hic, quia consules eiecit, rex postremo factus est. E Suetónio parece querer sublinhar intencionalmente a semelhança do nome com o de Marco Bruto, descendente daquele (cf. Plutarco, Brut.1), e de Décimo Bruto, pois os menciona logo a seguir como principes conspirationis, juntamente com Cássio (Jul. 80.4).

${ }^{164}$ Aug. 70.1-2. Os jogos de azar estavam proibidos em Roma, excepto durante as Saturnais. Vide NÉrAudau, J.-P. 1996, 113-114.

${ }^{165}$ Vit. 14.4. Recorde-se que os astrólogos lhe tinham já prognosticado um fim terrível desde o nascimento (Vit.3.2).

${ }^{166} \mathrm{Gal}$. 13. O passo é de difícil interpretação. Onesimus é emenda da lição corrupta dos códices, uenitione simus. Como diz o comentador Hofstee, C. 1898, 34-35, «et nomen Onesimi, a uerbo quod est ỏvıvával aptissimum est ad designandum hominem auarum». Mas também há quem leia uenit Dorsennus, ligando o conteúdo do verso transcrito à comicidade deste tipo da atelana: vide com. de Venini, P. 1977, 47. 
exagerados, que depois se hão-de revelar imprudentes, como combater na arena até à morte e oferecer, por escrito, a própria vida (Cal. 14.2). A ausência de reacções populares na segunda parte, parece resultar do facto de o monstrum afrontar acima de tudo a classe senatorial (Cal. 49.1). De forma semelhante, em resultado da boa actuação de Cláudio, a simples suspeita de que tinha sido assassinado provocou um levantamento popular que só acalmou quando foi confirmado que o imperador estava são e salvo (Cl.12.3). Mas, mais à frente, refere-se um panfleto difamatório a propósito da sua stulticia (Cl.38.3).

No que respeita à vida privada, Augusto é alvo de censura. Mas, no fim do elenco das actividades da vida pública, Suetónio faz saber que as qualidades do imperador lhe valem a estima geral e procura demonstrar que tal estima é sincera: Pro quibus meritis quanto opere dilectus sit, facile est aestimare. Omitto senatus consulta, quia possunt uideri uel necessitate expressa uel uerecundia (Aug. 57.1) («Devido a tais méritos, fácil é avaliar o quanto ele foi estimado. Deixo de parte os senato-consultos, porque podem parecer ditados pela obrigação ou pelo constrangimento»). As manifestações de apreço, donativos e honras culminam na atribuição do cognome de Patris patriae. ${ }^{167}$ A universalidade do reconhecimento público (Aug. 59-60) é depois apresentada em gradação (anónimos; nonnulli patrum familiarum; quaedam Italiae ciuitates; prouinciarum pleraeque e, por fim, reges amici atque socii), e engrandecida pela generalização: dizer que cada rei (singuli in suo quisque regno) fundou uma cidade com o nome de Cesareia parece exagero para acentuar a popularidade de Augusto. Além disso, Suetónio, ao dizer que os reis se apresentavam junto do imperador de toga (privilégio exclusivo daqueles a quem fora concedida a cidadania romana) e sem insígnias reais, parece concentrar em uma amálgama situações distintas, para, de forma «impressionista», como diz Gascou, melhor demonstrar "o quanto ele foi estimado". ${ }^{168}$ É já em contexto próximo da narrativa da morte, na viagem para Cápreas, que se insere um episódio que significa o reconhecimento do mundo ao poder de Augusto:

Forte Puteolanum sinum praeteruehenti uectores nautaeque de naui Alexandrina, quae tantum quod appulerat, candidati coronatique et tura libantes fausta omina et eximias laudes congesserant: "per illum se uiuere, per illum nauigare, libertate atque fortunis per illum frui' (Aug. 98.2).

«Quando atravessava, um dia, a baía de Putéolos, os passageiros e os tripulantes de um navio de Alexandria, que acabara justamente de aportar, vestidos de branco e coroados com grinaldas, não só lhe ofereceram incenso, como também o cumularam de bons augúrios e de extraordinários louvores: 'Por ele viviam, por ele navegavam; da liberdade e da felicidade por ele fruíam'».

${ }^{167}$ Aug. 58. Para obter o efeito, Suetónio não hesita em simplificar (não distingue entre as subscrições feitas para elevar estátuas a Augusto, e que ele usa para elevar estátuas aos deuses, e ofertas feitas em lugar das subscrições; não distingue entre o aureus que Augusto aceita de cada comunidade e o denário que aceita de cada pessoa) e generaliza as aclamações a partir de um facto único, como mostra Gascou, J. 1984, 206-241.

${ }^{168}$ Vide Gascou, J. 1984, 232-238; 240-241. 
Trata-se de uma cerimónia litúrgica, como se percebe pelo aparato (roupas, flores, incenso) e pelo ritmo da invocação. ${ }^{169}$ Suetónio apresenta agora Augusto como fonte de vida, de segurança no mar, de liberdade e de prosperidade. $\mathrm{O}$ seu culto estende-se ao Oriente. O imperador mostra-se comovido com estas manifestações e alarga-se em benesses.

O bom príncipe será aquele que, tal como Augusto, consegue a aprovação de todas as classes e de todo o Império. Por isso mesmo, mais significativas se tornam as reacções à morte. Por estas se pode deduzir quem eram as classes e os povos que mais odiavam ou amavam o imperador. A este respeito, o relato mais dramático e mais completo é a narrativa dos factos que se seguiram à morte de Júlio César. A abertura do testamento do ditador revela que entre os herdeiros estava Décimo Bruto, que o levara às mãos dos algozes, e o povo, que recebia bens públicos e uma quantia de dinheiro por cidadão (Jul. 83.2). No primeiro caso, acentua-se a ingratidão; no segundo, explica-se o sentimento de vingança de tão grande benfeitor, ${ }^{170}$ sem que Suetónio explicite a relação da causa-efeito entre a leitura do testamento e o desejo de vingança, como faz Plutarco (Caes. 68.1). Mas o resultado é curioso: César continua a subornar o povo, mesmo depois de morto. A ideia da ingratidão e da indignação é acentuada pelo aparato fúnebre, com exposição das roupas que César usava quando fora assassinado, e, sobretudo, por mais uma referência dramática:

Inter ludos cantata sunt quaedam ad miserationem et inuidiam caedis eius accomodata, ex Pacuui Armorum iudicio: 'men seruasse, ut essent qui me perderent?' et ex Electra Atili ad similem sententiam. Laudationis loco consul Antonius per praeconem pronuntiauit senatus consultum, quo omnia simul ei diuina atque bumana decreuerat, item ius iurandum, quo se cuncti pro salute unius astrinxerant; quibus perpauca a se uerba addidit. ${ }^{171}$

«Entre as representações se entoaram alguns cantos apropriados à deploração da morte e ao ódio contra os assassinos: do Julgamento das Armas de Pacúvio, 'E havia de ser eu a salvá-los, para haver quem me assassinasse?' e da Electra de Atílio, algo com a mesma intenção. Em lugar do elogio fúnebre, o cônsul António, pela voz de um arauto, pronunciou o senato-consulto, com o qual se

${ }^{169}$ Segundo RoccA-SerRA, G. 1974, 671-680, podemos perceber a expressão de um credo religioso e político que retoma um dos temas da propaganda de Augusto (a paz universal e a segurança dos mares) e que subentende a assimilação do príncipe a Júpiter, como causa última. $\mathrm{O}$ texto provirá de uma fonte em grego de origem egípcia, talvez Asclepíades de Mendes, já citado em 94.4. Para Benario, H. W. 1975, 84, é um exemplo da afeição e aprovação generalizada do Império à obra de Augusto e à estabilidade do governo proposta em Aug. 28.2.

${ }^{170}$ Vide Canfora, L. 2000, 373.

171 Jul. 84.2: pormenores não indicados por Plutarco; vide CANForA, L. 2000, 374-375. Quanto ao excerto de Pacúvio (Trag. 40): provavelmente faz parte de um lamento de Ájax, antes do suicídio, por ter sido privado do seu prémio, depois de ter salvo os Gregos no combate pelos barcos. Quanto ao passo da Electra, uma tradução da de Sófocles, seria provavelmente do lamento de Agamémnon; vide com. Butler, H. E. \& M. CAry 1927, 152. 
outorgavam a César todas as honras divinas e humanas, e ainda o juramento com o qual todos se tinham comprometido a velar pela segurança pessoal dele, ao que acrescentou, da sua lavra, muito poucas palavras».

Suetónio não cria grandes discursos, ${ }^{172}$ prefere sugerir o aspecto visual da cena. As manifestações de pesar, que Suetónio transmite (Jul. 84.4-5), mostram como e por quem César era amado. Perante a discussão (pars... pars...) que se gerou acerca da escolha do lugar para a cremação, apresenta-se uma reacção de estímulo-resposta (repente... confestimque) à iniciativa de dois desconhecidos que lançaram fogo ao leito fúnebre e desencadearam a elevação, de improviso, de uma pira junto aos rostra, onde o corpo tinha sido colocado (Jul. 84.3). É sintomático que os tocadores e actores dispam as roupas, que, retiradas do equipamento do triunfo, vestiram para a ocasião, e as lancem nas chamas; que os soldados veteranos lancem as armas e as matronas os seus ornamentos, bem como as bulas e togas pretextas dos filhos ( $\mathrm{Jul}$. 84.4). Ao luto se associaram também numerosos estrangeiros; significativos são os testemunhos de pesar dos Judeus (Jul. 84.5). ${ }^{173}$ As reacções à morte crescem de intensidade: de manifestações de dor passam a perigosa histeria colectiva. No quadro seguinte, de aspecto cinemático, temos a plebe em fúria a dirigir-se com archotes para as casas de Bruto e Cássio - César, que perdera atrás o apoio do populus (Jul.80.1), retoma-o, depois da morte, na plebs. ${ }^{174}$ A necessidade de uma vítima expiatória provoca o sinistro drama de Hélvio, linchado por ter sido confundido com seu homónimo Cornélio Cina, que, na véspera, pronunciara um violento discurso contra César. E, pormenor macabro mencionado apenas por Suetónio, levaram a sua cabeça pela cidade espetada na ponta de um pau. ${ }^{175}$ Neste sentido, a acção da multidão em fúria parece ser assimilada à das Ménades que, sob a liderança de Agave levam a cabeça de Penteu na ponta de um tirso (Eurípides, Bac. 1139 ss). Só este acto cruento aplacou a multidão, que segundo Suetónio depois erigiu uma coluna ao "Pai da Pátria". A reacção popular contribui, assim, para fazer esquecer as culpas de César e denota a controvérsia que existia em torno da sua figura.

No que se refere a Augusto, depois de indicar o local (uma curiosidade interessante: morreu no mesmo quarto do pai), a data e a hora da morte, a idade do defunto, Suetónio descreve as honras prestadas pelos decuriões das

${ }^{172}$ Contrariamente ao longo discurso de António indicado por Díon Cássio, 44.36-49; Plutarco, Brutus 20.4.; Ant. 14.6-7; e Apiano BC 2.20. Suetónio deve ter razão, pois até Cícero (Phil. 1.31-32 e Att. 14.10.1) louva António pela sua moderação no discurso. Além disso, Suetónio parece insistir em negar a versão do longo discurso ao empregar a palavra perpaucus, usada somente aqui. Mas a versão do inflamado discurso teve maior fortuna: em Shakespeare e nos filmes de Hollywood. Vide Liberanome M. 1968, 415; Lyons, M., \& Montgomery, H. C. 1968, 37-39; Baldwin, B. 1983, 233.

${ }^{173}$ César concedera-lhes vários privilégios por o terem ajudado na guerra de Alexandria: vide Canfora, L. 2000, 233-238.

${ }^{174}$ Pormenor semântico que, para BALdwin, B. 1983, 232, é uma marca da contaminação da visão de Tácito sobre o principado.

175 Jul. 85. Plutarco, Caes. 68. 3-7, desenvolve antes o processo que gerou a confusão de nomes e a morte do inocente. 
províncias, pelos cavaleiros e pelo senado (Aug. 100), mas não refere qualquer lamento popular, como fez com César. ${ }^{176}$ Esta pode ser a resposta à repetida inquietação de Augusto em saber se havia agitação. O povo, há muito tempo habituado à paz do novo regime, veria com naturalidade a morte do velho imperador. Suetónio opta pelo silêncio. É o final da biografia de um homem que compensou a crueldade da juventude com o comportamento posterior. As contas foram saldadas. E, segundo o testemunho de um pretor, a sombra de Augusto subiu ao céu, como já acontecera com a do pai adoptivo.

Pelo contrário, a reacção à morte de Tibério é uma explosão catártica: libertos do medo, os súbditos reagem finalmente com espontaneidade:

Morte eius ita laetatus est populus, ut ad primum nuntium discurrentes pars: 'Tiberium in Tiberim!' clamitarent, pars Terra matrem deosque Manes orarent, ne mortuo sedem ullam nisi inter impios darent, alii uncum et Gemonias cadaueri minarentur, exacerbati super memoriam pristinae crudelitatis etiam recenti atrocitate (Tib. 75.1).

«O povo ficou tão contente com a morte dele, que, mal chegou a notícia, correndo de todos os lados, uma parte gritava 'Tibério ao Tibre!'; outra parte rogava à Terra mãe e aos deuses Manes que lhe não concedessem assento senão entre os ímpios; outros ameaçavam o cadáver com o gancho e as Gemónias, exasperados pela recordação da antiga crueldade e da recente atrocidade».

É como se estas exclamações vingassem as atrocidades que cometera, pois os castigos requeridos são os que tradição propunha para os tiranos. Para agravar a ira popular, o vazio de poder fez com que alguns condenados fossem executados no interregno: creuit igitur inuidia, quasi etiam post mortem tyranni saeuitia permanente (Tib. 75.3) («aumentou então o ódio, pois era como se a crueldade do tirano permanecesse ainda depois da morte»).

Morto Calígula, o biógrafo toma a palavra, como raramente faz, para colocar a tónica na incerteza dos tempos: condicionem temporum illorum etiam per haec aestimare quiuis possit (Cal. 60) («a condição daqueles tempos cada qual a poderá julgar por estes acontecimentos»). De facto, as reaç̧ões são cautelosas. A insegurança continua a pairar e, consequentemente, a desconfiança: podia tratar-se apenas de mais uma farsa do imperador. Outra ideia é a da desilusão, expressa na vontade dos cônsules de apagar a memória dos Césares e restaurar a República.

A reacção à morte de Nero é paradoxal e mostra em que medida este imperador era, ao mesmo tempo, muito odiado e muito amado. Por um lado, o gaudium público, pela libertação do domínio do tirano. A plebe corre pilleata, isto é, com o barrete característico da libertação dos escravos e das Saturnais (Nero 57.1). Por outro lado, há manifestações secretas de pesar: deposição anual de flores sobre o túmulo; retratos nos rostra; promessas de retorno, em edictos, para ruína dos seus inimigos. De tal modo que, passados vinte anos,

${ }^{176}$ Vide Baldwin, B. 1983, 245-246. 
um falso Nero ainda teve grande acolhimento, sobretudo entre os Partos, o que revela a admiração que o Oriente lhe consagrava. ${ }^{177}$ Nero conseguiu, afinal, realizar a ambição de perpetuar a fama. E outros imperadores (Otão e Vitélio), no conturbado ano e meio que se segue, irão tentar imitar algumas acções deste príncipe, que, durante vários anos, seduziu o povo com os seus dotes de histriónicos.

Nas reaç̧ões à morte de Galba, é significativo que, depois das sevícias feitas à cabeça decapitada, só seja mencionada a resolução do senado, ao qual o imperador se ligou desde o primeiro momento (Gal. 10.1). Este conselho vota-lhe uma estátua no Foro, onde ele tinha morrido, mas Vespasiano anula o decreto, por julgar que Galba lhe enviara assassinos (Gal. 23).

De Vitélio não se referem reações à morte, uma vez que estas ficaram patentes durante o indigno linchamento deste imperador, acompanhado dos insultos da plebe ao cadáver e da efectivação do destino com que ameaçaram o de Tibério: foi arrastado com o gancho e lançado ao Tibre (Vit.17.2).

As reacções à morte de Domiciano contrastam com as manifestações de pesar pela morte de Tito. $\mathrm{O}$ povo acolheu com indiferença a notícia da morte do terceiro dos Flávios; os soldados, com agravo (quiseram inclusive vingá-lo); os senadores com tanta alegria, que correram para a Cúria, crivaram-no de injúrias e trataram de pôr em prática a damnatio memoriae. ${ }^{178}$

Verdadeiramente choradas são as mortes de Otão e de Tito; pelo menos na versão de Suetónio. Otão redime-se pela morte. A reaç̧ão dos soldados à sua morte é de histeria colectiva, semelhante às reacções dos fãs à morte de um chefe carismático, ou de uma estrela da música: por um lado, muitos dos presentes choram abundantemente, beijam-lhe as mãos e os pés; chamam-lhe fortissimus uir e unicus imperator e chegam ao ponto de se suicidarem junto à pira; por outro, muitos dos ausentes, ao receberem a notícia da morte, incapazes de conter a dor, lançam-se uns contra os outros para se matarem. ${ }^{179}$ A seguir, transmite Suetónio a reacção do público em geral: muitos dos que o haviam detestado em vida cumulavam-no agora de louvores. A morte corajosa faz esquecer os pecados da vida; e a cisão do duplo julgamento é, pelo elogio póstumo, anulada em favor da unidade da personagem. ${ }^{180}$ Perdoa-se-lhe a morte

177 Nero 57.2. Existem dois falsos Neros com cuja existência todos concordam: um em 69 e outro em 80, no principado de Tito. Suetónio indica aparentemente um terceiro em 88. Há quem pense que se trata de um erro e que Suetónio se referia ao do ano 80, de nome Terêncio Máximo, mas tal não se conforma com a expressão adulescente me, usada aqui pelo biógrafo (em 80, Suetónio teria apenas dez anos): vide Gallivan, P. A. 1973, 364-365; com. de Bradley, K. R. 1978, 294-295.

${ }^{178}$ Dom. 23.1. A indiferença do povo pode explicar-se pelo facto de ele não ter muito contacto com as massas. A história de Domiciano seria diferente se fosse escrita por militares: vide Амв rosio, F. G. D'1980 [1982], 238-239.

179 Otho 12.2. Quanto aos suicídios, Suetónio transforma em multi os quidam referidos

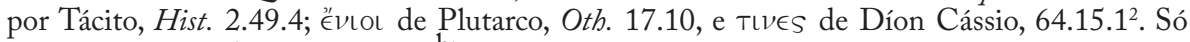

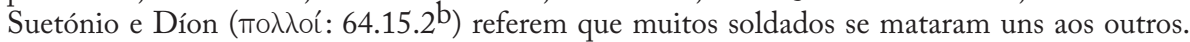
Vide Gascou, J. 1984, 313-314.

${ }^{180}$ Tácito, Hist. 2.50.1, diz que ele mereceu posteriormente uma fama tão boa como má; Plutarco, Oth. 18, diz que os que louvaram a morte não foram menos importantes nem menos 
de Galba pelo desejo de restituir a res publica ac libertas ao povo romano. ${ }^{181}$ É o reconhecimento universal, embora póstumo, de que estaria ali um bom imperador.

O prejuízo para os homens (bominum damnum) constituído pela morte de Tito é encarecido pelo sentimento que envolve as reacções populares e pela sinceridade da dor dos cidadãos. Prova disso é a equiparação do luto público com o luto familiar, a convergência dos senadores para a cúria antes de serem convocados oficialmente e o facto de o senado lhe dar mais graças e louvores morto do que quando estava vivo e na sua presença. ${ }^{182} \mathrm{O}$ engrandecimento do lamento fúnebre e dos elogios, no momento da sucessão, sugere que Domiciano não seria desejado: pelo confronto, tudo o que Tito ganha é o que Domiciano, desde já, perde. Mas o contraste é ainda maior quando se comparam as reacções à morte dos dois irmãos.

As Vidas dos Césares não terminam simplesmente com o anunciado castigo da saeuitia e da cupiditas do último dos Flávios. Depois de tantos horrores, que o biógrafo procurou salientar, por vezes morbidamente, ao longo das Vidas, o final é catártico e bastante optimista: os crimes são castigados; o bem triunfa. Poucos meses antes da morte do imperador, uma gralha, no Capitólio, disse, em grego, que tudo estava bem, e logo houve quem interpretasse que a ave só poderia ter dito que tudo «iria estar bem». ${ }^{183}$

Se Domiciano representa o regresso à tirania, ele é também, para Suetónio, o último dos tiranos. Além disso, o biógrafo indica, através de um sonho de Domiciano, as virtudes que presidirão a um beatior laetiorque rei publicae status: a abstinentia e a moderatio (Dom. 23.2). Com este final, Suetónio retoma a história no preciso momento em que a deixara ao fazer a súmula introdutória às vidas dos Flávios, quando dissera que Domiciano fora castigado pelos vícios contrários: cupiditas e saeuitia. ${ }^{184}$ Sem aquelas virtudes (a abstinentia e a moderatio), os méritos que existam são inoperantes ${ }^{185}$ - será esta a simples

numerosos do que os que censuraram a vida. Díon Cássio, 64.15.2, diz que a morte obscureceu a impiedade e perversidade. Só Suetónio fala de quase unanimidade (magna pars hominum) no póstumo louvor de Otão. Vide Gascou, J. 1984, 312. O desejo de restaurar a República faculta a absolvição do defunto através de um ideal político que, embora não seja o do biógrafo, salva moralmente Otão: Vide Gascou, J. 1984, 776-777.

${ }^{181}$ Nenhum dos outros autores menciona tal facto.

182 Tit. 11: Quod ut palam factum est, non secus atque in domestico luctu maerentibus publice cunctis, senatus prius quam edicto conuocaretur ad curiam concurrit, obseratisque adhuc foribus, deinde apertis, tantas mortuo gratias egit laudesque congessit, quantas ne uiuo quidem umquam atque praesenti. Tal como no final da Vida de Otão, há, no final da Vida de Tito, uma espécie de reconciliação popular com os seus actos, como nota Vidal SÁnchez, J. M. 1989, 332.

${ }^{183}$ Dom. 23.2: Nuper Tarpeio quae sedit culmine cornix / 'est bene' non potuit dicere, dixit 'erit'.

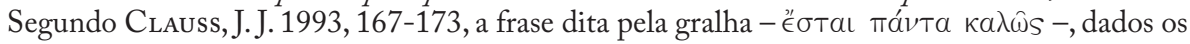
requisitos métricos, poderia ser uma reminiscência literária de um poema de Calímaco, Hecale, onde também aparece uma gralha. A semelhança de Domiciano com a infortunada gralha de Calímaco é que esta perde o favor de Atena e é substituída pelo mocho, como Domiciano perde o favor de Minerva. A gralha de Calímaco pronuncia a frase para o seu sucessor e o carácter auspicioso da mensagem fez com que a frase tivesse muitos imitadores.

${ }^{184}$ Ves. 1.1: ... constet licet Domitianum cupiditatis ac saeuitiae merito poenas luisse.

185 Como afirma Gascou, J. 1984, 784-785. Segundo este autor, é para a exaltação dos 
moralidade da História. Trata-se do restabelecimento do equilíbrio final. Tudo está bem, como diz a cornix, quando acaba bem.

A morte e as informações subsequentes tem de ser consideradas no todo de cada Vida. O tipo de vida tende a determinar o género de morte e as cambiantes de comportamento continuam presentes no desfecho. Por vezes, uma informação final vem enriquecer a personagem. A ligação entre a vida e a morte contribui para aproximar as narrativas de verdadeiros desenlaces trágicos. Mas, através do género de morte e das reacções subsequentes, Suetónio transmite implicitamente ao leitor o julgamento global sobre cada príncipe. A selecção que o biógrafo faz do material que lhe chegou obedece, em grande parte, a uma imagem de referência (mais ou menos idealizada) e tem, por isso, uma intenção moralizante. Assim, se quisermos falar de uma "catarse" nas Vidas, temos de a afastar do sentido aristotélico, para a centrar na relação entre as emoções que os actos do imperador provocam no leitor e o tipo de desfecho que determinado comportamento acarreta.

Antoninos que se encaminha a concepção do principado presente na obra de Suetónio. 


\section{Do teatro dos Césares ao teatro de Suetónio}

Os espectáculos têm larga representação nas Vidas dos Césares e, entre estes, o teatro é rei. Muito de teatral se deduz da actuação dos imperadores, com o intuito político de criar uma imagem positiva junto dos súbditos. A tónica colocada na capacidade de dissimulação de alguns príncipes põe em evidência a sua faceta de actores e permite explicar o começo favorável dos principados de Tibério, Calígula, Nero e mesmo Domiciano. Mas, abandonada a máscara, os maus imperadores mostram-se inventivos e requintados nos seus vícios, sobretudo na crueldade, na devassidão e na sumptuosidade. Os mais espectaculares são Calígula e Nero. Parece existir entre a cena e a vida destes uma interpenetração que é, contudo, mais notória na Vida de Nero. ${ }^{1}$ Mas a mentalidade romana tradicional não tolera que se tornem eles próprios histriões e ponham em risco a dignitas romana.

Em jeito de síntese do que temos vindo a analisar nesta segunda parte, debruçamo-nos agora sobre o efeito teatral que o próprio biógrafo parece buscar nas Vidas na sua procura de dar verosimilhança à imagem que pretende transmitir de cada príncipe. A forma dada ao texto mostra que o biógrafo não pretende apenas delectare, mas também mouere e docere.

Por um lado, Suetónio procura acentuar as mudanças inesperadas da Fortuna: um imperador mau que se torna bom, ou um bom que se torna mau; os obstáculos inesperados; os acontecimentos que podem fazer perigar um destino. Por outro, dramatiza determinados acontecimentos na mira de salientar traços do carácter. Se se fala da presença da "história trágica" de influência helenística, ${ }^{2}$ e até romana, em Tácito ${ }^{3}$ e em Plutarco ${ }^{4}$, também, com as devidas reservas impostas pelo estilo, é possível encontrar esse conceito no texto de Suetónio. Além de figurarem nas Vidas várias citações trágicas, certos episódios dos Césares assumem enredos ou características da tragédia. Antes de mais, tal como a tragédia, a biografia representa as acções de homens esforçados, ${ }^{5}$ que, muitas vezes, têm um fim desafortunado. Suetónio não tem como objectivo principal uma indagação rigorosa dos factos históricos, com as suas causas e consequências, mas, tal como Plutarco, apresenta um processo de construção de uma personalidade que se destaca do género histórico-narrativo para se aproximar da representação dramática da vida humana. ${ }^{6} \mathrm{~A}$ forma da biografia, construída em função do seu núcleo substancial, confere-lhe uma certa unidade

${ }^{1}$ Vide Dupont, F. 1985.430 ss.

${ }^{2}$ A distinção aristotélica (Po. 1451a 36-1451b 11) entre história e tragédia - de que a história trata do particular e a poesia do geral; a história do que aconteceu e a poesia do que poderia ter acontecido - é, geralmente, desrespeitada pelos historiadores, que preferem seguir a orientação de Isócrates, como demonstra Ullman, B. L. 1942, 25-53.

${ }^{3}$ Vide Foucher, A. 2000, 773-801; Malissard, A. 1990, 213-222.

${ }^{4}$ Vide Tagliasachi, A. M. 1960, 125-142.

${ }^{5}$ Cf. Aristóteles, Po. 1449b 9-10. Como diz Foucher, A. 2000, 777, «Or la tragédie est aussi la représentation des actions des grands hommes, dans une forme littéraire qui revêt la même unité que la biographie, laquele fédère une pluralité d'événements».

${ }^{6}$ Como afirma, a propósito de Plutarco, Tagliasachi, A. M. 1960, 131-132. 
de acção, ${ }^{7}$ não pelo facto de se tratar de uma só pessoa, ${ }^{8}$ mas porque Suetónio selecciona os factos em função da imagem do césar que quer transmitir e omite até acontecimentos importantes (sobretudo quando o biografado não participa directamente nessa acção) na procura de delinear um percurso definido em vista de um fim. Podemos encontrar uma progressão para a catástrofe nas mortes de César, de Calígula, de Nero e de Domiciano, mas também na de Galba, de Otão, de Tito e até na de Vitélio (Vit. 15). Também cada ciclo de $V i d a s$ tende para a um fim de algum modo anunciado, constituído, no ciclo dos Júlio-Cláudios, pela Vida de Nero; no dos três imperadores efémeros de 68-69, pela Vida de Vitélio; e, no dos Flávios, pela Vida de Domiciano.

A biografia, enquanto imitação da vida, pode relacionar-se com o conceito aristotélico de mimese da praxis, isto é dos homens em acção, ${ }^{9}$ por intermédio da qual o herói recebe os caracteres. ${ }^{10} \mathrm{E}$ a acção leva-o à felicidade ou infelicidade. ${ }^{11}$ Tendo em conta que, segundo Aristóteles, é mais trágica a passagem da felicidade à infelicidade, ${ }^{12}$ vários são os exemplos em que a acção dos protagonistas das Vidas se conforma com esse modelo. Mas, em Suetónio, a ruína parece ser resultado, em grande parte, de uma culpa, ${ }^{13}$ não tanto no sentido aristotélico de hamartia, ${ }^{14}$ mas, de modo mais restrito, em sentido de vício caracterológico: é que, do homem em acção o biógrafo deduz o carácter; e os caracteres assumem a designação das virtudes romanas do mos maiorum e dos vícios a elas opostos. ${ }^{15}$ Neste sentido, por influência da mentalidade romana, estabelece-se uma ligação entre o discurso intrinsecamente moralizador, que acentua virtudes e vícios, e o fim que Aristóteles atribuía à representação trágica - katharsis pathematon - se restringirmos esta noção a um valor moral. ${ }^{16}$

César, Calígula, Nero, Vitélio e Domiciano são as figuras mais trágicas das Vidas, pela magnitude, em sentido negativo, das suas acções: em comum, reúnem uma série de violações de leis divinas e humanas. O conceito de impietas aparece nas suas várias dimensões. Em relação aos deuses surge, antes de mais,

${ }^{7}$ A única recomendada por Aristóteles, Po. 1450a 24ss; 1451a 16ss; 1459a 17ss; vide Tagliasachi, A. M. 1960, 134-135.

${ }^{8}$ Tal não serve para conferir unidade de accção, como nota Aristóteles, Po. 1451a 16-17.

${ }^{9}$ Cf. Aristóteles, Po.1450b 3-4. Vide Fialho, M. C. 1977, 385.

${ }^{10}$ Cf. Aristóteles, Po. 1454a 16-20; 33-36.

${ }^{11}$ Cf. Aristóteles Po. 1450a 15-22. Vide Fialho, M. C. 1977, 381.

${ }^{12}$ Cf. Aristóteles, Po. 1453a 25ss.

${ }^{13}$ Segundo Tagliasachi, A. M. 1960, 138-141, o conceito de culpa moral ocorre em Plutarco e é justificado por alguns exemplos da tragédia ática, por exemplo, Ésquilo.

${ }^{14}$ Po. 1453a 3-12. Mas Fialho, M. C. 1977, 384, nota que a identificação de hamartia com culpa se deve sobretudo aos autores cristãos que a traduzem por peccatum.

${ }^{15}$ César é iure caesus por ambicionar honores nimii (Jul.76.1); Calígula é assassinado porque se tornara o monstro insuportável (Cal.56.1); Nero é destituído pelo terrarum orbis por causa dos probra e scelera (Nero 40.1); os actos de crueldade e de avareza de Galba ofendem todas as ordens (Gal.16.1) e precipitam a sua morte (Gal.17); Domiciano, cruel e rapace, torna-se odioso e é suprimido (Dom. 14.1); Vitélio é conduzido ao seu destino pelos actos de gula e de crueldade gratuita.

${ }^{16}$ Como afirma Foucher, A. 2000, 778. 
o desprezo da religião tradicional. ${ }^{17}$ Alguns carregam a culpa de bybris: Júlio César aceita, em vida, honras que ultrapassam a condição humana (Jul. 76.1), - de certo modo, cede à tentação da passadeira de púrpura de Agamémnon, sinal da arrogância dos tiranos. ${ }^{18}$ Estes mostram actos de impiedade em relação à pátria.$^{19} \mathrm{E}$ a impietas em relação aos familiares está largamente representada: parricídio, ${ }^{20}$ matricídio, ${ }^{21}$ fratricídios, ${ }^{22}$ morte de outros familiares, ${ }^{23} \mathrm{o}$ desrespeito pela memória dos antepassados. ${ }^{24}$

As uniões criminosas pertencem à tradição trágica do anosios gamos. ${ }^{25}$ Entre estas estão os incestos de Calígula, com a irmã Drusila, a quem tratava como iusta uxor (Cal.24.1); de Nero com a mãe (Nero 28.2), de Domiciano com a sobrinha, filha de Tito (Dom. 22), e de Cláudio com Agripina, embora esta última união fosse ratificada pelo senado como razão de Estado. ${ }^{26}$ Semelhante é a impiedade da violação da vestal Rúbria por Nero (Nero 28.1). ${ }^{27}$

Os imperadores pérfidos não se apresentam como figuras trágicas por terem um fim infeliz - tal provoca apenas sentimento de justiça realizada, ${ }^{28}$ mas pelas circunstâncias que envolvem a sua actuação e pela forma como se tornam, eles mesmos, vítimas do próprio carácter. O Tibério suetoniano parece ter consciência desta realidade: o seu carácter é o destino a que não pode fugir.

O destino e a sorte (tyche) fazem-se presentes num plano paralelo à ideia do mérito ou da culpa pessoal. Tito diz que o império é um dom do fatum (Tit. 9.1), e a sua popularidade é atribuída à Fortuna, a par do ingenium e da ars (Tit. 1). Augusto tem tanta confiança no seu fatum que publica o horóscopo (Aug. 94.12); Tibério confia em que tudo é governado pelo fatum (Tib. 69). A morte de Gaio e de Lúcio é atribuída por Augusto à atrox fortuna (Tib. 23). É a Fortuna que destrói a disciplina da casa de Augusto e provoca a desonra das duas Júlias e Agripa Póstumo (Aug. 65.1). Também Nero, na fase inicial,

${ }^{17} \mathrm{O}$ desprezo ou negligência dos deuses e dos auspícios. Jul. 59; Jul. 81.4; Tib. 69.1; Cal. 51.1; Nero 56; Vit.11.2 e 15.3. Atitudes ímpias: Nero 32.4; Tib. 61.5.

${ }^{18}$ Cf. Cal. 22; Nero 53; Vit. 10.3; Dom. 13.

${ }^{19} \mathrm{O}$ próprio Júlio César sugeria, citando um verso de Eurípides, que valia a pena violar a eusebeia para satisfazer a sua ambição de reinar (Jul. 30.5). Cf. Cal. 31; Nero 38; Vit. 10.3; 11.1; 15.3; Dom. 2.3.

${ }^{20}$ Perpetrado por Nero, na pessoa de Cláudio, pai adoptivo (Nero 33.1), e por Calígula, na pessoa de Tibério (Cal.12).

${ }^{21}$ Nero 34.1-4; Vit. 14.5. Tibério trata Lívia impiamente (Tib. 50.2-51).

${ }^{22}$ Cal.23.2; Nero 33.2; Dom. 2.3. Tibério revela ódio ao irmão Druso (Tib. 50.1).

${ }^{23}$ Tib. 52.3; Tib. 53; Tib. 54; Vit. 6, Nero 35.5.

${ }^{24}$ Cal. 23; Cl. 45; Nero 33.1.

${ }^{25}$ Vide Foucher, A. 2000, 788.

${ }^{26}$ Relação contra fas, considerada incesto, como se verifica na relutância que gerou: ... talium coniugiorum, quae ad id tempus incesta babebantur (Cl. 26.3); Ducturus contra fas Agrippinam uxorem (Cl.39.2).

${ }^{27}$ Também nesta categoria se podem incluir, do ponto de vista da moral romana, os casamentos ilícitos por arrebatamento de esposas a outros maridos: Cal. 25; Nero 35.1; Dom. 1.3 .

${ }^{28}$ Cf. Aristóteles, Po. 1453a 1-4. A situação menos trágica seria os pérfidos passarem de uma situação de infelicidade à de felicidade. 
confessa que o seu sucesso depende da Fortuna (Nero 23.3). É significativo o relevo que Suetónio dá a certas coincidências. Nero: recebe a notícia da revolta da Gália no mesmo dia em que, anos atrás, mandara assassinar a mãe (Nero 40.4); e morre no mesmo dia em que outrora Octávia fora morta por sua ordem (Nero 57.1). ${ }^{29}$ Uma palavra que sugere este género de tragédias é casus. ${ }^{30}$ Neste sentido se refere o casus dos assassinos de César (Jul. 89); o casus de Lúcio, o neto de Augusto adoptado pelo imperador (Aug. 65.2); o casus dos familiares de Calígula, mortos no principado de Tibério (Cal.10.2); o casus do astrólogo Ascletarião, desmembrado, como previra, pelos cães (Dom. 15.3). Com estes e muitos outros exemplos, Suetónio mostra como a história destes Césares é trágica. A forte presença quer do fatum, quer da vontade dos deuses faz-se sentir através da insistência em oráculos de renome, profecias e numerosos sinais ominosos de toda a espécie, prenúncios de felicidade ou desgraça. Estão presentes famosos oráculos. ${ }^{31}$ Perante estas forças os imperadores mais arrogantes têm de capitular. ${ }^{32}$

Há uma série de imperadores que aparecem, desde o início, predestinados para uma missão elevada. Júlio César, junto ao templo de Hércules em Gades, chora perante uma estátua de Alexandre. Este episódio é a mola que desencadeia a acção para maiores empresas. ${ }^{33} \mathrm{~A}$ missão sacrossanta de Augusto é indiciada, logo ao nascimento, pela religio, fonte de horror, que se manifesta na expulsão de um insolente do aposento onde Octávio nasceu (Aug. 5). Augusto teria profetizado o poder supremo a Galba, ainda menino; e, por Tibério, se fica a saber que só em idade avançada chegará ao império, prognóstico que lhe valeu não ser eliminado (Gal. 4.1). De Vespasiano Suetónio salienta que, apesar da origem humilde da família, representa a segurança do Estado (Ves. 1.1). De Tito diz o biógrafo, logo na frase de abertura, que é amor ac deliciae generis bumani (Tit.1). A origem humilde acentua o mérito pessoal da ascensão: a modéstia do lugar de nascimento é um dado comum aos bons imperadores: Augusto,

${ }^{29}$ Mas existem muitas outras. No final da Vida de Calígula, tira-se a conclusão de que todos os Césares, cujo primeiro nome seja Gaio, morrem assassinados (Cal. 60); Calígula sugere para o filho de Agripina o nome do tio Cláudio, como de facto aconteceu mais tarde por adopção (Nero 6.2); é considerado praesagium insequentis casus o facto de Galba ter exercido o consulado entre o do pai de Nero e o do pai de Otão, tal como depois ele mesmo sucedeu a Nero no poder e foi substituído por Otão ( $G a l$. 6.1). Cláudio nasceu em Lugduno no mesmo dia em que, pela primeira vez, foi dedicada a Augusto uma ara naquela cidade (Cl.2.1). É com uma cronologia forçada, e contraditória em relação às informações posteriores (Tit. 11), que Suetónio situa o nascimento de Tito três dias antes das calendas do insignis annus da morte de Calígula (Tit. 1). Outras coincidências marcam a vida de Tito: toma Jerusalém no dia do aniversário da filha (Tit. 5.2) e faleceu na mesma uilla do pai (Tit.11).

${ }^{30}$ Vide Foucher, A. 2000, 786.

${ }^{31}$ Estrangeiros, como o de Apolo, em Delfos (Nero 40.3), o de Vénus Páfia, em Cipro (Tit. 5.1), o do Carmelo, na Judeia (Ves. 5.6); e também itálicos, como a Fortuna de Âncio (Cal.57.3), a Fortuna de Preneste (Dom. 15.2), e o oráculo de Gérion, perto de Patávio (Tib. 14.3).

${ }_{32}$ Tib. 63.1; Dom. 15.3; Cl. 29.3.

${ }^{33} \mathrm{Jul}$. 7.1: missionem continuo efflagitauit ad captandas quam primum maiorum rerum occasiones in urbe. Neste contexto coloca Suetónio o sonho da violação da mãe (Jul. 7.2). 
Vespasiano e Tito. ${ }^{34}$ César, Augusto, Vespasiano e Tito serão contados no número dos deuses e recebem, por mérito próprio, o título de diuus.

Já o diuus Cláudio apresenta uma série de contrastes: parece um predestinado, como denotam as palavras da sua irmã Livila (Cl. 3.2) e os presságios favoráveis no início do seu consulado ( $C l .7)$, mas não reúne condições, uma vez que a debilidade do corpo e da mente lhe não permitem exercer ofício público ou privado $(C l$. 2.1). A própria mãe o classifica de portentum hominis (Cl.3.2) e as palavras de Augusto, longamente transcritas (Cl. 4), deixam claro, por um lado, a vergonha para a família e, por outro, as capacidades literárias do futuro imperador.

Calígula, Nero, Vitélio e Domiciano aparecem, desde o início, fadados para a desgraça. Calígula, que é, nas palavras pressagas de Tibério, uma Hidra e um Faetonte (Cal. 11), revela-se, na verdade, um monstrum insanum, que é necessário abater. O próprio pai de Nero confessa que dele próprio e de Agripina não podia nascer senão algo detestável e destinado à calamidade pública; e é sinal da futura infelicitas uma resposta de Calígula, que, solicitado pela irmã a atribuir um nome ao filho, lhe sugere, por brincadeira, o de Cláudio (Nero 6.2). Nero é perseguido por fatales mali (Nero 40.2), identificado com Orestes ou Alcméon (Nero 39.2) ou Édipo (Nero 46.3), e ele próprio tem consciência de que é um sceleratus e sente que, por isso, lhe é vedado o acesso aos mistérios de Elêusis (Nero 34.4). O destino adverso de Vitélio é conhecido desde o nascimento ( $V i t$. 3.2). No entanto, mostra-se cego para os sinais de desgraça que sobre ele pairam (Vit. 8.2; 9). Domiciano conhecia o dia, a hora e o género de morte desde o tempo em que era adulescentulus (Dom.14.1). A imagem deste imperador é negativa desde o primeiro momento: passou os primeiros tempos da juventude em grande inopia e infamia (Dom. 1.1). Também Otão, nos começos, parece indiciar que será um tirano semelhante a Nero, de quem é cúmplice nas relações carnais (Otho 2), no matricídio e na partilha de Popeia Sabina (Otho 3). Mas esta é a única Vida onde as observações iniciais acabam por ser enganosas, pois o verdadeiro carácter só se manifestará no miraculum da morte.

A Vida de Tibério sugere, logo de início, uma tendência para a misantropia e para a avareza (Tib. 7.1). Parecem ter influído na personalidade de Tibério a separação forçada de Agripina, filha de Agripa, e o infeliz casamento com Júlia (Tib. 7.2-3), um drama que poderá explicar o afastamento para Rodes (pelo menos o taedium em relação a Júlia é uma das explicações apresentadas) (Tib. 10.1) - sintoma da tendência para o isolamento que se concretizará mais tarde no retiro para a ilha de Cápreas.

A mudança na orientação dos presságios introduz a ideia da mudança no favor divino. Além disso, os presságios de morte de Calígula e Nero não se limitam a anunciar o fim, mas alguns deles sugerem vingança divina (Cal. 57; Nero 46.1.). A perseguição das Fúrias, evocação da Oresteia de Ésquilo,

\footnotetext{
${ }^{34}$ Aug. 6: Nutrimentorum eius ostenditur adhuc locus in auito suburbano iuxta Velitras permodicus et cellae penuariae instar, Ves. 2.1: Vespasianus natus est in Sabinis ultra Reate uico modico; Tit. 1: prope Septizonium sordidis aedibus, cubiculo nero perparuo et obscuro.
} 
está representada, de modo explícito, nos remorsos de Calígula, Nero, Otão. ${ }^{35}$ Para afastar o mal, são necessários sacrifícios expiatórios. Nero tenta aplacar os Manes de Agripina (Nero 34.4); Otão, os de Galba (Otho 7.2); Galba procura em vão reconquistar o favor da Fortuna com um sacrifício expiatório ( $G a l$. 18.2). Por vezes, as próprias execuções se transformam em rituais de expiação (Nero 36.1). Outras vezes, o ritual visa cumprir uma vingança ou um voto. ${ }^{36}$ Calígula vai mais longe: exige o cumprimento dos votos que se fizeram pela sua saúde (Cal.27.2); outras vezes transforma as execuções em rituais absurdos, não explicáveis por uma lógica humana civilizada. ${ }^{37}$

A crueldade dos imperadores, com as suas inevitáveis consequências, gera argumentos de tragédia em sentido lato. Tibério, Calígula, Nero, Vitélio, Domiciano tornam-se poluídos com o sangue das vítimas. Mas também os imperadores bons cometeram atrocidades em uma ou outra fase da sua vida. As de Augusto encontram-se na mocidade. O principado de Vespasiano é manchado pela execução de Helvídio Prisco (Ves. 15). Tito, enquanto regente do pai, mostra-se demasiado cruel (Tit. 6.1). Há pequenas unidades com tragédias individuais, como a história da filha e da neta de Augusto e de Agripa Póstumo (Aug. 65), de Germânico (Tib. 52; Cal.5-6), da esposa Agripina (Tib. 53) e da filha do mesmo nome (Nero 34), de Britânico (Nero 33.2; Tit.2) e de Berenice (Tit. 7.1-2), de Octávia, filha de Cláudio. ${ }^{38} \mathrm{~A}$ história (não atestada em outra fonte) da nobre Malónia, que, ao ver-se perseguida pelos instintos libidinosos de Tibério, se trespassa com um punhal (Tib.45), retoma a tragédia da virtuosa Lucrécia.

Há nas Vidas uma procura de tocar o leitor, através do apelo à comiseração e ao horror. ${ }^{39}$ Provoca-se a simpatia pelo encarecimento da clemência para além do que se esperaria, de que é exemplo a comovedora reacção de Tito às conjuras do irmão (Tit. 9.3). Os factos que envolvem a morte imerecida deste imperador estão imbuídos de uma atmosfera emotiva. Pelo contrário, o carácter hediondo dos crimes de Tibério, Calígula, Nero e Domiciano gera indignação e horror. Neste caso, o phobos resulta, não tanto do facto de o leitor

${ }^{35}$ Nero é atormentado, depois da morte de Agripina, pelo fantasma da mãe e pelas tochas ardentes das Fúrias: Nero 34. 4; cf. Nero 46.3; Otho 7.2; Cal.50.3; Dom.16.1.

${ }^{36}$ Augusto envia para Roma a cabeça de Bruto, para a lançar aos pés da estátua de César (Aug. 13.1); e, nos idos de Março, imola, hostiarum more, num altar erigido ao divino Júlio, trezentos dos vencidos de Perúsia (Aug. 15); um liberto compra a cabeça de Galba e lança-a no lugar onde o seu patrono foi morto por ordem daquele imperador (Gal.20.2).

${ }^{37}$ É o caso do sacrifício de Colósseros (Cal. 35.2). Certa vez, imola o sacrificador, em vez da vítima (Cal. 32.3). Parece tratar-se de restauração de ritos arcaicos. Vide VEYne, P. 1983, $18-25$.

${ }^{38}$ Nero 35.1-2. Uma narrativa mais longa é apresentada por Tácito, Ann. 14.60-64. Britânico e Berenice serviram de argumento para tragédias de Racine; Octávia é a protagonista da tragédia homónima, que alguns autores atribuem a Séneca.

${ }^{39}$ Cf. Aristóteles, Po. 1449b 27. Como afirma Fialho, M. C. 1997, 380, “O éleos kai phobos que Aristóteles apresenta como objectivo a atingir no espectador pela tragédia, tal como a catarse, qualquer que seja a sua natureza, baseiam-se, afinal, nessa possibilidade de comunicação profunda espectador-aç̧ão dramática que o atinge e por que se sente afectado"; vide ainda n. 14 do mesmo artigo. 
se identificar com a situação final do protagonista, mas de sentir que pode vir a encontrar-se subjugado a um imperador semelhante a um destes - pelo que tal sentimento é purgado com a justiça restabelecida no momento da morte.

Os elementos trágicos pertenciam ao substrato cultural em que o erudito Suetónio se movia e seriam até lugares-comuns difíceis de evitar. Mas há, evidentemente, objecções à visão trágica da biografia suetoniana: o estilo desadornado, o realismo de situações sórdidas e o recurso à obscenidade elementos que Tácito evita. O biógrafo, que presta especial atenção à vida sexual dos imperadores, mostra o seu realismo, nas situações mais sórdidas, e a vernaculidade, sem evitar palavras e situações obscenas, ${ }^{40}$ próprias da tradição da comédia. O biógrafo serve-se, por vezes, da deformação cómica na caracterização de um imperador. ${ }^{41}$ Tal processo é visível na ascensão de Cláudio ao trono e na inversão de papéis que se verifica em toda a vida desta personagem, caricaturada como um senex de comédia, dominado pelas mulheres e pelos libertos. Em Vespasiano, pelo contrário, a comicidade é usada para favorecer a imagem do imperador: torna-se simpática ao leitor uma personagem que mantém o humor até à hora da morte (Ves. 23.4). ${ }^{42}$

Mas também se podem fazer objecções a uma abordagem cómica das Vidas: o cómico não se coaduna com a majestade da função do príncipe; com o resultado funesto dos actos; com o derramamento de sangue. $\mathrm{O}$ facto de Cláudio ser imperador produz um efeito que está para além dos seus actos mais cómicos. ${ }^{43}$ Assume contornos de tragicomédia a já referida anedota, não atestada em outras fontes, do conluio de Messalina e Narciso na morte de Ápio Silano. ${ }^{44} \mathrm{O}$ realismo, a obscenidade, o sangue em cena são situações que se aproximam mais do enredo de um género que teve ampla difusão no início do império e que retoma, entre outros, alguns argumentos da palliata: o mimo. Não é de excluir que Suetónio sofra influência de um género tão popular e que parece ter afinidades com os objectivos do biógrafo. ${ }^{45} \mathrm{~A}$ sugestão do mimo figura algumas vezes em Suetónio. ${ }^{46} \mathrm{O}$ arquimimo predominava, de um modo individualista, sobre os outros actores (actores secundarum, tertiarum, quartarum) - também nas Vidas predomina a figura do biografado e são

${ }^{40}$ Cf. Aug. 69.2; Cal. 56.2.

${ }^{41}$ A comédia apresenta os homens piores do que eles são: cf. Aristóteles, Po. 1448a 17.

${ }^{42}$ De resto, o próprio Vespasiano usava o humor com esse objectivo: para quebrar a tensão gerada pelas formas pouco ortodoxas de conseguir rendimentos (Ves. 23.1).

${ }^{43}$ Como afirma Guastella, G. 1999, 43-44.

${ }^{44} \mathrm{~A}$ imperatriz e o liberto congeminam a perdição de Ápio Silano, com base num sonho inventado, em que o senador atentava contra a vida de Cláudio. E, no final, o imperador enganado ainda agradece, no senado, a dedicação do liberto que até a dormir velava pela sua segurança (Cl. 37.2).

${ }^{45}$ Segundo Dupont, F. 1985, 298, «L'existence de mimes à Rome, non seulement au théâtre mais dans plusieurs secteurs de la vie serait à elle seule l'objet d'une longue étude qui traverserait toute la civilizasation romaine».

${ }^{46}$ No final da Vida, Augusto pergunta se representou bem o mimum uitae (Aug. 99.1). E o biógrafo classifica explicitamente determinadas cenas como mimi - a assunção do poder por Tibério (Tib. 24.1); as manobras militares orientadas por Calígula na campanha da Germânia (Cal.45.2); a disputa erótica que envolve Nero, Popeia e Otão (Otho 3.2). 
omitidas personagens ou factos que lhe não digam directamente respeito. Das palavras de Augusto no leito de morte se pode tirar a ilação de que o imperador representa, na $V i d a$, o que o arquimimo representa na cena: o imperador é o arquimimo do mimus uitae. No funeral de Vespasiano, cabe ao arquimimo Fávor o papel de representar o falecido imperador (Ves. 19.2).

Suetónio tem em comum com o mimo o realismo. Foi de tal modo sangrenta a cena do mimo intitulado Lauréolo, que esta representação foi considerada um presságio da morte de Calígula (Cal.57.4). O facto de o actor de mimos estar liberto da máscara permitia-lhe usar a expressão facial. ${ }^{47} \mathrm{O}$ mimo tem como elemento principal a mimese, a imitação realista. Neste género, o conteúdo da mimese é a vida, no que ela encerra de lícito e ilícito, ${ }^{48}$ objecto que oferece clara semelhança com a biografia suetoniana. Ora a imitação dos factos torpes, no mimo, implica ou sugere uma condenação moral..$^{49} \mathrm{O}$ arquimimo Fávor põe em evidência o principal defeito de Vespasiano - a avidez de dinheiro. Também nas Vidas suetonianas, a apresentação dos factos vis tem implicações morais enquanto exemplificação dos uitia. Em conexão com o predomínio do arquimimo, aparece a tendência etológica ou etopeica para a representação de caracteres, mais do que da acção, como é o caso das sententiae presentes nos mimos de Publílio Siro. ${ }^{50}$ Ora as vidas suetonianas subordinam as acções humanas (históricas ou anedóticas) à ilustração de vícios e virtudes, o que implica um juízo moral sobre o carácter do césar.

Um dos temas mais comuns do mimo era o sexo ou o amor, onde predomina, como típica, a obscenidade e o desafio às proibições: adultérios, homossexualidade, violência ${ }^{51}$ - elementos que abundam nas Vidas dos Césares. ${ }^{52}$ Algumas intrigas amorosas das Vidas assemelham-se a enredos de mimo. Cláudio, marido enganado, para afastar um suposto presságio, é levado a assinar as tabuinhas do dote do casamento de Messalina com o amante Sílio (Cl. 29.3). Picaresca e digna do Satyricon é a relação de Vitélio com o liberto Asiático, com uma fiada de depravações, desentendimentos e reconciliações (Vit. 12). Explicitamente classificado como mimo é o trio

47 Neste sentido se poderá entender o treino de expressões que Calígula fazia em frente ao espelho (Cal. 50.1). O facto de Nero se apresentar em público descalço (Nero 51), poderá ser uma generalização de Suetónio a partir de um papel de mimo representado pelo imperador histrião. Se é que planipes significa actuar descalço. Poderá também indicar, realmente, que não era usado nem o coturno nem o soco, mas um calçado simples, com sola rasa. De facto, este imperador pensava dançar o Turno de Virgílio, se sobrevivesse à revolta da Gália (Nero 54).

${ }^{48}$ Segundo a definição de Diomedes, no séc. IV, (Art. Gramm. Lib. III, p. 491 Keil); vide Giancotti, F. 1967 28; Panayotakis, C. 1995, xiii.

${ }^{49}$ Vide Giancotti, F. 1967, 27; 295; Dupont, F. 1985, 298. Panayotakis, C. 1995, xvii, observa que em alguns mimos se encontram cenas de sádica crueldade e obscenidade vulgar e que noutros há máximas de grande elevação moral.

${ }^{50}$ Como refere Giancotti, F. 1967, 34-35.

${ }^{51}$ Cf. Ovídio, Tr. 2.497-498: quid, si scripsissem mimos obscena iocantes, / qui semper uetiti crimen amoris habent? Vide Giancotti, F. 1967, 65 ss; Fantham, R. 1989, 157-158; Panayotakis, C. 1995, xvii.

${ }^{52}$ Jul. 49-52; Aug. 68-71.1; Tib. 43-45; Cal. 24; 36; Nero 28-29; Gal. 22; Otho 2.2; Vit. 3.2; Ves. 21; Tit. 7.1 ; Dom.22. Só Cláudio é louvado por se abster de homens (Cl.33.2). 
amoroso que envolve Nero, Otão e Popeia (Otho 3), onde se explora o motivo do ciúme.53

O grotesco e o ridículo, característicos do mimo, ${ }^{54}$ sobressaem na caracterização de Calígula (Cal.50.1) e de Cláudio (Cl.30). Ridícula é a forma como o último salta do seu lugar e corre ao longo da margem do lago Fúcino a coxear e a ameaçar os marinheiros que, no decurso de uma naumaquia, se recusam a combater (Cl. 21.6). Este imperador, dada a sua stultitia e a subordinação a pessoas de categoria inferior, desempenha o papel do stupidus, o actor secundarum do mimo que tem como correspondente, no mimo grego, o moros phalakros. ${ }^{55}$ De facto, Cláudio é apelidado de moros (Cl. 38.3; Nero 33.1).

Muitas mais conexões com o mundo do teatro se poderiam apontar. Cremos, no entanto, que os passos analisados ao longo desta segunda parte sugerem muitas vezes a influência ou contaminação do modo dramático, de que já se queixava o próprio Tito Lívio (5.21.9), ou mesmo transposição de cenas de tragédia, de comédia, ou de mimo para os relatos histórico-biográficos. ${ }^{56}$

Ao compor cada vida, Suetónio opera continuamente, num processo dinâmico, a caracterização da sua personagem e salienta o seu desenvolvimento moral, desde o tratamento dos antepassados de cada imperador até à descrição das reacções à morte. $\mathrm{O}$ desenvolvimento de cada carácter, desligado da evolução cronológica, é organizado em função da intensidade dos factos descritos. Neste sentido, Suetónio não é um mero compilador de anedotas: as selecções ou omissões que opera no decorrer das Vidas têm em vista apresentar uma imagem de cada césar, como vimos pela comparação com testemunhos das demais fontes. A organização das virtudes e dos vícios na estrutura de cada Vida tem em vista salientar os topoi tradicionais da caracterização dos tiranos, tal como são apresentados em palco ou nas escolas de retórica, ou, pelo contrário, procura criar um ideal de governante na linha do que serão os espelhos de principes medievais e renascentistas. A estrutura das Vidas obedece, desta arte, a um objectivo moralizante.

${ }^{53} \mathrm{O}$ marido ou amante ciumento é um motivo do mimo alexandrino: vide FAnTHAM, R. 1989, 160.

${ }^{54}$ Vide Panayotakis, C. 1995, xv-xvi.

${ }^{55}$ Vide Panayotakis, C. 1995 , xvii-xviii.

${ }^{56}$ Vide Brandẽo, J. L. 2005a, 159-193. 
(Página deixada propositadamente em branco) 


\title{
Parte III
}

\author{
A Expressão da Moralidade \\ Juízos e Prejuízos
}


Os Césares transmitem uma mensagem não tanto política como moral. Suetónio não discute a legalidade do principado ou as questões políticas do relacionamento entre príncipe e senado, mas o ethos de cada imperador. Poderemos mesmo dizer que reduz toda a perspectiva política da actuação dos príncipes ao âmbito moral. Gascou chega a dizer que Suetónio tem uma obsessão moral, uma vez que apresenta uma visão do mundo dividido entre bem e mal, entre uirtutes e uitia. ${ }^{1}$ A divisão operada na biografia de Calígula entre actos do princeps e actos do monstrum, ou na de Nero entre factos louváveis e neutros por um lado e probra ac scelera por outro são a prova cabal de que Suetónio opera uma consideração moral de toda a actuação destes príncipes. $\mathrm{O}$ facto de a morte dos maus imperadores tender a ser apresentada como um castigo da tirania e os bons imperadores serem geralmente compensados com uma boa morte implica a concepção optimista de uma justiça imanente na história de que o biógrafo apresenta os efeitos. ${ }^{2}$

Não podemos, por isso, concordar com os que afirmam que Suetónio é unicamente descritivo, se abstém de julgar ou de tirar lições de moral e que deixa esse trabalho ao leitor. ${ }^{3}$ As intervenções directas do autor nas Vidas dos Césares, de que falámos atrás, bastam para desmentir tal afirmação. A manipulação que opera nos dados históricos, em função de determinados valores, o dramatismo que cria nas suas Vidas, como explicitámos na segunda parte, denunciam uma intenção de condicionar e atrair o leitor para a sua mensagem moral. ${ }^{4}$ A negação de uma moralidade em Suetónio parece assentar, por um lado, na consideração do biógrafo como simples erudito e na leitura da sua obra como um mero compêndio de anedotas; por outro, no realismo com que apresenta o vício em todo o seu horror, no que a natureza humana tem de mais sórdido e obsceno - de tal modo que frequentemente se esquece que Suetónio também apresenta a virtude em todo o seu esplendor. Mas, dissimulado por uma narrativa aparentemente objectiva e factual e por um realismo, por vezes mórbido, há um julgamento ao qual o biógrafo procura conduzir o leitor. ${ }^{5}$ Mas

${ }^{1}$ Vide Gascou, J. 1984, 787.

${ }^{2}$ Como afirma Gascou, J. 1984, 787-798.

${ }^{3}$ Como sugerem Ailloud, H. 1931-1932, xxiii, n. 4, na intr. à sua ed. (contra os que acusam Suetónio de imoralidade, considera-o antes "amoral") e xxxıI; Townend, G. B. 1967, 92-93; EктоR, J. 1980, 48 317-326.

${ }^{4}$ Vide Lewis, R. G. 1991, 3653: «It is sometimes argued that Suetonius is by contrast purely descriptive or 'objective', confining himself to recording information as he finds it and leaving it to the reader to make moral judgements. This is illusory. Suetonius is often enough perfectly explicit, and where he is not can still be sure of his readers' reactions in that he does manipulate his 'plan factual data' against a known background of established values and prejudices». Ideia semelhante expressa, na intr. ao com., BradLEY, K. R. 1978, 14-15.

${ }^{5}$ O que Cizek, E. 1977, 158, denomina pari et alibi, isto é, por um lado, a organização da narrativa de forma a levar o leitor a pensar como o biógrafo; por outro, a ostentação de objectividade, imparcialidade e distanciamento dos factos relatados. Segundo Wallace-Hadrill, A. 1984, 167-168, a aparente neutralidade traz implícitas fortes implicações morais. GiuA, M. A. 1990, 536-543, sublinha que os interesses de Suetónio não são apenas, como pretendia LEo, F. 1901, os de um erudito curioso, que aplicava às Vidas dos Césares um esquema erudito alexandrino, mas 
Suetónio, enquanto autor das biografias, não é um moralizador, à maneira de Tácito. Enquanto este faz dissertações moralizantes com base na oposição entre a virtude do passado e a decadência do seu tempo, ${ }^{6}$ Suetónio serve-se das figuras dos imperadores para transmitir, muitas vezes implicitamente, a mensagem moral. Acções que para o historiador antigo informam a trama narrativa, aparecem dispersas por rubricas de virtudes e vícios. ${ }^{7} \mathrm{~A}$ oposição passado / presente é substituída pela de bons / maus imperadores. São os próprios Césares que, enquanto actuantes, incarnam, pela positiva ou pela negativa, um código de valores referido discretamente em rápidas observações, que passam, por vezes, despercebidas aos leitores, e implícito na enunciação das virtudes e vícios com que se introduzem muitas das rubricas.

Não parece que o imperador seja a única pessoa para quem as Vidas são instrutivas, ${ }^{8}$ como, na tragédia, os governantes não são os únicos a aprender com os erros de um Agamémnon ou de um Creonte. Os Césares, porque são grandes figuras históricas, transformam-se, como as figuras trágicas, nas personagens que encarnam uma mensagem moral.

Os imperadores transmitem valores não só pelos seus actos, considerados maus ou bons, mas também pela sua simples apresentação em cena, isto é, pelos seus traços físicos, cuidados corporais e vestuário. Além disso, o biógrafo, para fazer a caracterização de determinado César, recua até muito antes do nascimento. Assume especial importância a hereditariedade: o indivíduo aparece, desde o início, integrado em uma linhagem familiar e a sua imagem pode ser, em parte, determinada por factores hereditários. ${ }^{9}$

que, por trás da aparente frieza das informações, existe uma mensagem moral e política. Vide também Dupont, F. et Éloi, T. 2001, 293ss.

${ }^{6}$ Vide Giua, M. A. 1990, 538.

${ }^{7}$ Como afirma Wallace-Hadrill, A. 1984, 143.

${ }^{8}$ Segundo Bradley, K. R. 1991, 3713, esta é a razão pela qual Suetónio não tenta educar o seu público à maneira de um historiador: a vanidade das tentativas em controlar um governante através de aconselhamento moral estava mais que provada, e disso é exemplo o De clementia de Séneca, dirigido ao jovem Nero.

${ }^{9}$ Vide Bradley, K. R. 1991, 3714-3715. 
(Página deixada propositadamente em branco) 


\section{Caracterização pela Ascendência}

A origem constitui uma chave de identificação do indivíduo. ${ }^{10} \mathrm{~A}$ rubrica da ascendência, colocada no início de uma Vida, serve essencialmente dois propósitos: por um lado, fazer a crónica das famílias, com os seus altos e baixos ao longo do tempo, até conseguirem a dita de atingirem, através de um dos seus membros, a glória imperial; por outro, tentar perceber as qualidades de cada César por referência aos seus antepassados, de modo a fundamentar geneticamente as virtudes ou vícios e perceber se ele degenera ou assume os traços familiares. As Vidas começam quase invariavelmente pela rubrica da ascendência. Exceptuam-se a César, a de Tito e a de Domiciano: no primeiro caso, porque se perderam os primeiros capítulos; nos dois últimos, porque os antepassados são tratados no início da Vida do pai, Vespasiano.

\subsection{Herança positiva}

Ao iniciar a Vida de Augusto, Suetónio assume um tom apologético. A preocupação do biógrafo é mostrar, contra as opiniões dos detractores mencionadas a seguir, que a família paterna de Octávio era praecipua (Aug. 1), e a materna contava com muitos senadores e magistrados (Aug. 4.1).

Parece significativo, embora justificado cronologicamente, que o biógrafo refira, logo a abrir, a lenda que liga o culto de Marte ao clã dos Octávios. Um pormenor de gosto antiquário - um altar que se mostrava, consagrado por um Octávio - é pretexto para a narração de um facto mítico com valor etiológico: perante o anúncio de uma incursão dos inimigos, aquele antepassado de Augusto interrompeu o sacrifício a Marte, retirou do fogo as vísceras meias cruas, na urgência de dar combate, e saiu vencedor. A partir daí, por decreto, os sacrifícios a Marte seriam realizados da mesma forma e os restos oferecidos aos Octávios (Aug. 1). Mais do que estabelecer a origem da gens Octávia, Suetónio apresenta, desde logo uma opinião favorável a Augusto, estabelecendo nos antepassados o fundamento da obra militar do futuro imperador (Aug. 20-25), bem como o seu respeito pela religião tradicional (Aug. 91-93). ${ }^{11}$ Além disso a presença de Marte é tanto mais importante quando este deus está presente na origem lendária de Roma, como pai do fundador. Também Augusto, pela escolha deste nome, irá apresentar-se como o novo Rómulo, o novo fundador de Roma («fundada com um augusto augúrio») (Aug. 7.2).

A versão da origem humilde é salientada através da polémica com Marco António, a propósito da situação social do bisavô e avô paternos de Augusto (Aug. 2.3.) e da ascendência materna, a que se juntam também as acusações de Cássio de Parma. ${ }^{12}$ Ao afirmar que não encontrou outros elementos sobre as ascendência paterna (Aug. 3.3), Suetónio sugere implicitamente que só

${ }^{10}$ Vide com. à Vida de Calígula de Guastella, G. 1992, 75.

${ }^{11}$ Vide Gascou, J. 1984, 692.

12 Aug. 4.2. Para Grimal, P. 1986, 736, Suetónio, embora não as refute expressamente, só menciona estas acusações para ser completo. Vide GAscou, J. 1984, 584-587. 
mencionou as acusações caluniosas de António para não ser omisso. Prefere centrar-se nas qualidades do pai do futuro imperador e expressa admiração (ut equidem mirer) pelas afirmações dos que querem apoucar a sua fortuna e prestígio social. As qualidades da iustitia e da fortitudo com que governou a província da Macedónia (Aug. 3.1) e a prudência no trato com os aliados (Aug. 3.2), atestada por Cícero, parece antecipar a política de Augusto no que diz respeito às relações com os povos submetidos e aliados, apresentada em tons verdadeiramente elogiosos (Aug. 21.2-3; 47-48). De qualquer modo, fica a ideia de que o futuro imperador (embora não fosse de origem humilde) não pertenceria a uma família das mais importantes de Roma, mas que compensava esse facto com o favor dos deuses, manifesto nos antepassados e reiterado no nascimento (Aug. 6) e ao longo da vida (Aug. 94).

Com Vespasiano o processo é semelhante ao de Augusto. O biógrafo integra o novo imperador (e a nova dinastia) em uma cepa emergente. Por outro lado, podem encontrar-se nos antepassados explicações para o comportamento do biografado. Tito Flávio Petrão, centurião, ou veterano reincorporado ad hoc (euocatus); do exército pompeiano, que escapara depois da derrota de Farsalo, exerceu, depois de concedida a amnistia aos pompeianos, o ofício de banqueiro de vendas a crédito (coactiones argentarias factitauit) ${ }^{13}$; e o filho deste, e pai do futuro imperador, exerceu o cargo de cobrador de impostos sobre a circulação de bens na Ásia, de que tinha direito a dois e meio por cento, ${ }^{14}$ e a actividade de usurário na Helvécia. Grande relevo dará Suetónio à avareza de Vespasiano e à forma exagerada como procede à cobrança de impostos durante o seu principado. $\mathrm{O}$ imperador parece apresentar algumas características sabinas, ou mesmo virtudes, de municeps Reatinus, mas que, na Urbe, o transformam em avaro provinciano. Tal pecha, no entanto, é atenuada pela nota imediata sobre a exemplar honestidade no ofício de publicano, que valera a Flávio Sabino a elevação de estátuas na Ásia. ${ }^{15}$ Estas homenagens denunciam também a ascensão da sua posição social. Contribui para sublinhar a progressão social e política o uso do termo

${ }^{13}$ Ves. 1.2. A perífrase pretenderá atenuar a impressão desagradável de coactor argentarius, ofício desempenhado sobretudo por libertos e descendentes de libertos. Tratava-se de uma actividade próxima da do usurário: os coactores aceitavam depósitos em dinheiro, e, a partir destes, faziam empréstimos. Emprestavam dinheiro, com uma comissão, a quem comprasse bens colocados em hasta. Tal actividade significa que não possuiriam bens fundiários. Vide com. de Cesa, M. 2000, 37.

${ }^{14}$ Mais uma vez publicum quadragesimae in Asia egit parece ser uma forma eufemística, com a qual se evita mencionar directamente o ofício de publicano: vide com. de CESA, M. 2000, 38.

${ }^{15}$ A observação é tanto mais válida quanto um publicano íntegro, no início do principado, era considerado uma excepção, dada a necessidade que Nero teve de moderar as publicanorum cupidines (Tácito, Ann. 13.50); vide com. de Braithwaite, A. W. 1927, 19. A nota, de cariz antiquário, sobre a permanência das estátuas pode ter sido informação de Plínio-o-Moço, que fora governador do Ponto e da Bitínia, ou de uma fonte escrita favorável aos Flávios; vide com. de Cesa, M. 2000, 39. Como observa Baldwin, B. 1983, 187, o uso do imperfeito manebant parece sugerir que as estátuas já não existiriam na altura da redacção das Vidas. 
processit: ${ }^{16}$ o irmão mais velho de Vespasiano atingiu a praefectura urbis, e Vespasiano chegou ao principado.

Suetónio introduz de seguida a origem materna, um contributo decisivo para nobilitar a família, através do casamento de Flávio Sabino com Vespásia Póla, oriunda de uma família nobre (bonestum genus), da antiga cepa equestre de Núrsia. O pai de Póla fez carreira militar: foi três vezes tribuno militar e prefeito do acampamento e o irmão foi senador. Apresentam-se ainda, como grande prova de esplendor e antiguidade da família os complura monumenta que subsistem na localidade que guarda o nome gentilício materno de Vespasiano: Vespasiae. O biógrafo, através do recurso a estátuas, inscrições e monumenta, ${ }^{17}$ reforça a credibilidade das afirmações favoráveis aos Flávios (integridade dos Flávios, nobreza dos Vespásios), como se quisesse desacreditar os detractores. A toada apologética adoptada parece apontar nesse sentido.É natural que Suetónio conhecesse propaganda hostil, que procurava sublinhar a origem humilde da família. Disso serão reflexo as afirmações, com que conclui a exposição sobre a origem familiar, com o condescendente non negauerim iactatum a quibusdam... (Ves. 1.4). Deste modo, e numa espécie de Ringcomposition, ${ }^{18}$ se retoma o motivo da origem paterna. Alguns insistem em que Petrão, avô de Vespasiano, era oriundo da região transpadana, com a depreciação que isso implica, ${ }^{19}$ e se aplicava a contratar anualmente trabalhadores sazonais, que transferia da Úmbria para a Sabina, pelo que acabou por casar e se fixar em Reate. Mas o biógrafo desvaloriza tais testemunhos: ipse ne uestigium quidem de hoc, quamuis satis curiose inquirerem, inuen $i^{20}$ ( por mim, apesar de ter cuidadosamente investigado, não encontrei prova alguma de tal facto»). Suetónio usa o argumento e silentio, como forma de apoucar aquelas afirmações, que eram desmerecedoras para os Flávios. O biógrafo sugere subtilmente, pelo contraste, que, para os aspectos que referiu acima, existem uestigia. No entanto, as provas (estátuas, inscrições, monumenta) que apresentara dizem respeito unicamente a aspectos mais favoráveis. E dir-se-ia que os apresentou sobretudo para poder realçar a falta de provas de que enfermam as afirmações difamantes. Suetónio quer mostrar que a ascendência era obscura, mas não sordida, como a que alguns atribuíam a Vitélio (Vit.1.1). Além disso, é por não encontrar forma de comprovar ou contestar aquelas afirmações que Suetónio, em vez de as transmitir no local próprio, as deixa para o fim. Anteriormente, foram apresentados os factos

${ }^{16}$ Vesp. 1.3: ... et duobus ex ea liberis, quorum maior Sabinus ad praefecturam urbis, minor Vespasianus ad principatum usque processit.

${ }^{17}$ Vide BALdwin, B. 1983, 187.

${ }^{18}$ Vide com. Cesa, M. 2000, 41.

${ }^{19}$ Como nota, no seu com., Braithwaite, A. W. 1927, 22, o avô de Vespasiano nem sequer era itálico. A Gália Transpadana ou Cisalpina, embora profundamente romanizada, continuou a ser província até 42-41 a. C. Na melhor das hipóteses, tal observação fazia do avô de Vespasiano um cidadão romano de recentíssimo reconhecimento. Vide com. de CESA, M. 2000, 42.

${ }^{20}$ Ves. 1.4. O com. de Braithwaite, A. W. 1927, 22, sublinha que todo o capítulo e, em especial, a última frase evidenciam a cuidadosa e independente pesquisa de Suetónio. Mas parece mais do que isso: a última frase vale como um verdadeiro argumento e a nota da imparcialidade é posta ao serviço da boa imagem da família. 
comprovados. Neste caso, o facto de transmitir as informações em último lugar não significa um aumento da intensidade, como acontecia, por exemplo, com os crimes de Nero (Nero 33-38), mas um decréscimo da importância, semelhante à desculpabilização empreendida acerca dos vícios de Augusto (Aug. 71) método que o biógrafo usa para reportar aspectos negativos dos imperadores que considera bons: gradação descendente ou anticlímax. ${ }^{21}$ Prevalece a imagem da inegável humilitas da família, resgatada pela excelência do ramo materno e pela ausência de provas para as situações aviltantes apresentadas em último lugar.

Dos ascendentes de Otão, Suetónio salienta a humilde linhagem do avô, M. Sálvio Otão: filho de um cavaleiro e de uma mulher de baixa condição, talvez não livre. Mas a condição social é superada pelo favor de Lívia, que o faz nomear senador, ${ }^{22}$ e pelo maternum genus praeclarum do pai, Lúcio Otão, a que se junta a suspeita de que poderia ser filho de Tibério: era muito querido deste imperador e muito parecido com ele (Otho 1.2). A este ascendente na corte, o pai de Otão acrescenta o mérito e verticalidade de carácter. A coragem fica bem patente ao colocar a honra e o rigor militares acima do tacto político. $\mathrm{Na}$ Ilíria, ousou condenar à morte uns soldados, que, por altura do levantamento de Camilo contra Cláudio, se arrependeram e mataram os seus oficiais como instigadores da revolta, quando sabia à partida que Cláudio os promovera por tal atitude. ${ }^{23}$ Como nota o biógrafo, quo facto sicut gloriam auxit, ita gratiam minuit («com tal acção, assim como aumentou a glória, fez diminuir o estado de graça») - desinteresse pessoal que se manifestará também no filho, no final da vida. Mas a sua isenção é também demonstrada pela forma como recuperou prontamente as boas graças de Cláudio ao desvendar um atentado que contra o imperador se preparava. O senado concede-lhe a honra raríssima de uma estátua no Palatino, e Cláudio admitiu-o entre os patrícios com o elogio: 'Vir, quo meliores liberos habere ne opto quidem'(Otho 1.3) («'Um homem tal, que não aspiro sequer ter filhos melhores do que ele'»). A verticalidade de carácter do pai contrasta com a juventude desregrada do filho (a quem aquele chegava a castigar severamente), mas tem continuidade na morte corajosa do imperador. Em relação à mãe de Otão, Álbia Terência, o epíteto de splendida femina tem de ser entendido como referência à sua ilustre linhagem, ${ }^{24}$ o que vem contribuir para justificar socialmente a ascensão de Otão ao principado.

${ }^{21}$ Vide Cizek, E. 1977, 66; 133.

${ }^{22}$ Otho 1.1. Através da referência às famílias de Otão e Vitélio nas biografias de Suetónio, podemos ver a emergência de uma nova nobreza no período júlio-cláudio; vide intr. ao com. de Murison, Ch. L. 1992, xi.

${ }^{23}$ Otho 1.2. Trata-se do conflito entre conveniência política (perdão e promoção por parte de Cláudio) e disciplina militar (o ponto de vista do comandante em exercício) com vista a manter o controlo dos revoltosos. Mas o problema - como lembra Murison, Ch. L. 1992, 92 - poderia ser resolvido com maior argúcia política através da transferência dos revoltosos para outras áreas.

${ }^{24}$ Vide com. de Murison, Ch. L. 1992, 94. 


\subsection{Herança negativa}

A Vida de Tibério implica uma exposição pela origem e honras da gens Claudia. Entre os cognomina adoptados destaca-se o de Nero, que em língua sabina significa 'forte' e 'intrépido' (Tib 1.2): mas esta característica pode ser usada para o bem ou para o mal. Antecipa as qualidades do bom chefe militar, mas contrasta com o futuro retrato de um Tibério cheio de fobias e muito indeciso. Desde logo, se dividem os Cláudios em dois grupos: Multa multorum Claudiorum egregia merita, multa etiam sequius admissa in rem p. extant («registam-se muitos feitos meritórios de muitos Cláudios, mas também muitas acções menos boas contra o Estado»). Esta parece ser uma primeira tentativa de explicar o carácter controverso de Tibério. ${ }^{25}$ Aos bons feitos de natureza política e guerreira de Ápio Ceco, Cláudio Cáudex, Cláudio Nero (cujo praenomen Suetónio parece confundir com o de Tiberius: Tibus), o biógrafo opõe (contra) o crime de Cláudio Regiliano contra a liberdade de uma virgem (trata-se de Virgínia, mas o biógrafo não a nomeia), facto que provocara a secessão da plebe; de Cláudio Druso (ou antes, Russo) contra o Estado, por acalentar aspirações tirânicas; ${ }^{26}$ de Cláudio Pulcro contra a religião tradicional (impiedade bem conhecida contra os frangos sagrados que atirou ao mar, por, na eminência de uma batalha, se recusarem a comer) e contra as instituições do Estado (por não tomar a sério a obrigação de nomear um dictator, depois de ter perdido uma armada) (Tib. 2.2). Paralelamente, são apresentados os exempla diuersa de duas Cláudias: a uma, exemplo de pudicitia, se opõe a superbia de outra (irmã de Cláudio Pulcro), acusada de iudicium maiestatis ${ }^{27}$ por umas palavras ímpias contra o Estado: palam optauerat 'ut frater suus Pulcher reuiuisceret atque iterum classem amitteret, quo minor turba Romae foret' («desejara abertamente 'que o seu irmão Pulcro voltasse à vida e perdesse outra frota, para que a multidão fosse menor em Roma'»). A descrição culmina com a ligação generalizada dos Cláudios (à excepção de Clódio) à classe aristocrática e da violência e contumácia contra a plebe, a culminar, depois de outros casos, no exemplo ilustrativo de uma Cláudia, que, sendo vestal, se serve do seu sacerdócio para evitar o veto dos tribunos da plebe ao triunfo do irmão. ${ }^{28}$

Depois de, através de uma gradação do positivo para o negativo e do predomínio dos maus feitos, deixar que a impressão negativa prevaleça no leitor, o biografo acrescenta: ex hac stirpe Tiberius Caesar genus trabit, $e<t>$ quidem

${ }^{25}$ Tib. 2.1. Vide intr. ao com. de Lindsay, H., 1995, 12.

${ }_{26}$ Tib. 2.2: (..) statua sibi diademata ad Appi Forum posita Italiam per clientelas occupare temptauit. Wiseman, T. P. 1986, 90-95, põe a hipótese de se tratar de uma deformação histórica, operada por um historiador que, para provar o topos da arrogância dos Cláudios, terá interpretado erradamente a coroa triunfal, já gasta pelo tempo, e o elogium, na base da estátua, que faria referência à conquista dos Picentes, levada a cabo por aquele filho de Cláudio Ceco, e, com a qual, quase toda a Itália ficava sob domínio romano.

${ }_{27}$ Tib. 2.3: Esta acusação parece um artifício de Suetónio a partir dos exemplos do governo de Tibério. Tácito, Ann. 1.72.2, afirma que, nesses tempos, os actos é que eram perseguidos, não as palavras (facta arguebantur, dicta impune erant); vide com. de Lindsay, H. 1995, 61.

${ }_{28}^{28}$ Tib. 2.4. Na realidade, seria filha; cf. Cícero, Cael. 14.34. 
utrumque («desta estirpe extrai Tibério César a sua origem, e mesmo de um e outro lado»). Tibério aparece desde logo subjugado a uma espécie de destino transmitido pela herança genética quer da mãe, quer do pai. O leitor esperará, portanto, um Tibério ligado aos aristocratas e arrogante em relação à plebe. ${ }^{29}$ Mas também se podem explicar certas atitudes políticas, como a vontade de dignificar a função do senado. Da figura do pai, Tibério Nero, destaca-se o seu abandono da causa de César depois dos Idos de Março e a proposta única de atribuir um prémio aos cesaricidas. Fica patente a sua tendência para a mudança de campo no sumário das manobras políticas, fugas e tribulações, até à cedência de Lívia a Augusto (Tib.4).

A ascendência materna de Nero (Druso e Germânico) é tratada respectivamente nas Vidas de Cláudio e de Calígula. Na Vida de Nero, Suetónio centra-se no ramo paterno: o dos Domícios Aenobarbos, cujo cognomen se ficara a dever a um prodígio relacionado com uma manifestação dos Dioscuros depois de uma batalha (Nero 1.1). ${ }^{30}$ Como Germânico é inatacável, o biógrafo pretende demonstrar que os vícios de Nero provieram sobretudo do ramo dos Domícios. Introduz assim a primeira referência ao carácter de Nero, com uma forte carga hereditária: Pluris e familia cognosci referre arbitror, quo facilius appareat ita degenerasse a suorum uirtutibus Nero, ut tamen uitia cuiusque quasi tradita et ingenita ret $<t>$ ulerit ${ }^{31}$ ("Julgo que interessa conhecer vários membros da família, para mais facilmente se tornar manifesto que Nero tanto degenerou das virtudes dos seus, como repetiu os vícios de cada um, como se fossem hereditários e nele inatos»). Mas trata-se de uma hereditariedade selectiva que só transmite o mal. ${ }^{32}$ De facto, Suetónio parece buscar no carácter dos Domícios Aenobarbos sinais da face negra de Nero. A característica de um dos antepassados é sintetizada pela boca do orador Licínio Crasso: 'non esse mirandum, quod aeneam barbam haberet, cui os ferreum, cor plumbeum esset' (Nero 2.2) («não é de admirar que tenha uma barba de bronze, quem tem uma cara de ferro, um coração de chumbo»). De outro, Lúcio Domício Aenobarbo, opositor de César, diz que era uir neque satis constans et ingenio truci («varão não muito constante e de carácter feroz») que se mostra, como mais tarde Nero, hesitante diante da morte: o medo leva-o a suicidar-se, mas, logo a seguir, arrepende-se e vomita o veneno. Pelo contrário, mostra-se intransigente com os neutrais da guerra civil (Nero 2.3).

Outra herança é a aurigandi ars de um homónimo de Nero, Lúcio Domício, que recebeu grandes honras de Augusto. Para mais, este era arrogans, profusus, immitis. Fez subir à cena, para representar um mimo, cavaleiros romanos e

${ }^{29}$ Tib. 3. Segundo Gascou, J. 1984, 692-693, Suetónio, manejando uma verdadeira arte de persuadir, procura sugerir, logo nos primeiros capítulos, uma imagem global determinante do juízo que o leitor deve fazer, neste caso, de Tibério: «nous sommes tout disposés à penser qu' en vertu d'un detérminisme qui ne s'était jamais démenti, Tibère devra se conduire en tyran imbu de préjugés aristocratiques et en ennemi du peuple».

${ }^{30}$ Trata-se da batalha do lago Regilo (século V a. C.).

${ }^{31}$ Nero 1.2. Vide Martin R. 1991, 74; Lounsbury, R. C. 1991, 3751.

32 Como observa Gascou, J. 1984, 244. 
matronas, desonra que Suetónio não deixa passar em claro. Ofereceu ainda uenationes, e jogos de circo e um combate de gladiadores, mas com tanta crueldade que o próprio Augusto se viu obrigado a intervir (Nero 4). Por último, aparece Gneu Domício, pai de Nero, homem detestabilis, que mata um liberto por um pretexto fútil; incita propositadamente os cavalos para atropelar um menino na via Ápia, arranca um olho a um cavaleiro no Foro (Nero 5.1). É ainda caracterizado como pérfido e, durante o reinado de Tibério, acusado de lesa-majestade, adultério e incesto. ${ }^{33}$ Parece ser a antecipação da lista dos probra (Nero 19.3 ss) de Nero. O carácter do futuro imperador está determinado: poderá ser apenas acobertado sob uma máscara de virtude, mas, mais tarde ou mais cedo, terá de se manifestar.

Galba não tem ligações com a casa dos Césares. ${ }^{34} \mathrm{O}$ peso da família anterior é tal, que Galba sente necessidade de criar uma linhagem divina rival. Quando se torna imperador, expõe no átrio uma árvore genealógica que o faz remontar a Júpiter pelo lado paterno e a Pasífae, esposa de Minos, pelo lado materno. ${ }^{35}$ Depois da discussão sobre o significado do nome de Galba, Suetónio refere alguns ascendentes ilustres e seus feitos. O orador Sulpício Galba, quando governador da Hispânia, operara, por perfidia, uma chacina de trinta mil lusitanos, que provocara a guerra de Viriato. Um neto deste orador conspirou com Cássio e Bruto contra César, pelo que foi condenado pela lei Pédia (Gal. 3.2). A nobilitas da família era apetecida: a bela e rica Lívia Ocelina quer a todo o custo casar com o pai do imperador. Este desnuda-se à frente dela e mostra-lhe a deformidade física (era corcunda), para não parecer que a enganava. Mas o irmão mais velho dilapida a fortuna e suicida-se (Gal. 3.4), facto que contrasta com avareza do futuro César e pode sugerir uma explicação psicológica para tal comportamento.

Uma família tão nobre e letrada podia ser uma boa alternativa à dinastia anterior. Mas fica também a marca da crueldade e perfídia da matança e da conspiração contra César. Também Galba há-de fomentar matanças cruéis e conspirar contra os Césares, na pessoa do último dos Júlio-Cláudios. ${ }^{36}$

Duas versões, antagónicas, abrem a exposição do biógrafo sobre a ascendência de Vitélio: uma versão, dos aduladores, considera a linhagem antiga e nobre, entroncada em Fauno, rei dos Aborígenes, e na divindade Vitélia (Vit. 1); e outra, dos detractores, considera a linhagem noua, obscura e mesmo sordida, porquanto remonta a um liberto, um sapateiro remendão, cujo filho, enriquecido à custa de bens confiscados e em processos do fisco, casou

${ }^{33}$ Nero 5.2. Tácito, Ann. 6.47.3, lança sobre Mácron a suspeita de forjar a maior parte das acusações; cf. Díon, 58.27.2.

${ }^{34} \mathrm{Cf}$. Gal. 2: Neroni Galba successit nullo gradu contingens Caesarum domum.

${ }^{35}$ Há um paralelo com a insistência de César em invocar a sua descendência de Vénus: vide Martin, R. 1991, 80. Estava implícita na árvore genealógica de Galba uma descendência do Sol, de quem Pasífae era filha.

${ }^{36}$ Como afirma Della Corte, F. 1967, 118-119. 
com uma prostituta. Como o biógrafo sabiamente diz, sed quod discrepat, sit in medio (Vit. 2.1) («mas, neste desacordo, o melhor é que se fique em um ponto intermédio»). Mas o conceito infamante ganhará relevância. $\mathrm{O}$ fundamento do vício da gula e atitudes vis de Vitélio parece encontrar-se já na família. $\mathrm{O}$ tio homónimo, Aulo, era famoso por uma mesa sumptuária (Vit. 2.2). O pai, Lúcio, era uir innocens et industrius, mas deixou-se dominar pelo amor perinfamis de uma liberta: chegava a usar publicamente, como remédio para a garganta, a saliva dela misturada com mel (Vit. 2.4). Era também dotado de engenho para a adulação: foi o primeiro a adorar Calígula como um deus; obteve o especial favor de descalçar Messalina e subtraiu-lhe um sapato, que trazia sempre consigo e cobria de beijos; venerava entre os deuses estátuas dos libertos de Cláudio; é o autor da frase caricata, dirigida a Cláudio, quando este celebrava os Jogos Seculares: 'Saepe facias' (Vit. 2.5) («'Que os repitas muitas vezes!'»). Tais comportamentos antecipam a adulação de Vitélio para com Nero (Vit.4).

\subsection{A negação dos genes}

A função da rubrica da ascendência não se apresenta uniforme ao longo das Vidas. Há contrastes com a ascendência se podem evocar. Apesar da rapacidade de Domiciano, que corresponde à superlativização da avareza de Vespasiano, a descrição do último dos Flávios contrasta com as virtudes dos seus antepassados, defendidas pelo biógrafo no início da Vida de Vespasiano, e com as qualidades do pai e do irmão. E, se é verdade que Nero dá continuidade aos vícios da linhagem paterna, a sua conduta contrasta, por outro lado, com a do avô e bisavô paternos, respectivamente Germânico e Druso, referidos no início das Vidas de Calígula e Cláudio. Mas há dois imperadores em que o contraste é flagrante, pois esta rubrica contém qualidades opostas às desenvolvidas ao longo da Vida: referimo-nos às biografias de Calígula e Cláudio.

O tratamento da ascendência de Calígula centra-se no resumo da carreira de Germânico, morto, ut opinio fuit, por crime de Tibério, com a cumplicidade de Pisão (Cal. 1-2). O louvor das virtudes físicas e morais de Germânico (Cal. 3) faria esperar um filho igualmente belo e bom. O encómio de Germânico inclui os dotes de orador e comediógrafo, a ciuilitas, a pietas, a lenitas - virtudes que Gaio se encarregará de subverter. $\mathrm{O}$ uirtutum fructus é o favor do povo (Cal. 4), expresso, numa gradação que culmina nas manifestações que se sucedem à morte: ${ }^{37}$ o reconhecimento universal das suas qualidades. A salvação de Germânico é identificada com a própria salvação do Estado, num verso que o povo canta, quando, perante um simples boato sobre o restabelecimento do herói, acorre em tumulto ao Capitólio para dar graças aos deuses. O próprio Tibério acorda ao som do refrão: 'Salua Roma, salua patria, saluus est Germanicus' (Cal. 6.1) («Salva está Roma, salva está a pátria, salvo está Germânico’»). Pelo que, em face de tais sentimentos, o luto público não pôde ser moderado por

\footnotetext{
${ }^{37}$ Cal. 5: tamen longe maiora et firmiora de eo iudicia in morte ac post mortem extiterunt.
} 
qualquer edicto. A crueldade que se seguiu fez aumentar a glória e a saudade do defunto: gerou-se uma consciência colectiva de que o respeito e o medo que Germânico inspirava a Tibério servira de freio à crueldade deste imperador (Cal. 6.2). A esta imagem de Germânico fica Calígula a dever o favor com que os súbditos o acolhem como sucessor de Tibério. Mas as expectativas são defraudadas e o filho apresenta-se como a antítese das qualidades do pai.

Como na biografia de Calígula, Suetónio inicia a Vida de Cláudio pela exposição das qualidades excepcionais do pai do biografado. E, tal como em Calígula, as capacidades militares e políticas do pai permitem estabelecer o contraste com a actuação do filho. São esclarecedoras, postas lado a lado, as palavras de Augusto acerca de Druso e de Cláudio. A suspeita, apresentada em tom jocoso, de que Druso seria filho de Augusto contribui subtilmente para aumentar a sua nobilitas (Cl. 1.1). As empresas militares, já de si egrégias, concluem-se com a narração de um prodígio: a visão (species) de uma mulher bárbara, de aspecto sobre-humano (humana amplior), que lhe proíbe avançar mais. ${ }^{38} \mathrm{Um}$ portento semelhante justificara uma decisão oposta, tomada por César (Jul. 32), na passagem do Rubicão. No caso de Druso, o prodígio engrandece o seu valor militar, na medida em que, na perspectiva de Suetónio, só a intervenção do sobrenatural põe fim, justificado, ao seu avanço (non prius destitit insequi, quam species...). Entre as honras concedidas a Druso figura o cognomen de Germânico, transmissível aos descendentes (Cl. 1.3). Suetónio, juntamente com a explicação da origem do nome, introduz assim Cláudio na lenda da família, filho que era da primeira geração, como o seu irmão mais velho, o que se tornara conhecido como Germânico. Mas este retrato do pai, como aconteceu com Calígula, e não acontecerá com o sucessor de Cláudio, é uma busca das virtudes dos antepassados. Druso apresenta-se como modelo de cidadão, que procura a glória através do serviço à comunidade. ${ }^{39}$ Carrega em si a imagem do príncipe ideal. A descrição vai ao ponto de o transformar em mártir da causa republicana. Se a suspeita da morte de Germânico recai sobre Tibério (Cal. 2), a de Druso vai pesar sobre Augusto. Mas Suetónio intervém na primeira pessoa para rejeitar o boato de que Augusto o mandara envenenar, invocando a afirmação pública, feita pelo imperador, do afecto que sentia por ele (Cl. 1.5). Apesar de o testemunho do fundador do principado ocorrer no contexto de um discurso fúnebre, onde de mortuis nibil nisi bonum, Suetónio aproveita-o para culminar o seu elogio de Druso. Tais qualidades mostram que, tal como Calígula, pelo menos era justificada a ascensão de Cláudio ao império.

${ }^{38}$ Cl.1.2. Cf. Díon Cássio, 55.1.3. Há uma discrepância nas fontes. Díon liga a aparição ao fracasso da travessia do Elba, em 9 a. C.: trata-se do modo eficaz de sublinhar a impossibilidade de um empreendimento. Suetónio situa o acontecimento entre 12-11 a. C.: a cena tem a finalidade de pôr fim à imparável sequência das empresas militares na Germânia. Vide coms. de Mottershead, J. 1986, 29-30; Guastella, G. 1999, 139-140.

${ }^{39}$ Cl. 1.4: fuisse autem creditur non minus gloriosi quam ciuilis animi. 
Em suma, o carácter, considerado como imutável, é determinado também pela ascendência: daí que as Vidas comecem com a descrição dos antepassados. No início das Vida de Nero e de Tibério, Suetónio demonstra claramente que não remonta aos antepassados meramente pelo gosto erudito de fazer genealogias, mas para, salientando o vigor da carga hereditária, demonstrar a origem dos vícios. ${ }^{40}$ É possível encontrar nos antepassados sinais das virtudes e dos vícios dos Césares: os mais evidentes são os gostos de Nero pelos jogos, da gula e da tendência para a infâmia de Vitélio, da pecuniae cupiditas de Vespasiano e da rapacidade de Domiciano. Em Calígula e Cláudio, a referência aos pais serve para evidenciar o contraste: os dois imperadores são o oposto respectivamente de Germânico e de Druso. Por continuidade ou por contraste, a rubrica da ascendência contribui para a caracterização moral dos imperadores. Neste sentido, o biógrafo revela uma intenção moralizante desde os primeiros capítulos das Vidas.

${ }^{40}$ Nero 1.2: Pluris e familia cognosci referre arbitror, quo facilius appareat ita degenerasse a suorum uirtutibus Nero, ut tamen uitia cuiusque quasi tradita et ingenita ret<t>ulerit. Tib. 3: ex hac stirpe Tiberius Caesar genus trabit, e<t> quidem utrumque. Vide Martin, R. 1991, 74; Lounsbury, R. C. 1991, 3751. 


\section{RETRATOS FALANTES}

\subsection{Retrato físico}

Inserida no final das biografias, antes ou depois da narrativa da morte, a rubrica do retrato físico vem criar na mente do leitor uma imagem visual, tanto quanto possível coerente com a personalidade do césar, ilustrada, mediante vários exemplos, ao longo da biografia, e integra-se, por isso, no intuito de caracterização moral. ${ }^{1}$ A consciência da relação entre o aspecto e o carácter é acentuada pelo facto de o biógrafo expressar surpresa, quando a aproximação não é possível. A constatação de que, perante a heróica morte de Otão, «a tão grande coragem não correspondiam, de forma alguma, nem o físico nem os modos» $\aleph^{2}$ - é a excepção que confirma a regra. Há quem afirme que Suetónio foi influenciado por teorias fisiognomónicas. ${ }^{3}$ Embora tais conceitos lhe não fossem certamente estranhos, o que o biógrafo quererá sugerir parece mais simples. Trata-se, por um lado, da adopção, moderada embora por certo realismo, ${ }^{4}$ do antigo preconceito de que o bom corresponde ao belo; e, por outro, da demonstração de que certas deformidades ou traços grotescos são consequência de desregramento moral.

Uma imagem de beleza predomina nos imperadores bons, um equilíbrio e harmonia que acentua a majestade. ${ }^{5} \mathrm{O}$ retrato físico de Augusto balança entre a imagem de estudada beleza, serenidade e majestade de um filho de Apolo, ${ }^{6}$ e uma descrição mais realista, que parece representar o homem. Do longo retrato, ${ }^{7}$ sobressai a forma eximia, que se mantém uenustissima ao longo das várias fases da vida, apesar da negligência de Augusto em relação aos cuidados corporais; um ar calmo e sereno, que demove do crime um agressor; uns olhos vivos e brilhantes. O biógrafo sugere que ele próprio cultivava esta imagem: pretendia fazer crer que possuía «uma espécie de fulgor divino» no olhar e gostava de fazer baixar os olhos aos interlocutores, «como se fitassem a luz do sol». Tal descrição reforça a ideia da incarnação de Apolo, assimilado ao Sol,

1 Um abordagem mais alargada deste assunto foi publicada em Brandẽo, J. L. 2004, 83-113.

${ }^{2}$ Otho 12.1: Tanto Othonis animo nequaquam corpus aut habitus competit.

${ }^{3}$ Vide Evans, E. C. 1950, 45 277-282; Couissin, J. 1953, 234-256; Sток, F. 1995, 109-135. Para a crítica da aplicação destas teorias aos retratos suetonianos, cf. GAscou, J. 1984, 592-616; BALDWIN, B. 1983, 498-501.

${ }^{4}$ GAscou, J. 1984, 615, sublinha a preocupação de Suetónio com o realismo, que acaba por servir de moderador: assim evita o exagero na sátira ou na idealização.

${ }^{5}$ Vide Gascou, J. 1984, 733.

${ }^{6}$ Aug. 79.2-3. Vide Grimal, P. 1986, 729-738, especialmente 734.

${ }^{7}$ Aug. 79.1: Forma fuit eximia et per omnes aetatis gradus uenustissima, quamquam et omnis lenocinii neglegens... Vultu erat uel in sermone uel tacito adeo tranquillo serenoque, ut quidam e primoribus Galliarum confessus sit inter suos, eo se inhibitum ac remollitum, quo minus, ut destinarat, in transitu Alpium per simulationem conloquii propius admissus in praecipitium propelleret. Oculos habuit claros ac nitidos, quibus etiam existimari uolebat inesse quiddam diuini uigoris, gaudebatque, si qui sibi acrius contuenti quasi ad fulgorem solis uultum summitteret. 
como o biógrafo o apresenta através de uma narrativa mítica do nascimento. ${ }^{8}$ A harmonia e proporcionalidade dos membros (commoditas et aequitas membrorum) é sinal de equilíbrio interior.

O equilíbrio físico caracteriza também Vespasiano, ${ }^{9}$ cuja statura quadrata sugere simetria e estabilidade. Os membros sólidos e rijos do fundador da dinastia flávia evocam a firmeza do general. A beleza de Augusto repete-se em Tito, cujo retrato sugere bem a ligação entre físico e carácter: In puero statim corporis animique dotes explenduerunt, magisque ac magis deinceps per aetatis gradus: forma egregia et cui non minus auctoritatis inesset quam gratiae; praecipuum robur. ${ }^{10}$ ( Logo em criança brilharam os dotes de corpo e dotes da alma, e cada vez mais pelas fases da vida: apresentava uma beleza distinta, e nele a autoridade igualava a graça e tinha grande robustez»). Tal como Augusto, Tito extrai a auctoritas do seu aspecto físico. A gratia aparece como contrapeso, a temperar a auctoritas, de acordo com a sentença de abertura da breve biografia: Tito era amor e delícias do género humano (Tit.1) e afabilíssimo por natureza (Tit. 8.1). A referência aos dotes do corpo e do espírito e a tendência para conquistar o afecto universal fazem dele outro Germânico, cuja reputação era exemplar. ${ }^{11} \mathrm{~A}$ indicação da especial robustez que lhe permitia ser assaz experto nas artes das armas e de cavalgar (Tit. 3.2), aproxima Tito de Júlio César. ${ }^{12}$

Apesar de César demonstrar ambição tirânica, e ser, por isso, considerado iure caesus, tem um lado bom e algo de divino, que tornam a sua morte uma profanação (Jul.89). O seu retrato aponta para a beleza e perfeição física que lhe conferem uma majestade natural: Fuisse traditur excelsa statura, colore candido, teretibus membris, ore paulo pleniore, nigris uegetisque oculis, ualitudine prospera... (Jul 45.1) («Era, segundo se diz, de estatura elevada, tez clara, membros bem proporcionados, o rosto um pouco mais cheio, ${ }^{13}$ olhos negros e vivos, saudável constituição...»). Com efeito, gostava de apregoar a sua descendência de Vénus (Jul.6.1). Os membros bem feitos, associados aos olhos vivos, sugerem também a excepcional resistência física que faz dele um intrépido homem de acção, como provam as inúmeras e heróicas façanhas descritas (Jul.57-65).

A imagem ideal de Augusto é temperada com pormenores realistas: o olho esquerdo mais fraco com a idade, os dentes ralos, pequenos e irregulares, o cabelo levemente ondulado e a tender para o louro, as sobrancelhas ligadas, as orelhas pequenas, o nariz alto no meio e curvado para baixo, a carnação

${ }^{8}$ Aug. 94.4. Cf. Díon Cássio, 45.1.

${ }^{9}$ Ves. 20: Statura fuit quadrata, compactis firmisque membris, uultu uelut nitentis (...);

${ }^{10}$ Tit. 3.1. Cf. Tácito, Hist. 2.1.2.

${ }^{11}$ Cal.3.1-2: Omnes Germanico corporis animique uirtutes, et quantas nemini cuiquam, contigisse satis constat: formam et fortitudinem egregiam, ingenium in utroque eloquentiae doctrinaeque genere praecellens, beniuolentiam singularem conciliandaeque hominum gratiae ac promerendi amoris mirum et efficax studium. (...) Orauit causas etiam triumphalis; atque inter cetera studiorum monimenta reliquit et comoedias Graecas.

${ }^{12}$ A mesma expressão, armorum et equitandi peritissimus, já caracterizara César (Jul. 57).

${ }^{13}$ Couissin, J. 1953, 242, pensa que ore paulo pleniore se refere não ao rosto, mas ao aspecto da boca. Gascou, J. 1984, 598-602, considera enigmático este traço (n. 534) . 
entre o castanho (aquilus) ${ }^{14}$ e o branco, a estatura pouco elevada. O biógrafo desvaloriza o efeito da pequena estatura, compensada com a proporcionalidade dos membros que fazem Augusto parecer maior e nota alguma contradição entre a statura breuis e os cinco pés e três quartos $(1.70 \mathrm{~m})$ indicados por Júlio Márato, biógrafo do imperador (Aug. 79.2). Com efeito, Suetónio diz em outro passo (Aug. 73) que Augusto usava sapatos altos, para parecer maior. É notório o esforço do imperador para alardear uma imagem de aparato, concretizada na conhecida estátua de Porta Prima. ${ }^{15}$ Mas Suetónio não desmascara a encenação. O retrato do homem, por oposição ao deus, é dado também pelas deformidades (fraqueza da perna esquerda; problemas no dedo indicador da mão direita; pedra na bexiga) (Aug. 80).

Ao retrato de Vespasiano acrescenta-se um pormenor de realismo não dignificante, que Suetónio tenta reverter a favor da imagem positiva que deste imperador quer transmitir: a característica expressão do rosto de quem está a fazer esforço. Mas tal característica associa-se a uma faceta largamente ilustrada nesta biografia até ao momento da morte: o sentido de humor. Vespasiano pediu a um brincalhão que dissesse algo espirituoso acerca do próprio governante e o interlocutor respondeu-lhe que diria, «quando o imperador deixasse de aliviar a tripa». ${ }^{16}$ Assim se faz referência, por associação de ideias, a um traço de carácter de grande relevo em Vespasiano: a comitas. ${ }^{17}$ É curioso que Suetónio omita, neste retrato, a calvície, mencionada por Díon Cássio (66.17.3), como se o biógrafo quisesse poupar o simpático imperador a esta deficiência incómoda para um romano, e que outros (César, Otão) procuravam disfarçar ${ }^{18}$. Também de Tito se refere, como menos positivo, a pequena estatura e o ventre saliente, ${ }^{19}$ mas sob a forma de concessão (quamquam) que não afecta o essencial. A ressalva feita ao ventre de Tito sugere o seu lado negro: o gosto das orgias. Este e outros vícios mudaram-se em virtudes depois de ascender a imperador (Tit.7.1).

O retrato físico de Cláudio é reflexo da descrição paradoxal que dele faz Suetónio: uma alternância contínua de aspectos positivos e negativos com propensão para os segundos. A descrição começa por ser altamente favorável:

${ }^{14}$ Aug. 79.2: (...) sed in senecta sinistro minus uidit; dentes raros et exiguos et scabros; capillum leuiter inflexum et subflaum; supercilia coniuncta; mediocres aures; nasum et a summo eminentiorem et ab imo deductiorem; colorem inter aquilum candidumque; staturam breuem. Couissin, J. 1953, 244-246, pensa que o uso do termo aquilus não é fortuito: acompanhado da referência ao nariz aquilino e às sobrancelhas juntas, pretende associar Augusto à águia, não só em sentido fisiognomónico, mas também devido ao simbolismo que a ave tem para um romano. Para Gascou, J. 1984, 602-606, Augusto não é aguia nem leão: é um ser apolíneo.

${ }_{15}$ Segundo Martin, R. 1991, 53, os sinais corporais, dispostos como as estrelas da Ursa Maior (Aug. 80), em paralelo com os sinais de sua mãe Ácia, contribuem para a formação do mito.

${ }^{16}$ Ves. 20: (...) de quo quidem urbanorum non infacete siquidem petenti, ut et in se aliquid diceret: 'dicam', inquit, 'cum uentrem exonerare desineris'.

${ }_{17}$ Ves. 22: Et super cenam autem et semper alias comissimus multa ioco transigebat.

${ }^{18}$ A calvície está implícita numa graça de Vespasiano sobre o aparecimento de um cometa (Ves. 23.4).

${ }^{19}$ Tit. 3.1: quamquam neque procera statura et uentre paulo proiectiore. 
auctoritas dignitasque formae non defuit ei, uerum stanti uel sedenti ac praecipue quiescenti, nam et prolixo nec exili corpore erat et specie canitieque pulchra, opimis ceruicibus... (Cl. 30.) ${ }^{20}$ («Não lhe faltava autoridade nem dignidade no aspecto físico, quer de pé, quer sentado e sobretudo em repouso. Tinha, de facto, uma estatura elevada sem ser descarnado, uma bela face e uma bela cabeleira branca, um pescoço forte»).

Esta parte do retrato reflecte a eugeneia do filho de Druso, que se manifesta, como o próprio Augusto reconhece, quando o seu espírito se não perturba e quando lê em público ( $C l$. 4.5-6). Mas a segunda parte do retrato revela a total falta de majestade e de dignitas: ... ceterum et ingredientem destituebant poplites minus firmi, et remisse quid uel serio agentem multa dehonestabant: risus indecens, ira turpior spumante rictu, umentibus naribus, praeterea linguae titubantia caputque cum semper tum in quantulocumque actu uel maxime tremulum (Cl. 30. $)^{21}$ («Quanto ao resto, ao caminhar, traíam-no os jarretes pouco firmes e, quer tratasse de assuntos ligeiros, quer de assuntos graves, muitos eram os aspectos grotescos que o desfeavam: um riso descomposto; uma cólera ainda mais repugnante, com o espumar da boca; o nariz a pingar; além do mais, uma voz entaramelada e a cabeça sempre a tremer, sobretudo quando fazia esforço, por pequeno que fosse»).

Tal retrato, em que Suetónio cede à caricatura, ${ }^{22}$ surge em consonância com a imagem de um homem totalmente inepto para o cargo que irá ocupar, como se salienta desde o início desta Vida, em que inversão de papéis é uma constante. A aclamação ridícula e ignominiosa ${ }^{23}$ e a submissão a mulheres e a libertos ( $C l$. 25.5), fazem de Cláudio não um princeps, mas um minister ( $C l$. 29.1), apesar de ser pessoa instruída. ${ }^{24}$

Quanto a Tibério, Suetónio deixa-nos uma positiva imagem física de robustez, ${ }^{25}$ consentânea com a do austero comandante militar que fora (Tib. 18). A estatura a exceder a média (statura quae iustam excederet) parece sugerir desequilíbrio. Por outro lado, a proporção dos membros encontra

${ }^{20}$ Preferimos a correcção, adoptada na ed. de Ailloud, de uerum em vez de et ueterum do manuscrito $M$, seguido, com uma crux desperationis, na ed. de Iнм.

${ }^{21}$ Estes traços são ainda mais caricaturados em Séneca, Apoc. 5.2-3. Gascou, J. 1984, 615, afirma: «Ici, Suétone s'abandonne à sa veine caricaturale et délaisse toute objectivité, comme l'indiquent les termes méprisants qu'il accumule (dehonestabant, indecens, turpior). Il ne manie plus les instruments du clinicien, mais le fouet de la satire». Vide Martin, R. 1991, 70-74; Sток, F. 1995, 127-129.

${ }^{22}$ Vide Gascou, J. 1984, 615.

${ }^{23}$ Cl. 10. Cf. Díon Cássio, 60.1.3-4, e Flávio Josefo, AJ. 19.212-225.

${ }^{24}$ Cl. 40.3: multaque talia etiam priuatis deformia, nedum principi, neque infacundo neque indocto, immo etiam pertinaciter liberalibus studiis dedito.

${ }_{25}^{25}$ Tib. 68.1-2: Corpore fuit amplo atque robusto, statura quae iustam excederet; latus ab umeris et pectore, ceteris quoque membris usque ad imos pedes aequalis et congruens; sinistra manu agiliore ac ualidiore, articulis ita firmis, ut recens et integrum malum digito terebraret, caput pueri uel etiam adulescentis talitro uulneraret. Colore erat candido, capillo pone occipitium summissiore ut ceruicem etiam obtegeret, quod gentile in illo uidebatur; facie honesta, in qua tamen crebri et subiti tumores, cum praegrandibus oculis et qui, quod mirum esset, noctu etiam et in tenebris uiderent, sed ad breue et cum primum e somno patuissent; deinde rursum hebescebant. 
correspondência na fase positiva do início do reinado, antes de se retirar para a ilha de Cápreas. A mão esquerda é mais forte, com as articulações tão firmes que, com um dedo, seria capaz de furar uma maçã acabada de colher ou ferir na cabeça, com um piparote, uma criança ou até um adolescente. Tal precisão realista ${ }^{26}$ - e nenhum outro autor refere esta particularidade sugere uma experiência feita, que recorda a pederastia de Tibério, associada à crueldade $^{27}$ (Tib. 44.2). Mas a força da sinistra manus pode também sugerir outras características de Tibério: a avareza (Tib. 46-48) e a tendência para a rapina (Tib. 49) - basta lembrar as funções infamantes conferidas à mão esquerda na literatura antiga. ${ }^{28}$ Mesmo no momento da morte, Tibério tira o anel para transmitir o seu poder, mas logo se arrepende e o retém, apertando a mão esquerda (Tib. 73.2).

O cabelo crescido até abaixo, por detrás da cabeça, é visto como uma característica da família (quod gentile in illo uidebatur). A carga hereditária tem para o biógrafo grande peso no carácter dos Césares, como vimos no capítulo anterior; e na biografia de Tibério a influência é sensível. ${ }^{29}$ Ora na descrição da família cláudia, com que Suetónio abre esta biografia, embora se diga que há muitas obras meritórias e muitas más, ${ }^{30}$ prevalecem os aspectos negativos. A observação de que possuía uma facies honesta, é ensombrada (com um tamen) pelos numerosos e súbitos tumores, ${ }^{31}$ que parecem sugerir as manchas morais, ou até o tumor animi, ${ }^{32}$ o estado de perturbação em que Tibério vivia. À afirmação de que tinha os olhos muito grandes ${ }^{33}$ se acrescenta um dado sinistro: a capacidade de ver de noite, que contribuiria para tornar o tirano mais temido. ${ }^{34} \mathrm{~A}$ ligação entre o retrato físico e o psicológico faz-se através da referência à forma de caminhar de Tibério, com o pescoço rígido e inclinado para trás, e ao feitio taciturno: atitudes desagradáveis e cheias de arrogância que Augusto desculpara como vícios da natura e não do animus, ${ }^{35}$

${ }^{26}$ Vide Gascou, J. 1984, 611-612, n. 582.

${ }^{27}$ Vide Lindsay, H. 1995, 17. Pelo contrário, Martin, R. 1991, 60, acha que se não deve interpretar como sinal de crueldade.

${ }^{28}$ Cf. Plauto, Per., 227: furtifica laeua ; Catulo 12.1-2: Marrucine Asini, manu sinistra / non belle uteris... ; Ovídio, Met. 13.111: nataeque ad furta sinistrae.

${ }^{29}$ Ex hac stirpe Tiberius Caesar genus trahit, e<t> quidem utrumque.

${ }^{30}$ Tib. 2.1: Multa multorum Claudiorum egregia merita, multa etiam sequius admissa in rem $p$. extant.

${ }^{31}$ Tácito, que faz um retrato ainda mais sombrio de Tibério na velhice (Ann. 4.57.2), fala de ulcerosa facies.

32 A expressão é de Cícero (Tusc. 3.26; 76) de quem Suetónio era um conhecedor e admirador.

${ }^{33}$ Segundo Martin, R. 1991, 62-63, pode ser sinal de miopia, o que explica a fraqueza de vista referida por Díon Cássio, 57.2.4.

${ }^{34}$ Tal acuidade demorava pouco tempo e sucedia ao despertar do sono. Esta fama pode ter sido divulgada pelo próprio Tibério, temeroso de atentados nocturnos; vide MARTIN, R. 1991, 63-64. Segundo ANDrÉn, A. 1957, 59-60, um busto de mármore, que se encontra na Villa de San Michele, corresponde traço a traço ao retrato descrito por Suetónio, até no que diz respeito à expressão: os olhos grandes lembram a capacidade de ver no escuro.

${ }_{35}$ Tib. 68.3: Incedebat ceruice rigida et obstipa, adducto fere uultu, plerumque tacitus, nullo aut rarissimo etiam cum proximis sermone eoque tardissimo, nec sine molli quadam digitorum gesticulatione. 
imputando-os assim à hereditariedade. Como hereditária é sugerida a saeua ac lenta natura, que Tibério manifesta desde a infância, e que leva o seu professor de retórica a denominá-lo «barro amassado em sangue», mas que o imperador soube dissimular sob uma capa de moderatio no início do seu governo (Tib. 57.1). A natura saeua leva-o a dizimar a família e os que lhe estão próximos, até que, por fim, se sente profundamente desgostoso de si próprio (Tib. 67). A taciturnidade, a lentidão no falar, o movimento dos dedos sugerem também insegurança e timidez nunca superadas, que parecem explicar a tendência para o isolamento, que o condena a dois auto-exílios (em Rodes, durante o governo de Augusto; e em Cápreas, na segunda parte do seu principado) e a tendência para a crueldade. Tal misantropia é explicada pelo medo contínuo em que vivia, ${ }^{36}$ que o fizera escolher o refúgio de Cápreas, pela sua inacessibilidade, ${ }^{37} \mathrm{e}$ ditara a punição bárbara de um pescador que, ao subir as escarpas para oferecer ao imperador o melhor peixe que pescara, o deixara territus com a proeza, pois revelava, assim, a vulnerabilidade do refúgio (Tib.60).

O único traço verdadeiramente positivo de Galba é a statura iusta: o resto são traços neutros ou degenerativos da velhice: statura fuit iusta, capite praecaluo, oculis caeruleis, adunco naso, manibus pedibusque articulari morbo distortissimis, ut neque calceum perpeti neque libellos euoluere aut tenere omnino ualeret. Excreuerat etiam in dexteriore latere eius caro praependebatque adeo ut aegre fascia substringeretur (Gal. 21) («Tinha uma estatura normal, a cabeça completamente calva, os olhos de um azul carregado, o nariz aquilino, as mãos e pés de tal sorte deformados pela gota, que não suportava calçado nem conseguia desenrolar um documento ou segurá-lo sequer. Aparecera-lhe do lado direito uma excrescência de carne pendente e tão grande, que a custo a continha com uma faixa»).

Como no caso de Otão e de Vitélio, este retrato aparece na sequência da narrativa da morte e em íntima ligação com esta. A calvície, que envergonhava um romano, e que César e Otão procuram dissimular, em Galba é total (capite praecaluo). Esta nota torna-se ainda mais infamante pela relação com o pormenor macabro referido atrás (o soldado que lhe cortou a cabeça, «porque não podia agarrar-lhe pelo cabelo, escondeu-a no regaço; depois, metendo-lhe o polegar pela boca dentro, levou-a a Otão»), ${ }^{38} \mathrm{com}$ as palavras trocistas dos soldados ${ }^{39}$ e com o ridículo em que o ancião caía, ao afirmar que as suas forças ainda estavam intactas. $\mathrm{O}$ retrato físico contrasta com o do excelente general que fora em tempos, capaz de restabelecer a disciplina no exército da Germânia (Gal.6.2), de dirigir os exercícios militares e correr ao lado do carro de Calígula

Quae omnia ingrata atque arrogantiae plena et animaduertit Augustus in eo et excusare temptauit saepe apud senatum ac populum professus naturae uitia esse, non animi.

${ }^{36}$ Tib. 63.1: non modo inuisus ac detestabilis, sed praetrepidus quoque atque contumeliis obnoxius uixerit.

${ }^{37}$ Tib. 40: (...) quod uno paruoque litore adiretur, saepta undique praeruptis immensae altitudinis rupibus et profundo mari[s].

${ }^{38} \mathrm{Gal}$. 20.2: et quoniam capillo arripere non poterat, in gremium abdidit, mox inserto per os pollice ad Othonem detulit.

${ }^{39}$ Gal. 20.2: 'Galba, Cupido, fruaris aetate tua'. 
numa distância de vinte mil passos (Gal. 6.3) e de atrair as solicitações de Agripina (Gal.5.1) (se bem que não seriam só, nem principalmente, os atributos físicos de Galba a moverem esta ambiciosa mulher). Trata-se, pois, do retrato do imperador já ancião, que chegou tardiamente ao poder. Tácito diz-nos que a «sua velhice era objecto de troça para as pessoas habituadas à juventude de Nero e que comparam os imperadores, como é costume do vulgo, com base na beleza e graciosidade do físico». ${ }^{40}$ Suetónio não tem por Galba a simpatia que Tácito demonstra, seduzido pela sua austeridade e culto dos bons costumes. O retrato suetoniano está em consonância com a má reputação que Galba adquire depois de ascender ao império, ${ }^{41}$ já precedida da fama de crueldade e avareza. ${ }^{42} \mathrm{~A}$ imagem de decrepitude física parece implicar senilidade, sugerida pela total dependência de três ministros corruptos. Torna-se incoerente nas decisões e a antítese da tradicional imagem de sabedoria que se atribui a um ancião, ${ }^{43}$ incapaz de ter uma noção correcta dos problemas. ${ }^{44} \mathrm{~A}$ gota nas mãos (articularis morbus) poderá associar-se, como faz Marcial, ${ }^{45}$ à ideia de avareza, característica de Galba. Com efeito, Suetónio apresenta-nos o retrato de um avaro. ${ }^{46}$ É este vício que precipita o seu fim: ao adoptar Pisão, não concedeu às tropas o habitual donativo - facto que, como nota o biógrafo, favoreceu Otão (Gal. 17), que se mostrava muito mais generoso para os soldados.

A descrição física de Vitélio aparece muito oportunamente inserida na narrativa da morte do imperador - um linchamento popular -, no momento em que se afirma que, além de lhe chamarem incendiário e alarve, havia quem the censurasse os defeitos do corpo. O próprio biógrafo contribui para o linchamento, ao expor, sem piedade, os defeitos físicos de Vitélio: Erat enim in eo enormis proceritas, facies rubida plerumque ex uinulentia, uenter obesus, alterum femur subdebile impulsu olim quadrigae, cum auriganti Gaio ministratorem exhiberet (Vit. 17.2) («Era de uma corpulência desmesurada, tinha a face geralmente avermelhada pela embriaguez, o ventre obeso, uma coxa um pouco fraca, devido ao choque de uma quadriga, quando outrora prestava assistência a Gaio, que actuava como auriga»). E um retrato muito negativo, em que os vícios corporais denunciam os vícios morais: a imagem apresentada ao longo de toda a Vida é a de um glutão e de um ébrio. Galba nomeia-o legado do exército da Germânia, porque quem só pensa em comer e

${ }^{40}$ Hist. 1.7.3: Ipsa aetas Galbae inrisui ac fastidio erat adsuetis iuuentae Neronis et imperatores forma ac decore corporis, ut est mos uolgi, comparantibus.

${ }^{41}$ Gal. 14.1: Maiore adeo fauore et auctoritate adeptus est quam gessit imperium, quanquam multa documenta egregii principis daret; sed nequaquam tam grata erant, quam inuisa quae secus fierent.

${ }^{42}$ Gal. 12.1: Praecesserat de eo fama saeuitiae simul atque auaritiae.

${ }^{43} \mathrm{Gal}$. 14.2: modo acerbior parciorque, modo remissior ac neglegentior quam conueniret principi electo atque illud aetatis. Vide MARTin, R. 1991, 286-287.

${ }^{44} \mathrm{Gal}$. 17. O motivo que o leva a adoptar Pisão é estar convencido de que não era tanto a velhice que o tornava objecto de desprezo, mas o facto de não ter filhos

${ }^{45}$ Marcial, 1.98: Litigat et podagra Diodorus, Flacce, laborat. / Sed nil patrono porrigit: haec cheragra est.

${ }^{46}$ Gal. 12.3. Tácito, Hist. 1.49.3, dá uma imagem positiva do rigor de Galba. 
beber não pode ser perigoso e, com a abundância da província, poderia encher a sua goela sem fundo (Vit. 7.1). Na viagem, para ostentar familiaridade com os acompanhantes, mostra, com um arroto, que já almoçou (Vit. 7.3). Quando se torna imperador, os seus banquetes são uma caricatura dos de Nero. Tinha capacidade para tal quantidade de comida graças ao seu costume de vomitar. A magnificência gastronómica leva-o a inventar um prato a que chamou «escudo de Minerva protectora da cidade». Nisto consiste a falta de moderação de Vitélio, abertamente censurada pelo biógrafo: homo non profundae modo, sed intempestiuae quoque ac sordidae gula ... («homem não só de uma gula sem fundo, mas também sem hora e abjecta»). ${ }^{47} \mathrm{Na}$ sua fuga desesperada para o Aventino, o seu séquito é apenas composto por um padeiro e um cozinheiro (Vit.16.1). A gula aparece ainda associada à crueldade atroz: manda reconduzir um condenado à sua presença e, quando todos celebravam já a clemência do imperador, ordenam que o executem à sua frente, dizendo que "queria dar alimento aos olhos». ${ }^{48} \mathrm{~A}$ ebriedade e a gula de Vitélio vêm também associadas à impiedade: bebe - e, para mais, merum - para disfarçar o odor dos cadáveres, ao visitar o campo de batalha de Betríaco. ${ }^{49} \mathrm{Na}$ guerra com os partidários de Vespasiano, contempla, no meio de um banquete, o incêndio do Capitólio, cuja responsabilidade Suetónio, ao contrário de Tácito, atribui a Vitélio. ${ }^{50}$ Como o retrato físico, toda a vida de Vitélio é indigna e praticamente desprovida de aspectos positivos: está associado aos piores vícios dos últimos Júlio-Cláudios. ${ }^{51}$ À indignidade na vida corresponde a indignidade na morte. A narrativa da execução humilhante, interrompida pela inserção do retrato, é rematada de forma atroz: foi dilacerado junto às Gemónias, e arrastado com um gancho para o Tibre. ${ }^{52}$ É o imperador mais odioso das Vidas. Suetónio não lhe perdoou ter sido responsável pela morte de Otão.

Embora Domiciano seja apresentado como um terrível tirano, o seu retrato não é tão negro como o de Vitélio e apresenta aspectos bastante positivos:

Statura fuit procera, uultu modesto ruborisque pleno, grandibus oculis, uerum acie hebetiore; praeterea pulcher ac decens, maxime in iuuenta, et quidem toto corpore exceptis pedibus, quorum digitos restrictiores habebat; postea caluitio quoque deformis et obesitate uentris et crurum gracilitate, quae tamen ei ualitudine longa remacruerant. Commendari se uerecundia oris adeo sentiebat, ut apud senatum

${ }^{47}$ Vit. 13.3: Vide Martin, R. 1991, 115.

48 Vit. 14.2: 'uelle se' dicens 'pascere oculos'.

${ }^{49} V$ it. 10.3. Este é um dos vários gestos referidos por Suetónio e que não figuram na descrição da mesma cena em Tácito, Hist. 2.70.

${ }^{50}$ Vit. 15.3. Cf. sucessão dos acontecimentos relacionados com o incêndio em Tácito, Hist. 3.69-71.

${ }^{51}$ A Tibério, porque é um dos prostitutos (Vit. 3.2); a Calígula, no gosto pelas corridas; a Cláudio, na paixão pelo jogo dos dados; a Nero, nas mesmas paixões e porque, ao presidir aos jogos Neronianos, rogara ao imperador que participasse no concurso dos citaredos (Vit. 4; cf. Vit. 11.2; Vit. 12).

${ }^{52}$ Vit. 17.2. Mas Tácito, Hist. 3.85, concede-lhe alguma dignidade no momento da morte e censura a volubilidade das massas. Cf. Díon Cássio, 65.21.2. 
sic quondam iactauerit: 'usque adhoc certe et animum meum probastis et uultum'. Caluitio ita offendebatur, ut in contumeliam suam traheret, si cui alii ioco uel iurgio obiectaretur (Dom. 18.1-2).

«Tinha estatura elevada, o rosto modesto e muito ruborizado, olhos grandes, mas a vista bastante fraca. Além do mais, era bem belo e bem-feito, sobretudo na juventude, em todo o corpo, à excepção dos pés, cujos dedos eram demasiado curtos. ${ }^{53}$ Mais tarde, desfiguraram-no a calvície, o ventre obeso e as pernas delgadas, que emagreceram ainda mais, devido a uma longa doença. Confiava tanto no aspecto tímido do rosto, que certa vez disse no senado: 'até aqui, sem dúvida, aprovastes não só o meu carácter, como também a minha face'. Desgostava-o tanto a calvície, que tomava mesmo como ofensa pessoal, se se apontava a outro este defeito numa brincadeira ou numa altercação».

Embora sejam visíveis certos traços comuns ao pai e ao irmão - a beleza de Tito e a tendência para a obesidade, bem como a calvície de Vespasiano -, sugere-se uma degeneração. A magreza das pernas, comum aos príncipes que levam um regime de vida decadente (Calígula e Nero), associada ao ventre obeso (que partilha com Nero e Vitélio), são traços congruentes com a vida sedentária de Domiciano: inimigo da fadiga, não andava a pé nem a cavalo (Dom. 19). ${ }^{54} \mathrm{~A}$ calvície despertaria comentários - Juvenal (4.38) chama-lhe "Nero calvo». Domiciano escreve mesmo um livro De cura capillorum (Dom. 18.2). Com a decadência física (postea ... deformis), Suetónio parece querer sugerir ${ }^{55}$ a degradação moral que descortina na condução do império. ${ }^{56}$ As afirmações sobre a forma como usava a aparência modesta do rosto ruborizado evocam a capacidade de dissimulação, partilhada por outros maus príncipes, como Tibério, Calígula e Nero. Já durante a guerra com Vitélio, a forma como escapa do Capitólio, disfarçado de sacerdote de Ísis (Dom.1.2), revela os seus dotes. Diz o biógrafo que Domiciano, durante o principado do pai e do irmão, simulou admiravelmente modéstia e dedicação à poesia (Dom.2.2). Tal propensão levanta suspeitas sobre o horror que manifestava, no início, por todo o género de morte e a liberalidade que demonstrava (Dom. 9.1), pois em breve descamba claramente para a saeuitia e para a cupiditas (Dom. 10.1).

O retrato de Nero não apresenta uma continuidade tão visível com a vida, mas não deixa de haver correspondências: statura fuit prope iusta, corpore maculoso et fetido, subflauo capillo, uultu pulchro magis quam uenusto, oculis caesis et

${ }^{53}$ Couissin, J. 1953, 252, sugere que restrictiores se deve traduzir antes por 'recurvados', como garras, traço que, segundo as teorias fisiognomonistas, seria sinal da rapacitas característica de Domiciano. GAscou, J. 1984, 613, n. 598, contesta o significado de tal característica, a intenção fisiognomónica de Suetónio e a nova tradução sugerida para a palavra.

${ }^{4}$ Os exercícios de equitação são considerados benéficos para a saúde: cf. Cal. 3.1. Vide Sток, F. 1995, 127.

55 Como sugere Sток, F. 1995, 130-131.

${ }^{56}$ Dom. 3.2: Circa administrationem autem imperii aliquamdiu se uarium praestitit, mixtura quoque aequabili uitiorum atque uirtutum, donec uirtutes quoque in uitia deflexit. Cf. Dom. 9.1; 10.1 . 
hebetioribus, ceruice obesa, uentre proiecto, gracillimis cruribus (Nero 51) («Tinha uma estatura quase mediana, o corpo com manchas e malcheiroso, o cabelo alourado, o rosto mais belo do que gracioso, os olhos esverdeados e muito fracos, o pescoço obeso, a barriga proeminente, as pernas muito delgadas»).

Nota-se um misto de beleza e fealdade, que pode corresponder à divisão que Suetónio opera na biografia entre acções boas ou neutras e acções más (Nero 19.3). O pescoço e o ventre reflectem os excessos da mesa (Nero 27.2); a debilidade das pernas superlativada (gracillimis cruribus), sugere, como vimos, degeneração. $\mathrm{O}$ corpo manchado e fétido recorda as manchas morais resumidas nos probra e nos scelera (Nero 19.3; 39.1). Desde o início da biografia se acentua a ligação aos Domícios, de quem, diz o biógrafo, Nero degenerou nas virtudes e repetiu os defeitos. ${ }^{57} \mathrm{~A}$ vida de Nero no seu todo é bastante reveladora: não é necessário um longo retrato físico para ajudar a interpretar o carácter.

Maior luz sobre o carácter traz o retrato de Calígula. Suetónio divide esta biografia entre actos de princeps e actos de monstrum, mas o retrato físico representa apenas o segundo e, ao contrário do habitual tratamento em separado, insere-se claramente na parte da biografia que descreve o monstrum:

Statura fuit eminenti, colore expallido, corpore enormi, gracilitate maxima ceruicis et crurum, oculis et temporibus concauis, fronte lata et torua, capillo raro at circa uerticem nullo, hirsutus cetera. Quare transeunte eo prospicere ex superiore parte aut omnino quacumque de causa capram nominare criminosum et exitiale babebatur. Vultum uero natura horridum ac taetrum etiam ex industria efferabat componens ad speculum in omnem terrorem ac formidinem. ${ }^{58}$

«Era de estatura elevada, tez muito pálida, corpo desproporcionado, o pescoço e as pernas extremamente delgados, os olhos e as têmporas encovados, uma fronte vasta e sanhuda, o cabelo ralo e nenhum no alto da cabeça, o resto do corpo hirsuto, pelo que era considerado crime, e de morte, olhar de cima, à passagem dele, ou sequer pronunciar a palavra "cabra" a qualquer pretexto. Quanto ao rosto, medonho e repugnante por natureza, tornava-o de propósito ainda mais feroz, trabalhando-o ao espelho para assumir todas as expressões aterradoras e medonhas».

A imagem de Calígula é expressão do desequilíbrio levado ao extremo, como sugerem os superlativos e o jogo de contrastes: o color expallidus excede largamente o color candidus de César e de Tibério ${ }^{59}$ e pode ser associado pelo senso comum a um semblante doentio (pelo seu significado de 'macilento', diferente de candidus); o corpus enorme contrasta com o pescoço e as pernas excessivamente delgadas (gracilitas maxima); os olhos e têmporas encovadas

${ }^{57}$ Nero 1.2: Pluris e familia cognosci referre arbitror, quo facilius appareat ita degenerasse a suorum uirtutibus Nero, ut tamen uitia cuiusque quasi tradita et ingenita ret $<t>$ ulerit.

${ }^{58}$ Cal. 50.1: Suetónio mostra-se dependente de uma tradição literária. No extremo oposto, a iconografia apresenta Calígula como o mais belo dos príncipes: mas deve-se ter em conta a idealização. Vide Gascou, J. 1984, 614, n. 602.

${ }^{59}$ Cf. Jul. 45.1; Tib. 68.2. Para as teorias fisiognomonistas, a cor clara indicia um carácter libidinoso e mole: vide Couissin, J. 1953, 243, e 249-250; Gascou, J. 1984, 608. 
brigam com a fronte vasta e torva; por seu turno, a frons lata et torua opõe-se ao capillus rarus; e, no que se refere ao cabelo, circa uerticem nullus contrasta com birsutus cetera. Completa-se o aspecto monstruoso através da associação à figura de uma cabra. ${ }^{60}$ Esta descrição contrasta com o retrato físico e moral do pai de Calígula, Germânico, apresentado no início da biografia. Em comum com ele, tem apenas a magreza das pernas. Mas o biógrafo diz-nos que Germânico corrigiu esse defeito com o hábito da equitação. ${ }^{61}$

Não é necessário recorrer aos conhecimentos das teorias fisiognomonistas ${ }^{62}$ para perceber que este retrato descreve alguém que não tem sanidade nem no corpo nem na mente, como o biógrafo conclui logo a seguir. ${ }^{63} \mathrm{~A}$ imagem visual de Calígula torna-se consonante com o seu carácter monstruoso. Desde cedo, se mostra incapaz de dominar a natura saeua atque probrosa - a «natureza cruel e infame», que o leva a assistir cupidissime aos suplícios dos condenados (Cal. 11), tem continuidade, na parte relativa à descrição do monstrum (Cal. $22 \mathrm{ss}$ ), na saeuitia ingenii (Cal. 27.1) - crueldade de carácter depois agravada pela inveja (Cal.34-35). A «a natureza infame» é manifesta inicialmente nas deambulações nocturnas por tabernas e bordéis e na forma empenhada como se entregava às artes cénicas do canto e da dança, desmandos que Tibério tolerava, na esperança de que lhe amenizassem a índole feroz (Cal. 11). A associação entre o aspecto físico e o psicológico é feita pelo próprio Calígula, que explora o seu aspecto. A preocupação de ensaiar semblantes terríficos frente ao espelho pode associar-se ao carácter histriónico do imperador e à necessidade de dominar pelo recurso ao terror.

Em oposição aos retratos que acabamos de referir, o de Otão apresenta-se contrário ao julgamento moral que dele faz o biógrafo. Suetónio, certamente influenciado pelo pai, Suetónio Leto, que militara no exército deste imperador, mostra, ao contrário do senador Tácito, simpatia por Otão, mas observa que tanto o físico como os hábitos contrastam, surpreendentemente, como dissemos, com a grandeza do seu suicídio. O retrato físico é apenas esboçado: «de pequena estatura, tem pés deformados e é cambaio». ${ }^{64}$ Tais características, juntamente

${ }^{60}$ Contra Couissin, J. 1953, 247-248, que vê aqui uma alusão à fisiognomonia zoológica, Gascou, J.1984, 609-610, diz que a analogia é apenas impressionista e resulta dos traços físicos indicados.

${ }^{61}$ Cal. 3.1: Omnes Germanico corporis animique uirtutes, et quantas nemini cuiquam, contigisse satis constat: formam et fortitudinem egregiam.... Formae minus congruebat gracilitas crurum, sed ea quoque paulatim repleta assidua equi uectatione post cibum. Quase todos os imperadores eram bons antes de serem governantes e a morte prematura deste popular general favoreceu a idealização da imagem.

${ }^{62}$ Os estudos sobre as teorias fisiognomonistas, a partir do retrato de Calígula, indicam um carácter libidinoso, despudorado, louco, criminoso e pérfido. Vide Couissin, J. 1953, 249-251. Este autor acha que o retrato foi composto ou ajustado para confirmar o carácter de Calígula. Gascou, J. 1984, 607-610, admite que o retrato de Calígula seja o que mais se conforma à teoria de Couissin, embora note que a coerência não é perfeita.

${ }^{63}$ Cal. 50.2: Valitudo ei neque corporis neque animi constitit; Cal. 51.1: Non inmerito mentis ualitudini atribuerim diuersissima in eodem uitia, summam confidentiam et contra nimium metum.

${ }^{64}$ Otho 12.1: Tanto Othonis animo nequaquam corpus aut habitus competit. Fuisse enim et modicae staturae et male pedatus $\langle s\rangle$ cambusque traditur. 
com o aspecto efeminado de que falaremos mais à frente, contrastam com a imagem de um strenuus. $\mathrm{O}$ mérito de Otão está no ódio às guerras civis, que só Suetónio menciona, e no suicídio altruísta, para evitar mais derramamento de sangue, quando nem tudo estava perdido (Otho 9.3; Cf. Marcial, 6.32). A intenção de restituir a res publica ac libertas (Otho 12.2) é mencionada numa perspectiva moral, mais do que política, pois demonstra a falta de ambição de Otão e absolve-o da morte de Galba, considerada facinus flagitiosissimum por Tácito (Hist. 2.50.1).

Varia a relação entre a personalidade apresentada ao longo da biografia e o retrato físico. Num extremo está Calígula, cujo retrato se conforma com o monstro louco, como é explicitamente apresentado, e no outro situa-se Otão, cuja debilidade física e modos, embora coerentes com a primeira parte da vida, contrastam, como nota o próprio biógrafo, com a virilidade demonstrada na morte, onde o verdadeiro carácter se revela.

Está presente a ideia de que o equilíbrio psicofísico pressupõe um regime de vida moderado. ${ }^{65}$ Destacam-se alguns traços comuns aos maus príncipes: $\mathrm{o}$ ventre obeso, evidente sinal de excessos, figura em Nero, em Vitélio, um pouco em Tito e em Domiciano, e a gracilitas crurum é comum a Calígula, em quem é extrema, Nero e Domiciano. O color candidus de Júlio César e Tibério aparece transformado em expallidus em Calígula.

Certos dados são neutros: a força e o vigor do corpo podem ser usados para o bem ou para o mal. A harmonia dos membros parece sugerir o equilíbrio psicofísico de Augusto, Vespasiano e César: por isso falta a Tibério, a Calígula e a Vitélio. A beleza tende a acentuar-se nos bons imperadores (Augusto, Tito, Vespasiano) e no potencial imperador Germânico, embora seja referida nos maus (Nero, Domiciano). Os bons podem apresentar traços negativos; e os maus, traços positivos. Também do ponto de vista moral dificilmente haverá imperadores exclusivamente bons, ou exclusivamente maus. Só Vitélio parece ser a excepção: nem apresenta traços físicos positivos, nem virtudes, pois só duas medidas positivas lhe são atribuídas, e de passagem (Vit.10.1).

\subsection{O adorno}

A excessiva preocupação com o aspecto é sinal de um espírito efeminado. As roupas não devem, em princípio, merecer comentário especial. Se são alvo de atenção, é porque se afastam dos padrões de decência estabelecidos: respeito pela tradição, pelo sexo, pela condição, pelo contexto em que são usadas. O retrato de Augusto deixa claro que o imperador se não preocupava demasiado com os cuidados corporais: era incuriosus no arranjo do cabelo e da barba. ${ }^{66}$ Traem, no entanto, a afirmação do desprendimento de Augusto em relação à sua imagem a nota de que usava sapatos altos, para parecer

${ }^{65}$ Vide Sток, F. 1995, 129.

${ }^{66}$ Aug. 79.1: (...) quamquam et omnis lenocinii neglegens; in capite comendo tam incuriosus, ut raptim compluribus simul tonsoribus operam daret ac modo tonderet, modo raderet barbam eoque ipso tempore aut legeret aliquid aut etiam scriberet. 
maior, e o facto de, à beira da morte (Aug. 99.1), pedir um espelho e mandar compor os cabelos e as faces. O biógrafo refere ainda a acusação de Lúcio António (irmão do triúnviro) de que Augusto, efeminado na juventude, costumava depilar as pernas com casca de noz a $\operatorname{arder}{ }^{67}$ mas não the dá demasiado crédito, com base na conduta posterior do imperador, ${ }^{68}$ pelo que esse comportamento fica minimizado como incerto pecadilho da juventude ou mera invectiva política.

$\mathrm{Na}$ indumentária e calçado se manifesta a parsimonia de Augusto e o respeito pela tradição (Aug. 73): usava roupas feitas pela irmã, pela esposa, pela filha e pelas netas; as togas, não as trazia nem apertadas nem demasiado folgadas, e a banda de púrpura não era muito larga nem muito estreita. Mesmo entre as várias camadas de roupas, mencionadas a propósito dos cuidados com a saúde (Aug. 82), a toga figura à cabeça da lista, como peça insubstituível sobre todas as outras vestimentas. Este imperador, preocupado com a restauração dos costumes antigos, manifesta a sua repulsa pelo facto de muitos cidadãos se apresentarem em público vestidos de negro (isto é, cobertos com a lacerna, o manto gaulês, que se usava por cima da toga) e exigiu que ninguém entrasse na zona do Foro a não ser de toga (Aug. 40.5).

Já no que respeita a César, a nota negativa da rubrica do retrato está no zelo excessivo com o físico, e na forma efeminada de usar o vestuário:

Circa corporis curam morosior, ut non solum tonderetur diligenter ac raderetur, sed uelleretur etiam, ut quidam exprobrauerunt, caluitii uero deformitatem iniquissime ferret saepe obtrectatorum iocis obnoxiam expertus. Ideoque et deficientem capillum reuocare a uertice adsueuerat et ex omnibus decretis sibi a senatu populoque honoribus non aliud aut recepit aut usurpauit libentius quam ius laureae coronae perpetuo gestandae. Etiam cultu notabilem ferunt: usum enim lato clauo ad manus fimbriato nec umquam aliter quam <ut> super eum cingeretur, et quidem fluxiore cinctura. ${ }^{69}$

«Com os cuidados corporais era bastante minucioso: não só punha todo o afinco a aparar o cabelo e a fazer a barba, mas até se depilava, na opinião censuradora de alguns. Suportava muito mal o defeito da calvície, por perceber que o expunha amiúde às zombarias dos seus detractores. Por isso, costumava recompor o cabelo em falta, puxando-o do alto da cabeça; e, de todas as honras que the foram decretadas pelo senado e pelo povo, nenhuma recebeu e aplicou com maior vontade do que o direito de usar sempre uma coroa de louros. Dizem que era digna de nota também a forma de vestir: usava a túnica laticlávia com franjas até às mãos e sobre ela se cingia, deixando sempre a cintura bastante folgada»

O carácter efeminado está de acordo com as acusações que lhe faziam de ter partilhado o leito de Nicomedes da Bitínia (Jul. 2; 49). As preocupações

\footnotetext{
${ }^{67}$ Aug. 68.

${ }^{68}$ Aug. 71.1.

${ }^{69} \mathrm{Jul}$. 45.2-3. Por isso Sula advertia os optimates de que se guardassem daquele jovem «mal cingido».
} 
com a aparência e a susceptibilidade às críticas ao aspecto físico revelam uma vontade de seduzir, que lhe valeu a fama expressa nos versos fesceninos dos soldados durante o triunfo ${ }^{70}$ e nos discursos dos adversários. ${ }^{71}$

A imagem de César, sempre coroado de louros, tornava-o imperator perpétuo ${ }^{72}$ e proporcionaria a transição para concretizar as suas aspirações monárquicas (Jul.79), ambição detestável para um romano (e sobretudo para o senado), comprovada por facta e dicta que tornam justa a sua morte (Jul.76.1), e que é apresentada como a causa do assassínio de que foi vítima (Jul. 80). Mas a coroa de louros, transformada em adorno pessoal de César, é também o símbolo da progénie dos Césares, que acabará com Nero, como se acentua na introdução à Vida da Galba, ${ }^{73}$ e de um novo tipo de designação da soberania, à qual Júlio César dá o nome. Um dia em que a plebe o aclama como rex, ele, querendo afastar a infâmia, afirma que é «César», não «rei». ${ }^{74} \mathrm{~A}$ coroa de louros ficará para sempre ligada ao seu nome. Mas a origem desta prática é conotada com uma vaidade desmedida.

São os costumes efeminados de Otão que tornam surpreendente a virilidade demonstrada na morte: depilava-se e, como tinha o cabelo ralo, usava uma peruca, mas tão bem adaptada que ninguém dava conta; barbeava-se diariamente e aplicava sobre a face um bocado de pão humedecido; participava publicamente nos mistérios de Ísis, vestido, como os sacerdotes da deusa, com um hábito de linho. ${ }^{75} \mathrm{E}$ na altura em que se rebela contra Galba, Suetónio regista que se dirigiu para o campo pretoriano escondido numa liteira de mulher. ${ }^{76} \mathrm{O}$ biógrafo pretende acentuar o miraculum que foi a sua morte, por contrastar com a vida que levava, ${ }^{77}$ e que estava longe de ser exemplar. Fica a manchá-lo a associação a Nero, de quem se tornara amigo íntimo, pela compatibilidade de hábitos, e ainda, segundo o boato, pelas recíprocas relações carnais. ${ }^{78}$ Mesmo imperador, não rejeita o apelido de Nero e segue uma política filoneroniana (Otho 7.1).

O carácter insano de Calígula é reforçado pela indumentária, classificada

${ }^{70}$ Jul. 51: Vrbani, seruate uxores: moechum caluom adducimus. / Aurum in Gallia effutuisti, bic sumpsisti mutuum.

${ }^{71} \mathrm{Jul}$. 52.3: At ne cui dubium omnino sit et impudicitiae et adulteriorum flagrasse infamia, Curio pater quadam eum oratione omnium mulierum uirum et omnium uirorum mulierem appellat.

${ }_{72}$ Como sugere, citando Carcopino, Martin, R. 1991, 51-52. Suetónio, Jul. 76.1, refere, entre os honores nimii, o facto de receber insuper praenomen imperatoris.

${ }^{73}$ Cf. Gal. 1.

${ }^{74}$ Jul.79.2: (...) et plebei regem se salutanti 'Caesarem se, non regem esse' responderit.

75 Otho 12.1: (...) munditiarum uero paene muliebrium, uulso corpore, galericulo capiti propter raritatem capillorum adaptato et adnexo, ut nemo dinosceret; quin et faciem cotidie rasitare ac pane madido linere consuetum, idque instituisse a prima lanugine, ne barbatus umquam esset; sacra etiam Isidis saepe in lintea religiosaque ueste propalam celebrasse.

${ }^{76}$ Otho 6.3: (...) abditus propere muliebri sella. Tácito (Hist. 1.27.2) diz só et sellae festinanter impositum. fuerit.

77 Otho 12.2: per quae factum putem, ut mors eius minime congruens uitae maiore miraculo

${ }^{78}$ Otho 2.2: (...) congruentia morum, ut quidam tradunt, et consuetudine mutui stupri. Díon Cássio, 64.8, relaciona a homossexualidade de Otão com os favoritos de Nero. 
em sugestiva gradação: Vestitu calciatuque et cetero habitu neque patrio neque ciuili, ac ne uirili quidem ac denique bumano semper usus est ${ }^{79}$ ( Nas roupas e no calçado e no restante trajar não usou o tradicional do seu país, nem o habitual dos cidadãos, nem sequer masculino e, em suma, nem humano»). Segue-se um rol de adereços que podem estar, como vimos, ligados às actividades histriónicas: na sua loucura, Calígula parece não conseguir separar a licentia de cena da realidade. A descrição é uma lição de moral pela negativa: devem-se respeitar os hábitos da pátria, não ceder ao filelenismo, e os hábitos dos cidadãos. $\mathrm{O}$ vestuário patrius e ciuilis é a toga, cujo uso Augusto procurara incentivar. ${ }^{80}$ Trata-se aqui de uma afirmação da ciuilitas através do vestuário. Além do mais, as roupas dos monarcas orientais são consideradas efeminadas. Condena-se o travestismo ${ }^{81}$ e o uso de roupas das divindades, pois a imitação dos deuses é o máximo da inciuilitas. Também se acusa Augusto de se travestir de Apolo, num banquete chamado dodekatheos (Aug. 70.1), mas onde Augusto sabe parar, Calígula continua: ${ }^{82}$ comporta-se como um deus e recebe honras divinas, ${ }^{83}$ que Augusto e Tibério recusaram, demonstrando ciuilitas. ${ }^{84}$ Calígula chega ao ponto de se mostrar insolente em relação aos deuses. ${ }^{85}$

A descrição da forma de Nero se apresentar em público assume um tom de censura: circa cultum habitumque adeo pudendus, ut comam semper in gradus formatam peregrinatione Achaica etiam pone uerticem summiserit ac plerumque synthesinam indutus ligato circum collum sudario prodierit in publicum sine cinctu et discalciatus (Nero 51) («Em relação aos cuidados corporais e vestuário, apresentava-se tão indecente que trazia a cabeleira sempre penteada em degraus e, na viagem à Acaia, mesmo caída sobre a nuca, e geralmente apresentava-se de roupão em público, com um lenço atado à volta do pescoço, sem cinto e descalço»).

Há nesta descrição um claro juízo moral (adeo pudendus), que nos recorda os probra de Nero. Entre estes predominam as tendências histriónicas, evocadas nas roupas, e o gosto pela arte do auriga. O estilo do cabelo, quer fosse a moda entre os aurigas, quer fosse o penteado de Alexandre - sinal de filelenismo -, tornava-se escandaloso. ${ }^{86} \mathrm{O}$ facto de o imperador se tornar actor constituía, para a mentalidade romana, não só degradação social, mas também moral.

Os hábitos efeminados são comuns a Otão e a César, mas neste são

${ }^{79}$ Cal. 52.

${ }^{80}$ Aug. 40.5.

${ }^{81}$ Como faz Séneca, Ep. 122.7: non uidentur tibi contra natura uiuere qui commutant cum feminis uestem?

${ }^{82}$ Vide com. de Wardle, D. 1994, 336-341.

${ }^{83}$ Cal. 22.2-3.

${ }^{84}$ Augusto, (Aug. 51.1: Clementiae ciuilitatisque eius multa et magna documenta sunt), não consentiu que lhe erguessem templos nas províncias, sem que, ao seu nome, fosse associado o de Roma; e, na Urbe, recusou pertinacissime esta distinção (Aug. 52). Igual reserva mostra Tibério; Tib. 26.1: Verum liberatus metu ciuilem admodum inter initia ac paulo minus quam priuatum egit. Ex plurimis maximisque honoribus praeter paucos et modicos non recepit.

${ }^{85}$ Cal. 22.4.

${ }^{86}$ Vide com. de Bradley, K. R. 1978, 284-285. 
atenuados pelo vigor e beleza física. Mais exagerados são o cultus e o habitus de Calígula e de Nero, cujo modo de vestir vai contra todas as convenções sociais romanas. Porque se trata de principes, pela responsabilidade política e social, a forma como o imperador se apresenta em público tem um valor moral. A continuidade entre o retrato físico e o carácter de cada imperador contribui para assegurar a unidade de cada Vida e abona a favor da técnica compositiva de Suetónio. 


\section{Juízo sobre actos e palavras}

A narrativa suetoniana, ao centrar-se na pessoa do imperador - o sujeito gramatical de cada Vida-, torna-o único responsável pelos bons e maus actos. ${ }^{1}$ Os acontecimentos só têm interesse se ajudam a definir o imperador. Assim omitem-se acontecimentos históricos importantes, e esquece-se o contributo de grandes generais como Aulo Pláucio, Corbulão ou Agrí́cola. ${ }^{2} \mathrm{Na}$ Vida de Augusto (Aug. 21.3), não se menciona o papel de Tibério no estabelecimento de Tigranes no trono da Arménia e na devolução dos estandartes militares subtraídos pelos Partos a Crasso e a Marco António; ao passo que na Vida de Tibério (Tib.9.1) se verifica que este é o agente daqueles feitos diplomáticos. $\mathrm{O}$ mesmo se passa com a responsabilidade de Tibério, omitida na Vida de Augusto, no processo de lesa-majestade contra Fânio Cepião (Tib. 8; cf. Aug. 19.1), que conspirara com Murena, e na inspecção das prisões de escravos (os ergastula), cujos donos eram suspeitos de escravizarem viajantes e refractários ao serviço militar (Tib. 8; cf. Aug. 32.1). ${ }^{3} \mathrm{O}$ papel de Sejano é deliberadamente apagado e transferido para Tibério, ${ }^{4}$ com o que se aumenta o grau da sua crueldade: o tão detestado prefeito do pretório, que Tácito considera de uma influência insidiosa, ${ }^{5}$ transforma-se em mais uma vítima do cruel imperador (Tib. 65). Esta centralização na pessoa do príncipe faz dele o agente transmissor, pela negativa ou pela positiva, de uma moral implícita na forma de veicular as suas acções e afirmações.

Uma característica da abordagem moral é que, ao contrário de uma abordagem política, não distingue vida pública de vida privada, mas antes o bem do mal. Eticamente o indivíduo funciona como um todo indivisível. Além disso, o imperador tem um papel moralizador da sociedade: como está no topo da pirâmide, deve ser modelo de cidadão - membro de uma sociedade - e de pai, marido, irmão, padrasto, tio, sobrinho, neto, avô - membro de uma família.

A discussão das virtudes e dos vícios assume, como já vimos, posição de relevo nas Vidas. Os erros políticos são frequentemente causados por um vício: a avareza de Galba ou o fausto de Nero, a crueldade e rapina de Domiciano ou a arrogância de César explicam mudanças políticas. Mas mesmo na descrição

${ }^{1}$ Parece ter significado a excepção de Nero 16.2-17, onde se inumeram uma série de medidas de bom governo: multa sub eo et animaduersa seuere et coercita nec minus instituta. Apesar de afirmar que a variação da activa para a passiva não será mais do que estilística, BrADLEY, K. R. 1978, 102, reconhece que Suetónio deve atribuir uma quota escassa de responsabilidade a Nero no que respeita àquelas medidas. A tradição prefere referir as melhores acções do governo a Séneca e a Burro. De qualquer modo, Suetónio não menciona explicitamente a intervenção dos dois conselheiros, como fazem os historiadores: Tácito, Ann. 13.2; Díon Cássio, 61.4. Vide Wallace-Hadrill, A. 1984, 122-123.

${ }^{2}$ Vide Townend, G. B. 1967, 84.

${ }^{3}$ Vide Gascou, J. 1984, 374-376.

${ }^{4}$ Tib. 61.1: Post cuius [sc. Seiani] interitum uel saeuissimus extitit. Quo maxime apparuit, non tam ab Seiano concitari solitum, quam Seianum quaerenti occasiones sumministrasse.

5 Tácito, Ann. 4.59 ss. 
das guerras, das medidas políticas e administrativas há um tom de aprovação ou censura: Suetónio procura determinar em que medida um imperador é virtuoso ou vicioso. Os actos e as palavras dos imperadores estão ao serviço da transmissão de uma moral, ao serem catalogados sob designações de virtudes e vícios.

O processo de construção da personagem parece ser o seguinte: as qualidades do carácter de cada imperador são, antes de mais, inferidas, por indução, a partir de uma base fundamental: os actos e palavras que constam do material recolhido pelo autor. Feito este trabalho prévio, o biógrafo, ao redigir cada $V i d a$, enuncia, mais ou menos explicitamente, as qualidades, e reagrupa o material recolhido de forma a ilustrar as species com exempla: devolve assim ao leitor as palavras e os actos, mas já reinterpretadas e catalogadas. As qualidades são os universais - os uitia e as uirtutes de cada princeps -, mas os principes são individualizados. Apesar do esquema repetitivo, é difícil agrupar os Césares por categorias: alguns aproximam-se de outros, mas nunca totalmente. $\mathrm{O}$ carácter de cada imperador não pode ser determinado apenas pelo somatório dos vícios e virtudes. Cada princeps é individuado, sem dúvida, pelas virtudes e pelos vícios que apresenta, mas não menos pelo grau em que os revela e pela relação de forças entre vícios e virtudes. $\mathrm{O}$ grau das qualidades e a relação de forças entre elas são estabelecidos pelo número dos exempla, pelo seu peso, pela forma de os organizar dentro das species (em crescendo ou decrescendo, generalizando ou omitindo) e pela ordem de composição da biografia no seu todo. O biógrafo altera amiúde a cronologia; suspende ou antecipa informação; divide a biografia em actos louváveis e censuráveis ou simplesmente alterna aspectos positivos e negativos; insinua mudança abrupta ou sugere progressiva revelação do carácter; aduz opiniões de terceiros, de modo especial, as reaç̧ões à morte; recorre à deformação cómica ou à tensão trágica - gera, em suma, maior ou menor dramatismo, na mira de incutir determinado juízo no leitor. Em cada césar o resultado é diferente e complexo, apesar da aparência simples e da leitura fácil das Vidas.

\subsection{Os "freios" de um imperador: a moderatio e a abstinentia}

A forma como cada príncipe incarna o principado é analisada numa perspectiva moral. Disso é testemunha a forma como Suetónio termina as Vidas: à tirania de Domiciano segue-se um período mais feliz (beatior laetiorque status), graças às virtudes da abstinentia et moderatio dos príncipes seguintes. ${ }^{6}$ Tal afirmação pressupõe um modelo de actuação dos imperadores face ao principado e poder que ele implica, e face às riquezas, quer as alheias, quer as do erário e do fisco.

\subsubsection{Atitude face ao poder: da moderatio à ciuilitas, clementia $e$ pietas}

O facto de Suetónio começar as Vidas pela de César parece significativo: da Vida de César para a de Augusto há uma evolução e elevação moral na

${ }^{6}$ Dom. 23.2. Estes princípios pautam a actuação de Otão, enquanto legado na Lusitânia: Prouinciam administrauit quaestorius per decem annos, moderatione atque abstinentia singulari (Otho 3.2). 
forma como o imperador encara o seu poder. $\mathrm{O}$ projecto de César fica aquém do de Augusto, uma vez que resulta apenas da ambição pessoal e não se destaca, visivelmente, de qualquer outra monarquia oriental. $\mathrm{O}$ pretexto que leva à travessia do Rubicão é a violência do senado contra os tribunos da plebe, que, com o veto, intercediam por César - mas crê-se que as verdadeiras causas sejam outras. ${ }^{7}$ As palavras citadas de César são significativas: mostram o sentimento do despeito de passar para um plano secundário na política, ${ }^{8}$ o medo de, reduzido a cidadão privado, ser castigado por irregularidades cometidas no exercício do primeiro consulado, ${ }^{9}$ mas sobretudo a ambição da tirania (dominatio), ${ }^{10}$ que o leva a violar a lei regnandi gratia, como ele próprio confessa através de um verso de Eurípides que citava amiúde. ${ }^{11}$ Mais à frente, são apresentados facta dictaque que fazem com que se considere que abusou da dominatio e que, por conseguinte, a morte é justa. ${ }^{12}$ Entre os facta se refere a aceitação de honras exageradas (o consulado ininterrupto, a ditadura perpétua, a prefeitura dos costumes e sobretudo o praenomen de imperator, o cognomen de Pater Patriae e uma estátua entre as dos reis); privilégios que superam os limites humanos (bumanum fastigium) (trono de ouro, estátuas, altares, leito divino, um culto com sacerdotes, o nome de um mês), e uma actuação política onde impera a arbitrariedade (licentia) e o desrespeito do patrius mos. ${ }^{13}$ Tais honras são agravadas por uma série de dicta que manifestam verbalmente do mesmo mesmo excesso (inpotentia), na consideração da res publica, e a arrogantia face aos presságios funestos, que se tornariam favoráveis, quando ele assim quisesse. ${ }^{14}$ César não mais se consegue livrar da infamia de que desejava o título de rex, apesar de afirmar que «era César e não rei» e de afastar - gesto teatral suspeito - a coroa que António repetidamente lhe colocava sobre a cabeça e de a consagrar a Júpiter Óptimo Máximo. ${ }^{15}$ César, como candidato à

${ }^{7}$ Jul. 30.2: Et praetextum quidem illi ciuilium armorum hoc fuit; causas autem alias fuisse opinantur.

${ }^{8}$ Jul. 29.1: Commotus his Caesar ac iudicans, quod saepe ex eo auditum ferunt, 'difficilius se principem ciuitatis a primo ordine in secundum quam ex secundo in nouissimum detrudi, summa ope restitit, partim per intercessores tribunos, partim per Seruium Sulpicium alterum consulem.

${ }^{9}$ Jul. 30.3-4: Alii timuisse dicunt, ne eorum, quae primo consulatu aduersus auspicia legesque et intercessiones gessisset, rationem reddere cogeretur ... Quod probabilius facit Asinius Pollio, Pharsalica acie caesos profligatosque aduersarios prospicientem haec eum ad uerbum dixisse referens: 'boc uoluerunt; tantis rebus gestis Gaius Caesar condemnatus essem, nisi ab exercitu auxilium petissem'.

${ }^{10} \mathrm{Jul}$.30.5: Quidam putant captum imperii consuetudine pensitastisque suis et inimicorum uiribus usum occasione rapiendae dominationis quam aetate prima concupisset.

${ }^{11} \mathrm{Jul}$. 30.5. Trata-se de uma citação das Fenícias, 524. César assume assim as palavras de Etéocles.

${ }^{12} \mathrm{Jul}$. 76.1: Praegrauant tamen cetera facta dictaque eius, ut et abusus dominatione et iure caesus existimetur.

${ }^{13} \mathrm{Jul}$. 76.3: Eadem licentia spreto patrio more magistratus in pluris annos ordinauit... eoque arrogantiae progressus est (...)

${ }^{14} \mathrm{Jul}$. 77: Nec minoris inpotentiae uoces propalam edebat (...)

${ }^{15} \mathrm{Jul}$. 79.2: Neque ex eo infamiam affectati etiam regii nominis discutere ualuit, quamquam et plebei regem salutanti 'Caesarem se, non regem esse' responderit et Lupercalibus pro rostris a consule Antonio admotum saepius capiti suo diadema reppulerit atque in Capitolium Ioui Optimo Maximo miserit. 
dominatio e ao regnum, torna-se uma afronta para o povo romano, que há muito considerava um imperator romano acima dos reis. ${ }^{16}$ Além disso, recaía sobre César a acusação infamante de se ter submetido sexualmente ao rei Nicomedes da Bitínia (Jul. 49).

Dominatio e dominus têm, como nota Bradley, implicações servis: daí que seja necessário distinguir entre princeps e imperator, por um lado, e dominus ou tyrannus por outro. ${ }^{17}$ Mas a diferença entre princeps e dominus não é de caracter constitucional, mas de natureza moral. ${ }^{18} \mathrm{~A}$ inpotentia de César, que lhe valeu a morte,opõe-se a moderatio de Augusto. Depois de se decidir pela não restauração da República, com a aprovação do biógrafo, ${ }^{19}$ as palavras de Augusto exprimem o desejo de ser considerado auctor de um optimus status: com este superlativo se qualifica o nouus status. ${ }^{20}$ Suetónio não diz, com Augusto ( $\left.R G .7 .2\right)$, que este se tornou princeps senatus - expressão politicamente correcta, oriunda da tradição republicana,$-{ }^{21}$ prefere acentuar que funda um regime verdadeiramente novo. Mas a tónica também não é colocada na denúncia da habilidade política do fundador do principado, mas na qualidade dos efeitos do seu projecto. ${ }^{22}$ Este êxito fica a dever-se à elevação moral que distancia Augusto de César: a recusa de templos nas províncias, se ao seu nome não fosse associado o de Roma, e definitivamente na urbe; a fusão e dedicação a Apolo Palatino das estátuas de ouro que lhe erigiram; a recusa da ditadura $;{ }^{23}$ e sobretudo o horror que

${ }^{16}$ Como afirma Grimal, P. 1993, 16, a "superioridade” não era de ordem político-militar, mas de ordem moral. Já no século III, Cipião Emiliano recusara o título de rei, que os Hispanos lhe ofereciam, porque, dizia, um cônsul nada tinha em comum com um rei; e Cornélia, mãe dos Gracos, recusara a proposta de casamento com um Ptolemeu, rei de Cirene, porque uma matrona romana não se rebaixava a ser rainha.

17 Bradley, K. R. 1991, 3715-3716. Nota Gascou, J. 1984, 721-722, que, neste ponto, Suetónio está de acordo com Plínio, Pan. 45.3: Scis ut sunt diuersa natura dominatio et principatus, ita non aliis esse principem gratiorem quam qui maxime dominum grauentur. Cf. Cícero, Rep. 1.50 .

${ }^{18}$ Como sublinha Gascou, J. 1984, 721-722.

${ }^{19}$ Aug. 28.1. Suetónio não tem ilusões de que Augusto in retinenda [sc. re p.] perseuerauit e contradiz assim a afirmação de $R G$ 34.1: rem publica ex mea potestate in senatus populi Romani arbitrium transtuli. A expressão de Suetónio dubium euentu meliore an uoluntate parece querer dizer que, para o biógrafo, tanto a intenção de Augusto em desistir de restabelecer a República como os efeitos do novo regime são igualmente bons: assim a interpreta, na sua ed. Rolfe, J. C. 1913-1914, I, 164, n. b., seguido por Gascou, J. 1984, 719.

${ }^{20}$ Aug. 28.2: 'Ita mibi saluam ac sospitem rem p. sistere in sua sede liceat atque eius rei fructum percipere, quem peto, ut optimi status auctor dicar et moriens ut feram mecum spem, mansura in uestigio suo fundamenta rei p. quae iecero.' O auctor, possuidor da auctoritas do chefe da gens, do patronus, tem um papel de direcção moral, enquanto toma a iniciativa e dá o exemplo a seguir: vide Hellegouarc' H, J. 1987, 85-86.

${ }^{21}$ Em Cal. 22.1, Suetónio fala de species principatus, demonstrando assim ter consciência de que o nome de princeps, e, por consequência, principatus, é uma forma hábil de iludir os legalistas. Mas Suetónio é realista: tem consciência da inevitabilidade do principado e da impossibilidade do retorno ao regime republicano.

22 Aug. 28.2: Fecitque ipse se compotem uoti nisus omni modo, ne quem noui status paeniteret.

${ }^{23}$ Aug. 52. É verdade que Augusto dá o seu nome ao mês Sextilis (Aug. 31.2). Mas esta referência aparece elencada, sem conotações morais, na regulamentação religiosa de Augusto, enquanto pontífice máximo, e acrescida da nota de que não se tratava do mês do 
Augusto manifesta à «maldição e desonra» do apelido de dominus ${ }^{24}$ e o respeito pelo senado (Aug. 53.3) são apresentados como documenta da ciuilitas, ${ }^{25}$ virtude que, a par da clementia, vem, em Suetónio, associada à moderatio. ${ }^{26}$ A ciuilitas traduz a consciência de cidadão, a urbanidade que, se está presente no príncipe, evita a progressão para uma monarquia teocrática, à maneira oriental, ou para uma tirania (dominatio), que cercearia a libertas, entendida como liberdade de expressão, que Augusto mostra respeitar. ${ }^{27} \mathrm{O}$ uso da ciuilitas compensa: ao contrário de César, que pelo abusus dominatione e pela inpotentia mereceu a morte, Augusto é objecto da estima geral..$^{28}$ Augusto incarna, assim, uma lição de moral na condução do principado e torna-se o modelo dos sucessores. Também Cláudio revela ciuilitas ao recusar o praenomen de imperator e honras excessivas, ${ }^{29}$ ao mostrar respeito pelo senado e magistrados, incluindo os tribunos da plebe (Cl.12.2). Por esta atitude, Cláudio colheu o amor e fauor: ${ }^{30}$ de forma que uma sua ausência quase provocou uma revolta popular, por se pensar que ele tinha sido assassinado. Vespasiano, ciuilis, não desdenha a origem humilde e provinciana (mediocritas pristina), troça da linhagem que um cortesão the quer atribuir (e que remontaria a um companheiro de Hércules), mostra-se adverso à pompa do protocolo e entediado no triunfo; só tardiamente aceita a tribunicia potestas e o título de pater patriae, põe fim ao hábito de revistar os que pela manhã o vinham saudar (Ves. 12). De âmbito semântico próximo é a comitas, a afabilidade ilustrada através do sentido de humor de Vespasiano. ${ }^{31}$

Tibério, na fase boa do principado, revela ciuilitas, ao recusar maximi bonores que incluíam culto divino (que já César tinha aceitado), ${ }^{32}$ ao rejeitar o praenomen de imperator, o cognomen de pater patriae, a coroa cívica no vestíbulo da sua casa, ao limitar o uso do nome de Augusto, que lhe pertencia por herança, às cartas dirigidas aos reis (Tib. 26.2), e sobretudo ao recusar o apelido de dominus (Tib.27), e ao defender repetidamente a liberdade de expressão e

nascimento (Setembro), mas do mês do seu primeiro consulado e de grandes vitórias. Há quem proponha, depois da morte do imperador, a transferência da designação deste mês para o de Setembro, com base no facto de ser o do nascimento - facto que revela o quanto a honra era publicamente reconhecida.

${ }^{24}$ Aug. 53.1: Domini appellationem ut maledictum et obprobrium semper exhorruit. Suetónio não denuncia a habilidosa simulação de horror.

${ }^{25}$ Aug. 51.1: Clementiae ciuilitatisque eius multa et magna documenta sunt.

${ }^{26}$ Como demonstra Gascou, J. 1984, 722-723.

${ }^{27}$ Cf. Aug. 54: Nec ideo libertas aut contumacia fraudi cuiquam fuit.

${ }^{28}$ Aug. 57.1: Pro quibus meritis quanto opere dilectus sit, facile est aestimare.

${ }^{29}$ Cl. 12.1: At in semet augendo parcus atque ciuilis praenomen Imperatoris abstinuit, nimios bonores recusauit.

${ }^{30}$ Cl. 12.3: Quare in breui spatio tantum amoris fauorisque collegit.

${ }^{31}$ Ves. 22: Et super cenam autem et semper alias comissimus multa ioco transigebat...

${ }^{32}$ Tib. 26.1: Verum liberatus metu ciuilem admodum inter initia ac paulo minus quam priuatum egit. Ex plurimis maximisque honoribus praeter paucos et modicos non recepit. Na Vida de Tibério não parece haver diferença, como mostra GAscou, J. 1984, 723, entre ciuilitas e moderatio, visto que depois, 32.2, afirma: Parem moderationem minoribus quoque et personis et rebus exhibuit, e em outro passo, 57.1: (...) etiam inter initia cum adhuc fauorem hominum moderationis simulatione captaret. 
de pensamento: ${ }^{33}$ chega mesmo a restabelecer uma species libertatis. ${ }^{34}$ Suetónio não tem ilusões, pois sabe que se trata apenas de aparência (species). Mais à frente, o biógrafo há-de censurar a forma exagerada como Tibério aplica a lei da maiestas (Tib. 58).

Como não há formas constitucionais de controlar o poder do imperador - as palavras de Calígula e Nero revelam bem o fascínio que lhes causa este poder ilimitado ${ }^{35}$ - e o papel moderador do senado depende unicamente da condescendência de cada príncipe, as restrições são apenas de ordem moral: só cada imperador as pode colocar a si próprio. Mas, também a esse respeito, Suetónio é realista: o autocontrolo é muito difícil, quando se está na posse de tais poderes (in imperio). ${ }^{36} \mathrm{O}$ caminho mais fácil e mais frequente é o da inpotentia ou arrogantia ou superbia: o traço típico do comportamento tirânico. ${ }^{37} \mathrm{O}$ principal obstáculo é o senado, símbolo do regime republicano: por isso Nero chega a pensar em eliminar esta ordem (Nero 37.3). Calígula não mostra reuerentia ou lenitas em relação ao senado ${ }^{38}$ e obriga mesmo uns senadores a correrem ao lado do seu carro (Cal.26.2). A superbia e a violentia qualificam, em geral, a sua relação com as diferentes classes (Cal. 26.4; 30.2). $\mathrm{Na}$ altura em que foi morto, projectava facinora maiora, a saber, a eliminação dos membros mais eminentes das classes senatorial e equestre e a transferência da sede do governo para Âncio, a sua terra natal (Cal. 8), e depois para Alexandria (Cal.49.2) - num paralelo com Júlio César. ${ }^{39}$ Semelhanças verbais e de conteúdo, em relação ao que se disse de César, se apresentam no catálogo de honras que denunciam a aspiração de Calígula a uma monarquia teocrática, de tipo oriental, sem respeito pelo mos maiorum. As pretensões de Calígula à substituição da species principatus pelo regnum ${ }^{40} \mathrm{e}$ à autodivinização ${ }^{41}$ dão início à narrativa da parte que diz respeito ao monstrum. Se Domiciano manifesta, já na juventude, propensão para a dominatio, ${ }^{42}$ não espanta vê-lo proceder minime

${ }^{33}$ Tib. 28: Sed et aduersus conuicia malosque rumores et famosa de se ac suis carmina firmus ac patiens subinde iactabat 'in ciuitate libera linguam mentemque liberas esse debere'.

${ }^{34}$ Tib. 30: Quin etiam speciem libertatis quandam induxit conseruatis senatui ac magistratibus et maiestate pristina et potestate. Também Tácito, Ann. 1.77.3, fala de simulacra libertatis.

${ }^{35}$ Cal.29.1: 'memento,' ait, 'omnia mibi et <in> omnis licere'; Nero 37.3: Elatus inflatusque tantis uelut successibus negauit 'quemquam principum scisse quid sibi liceret'. Dentro do mesmo espírito se inclui o verso de Acio que Calígula repetia: 'oderint, dum metuant'(Cal.30.1).

${ }^{36}$ Esta constatação encarece o carácter de Tito - Tit. 1: (...) tantum illi ad promerendam omnium uoluntatem uel ingenii uel artis uel fortunae superfuit, et quod difficillimum est, in imperio...

${ }^{37}$ Vide, a propósito de Plínio-o-Velho, Oliveira, F., 1992, 26-27.

${ }^{38}$ Cal. 26.2: Nibilo reuerentior leniorue erga senatum (...) Cal. 49.1: Edixit et 'reuerti se, sed iis qui optarent, equestri ordini et populo; nam se neque ciuem neque principem senatui amplius fore'.

${ }^{39} \mathrm{Jul}$. 79.3: Quin etiam uaria fama percrebruit migraturum Alexandream uel Ilium. Também Nero, perante a revolta da Gália, chega a sonhar com uma dominatio no Oriente (Nero 40.2) e, em desespero de causa, pensa pedir que lhe confiem, ao menos, a prefeitura do Egipto (Nero 47.2).

${ }^{40}$ Cal. 22.1: Nec multum afuit quin statim diadema sumeret speciemque principatus in regni formam conuerteret.

${ }^{41}$ Cal. 22.2: Verum admonitus et principum et regum se excessisse fastigium, diuinam ex eo maiestatem asserere sibi coepit.

42 Dom. 1.3: ceterum omnem uim dominationis tam licenter exercuit, ut iam tum qualis futurus 
ciuilis e immodicus nas palavras e nos actos: ${ }^{43}$ depois de se tornar imperador, aceita libenter que o apelidem de dominus (Dom.13.1), e - pari arrogantia autoproclama-se, ele próprio, dominus et deus (Dom.13.2), recebe honras, que, como César e Calígula, ultrapassam os limites humanos (Dom. 13.2-3), ao ponto de, como eles, se tornar odiado e ser castigado com morte violenta. ${ }^{44}$

No que respeita ao exercício do poder, a moderatio opõe-se à arrogância da actuação tirânica, mas também à crueldade ${ }^{45}$ pelo que, além da ciuilitas, implica também, como dissemos, a virtude da clementia, cujo vício correspondente é a saeuitia ou crudelitas. O bom princeps sabe moderar a sua cólera contra os inimigos. Com o decorrer dos anos, revela-se o verdadeiro carácter. Augusto, na juventude, sem noção de moderatio, procede com saeuitia em actos e palavras. ${ }^{46}$ Mas, como imperador, manifesta sobretudo clementia (Aug. 51.1): as palavras de uma carta a Tibério aconselham o comedimento na indignação, predicado que se alcança com a idade. ${ }^{47}$ Também Tito revela inciuilitas, e usa de uiolentia e saeuitia enquanto co-regente de seu pai, ${ }^{48}$ para depois inverter o seu comportamento: os actos e palavras mostram-no campeão da clemência, ao ponto de favorecer uns conjurados (Tit.9.1-2). Vespasiano, que chega ao Império em idade mais avançada, mostra-se ciuilis et clemens do princípio ao fim do principado: ${ }^{49}$ os actos e palavras reveladores de clementia são abundantes (Ves. 13-15); a própria morte de Helvídio Prisco se converte em exemplo de clementia. A progressão inversa ocorre em Calígula e Nero: entre outras virtudes, ostentam clementia no início do principado, ${ }^{50}$ a que ascenderam muito jovens, para depois mudarem radicalmente de atitude. Galba, apesar de assumir o comando do Império em idade avançada, confirma e agrava,

esset ostenderet.

${ }^{43}$ Dom. 12.3: Ab iuuenta minime ciuilis animi, confidens etiam et cum uerbis tum rebus immodicus.

${ }^{44}$ Dom. 14.1: Per haec terribilis cunctis et inuisus, tandem oppressus est.

${ }^{45}$ Vide Gascou, J. 1984, 724-725.

${ }^{46}$ Depois da vitória de Filipos: Nec successum uictoriae moderatus est (...) non sine contumelia saeuiit (Aug. 13.1); depois da tomada de Perúsia: Perusia capta in plurimos animaduertit, orare ueniam uel excusare se conantibus una uoce occurrens 'moriendum esse' (Aug. 15); durante o triunvirato (Aug. 27.1-4).

${ }^{47}$ Aug. 51.3: 'aetati tuae, mi Tiberi, noli in hac re indulgere et nimium indignari quemquam esse, qui de me male loquatur; satis est enim si hoc habemus ne quis nobis male facere possit.'

${ }^{48}$ Tit. 6.1: egitque aliquanto inciuilius et uiolentius; 7.1: Praeter saevitiam suspecta in eo etiam luxuria erat (...)

${ }^{49}$ Ves. 12: Ceteris in rebus statim ab initio principatus usque ad exitum ciuilis et clemens.

${ }^{50}$ Cal. 15.4: Pari popularitate damnatos relegatosque restituit; criminum, si quae residua ex priore tempore manebant, omnium gratiam fecit; commentarios ad matris fratrumque suorum causas pertinentis, ne cui postmodum delatori aut testi maneret ullus metus, conuectos in forum, et ante clare obtestatus deos neque legisse neque attigisse quicquam, concremauit; libellum de salute sua oblatum non recepit contendens 'nibil sibi admissum cur cuiquam inuisus esset', negauitque se delatoribus aures habere. Ideia semelhante em Nero 10.1. Um dito de Nero ilustra a ostentação desta virtude: Et cum de supplicio cuiusdam capite damnati ut ex more subscriberet admoneretur: 'quam uellem', inquit 'nescire litteras' (Nero 10.2). 
pela sua actuação, a anterior fama de crueldade (Gal.12.1-2) - e o biógrafo regista que não procedia de modo conveniente a um príncipe eleito e, para mais, da sua idade. ${ }^{51}$

Em César a moderatio não se pode associar à ciuilitas - dadas as suas ambições tirânicas -, mas vem acompanhada da clementia. ${ }^{52} \mathrm{O}$ facto de o espírito tirânico não aparecer, em César, associado à saeuitia, faz com que o julgamento de Suetónio sobre o ditador não seja tão negativo. Já em Tibério, Calígula, Nero e Domiciano o espírito tirânico é agravado por essa saeuitia, ${ }^{53}$ até atingir o grau do insuportável. Campeiam os delatores e os processos de maiestas. $\mathrm{O}$ tirano baseia o seu poder no medo e não no amor dos súbditos, como os bons imperadores. Por isso é preciso dominar o ódio com o terror. Calígula treina expressões terríficas em frente ao espelho (Cal.50.1) e a sua máxima é «que me odeiem, desde que me temam!». ${ }^{54}$ As palavras são uma agravante da crueldade de Calígula ${ }^{55}$ - a tirania manifesta-se ainda no humor negro ${ }^{56}$-, cinismo também presente em Tibério, Nero, Vitélio e Domiciano. ${ }^{57}$ A atrocitas, que aparece unicamente referida nas Vidas de Tibério, Calígula, Nero e Domiciano, ${ }^{58}$ indica situações assaz adversas ${ }^{59}$ ou actos e palavras dos visados. ${ }^{60} \mathrm{~A}$ falta de moderação é ainda expressa pela immanitas dos actos de Calígula e dos actos e da própria natura de Nero. ${ }^{61}$

${ }^{51}$ Gal.14.2: Maiore adeo fauore et auctoritate adeptus est quam gessit imperium, quanquam multa documenta egregii principis daret; sed nequaquam tam grata erant, quam inuisa quae secus fierent. Só no biógrafo encontrámos esta censura com base no que seria de esperar da sua idade. Suetónio distingue os passageiros vícios da juventude dos entranhados vícios da natura e do ingenium; cf. Nero 26.1: (...) sed ut tunc quoque dubium nemini foret naturae illa uitia, non aetatis esse. Tibério tolerava as extravagâncias do jovem Calígula na esperança de que pudessem amansar o ferum ingenium do neto por adopção ( Cal.11).

52 Jul. 75.1: Moderationem uero clementiamque cum in administratione tum in uictoria belli ciuilis admirabilem exbibuit.

${ }^{53}$ Tib. 57-62; Cal. 27-33; Nero 33-38; Dom. 10-11. Vide Gascou, J. 1984, 723 e 725.

${ }^{54}$ Cal. 30.1: 'oderint, dum metuant' (cit. de Ácio); cf. Tib 59.2: oderint, dum probent.

${ }_{55}$ Cal. 29.1: immanissima facta augebat atrocitate uerborum; 32.1: Animum quoque remittenti ludoque et epulis dedito eadem factorum dictorumque saeuitia aderat.

${ }^{56}$ Brinca com a ameaça da decapitação, como demonstra a sua expressão 'Vtinam p. R. unam ceruicem haberet!'(Cal.30.2); ou a cruel resposta aos cônsules, que lhe perguntavam de que estava a rir: 'Quid', inquit, 'nisi uno meo nutu iugulari utrumque uestrum statim posse?' (Cal. 32.3); ou as palavras que acompanhavam o acto de beijar o pescoço da mulher ou da amante: 'Tam bona ceruix simul ac iussero demetur' (Cal. 33).

${ }^{57}$ Tib. 58-62 passim; Nero 33-38 passim; Vit. 14.3; Dom. 11.

${ }_{58}^{5}$ Nas suas variantes de nome, adjectivo e advérbios: vide Index de Howard / Jackson.

${ }^{59}$ A atrocitas aparece referida à má fortuna que fez com que Tibério fosse o herdeiro de Augusto (Tib. 23); à condição dos tempos de Tibério e Calígula (Tib. 48.1; Cal. 6.2).

60 Tib. 58: atrocissime exercuit; Tib. 59.1: ita saeue et atrociter factitauit; Tib. 75.1: (...) exacerbati super memoriam pristinae crudelitatis etiam recenti atrocitate; Cal. 12.2: (...) liberto, qui ob atrocitatem facinoris exclamauerat, confestim in crucem acto; Cal.29.1: immanissima facta augebat atrocitate uerborum; Cal. 48.1: Prius quam prouincia decederet, consilium iniit nefandae atrocitatis legiones (...) contrucidandi; Nero 34.4: Adduntur his atrociora nec incertis auctoribus; Dom. 11.1: (...) ut non aliud iam certius atrocis exitus signum esset quam principii lenitas; Dom. 11.3: deinde atrocitate poena conterritus, ad leniendam inuidiam intercessit bis uerbis.

${ }^{61}$ Cal. 29.1: immanissima facta; Nero 7.2: et fidem somnio breui Nero fecit prodita immanitate 
A saeuitia manifesta-se também em Cláudio, Galba e Vitélio. ${ }^{62}$ Mas estes, mais que tiranos propriamente ditos, tornam-se maus por serem imperadores fracos, vergados aos seus defeitos e à acção de terceiros. Insiste-se no facto de Cláudio ser dominado pelo medo (Cl.35-37) e pelos caprichos das mulheres e de libertos; ${ }^{63}$ Galba, pela avareza ( Gal. 12.2-3) e por três ministros corruptos; ${ }^{64}$ e Vitélio, pela gula (Vit. 13) e por histriões dos mais vis, aurigas e o liberto Asiático. ${ }^{65}$

Associada à clementia, pode considerar-se a pietas, no que diz respeito aos deveres para com os familiares, mortos e vivos - a acepção de pietas que mais figura em Suetónio, ${ }^{66}$ pois a sua ausência provoca os piores exemplos de crueldade.É inequivocamente louvada em Cláudio a pietas para com a memória de Augusto e de Lívia, dos pais, do irmão Germânico, de Marco António, de Tibério, e mesmo do sobrinho Gaio - proíbe que se considere festivo o dia do assassínio deste imperador, apesar de coincidir com o do início do seu próprio principado (Cl.11.2-3). Vespasiano visita frequentemente e preserva o lugar da sua infância ${ }^{67}$ e guarda com afecto a memória da avó paterna, Tertula, que ali o tinha criado: nos dias festivos, bebe pela pequena taça que ela usara. ${ }^{68}$ Tito é paciente e tolerante com o irmão, apesar das insídias que este lhe arma (Tit. 9.3). Calígula e Nero procuram ostentar pietas no início do principado: o primeiro para com a memória de Tibério, da mãe, do irmão, do pai, mas também para com os vivos: a avó Antónia, o tio Cláudio, o irmão (por adopção) Tibério Gemelo (neto do imperador homónimo), as irmãs (Cal. 15.1-3); o segundo, para com a memória de Cláudio, do pai Domício, e para com a mãe e a terra natal, Âncio (Nero 9). Mas o biógrafo acaba por desmascarar estas manifestações teatrais, ao descrever a actuação do monstrum Calígula e dos probra ac scelera de Nero. A pietas de Calígula torna-se logo suspeita. Já atrás se

naturae; 43.1: Initio statim tumultus multa et immania, uerum non abhorrentia a natura sua creditur destinasse.

${ }^{62}$ Cl.34.1: Saeuum et sanguinarium natura fuisse, magnis minimisque apparuit rebus; Gal.12.1: Praecesserat de eo fama saeuitiae (...); Gal.14.3: Quosdam claros ex utroque ordine uiros suspicione minima inauditos condemnauit; Vit. 13.1 (...) saeuitiaeque deditus; Vit. 14.1: Pronus uero ad cuiusque et quacumque de causa necem atque supplicium nobiles uiros, condiscipulos et aequales suos.

${ }^{63}$ Cl. 25.5: Sed et haec et cetera totumque adeo ex parte magna principatum non tam suo quam uxorum libertorumque arbitrio administrauit, talis ubique plerumque, qualem esse eum aut expediret illis aut liberet; Cl. 29.1: His, ut dixi, uxoribusque addictus, non principem [se], sed ministrum egit, compendio cuiusque horum uel etiam studio aut libidine honores exercitus impunitates supplicia largitus est, et quidem insciens plerumque et ignarus.

${ }^{64}$ Gal. 14.2: Regebatur trium arbitrio, quos una et intra Palatium habitantis nec umquam non adhaerentis paedagogos uulgo uocabant.... His diuerso uitiorum genere grassantibus adeo se abutendum permisitt et tradidit, ut uix sibi ipse constaret, modo acerbior parciorque, modo remissior ac neglegentior quam conueniret principi electo atque illud aetatis.

${ }^{65}$ Vit. 12: Talibus principiis magnam imperii partem non nisi consilio et arbitrio uilissimi cuiusque histrionum et aurigarum administrauit et maxime Asiatici liberti.

${ }^{66}$ Tib. 70.2; Cal. 1.2; 12.3; 15.1; Cl.11.2; Nero. 9.1. Vide GAscou, J. 1984, 727-728.

${ }^{67}$ Vesp. 2.1: Quare princeps quoque et locum incunabulorum assidue frequentauit, manente uilla qualis fuerat olim, ne quid scilicet oculorum consuetudini deperiret.

${ }^{68}$ Ves. 2.1: et auiae memoriam tanto opere dilexit, ut sollemnibus ac festis diebus pocillo quoque eius argenteo potare perseuerauerit. 
dissera que ele teve responsabilidade na morte de Tibério (Cal.12.2). Depois vê-se que ele desrespeita a memória do avô Agripa, de Augusto, da bisavó Lívia e é a causa da morte da avó Antónia; manda depois assassinar o irmão, Tibério Gemelo; coage ao suicídio o sogro Silano; se poupa o tio Cláudio, é apenas para o tornar objecto de ludibrium (Cal.23); pratica incesto com as irmãs (Cal. 24). Nero desmente a pietas com os parricidia, do pai (Nero 33.1) e da mãe, que o tornam impius et sceleratus (Nero 34.1-4), acresce o desrespeito pela memória de Cláudio (Cl. 45; Nero 33.1) e o incesto com a mãe (Nero 28.2). A estes crimes acrescenta o assassínio de Britânico (Nero 33.2), da tia (Nero 34.5), das esposas (Óctávia e Popeia) e do enteado, filho de Popeia (Nero 35). Em relação a Tibério, fala-se de odium aduersus necessitudines: ${ }^{69}$ divulga uma carta do irmão Druso, em que este projectava conspirar para obrigar Augusto a restaurar a República; agrava a pena da esposa Júlia; nega honras à mãe (Tib. 50.2) e trata-a com rancor; ${ }^{70}$ é culpado das mortes do filho adoptivo Germânico (Tib. 52.3), da nora, Agripina (Tib.53), e dos netos, filhos daqueles (Tib.54). Vitélio envenena o filho da primeira mulher, com a agravante de o acusar de parricídio (Vit. 6), e é acusado da morte da própria mãe (Vit.14.5). Domiciano torna-se culpado da morte de Tito, ao abandoná-lo na sua extrema enfermidade (Dom. 2.3), ordena a morte do familiar Arrecino Clemente (Dom.11.1), dos primos Flávio Sabino (Dom.10.4) e Flávio Clemente (Dom.15.1), provoca a morte da sobrinha e amante (Dom.22).

A pietas pressupõe o respeito pelo sagrado. Estes imperadores juntam à impiedade para com os familiares a impiedade para com os deuses. O desprezo da religio e dos deuses tradicionais é, como já vimos, comum aos tiranos. ${ }^{71}$ Suetónio mostra-se, neste campo, favorável à restauração do mos maiorum e contrário à introdução dos cultos estrangeiros, à excepção dos helénicos. Augusto, ao contrário de César, presta atenção aos presságios ${ }^{72}$ e constrói diversos templos (Aug. 29.1-3). Este imperador e Cláudio são louvados pelo seu papel de restauradores de antigas práticas religiosas ${ }^{73}$ Domiciano, na parte favorável do principado, pelo facto de restabelecer o velho costume de reprimir os incesta das vestais ${ }^{74}$ e punir as ofensas aos deuses. ${ }^{75}$ Augusto e Cláudio são aplaudidos, no que concerne aos cultos estrangeiros, pela preocupação

${ }^{69}$ Tib. 50.1: Odium aduersus necessitudines in Druso primum fratre detexit.

70 Tib. 51.1: Dehinc ad simultatem usque processit...

71 César não manifesta temor religioso nem fé nos presságios (Jul.59), mostra-se arrogante para com os harúspices (Jul. 77) e nos idos de Março entra na cúria spreta religione (Jul. 81.4); Tibério é circa deos ac religiones neglegentior (Tib. 69.1); Calígula despreza os deuses (Cal. 51.1); Nero é religionum contemptor (Nero 56), Vitélio despreza todo o direito divino e humano ( $V i t$. 11.1) e incendeia o templo de Júpiter no Capitólio; Domiciano venera Minerva superstitiose (Dom. 15.3).

72 Aug. 91.1: Somnia sua neque aliena de se neglegebat; 92.1: Auspicia et omnia quaedam pro certissimis obseruabat.

${ }^{73}$ Aug. 31.4: Nonnulla etiam ex antiquis caerimonis paulatim abolita restituit, Cl. 25.5: Cum regibus foedus in foro i[e]cit porca caesa ac uetere fetialium praefatione adbibita.

${ }_{74}$ Dom. 8.3: incesta Vestalium uirginum, a patre quoque suo et fratre neglecta, uarie ac seuere coercit, priora capitali supplicio, posteriora more ueteri.

75 Dom 8.5: Ac ne qua religio deum impune contaminaretur... 
de respeitarem só os antigos e consagrados pela tradição e desprezarem os restantes, de acordo com a distinção estabelecida na Vida de Augusto ${ }^{76}$ : em relação aos cultos antigos e consagrados, Augusto inicia-se nos mistérios de Elêusis (Aug. 93), culto que Cláudio pensou mesmo em transferir para Roma; ${ }^{77}$ no que diz respeito aos outros cultos, Augusto menosprezou o do boi Ápis no Egipto e o hebraico (Aug. 93); Cláudio expulsa os judeus, chefiados pelo impulsor Chrestus, ${ }^{78}$ e pró́be a religião dos Druidas, pela sua dira immanitas (Cl.25.5). Suetónio coloca na parte positiva da Vida de Tibério a perseguição aos cultos egípcios e judaicos (Tib. 36) e na parte positiva da Vida de Nero a perseguição aos cristãos, porque se tratava de genus hominum superstitionis nouae ac maleficae. ${ }^{79}$ Suetónio, tradicionalista, ${ }^{80}$ não gosta destas inovações e considera-as superstições, porque o antigo equivale a consagrado. Condena a Nero o culto da Deusa Síria (Atargátis ou Magna Mater) e de uma pequena imagem de uma donzela (alia superstitio) (Nero 56); a Otão, o culto público de Isis, referido entre os seus costumes corrompidos (Otho 12.1); mas louva a Tibério, na parte recomendável do seu principado, a expulsão dos astrólogos (Tib. 36). Adverso, como vimos, a toda a divinização do imperador em vida, Suetónio mostra-se céptico em relação à apoteose dos imperadores: dá uma explicação naturalista para a de César; ${ }^{81}$ expressa subtil ironia ao referir-se à de Augusto; ${ }^{82}$ dá crédito aos gracejos de Vespasiano sobre a sua própria deificação (Ves. 23.4).

A impiedade no tocante à pátria também caracteriza, como já vimos, os tiranos. ${ }^{83}$ Se não houver moderatio, nem estão a salvo os homens nem a pátria nem os deuses. Conclui-se que, regra geral, os imperadores que não respeitam

${ }^{76}$ Aug. 93: Peregrinarum caerimoniarum sicut ueteres ac praeceptas reuerentissime coluit, ita ceteras contemptui habuit.

${ }^{77}$ Cl.25.5. Esta medida aparece em oposição (indicada por contra) aos outros cultos proibidos por Cláudio.

${ }^{78} \mathrm{Cl}$. 25.4. Alguns autores identificam este Chrestus com Cristo, admitindo uma anacronia (Cristo foi crucificado no tempo de Tibério), pois os primeiros cristãos não se distinguiam, em Roma, dos Judeus. Outros pensam que se trataria de um agitador judeu em Roma. Vide Gascou, J. 1984, 731 n. 114.

${ }^{79}$ Nero 16.2. Tácito, Ann.15.44.2-5, embora hostil aos cristãos, considera-os bodes expiatórios apresentados por Nero, quando se levantaram rumores sobre a culpa do imperador no incêndio. $\mathrm{O}$ historiador acha exagerado o castigo e diz que os condenados suscitavam a piedade, por serem vítimas da crueldade do imperador.

${ }^{80}$ Vide Gascou, J. 1984, 732.

$81 \mathrm{Jul}$. 88: (...) stella crinita per septem continuos dies fulsit exoriens circa undecimam horam, creditumque est animam esse Caesaris in caelum recepti; et hac de causa simulacro eius in uertice additur stella.

${ }^{82}$ Aug. 100.4: Nec defuit uir praetorius, qui se effigiem cremati euntem in caelum uidisse iuraret.

${ }^{83}$ Júlio César diz-se capaz de violar a pietas para satisfazer a ambição de reinar (Jul. 30.5); Calígula lamenta que o povo romano não tenha uma só cabeça (Cal.30.2) e a falta de calamidades no seu reinado (Cal. 31); Nero não poupa nem os muros da pátria (Nero 38); Vitélio, junto ao campo de batalha de Betríaco, profere palavras ímpias sobre os concidadãos mortos, e bebe para atenuar o cheiro dos cadáveres (Vit. 10.3); entra em armas em Roma (Vit.11.1) e contempla a luta e o incêndio do Capitólio, enquanto se banqueteia (Vit.15.3); Domiciano, embora associado por Tito ao império, não cessa de conjurar (Dom.2.3). 
os homens, também não respeitam os deuses. No entanto, a clementia é contada a favor de César, apesar do seu pendor tirânico, e a pietas favorece Cláudio, apesar das crueldades.

\subsubsection{Atitude face às riquezas: $d a$ abstinentia à liberalitas}

A par da moderatio, Suetónio, no final da Vida de Domiciano, coloca a abstinentia como virtude fundamental para o desempenho do bom príncipe. Esta virtude implica o respeito pela propriedade alheia; evita que o imperador use o seu poder para conseguir lucros indevidos. Augusto, das ofertas que espontaneamente lhe fazem para reconstruir a casa do Palatino, aceita apenas uma parte simbólica (Aug. 57.2). Tito, a quem se imputava uma suspecta rapacitas (Tit. 7.1), vem a revelar-se um modelo de abstinentia. ${ }^{84} \mathrm{Na}$ parte positiva do reinado, Domiciano, longe de mostrar cupiditas ou auaritia, dá provas de abstinentia. ${ }^{85} \mathrm{~A}$ ausência desta virtude é notada no exercício do imperium e das magistraturas de César. ${ }^{86} \mathrm{~A}$ abstinentia opõe-se à auaritia, à cupiditas, à rapacitas, que definem a actuação dos maus imperadores no que diz respeito aos bens dos cidadãos, mortos ou vivos, das cidades, das províncias, dos templos. Como auaritia designa Suetónio a avidez de riquezas de Nero (Nero 26.1) e de Galba (Gal.12.1). A cupiditas pecuniae é apresentada como o único vício de Vespasiano, ${ }^{87}$ de cuja fama se não consegue livrar, ${ }^{88}$ e como segundo vício de Domiciano, suplantado pela saeuitia.$^{89} \mathrm{O}$ grau mais elevado é a rapacitas, que, além de qualidade moral, designa já uma forma de agir. Deste vício fora suspeito também Tito, antes de assumir sozinho o império (Tit. 7.1). A rapacitas concretiza-se nas rapinae (ou, termo menos usado, praedae), apresentadas como o culminar de um processo gradativo da falta de abstinentia de César e da avareza de Tibério ${ }^{90}$ e como o efeito do esbanjamento a que se entregam Calígula, Nero e Domiciano. ${ }^{91}$ Vitélio é culpado de permitir a rapina

${ }^{84}$ Tit. 7.3: Nulli ciuium quicquam ademit; abstinuit alieno, ut siquis umquam; ac ne concessas quidem ac solitas conlationes recepit.

${ }^{85}$ Dom. 9.1: Cupiditatis quoque atque auaritiae uix suspicionem ullam aut priuatus umquam aut princeps aliquamdiu dedit, immo e diuerso magna saepe non abstinentiae modo sed etiam liberalitatis experimenta.

${ }^{86} \mathrm{Jul}$.54.1: Abstinentiam neque in imperiis neque in magistratibus praestitit.

${ }^{87}$ Ves. 16.1: Sola est in qua merito culpetur, pecuniae cupiditas; Ves. 16.3: Quidam natura cupidissimum tradunt.

${ }^{88}$ Ves. 19.1: Et tamen ne sic quidem pristina cupiditatis infamia caruit.

${ }^{89}$ Ves. 1.1: (...) constet licet Domitianum cupiditatis ac saeuitiae merito poenas luisse; Dom 10.1: (...) et tamen aliquanto celerius ad saeuitiam desciuit quam ad cupiditatem (desenvolvimento em 12.1-2).

${ }^{90} \mathrm{Em}$ Jul. 54.3 (Postea uero euidentissimis rapinis ac sacrilegis et onera bellorum ciuilium et triumphorum ac munerum sustinuit impendia), corresponde ao ponto mais alto da falta de abstinentia, desenvolvida numa gradação ao longo do capítulo. Em Tib. 49.1 (Procedente mox tempore etiam ad rapinas conuertit animum), corresponde ao grau mais elevado da avareza de Tibério, enquanto pecuniae parcus ac tenax (Tib. 46).

${ }^{91}$ Cal. 38.1: Exhaustus igitur atque egens ad rapinas conuertit animum uario et exquisitissimo calumniarum et auctionum et uectigalium genere; Nero 32.1: Verum ut spes fefellit, destitutus atque ita iam exhaustus et egens ut stipendia quoque militum et commoda ueteranorum protrahi ac differri 
no seu avanço a caminho de Roma. ${ }^{92}$ Vespasiano, pelo contrário, é absolvido das manubiae et rapinae, dadas as dificuldades do erário e do fisco. ${ }^{93}$

Outro foco de análise situa-se na atitude do imperador para com os recursos de que dispõe. A abstinentia impede que o imperador se torne rapace. Um príncipe com aquele predicado não é tirânico, mas, para se tornar bom, deve ir mais além. Se o princeps, pela negativa, não deve ser um dominus, pela positiva, deve ser um patronus para os cidadãos, para as cidades de Itália, para as províncias, para os reis aliados. ${ }^{94}$ Além da abstinentia, exige-se de um príncipe a liberalitas: nobreza e bondade natural naquele que é o primeiro dos homens livres, o primeiro dos patroni. Suetónio aproxima-se inclusive de uma concepção "paternalista" do imperador, presente, em particular, na descrição da actuação de Tito por altura das calamidades. ${ }^{95}$

Tibério, pecuniae parcus ac tenax, é o eloquente modelo da ausência de liberalitas: a sua avareza é considerada de mau gosto. O biógrafo insiste nas excepções que confirmam a regra: só uma vez manifestou liberalitas para com os companheiros de viagem, e à custa do padrasto ( $T i b$. 46); não embeleza a cidade com obras grandiosas, já que não termina as que começou; não dá espectáculos e poucas vezes assiste a eles, para lhe não pedirem mercês; remedeia a situação de poucos senadores, mas, para evitar estas ajudas, passou a exigir que os interessados provassem a sua carência no senado, o que muitos evitavam por modestia ou pudor (Tib. 47); só duas vezes dá mostras públicas de munificentia com o povo (Tib. 48.1); mostra-se parco (nibil umquam largitus est) nas recompensas aos soldados e aos veteranos e não acode com alguma liberalitas às províncias, à excepção da Ásia, assolada por um terramoto (Tib. 48.2). A contenção das despesas dos jogos - anteriormente considerada entre os méritos do imperador ${ }^{96}$-, torna-se moralmente reprovável, como reflexo da avareza de Tibério, que já se manifestara quando oferecia jogos à custa de Lívia e Augusto (Tib. 7.1). Pela negativa, o modelo de Tibério indica as áreas de intervenção da liberalitas dos imperadores. Avara é também a atitude de Galba, ridiculizada pela opinião pública por recurso a diversas anedotas ( $G a l .12)$; este acabou por ofender todas as classes, especialmente os soldados pretorianos, a quem nega qualquer donativo (Gal. 16.1).

Pelo contrário, Augusto exibe a liberalitas com todas as ordens. ${ }^{97}$ Vespasiano,

necesse esset, calumniis rapinisque intendit animum; Dom. 12.1: Exhaustus... nibil pensi habuit quin praedaretur omni modo.

92 Vit. 10.2: (...) rapinas ac petulantiam omnium in iocum uertens.

${ }^{93}$ Ves. 16.3: Sunt contra qui opinentur ad manubias et rapinas necessitate compulsum summa aerarii fiscique inopia, de qua testificatus sit initio statim principatus, professus 'quadringenties milies opus esse, ut res p. stare posset'. Quod et ueri similius uidetur, quando et male partis optime usus est.

${ }^{94}$ Vide Grimal, P. 1993, 17.

${ }^{95}$ Tit. 8.3: In iis tot aduersis ac talibus non modo principis sollicitudinem sed et parentis affectum unicum praestitit, nunc consolando per edicta, nunc opitulando quatenus suppeteret facultas. Vide Gascou, J. 1984, 743.

${ }_{96}$ Tib. 34: Ludorum ac munerum impensas corripuit.

${ }^{97}$ Aug. 41.1: Liberalitatem omnibus ordinibus per occasiones frequenter exhibuit. 
depois de minimizada a má fama da cupiditas pecuniae, é definido como in omne hominum genus liberalissimus (Ves. 17). A liberalitas figura explicitamente entre as virtudes ostentadas por Nero e Domiciano no início do principado (Nero 10.1; Dom.9.1). Os príncipes manifestam, em geral, consciência da importância do evergetismo como sustentáculo do poder imperial: Augusto prefere prestar atenção durante a assistência aos jogos, quando percebe que o povo censurava a César o facto de aproveitar aquele momento para pôr a correspondência em dia (Aug. 45.1), e Vespasiano, em vez de usar um novo invento, que lhe permitiria poupar esforço e dinheiro no transporte de umas colunas para o Capitólio, prefere «apascentar a plebicula»..$^{9}$ Otão sabe aproveitar em seu favor a avareza de Galba e faz diversos donativos aos soldados, ao ponto de contrair muitas dívidas (Otho 4.2-5). As enumerações apresentadas por Suetónio sugerem a importância social e política que o biógrafo atribui a estes aspectos: distribuições às diferentes classes ${ }^{99}$ embelezamento da Urbe, ${ }^{100}$ obras fora da Urbe e nas províncias, ${ }^{101}$ jogos, ${ }^{102}$ ofertas durante os jogos. ${ }^{103} \mathrm{O}$ evergetismo é entendido como uma componente ético-social dos deveres inerentes à função do imperador e uma estratégia política: uma forma de manter a concórdia social, ao minorar os defeitos decorrentes das desigualdades sociais. É um meio eficaz de propaganda do regime.

Contudo, também nestas liberalidades é preciso moderação. Mais uma vez, Augusto representa o modelo. A seguir aos exemplos da liberalitas, no que respeita aos donativos às várias classes, Suetónio mostra que Augusto coloca a preocupação com a salubritas do Estado à frente da sua ambitio, ao resistir à tentação de ceder à demagogia, sem medo de tomar medidas impopulares: responde com ironia ao povo que se queixa da escassez e carestia de vinho; ${ }^{104}$ dá os donativos que prometeu e nega os que não prometeu. São apresentadas como demonstração de grauitas e constantia as restrições às distribuições pecuniárias e de cereais (Aug. 42.2-3). A temperantia, como se deduz das palavras do biógrafo ao encerrar este assunto, é o critério de sageza que permite manter o equilíbrio e a salubritas do Estado. ${ }^{105}$

Mais à frente, Suetónio procura absolver Augusto da culpa de luxo e

${ }^{98}$ Ves. 18. A interpretação do passo tem, no entanto, suscitado algumas dúvidas: vide CAsson, L. 1978, 43-51; Brunt, P. A. 1980, 81-100; com. de Cesa, M. 2000, 90-91. 4.5 .

${ }^{99}$ Jul. 38; Aug. 41; 74; Cal.17.2; 18.2; Cl. 21.1; Nero 10.1; 11.2; Ves. 17; 19.1; Tit. 7.2; Dom. 5 .

${ }^{100}$ Jul 44.1-2 (projectos); Aug. 28.3-30; Cal. 21; Cl. 20.1; Nero 16.1; Ves. 9.1; Tit. 7.3; Dom.

${ }^{101}$ Jul. 44.3 (projectos); Cal. 21; Cl. 20; Ves. 17.

${ }_{102}$ Jul.39; Aug. 43; Cal.18-20; Cl.21; Nero 11-13; Tit.7.3; Dom.4.1-4. Suetónio não adopta os preconceitos do seu amigo Plínio (Ep.9.6.1) contra os jogos, tanto mais que escreveu uma ludicra historia. Vide Della Corte, F. 1967, 100-102.

${ }^{103}$ Cal.18.2; Nero 11.2; Dom. 4.5. Vide Pociña, A. \& Uвiñ A, J. F. 1985, 577-602.

${ }^{104}$ Aug. 42.1: Sed ut salubrem magis quam ambitiosum principem scires, querentem de inopia et caritate uini populum seuerissima coercuit uoce: 'satis prouisum a genero suo Agrippa perduct is pluribus aquis, ne homines sitirent'.

${ }_{105}$ Aug. 42.3: Atque ita postha[n]c rem temperauit, ut non minorem aratorum ac negotiantium quam populi rationem deduceret. 
opulência que caracterizam os tiranos. É certo que censuravam a Augusto o gosto por móveis de luxo e vasos coríntios (Aug. 70.2). Mas ele afasta a lautitiarum inuidia com a atitude posterior (Aug. 71.1), onde predominava a continentia. ${ }^{106}$ Percebe-se uma defesa apologética de Augusto face aos topoi da diatribe contra os tiranos: ${ }^{107}$ contra as construções luxuosas, a sobriedade da habitação de Augusto (Aug. 72); contra a profusão de estátuas e pinturas, o ornamento das casas de campo com áleas, jardins e objectos de antiquária, como ossos enormes (Aug. 72.3); contra as mesas caras e leitos requintados e vestuário e calçado exóticos, a parsimonia do mobiliário e das roupas de fabrico caseiro (Aug. 73). Tito sabe moderar-se e transforma as prolongadas orgias em banquetes mais agradáveis que dispendiosos. ${ }^{108}$ Esta é a forma de evitar a nociva profusão de Calígula, Nero e Vitélio, que ressurgirá com Domiciano. ${ }^{109}$

Nos tiranos, passa-se rapidamente de liberalidade para a dilapidação de recursos e sumptuosidade: o evergetismo deixa de ser preocupação com o bem público para se transformar em puro narcisismo. No pólo oposto a Tibério, certas acções, consideradas em si positivas, acabam por ter como negativo o exagero dos gastos: a recepção de Nero a Tiridates, descrita entre os espectáculos (Nero 13), vista por outro prisma (o dos probra ac scelera), mostra-se incrivelmente ruinosa (Nero 30.2), e a forma aedificiorum urbis noua (Nero 16.1) é entenebrecida pela dispendiosa construção dos palácios; ${ }^{110}$ os gastos com construções, espectáculos e aumento do soldo, medidas louvadas em Domiciano, ${ }^{111}$ tornam-se más a partir do momento em que o deixam sem recursos (Dom.12.1). Se a atitude de Tibério é reprovável, também reprovável é a forma como Calígula, em apenas um ano, desbarata as imensas riquezas acumuladas pela avareza do velho imperador (Cal. 37.3). Por esta atitude de Calígula, Nero apresenta-se como seu admirador. ${ }^{112}$ Os dois mostram-se incapazes de moderação: o biógrafo torna patente a inversão de valores, por eles preconizada, quando verbalizam o elogio da sumptuosidade como atitude verdadeiramente digna de um imperador. ${ }^{113} \mathrm{O}$ cúmulo da extravagância de Nero é a dispendiosa construção da Domus Aurea ${ }^{114}$ cuja descrição representa

\footnotetext{
${ }^{106}$ Aug. 72.1: In ceteris partibus uitae continentissimus constat ac sine suspicione ullius uitii.

${ }^{107}$ Presentes também em Plínio-o-Velho, como demonstra Oliveira, F. 1992, 32-39.

108 Tit. 7.1: ad mediam noctem comissationes; Tit. 7.2: Conuiuia instituit iucunda magis quam

${ }^{109}$ Cal.37; Nero 30-31; Vit.13. Dom. 12.1.

110 Nero 31.1. Vide Gascou, J. 1984, 370-371. Constitui uma motivação para o incêndio

${ }^{111}$ Dom. 4-5. Vide Gascou, J. 1984, 372.

112 Nero 30.1: Laudabat mirabaturque auunculum Gaium nullo magis nomine, quam quod ingentis a Tiberio relictas opes in breui spatio prodegisset.

${ }^{113}$ Cal. 37.1: Nepotatus sumptibus omnium prodigorum ingenia superauit... 'aut frugi hominem esse oportere' dictitans 'aut Caesarem'; Cal. 37.2: ... nibil tam efficere concupiscebat quam quod posse effici negaretur; Nero 30.1: Diuitiarum et pecuniae fructum non alium putabat quam profusionem, sordidos ac deparcos esse quibus impensarum ratio constaret, praelautos uereque magnificos qui abuterentur ac perderent'; Nero 30.2: Quare nec largendi nec absumendi modum tenuit.

${ }^{114}$ Nero 31.1: Non in alia re tamen damnosior quam in aedificando domum a Palatio Esquilinas
} profusa. (Nero 38.1). usque fecit. 
uma cabal diatribe contra a luxuria, com paralelos literários na descrição da moradas sumptuosas: ${ }^{115}$ o próprio imperador agrava a imoralidade dos gastos com a arrogância das palavras (Nero 31.2). A luxuria de Vitélio é determinada por um vício pessoal: uma gula sem fim, destemperada e sórdida. ${ }^{116}$ Assim, num limite se situa a avareza de Tibério e, no outro, o impendiorum furor de Nero. ${ }^{117}$ Mas os extremos tocam-se, pois o efeito acaba por ser semelhante: a progressão para a rapina, que acontece tanto no avaro Tibério, como nos perdulários Calígula, Nero e Domiciano. ${ }^{118}$

Do exposto se conclui que, quando Suetónio, no final das Vidas, menciona as virtudes dos príncipes seguintes, que possibilitam uma ordem melhor, se refere aos "freios" que o imperador terá de impor a si próprio para se não transformar em tirano arrogante, cruel e rapace: a moderatio implica, pela positiva, ciuilitas, clementia e mesmo pietas; e a abstinentia é complementada com a liberalitas. Mas a atitude depende única e exclusivamente da formação moral do próprio.

\subsection{A defesa dos bons costumes: a dignitas e a castitas}

Faz parte do conceito "paternalista" do imperador uma função moralizadora, ${ }^{119}$ pautada sobretudo pelo esforço de retorno aos costumes antigos. Diversas vezes se constata, nas Vidas, a necessidade de correcção de uma sociedade que se afastou da virtude, sobretudo depois de períodos de guerras civis. ${ }^{120}$ Augusto, mais uma vez, é modelo: o que preconiza é o retorno ao mos maiorum. ${ }^{121} \mathrm{~A}$ ele se atribui uma série de medidas, adoptadas ou reformuladas, que versam sobre a moralização da vida pública e privada: leis sumptuárias, leis de adulteriis et de pudicitia, de ambitu, de maritandis ordinibus (Aug. 34.1). Numa perspectiva moral, mais do que propriamente racista, ${ }^{122}$ parece ser encarada a preocupação de Augusto em evitar a contaminação do sangue romano e a usurpação do direito de cidade: este tem de ser conseguido

${ }^{115}$ Nero 31.2. Cf. Tácito, Ann. 15.42-43. Vide Morford, M. P. 1968, 158-179; Blaison, M. 1998, 617-624.

${ }^{116}$ Vit. 13.3: Vt homo non profundae modo intempestiuae quoque ac sordidae...

117 Nero 31.4. Vide Gascou, J. 1984, 747-749.

118 Tib. 49.1: Procedente mox tempore etiam ad rapinas conuertit animum; Cal. 38.1: Exhaustus igitur atque egens ad rapinas conuertit animum; Nero 32.1: iam exhaustus et egens... calumniis rapinisque intendit animum; Dom. 12.1: Exhaustus operum ac munerum inpensis stipendioque, quod adiecerat... nibil pensi habuit quin praedaretur omni modo.

${ }^{119}$ Vide Gascou, J. 1984, 743 ss.

${ }^{120}$ Cf. Aug. 32.1: Pleraque pessimi exempli in perniciem publicam aut ex consuetudine licentiaque bellorum ciuilium durauerant aut per pacem etiam extiterant; Tib. 33: (...) atque etiam, si qua in publicis moribus desidia aut mala consuetudine labarent, corrigenda suscepit; Cl. 22: Quaedam circa caerimonias ciuilemque et militarem morem, item circa omnium ordinum statum domi forisque aut correxit aut exoleta reuocauit aut noua instituit; Ves. 9.2: Amplissimos ordines et exhaustos caede uaria et contaminatos ueteri neglegentia purgauit...; Ves. 11: Libido atque luxuria coercente nullo inualuerat.

${ }^{121}$ Vide Hellegouarc'h, J. 1987, 84.

${ }^{122}$ Como pretende Gascou, J. 1984, 744. 
por mérito pessoal (iustae causae) e não por favor a um cliente. ${ }^{123}$ Cláudio, além de proibir aos estrangeiros a utilização indevida de nomes romanos, pune com a decapitação os que usurpam a cidadania romana ( $C l$. 25.3). A mesma intenção se vislumbra no restauro do uso da toga, enquanto uestitus pristinus (Aug. 40.5).

Grande importância se dá ao restabelecimento da disciplina nos espectáculos: ${ }^{124}$ distribuição hierárquica dos lugares dos espectadores (Aug. 44); repressão da licentia dos actores (Aug. 45.4). Tibério expulsou os actores e seus sectários de Roma, apesar dos rogos do povo (Tib. 37.2). Também Domiciano, na parte positiva do principado, promove uma série de medidas de teor semelhante, com vista à correctio morum: os alvos são a licentia theatralis, os scripta famosa, o gesticulandi saltandique studium, bem como as probrosae feminae, os adulteria, os homossexuais, visados pela lex Scantinia, os incesta das virgens vestais. ${ }^{125}$ Mesmo Calígula é louvado (na parte referente à descrição do princeps) pelo facto de pretender afogar os spintriae, organizadores de monstrosae libidines, e só a custo condescender em desterrá-los (Cal.16.1). A austeridade romana é apregoada: as medidas contra o excesso de luxo são louvadas em César (Jul. 43), em Tibério (Tib. 34.1), em Vespasiano, ${ }^{126}$ e mesmo em Nero, na fase positiva do seu principado. ${ }^{127}$

Trata-se de uma moral baseada nas noções de povo, de classe social, de família, de cidadão romano. Della Corte aponta como critério suetoniano de avaliação dos príncipes a atitude para com a classe a que Suetónio pertencia: os cavaleiros. ${ }^{128}$ Mas Gascou refuta de forma cabal esta teoria. Bastará recordar que o biógrafo relata entre as piores acções de Calígula o facto de este imperador dizer que regressa a Roma unicamente para os cavaleiros e para o povo e que, para os senadores, não seria mais nem cidadão nem príncipe (Cal. 49.1); e entre os crimes de Nero a intenção de exterminar os senadores e entregar os cargos senatoriais aos cavaleiros e libertos (Nero 37.3). Suetónio tem uma concepção tradicional e hierárquica da sociedade e contesta os imperadores que tentam subverter esta ordem estabelecida. ${ }^{129}$ Os melhores imperadores são os que são favoráveis a todas as classes: os que conseguem o consensus ordinum, verificável pelas reacções à morte. Ora também esta diferenciação social apresenta uma base moral. Sendo a libertas comum a todos os cidadãos livres, a dignitas distingue as classes. $\mathrm{O}$ fundamento da dignitas encontra-se não só nos feitos dos antepassados, mas também nas acções louváveis do cidadão. ${ }^{130}$ Vespasiano destitui senadores e cavaleiros por serem indignissimi, e deixa claro

${ }^{123}$ Aug. 40.3. Vide Tompson, L. A. 1981, 35-46.

${ }^{124}$ Aug. 44.1: Spectandi confusissimum ac solutissimum morem correxit ordinauitque.

125 Dom. 8.3. Vide Baumann, R. 1982, 121-122..

${ }^{126}$ Ves. 11: restabelecimento de leis sobre libido atque luxuria.

${ }^{127}$ Nero 16.2. Mas é-lhe censurado, como acto de rapina, o despojamento das roupas e dos bens de uma matrona vestida com a púrpura proibida (Nero 32.3).

${ }^{128}$ Vide Della Corte, F. 1967, 165-190. Teoria aceite acriticamente por Brugnoli, G. 1968, 37.

${ }^{129}$ Vide Gascou, J. 1976, 257-277.

${ }^{130}$ Vide Lewis, R. G. 1991, 3655. 
que a distinção entre as duas ordens se faz com base na dignitas e não tanto na libertas ao dizer que, se um cavaleiro não deve ofender um senador, tem, no entanto, o direito de responder a uma ofensa (Ves. 9.2). Tal concepção de dignitas aproxima-se do nosso conceito de "nobreza" que, a partir da noção de elevação social, passou a indicar elevação de carácter. Ao imperador, enquanto topo da pirâmide social, exige-se que tenha um carácter nobre e que mantenha a concórdia entre todas as classes de modo a consolidar a paz social.

$\mathrm{Na}$ mira de preservar a dignidade das classes mais elevadas, Tibério numa fase ainda positiva, mas em que paulatinamente se vai manifestando o despotismo do princeps ${ }^{131}$ - retirou o laticlavo a um senador que, dias antes das calendas de Julho (data em que se faziam os contratos de arrendamento urbano), se retirou para o campo, para, depois daquela data, poder arrendar uma casa na cidade a um preço mais baixo; retirou o cargo de pretor a um senador que casara na véspera do sorteio das províncias e se divorciou no dia seguinte (talvez porque, tendo-lhe calhado em sorte um província rica, já não necessitava do dinheiro da esposa: o que tornava patente que casara com ela por interesses materiais e não cívicos) (Tib. 35.2) - a dignidade de senador não se coadunava com este tipo de expedientes. Além disso, dispôs que as matronas adúlteras fossem, à falta de acusador público, julgadas em conselho de família, segundo o mos maiorum; ${ }^{132}$ condenou ao desterro as matronas que, para contornar a lei, se declaravam prostitutas ${ }^{133}$ e os jovens das classes senatorial e equestre que, para não serem impedidos de tomar parte nos jogos teatrais e da arena, se expunham voluntariamente a um processo infamante.

O próprio imperador devia esforçar-se por, sem se tornar arrogante, conservar a dignitas inerente à sua função. Apesar de a toada dos gracejos de Vespasiano não ser negativa, Suetónio sugere que este imperador exagerava por vezes ${ }^{134}$ - mas o próprio não nega que é um provinciano. Já Tito trata o povo com comitas, enquanto assiste aos jogos, sem contudo perder a compostura. ${ }^{135}$ Não assim Cláudio, cujo desejo de se mostrar acessível e afável o leva a ter gestos e palavras pouco dignas e ao invés do seu estatuto, provocando mesmo a hilaridade dos espectadores, ao tratá-los por domini. ${ }^{136}$ Indigna é a também sua reaç̧ão contra os naumacbiarii que se recusam a combater: desata a correr com um disforme coxear a ameaçá-los e a exortá-los ao combate (Cl. 21.6). Pior é o tratamento de Vitélio, cuja comitas, associada ao seu facilis ac prodigus animus, o faz descer a um nível demasiado vil. ${ }^{137}$ Também neste

${ }^{131}$ Tib.33: Paulatim principem exeruit praestititque etsi uarium diu, commodiorem tamen saepius et ad utilitates publicas proniorem.

${ }^{132}$ Tib.35.1. O caso de Apuleia Varila descrito em Tácito, Ann. 2.50.

${ }^{133}$ Atitude de Vistília, segundo Tácito, Ann. 2.85.2-3.

${ }^{134}$ Ves. 22: (...) erat enim dicacitatis plurimae, etsi scurrilis et sordidae, ut ne praetextatis quidem uerbis abstineret.

135 Tit. 8.2: Populum in primis uniuersorum tanta per omnis occasiones comitate tractauit.... uerum maiestate salua nec minus aequitate.

${ }^{136}$ Cl. 21.5: ac saepe hortando rogandoque ad hilaritatem homines prouocaret, 'dominos' identidem appellans.

${ }^{137}$ Vit. 7.3: tota uia caligatorum quoque militum obuios exosculans perque stabula ac deuersoria mulionibus ac uiatoribus praeter modum comis, ut mane singulos 'iamne iantassent' sciscitaretur seque 
aspecto se requer moderação.

Além do reforço da ordem social, o bom imperador procura consolidar a família, com o incentivo ao casamento e com a garantia da fiabilidade da paternidade, através de leis repressivas do adultério. O biógrafo dá o seu acordo à aplicação da lei com uma severidade que nos parece exagerada: Vespasiano propõe ao senado que toda a mulher que se una a um escravo alheio seja considerada escrava. ${ }^{138}$

O príncipe deve ser coerente com o que exige dos súbditos. Surpreende, dado o comportamento posterior, que também Nero, de início, se preocupasse em refrear a licentia dos aurigas, que se divertiam a vagabundear e a pilhar, e desterrasse os actores de pantomimas e suas claques belicosas (Nero 16.2), quando, depois, se verifica que ele próprio vagueava de noite, para se divertir com desacatos (Nero 26.1), e provocava confrontos entre as facções do pantomimos, chegando mesmo a participar neles. ${ }^{139}$ Também Tibério, Calígula, Domiciano, e mesmo Augusto, não cumprem as leis que promulgam sobre o adultério e a pudicitia. $\mathrm{O}$ facto de nem os bons imperadores escaparem à imoralidade parece, numa primeira análise, revelar pessimismo da parte do biógrafo.

Uma abordagem moral não distingue, como dissemos, vida pública de vida privada. A vida privada dos imperadores é objecto de integral devassa. Neste aspecto reside o lado mais negro de Augusto. Comportamentos homossexuais são censurados a César, Augusto na sua juventude, Tibério, Calígula, Nero, Galba, Otão, Vitélio, Tito, Domiciano. ${ }^{140}$ Neste particular, Otão aparece associado a Nero, e Vitélio a Tibério. Aos tiranos é imputado o crime de sodomia, com requintes de sadismo, como o caso do minister de Tibério (Tib. 44.2) e de Esporo, mandado castrar por Nero (Nero 28.1). Sobretudo condena-se severamente a homossexualidade passiva, classificada como impudicitia: ${ }^{141}$ evidenciam-se traços da invectiva política, com indicação das fontes da acusação, em César, Augusto e Domiciano. Mas Suetónio, enquanto absolve Augusto e Tito e não volta a referir este traço em Domiciano imperador, ${ }^{142}$ permite que esta acusação fique para sempre ligada a César, ${ }^{143}$

fecisse ructu quoque ostenderet.

${ }^{138}$ Ves. 11. Tanto esta lei como a do empréstimo de dinheiro aos filii familias estão erradamente atribuídas a Vespasiano, uma vez que são obra de Cláudio. É natural que Vespasiano as tenha restabelecido juntamente com a deificação de Claúdio, antes cancelada por Nero (Cl. 45.): vide BaUmann, R. 1982, 114.

139 Nero 26.2. Tácito, Ann. 13.25, refere em conjunto os confrontos e a expulsão dos pantomimos como consequência de uma situação que se torna insustentável.

${ }^{140}$ Jul. 49; Aug. 68; Tib. 44.2; Cal. 36.1; Nero 28.2-29; Gal. 22; Otho 2.2; Vit. 3.2; Vit. 12; Tit. 7.1; Dom. 1.1. Provavelmente resultado da influência da cultura helénica na alta sociedade romana: vide WALLACE-HADRILL, A. 1984, 184.

${ }^{141}$ Termo eufemístico para designar "sexualidade passiva”, segundo VEYne, P., 1990, 179.

${ }^{142}$ Embora se diga que, quando jovem, foi corruptus por Nerva, seu imediato sucessor (Dom.1.1).

${ }^{143}$ Jul. 2: non sine rumore prostatae regi pudicitiae; Jul. 49.1: Pudicitiae eius famam nibil quidem praeter Nicomedis contubernium laesit; cf. Jul. 52.3: a impudicitiae infamia - não parece que Suetónio sugira que é improvável, como pretende CARneY, T. F. 1968, 12 n. 24. 
Calígula ${ }^{144}$ e Nero. ${ }^{145}$ De Cláudio se diz claramente que se abstém de homens (Cl. 33.2). Adultérios são apontados a César, Augusto, Tibério, Calígula, Cláudio, Nero, Vespasiano, Tito, Domiciano. ${ }^{146}$ Mas se é censurável a sedução de mulheres nobres casadas por parte de César e Augusto, ${ }^{147}$ os tons tornam-se mais negros no ultraje às matronas ilustres, por parte de Tibério, ${ }^{148}$ que provoca o suicídio de Malónia; por parte de Calígula, que as examinava mercantium more (Cal.36.2), e na violação da vestal Rúbria por parte de Nero. ${ }^{149} \mathrm{O}$ incesto mancha Calígula, Nero (Cal. 24; Nero 28.2), e, também, Domiciano, que acaba por provocar a morte da sobrinha. ${ }^{150}$ Os abomináveis actos de pedofilia de Tibério são apresentados como incríveis até de conceber. ${ }^{151}$ Por conseguinte, os piores governantes são libidinosos e exercem a sua tirania também no domínio sexual: através da abuso de matronas; através dos incestos, que lembram as uniões dos monarcas egípcios; através da sodomia e do sadismo. Mas, por outro lado, parecem desejar ser dominados através da pederastia passiva. Estes são topoi habituais da descrição dos tiranos. A libido faz parte integrante do discurso contra a tirania. ${ }^{152}$

É claro que o biógrafo contribui largamente para condicionar o julgamento do leitor. A própria colocação da rubrica da vida sexual do imperador na estrutura da biografia fornece a chave de leitura. Não é ingenuamente que, para Tibério, a rubrica dos comportamentos sexuais é colocada entre os cuncta simul uitia male diu dissimulata (Tib. $42 \mathrm{ss);} \mathrm{para}$ Calígula, na descrição do monstrum (Cal. 22 ss); para Nero, entre os probra ac scelera (Nero 19.3 ss) - uma apresentação subjectiva, que pressupõe um julgamento moral desfavorável à partida. No caso de Domiciano, a posição não é determinante, mas as circunstâncias da morte da filha de Tito, que culminam na descrição da libido, já de si nimia, contribuem para denegrir a imagem do filho mais novo de Vespasiano. ${ }^{153} \mathrm{O}$ elogio de Galba, viúvo, que se absteve de novo casamento e resistiu mesmo às solicitações de Agripina ( Gal. 5.1), parece ensombrado, no final, pela constatação de que tinha preferência

${ }^{144}$ Cal.36.1: Pudicitiae <neque suae> neque alienae pepercit.

145 Nero 29: Suam quidem pudicitiam usque adeo prostituit...

${ }^{146}$ Jul. 50-52; Aug. 69-70; Tib. 45; Cal. 36; Cl.33.2; Nero 28.1; Ves. 3; 21; 22, Tit. 7.1; Dom. 22.

${ }^{147} \mathrm{Jul}$. 50.1: Pronum et sumptuosum in libidines fuisse constans opinio est, plurimasque et illustres feminas corrupisse; Aug. 69.1: condiciones quaesitas per amicos qui matres familias et adultas aetate uirgines denudarent atque perspicerent, tanquam Toranio mangone uendente.

${ }_{148}$ Tib. 45: Feminarum quoque, et quidem illustrium, capitibus quanto opere solitus sit inludere (...).

${ }^{149}$ Nero 28.1. Este imperador organizava orgias em que matronas imitavam as taberneiras (Nero 27.3).

${ }^{150}$ Dom. 22. Tal relação era considerada incestuosa, pelo que o casamento de Cláudio com Agripina teve de ser ratificado pelo senado: (...) talium coniugiorum, quae ad id tempus incesta habebantur (Cl.26.3); Ducturus contra fas Agrippinam uxorem (Cl. 39.2).

${ }^{151}$ Tib. 44.1: Maiore adhuc ac turpiore infamia flagrauit, uix referri audiriue, nedum credi fas sit.

${ }^{152}$ Vide Dupont, F. et Éloi, T. 2001, 263-323.

${ }^{153}$ Dom. 22. Vide Bradley, K. R. 1985a, 77-83. 
por homens. ${ }^{154}$ No caso de César e de Augusto, a rubrica integra-se, como se vê pelo conteúdo da diuisio que a antecede, na descrição da vida privada, ${ }^{155}$ e no caso de Vespasiano, é dissimulada na descrição da vida diária ${ }^{156}$ - o que lhe dá uma aparência mais objectiva e neutral. Em Tito, a vida sexual é, juntamente com os outros vícios, dividida simetricamente ${ }^{157}$ entre parte má e parte boa, tomando como ponto de charneira a referência à mudança operada quando ea fama pro bono cessit conuersaque in maximas laudes (Tit. 7.1). Além disso, nos imperadores bons acentua-se a mudança de atitude ou a pureza do espírito. Augusto refuta facilmente a acusação de impudicitia com a uitae castitas (Aug. 71.1). Os adultérios, inegáveis, são desculpados pelos amigos como meio de espionagem e não fruto da libido. Suetónio admite que Augusto continuou preso às libidines, pois diz-se que gostava de desflorar virgens, mas tal comportamento parece atenuado pela complacência da própria esposa ${ }^{158}$ - ao menos não a enganava. Abona a seu favor o amor que toda a vida o liga a Lívia e que é relembrado à hora da morte. ${ }^{159} \mathrm{Em}$ Tito, é valorizado o autodomínio espelhado na mudança de comportamento: distancia-se dos favoritos e eunucos ${ }^{160}$ e, apesar de, como outrora César (Jul. 52.1), amar uma rainha oriental, Berenice, sabe mostrar sentido de Estado ao separar-se dela, contra a vontade de ambos (Tit. 7.2). A vida sexual de Vespasiano não é apresentada em tom de censura: o biógrafo deixa claro que a única pecha deste imperador - in qua merito culpetur - é a pecuniae cupiditas (Ves. 16.1). Não lhe é imputada qualquer acusação de homossexualidade e os adultérios são inocentes: a anedota em que Vespasiano se limita a aceder aos rogos de uma apaixonada, a quem dá uma retribuição, é apresentada para ilustrar o seu sentido de humor, reflexo da comitas (Ves. 22). Depois da morte de Flávia Domitila, Cénis, que tem a seu favor o facto de ser liberta de Antónia, é tratada como uma legítima esposa (Ves. 3), a tal ponto que o

${ }^{154}$ Gal. 22. Ao contrário do que sugere BradLey, K. R. 1985a, 82, é a nota negativa que, ao aparecer no final da $V i d a$, prevalece: Libidinis in mares pronior et eos non nisi praeduros exoletosque (...).

$155 \mathrm{Jul}$.44.4: Talia agentem atque meditantem mors praeuenit. De qua prius quam dicam, ea quae ad formam et habitum et cultum et mores, nec minus quae ad ciuilia et bellica eius studia pertineant, non alienum erit summatim exponere; Aug. 61.1: Quoniam qualis in imperis ac magistratibus regendaque per terrarum orbem pace belloque re p. fuerit, exposui, referam nunc interiorem ac familiarem eius uitam quibusque moribus atque fortuna domi et inter suos egerit a iuuenta usque ad supremum uitae diem.

${ }^{156}$ Ves. 21: Ordinem uitae bunc fere tenuit.

${ }^{157}$ Como mostra a disposição quiástica entre Tit. 7.1 (nec minus libido propter exoletorum et spadonum greges propterque insignem reginae Berenices amorem, cui etiam nuptias pollicitus ferebatur) e Tit. 7.2 (Berenicen statim ab urbe dimisit inuitus inuitam. Quosdam e gratissimis delicatorum... non modo fouere prolixius, sed spectare omnino in publico coetu supersedit). 58.2.5.

${ }_{158}$ Aug. 71.1. A mesma complacência é atribuída ao carácter de Lívia por Díon Cássio,

${ }^{159}$ Aug. 62.2: dilexitque et probanit unice ac perseueranter, cf. Aug. 99.1: 'Linia, nostri coniugii memor uiue, ac uale!'.

${ }^{160}$ Carney, T. F. 1968, 12 n. 24, sugere que a homossexualidade é falsamente imputada a Tito. De facto, esta é apresentada como suspecta (Tit.7.1). Mas o que se acentua é a mudança de comportamento. 
biógrafo censura Domiciano, como minime ciuilis, por lhe não manifestar a devida cortesia (Dom. 12.3). As diversas concubinas de Vespasiano são apresentadas apenas como substitutas da amante defunta (Ves. 21), e não lhes é imputada a vulgaridade atribuída às meretrizes de Domiciano (Dom. 22). Vespasiano permanece, no essencial, puro.

Como se vê, o pessimismo não é completo. $\mathrm{O}$ mérito não está tanto em não haver culpas, mas em algumas atitudes louváveis. Nenhum dos Césares corresponde a um ideal de castidade que, pela negativa, se vislumbra nas descrições, ${ }^{161}$ mas Suetónio mostra-se realista, não puritano. Não exige aos seus Césares que, neste campo, sejam melhores que o comum dos mortais (e imortais): espera apenas moderação, que também se requer neste domínio.

Como vimos, há quem leia nas Vidas dos Césares partidarismos sociais, a favor dos cavaleiros; ${ }^{162}$ uma censura ou uma admonenda a Adriano; ${ }^{163}$ uma propaganda dos Antoninos, ${ }^{164}$ ou até o reflexo das fraquezas do próprio Suetónio. ${ }^{165}$ Outros autores vêem na lista de virtudes e vícios a tradição literária do Panegírico de Trajano, da autoria de Plínio, ${ }^{166}$ e das Res gestae de Augusto, ou influência das legendas das cunhagens, ou então o resultado da reflexão sobre o ethos do principado, ${ }^{167}$ ou topoi da oratória forense romana, seja ela polémica ou apologética. ${ }^{168}$ Parece certa a influência da moral romana tradicional (também presente na tradição dos encomia e nas cunhagens). A verdade é que todos estes contributos não podiam deixar de estar presentes na mente do biógrafo, que bem os conhecia, e que, consciente ou conscientemente, os tomaria em conta.

A forma como Suetónio termina as Vidas, com referência às virtudes dos príncipes seguintes, parece dar peso à influência do Panegírico. De facto, Suetónio adopta o processo inverso de Plínio: enquanto este louva Trajano por comparação com os príncipes anteriores, Suetónio passa a maior parte do tempo

${ }^{161}$ Vide Bradley, K. R. 1985a, 83.

${ }^{162}$ A principal tese de Della Corte, F. 1967, 165-190.

163 Carney, T. F. 1968, 7-24, afirma que as Vidas dos Césares contêm uma série de críticas dissimuladas a Adriano. Cızeк, E. 1977, 181-192, é de opinião que Suetónio dá conselhos discretos a Adriano, mas acaba por ofender este imperador e cai, por isso, em desgraça. Pelo contrário, BARDon, H. 1968, 439-444, acha que Suetónio não toma partido a favor de Adriano nem contra. Bradley, K. R. 1976, 245-253, refuta a ideia de CARnEy de que Suetónio critica este imperador através da omissão das legendas das virtudes presentes nas cunhagens de Adriano. Gascou, J. 1984, 758-773, refuta quer Bardon quer Carney e Cize k e demonstra que há nas Vidas muito mais aspectos favoráveis a Adriano do que desfavoráveis.

${ }^{164}$ Vide Dupont, F. et ÉLoI, T. 2001, 293.

${ }^{165}$ Newbold, R. F. 1984, 118-132, vê nas fraquezas dos Césares a projecção das fraquezas do biógrafo.

${ }^{166}$ Segundo Della Corte, F. 1967, 79-80, Plínio forneceu a Suetónio o paradigma para a contraposição de virtudes e vícios. Depois de comparar as virtudes presentes em Suetónio com as do escudo oferecido a Augusto e com as cunhagens de Adriano, Wallace-Hadrill, A. 1984, 154-155, conclui que o modelo mais aproximado de Suetónio é o Panegírico de Trajano. Vide Baldwin, B. 1983, 269-270.

${ }^{167}$ Como pensa Bradley, K. R. 1991, 3701-3732. Seja como for, o Panegírico de Trajano também será o resultado dessa reflexão.

${ }^{168}$ Tese de Lewis, R. G. 1991, 3623-3674. 
a censurar os seus Césares, por comparação com os príncipes seguintes. De uma primeira leitura das Vidas retira-se a impressão de um ultraje continuado. Só uma leitura mais atenta nos permite verificar que Suetónio tem um juízo positivo de Augusto, Tito, Vespasiano e Otão; um juízo moderadamente negativo de César, negativo de Cláudio e de Galba; e péssimo de Tibério, Calígula, Nero, Vitélio e Domiciano.

A parte esporádicos comentários do biógrafo, a conclusão a tirar sobre determinado césar é, necessariamente, condicionada pela técnica biográfica. Nos imperadores essencialmente bons, há um processo evolutivo do negativo para o positivo (Augusto, Otão, Tito), a deixar uma impressão favorável ao leitor. Nos maus, observa-se a progressão contrária (Tibério e Galba), ou a apresentação em primeiro lugar das virtudes e depois dos vícios, deixando os piores escândalos para o fim (Calígula, Nero, Domiciano), de tal sorte que a morte surge como consequência do comportamento em vida. Quanto a César, a imagem positiva do seu governo e da sua clementia, é depois fortemente ensombrada pela culpa da ambição monárquica, que torna justo o seu assassínio; mas volta a ser, de algum modo, reabilitada depois da narrativa da morte, sobretudo devido às reacções do povo e à referência ao castigo dos cesaricidas. A Vida de Cláudio, apesar da pietas e religio, é uma continua alternância de aspectos positivos e negativos, com claro pendor para os segundos, a sugerir incongruência e incapacidade. Vespasiano tem como único vício a pecuniae cupiditas, e Vitélio praticamente só patenteia defeitos: o primeiro mantém-se bom durante quase toda a biografia, e o segundo permanece indigno do princípio ao fim.

O balanço pode parecer pessimista. Mas Suetónio, como afirma Gascou, revela uma concepção optimista da história, enquanto portadora de uma justiça imanente: os imperadores bons são, no final da Vida, compensados com uma morte serena, os maus, com uma morte violenta, nem que para isso seja preciso forçar os relatos das fontes: Suetónio evita o boato, transmitido por Díon Cássio, segundo o qual Vespasiano fora envenenado por iniciativa de Tito; ${ }^{169}$ silencia no final da Vida de Tito os pormenores que relata no início da Vida de Domiciano ${ }^{170}$ - coroa, assim, estas duas Vidas com a morte que os príncipes mereceram. ${ }^{171}$ Otão representa a excepção que confirma a regra. ${ }^{172} \mathrm{E}$ com a morte heróica que Otão redime a sua vida indigna e se torna in extremis um bom imperador.

Podemos ver o imperador ideal concretizado em Trajano ${ }^{173}$ ou em Adriano. ${ }^{174}$ Mas o mais provável é que, exactamente porque ideal, seja abstracto

${ }^{169}$ Ves. 24; Díon Cássio, 66.17.1-3.

${ }^{170}$ Tit. 10.1; cf. Dom. 2.3. Segundo Aurélio Victor, 10.5, foi envenenado por Domiciano. Vide Gascou, J. 1984, 385-386 e 793.

${ }^{171} \mathrm{O}$ assassínio era banido da narrativa encomiástica do século IV a. C. Isócrates omite o assassínio de Evágoras: diz que ele viveu uma longa vida e escapou às enfermidades (Ev. 71). Vide Stuart, D. R. 1928, 63.

172 Vide Gascou, J. 1984, 787-798; Newbold, R. F. 1984, 121-122.

${ }^{173}$ Segundo Della Corte, F. 1967, 79, o termo de confronto é o optimus Trajano, tal como se apresenta no Panegírico de Plínio.

${ }^{174}$ Como propõe Gascou, J. 1984, 758-773 e 785. 
e inatingível e só vislumbrado por aproximações concretas, mais ou menos distantes desse ideal - e Suetónio é realista. O biógrafo privilegia o concreto e o imperador enquanto indivíduo. Condicionados embora pela sua pena, Suetónio procura apresentar-nos factos e palavras que dêem uma existência convincente aos seus Césares. É verdade que enuncia, geralmente no início de determinada rubrica, virtudes e vícios, mas, sem os discutir, logo transita para uma exposição, por vezes longa, de exemplos concretos, que se tornam os porta-vozes de uma moral. Assim, recorrendo a um esquema algo repetitivo, o biógrafo escreveu doze Vidas que permanecem diferenciadas e individualizadas, cada qual com sua mensagem diferente. 


\section{ConClusão}

Inserido em uma longa tradição biográfica, Suetónio estrutura as suas Vidas com base em rubricas. A narração cronológica tem um carácter secundário e aparece sobretudo na primeira parte da Vida - a que trata a ascensão do biografado ao trono imperial - e na última parte - para organizar a sucessão de acontecimentos relacionados com a aproximação da morte. Assim, o núcleo central de cada Vida aparece estruturado segundo as categorias que o biógrafo conseguiu reunir para cada príncipe. No que respeita à vida pública, referem-se cargos, honras, actividade legislativa, obras de vulto, guerras, espectáculos, virtudes e vícios na condução do poder; quanto à vida privada, casamentos, filhos, tendências sexuais, cultura e actividade literária, virtudes e vícios privados. Neste contexto se insere também o retrato físico, como reflexo visível do ethos. Cada um destes aspectos é ilustrado com uma série mais ou menos numerosa de exemplos.

Suetónio revela-se muito mais do que um mero erudito ou um compilador de anedotas e curiosidades. As várias rubricas encontram-se relacionadas entre si por motivos que se reiteram: Leitmotiven que, ao longo das Vidas, estabelecem um fio condutor, desde o nascimento até à morte, e contribuem para individualizar cada um dos biografados.

Uma das rubricas diz respeito aos espectáculos. Mas este topos, sobretudo no que se refere ao teatro, extravasa largamente a rubrica própria. A actuação dos imperadores apresenta muito de calculado e teatral para o bem e para o mal. Se apareceu uma figura sobre-humana a presidir à passagem do Rubicão (Jul. 32), terá sido encenação do próprio César, para motivar os soldados, que estariam hesitantes em prosseguir o seu avanço armado em território pátrio. $\mathrm{O}$ papel do espectáculo verifica-se também na cena seguinte (Jul.33), em que o general, na arenga às tropas, chora e rasga as vestes para conseguir a fidelidade dos soldados - ao vê-lo gesticular e apontar o anel, os que estão mais distantes até pensam que ele está a prometer a todos o censo equestre. Também Augusto se mostra um perito na arte do espectáculo: no seu primeiro consulado, durante a consulta aos augúrios, doze abutres se mostraram (se ostenderunt), como outrora a Rómulo (Aug. 95) - certamente uma encenação do próprio Augusto. ${ }^{1}$ Assaz teatral é a forma como, de joelhos e de peito nu, suplica ao povo que lhe não conceda a ditadura (Aug. 52) e como manifesta horror ao título de dominus (Aug. 53.1). O imperador procura, assim, alardear modéstia e moderação. ${ }^{2}$ Muito de calculado há obviamente no processo que vai da educada recusa à condescendente aceitação do cognome de Pai da Pátria (Aug. 58), ou na ostensiva demolição da casa da neta Júlia, por ter sido construída com demasiado luxo (Aug. 72.3). ${ }^{3}$ Vimos que o fundador do principado mantém

\footnotetext{
${ }^{1}$ Parece que os abutres se mostraram hesitantes no voo, sinal de que estavam há longo tempo engaiolados. Vide Southern, P. 1998, 50 e n. 6, p. 214-215.

${ }^{2}$ Procura ostentar ciuilitas (Aug. 56.2).

${ }^{3}$ Serve de contrapeso às acusações que lhe faziam de sumptuosidade, devido ao gosto que nutria por móveis de luxo e vasos coríntios (Aug. 70.2).
} 
a mise-en-scène até ao último momento, em que identifica a sua vida com um mimus e pede o aplauso final (Aug. 99.1). Vespasiano só tardiamente aceitou a tribunicia potestas e o título de Pai da Pátria (Ves.12) e não deixava de chorar qualquer execução, mesmo que fosse uma pena justa (Ves. 15). Tito afirma categoricamente que ninguém deve sair descontente da entrevista com o imperador e, no dia em que não concedera nenhum favor, exclama Amici, diem perdidi (Tit. 8.2); convida dois patrícios conspiradores para um jantar íntimo, fá-los sentar a seu lado durante um espectáculo de gladiadores e concede-lhes a honra da inspecção das armas dos combatentes (Tit. 9.2).

Mas, se nos bons imperadores não se questiona a sinceridade desta demonstração teatral de virtudes, nos maus príncipes os actos bons são atribuídos à dissimulação, que faz de Tibério, de Calígula, de Nero e de Domiciano verdadeiros actores, quando, no início do principado, alardeiam uma imagem positiva. Torna-se patente uma luta entre o eidos e o ethos, que enriquece substancialmente a trama das Vidas. Tibério revela a sua verdadeira natureza quando se retira para Cápreas e se entrega sem peias aos vícios, que há longo tempo mal dissimulara (Tib. 42.1). Calígula, que se há-de revelar um monstro, manifestava desde a juventude uma incredibilis dissimulatio (Cal. 10.2). ${ }^{4}$ Também Nero, no início do principado, não perdia oportunidade de exibir pietas, liberalitas, clementia, comitas (Nero 9; 10.1). ${ }^{5}$ Domiciano confia no aspecto ruborizado do seu rosto que sugere uerecundia (Dom. 18.2). ${ }^{6}$ Vitélio não é dissimulado: é declaradamente mau. $\mathrm{O}$ aparato deste imperador está de acordo com o seu vício principal: a gula. ${ }^{7}$

A crueldade e a devassidão de certos tiranos é expressa em espectáculos sangrentos. Tibério, do alto do rochedo de Cápreas, compraz-se em observar os condenados que são, depois de refinadas torturas, projectados no mar, onde um grupo de marinheiros completa a execução a golpes de bastão e de remos ( $T i$ b. 62.2). ${ }^{8}$ De modo semelhante, também Calígula, durante a dedicação da ponte de Baias, convida os curiosos a aproximarem-se, precipita-os, de rompante, no

${ }^{4}$ É suspeita a sinceridade da pietas com que Calígula faz a trasladação para Roma dos corpos do irmão e da mãe com uma aparatosa exibição (Cal. 15.1). A queima pública dos processos relativos à mãe e aos irmãos, acompanhada do juramento de que os não tinha lido nem tocado, para tranquilizar os que neles foram testemunhas (Cal. 15.4), não passara de simulatio (Cal. 30.2).

${ }^{5}$ Se, nesta altura, o facto de passear com a mãe na liteira é manifestação de pietas, mais tarde se verificará que é prova de incesto (Nero 28.2). A princípio, ao ser convidado a assinar uma execução, afirma que gostaria de não saber escrever (Nero 10.1), mais tarde condena a qualquer pretexto (Nero 37.1) e afirma que os príncipes anteriores não imaginavam o poder que possuíam (Nero 37.3).

${ }^{6}$ Simula admiravelmente modéstia e inclinação para a poesia (Dom. 2.2), quando, mais tarde, se verifica que se mostrara minime ciuilis, confidens e immodicus em palavras e actos (Dom. 12.3) e que, durante o principado, só lê os commentarii de Tibério (Dom. 20).

${ }^{7}$ Procura impressionar os convivas com os seus banquetes trimalquiónicos (Vit. 13).

${ }^{8} \mathrm{O}$ castigo do pescador, que se dera ao trabalho de escalar o rochedo para presentear o imperador com o melhor peixe que pescara (Tib. 60), é um suplício exemplar e inventado ex abrupto para dissuadir os que se atrevessem a aproximar-se do refúgio do misantropo e desconfiado imperador. 
mar e manda-os fustigar a golpes de varas e de remos (Cal. 32.1). Tibério e Domiciano mostram-se inventivos na crueldade. ${ }^{9}$ Corria o boato de que Nero dava homens vivos a um glutão (polyphagus) egípcio (Nero 37.2). Calígula entre muitas atrocidades, manda encerrar os celeiros e anuncia ao povo um período de fome (Cal. 26.5).

O espectáculo estende-se à vida íntima onde os requintes levam a verdadeiras encenações: o banquete dos doze deuses, em que Augusto assume o papel de Apolo (Aug. 70); as artificiosas encenações eróticas de Tibério, em Cápreas, com alusões mitológicas a Pãs e Ninfas (Tib. 43); ${ }^{10}$ a exibição de Cesónia aos soldados, a cavalgar ao lado de Calígula, adornada como uma Amazona (Cal. 25.3), ${ }^{11}$ e a sua ostentação, nua, aos amigos; as pousadas, ao longo das margens do Tibre e no litoral, onde matronas romanas imitavam as taberneiras e convidavam Nero desembarcar (Nero 27.3). Mais espantosos são os casamentos parodiados por Nero. ${ }^{12}$ Inventa mesmo um novo jogo obsceno que parece evocar a sorte dos condenados às feras (Nero 29). Também Domiciano considera a actividade sexual como um jogo: apelida o concubitus de «ginástica de cama» e nada no meio das mais ordinárias meretrizes (Dom. 22).

Os mais teatrais são Calígula e Nero. Além das exibições aparatosas de virtudes (Cal. 15; Nero 10), Calígula, nas suas construções, desafia o impossível (Cal. 37.2) e Nero alardeia o seu sumptuoso prazer estético na construção da Domus Aurea, onde recria o mundo e o movimento dos astros (Nero 31). ${ }^{13}$ Entre os espectáculos, e, por isso, na parte positiva das Vidas, apresenta Suetónio a ponte de Baias - uma inovação de Calígula -, onde participa inclusive Dario, um dos reféns partos (Cal. 19) ; e, no principado de Nero, a recepção espectacular e coroação de Tiridates da Arménia (Nero 13): acontecimentos com evidente significado político.

Estes imperadores não escondem o seu gosto pelas artes cénicas; revelam-se histriões - atitude infame e ofensiva para a grauitas romana - e tendem a confundir a ficção com a realidade; vida com a cena. Nos jogos que Nero oferece impera o realismo. ${ }^{14}$ Nos espectáculos públicos, Calígula gostava de imitar a voz do actor trágico e os gestos do histrião e tinha a sua estreia

${ }^{9}$ Tib. 62.2; Dom. 10.5; Dom. 3.1.

${ }^{10}$ Talvez uma interpretação hostil do gosto por grutas adornadas (cf. Tib. 39).

${ }^{11}$ Cf. Nero 44.1.

${ }^{12} \mathrm{Um}$ com Esporo, em que este, depois de castrado, faz de mulher, a ponto de usar o fammeum (Nero 28.1), e outro com Doríforo, em que, pelo contrário, é Nero a fazer de esposa, chegando inclusive a imitar os gemidos das virgens ao serem desfloradas (Nero 29). Talvez ritos de iniciação deturpados.

${ }^{13}$ Suetónio acentua a influência da estética sobre a actuação política deste imperador ao sugerir que Nero incendiou Roma por não suportar a fealdade dos edifícios e das ruas e na mira de se apoderar de mais espaço para construir a Domus Aurea (Nero 38.1).

${ }^{14}$ Entre os argumentos das danças pírricas, figurava o mítico amor de Pasífae, supostamente encerrada dentro de uma vaca de madeira, coberta por um touro, e o voo de Ícaro - o sangue do infeliz chegou a salpicar o imperador (Nero 12.2). Depois de representada a togata $O$ incêndio de Afrânio, deu-se permissão aos actores para saquearem a casa que fora pasto das chamas (Nero 11.2). 
em cena marcada para a noite do dia em que foi assassinado; e chegou a convocar os senadores para assistirem a uma pantomima a meio da noite (Cal. 54). Também Nero decide estrear-se no palco, primeiro em Neápolis (Nero 20.2), em ambiente grego, e depois em Roma (Nero 21.1-2). Cria mesmo um concurso musical, gímnico e equestre denominado Neronia (Nero 12.3). O gosto de Calígula parece ir para a pantomima, na fase em que esta se cinge ao virtuosismo dos gestos. Nero representa a primazia dos cantica que, com o tempo, obscureceram os outros elementos da tragédia latina e se tornaram autónomos. ${ }^{15}$

Até o modo de vestir e calçar de Calígula, sinal da sua loucura, parece revelar os papéis que encarnava (Cal. 52). Também Nero representava papéis de heróis e deuses ou heroínas e deusas (Nero 21.3). Apresentava-se em público de modo não convencional e considerado vergonhoso (adeo pudendus) pelo biógrafo (Nero 51).

As suas vidas transformam-se em representações contínuas: rubricas sérias transformam-se em descrições de farsas. O desinteresse de Calígula e de Nero pela actuação política e militar é visto com maus olhos: estes imperadores atentam contra a uirtus militar. Calígula só uma vez se interessa pelas actividades bélicas, ${ }^{16}$ e Nero abandona a imagem tradicional do chefe romano perito na arte militar e na arte do foro (de que são modelos César, Germânico ou Tito). ${ }^{17}$ É significativo que, ao preparar a expedição para sufocar a revolta da Gália, a primeira preocupação de Nero seja providenciar transporte para os órgãos de cena e vestir de Amazonas as concubinas (Nero 44.1). O triunfo celebrado por Nero - colocado pelo biógrafo entre os probra - é uma paródia de triunfo militar: na verdade é o triunfo do actor (Nero 25.1-2).

Como no teatro, mito e realidade interpenetram-se. Calígula, ao arrebatar Lívia Orestila ao marido, disse que procurava um matrimónio segundo o exemplo de Rómulo e de Augusto (Cal.25.1), a sugerir clara imitação do mítico rapto das sabinas e do já mítico casamento de Augusto com Lívia. Quando foi assassinado, muitos acreditaram que se tratava de mais uma encenação, para avaliar a devoção dos homens pelo seu imperador (Cal. 60).

Em Nero, as acções reais parecem inspiradas em referências dramáticas, ${ }^{18} \mathrm{e}$ os papéis trágicos que representa têm continuidade no mundo real: a confissão do imperador de que era perseguido pelas Fúrias, juntamente com a tentativa de aplacar os Manes (Nero 34.4) ${ }^{19}$ poderá ser uma forma de ele próprio, por

${ }^{15}$ Nos funerais de César canta-se, do Armorum iudicium de Pacúvio, Men seruasse ut essent qui me perderent? (Jul. 84.2).

${ }^{16}$ Cal. 43. As manobras militares na Germânia são relatadas como um mimus (Cal. 45; cf. Cal. 46).

${ }^{17}$ Só não retirou o exército da Britânia para não parecer que difamava a glória de Cláudio (Nero 18).

${ }^{18} \mathrm{Na}$ narrativa da morte de Agripina, o termo machina que designa o expediente (depois não usado) para o desabamento do tecto do quarto e machinosum referido ao nauigium destinado a naufragar remetem para o mundo do teatro; Machinamentum em Tácito, Ann. 14.6.1. Vide Foucher, A. 2000, 793-794.

${ }^{19}$ Cf. Cal. 50.3; Otho 7.2. 
capricho de artista, sugerir a assimilação a um Orestes matricida; a morte do pai, adoptivo embora, e os alegados incestos com a mãe (da iniciativa de Nero, segundo Suetónio (Nero 28.2) assimilam-no a Édipo cego, castigado pelo remorsos; ${ }^{20}$ ao destruir a vida dos que lhe estão próximos, é assimilado a Hércules furioso. ${ }^{21}$ Assumindo a continuidade entre o mito e a vida, Nero representa os papéis de heróis e deuses ou heroínas e deusas, servindo-se de máscaras que reproduzem os seus traços ou de mulheres que ama (Nero 21.3): neste sentido, podemos dizer que representa o papel de si próprio - uma espécie de reality show anacrónico. $\mathrm{Na}$ sua busca de realismo, Nero, depois de alegadamente ter incendiado Roma, fascinado pela beleza das chamas, que contemplava do alto da torre de Mecenas, encontra o cenário perfeito para cantar, em traje de cena, o seu poema $A$ tomada de Tróia (Nero 38.2). ${ }^{22} \mathrm{O}$ atentado contra os muros da pátria é apresentado como o ponto culminante dos crimes de Nero. Assim o biógrafo estabelece a ligação entre a arte ignominiosa de histrião - os probrae os crimes - scelera - que Nero perpetrou. Nero apresenta-se, diante da morte,

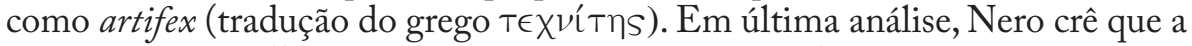
sua arte o salvará, ${ }^{23}$ o que contribui para o seu drama. Alguns estudiosos notam que a Vida de Nero, particularmente a cena de morte, está organizada como se se tratasse de uma peça trágica, com uma bem delineada progressão para a catástrofe.

A escrita de Suetónio não consiste num relato frio dos factos, como alguns pensam. A própria organização das acções sob a designação de virtudes e vícios prova o contrário. Uma reprodução impassível não se compadeceria com a divisão da Vida de Calígula entre actos do princeps e actos do monstrum (Cal. 22.1); ou da Vida de Nero entre os factos dignos de louvor - ou, ao menos, não reprováveis - e as infâmias e os crimes (Nero 19.3), para dar dois exemplos flagrantes. Mais do que isso, ainda que alguns críticos o neguem, o biógrafo expressa, com alguma frequência, o seu juízo directamente no texto. Uma das principais linhas da narrativa, que vai desde os antepassados até à morte, é constituída pelo reiterar de determinados traços caracterológicos que assumem a designação de virtudes e vícios: neste sentido, as Vidas assentam numa estrutura essencialmente moral.

Além de se não mostrar impassível, Suetónio não parece querer deixar o leitor indiferente. A forma viva como apresenta os factos, o recurso às anedotas e curiosidades e ao cómico indiciam uma procura de deleitar os curiosos. Não

${ }^{20}$ Nero 33.1: Parricidia et caedes a Claudio exorsus est. A última fabula que Nero cantou foi Édipo no exílio, que termina com o verso «que eu morra me ordenam a minha esposa, a minha mãe, o meu pai» (Nero 46.3). Díon Cássio, 63.28.5, diz que Nero tinha este verso sempre em mente.

${ }^{21}$ Certa vez, em que Nero representava este papel, um soldado da guarda, ao vê-lo amarrado a um poste, toma a ficção pela realidade e vem prestar auxílio ao imperador (Nero 21.3).

${ }_{22}$ Tácito considera a responsabilidade de Nero no incêndio (Ann. 15.38.1) como uma das versões que corriam acerca da calamidade; e como um rumor o canto do poema (Ann. 15.39.3).

${ }^{23}$ Perante o prenúncio de que será destituído, diz que viverá da arte de citaredo (Nero 40.2); e pensa demover os revoltosos com os seus dotes melodramáticos (Nero 43.2). 
apresenta virtudes e vícios em abstracto: ilustra-os com exemplos que incluem - diz o biógrafo repetidamente - acções e ditos significativos. Mas as intenções do autor vão ainda além do simples deleite dos sentidos. Com efeito, Suetónio visa também afectar mais profundamente o leitor. Não é isenta a selecção de determinados factos e a omissão de outros. Muitas vezes, simplesmente pelo seu horror, os exemplos apresentados ganham tal força que não podem deixar o leitor indiferente. Mas, para potenciar ainda mais este efeito, o biógrafo serve-se de alguns recursos. Um deles consiste em, através da generalização, transformar em hábitos ocorrências pontuais; outro, em gerar um progressivo crescendo.

O biógrafo parece procurar deliberadamente efeitos teatrais. Podemos mesmo aplicar a Suetónio a noção de "história trágica". Certos motivos recorrentes, como o relevo e a abundância de prodígios e presságios de toda a espécie, o gosto por relatos fabulosos, referência a acções ímpias, a presença do destino e o recurso aos rumores, mostram que se abandona a distinção aristotélica entre história e poesia (seguida, de resto, por poucos historiadores), uma vez que à história se prefere a mimese, enquanto processo de representação por selecção e abstracção. Por isso, se trata não só o particular, mas também o geral; se descrevem não só personagens históricas, mas também caracteres; se relatam não só acções factuais, mas também potenciais, de acordo com a conduta habitual de um imperador (por exemplo, rumores são considerados a par de factos confirmados). Além disso, há uma procura de, como na tragédia, incutir sentimentos. $O$ intuito de apelar às emoções do leitor parece determinar a qualidade e a ordem das species e da ordenação dos factos no interior destas. Suetónio, como demonstrou Cizek (e, mais tarde, Gascou) tende a alterar, mesmo dentro de uma mesma rubrica, a cronologia relativa dos acontecimentos e a apresentar os factos em gradação ascendente, deixando para o final os mais significativos, quando quer acentuar determinada qualidade; ou em gradação descendente, se pretende atenuar uma categoria. Assim consegue acentuar os vícios dos piores imperadores até à saciedade e minimizar os dos príncipes que considera bons. Este processo acaba por se estender à distribuição das rubricas ao longo de determinada Vida. Nos bons imperadores, as virtudes, ao aparecerem em último lugar, deixam prevalecer uma imagem positiva; nos imperadores maus, tende a ocorrer o movimento inverso: os piores vícios, exemplificados com acções e ditos que provocam horror, são deixados para o fim, de forma a provocarem uma imagem de repulsa. Deste modo, Suetónio gera uma certa progressão ao longo das Vidas em vista de um desenlace: o Té $\lambda$ os para onde o encadeamento das rubricas parece apontar. A estrutura das Vidas apresenta-se construída em gradatio ou clímax que culmina no momento da plenitude do biografado, isto é a morte, lugar da revelação derradeira do ethos. Tal mostra que Suetónio visa delectare, docere e mouere.

Em determinados passos, particularmente na Vida de Cláudio, Suetónio parece optar pela deformação cómica. Mas o realismo e a obscenidade à mistura com elementos trágicos e cómicos, e, ao mesmo tempo, intuitos moralizadores, 
parecem denunciar a influência do mimo - género que parece atravessar toda a cultura da época e, como demonstra Panayotakis, já se fazia sentir no romance de Petrónio.

Parece haver relação entre a procura de efeitos teatrais e os intuitos moralizadores do biógrafo, por influência da mentalidade romana. Muitos dos imperadores são marcados pelo seu carácter que se transforma no seu próprio destino. No final das Vidas, os piores imperadores são castigados com o ódio dos súbditos e com uma morte terrível ou solitária; os bons são compensados com manifestações generalizadas de amor e uma boa morte. Ser bom ou mau governante depende do carácter de cada imperador. Os traços do carácter são determinados a partir do homem em acção, e, por isso, acabam por se manifestar nos diferentes aspectos da vida, incluindo os hábitos pessoais e mesmo o retrato físico, apresentado como reflexo do rigor ou do desregramento moral. Mas também são determinados pela gens, segundo sugere a rubrica dos antepassados. Às qualidades do carácter atribui Suetónio a designação das virtudes romanas do mos maiorum, concretizadas quer pelas acções, quer pelas palavras dos imperadores.

As Vidas dos Césares terminam de forma optimista com a promessa de uma idade de ouro devida precisamente às virtudes da moderatio e da abstinentia, qualidades principais dos imperadores que sucederam a Domiciano e que ficam, portanto, fora da série suetoniana. Assim se enunciam duas virtudes essenciais ao bom governante. A primeira define, em Suetónio, a atitude face ao poder que contraria a arrogância e abre o caminho, pela positiva, à ciuilitas; que refreia a saeuitia e favorece clementia e a pietas. A abstinentia representa, face às riquezas, a atitude do que não cede à auaritia e, muito menos, à rapacitas; e abre, pela positiva, caminho para a liberalitas - qualidade do princeps enquanto patrono universal. Além disso, espera-se da função moralizadora do princeps o respeito pela dignitas e pela castitas - virtudes que, poucas vezes mencionadas, são mais deduzidas pelos seus opostos. $\mathrm{O}$ imperador deve, pela sua conduta, mostrar-se digno da função que desempenha no topo da pirâmide social. E Suetónio defende a manutenção da sociedade tradicional, hierarquizada segundo senadores, cavaleiros e plebe. No que respeita à moral familiar, louvam-se os incentivos dados ao matrimónio e a manutenção dos laços conjugais, e critica-se a leviandade dos tiranos em fazer e desfazer casamentos; louva-se a repressão da devassidão, e criticam-se os adultérios, os abusos de mulheres e homens livres e, sobretudo, a impudicitia (homossexualidade passiva) - forma de submissão servil e indigna para um cidadão romano.

Por estar no topo da hierarquia e pelo poder que possui, o imperador representa um arquétipo comportamental, isto é, a representação do extremo ao qual determinado vício ou determinada virtude podem conduzir. $\mathrm{O}$ leitor, enquanto súbdito, sofre, por empatia, os efeitos do comportamento de determinado imperador e experimenta compaixão, gratidão, impotência, revolta ou medo; por outro lado, enquanto carácter e cidadão, identifica-se, por aproximação, com esse modelo, na medida em que participa da mesma sociedade e do mesmo conjunto de valores de que faz parte o imperador 
retratado. Ora, ao considerar o desenlace de determinado comportamento, sai purificado dos referidos sentimentos e, ao mesmo tempo, edificado, enquanto homem e enquanto cidadão.

Fica patente que as Vidas dos Césares foram compostas para serem lidas de forma continuada. Só assim se podem abarcar plenamente as qualidades literárias e os objectivos do biógrafo. Uma consulta erudita de excertos não permite compreender a progressão das Vidas, de cada uma em particular e do conjunto das doze. Leituras parcelares têm levado alguns estudiosos a perspectivas demasiado restritivas.

O público de Suetónio é o romano culto do seu tempo, mas também o leitor de todos os tempos: daí a imortalidade da obra e o interesse que tem provocado ao longo dos séculos em eruditos grados, como Erasmo ou Poliziano. Os vícios da tirania repetem-se, mutatis mutandis, em todas as épocas; podemos encontrá-los habilmente dissimulados nas sociedades mais ostensivamente democráticas, enquanto ciuilitas, moderatio, liberalitas, abstinentia, clementia, pietas continuam a ser alardeadas de forma teatral.

Nibil noui sub sole! 


\section{BibLIOgRAFIA}

\section{Edições integrais}

a) Suetónio

Ailloud, H. 1931-1932, Suétone. Vie des douze Césars, texte établi et traduit par -, vol. I-III, Paris, Les Belles-Lettres [usada a segunda ed.: 1989 (vol. I); 1993 (vol. II); 1980 (vol. III)].

Bassols de Climent, M. 1964 (vol. I-III); 1970 (vol. IV), C. Suetonio Tranquilo. Vida de los Doce Césares, testo revisado y traducido por -, Barcelona, Alma Mater [dos três primeiros volumes, usada 2a ed. 1990 (vol. I); 1991 (vol. II); 1996 (vol. III)].

Iнм, M. 1908, C. Suetoni Tranquilli Opera, I : De vita Caesarum: libri VIII, recensuit -, editio minor; Stuttgart et Lipsiae, Teubner [usada a reimpr. de 1993: editio stereotypa editionis prioris (1908)].

Rolfe, J. C. 1913-1914, Suetonius, I e II. The Loeb Classical Library (reimpr. de 1979) Cambridge (Mass.), Harvard University Press / London, Heinemann. .

\section{b) Outros autores ${ }^{1}$}

\section{Dion Cássio}

CAry, E. 1914-1927, Dio's Roman History, with an English translation by -, 9 vol., Cambridge, Massachusetts, Harvard University Press / London, Heinemann. The Loeb Classical Library.

\section{Plutarco}

- para César:

Flacelière, R. et Chambry, E. 1975, Plutarque. Vies, tome ix, texte établi et traduit par -, Paris, Les Belles Lettres.

- para Galba e Otão:

Flacelière, R. et Chambry, E. 1979, Plutarque. Vies, tome xv, texte établi et traduit par -, Paris, Les Belles Lettres.

\section{Tácito}

Koestermann, E. 1960, P. Cornelii Taciti libri qui supersunt, edidit -, tom. I: Annales (ab excessu diui Augusti), Lipsiae, Teubner.

Koestermann, E. 1969, P. Cornelii Taciti libri qui supersunt, edidit -, tom. II, fasc. I: Historiarum libri, Lipsiae, Teubner.

${ }^{1}$ Apenas se mencionam os autores e as obras que são sistematicamente citados. Ficam de fora numerosas citações esporádicas. 


\section{Edições parciais comentadas}

Bradley, K. R.1978, Suetonius' Life of Nero. An historical commentary, Bruxelles, Latomus.

Braithwaite, A. W. 1927, C. Suetoni Tranquilli Diuus Vespasianus, with an intr and com. by -, Oxford, Clarendon Press.

Butler, H. E. \& Cary, M. 1927 (1993), Suetonius Diuus Iulius, edited with comm. by-, New-York, Oxf. Univ. Pr. (with new intr., bibliography and additional notes by Townend, G. B., 1982, 1993).

Cesa, M. 2000, Svetonio. Vita di Vespasiano, Bologna, Cappelli.

Galli, F. 1991, Svetonio, Vita di Domiziano, intr., trad. e comm. a cura di -, Roma, Ateneo.

Grassi, C. 1972, Svetonio. Antol. della lett. lat., con intr., trad., com. a cura di - Brescia, Paideia.

Guastella, G. 1992, Gaio Svetonio Tranquillo, La vita di Caligola, [testo, trad. e comm.] a cura di -, Roma, La Nuova Italia Scientifica.

1999, Gaio Svetonio Tranquillo. L'imperatore Claudio, a cura di -, Venezia, Marsilio.

Hofstee, C.1898, C. Suetonii Tranquilli uitae Galbae, Othonis, Vitellii, specimen literarium inaugurale, Gronegae, apud J. R. Wolters.

Hurley, D. W. 1993, An historical and historiographical commentary on Suetonius'Life of C. Caligula, Atlanta, Scholars Pr.

Jones, B. W. 1996, Suetonius. Domitian, ed. with intr., com. and bibl. by -, London, Bristol Classical Press.

Jones, B. \& Milns, R. 2002, Suetonius: the Flavian emperors, a bistorical commentary, London, Bristol Classical Press.

Kaster, R. A. 1995, C. Suetonius Tranquillus. De grammaticis et rhetoribus, ed. with transl., intr., and com. by -, Oxford, Clarendon Press.

Lindsay, H. 1995, Suetonius, Tiberius edited with intr., com. and Bibliography by -, London, Bristol Classical Press.

Martinet, H. C. 1981, Suetonius Tranquillus, Divus Titus; Kommentar, Königstein, Hain.

Mottershead, J. 1986, Suetonius Claudius, ed. with intr. and com. by -, Bristol, Bristol Classical Press.

Murison, Ch. L. 1992, Suetonius Galba, Otho, Vitellius, ed. with intr. and notes by -, London, Bristol Classical Press. 
Venini, P. 1977, C. Suetonio Tranquillo.Vite di Galba, Ottone, Vitellio, con comm. di-, Torino, Paravia.

Wardle, D. 1994, Suetonius' Life of Caligula. A commentary, Bruxelles, Latomus.

Warmington, B. H. 1999, Suetonius Nero, text, with intr. \& notes by -, Bristol Class. Pr. (2a ed.).

\section{III. Índice suetoniano}

Howard, A. A. / Jackson, C. N. 1922, Index uerborum C. Suetoni Tranquili stilique eius proprietatum nonnullarum, Cambridge (Mass.), Harvard University Press.

\section{Estudos}

Alföldy, G. 1965, "La politique provinciale de Tibère" : Latomus 24 824-844.

Allen, W. 1958, "Imperial mementos in Suetonius" : CB 35 1-4.

1962, "Nero's eccentricities before the fire": Numen 9 99-109.

Almeida, J. M. 1959, As informações linguísticas de Suetónio nas Vidas dos Doze Césares, (diss.) Lisboa.

Ambrosio, F. G. D’ 1980 [1982], “End of the Flavians. The case for senatorial treason": RIL 232-241.

André, J.- M. 1995, "La peregrinatio Achaica et le philhellénisme de Néron” : REL 73 168-182.

André, J.-M. \& Hus, A. 1974, Histoire à Rome. Historiens et biographes dans la littérature latine, Paris, P.U.F.

Andrén, A. 1957, "Un portrait de Tibère à la villa San Michele, Anacapri” : Hommages à W. Deona, Bruxelles-Berchem, Latomus, 59-60.

Antonelli, G. 2001, Caligola. Imperatore folle o principe inadeguato al ruolo assegnatogli dalla sorte?, Roma, Newton \& Compton.

Arnaud, P. 1998, "Toi aussi, mon fils, tu mangeras ta part de notre pouvoir" : Latomus 57 61-71.

Badian, E. 1966, "The early historians" : Latin historians edit. by Dorey, T. A., London, Routledge \& Kegan Paul, 1-38.

1974, "The Thessalian clients of Tiberius Nero" : CR 24186.

Bajoni, M. G. 1983, "Le virtù del principe dal Seneca a Suetonio, biografo di Tito": Atti del Congresso Internazionale di Studi Flaviani, Rieti, settembre 
1981, II, Rieti, Centro di Studi Varroniani, 189-194.

BAldwin, B. 1967, "Executions, trials, and punishment in the reign of Nero": PP 22 425-439.

1975a, "Was Suetonius disgraced?" : EMC 19 22-26.

1975b, "Suetonius: birth, disgrace and death" : AClass. 18 61-70.

1977, "Polyphagus. Glutton or crocodile?” AJPh 98 406-409.

1979, “Nero and his mother's corpse" : Mnemosyne 32 380-381.

1983, Suetonius. Amsterdam, Hakkert.

1997, "Hadrian's dismissal of Suetonius: a reasoned response" : Historia 46 254-256.

BALsdon, J. P. 1957, “The veracity of Caesar” : GछR 2nd ser. 4 19-28.

1964, "Gaius and Egyptian cults" (recensão a Köberlein, E. 1962, Caligula und die ägyptishen Kulte) : CR 14 91-92.

1975, “The principates of Tiberius and Gaius": ANRW II. 2 86-94.

Bardon, H. 1952, La littérature latine inconnue, Paris, Klincksieck.

1968, Les empereurs et les lettres latines d'Auguste à Hadrien, Paris, Les Belles Lettres.

Barrett, A. A. 1983, "Did Galba visit Britain in A.D. 43?” :CQ 33 243-245. 1989 (2000), Caligula. The corruption of power, London / New York, Routledge.

Bartsch, S. 1994, Actors in the audience. Theatricality and doublespeak from Nero to Hadrian, Cambridge (Mass.), Harvard University Press.

BeAto, J. 2000, Nero, Lisboa, Inquérito.

Baumann, R. 1982, "The résumé of legislation in Suetonius" : ZRG 99 81-127.

Baurain, C. 1976, "Suétone et l'inscription d'Hippone" : LEC 44 124-144.

Beaujeu, J. 1960, “L'incendie de Rome en 64 et les chrétiens": Latomus 19 65-80.

Bejarano, V.1974, "Augusto escritor": HAnt 4 87-109.

Bell, A. 2004, Spectacular power in the Greek and Roman city, Oxford, Un. Press.

Benario, H. W. 1975, "Augustus princeps" : ANRW II. 2. 75-85.

Benediktson, D. Th. 1988, "Caligula's madness. Madness or interictal temporal lobe epilepsy?”: $C W 82$ 370-375. 
1992, "Nero and Agrippina's goodbye kiss: papillas or pupillas?": Maia 44 161-163.

1992-1993, “A survey of Suetonius scholarship: 1938-1987" : CW 86 377-447.

Bernardi, A.1953, "L'interesse di Caligola per la successione del rex Nemorensis e l'arcaica regalità nel Lazio": Athenaeum 41 (Studi Fraccaro) 273-287.

Berthet,J. F. 1978, “La culture homérique des Césars d'après Suétone” : REL 56 314-334.

Bertinelli Angeli, M. G. 1969, "I dodici Cesari nell'Historia Augusta (confronto con Tacito e Suetonio)" : Studi di storia antica in memoria di Luca de Regibus, Genova, Ist. di Storia Antica, 145-166.

Bessone, L. 1976-1977, "Suet. Nero XL,7 e gli inizi del Bellum Neronis" : RSA 6-7 343-349.

Bickel, E. 1952, “Observationum satura, I: Iacta alea est”: Paideia 7 269-273.

Bicknell, P. 1962, "Gaius and the sea-shells" : AClass 5 72-74.

1968, “The emperor Gaius' military activities in A.D. 40" : Historia 17 496-505.

Billerbeck, M. 1981, "Hercules bound. A note on Suetonius, Nero 21.3" : AJPh 102 54-57.

Birley, A. R. 1984, "Reviews of Baldwin, Wallace-Hadrill, and De Coninck" : JRS 74 245-251.

Blaison, M. 1998, "Suétone et l' ekphrasis de la Domus Aurea": Latomus 57 617-624.

Borleffs, J. W. 1952, “Institutum Neronianum” : VChr 6 129-145.

Bowersock, G. W. 1969, "Suetonius and Trajan” : Hommages à M. Renard ed. Bibauw J., Bruxelles, Latomus, I 119-125.

Bradley, K. R. 1972, “A publica fames in A.D. 68”: AJPh 93 451-458.

1973, "The composition of Suetonius' Caesares again" : JIES 1 257-263.

1976, "Imperial virtues in Suetonius' Caesares" : JIES 4 245-253.

1977, "Nero and Claudia Antonia" : SO 52 79-82.

1985a, "Ideals of mariage in Suetonius' Caesares": RSA 15 77-95.

1985b, “The rediscovery of Suetonius”: CPh 80 254-265.

1991, "The imperial ideal in Suetonius' Caesares": $A N R W$ II, 33, 5

3701-3732. 
Brandão,J. L. 2002, "Rumores e escândalos nas Vidas dos Césares de Suetónio": Nascimento, A. A. (coord.) De Augusto a Adriano. Actas de Colóquio de Literatura Latina (Lisboa 2000. Novembro 29-30), Lisboa, Centro de Estudos Clássicos / Faculdade de Letras, 331-339.

2004, "Retratos dos Césares em Suetónio" : Pérez Jiménez, A., Ferreira, J. R., Fialho, M. C. (coord.), O retrato e a biografia como estratégia de teorização política, Málaga, Imprensa da Universidade de Coimbra / Universidade de Málaga, 83-113.

159-193.

2005a, "Suetónio e drama: da tragédia ao mimo" : Humanitas 57 2005b, "Os políticos e as humanidades (a cultura nas Vidas dos Césares de Suetónio)” : Biblos 3 (2a sér.) 55-67.

2005c "Suetónio e o fascínio do Oriente" : Oliveira, F. (coord.), Génese e consolidação da ideia da Europa III. O mundo romano, Coimbra, Imprensa da Universidade, 81-102.

2006a, "Vida suetoniana de Terêncio. Estrutura e estratégias de defesa do poeta": Pociña, A., Silva, M. F., Rabaza, B. (coord.), Estudos sobre Terêncio, Granada, Universidade de Granada / Universidade de Coimbra, 111-123.

2006b, "O tempo nos Césares de Suetónio": Marnoto, R., Fausto, R. (coord.), Tempo e ciência, Lisboa, Gradiva, 233-250.

2008, "Tirano ao Tibre. Estereótipos de tirania nas Vidas dos Césares de Suetónio": Humanitas 60 115-137.

Brind'Amour, P. 1981, “Problèmes astrologiques et astronomiques soulevés par le récit de la mort de Domitien chez Suétone" : Phoenix 35 338-344.

BRiquel, D. 1988, "Que savons-nous des Tyrrhenika de l'empereur Claude?": RFIC 116 448-470.

Brugnoli, G. 1968, Studi suetoniani, Lecce, Milella.

1987, "La rappresentazione della storia nella tradizione biografica romana": Il protagonismo nella storiografia classica, Genova, Dipartimento di Archeologia, Filologia classica e loro tradizioni, 37-69.

1993, "Svetonio eques Romanus" : Giornate filologiche F. Della Corte, Atti, Genova, Univ. di Genova, Facoltà di Lettere, 47-61.

Brunt, P. A. 1959, "The revolt of Vindex and the fall of Nero" : Latomus 18 531-559.

1980, "Free labour and public works at Rome" : JRS 70 81-100.

Buttrey, T. V. 1973, "The spintriae as a historical source" : NC13 52-63. 
Campanille, D. 1990, "Praecipua cenationum rotunda" : Athenaeum 78 186-191.

Canfora, L. 1970, “Cesare continuato” : Belfagor 25 419-429.

2000, Giulio Cesare. Il dittatore democratico, Roma / Bari, Laterza (5 $5^{\mathrm{a}}$ ed.) .

Carcopino, J. 1990, Jules César, Paris, P.U.F.

Carney, T. F. 1968, "How Suetonius' lives reflect on Hadrian” : PACA 11 $7-24$.

Casson, L. 1978, "Unemployment, the building trade, and Suetonius, Vesp. 18": BASP 15 43-50.

Ceausescu, P. 1973, "Caligula et le legs d'Auguste": Historia 22 269-283.

Cels-Saint-Hilaire, J. 1985, "Les libertini, des mots et des choses" : DHA 11 331-379.

Chastagnol, A. 1976, "Le laticlave de Vespasien” : Historia 25 253-256.

Chausserie-Laprée, J. P. 1969, L'expression narrative chez les historiens latins. Histoire d'un style, Paris, de Boccard.

Cizek, E. 1961, "Sur la composition des Vitae Caesarum de Suétone" : StudClas 3 355-360.

1975a, "Suètone et le théâtre" : Assoc. Guillaume Budé, Actes IX Congrès. Rome, 13-18 avril 1973, Paris, Les Belles Lettres, 480-485.

1975b, "La mort de Vitellius dans les Vies des douze Césars de Suétone" : REA 77 125-130.

1977, Structure et idéologie dans les Vies des douze Césars de Suétone, Paris, Les Belles Lettres.

1982, Néron, Paris, Fayard.

Clauss,J.J.1993, “An Attic-speaking crow on the Capitoline: a literary émigré from the Hecale" : ZPE 96 167-173.

CoAle, A. J. 1971, “Dies Alliensis” : TAPhA 102 49-58.

Coleman, K. M. 1986, "The emperor Domitian and literature" ANRW II. 32.5 3087-3115.

Colin, J. 1954, "Les consuls du césar-pharaon Caligula et l'héritage de Germanicus" : Latomus 13 394-416.

Couissin, J. 1953, "Suétone physiognomoniste dans les Vies des XII Césars" : REL 31 234-256.

Croisille, J. M. 1970, "L'art de la composition chez Suétone d'après les Vies 
de Claude et de Néron": AIIS 2 73-87.

D’Anna, G. 1954, Le idee letterarie di Suetonio, Firenze, La Nuova Italia.

Dack, E. Van't 1963 , “A studiis, a bybliothecis" : Historia 12 177-184.

Dalmasso, L. 1906, La grammatica di C. Svetonio Tranquillo, Torino, Casanova.

Davies, R. W. 1966, "The abortive invasion of the Britain by Gaius" : Historia 15 125-128.

De Coninck,L.1980-1981, “Un projet d'études sur les sources primaires littéraires et documentaires des historiens à Rome": AnSoc. 11-12 387-407.

- 1983, Suetonius en de Archivalia, Brussels, Royal Belgian Academie.

1991, "Les sources documentaires de Suétone, Les XII Césars" : ANRW II. 32.5 3675-3699.

De Filippis Cappai, C. 1992,"Suet. Nero 18 e il progetto neroniano di evacuazione della Britannia" : QUCC 41 (70) 137-145.

Della Corte, F. 1954, "Marmor Hipporegium Suetonianum" : Orpheus 1 133-136.

1967, Svetonio eques Romanus, Firenze, La Nuova Italia.

1989, Cesare a Gades : Maia 41 95-98.

Derchain, Ph. 1953, "La visite de Vespasien au Sérapéum d'Alexandrie” : CE 28 no 56 261-279.

Derchain, Ph. et Hubaux, J. 1953, "Vespasien au Sérapéum" : Latomus 12 38-52.

Detweiler, R. 1970, "Historical perspectives on the death of Agrippa Postumus" : CJ 65 289-295.

Devijver, H. 1970, "Suétone, Claude 25, et les milices équestres" : AncSoc 1 69-81.

Dickison, S. K. 1977, "Claudius: Saturnalicius princeps": Latomus 36 634-647.

Dubuisson, M. 1980, “Toi aussi, mon fils!”: Latomus 39 881-890.

1986, "Purisme et politique. Suétone, Tibère et le grec au Sénat" : Hommages à Jozef Veremans ed. par Decreus F. \& Deroux C., Bruxelles, Latomus, 109-120.

1998, "L’ ảoı atpełía de Caligula (Suét., Cal. 29.1)" : Latomus 57 589-594.

Duckworth, E. 1971, The nature of Roman comedy. A study in popular entertainment, Princeton, Princeton University Press. 
Ducroux, S. 1978, "Histoire d'un portrait, portraits d'historiens: Tacite lecteur de Salluste" : MEFRA 901 293-315.

Dupont, F. 1985, L'acteur-roi ou le théatre dans la Rome antique, Paris, Les Belles Lettres.

Ектоr, J. 1980, “L'impassibilité et l'objectivité de Suétone” : LEC 48 317-326.

Erce, F. D' 1966, "La tour de Caligula à Boulogne-sur-Mer" : RA 1 89-96.

Evans, E. C. 1950, "Physiognomics in the Roman empire" : CJ 45 277-282.

Fantham, R. 1989, "Mime: the missing link in Roman litterary history": $C W$ 82 153-162.

Fasciato, M. 1949, "Note sur l'affranchissement des esclaves abandonnés dans l'île d'Esculape": RD 27 454-464.

Faur, J.-C. 1973, "Caligula et la Maurétanie: la fim de Ptolémée" : Klio 55 249-271.

Fera, V. 1983, Una ignota expositio Suetoni del Poliziano, Messina, Centro di Studi Umanistici.

Fernández Uriel, P.1994, “Tácito, Annales XV,37,8 y Suetonio, Nero XXVIII y XXIX. ¿Interpretación sexual o religiosa?” : Sexo, muerte y religión en el mundo clásico ed. Alvar, J.; Blánquez, C.; Wagner, C., Madrid, Ed. Clásicas, 111-124.

Ferreira, P. S. 2000, Os elementos paródicos no Satyricon de Petrónio e o seu significado, Coimbra, Colibri / Faculdade de Letras da Universidade de Coimbra.

Fialho, M. C. 1977, "Algumas considerações sobre o homem trágico" : Biblos 53 375-388.

Fini, M. 1993, Nerone. Duemila anni di calunnie, Milano, Mondadori.

Fishwick, D. 1965, "Vae, puto deus fio" : CQ 15 155-157.

FLORY, M. B. 1988-1989, "Octavian and the omen of the gallina alba" : CJ 84 343-356.

Fornaro, P. 1988, "Una vita senza maschera, Suet. Aug. xcix, 1" : CCC 9 155-167.

Foucher, A. 2000, "Nature et formes de l' histoire tragique à Rome": Latomus 59 773-801.

Frade, M. 2002, "Tradição e morte no principado de Tibério": Nascimento, A. A. (coord.) De Augusto a Adriano. Actas de Colóquio de Literatura Latina 
(Lisboa 2000. Novembro 29-30), Lisboa, Centro de Estudos Clássicos / Faculdade de Letras, 469-478.

2005, "Oderint, dum metuant: Suetónio e a prepotência de Calígula"

: Mora, C. (Coord.), Vt para delicto sit poena: crime e justiça na Antiguidade, Aveiro, Centro de Línguas e Culturas / FCT, 277-290.

Franchet D'Espèrey, S. 1986, "Vespasien, Titus et la littérature" : ANRW II. 32.5 3048-3086.

Franco, C. 1989, "Il lungo sonno di Ottaviano” : SCO 39 257-264.

Frazer, R. M. 1966, "Nero the artist-criminal” : CJ 62 17-20.

Gagé, J. 1969, "L'étendard d'Eutychus: sur un mot the Cassius Chaeréa, le meurtrier de Caligula": Hommages à M. Renard, ed. Bibauw J, Bruxelles, Latomus, I, 275-283.

Gallivan, P. A. 1973, “The false Neros. A re-examination”: Historia 22 364-365.

1974a," Historical comments on Suetonius, Nero 6" : Latomus 33 385-396.

1974b, "Some comments on the Fasti for the reign of Nero": CQ 24 290-311.

1974 c, "Suetonius and chronology in the De vita Neronis" : Historia 23 297-318.

Garuti, G. 1983, "Sulla docilitas ed extemporalitas dell'imperatore Tito (Suet. Tit. 3)" : Atti del Congresso Internazionale di Studi Flaviani, Rieti, settembre 1981, II, Rieti, Centro di Studi Varroniani, 307-312.

Gascou, J. 1976, “Suétone et l'ordre équestre” : REL 54 257-277.

1978, "Nouvelles données chronologiques sur la carrière de Suetóne": Latomus 37 436-444.

1984, Suétone historien, Paris, de Boccard.

Geiger, J. 1980, "An overlooked item of the war of propagande between Octavian and Antony" : Historia 29 112-114.

Genette, G. 1972, Figures III, Paris, Seuil.

Giancotti, F. 1967, Mimo e gnome. Studio su Decimo Laberio e Publilio Siro, Firenze, Anna.

Gillis, J. 1974, “Caligula. De Suétone à Camus” : LEC 42 393-403.

Girard, J.-L. 1981, "Domitien et Minerve: une prédilection impériale” : ANRW II 17.1 233-245.

1987, “Lidée dynastique sous les Flaviens": Ktema 12 169-173. 
Giva, M. A. 1975, "Tiberio simulatore nella tradizione storica pretacitiana”: Athenaeum 53 352-363.

1978, "Sulla biografia suetoniana di Tiberio. Tradizione e struttura" :Athenaeum 56 329-345.

1990, "Aspetti della biografia latina del primo impero" : RSI 12 535-559.

1991, "Una lettura della biografia svetoniana di Tiberio" : $A N R W$ II. 33, 5 3733-3747.

Grelle, F. 1980, "La correctio morum nella legislazione flavia" : ANRW II. 13 340-365.

Griffin, M. T. 1984, Nero. The end of a dynasty, London, Routledge.

Griffiths, J. G. 1970, "Tacitus, Hist. 5,13,2 and the Dead Sea scrolls" : RhM 113 363-368.

Grimal, P. 1955, “Sur deux mots de Néron”: AFLT Pallas 3 15-20.

1986, "Suétone historien dans la Vie d'Auguste" : Rome. La littérature et l'histoire 2, Paris / Roma, École Française de Rome, II, 729-738.

—_ 1993, O Império Romano, trad. portuguesa, Lisboa, Edições 70.

Grisart, A. 1961, "Suétone et les deux Sénèque" : Helikon 1 302-308.

Grosso, F. 1959, "Lepigrafe di Ippona e la vita di Suetonio con i Fasti dei pontefici di Vulcano a Ostia": RAL 14 263-296

Gugel, J. 1970, "Caesars Tod (Sueton, Div. Iul. 81,4-82,3). Aspekte zur Darstellungskunst und zum Caesarbild Suetons" : Gymnasium 77 5-22.

Guillemin, A. 1938, "La lettre de Cicéron à Lucéius": REL 16 96-103.

HaArberg, J. M. 1982, "The emperor as a Saturnalian king: on the title of Apocolocyntosis": SO 57 109-114.

Hallet, J. P. 1978, “Morigerari. Suetonius, Tiberius, 44” : AC 47 196-200.

Harris, B. F. 1962-63, "Tacitus on the death of Otho" : CJ 58 73-77

Hellegouarc'H, J. 1987, "Suétone et le principat d'après la Vie d'Auguste" :

Filologia e forme letterarie. Studi offerti a F. della Corte, Urbino, Quattro Venti, IV, 79-94.

Henrichs, A. 1968, "Vespasian's visit to Alexandria" : ZPE 3 51-80.

Herrmann, L. 1951, "La révolution des idiots" : Latomus 10 143-145. 1953, "Basilides" : Latomus 12 312-315. 1962, "Notes de lecture" : Latomus 21860. 
1968, "Notes de lecture" : Latomus 27 436-437.

Higgins, J. M. 1985, “Cena rosaria, cena mitellita. A note on Suetonius Nero 27,3" : AJPH 106 116-118.

Hind, J. F. 1971, “The middle years of Nero's reign” : Historia 20 488-505.

Hoнl, E. 1952, "Cäsar am Rubico": Hermes 80 246-249.

Holson, P. 1976, "Nero and the fire of Rome. Fact and fiction" : Pegasus 19 37-44.

Hubaux, J. 1946, “Tibère et le grammairien de Rhodes” : Latomus 5 99-102.

Hurley, D. W. 1989, “Gaius Caligula in the Germanicus tradition” : AJPh 110 316-338.

Jabouille, V. 1996, Júlio César, Lisboa, Inquérito.

Jabouille, V. 2000, Calígula, Lisboa, Inquérito.

Jameson, S. 1975, “Augustus and Agrippa Postumus" : Historia 24 287-314.

Jenkinson, E. 1967, "Nepos. An introduction to Latin biography" : Latin biography, ed. by Dorey, T. A., London, Routledge \& Kegan Paul, $1-15$.

Jones, B. W. 1970, “Suétone et Aurélius Victor” : PP 25 346-347.

1972, "La chute de M. Arrecinus Clemens": PP 27 320-321.

1975, "Titus and some Flavian amici": Historia 24 454-462.

1983, "Sallustius Lucullus": Latomus 42 629-633.

1984, "Agrippina and Vespasian": Latomus 43 581-583.

1989, “Titus in Judaea, A.D. 67”: Latomus 48 126-134.

Katz, R. S. 1972, “The illness of Caligula” : CW 65 223-225.

Keaveney, A. 1987, "Vespasian's gesture. (Suet. Vesp. 8,5 and Dio 65.10.2)" : GIF 39 213-216.

Keresztes, P. 1973, "The Jews, the Christians and the emperor Domitian" : VChr 27 1-28.

Kessissoglu, A. I. 1988, “Mimus vitae”: Mnemosyne 41 385-388.

Kraft, K. 1967, “Zu Sueton, Divus Augustus 69,2. M. Anton and Kleopatra”: Hermes 95 496-499.

La Penna,A.1987,"Callimaco e i paradossi dell'imperatore Tiberio (Svetonio, Tib. Lxx, 6; LXII, 6)” : SIFC 5 181-185.

Lambrechts, P. 1953, "Caligula dictateur littéraire" : BIBR 28 219-232. 
Lana, I. 1975, "Gli scritti di Augusto nelle Vite dei Cesari di Suetonio" : StudUrb 49 437-458.

LeÃo, D. F. 1998, As ironias da Fortuna. Sátira e moralidade no Satyricon de Petrónio, Coimbra, Colibri / Faculdade de Letras da Universidade de Coimbra.

Leo, F. 1901, Die griechisch-römische Biographie nach ibrer litterarischen Form, Leipzig, Teubner.

Le Roux, P. 1984, "Galba et Tarraco. À propos de Suétone, Galba xII, 1" : Pallas 31 113-124 et 192.

Lesuisse, L. 1961, "Suétone et l'aspect juridique de l'avènement de Néron" : LEC 29 383-390 .

Levi, M.A.1937, "Dopo Azio. Appunti sulle fonti augustee. Suetonio" : RFIC 16 1-24.

1954, "La clemenza di Tito" : PP 9 288-293.

Levick, B. 1971, “The beginning of Tiberius' career” : CQ 21 478-486.

1972, "Abdication and Agrippa Postumus": Historia 21 674-697.

1989, "Claudius speaks; two imperial contretemps" : Historia 38 112-116.

-1990, Claudius, London, Batsford /Yale, Univ. Press.

1991, "A note on the latus clauus": Athenaeum 79 239-244.

ed.). 1999a, Tiberius the Politician, London / New York, Routledge (rev. 1999b, Vespasian, London / New York, Routledge.

Lewis, R. G. 1966, “Pompeius' freedman biographer”: CR 16 271-273.

1991, "Suetonius' Caesares and their literary antecedents" : ANRW II, 33,5 3623-3674.

Liberanome, M. 1968, "Alcune osservazioni su Cesare e Antonio" : RFIC 96 407-418.

Liders ki, J. 1974, "The mother of Livia Augusta and the Aufidii Lurcones of the Republic": Historia 23 463-480.

Lindsay, H. 1994, "Suetonius as ab epistulis to Hadrian and the early history of the imperial correspondence": Historia 43 454-468.

Littman, R. J. 1976, “The meaning of polyphagus” : AJPh 97369.

Lopez Eire, A. 2001, "Reflexiones sobre la poética de Aristóteles": Humanitas 53 183-216. 
Lorenzo, E. DI 1981, "A proposito dell'espressione neroniana qualis artifex pereo (Suet., Nero 49)" : Studi salernitani in memoria di R. Cantarella a cura di Gallo I., Univ. di Salerno, Istituto di Filologia Classica, Laveglia, 523-535.

Lorsch, R. S. 1997, “Augustus' conception and the heroic tradition” : Latomus $56790-799$.

Lounsbury, R. C. 1987, The arts of Suetonius; an introduction, New York / Bern / Frankfurt am Main / Paris, Lang.

1991, "Inter quos et Sporus erat: The making of Suetonius' Nero" : ANRW II, 33,5, 3748-3779.

LuCAs, J. 1967, “Un empereur psychopathe. Contribution à la psychologie du Caligula de Suétone" : AC 36 159-189.

Lugand, R. 1929, "Suétone et Caligula" : REA 31 9-13.

Luibheid, C. 1970 , “The Luca conférence” : CPh 65 88-94.

Lyons, M. \& Montgomery, H. C. 1968, "Friends, Romans and countrymen" : $C B 44$ 37-39 e 41.

MacÉ, A. 1900, Essai sur Suétone, Paris.

Magnino, D. 1986, "Una testimonianza dall'autobiografia di Augusto?”: Athenaeum 64 501-504.

Major, A. 1995, "Claudius' recognition of the medicinal properties of the yew tree”: Scholia 4 101-104.

Malcovati E, 1972, “Tiberio e le Muse” : Athenaeum 50 385-389.

Malissard, A. 1990, "Tacite et le théâtre ou la mort en scène" : Theater un Gesellschaft im Imperium Romanum / Théâtre et société dans l'empire romain, hrsg. von Jürgen Blänsdorf in Verb. mit Jean-Marie André u. Nicole Fick. Tübingen, Francke, 213-222.

Manfredini, M. 1986 , “L'asinaio di Azio” : ASNP 16 481-483.

Manni, E. 1975, "Dall' avvento di Claudio all'acclamazione di Vespasiano" : ANRW II.2 131-148.

Marastoni, A. 1983, "La biografia suetoniana di Tito e il discorso sulla regalità" : Atti del Congresso Internazionale di Studi Flaviani, Rieti, settembre 1981, I, Rieti, Centro di Studi Varroniani, 105-123.

Marec, E. \& Pflaum, H. G. 1952, "Nouvelle inscription sur la carrière de Suétone l'historien" : CRAI 76-85.

Martin, R. 1991, Les douze Césars: du mythe à la réalité, Paris, Les Belles Lettres. 
Martin, R. H. 1955, "Tacitus and the death of Augustus" : CQ 49 (5, new ser.) 123-128.

Massaro, V. \& Montgomery, I. 1978, “Gaius — Mad, Bad, Ill, or all Three?”: Latomus 37 894-909. 1979, "Gaius (Caligula) doth murder sleep" : Latomus 38 699-700.

Mastellone, E. 1990, "Un esempio della licentia del princeps da Tacito all'Historia Augusta" : BStudLat 20 365-374.

Mattingly, H. B. 1969, "Suetonius Claud. 24,2 and the «Italian Quaestors»": Homm. Renard ed. Bibauw J., Bruxelles, Latomus, I, 505-511.

Mayer, R. 1982, “What caused Poppaea's death ?”: Historia 31 248-249.

McDermotт, W. C. 1971, "Pliny the younger and inscriptions" : CW 65 84-94.

___ 1972, "Suetonius and the second proscription" : Gymnasium 79 495-499.

1980, "Suetonius and Cicero" : Gymnasium 87 485-495.

1982-1983, "Caesar's projected Dacian-Parthian expedition” : AncSoc 13-14 223-231.

Medeiros, W. DE 1981, “A apoteose do escravo na cena final do Epídico de Plauto" : Biblos 57 379-394.

Mogenet, J. 1954, "La conjuration de Clemens" : AC 23 321-330.

Moles, J. 1992, "Plutarch, Vit. Ant. 31.3 and Suetonius, Aug. 69. 2" : Hermes 120 245-247.

Momigliano, A. 1932, "Osservazioni sulle fonti per la storia di Caligula, Claudio, Nerone" : RAL 8 293-336.

1990, The classical foundations of the modern historiography, with a foreword by Riccardo Di Donato, Berkeley / Los Angeles / Oxford, University California Press.

- 1993, The development of Greek biography, Cambridge (Mass.) / London, Harvard University Press (ampliação, com mais um capítulo, da edição de 1971).

Monaco, G. 1970, "Spectatores, plaudite": Studia Florentina A. Ronconi oblata, Roma, Ateneo, 255-273.

Monti, S. 1953, "Una nota tacitiana” : RAAN 28 141-144.

Morford, M. P. 1968, "The distortion of the Domus Aurea tradition" : Eranos 66 158-179.

Morgan, M. G. 1973, “Caligula’s illness again” : CW 66 327-329. 
1996, "Vespasien and the omens in Tacitus Histories 2.78": Phoenix $5041-55$.

Morgan, L. 1997, "Leui quidem de re... Julius Caesar as tyrant and pedant" : JRS 87 23-40.

Murison, C. L. 1985, “Galba in Germany, A.D. 43?” : Historia 34 254-256.

1987, “Tiberius, Vitellius and the spintriae": AHBI 97-99.

Murphy,J.P. 1991, “The anecdote in Suetonius' Flavian Lives”: ANRWII.33.5 3780-3793.

Nelson, N. 1941, "The value of epigraphic evidence in the interpretation of Latin historical literature" : CJ 37 281-290.

Néraudau, J. P. 1988, "Sur un rituel archaïque d'expulsion redécouvert par Caligula” : Hommages à Henri le Bonniec. Res sacrae, publ. par PorTe, D. \& Néraudau J. P., Bruxelles, Latomus, 324-341.

1996, Auguste. La brique e le marbre, Paris, Les Belles Lettres.

Newbold, R. F. 1984, “Suetonius' boundaries” : Latomus 43 118-132.

1997, "Hostility and goodwill in Suetonius and the Historia Augusta" :AncSoc 28 149-173.

2000, "Non-verbal communication in Suetonius and the Historia Augusta: power, posture and proxemics": AClass 43 101-118.

Niccoli, G. 1976, "Tradizione biografica suetoniana e orientamenti ideologici nei necrologi inperiali di Ammiano Marcelino" : CS 13 610-620.

Nutting, H. C. 1933, "Suetonius, Galba 20. 2": CW 2745.

Oliveira, F. 1986, Ideias morais e politicas em Plinio-o-Antigo, Coimbra, Faculdade de Letras.

1992, Les idées politiques et morales de Pline l'Ancien. Coimbra, INIC/ $\mathrm{CECH.}$

67-84.

1995, "Biografia dos imperadores em Plínio o Antigo", Biblos 71

1997, “La imagen del gobernante ideal en Plinio el Viejo”: SÁnchez Marín, J. A., Lens Tuero, C. López Rodríguez (ed.), Historiografía y biografía. Madrid, Ediciones Clásicas, 119-138.

2004, "Biografia dos imperadores em Plínio o Antigo" : PÉrez Jiménez, A., Ferreira, J. R., Fialho, M. C. (coord.), O retrato e a biografia como estratégia de teorização política, Málaga, Imprensa da Universidade de Coimbra / Universidade de Málaga, 115-129.

Oliver, R. P. 1980, “Thrasyllus in Tacitus , Ann. 6.21”: ICS 5 130-148. 
Paladini, M. L. 1954 , "La morte di Agrippa Postumo e la congiura di Clemente": Acme 7 313-329.

Panayotakis, C. 1995, Theatrum Arbitri. Theatrical elements in the Satyrica of Petronius, Leiden / New York / Köln, Brill.

Paratore, E. 1959, "Claude et Néron chez Suétone” : RCCM 1 326-341.

1980, "Tito Flavio Vespasiano (nel diciannovesimo centenario della morte)": StudRom 28 7-22.

PAuw, D. 1980, "Impersonal expressions and unidentified spokesmen in Greek and Roman historiography and biography": AClass 23 83-95.

Pennacini, A. 1985, "Strutture retoriche nelle biografie di Svetonio": Retorica e storia nella cultura classica, a cura di Pennacini, A., Bologna, Pitagora, 81-88.

Pergola, Ph.1978, "La condamnation des Flaviens "chrétiens” sous Domitien: persécution religieuse ou répression à caractère politique?” : MEFRA 90 407-423.

Perrochat, P. 1935, “À propos de l'infinitif de narration. Tacite imitateur de Salluste dans l'Agricola" : REL 13 261-265.

Picard, Ch. 1950, "Léleusinisme à Rome au temps de la dynastie julio-claudienne" : REL 77-80.

Picard, G.-Ch. 1990, “Le monument qui réconforta Néron” : CRAI 659-664.

Picón García, V.1984, "Superstitio, un indicio de la romanidad de Suetonio": Apophoreta philologica E. Fernández-Galiano oblata (EClás 26) 323-328.

Picón, J. 1993, Drusus imperator: an episode in the fall of Sejanus in Tacitus, Suetonius, and Cassius Dio: Études sur l'bistoire gréco-romaine = Studia $Z$ dziejów Grecji i Rzymu, Antiquitas 18, Wroclaw, Wydawnictwo Uniwersytetu wroclawskiego, 183-190.

Pimentel, M. C. 1993, “A. D. XIV KaL. OCT., hora quinta...” : Boletim de Estudos Clássicos, 20 94-102.

2001, “Teatro, actores e público no Alto Império Romano”: Máscaras, vozes e gestos: nos caminhos do teatro clássico, Aveiro, Universidade, 329-348.

Pociña, A. \& Ubiña, J. F. 1985, "El evergetismo imperial en Suetonio" : Latomus 44 577-602.

Poulle, B. 1997, “Les poignards de l'année 68-69” : RPh 71 243-252.

Questa, C. 1959, "La morte di Augusto secondo Cassio Dione": PP 14 41-55.

Raoss, M. 1958, "La rivolta di Vindice ed il sucesso di Galba" : Epigraphica 20 46-120. 
Reekmans, T.1992, "Verbal humour in Plutarch and Suetonius' Lives": AncSoc 23 189-232.

Reis, C. - Lopes, A. C. 1991, Dicionário de Narratologia Coimbra, Almedina ( $3^{\mathrm{a}}$ ed.).

Renard, M. 1937, "Suétone et l'Apocoloquintose": RBPh 16 5-13.

Rocca-Serra, G. 1974, "Une formule cultuelle chez Suétone (Divus Augustus, 98,2)” : Mélanges de philosophie, de littérature et d'histoire ancienne offerts à P. Boyancé. Rome, Palais Farnèse, 671-680.

Rocha Pereira, M. H. da 2002, Estudos de História da Cultura Clássica. II: Cultura Romana, Lisboa, Fundação Calouste Gulbenkian (3a ed.).

2003, Estudos de História da Cultura Clássica. I: Cultura Grega, Lisboa, Fundação Calouste Gulbenkian (9a ed.).

Rodrigues, N. S.2002, “O retrato de Augusto em Flávio Josefo”: Nascimento, A. A. (coord.) De Augusto a Adriano. Actas de Colóquio de Literatura Latina (Lisboa 2000. Novembro 29-30), Lisboa, Centro de Estudos Clássicos I Faculdade de Letras, 89-102.

2005, Mitos e lendas. Roma antiga, Lisboa, Livros e Livros.

Rogers, P. 1980, “Titus, Berenice and Mucianus”: Historia 29 86-95.

Romilly, J. 1969, "Il pensiero di Euripide sulla tirannia” : Dioniso 43 175-187.

Rosborough, R. R. 1920, An epigraphic commentary on Suetonius's Life of Gaius Caligula, Philadelphia, University of Pennsylvania.

Rossi, R. F. 1971 , “Tracce di lotta politica nel senato di Caligola” : RFIC 99 164-171.

Rougé, J. 1978, "Néron à la fin du $\mathrm{Iv}^{\mathrm{e}}$ et an début du v $\mathrm{v}^{\mathrm{e}}$ siècle" : Latomus 37 73-87.

Saddington, D. B. 1992, "Felix in Samaria : a note on Tac. Ann. 12.54.1 and Suet. Claud.28.1” : AClass 35 161-163.

SAGE, P. 1979a, "L'expression narrative dans les XII Césars de Suétone; analyse d'une structure de phrase" : Latomus 38 499-524.

1979b, "Quelques aspects de l'expression narrative dans les XII Césars de Suétone": RBPh 57 18-50.

Salles, C. 1985, Tibère. Le seconde César, Paris, Laffont.

SAlmon, E. T. 1956, “The evolution of Augustus' principate” : Historia 5 456-478.

SAnders, H. A. 1944, "Suetonius in the civil service under Hadrian" : AJPh 64 113-123.

SARTORI, A. 1990, "L'evergetismo dei militari graduati in congedo: in margine 
a Svet. Tib.37”: MEFRA 102 687-697.

Scanlan, T. M. 1976, "Suetonius' influence on Jean-Jacques Rousseau in $L a$ nouvelle Héloïse" : CB 52 60-61.

Scarcia, R. 1991, "Fragmentum Agrippinae: ipotesi di un ricupero (e in riscontro Shakespeariano): GIF 43 243-263.

Schmidt, V. 1983, "La ruine du mime Mnester. À propos de Suétone, Cal. 57,4” : Latomus 42 156-160.

Schwartz, J. 1948a, "L'ombre d'Antoine et les débuts du principat (à propos des commentaires perdus d'Horace)" : MH 155-167.

- 1948b, "Sur quelques anecdotes concernant César et Cicéron" : REA 50 264-271.

Scotт, K. 1934, "Domitian's intended edict on sacrifice of oxen" : AJPh 55 225-226.

Seager, R. 1972, Tiberius, London, Eyre Methuen.

Shotter, D. 1997, Nero, London / New York, Routledge.

Sijpesteijn, P. J. 1990, “The astrologer Askletarion” : Mnemosyne 43 164-165.

Silva, M. F. 1987, Crítica do teatro na comédia antiga, Coimbra, Gulbenkian / JNICT.

Simpson, C. J. 1979, "The conspiracy of A.D. 39" : Studies in Latin literature and Roman history, ed. by Deroux C., Bruxelles, Latomus, II, 347-366.

1987, "The birth of Claudius and the date of dedication of the altar Romae et Augusto at Lyon": Latomus 46 586-592.

Smallwood, E. M. 1956, "Some notes on the Jews under Tiberius" : Latomus 15 314-329.

SoAres, N. C. 1993, "A história antiga no humanismo renascentista português": Actas do II congresso peninsular de história antiga. Coimbra, 18 a 20 de Outubro de 1990, Coimbra, Instituto de Estudos Clássicos / Instituto de Arqueologia da F.L.U.C., 279-305.

Southern, P. 1997, Domitian tragic tyrant, London / New York, Routledge. 1998, Augustus, London / New York, Routledge.

Spaeth Jr., J. W. 1943-1944, “Martial's equestrian cobbler” : CW 37 171-172.

Steidle, W. 1951, Sueton und die antike Biographie, München, Beck (há 2a ed. de 1963).

Sterckx, C. 1969, "Claudius palliolatus (Suétone, Claude, II, 5)” : Latomus 28 477-478. 
Sток, F. 1995, "Ritratti fisiognomici in Svetonio" : Biografia e autobiografia degli antichi e dei moderni, a cura di Italo Gallo e Luciano Nicastri, Napoli, Ed. Scientifiche Italiane, 109-135.

Strauss, W. A. 1951, “Albert Camus' Caligula. Ancient sources and modern paralels" : CompLit 3 160-173.

Stewart, A. F. 1977, "To entertain an emperor. Sperlonga, Laokoon, and Tiberius at the dinner table" : JRS 67 76-90.

Stuart, D. R. 1928, Epochs of Greek and Roman biography, New York, Biblo and Tannen (repr. 1967).

Syme, R. 1974, "History or biography. The case of Tiberius Caesar": Historia 23 481-496.

1980, "Biographers of the Caesars" : MH 37 104-128

1981, "The travels of Suetonius Tranquillus" : Hermes 109 105-117.

Tagliasachi, A. M. 1960, "Plutarco e la tragedia greca": Dioniso 34 125-142.

TAYlor, A. 1945 , "An allusion to a riddle in Suetonius" : AJPh 408-410.

Thomasson, B. 1969, "Post aurea tecta” : Hommages à M. Renard, ed. Bibauw J, Bruxelles, Latomus, II, 715-717.

Timonen, A. 1993, "Emperors ars recusandi in biographical narrative" : Arctos 27 133-148.

Tissoni, G. G. 1965, "Sul consilium principis in età traianea”: SDHI 31 222-245.

Tompson, L. A. 1981. "The concept of purity of blood in Suetonius' life of Augustus" : MusAfr 7 35-46.

Townend, G. B. 1959, "The date of composition of Suetonius' Caesares" : CQ $9285-293$.

1960, “The sources of the Greek in Suetonius”: Hermes 88 98-120.

1961a, "The Hippo inscription and the career of Suetonius" : Historia 10 99-109.

1961b, "Traces in Dio Cassius of Cluvius, Aufidius and Pliny" : Hermes 89 227-248.

1962, "The trial of Aemilia Lepida in A. D. 20" : Latomus 21 484-493.

1967, "Suetonius and his influence" : Latin biography ed. by Dorey, T. A., London, Routledge \& Kegan Paul, 79-111.

1980, "Tacitus, Suetonius and the temple of Janus" : Hermes 108 233-242. 
1987, “C. Oppius on Julius Caesar”: AJPh 108 325-342.

Tränkle, H. 1980, “Zu Cremutius Cordus fr. 4 Peter” : MH 37 231-241.

Treggiari, S. 1969, “Pompeius' freedman biographer again” : CR 19 264-266.

Tuplin, C. 1979, "Nepos and the origins of political biography": Studies in Latin literature and Roman history ed. by Deroux, C., Bruxelles, II, 124-161.

Turner, A. 1943, "A Vergilian anecdote in Suetonius and Dio" : CPh 38261.

Ullman, B. L. 1942, "History and tragedy": TAPhA 73 25-53.

Vara Donado, J. 1996, Origen de la tragedia griega, Salamanca, Universidad de Extremadura.

Vassileiou, A. 1984, "Crispinus et les conseillers du prince (Juvènal, Satires, IV)" : Latomus 43 27-68.

VAsto, F. DI 1985, "Il soprannome di Augusto e un'osservazione sull'itinerario di C. Ottavio": PP 40 39-40.

Vattuone, R. 1983-1984, "Tre note a Suetonio, Vita Tiberii 52" : RSA 13-14 213-235.

Venini, P. 1974, "Sulle Vite suetoniane di Galba, Otone e Vitellio": RIL 108 991-1014.

Verdière, R.1960, “Le baiser d'adieu de Néron”: Hommages à Léon Herrmann, Berchem / Bruxelles, 774-776.

1971, "Un amour secret d'Ovide" : AC 40 623-648.

1975, "À verser au dossier sexuel de Néron" : PP 30 5-22.

Veyne, P. 1983, "Le folklore à Rome et les droits de la conscience publique sur la conduite individuelle": Latomus 42 3-30.

1990, A sociedade romana, trad. port., Lisboa, Edições 70.

VIDAL SÁNchez,J.M. 1989, “Los prodigios y su utilización política de Galba a Domiciano": Actas del VII Congresso Español de Estudios Clasicos (Madrid, 20-24 de abril de 1987), Universidade Complutense, 329-334.

VIDÉN, G. 1993, Women in Roman literature. Attitudes of authors under the early empire, Acta Universitatis Gothoburgensis, 65-90.

Vigourt, A. 1993, "Les présages impériaux et le temps dans le De uita Caesarum de Suétone": Ktema 18 131-145.

Wallace-Hadrill, A. 1984, Suetonius. The scholar and his Caesars, New Haven (Conn.) Yale Univ. Pr.

Wankenne, J. 1981, “Faut-il réhabiliter l'empereur Néron ?”: LEC 49 135-152.

Wardle, D. 1992, Cluvius Rufus and Suetonius: Hermes 120 466-482. 
1993, “Did Suetonius write in Greek?”: AClass 36 91-103.

2001, "Suetonius: the 'change' in, and the 'generosity' of Titus" : Antichthon 35 64-69.

Wellesley, K. 2000, The year of the four emperors, with a new introduction by B. Levick, London / New York, Routledge ( $3^{\mathrm{a}} \mathrm{ed}$. .).

Wiedemann, T. 1989, The Julio-Claudian emperors: AD 14-70, Bristol, Bristol Classical Press.

Williams, M. H. 1995, “Tiberius and the disobliging grammarian of Rhodes: Suetonius, Vita Tiberi XXXII, 2 re-considered": Latomus 54 625-633.

Wiseman, T. P. 1978, Roman drama and Roman history, University of Exeter Press.

Wiseman, T.P.1986, "Monuments and the Roman annalists": Past Perspectives. Studies in Greek and Roman bistorical writing. Papers presented at a conference in Leeds, 6-8 April 1983, ed. by Moxon, I. S., Smart, J. D.\& Woodman, A. J., Cambridge, University Press, 87-100.

Woods, D. 2000, "Caligula's seashells": GER $2^{\text {nd }}$ ser. 47 80-87.

ZINn, T. 1951, “A pun in Suetonius” : CR n. s. 110. 
ÍNDICES 
(Página deixada propositadamente em branco) 


\section{ÍNDICE DE PERSONALIDADES E LUGARES HISTÓRICOS ${ }^{1}$}

Acaia (região do Peloponeso que se tornou no nome oficial da província romana da Grécia): 111; 163 e n.23; 164 n. $24 ; 170 ; 355$.

Áccio (promontório da costa da Grécia, famoso pela vitória de Augusto sobre António e Cleópatra): 105 n.40; 123; 139; 186 e n. 128; 193 n.155; 205.

Ácia (mãe de Augusto): 207; 343 n.15.

Acílio Glabrião (cônsul em 91 d.C., vítima de Domiciano): 232 e n.158; 233 n.170.

Acte (liberta e amante de Nero): 227; 296; 305.

Ad Gallinas (nome de uma propriedade de Lívia): 72.

Adriano, Públio Élio Trajano (imp. 117 -138): 24. n.49; 34 n.13, 40; 42 n.63; 49 n.104; 62; 177 n.74; 193 n.155; 273 n.11.; 283 n.62; 378 e n.163,166; 379.

Afrânio, L. (poeta cultor da togata; sec. II a.C.): vide índice de autores antigos.

Afrânio Potito, P. (plebeu, vítima de Calígula): 184 n.116.

África (província fundada em 146 a.C.; compreendia o território de Cartago e zonas adjacentes): 42 n.66; 78; 108 e n. 55; 109; 111 e n.71; 303 n.138.

Agamémnon (mítico chefe supremo dos Gregos na guerra de Tróia): 42; 311 n. $171 ; 319 ; 330$.

Agermo, L. (liberto de Agripina): 186; 187 e n.131.

Agesilau (II, rei de Esparta, 400-360 a.C.): 17 e n.10.

Agrícola (general romano, sogro de Tácito): 60 n.145; 357.
Agripa, M. (famoso general, colaborador e genro de Augusto): 118; 119; 185; 200; 365; 370 n.104.

Agripa Póstumo (filho de Agripa e Júlia; exilado devido ao seu temperamento): 121; 122; 144; 147; 200 e n.5; 201; $241 ; 319 ; 322$.

Agripina, Vipsânia (filha de Agripa; primeira esposa de Tibério): 118; 119 e n. $116 ; 175 ; 321$.

Agripina (Maior; esposa de Germânico; condenada por Tibério): 37; 38; 47; 122 e n. $126 ; 123 ; 176 ; 185 ; 217 ; 322$; 366; 384 n.5.

Agripina (Menor; filha de Germânico e mãe de Nero): 50; 51 e n.113; 74; 86; 90; $107 ; 111$ e n.70; $124 ; 125 ; 126$ e n. 143; 127 e n. $146 ; 148 ; 154 ; 163$ n.18; 177 e n.75; 185; 186-187 e n.131, 132, 133; 198; 203; 205 n.24; 216 n.83; 227; 238; 256 n.272; 260 n.285; 261 e n.285, 287; 265; 273 n. $10 ; 298$ e n. $120 ; 299$ e n. $124 ; 303 ; 319$ e n.26; 320 n.29; 321; 322 e n.35; 347; 376 e n. $150 ; 386$ n.18.

Ajax (mítico herói grego da guerra de Tróia): 181 n.98; 252 e n.261; 268; 311 n.171.

Albano (território do monte Albano, onde existia um santuário de Júpiter Laciar; zona de Alba Longa) : 164; 165.

Álbia Terência (mãe de Otão): 334.

Albucila (condenada no principado de Tibério): 219 n.95.

Alexandre Magno (Filho de Filipe II e Olímpia; modelo de conquistador e de monarca divinizado: 356-323 a.C.): 18; 98 e n.9; 99; 99 n.10; 106; 116 n.105; 139; 140 n.20; 181 e n.101; 208; $212 ; 241 ; 320 ; 355$.

\footnotetext{
${ }^{1}$ Acompanham os nomes alguns apontamentos, que não pretendem ser exaustivos, mas apenas facilitar a identificação (incluem-se alguns heróis míticos em que história e lenda se fundiam na antiguidade). Quando se trata de autores, figuram no índice próprio.
} 
Alexandria (cidade do Egipto famosa pela sua biblioteca e hegemonia cultural na época helenística): 20; 139; 143 e n. $39 ; 162$ n. $16 ; 205 ; 224$ e $118 ; 268$ e n. $315 ; 276 ; 303 ; 310 ; 312$ n. $173 ; 362$ e n.39.

Alfídio, M. (avô de Lívia, segundo inscrições): 186 n.129.

Ália (afluente do Tibre): 155.

Alpes (famosa cadeia de montanhas): 341 n.7.

Ambitárvio (localidade da Germânia, abaixo da junção do Mosela com o Reno): 37.

Âmpio (pompeiano; biógrafo): vide índice de autores antigos.

Âncio (cidade costeira do Lácio, a sul de Roma; local de nascimento de Calígula e de Nero): 37; 38; 122; 124; 164; 165; 167; 192 n.151; 224; 320 n. $31 ; 362 ; 365$.

Anfiteatro Flávio (anfiteatro construído pelos Flávios; conhecido como Coliseu, por estar junto ao colosso, construído por Nero): 159; 179.

Aniceto (liberto, mestre de Nero): 124 n.135.

Ânio Cimbro (orador; elevado à pretura por M. António): 61.

Antioquia (Capital da Síria): 216.

Antónia, Cláudia (filha de Cláudio e Élia Petina): 228 n.135.

Antónia Menor (filha de M. António; mãe de Germânico e Cláudio): 110 e n. $65 ; 123 ; 128 ; 175 ; 186$ e n. $128 ; 190$; 221 n. 105, 107; 321; 365; 366; 377.

Antoninos (nome genérico dado à dinastia que começa com Nerva e termina com Cómodo): 24; 91; 211; 315 n. $185 ; 378$.

António, A. (filho mais velho de M. António): 139.

António, M. (triúnviro): 26; 38 e n.36; 41; 44; 45 e n.84, 86; 47 e n.95; 49; $61 ; 64 ; 74 ; 78 ; 105 ; 106$ e n. $43 ; 118$ n.112; $119 ; 123 ; 139 ; 174 ; 186$ n.128; 192 n.155, 156; 200 n.3; 207 n.39; 209 n.50; 222; 240 e n.203; 253 e n.264, 265; 276; 311; 312 n.172; 331; $332 ; 357 ; 359 ; 365$.

António Primo (enérgico general, natural de Tolosa, partidário dos Flávios): 210; 210 n.52; 290.

Apeninos (cordilheira ao longo da Itália Central): 154.

Ápio Cláudio Ceco (censor em 312; cônsul em 307 e 296 a.C. Ligado à construção da Via Ápia): 335 e n.26.

Ápio Silano (acusado por Messalina e Narciso de atentar contra a vida de Cláudio e executado): 264 e n.299; 323 n. 44 .

Apolónia (cidade do sul da Ilíria, em frente a Brundísio): 207.

Apolónio Mólon (mestre de oratória de Rodes): 98.

Apolónio de Tíanos (neopitagórico e asceta com fama de santo do séc. I d.C.): 232 n. 157.

Appi Forum (cidade fundada por Ápio Cláudio na Via Ápia): 335 n.26.

Apuleia Varila (filha de Octávia Maior e de Sexto Apuleio, julgada por adultério no tempo de Tibério): 374 n.132.

Aquileia (cidade do norte de Itália): 118.

Aquílio Nigro (fonte rara de Suet.): vide índice de autores antigos.

Aquitânia (região sudoeste da Gália): 140.

Arato (general impulsionador da liga Acaia contra o domínio macedónio): 208 n. 40

Arcádia (região do Peloponeso): 144.

Argivo (administrador de Galba): 287.

Aristómenes (herói da resistência de Messene contra Esparta): 208 n.40.

Aristóteles (o famoso filósofo): Vide índice de autores antigos. 
Arménia (protectorado romano a este da Ásia Menor, entre os impérios romano e parto): 119; 121 n.121; 169; 300; 357; 385.

Arrecino Clemente (cunhado de Tito, vítima de Domiciano): 189 e n.139; 366.

Árria (heróica esposa de Cecina Peto, que se suicidou para dar coragem ao marido): 204 n.21; 233 n.166.

Artábano III (rei dos Partos da $1^{\text {a }}$ metade do séc. I d.C.): 168; 219.

Artemidoro de Cnidos (mestre de Letras Gregas, filho de Teopompo e amigo de César): 277 n.34.

Aruleno Rústico, Quinto Júnio (filósofo estóico, vítima de Domiciano, autor de um panegírico de Peto Trásea): 22; 24 n.47, 48; 232; 233 n.164, 166, 170.

Ascletarião (astrólogo): 293 e n.104; 320.

Ásia (província romana, que, no Império, fazia fronteira a norte com a Bitínia, a Sul com a Lícia; a este com a Galácia e a oeste com o mar): 39; 98 e n.6; 101; 216 e n. $79 ; 281 ; 332$ e n. $14 ; 369$.

Asiático (liberto de Vitélio): 254; 324; 365 e n.65.

Asínio Epicado (conspirador contra Augusto): 200 n.5.

Asínio Galo (neto de Asínio Polião; conspirou contra Cláudio): 249.

Asínio Marrucino (irmão de A. Polião): 345 n. 28.

Asínio Polião (famoso político do séc. I a.C., homem de letras, historiador, patrono das artes): víde índice de autores antigos.

Ateio Filólogo (gramático do séc. I a.C.): víde índice de autores antigos.

Atenas (na Ática: mais influente polis da Grécia antiga - centro de estudos): 146 n. 51.

Ático, Pompónio (cavaleiro amigo de Cornélio Nepos e de Cícero, com o qual este manteve assídua correspondência): 22; 118; 119.

Ático, Q. Cecílio (nome que Pompónio Ático recebeu por adopção).

Atrébates (tribo da Gália que se estendeu para a Britânia): 110 n.66.

Atrium Libertatis (edifício onde estavam os arquivos dos censores e onde se alojavam hóspedes; Asínio Polião criou ali a $1^{\text {a }}$ biblioteca pública): 286 n.72.

Aufídio Basso (historiador da $1^{\mathrm{a}}$ metade do Séc. I d.C.): vide índice de autores antigos.

Aufídio Lurcão (avô de Lívia, segundo Suetónio): 186 e n.129.

Augusto, Gaio Júlio César (imp. 31 a.C-14d.C.): 15; 21 en.31, 32; 23 n.44; 25; $26 ; 34$ e n. $12 ; 35$ n.22; 36 e n.27; 38 e n. $36,41,42 ; 39$ e n. $44 ; 41$ e n. 61 ; 42 e n. $68 ; 43$ e n. $71 ; 44 ; 45$ e n. 84 , 85; 46; 47 e n.95; 48; 49 e n.102, 103, $104 ; 50$ e n. $105 ; 55 ; 60 ; 61 ; 62 ; 64 ; 72$; $73 ; 74-75 ; 78 ; 79 ; 80 ; 82 ; 84$ e n.54; 85; 89; 90; 95; 97; 99; 102-106; 107 n.46; 109; 112 n.78; 117; 118; 119 e n.117; $121 ; 122 ; 123 ; 124 ; 128 ; 132$ n.171; 139-140; 144; 145; 145 n.50; 146 n. $54 ; 147$ n.61; 148 n.67; (153); 159; $162 ; 164 ; 165 ; 166$ e n. $32 ; 167$ e n.34; 170 e n.47; $171 ; 172$ n.51; 173; 174; 175; 177; 179; 181 n.102, 104; 182; 186; 186 n.128; 192 n.155; 194; 196; 199; 200 e n.3,4, 5; 201 e n.6; 204 n.23; 205 e n.25, 27; 207 e n.34; 208 e n. $42 ; 208$ n. $43 ; 209$ e n.50; 210 ; 214; 216 e n.83; 218 e n.94; 220; 222 n.110; 224; 224; 226; 238 n.195; 239-243; 244; 247 n.237; 252-253; $255 ; 261$ n.287; 270; 271-273; 274 e n.14; 280 n.47; 282; 298; 309-310; 312-313; 319; 320 e n.29; 321; 322 e n. $36 ; 323$ n. $46 ; 324 ; 331-332 ; 334$; 336; 337; 339; 341 e n.7; 342; 343 e n. $14 ; 344 ; 345 ; 346$ e n. $35 ; 352-353$; 355 e n.84; $358 ; 359 ; 360$ e n.19, 23; 361; 363; 364 n.59; 365; 366; 367; 
$368 ; 369 ; 370 ; 371 ; 372 ; 375 ; 376$; 377; 378 e n.166; 379; 383-384; 385; 386.

Aulo Cecina (autor de um livro contra César que o obrigou a exilar-se): vide índice de autores antigos.

Aulo Cecina Alieno: vide 'Cecina'.

Aulo Pláucio (governador da Britânia no tempo de Cláudio): 110 n.68; 191; 357.

Aulo Pláucio (suposto amante de Agripina e vítima de Nero): 228 n.136.

Aventino (uma das colinas de Roma): 289 e n. $82 ; 348$.

Averno (famoso lago da campânia): 171.

Áxio (senador rico, destinatário de cartas de Cícero perdidas): 40 e n.53.

Bacantes (ou Ménades; mulheres que celebravam o culto de Dioniso ou Baco): 286 n.72; 312.

Baias (Cidade da Campânia, destino de férias da nobreza romana): 39; 46; 72; 168; 169; 181 n.101; 184; 186; 197; 221 n. $105 ; 255$ n.270; 256; 280; 384; 385.

Balbilo (astrólogo do tempo de Nero): 184.

Balbo, Cornélio (homem de confiança de César): 47 e n. 97.

Baleares (ilhas): 140.

Basílides (sacerdote da Judeia): 113 n.84.

Basílides (liberto ou ilustre do Egipto): 143 e n.38.

Baulos (povoado entre o Miseno e Baias): 186.

Behistun (ou Bisitun: local da famosa inscrição gravada por Dario I): 16 n.6.

Belgas (povo guerreiro do norte da Gália; algumas tribos instalaram-se na Britânia): 110 n.66.

Berenice IV (filha e sucessora de Ptolemeu XIII Auletes): 268 n.315.

Berenice (filha de Herodes Agripa I e amante de Tito): 117 n.110; 246 e n.245; 322 e n.38; 377 n.157.

Berilo (liberto de Nero): 124 n.135.

Betilieno Capitão (procurador vítima da crueldade de Calígula): 279 n.46.

Betríaco (entre Cremona e Mântua, lugar de duas batalhas, em 69 d.C.: entre as tropas de Otão e Vitélio e entre os partidários de Vitélio e os de Vespasiano): 113 e n.88; 155 n.88; 248; 287; 306 e n.150; 307; 348; 367 n. 83 .

Bíbulo, M. (opositor e colega de César como edil, pretor e cônsul): 40 e n. 52; 44; 77; 80; 100; 101.

Bitínia (território no noroeste da Ásia Menor): 73; 74 n.10; 77; 81; 97; 98 n.6; 332 n.1.

Bizâncio (actual Istambul): 205 n.27.

Bonónia (a actual Bolonha): 139.

Bóter (liberto de Cláudio): 261.

Boudica (rainha revoltosa da Britânia no tempo de Nero): 177 n.74.

Britânia (nome da província romana que ocupava parte da actual Grã -Bretanha): 39 n.49; 108 e n.54; 110; 115 n.99; 177 e n. 74; 201; 226; 232 n. $162 ; 257$ n. 274,$275 ; 259 ; 259$ n.281; 300; 386 n.17.

Britânico (filho de Cláudio e de Messalina): 36; 111 n.70; 114 e n.93; 115 e n.99; $124 ; 125$ e n.138; 193; 194 n. $158 ; 261$ n.287; 266 n. 304; 298 e n. $120 ; 322$ e n. $38 ; 366$.

Brundísio (importante porto da costa do Adriático; actual Brindes): 138.

Bruto, Décimo Júnio (também chamado Albino; íntimo e assassino de César): 104; 277; 309 n.163; 311.

Bruto, L. (o primeiro cônsul de Roma): 265 n.302; 309.

Bruto, M. Júnio (filho de Servília e um dos mais destacados assassinos de César): 24. n.49; 25 n.51; 41 n.61; 42; 44; 47; 77; 79; 104; 107; 
141 n. $27 ; 153$ n.79; 218 n.94; 278 e n.39; 309 n.163; 312; 322 n.36; 337.

Bucéfalo (famoso cavalo de Alexandre): 212.

Burro, Afrânio (prefeito da guarda pretoriana e conselheiro de Nero): 111 n. 70; 228 e n. $137 ; 357$ n.1.

Calígula: Gaio César Germânico (imp. 37-41d.C.): $34 ; 36$ e n.30; 37-38 e n. 36,$38 ; 39$ e n. $45 ; 42$ n. $65 ; 43 ; 47 ; 50$ e n. $105 ; 51$ n. $107 ; 58 ; 59 ; 61 ; 65 ; 66$; $72 ; 73 ; 74$ e n.12; 75; 78; 80; 81; 82; $83 ; 85 ; 86 ; 87 ; 88 ; 89 ; 90 ; 106 ; 108$; 109 n.57; 110 e n.62, 65; 111; 112 e n.79; 114 e n.93; 122-123; 124 e n.133; $125 ; 129 ; 130$ e n.159, 160; $147-148 ; 149 ; 150 ; 151 ; 155 ; 157$; $159 ; 160$ e n. 5,$6 ; 161 ; 163$ e n. 19 , 20; $166 ; 168$ e n. $37 ; 169$ e n.39; 170; $171 ; 172 ; 175 ; 176$ e n.71, 73; 180 e n. $93,95,96,97 ; 181$ e n. 98,$102 ; 182$; 183 e n. $109 ; 184$ e n.116, 117,118 , 119; 185; 186 n.127, 128; 190; 191; 192 e n. $155 ; 193 ; 193$ n. 155,$156 ; 195$ n.162; 196 e n.165; 202 e n.14; 204; 211; 212; 220-226; 227; 228; 229; 234; 236; 239 e n. $199 ; 242 ; 244 ; 249$ n.250; 250; 255-258; 259; 265; 277 n.32; 279-282; 284 n.64; 285 e n.70; 286; 290; 291; 292 n.100; 294; 295; 296 e n.111; 297; 298 n.119; 299; 300; 309; 313; 317; 318 e n. $15 ; 319$ e n. $20 ; 320$ e n. $29 ; 321 ; 322 ; 323$ n. 46 ; 324 e n. $47 ; 325 ; 329 ; 338-339 ; 340$; 346; 347; 348 n.51; 349; 350-351; 352; 354-355; 356; 362 e n. $35 ; 363$; 364 e n. $51 ; 365-366$ e n. $71 ; 367$ n. 83; $368 ; 371$ e n. $112 ; 372 ; 373 ; 375 ; 376$; 379; 384 e n. $4 ; 385 ; 386 ; 387$.

Calisto (liberto de Calígula; a libellis de Cláudio): 279 n. 46.

Calpúrnia (3 $3^{\text {a }}$ esposa de César): 101 n.20; 277.

Camilo: vide 'Fúrio'.

Campânia (costa Ocidental de Itália, de ambos os lados do golfo de Neápolis):
196; 201 e n.9; 213; 214 n.69; 289.

Campo de Marte (vasta zona fora das muralhas de Roma, usada para exercícios militares e comícios por centúrias) : 192 n.151; 259 n.281.

Caninefates (povo do delta do Reno): 257 n. 275 .

Cano (flautista): 269.

Cantábria (costa montanhosa do norte da Hispânia, a este das Astúrias): 109 n.58.

Capitólio (colina de Roma na qual se elevava o templo de Júpiter): 100 n.16; 128; 132; 151; 164; 169; 170; $179 ; 181 ; 256 ; 257 ; 288$ e n. $79 ; 293$; 315; 338; 348; 349; 359 n.15; 366 n. $71 ; 367$ n. $83 ; 370$.

Cápreas (actual ilha de Cápri, onde Tibério se instalou no final da vida): 40; 50 n.106; 59; 72; 74; 79; 86; 87; $120 ; 123 ; 130$ e n. $161 ; 172 ; 183 ; 194$; 199; $214 ; 215$ e n.78; $217 ; 218$ e n.90; 271; 297; 298; 310; 321; 345; 346; $384 ; 385$.

Cápua (um das principais cidades da Campânia, ligada a Roma pela Via Ápia, em 312 a.C.): 47; 214; 277 e n. 30; 280; 280 n.47.

Carmelo (divindade e monte da Palestina): 113 e n. $85 ; 143$ n. $38 ; 320$ n.31.

Cárnulo (condenado no principado de Tibério): 188; 189.

Cássio, Gaio (mentor do assassínio de César; suicidou-se depois da batalha de Filipos): 24. n.49; 25 n.51; 41 n.61; 42; 84; 104 n. 37; 141 n.27; 153 n.79; 218 n. $94 ; 229 ; 279$ n. $44 ; 312 ; 337$.

Cássio de Parma (amigo de Bruto e Cássio, participou também na conjura contra César): 39; 49 n. 102; 331.

Cássio Longino, G. (famoso jurisconsulto, irmão do marido de Drusila, irmã de Calígula; governador da Ásia no principado de Calígula e da Síria no tempo de Cláudio; exilado por Nero para a 
Sardenha): 229; 280 e n.48.

Cássio Quérea (tibuno da coorte pretoriana e assassino de Calígula): 66 n. $167 ; 78 ; 160$ n. $5 ; 280 ; 281 ; 282$.

Cássio Severo (famoso orador do tempo de Augusto): 38 .

Catão, o Censor, M. Pórcio (famoso político, orador e prosador $\mathrm{da} 1^{\mathrm{a}}$ metade do séc. II a.C.; protótipo da severidade romana): 23 n.41, 45.

Catão de Útica, M. Pórcio (neto do anterior e inimigo de César; suicidou -se em Útica, África, em 45 a.C.): 25 n. $51 ; 45$ e n. $85 ; 80 ; 99 ; 101$.

Catilina (promotor de uma conspiração para tomar o poder, debelada por Cícero): 99; 100; 103 n.30; 135 n.3.

Catos (antigo povo germânico; poderoso inimigo de Roma no séc. I d.C.): 230.

Cátulo: vide 'Quinto'.

Cecílio Ático, Q.: vide 'Ático'

Cecina Alieno, Aulo (comandante de uma legião na Germânia Superior; era amigo de Vespasiano, mas, implicado numa conspiração, foi morto por ordem de Tito): 116 e n.107; 153 n.82; 210 n. 53; 232; 246 n. $235 ; 275$ n.24.

Cecina Peto (implicado na conjura de Fúrio Camilo contra Cláudio, suicidou-se juntamente com a heróica esposa Árria): 204 n.21; 233 n.166.

Cénis (a amante de Vespasiano): 110 e n.65; 235; 245 n.226; 377.

César: vide 'Gaio', 'Júlio', 'Lúcio'.

Cesareia (nome adoptado por várias cidades em homenagem a Augusto): 310.

Cesarião (filho de Cleópatra e, supostamente, de César): 44; 139.

Cesélio Basso (cartaginês "sonhador"): 228 n.131.

Cesónia, Milónia (4a esposa de Calígula, assassinada a seguir ao imperador): 190 e n.145; 196; 222; 225 e n.120;
279 n. 46; 282 n. $56 ; 303$ n. 137; 385.

Chrestus (agitador Judeu de Roma ou uma referência vaga a Cristo): 367 e n.78.

Cícero (o famoso orador): vide índice de autores antigos.

Cimbros (povo germânico combatido por Mário; originários da Jutlândia, actual Dinamarca) : 167.

Címon (estadista e general ateniense do séc. V a.C.): 16.

Cingónio Varrão (condenado por Galba como cúmplice de Ninfídio Sabino): 84.

Cipião Africano (vencedor de Aníbal em Zama): 208 n. 40.

Cipião Emiliano (neto de C. Africano por adopção; vencedor de Cartago e de Numância): 360 n.16.

Cipro (actual Chipre): 320 n.31.

Circo Máximo (situado entre o Palatino e o Aventino):163; 164; 165.

Cirene (antiga colónia grega entre Cartago e Alexandria; formava província com Creta): 110.

Ciro (rei da Pérsia entre 559 e 530 a.C.): 18 e n. $12 ; 279$ e n.43.

Cívica Cereal, C. Vetuleno (Senador romano, condenado à morte por Domiciano): 231; 231 n.156; 233 n.170.

Cláudia (irmã de Cláudio Pulcro): 335.

Cláudia (vestal): 335.

Cláudia (filha de Cláudio e Pláucia): 261 e n.289.

Cláudio: Tibério Cláudio César Augusto Germânico (imp. 37-41 d.C.): 21 e n. $27 ; 36$ e n. $27 ; 42$ n.66; 43 n. $70 ; 47$ n. $96 ; 50$ e n. $105 ; 51$ e n. $107 ; 59 ; 73$; 78; 79; 80; 81; 82; 86 n.60; 87 n.69; $88 ; 89 ; 90 ; 106 ; 108$ e n. $54 ; 110 ; 110$ n.68; 111; 114; 124 e n.133; 125; $128-130 ; 131 ; 133 ; 148$ e n.67; 149; $150-152 ; 155 ; 159 ; 170 ; 172 ; 175$; 176; 177 e n.84; 184; 193; 198; 201 n.6; 204; 206; 209; 210; 237; 238; 247 
n.240; 249-251; 254; 258-267; 273 n.10; 290; 296 n.111; 298-299; 298 n.119; 303; 309-310; 319; 320 n.29; 321; $322 ; 323$ e n. $44 ; 3243$ n.52; 325; 334 e n.23; 338; 339; 340; 343-344; 348 n.51; 361; 365; 366; 367 e n.77; 368; 372; 374; 375 e n.138; 376 e n.150; 379; 386 n.17; 388.

Cláudio Cáudex (irmão de Ápio Cláudio Ceco, obteve uma vitória contra os cartagineses em 264 a.C.): 335 .

Cláudio Druso (ou Russo; filho de Ap. Cláudio Ceco): 335 e n.26.

Cláudio Marcelo, M. (cônsul em 51 a.C., opositor de César; o protagonista do Pro Marcello de Cícero): 102.

Cláudio Nero, Tibério ou Gaio (?) (venceu Asdrúbal em Metauro, em 207 a.C., quando este se tentava reunir a Aníbal): 335.

Cláudio Nero, Tibério (pai do imp. Tibério): 118.

Cláudio Pulcro, P. (cônsul em 249 a.C., filho de Cláudio Ceco, sofreu uma pesada derrota naval em Drépano): 335.

Cláudio Regiliano, Ápio (decênviro que atentou contra Virgínia): 335.

Clemente (escravo de Agripa Póstumo, neto de Augusto): 147.

Cléon (famoso político ateniense): 16 n.4.

Cleópatra (VII; A famosa rainha do Egipto: amante de César e, depois, de António): 139; 212; 246 n.235; 253 n.264, 265.

Clodiano (ordenança de Domiciano): 296.

Clódio Macro, L. (governador da África em 68; foi depois executado por Galba): 142; 303 n.138.

Clódio Polião (político do tempo dos Flávios): 131

Clódio Pulcro (dirigente popular do fim da República, inimigo de Cícero; foi assassinado em 52 a.C.): 101; 335.

Clúnia (cidade do norte da Hispânia):

Clúvio Rufo (político e historiador, cuja obra cobriria os principados de Calígula a Otão): vide índice de autores antigos.

Colónia Agripinense (capital da Germânia Inferior, actual Colónia): 154.

Colósseros (alcunha de Ésio Próculo, vítima de Calígula): 184; 322 n.37.

Confluentes (posto da confluência do Mosela e do Reno, actual Coblença): 37.

Corbulão (general que, no principado de Nero, resolveu o conflito com os Partos a propósito do trono da Arménia): 357

Corinto (capital da Acaia): 164 n.24; 170; 171; 188 n.136; 211.

Cornélia (mãe dos Gracos): 360 n.16.

Cornélia (vestal sentenciada por Domiciano): 59 n.136; 231 e n.149.

Cornélio Aquino (comandante de uma legião na Germânia nas convulsões de 68-69 d.C.): 142 n.29.

Cornélio Cina (cunhado de César, republicano, terá aprovado o assassínio nos idos de Março): 312.

Cornélio Galo (o poeta e prefeito do Egipto): 61 n.148.

Cornélio Lacão (íntimo de Galba; comandante da guarda pretoriana): 237.

Cornélio Marcial (militar partidário dos Flávios): 288 n.79.

Córsega (ilha que com a Sardenha formava província desde 238 a.C.): 100 n.19.

Cós (ilha do Egeu): 120 n.120.

Cosa (cidade da Etrúria): 109.

Cota Messalino, M. Aurélio (amigo de Ovídio; alvo de uma série de acusações, foi protegido por Tibério): 201 n.10. 
Crasso, Lícinio (Um dos elementos do chamado $1^{\circ}$ triunvirato; derrotado na batalha de Carras contra os Partos): 40; 100; 102; 119; 240; 357.

Cremona (cidade do norte de Itália; importante base militar): 143 n.37, 39; 210 n.52; 287 n.77.

Cremúcio Cordo (historiador condenado por Tibério): vide índice de autores antigos

Creta (ilha que formava província com Cirene): 110.

Crispo, Passieno (sobrinho neto do historiador Salústio, casa com Agripina, a mãe de Nero, quando esta regressa do exílio): 124 .

Cristo, Jesus: 207; 367 n.78.

Crítias (sofista, e um dos trinta tiranos de Atenas: Platão menciona-o em vários diálogos): 33 n. 8 .

Cúria (edificio da reunião do senado): 101; 148; 151; 167; 189; 219 n.95; $277 ; 314$

Curião pai (orador, amigo de Cícero; escreveu um diálogo contra César): 40; 44; 45 e n. 83; 77; 78; 99 n. 14; 354 n.71.

Curião filho (filho do anterior; apoiante de César; tenta evitar a guerra civil): 44 .

Cybiosactes ('mercador de peixe salgado': alcunha que os alexandrinos deram a Vespasiano pela sua suposta avareza): 268.

Dácios ou Dacos (também denominados Getas; povo que vivia na zona entre os Cárpatos e o Danúbio): 214 n.73; 230.

Dacos: vide 'Dácios'.

Dalmácia (província romana na costa do Adriático a norte do Epiro): 306.

Dâmocles (cortesão de Dioniso, tirano de Siracusa): 223.

Danúbio (rio - fronteira do Império Romano): 35 n.22.

Dario (jovem refém parto): 168 e n.37;
385.

Décimo Labério (cavaleiro autor de mimos): vide índice de autores antigos.

Delfos (local do famoso oráculo de Apolo; centro sagrado de todo o mundo grego): 320 n.31.

Dídimo (detractor do De Rep. de Cícero; talvez D. Calcentero): 57 n.128.

Dido (rainha, mítica fundadora de Cartago): 228.

Diomedes (herói mítico da saga de Tróia): 188 n.137.

Dolabela, Cornélio (partidário de Pompeio e, depois, de César): 44; 77.

Domícia (ou Domicia Lépida Maior; tia de Nero; por vezes confundida com Lépida Menor; poderosa rival de Agripina): 190

Domícia Longina (esposa de Domiciano): 132; 231 n.151; 233; 236 n.185; 254 e n. $269 ; 275$.

Domiciano, Tito Flávio (imp. 81-96 d.C.): 24 n. 47,$48 ; 24$ n. $50 ; 25$ n. 51 ; 26; 33; 35 n. $22 ; 36$ e n. 26,$27 ; 40 ; 47$; 49 n. $104 ; 50$ n. $105 ; 58 ; 59$ e n. $135 ; 65$; 66; 72; 78; 80; 81; 83; 85; 86 n.60; 87; $91 ; 114$ n.91; 115; 131-132; 133; 149 -150; 157; 159 e n.2; 163 n.20; 166; $170 ; 171$ n. $48 ; 172$ e n. 55,$56 ; 173$ e n. $59 ; 177$ e n.80; 178 e n.85; 179 n.88; 181 e n.105; 182; 183 n.112; 189 e n.139; 190; 195 e n.162, 163; 205; 206; 210 e n.54; 211 n.57; 230 -236; 233; 239 n. $199 ; 244 ; 246$ n.234; 254 e n. 268,$269 ; 271 ; 274 ; 275$ e n.24, 26; 291-296; 304 n.143; 309; 314 e n.178; 315 e n.183; 317; 318 e n. $15 ; 319 ; 321 ; 322 ; 331 ; 338 ; 340$; $348-349 ; 352 ; 357 ; 358 ; 362 ; 364 ; 366$ e n. $71 ; 367$ n. $83 ; 368$ e n. $89 ; 370 ; 371$; $372 ; 373 ; 375 ; 376 ; 377 ; 378 ; 379 \mathrm{e}$ n. $170 ; 384$ e n. $6 ; 385 ; 389$.

Domício Aenobarbo, L. (feroz opositor de César: pretor em 98 a.C.; cônsul em 54 a.C.): 102; 336. 
Domício Aenobarbo, L. (avô de Nero; ligado à família de Augusto; Cônsul em 16 a.C.): 336.

Domício Aenobarbo, Gneu (pai de Nero): 108 e n.52; 124 e n. $133 ; 125 ; 320$ n. $29 ; 337 ; 365$.

Domitila: vide 'Flávia'.

Domus Aurea (palácio de Nero construído depois do incêndio de 64 d.C.): 67; 125 n.137; 171 e n.50; 191 e n.150; 193 n. $157 ; 228 ; 229-230 ; 248 ; 304$ e n. $142 ; 371 ; 385$ e n.13.

Domus Transitoria (palácio de Nero que ardeu no incêndio de 64): 191 n.149.

Doríforo (liberto de Nero; Pitágoras, segundo Tácito): 78 n.29; 81; 86; 163 n.18; 171; 197 e n.172; 227 n.128; 254; 385 n.12.

Druidas (sacerdotes celtas): 367.

Drusila, Júlia (filha de Germânico; irmã predilecta de Calígula): 74; 186 n.127; 196 e n. $165 ; 221 ; 319$.

Druso (avô de Tibério): 118; 188; 201 e n. $9 ; 219$.

Druso (filho de Lívia; pai de Cláudio e Germânico): 25; 118; 119; 129; 216; 271; 272; 319 n.22; 338; 339; 340; $344 ; 366$ e n.69.

Druso (filho de Germânico): 122 n.123; $185 ; 217 ; 336$.

Druso (filho de Cláudio e Pláucia): 261.

Druso César (filho de Tibério): 39 n.44; 118; 119; 128 n.151; 145; 147; 217.

Durotriges (uma das tribos celtas da Britânia): 110 n.66.

Eárino (favorito de Domiciano): 172 n.55.

Egipto (país do Nilo): 61 n.148; 116 n. $105 ; 142 ; 143$ n. $38 ; 175 ; 193$ n. 155 ; 208 n. $42 ; 362$ n. $39 ; 367$.

Elba (rio da Europa Central): 339 n.38.

Elêusis (demo da Grécia onde se realizavam os célebres mistérios): $203 ; 243 ; 321 ; 367$.

Elefântis (autora de poesia erótica): 194.
Élio Lâmia (primeiro marido de Domícia Longina e vítima de Domiciano): 232 e n. $160 ; 233$ n.170.

Emília Lépida (bisneta de Augusto; prometida a Cláudio): 201 n.6.

Emílio Paulo, L. (marido de Júlia, neta de Augusto, e conspirador): 200 n.6.

Emílio Recto (prefeito do Egipto): 175.

Eneias (herói troiano, mítico fundador de Lavínio): 80 n.33.

Énia Névia (esposa do prefeito Mácron): 222.

Epafrodito (liberto secretário de Nero): 68 e n.173; 292; 304 e n.143; 307.

Éprio Marcelo (conselheiro íntimo de Vespasiano, acusado de conspiração por Tito): 210 n.53; 246 n.235.

Escribónia (2a esposa de Augusto e mãe de Júlia): 45 e n.84; 200 n.5.

Escribónio Libão (bisneto de Pompeio Magno e sobrinho de Escribónia, conspirou contra Tibério): 147.

Escribónio Próculo (senador envolvido numa conjura contra Calígula e executado): 183 n.114.

Espártaco (o famoso líder da revolta de escravos de 73 a.C.): 103 n.30.

Espículo (gladiador): 227.

Esporo (eunuco de Nero): 67 n.173; 86; 187 n.132; 197 e n.171, 172; 227 e n. $128 ; 254 ; 385$ n.12.

Espurina (harúspice do tempo de César): $277 ; 278$ n.35.

Esquilino (uma das sete colinas de Roma): 371 n.114.

Estatília Messalina (terceira esposa de Nero): 228 n.135; 307 e n.156.

Estatílio Corvino (Neto de Valério Messala Corvino; conspirou contra Cláudio): 249

Estéfano (administrador de Flávia Domitila; assassino de Domiciano): 66 n.169; 295 e n.108; 296.

Etrúria (região a norte do Lácio): 109. 
Êunoe (rainha da Mauritânia, amante de César): 44; 212.

Eurípides (tragediógrafo): vide índ. Autores antigos.

Êtico (um auriga): 160.

Evágoras (famoso rei de Salamina, em Chipre, objecto de um panegírico da autoria de Isócrates): 17 e n.10; 379 n.171.

Fábio Rústico (historiador do tempo de Cláudio e Nero, indicado por Tácito como fonte): vide índice de autores antigos.

Fábio Valente (comandante de uma legião na Germânia Inferior, em 68 d.C.; apoiou Galba, mas instigou, depois, a aclamação de Vitélio): 142 n.29; 153 n. 78,82 .

Fáon (liberto de Nero, em casa de quem este se refugiou quando perseguido): $48 ; 67$ e n. $172-173 ; 71 ; 289 ; 304$; 305.

Fânia (filha de Trásea Peto e esposa de Helvídio Prisco filho): 233 n.166.

Fânio Cepião (conspirou contra Augusto e foi condenado por intervenção de Tibério): 119 e n.117; 357.

Fárnaces (II, filho de Mitridates VI, derrotado por César na batalha de Zela): 138.

Farsalo (cidade da Tessália onde César derrotou Pompeio): 40; 41 n.57; 135; 138; 332; 359 n.9.

Fávor (mimo do tempo de Vespasiano): $269 ; 324$

Febe (uma liberta de Augusto): 200.

Febo (liberto de Nero): 111 n.74; 178 n.87.

Fídias (o célebre escultor grego): 16 n.7; 180.

Filipe da Macedónia (pai de Alexandre Magno): 18; 280.

Filipos (cidade da Macedónia, local da vitória de Octávio e Marco António sobre Bruto e Cássio): 104; 105; 205;
363 n. 46 .

Fílis (ama de Domiciano): 296.

Flávia Domitila (esposa de Vespasiano): $110 ; 268$ n. $313 ; 377$.

Flávia Domitila, (sobrinha de Domiciano e esposa de Flávio Clemente): 292 n. $98 ; 295$ e n.108.

Flávio Clemente (primo de Domiciano, cônsul em 95 d.C., executado por impiedade): 292 e n.98; 295 n.108, 109; 366.

Flávio Petrão, Tito (avô de Vespasiano): 332; 333 e n.19.

Flávio Sabino (pai de Vespasiano): 39; $332 ; 333$

Flávio Sabino (irmão mais velho de Vespasiano, morto em 69 d.C., na sequência do ataque ao Capitólio): 288 n.79; 333 e n.16.

Flávio Sabino (sobrinho de Vespasiano): 232 e n. $163 ; 233$ e n. $167 ; 366$.

Flávios (dinastia constituída por Vespasiano, Tito e Domiciano): 25; 39; 52; 61; 90; 96; 113 n.82; 116 n.105; 131; 178; 195; 205; 210; 270 n. $319 ; 287 ; 288$ n.79; 293 n. $103 ; 296$; 314; 315; 318; 332 n.15; 333; 338.

Floro: vide 'Méstrio'.

Fonteio Capitão (cônsul ordinário de 68 d.C.; legado na Germânia Inferior em 69): 142.

Foro (local da vida pública de Roma): 101; 151; 154; 155; 363 n.50; 366 n.73.

Fúcino (lago que Cláudio tentou drenar): 325.

Fúlvia (esposa de M. António): 139; 200 n.3.

Fundos (povoado da Via Ápia): 182 n.129.

Fúrio Camilo Escriboniano (tentou rebelar-se contra Cláudio): 204 e n. $21 ; 249 ; 263 ; 334$.

Gades (cidade da Hispânia, actual Cádis): 98; 320 . 
Gaio César (neto de Augusto, filho de Júlia e Agripa): 42 n.69; 120; 121; 145; 200; 201 n.8; 241; 319.

Gaio Druso (incerto): vide índice de autores antigos.

Gaio César (irmão mais velho de Calígula falecido na infância): 204 n.23.

Gaio Graco (o famoso tribuno da plebe de 123 e 122 a.C., irmão de Tibério Graco): 21.

Galba, Sérvio Sulpício (imp. Jun. de 68 Jan. 69 a.C.): 36 n.27; 47; 50 n.105; 51; 52; 63 e n. $159 ; 66 ; 67$ n.172; 72; $76 ; 79 ; 82 ; 84 ; 96 ; 97 ; 106-109 ; 113$ n.87; 116 e n.107; 117; $127 ; 131$; $140-142 ; 143 ; 144 ; 152$ n.78; 153 e n.79; 153 n.81; 154; 155; 156; 163 n.19; 178 n.83; 199; 203; 204; 207; 208 ; 209; 210; 236-238; 243; 244 n. $225 ; 256$ n. $272 ; 269$ e n. $316 ; 282$ 287; 290; 293; 295; 296 n.111; 300 e n. $128 ; 301$ e n. $131 ; 302$ e n.134; 305 e n.145; 306; 307 e n.154, 156; 308 e n. $161 ; 309 ; 314 ; 315 ; 318$ e n. $15 ; 320$ e n. $29 ; 322$ e n. $36 ; 337 ; 346-347 ; 352$; $354 ; 357 ; 363 ; 365 ; 369 ; 370 ; 375$; $376 ; 379$.

Gália (s) (ou Gália Transalpina, dividida por Augusto em 4 províncias): 38; 44 n.78, 80; 56; 78; 101; 102; 132; 136; $138 ; 140 ; 153$ n.79; 194; 203; 212 n.64; 236; 244 n. 225; 300; 301 n.130, 131; 320; 324 n. $47 ; 341$ n.7; 354 n.70; 362 n. $39 ; 386$.

Gália Citerior (ou Cisalpina): 135; 333 n.19.

Gálio, M. (senador que adoptou Tibério): 118 e n.112.

Gálio, Quinto (pretor, vítima de Augusto): 42; 118 n.112; 182.

Galli (sacerdotes castrados de Cíbele): 253 n. $262 ; 303$.

Galo: vide 'Asínio'

Gamala (cidade da Judeia): 116.

Gaugamelos (local da vitória de Alexandre sobre Dario III da Pérsia, em 331
a.C.): 106 .

Gauleses (Galli: nome dado aos povos celtas que habitavam as Gálias, Transalpina e Cisalpina): 79; 153 n. $79 ; 155 ; 300$.

Gemelo: vide 'Tibério'.

Gemónias (lanço das escadas do Foro ao Capitólio): 185; 219 e n.95; 290; 313; 348.

Germânia (designação genérica para os povos que habitavam a este do Reno e para as províncias junto a este rio): 39 e n. $49 ; 108$ e n.54; 109; 110; 115 n.99; 118; 119; 122; 130; 132; 133; 142; 143 n.36; 147; 153 n.79; 166; 248; 283 n.59; 286; 295; 323 n.46; 339 n. 38; 346; 347; 386 n.16.

Germânia Inferior (província da parte baixa do Reno, com capital em Colónia Agripinense): 131.

Germânia Superior (província da parte alta do Reno, com capital em Mongotiacum, actual Mainz): 256 n. $272 ; 283$ e n. 61.

Germânico (brilhante general, filho de Druso e Antónia Menor; casado com Agripina Maior; pai de Calígula e Agripina Menor, entre outros): 25; 38; 50 n. 106; 75; 84 n. $53 ; 115 ; 122$ e n. $122 ; 123 ; 124 ; 129 ; 147$ e n.62; (153); 185; 186 n.128; 201 e n.9; 217; 218; 224; 255; 260 n.285; 261 n.287; $322 ; 336 ; 338 ; 339 ; 340 ; 342$ e n.11; 351 e n. $61 ; 352 ; 365 ; 366 ; 386$.

Germanos (grupo de povos indo-europeus do norte da Europa): 214 n.73; 255.

Gesoríaco (actual Boulogne-sur-Mer, no norte de França; normal porto de embarque para a Britânia): 108 n.54.

Getúlico, Lêntulo (historiador e poeta, legado da Germânia Superior, implicado numa conspiração e executado por ordem de Calígula): 37 e n. 37; 108; 130; 193 n. 156; 256 n.272.

Grécia (nome romano da Hélade): 164 e 
n.25; 165; 178 n.87; 180; 193 n.157; 203; 227 n.128.

Gregos (naturais da Grécia): 120 n.119; 164; 311 n.171.

Hadrumeto ( porto a sul de Cartago; hoje Sousse, na Tunísia): 111 e n.71.

Haloto (provador oficial de Cláudio; sobreviveu a vários imperadores): 237; 299.

Hatério, Q. (distinto orador, de família de senatorial, que censurou Tibério no senado pela sua hesitação e assumir o poder): 174 n.65.

Heitor (o mítico príncipe troiano, filho de Príamo): 163; 188; 201 n.7.

Helesponto (estreito entre o Mar Egeu e o Mar de Mármara): 168.

Helvécia (província romana, fundada em 15 a.C., que correspondia aproximadamente à parte ocidental da actual Suíça): 332.

Hélvio Cina (poeta, amigo de Catulo, tribuno da plebe em 44, linchado na altura dos funerais de César): 312 .

Helvídio Prisco (filósofo estóico, genro de Trásea Peto, exilado em 66 e, de novo, em 75 d.C., e depois executado): 24 n. $48 ; 179$ n. $89 ; 232 ; 233$ e n. $166 ; 244$ e n. 222,$223 ; 322 ; 363$.

Helvídio Prisco (filho do anterior, executado por Domiciano): 233 e n.166; 244 n.222.

Heraclides (tiranode Mílasa; provavelmente, um general que se distinguiu na guerra contra os Persas): 17.

Herénio Senecião (autor de uma Vida de Helvídio Prisco, condenado por Domiciano, celebrado nas Cartas de Plínio): 22; 24 n.47, 48; 232; 233 n.166.

Hermógenes de Tarso (escritor incerto, vítima de Domiciano; seguramente não se identifica com o famoso retor Hermógenes de Tarso, que nasceu no principado de Antonino Pio): 178 n. $85 ; 231$.
Herodes Agripa I (rei da judeia, pai de Berenice): 117 n.110.

Hípias (sofista natural de Élis, que deu o nome a 2 diálogos de Platão): 33 n.8.

Hipona (Hippo Regius: actual Annaba, na Argélia): 27 n.65.

Hírcio (general de César; autor do VIII livro da Guerra da Gália; côns. em 43 a.C., morreu no cerco de Mútina, contra António): 42; 45; 46; 104; 253.

Hispânia (nome dado pelos romanos a toda a Península Ibérica): 98 n.9; 100; 138; 236; 244 n.222; 283; 301; 302; 337.

Hispânia Tarraconense (ou H. Citerior): $82 ; 109$.

Hispânia Ulterior (para além do Ebro; dividida por Augusto em Lusitânia e Bética): 98; 140 n.21.

Hispanos (os povos da Hispânia): 360 n.16.

Hortênsio (um dos maiores oradores romanos, contemporâneo de Cícero): 57 n. 127.

Ibéria: vide 'Hispânia'.

Ícelo (liberto de Galba): 141 n.26; 237; $238 ; 305$.

Ílion: vide 'Tróia'.

Ilíria (costa oriental do Adriático até à Dalmácia): 122; 144; 334.

Isidoro (cínico do tempo de Nero): 230

Itália (designação genérica da região a sul dos Alpes, incluindo oficialmente, a partir de Augusto, a Gália Cisalpina): 43 n.73; 111 n.74; 139; 143; 177 n.80; 233 n. 170; 277; 309; 335 n.26; 369.

Iunco (governador da Ásia em 75-74 a.C.): 98 n.6.

Jerónimo (tirano de Siracusa em 216-215 a.C.): 182 .

Jerusalém (centro religioso e político da judeia): 113; 116; 275 n.22, 24.

Josefo, Flávio (famoso historiador judeu, 
oriundo de uma família sacerdotal, capturado por Vespasiano e depois tornado cidadão romano): vide índice de autores antigos: 'Flávio'.

Judeia (província romana do território habitado pelos Judeus): 112 e n.76; 113; 116; 142 n.34; 320 n.31.

Judeus (grupo étnico e religioso oriundo da Judeia): 312; 367 e n.78.

Júlia (tia de César, esposa de Mário): 21; 40; 98.

Júlia (irmã de César): 21; 103.

Júlia (filha de César e Cornélia, esposa de Pompeio): 101 n.20; 102.

Júlia (filha de Augusto e de Escribónia, exilada em 2 a.C.): 45; 46; 118 e n.115; 119; 120 e n.118; $121 ; 145$; 186; 200; 200 e n. 3,$5 ; 201 ; 216 ; 242$; 260 n. $283 ; 319 ; 321 ; 322 ; 366 ; 383$.

Júlia (neta de Augusto, filha de Júlia e Agripa; exilada em 8 a.C.): 46; 200 e n.6; 201; 319; 322.

Júlia (filha de Tito; esposa de Flávio Sabino e amante de Domiciano): 189 n.139; 195 e n.163; 231 n.149; 236 e n. $185 ; 254$ n. $269 ; 296 ; 366 ; 376$.

Júlia Drusila (filha de Calígula e Cesónia): (222); (282).

Júlio Calváster (jovem tribuno no principado de Domiciano): 234 n.172.

Júlio César (pai de César): 204 n.23.

Júlio César (o ditador que abriu o caminho para o principado; assassinado em 44 a.C.): $21 ; 33 ; 36 ; 39 ; 40$ e n. $52,54,56$; 41 e n. $57,59,60 ; 43$ e n. $73 ; 44$ e n. 76 , $78 ; 45$ e n. 82,$85 ; 46 ; 47$ e n. 94,97 ; $48 ; 49 ; 50$ e n. $105 ; 55 ; 56 ; 56$ n. 123 ; $59 ; 61 ; 65 ; 72 ; 73-74 ; 77-78$ e n.24; 79; 81; 82; 86; 89 e n.76; 97-102; 103; $104 ; 105 ; 106 ; 107$ e n.49; 109; 113 e n. $87 ; 115$ n. $96 ; 117 ; 135-138 ; 139$; 141 n. $27 ; 148 ; 152 ; 153$ e n.79, (80); $154 ; 155 ; 159 ; 170 ; 173 ; 174$ n.60; 175 n.68; 176 n.70; 177 n.74; 180; 181 n.105; 182; 194; 204; 205; 209 n.50; 211-213; 224; 228; 229; 235; 240; 241; 252; 253; 257 n.274 276 $-279 ; 280$ n. 47,$48 ; 281 ; 291 ; 294 ; 296$ n.111; 299; 308 e n.161; 311-312; 318 e n. $15 ; 319$ e n. $19 ; 320 ; 321 ; 322$ n.36; 331; 336; 337 n.35; 342; 343; $346 ; 350 ; 352 ; 353-354 ; 355 ; 357$; $358 ; 359$ e n. $8,9,10,15 ; 360 ; 361 ; 362$; 363; 364; 366 e n.71; 367 e n.81, 83; 368; 370; 373; 375; 376; 377; 379; $383 ; 386$.

Júlio Márato (liberto e secretário de Augusto): 21 n.32; 39; 46; 49 n.102; 207; 343 .

Júlio Montano (senador que sovou Nero e foi coagido a suicidar-se): 183 n.110.

Júlio Saturnino (fonte rara): vide índice de autores antigos.

Júlio Secundo (Secretário de Otão; orador e biógrafo): vide índice de autores antigos.

Júlio-Cláudios (dinastia que vai de Augusto a Nero): $114 ; 236 ; 238 ; 318$; 337; 348.

Julo António (filho de M. António e Fúlvia): 200 n.3.

Júnia Calvina (filha da bisneta de Augusto Emília Lépida): 270.

Júnio Bleso (governador da Gália Lugdunense partidário de Vitélio, e por este envenenado): 239 .

Júnio Rústico: vide 'Aruleno'.

Juvêncio Celso (Jurista que conspirou contra Domiciano; há dúvidas se se trata do pai ou do filho): 181 n.105.

Lacedemónia (região de Esparta): 117.

Lágidas: vide 'Ptolemeus'.

Largino Próculo (astrólogo que pressagiou a morte de Domiciano): 295 n.106.

Latino (famoso actor de mimos do tempo de Domiciano): 293; 294.

Lêntulo, Gneu (conhecido como 'Áugure'; cônsul em 14 d.C.; muito rico, condenado por maiestas no principado de Tibério): 216. 
Lépida (esposa de Quirínio condenada): 216 e n.81.

Lépida, Domícia (Menor: tia de Nero pelo lado do pai): 88; 124 e n.134; 125 e n.140.

Lépida (esposa de Galba): 107.

Lépido, M. Emílio (triúnviro): 106; 240 n.203.

Lépido, M. Emílio (casado com Drusila, irmã de Calígula, esperava suceder -lhe; condenado por conspiração): 130; 256 n.272.

Libão: vide 'Escribónio'.

Licínio Calvo (poeta amigo de Catulo): vide índice de autores antigos.

Licínio Crasso (censor em 92 a.C.; famoso orador): 79; 336.

Lisipo (escultor grego do séc. IV a.C.): 17 n. 8.

Lívia Drusila (Augusta; 3a esposa de Augusto): 42; 43; 46; 64 n.162; 72; $107 ; 117 ; 121 ; 123 ; 128 ; 145 ; 186$ e n.129; 196; 209 e n.50; 216; 221 n.107; 241; 242 e n.210, 211; 252; 253; 271 e n.1; 272; 273 n.10; 319 n.21; 334; 336; 365; 366; 369; 377 n. $158 ; 386$.

Lívia Júlia (Livila) (irmã de Germânico e de Cláudio; esposa de Druso, filho de Tibério): 218 n.94; 321.

Lívia (Cornélia) Orestila (esposa de Gaio Calpúrnio Pisão; 2a esposa de Calígula): 196 e n.167; 386.

Lívia Ocelina (madrasta de Galba): 337.

Livila, Júlia (filha de Germânico): 128 e n.154; 256 n.272.

Locusta (especialista em venenos ao serviço de Agripina e Nero; executada por Galba): 193.

Lólia Paulina (3a esposa de Calígula, arrebatada a Públio Mémio Régulo; candidata a esposa de Cláudio, forçada ao suicídio por Agripina): 223 n.116.

Lólio, M. (próximo de Augusto; quando legado na Gália, foi derrotado pelos germanos que atravessaram o Reno): 121.

Luca (cidade da Ligúria): 102.

Lucano (poeta condenado por Nero): vide índice de autores antigos.

Lúcio António (irmão do triúnviro): 45; 105 n. $42 ; 233 ; 253 ; 353$.

Lúcio António Saturnino (governador da Germânia Superior que liderou uma revolta contra Domiciano): 87; 205; 232 n. 162; 234 n. $172 ; 292$.

Lúcio Audásio (conspirador contra Augusto): 200 n.5.

Lúcio César (neto de Augusto; filho de Júlia e Agripa): 42 n.69; 120; 121; 145; 200; 201 n. 8; 241; 319; 320.

Lúcio Luculo (famoso pelas campanhas contra Mitridates e pela vida faustosa): 101.

Lúcio Otão: vide 'Sálvio'.

Lúcio Vero (imp.161-169 d.C.): 183 n.109.

Lucrécia (esposa de Tarquínio Colatino; modelo de matrona heróica e casta): 196; 260 n.285; 322.

Lugduno (cidade da Gália, actual Lião): 39; 128; 182; 184; 220; 221 e n.105; 320 n. 29.

Lusitânia (região ocidental da Hispânia com capital em Mérida): 76; 126 e n.143, 144; 358 n.6.

Macedónia (região entre a Grécia e a Trácia): 138; 332.

Mácio (amigo de César e de Cícero; reconciliou-os): 44.

Mácron (prefeito da guarda pretoriana depois de Sejano): 42 n.64; 147 e n.63; 222; 337 n.33.

Malónia (matrona vítima de Tibério): 195; 196; 215; 309; 322; 376.

Mamerco Escauro (senador poeta, cônsul em 21 d.C., acusado de maiestas contra Tibério): 42 n.64; 84 n.54; 218 n.94. 
Mamurra (cavaleiro, prefeito dos engenheiros do exército de César): 43.

Marco Actório Nasão (historiador contemporâneo de Júlio César): vide índice de autores antigos.

Marco Emílio Escauro (cônsul em 115 a.C., censor em 109, famoso princeps senatus; autor de uma autobiografia): 21 e n.31.

Marco Gálio: vide 'Gálio’.

Marcelo, M. (sobrinho de Augusto: filho de M. Cláudio Marcelo e Octávia): 118.

Marcelo: vide 'Éprio'.

Marco Aurélio (imp. 161-180 d.C.): 262 n.294.

Mário (o general vencedor de Jugurta e dos Cimbros e Teutões, apoiado pelos populares): 97.

Marsos (antigo povo da Itália Central): 167.

Massada (planalto rochoso perto do Mar Morto; último reduto da revolta dos Judeus, expugnado pelo engenho militar romano em 73 d.C.): 113.

Massília (colónia grega, actual Marselha): 138.

Mauritânia (estado cliente de Roma, depois transformado em província romana por Cláudio): 44.

Máximo (liberto de Parténio): 296.

Mecenas (famoso cavaleiro de origem etrusca, amigo de Augusto): 60; 192; 242 e n. $211 ; 253$ e n. $263 ; 387$.

Mémio, G. (pretor hostil a César em 58 a.C., cônsul em 54 ; poeta e orador): 43; 44; 77.

Mémio Régulo, P. (homem novo, promovido no tempo de Tibério; marido de Lólia Paulina, coagido a ceder a esposa a Calígula): 223 n.116.

Mena (liberto de Augusto): 46.

Menécrates (citaredo): 227.
Mênfis (capital do antigo Egipto, cujas ruínas se situam a $20 \mathrm{Km}$ a sul do Cairo): 116; 116 n.105.

Mésia (província romana a sul do baixo Danúbio, a leste da Ilíria: a $\mathrm{M}$. Superior a norte da Macedónia; a M. Inferior a norte da Trácia e a oeste do Mar Negro): 306.

Messala Barbato, V. (primo de Cláudio e pai de Messalina): 260.

Messala Corvino, Valério (político proeminente do séc. I a.C. e do principado emergente; orador, poeta, protector das Letras, autor de umas Memórias): 44 e n.74; 46; 49 n.102; 61; 167 e n.34.

Messalina, Valéria (esposa de Cláudio, famosa pelo seu deboche): 51 n.109; $124 ; 260$ e n.283; 262; 263; 264 e n. $300 ; 265 ; 266$ n. $303 ; 323$ e n.44; $324 ; 338$.

Méstrio Floro (historiador romano do tempo de Vespasiano; obteve a cidadania romana para Plutarco e acompanhou-o na visita ao campo de batalha de Betríaco): 80; 268 e n.312.

Métio Pompusiano (cônsul vítima de Domiciano): $178 ; 233$ e n.170.

Mevânia (cidade da Úmbria): 255 n.270; 284 n. 64.

Milas (cidade da Sicília perto da qual Agripa venceu Sexto Pompeio): 106.

Mileto (antiga colónia grega da Jónia): 16.

Mirmilões (tipo de gladiadores; a figura de um peixe a adornava o capacete): 231 n.153.

Miseno (promontório da Campânia e porto onde estava instalada a principal base naval romana): 171; 268 n.314.

Mitilene (cidade da ilha de Lesbos): 97.

Mitridates VI (rei do Ponto, 120-63 a.C.; poderoso inimigo de Roma, combatido por Sula e por Pompeio Magno): 98; 138. 
Mnester (pantomimo favorito de Calígula): $74 ; 160 ; 223 ; 225 ; 258$; 280.

Múcia (esposa de Pompeio Magno): 79.

Muciano, Licínio (governador da Síria, apoiante dos Flávios): 143 e n.36; 244 n.223, 224; 245 n.226.

Murena, Varrão (cunhado de Mecenas, que conspirou contra Augusto): 119; 357.

Mútina (cidade da Gália Cisalpina, actual Modena): 104.

Narciso (poderoso liberto e secretário de Cláudio): 110; 111; 261; 262 n.292; 264 e n.301; 266 n.303; 323 e n.44.

Náuloco (localidade da Sicília, junto da qual Agripa obteve uma importante vitória naval sobre Sexto Pompeio): 106.

Neápolis (cidade da Campânia, hoje Nápoles): 162; 164; 165; 301 n.130.

Nemauso (cidade da Gália Narbonense, actual Nîmes): 121.

Nero (filho de Germânico): 122 n.123; $175 ; 185 ; 217$.

Nero Cláudio César Augusto Germânico (imp. 54-68 d.C; Lúcio Domício): 21 e n. $27 ; 25 ; 34 ; 35 ; 36$ e n. $26 ; 40 ; 43$; $48 ; 50 ; 51 ; 56 ; 57 ; 58 ; 59 ; 61 ; 64 ; 67$ -69 e n.172-173; 71;72;73;74;75; 76 e n. $18 ; 78 ; 80 ; 81 ; 82 ; 83 ; 84 ; 85 ; 86$; 87; 88; 90; 106; 108; 109; 111 e n.70; 112; $113 ; 114$ e n. $3 ; 115 ; 117$ e n.110; 124-125; 126 e n.142, 144; 127 e n. $146 ; 131 ; 140 ; 141$ e n. $26 ; 144 ; 148$ -149; 150; 154; 155; 159; 161-165; $166 ; 169 ; 170$ e n. $45 ; 171$ e n.50; 173 ; 176; 177 e n.74, $75 ; 178$ e n.87; 182 e n.107; 183 n.109, 110, 111; 184; 185 e $122 ; 186-187$ e n.131, 132, 133; 188 e n.135, 136, 137; 190-192; 193 e n.157; 194 e n.158; 195 n.162; 197 e n.168, 172; 198; 199; 201; 202; 203 e n. $16 ; 205$ e n. $24 ; 209 ; 210 ; 211 ; 212$; 220 n.101; 226-230; 231 n.156; 232 n.157; 234 e n.176, 177; 235 e n.184; 236; 237 e n. $193 ; 238 ; 239 ; 244 ; 247$ e n.240; 248 n.244; $254 ; 261$ n.287; 265 e n.304; 269 e n. 315,$316 ; 283$; 287 e n.76; 288; 289; 291; 292; 293; 296 n.111; 298; 298 n.120; 300-306; 307 e n.156, 157; 308 e n.161; 309; 313; 317; 318 e n. $15 ; 319$ e n. $20 ; 320$ e n.29; 321; 322 e n. $35 ; 323$ n. $46 ; 324$ n. $47 ; 325 ; 329 ; 330$ n. $; 332$ n. $15 ; 336$ -337; 338; 340 e n. $40 ; 347$ n. 40; 348; 349-350; 352; 354 e n.78; 355; 356; 357 e n. $1 ; 362$ e n. $39 ; 363$ e n. $50 ; 364$ n. $61 ; 365 ; 366$ e n. $71 ; 367$ e n.79, 83; 368; 370; 371; 372; 373; 375 e n.138; 376; 379; 384; 385 e n.12,13; 386; 387 e n. $20,21,22,23$.

Nerópolis (nome que Nero queria dar a Roma): 306.

Nerva, Marco Coceio (imp. 96-98 d.C.; o último imperador italiano): 25 n.51; 26 e n. 59; 131; 132; 232 n. 157; 295 n.106; 375 n.142.

Nicomedes (IV; rei da Bitínia c. 94-75 a.C.; à morte, legou o reino a Roma): 44 e n. 78; 45 n.83; 73-74 e n.11; 77; 81; 86; 97; 102; 212; 353; 375 n.143.

Nicópolis (cidade fundada por Augusto no Epiro, para comemorar a vitória de Áccio): 139; 205 n.27.

Nigídio, Públio. (conhecido como P. Nigídio Fígulo; místico e grande erudito, amigo de Cícero e apoiante de Pompeio): 208.

Ninfídio Sabino (prefeito da guarda pretoriana que apoiou a aclamação de Galba): 141-142; 142 n.28.

Nola (localidade entre Benevento e Neápolis): 213; 271 n.1.

Núrsia (cidade da Úmbria, actual Nórcia): 104; 333.

Octávia (Menor, irmã de Augusto, esposa de Marcelo e depois de M. António): 253 n.264.

Octávia (filha de Cláudio e Messalina e primeira esposa de Nero): 126 n.144; 188 e n. $135 ; 203$ e n. $17 ; 303 ; 320 ; 322$ e n. $38 ; 366$. 
Octávio, vide Augusto.

Octávio (antepassado de Augusto): 331.

Octávio, Gaio (pai de Augusto): 39; 103 n.30; 207; 208; 332.

Óctávio (quidam: incerto): 44; 77.

Olímpia (região onde se situava o santuário panelénico de Zeus e se realizavam os celebrados jogos): 164; 298 n.119.

Ópio, G. (amigo de César, responsável pela correspondência de César; autor de biografias): vide índice de autores antigos.

Orestila: vide 'Lívia'.

Óstia (porto de Roma na foz do Tibre): 120; 171; 197; 266; 268 e n.314.

Otão, L. Sálvio (pai do imp. Otão): 108.

Otão, Marco Sálvio (imp. Jan.-Abr. de 69 d.C.): 36 n. $27 ; 51 ; 52$ e n. $114 ; 63$ n.159; 72; 74; 76 e n.18; 83; 84; 89; 96; 108 n.52; 113 n. 87,$88 ; 116 ; 125$ $-127 ; 142 ; 153 ; 153$ n.81; 154; 155 -157; 157; 170; 178 n.83; 203; 204; 209; 210; 238; 247-248; 283; 284 e n.65; 285 e n.70; $286 ; 288$ n.79; 289; 290; 306-308; 314; 314 e n. $180 ; 318$; 320 n.29; 321; 322; 323 n.46; 325; 334 e n. $22 ; 341 ; 343 ; 346$ e n. $38 ; 347$; 348; 348 n. $51 ; 351 ; 354 ; 355 ; 358$ n.6; $367 ; 370 ; 375 ; 379$.

Pacúvio (dramaturgo; séc. II a.C.): vide índice de autores antigos.

Pafo (cidade da ilha de Chipre onde estava um Santuário consagrado a Vénus): 116; 320 n.31.

Palamedes (herói mítico da saga de Tróia): 188 n.137

Palante (liberto Antónia Menor e encarregado das finanças de Cláudio): 261; 261 n.287.

Palatino (colina em que foi fundada Roma, local da residência dos imperadores): 164; 165; 193 n.155; 256; 257; 293; 334; 368; 371 n.114.

Pâmenes (citaredo vítima da inveja de
Nero): 84; 193 n.157.

Pandatária (ilha do Mar Tirreno: local do exílio de Júlia e Agripina, entre outros): 292 n. 98.

Panónia (província romana situada entre a Dácia, o Nórico e a Ilíria): 147; 306.

Pansa (cônsul em 43 a.C., colega de Hírcio; morreu em Mútina): 104.

Páris (actor, vítima de Nero): 165.

Páris (pantomimo, vítima de Domiciano): 173 n.59; 231 n.151; 254 e n.269.

Páris (mítico filho de Príamo que raptou Helena): 193 n. 155; 201 n.7.

Parrásio (pintor de Atenas rival de Zêuxis): 215.

Parténio (criado de quarto de Domiciano): 295; 296 n.110.

Pártia (ou Império Arsácida, no Planalto Iraniano; poderoso inimigo do Império Romano): 121 n.121.

Partos (povo de origem indo-europeia que se instalou no norte da Pérsia e deu origem a um Império): 143; 168 n.37; 211; 214 n.73; 216; 219; 240; $270 ; 276 ; 313 ; 357$.

Passieno Crispo: vide 'Crispo'.

Patávio (cidade da Gália Cisalpina, actual Pádua): 320 n.31.

Patróbio Neroniano (liberto de Nero): 287.

Pélagon (eunuco de Cláudio): 267 n.309.

Periandro (opressivo tirano de Corinto, c. 627-587 a.C.): 188 n.136.

Péricles (o famoso político ateniense do séc. V): 17 n.7.

Perúsia (originalmente uma cidade etrusca, actual Perúgia; local de sangrentas lutas entre Octávio e Lúcio António): 104 n.36; 105; 205; 322 n. 36; 363 n.46.

Petrão: vide 'Flávio'.

Petrónia (1 ${ }^{\mathrm{a}}$ esposa de Vitélio): 131 n.164. 
Petroniano (filho de Vitélio): 131 e n.164.

Petrónio (autor do Satyricon; identificado com o "árbitro das elegâncias de Nero"): vide índice de autores antigos.

Petrónio Turpiliano (côns. em 61 d.C., governador da Britânia 61-63, condenado por Galba): 84.

Picentes (povo de origem sabina da Itália Central): 335 n.26.

Pirális (cortesã de Calígula): 223.

Pisão, Gaio Calpúrnio, (exilado por Calígula, acusado de adultério com a ex-mulher, Lívia Orestila; mentor da conspiração contra Nero, em 65): 51 n. 113 ; 61 n. $148 ; 184$ e n. 120; 196; 228 n.135.

Pisão, Gneu Calpúrnio (Governador da Síria no principado de Tibério; suspeito de envenenar Germânico): 75.

Pisão, L. Calpúrnio (sogro de César; censor em 50, tentou evitar a guerra civil, antes e depois da morte de César): 101 n.20.

Pisão, L. Calpúrnio (o nome completo era L. Calpúrnio Pisão Frugi Liciniano; adoptado por Galba, em 69, e morto juntamente com ele): 63 ; 155 e n.89; 283; 285 n.67, 69; 287 n.76; 347 e n. 44 .

Pisístrato (tirano de Atenas, $2^{\text {a }}$ metade do séc. VI): 138 n.14; 146 n. 51.

Pitágoras (filósofo e matemático natural de Samos que deu origem ao pitagorismo): 18 n.16; 19.

Pitágoras (liberto de Nero): vide Doríforo.

Pitolau (liberto e biógrafo de Pompeio Estrabão; talvez seja o mesmo que Voltacilius Pilutus e Pitoleonte de Rodes): vide índice de autores antigos.

Platão (o famoso filósofo grego, discípulo de Sócrates e mestre de Aristóteles; fundador da Academia): vide índice de autores antigos.

Plínio-o-Moço (orador e político influente, sobrinho de Plínio-o-Velho e amigo e protector de Suetónio; autor de 10 livros de cartas literárias e do Panegírico de Trajano): vide índice de autores antigos.

Plínio-o-Velho (historiador e naturalista; comandante da esquadra do Miseno, morreu na erupção do Vesúvio, em 79 d.C): vide índice de autores antigos.

Plotina (esposa de Trajano; favoreceu a ascensão de Adriano): 283 n.62.

Póla Argentária (viúva do poeta Lucano): 61.

Polência (cidade da Ligúria, actual Pollenzo): 213.

Polícrates (tirano de Samos, do séc. VI): 300.

Pólo (liberto de Augusto): 241.

Pompeia (irmã de Sexto Pompeio): 39.

Pompeio Estrabão (pai de Pompeio Magno; destacou-se como general na Guerra Social): 21 n.32; 43 n.73.

Pompeio Macro (bibliotecário, filho do historiador Teófanes de Mitilene, amigo de Pompeio Magno): 47.

Pompeio Magno, Gneu (vencedor de Mitridates e dos piratas; membro do chamado $1^{\circ}$ triunvirato e, depois, opositor de César): 21 n.32; 43 n.73; 44; 77; 79; 99 n.10; 100 e n.16; 101 e n. $20 ; 102 ; 135 ; 138$ e n. $18 ; 209$ n. 50 ; $277 ; 278$.

Ponto (região norte da Ásia Menor, junto ao Mar Negro: pertencia à província conjunta Ponto e Bitínia): 138; 332 n.15.

Popeia Sabina (a Maior: mãe da futura esposa de Nero; foi vítima de Messalina): 265; 266 n.303.

Popeia Sabina (amante de Otão e, depois, esposa de Nero): 76 e n.18; 126 e n.144; 127 n.146; 188 e n.136; 197 n. $171 ; 227$ n. $128 ; 321 ; 323$ n. 46; 325; 
366.

Pório (essedarius: gladiador que combatia num carro): 193.

Porta Prima (local a norte de Roma, onde Lívia Augusta tinha uma villa): 343.

Praxíteles (o famoso escultor grego do séc. IV): 17 n. 8 .

Preneste (cidade do Lácio, actual Palestrina, onde existia um templo da Fortuna com o mais famoso oráculo de Itália): 293; 298; 320 n.31.

Príamo (mítico rei de Tróia): 185 e n.125; 188 n.137; 192.

Probo, M. Valério (gramático do séc. I d.C.): vide índice de autores antigos.

Psilos (antiga tribo do norte de África especialista em serpentes): 139.

Ptolemeu (VIII; rei de Cirene e do Egipto, pretendente à mão de Cornélia, mãe dos Gracos): 360 n.16.

Ptolemeu ( rei da Mauritânia, filho de Juba e de Cleópatra Selene, a filha de Marco António e Cleópatra): 193; 222.

Ptolemeu (um astrólogo que acompanha Otão à Lusitânia; Suetónio confunde-o com Seleuco): 127 e n.149.

Ptolemeus (ou Lágidas: dinastia grega dos sucessores de Alexandre no Egipto. Fundada por Ptolemeu I, Soter, filho de Lago): 180 n.94; 196 n.165.

Publílio Siro (autor de mimos): vide índice de autores antigos.

Putéolos (Cidade da Campânia, actual Pozzuoli): 72; 168; 254; 268 e n.314; 310.

Q. Elógio (muito incerto): 38.

Quérea: vide 'Cássio'.

Quintílio Varo (general de Augusto que perdeu 3 legiões na floresta de Teutoburgo, na Germânia): 166; 167.

Quinto Cátulo Capitolino (cônsul em 78 a.C.; princeps senatus; opositor de
César): 99 n.13; 100 n.16; 208.

Quirínio, P. Sulpício (conhecido sobretudo por, enquanto governador da Síria, realizar o censo associado ao nascimento de Jesus; acusa a esposa Emília Lépida, neta do Triúnviro, de adultério): 216 .

Ravena (cidade da Gália Cisalpina): 136; 138.

Reate (cidada da Sabina, onde nasceu Vespasiano; actual Rieto): 178; 273; 321 n. 34; 333.

Regilo (lago; local de uma batanha heróica dos Romanos contra a Liga Latina) : 336 n.32.

Reno (o rio que, no tempo de César, se tornou fronteira do Império Romano): 35 n. 22; 206; 255.

Rodes (ilha do Mar Egeu, famosa pelo colosso): 42; 98 e n.6; 120 e n.120; 121 e n.121; 178 n.87; 181 n.100; $214 ; 321 ; 346$.

Roma (capital do Império): passim

Rómulo (1 rei e fundador de Roma, segundo a tradição): 103; 196; 205 n. $25 ; 207 ; 271 ; 331 ; 386$.

Rubicão (pequeno rio do norte de Itália que, no final da República, ganhou o estatuto de fronteira de Itália; César violou a lei ao atravessá-lo com o exército em 49 a.C.): 41; 64; 98 n.9; 99; 102; 135; 136; 137 e n.10; 155; $277 ; 359 ; 383$.

Rúbria (vestal supostamente violada por Nero): 227 e n. $126 ; 319$.

Rufila (amante de Augusto): 64 n.162; 253.

Rúfrio Crispino (enteado de Nero, filho de Popeia Sabina): 188; 366.

Rutílio Rufo, P. (político, orador e historiador; acusado injustamente de concussão, por ter afrontado a classe equestre, foi para o exílio, onde escreveu uma autobiografia e uma História de Roma em grego): 21. 
Sabino: vide 'Flávio'.

Sabina (região da Itália Central povoada pelos Sabinos): 333.

Sabinos (povo de língua osco-úmbria que habitava a região central de Itália): 274; 275; 321 n.34.

Sálios (sacerdotes de Marte): 263.

Salomão ( $3^{\circ}$ rei de Israel; tomado como modelo de juiz): 108; 249 n.250.

Salústio Crispo, G. (filho adoptivo do historiador homónimo; conselheiro de Augusto e de Tibério): 145.

Salústio Luculo (governador da Britânia, depois de Agrícola; condenado por Domiciano): 232; 233 n.170.

Sálvia Titisénia (amante de Augusto): 64 n.162; 253.

Salvidieno Órfito, Sérvio Cornélio (côns. 51d.C.; executado por Nero em 66): 232; 233 n.170.

Salvidieno Órfito, Sérvio Cornélio (filho do anterior; exilado e executado por ordem de Domiciano): 229 e n.157.

Sálvio Otão Coceiano (sobrinho do imp. Otão; executado por ordem de Domiciano): 232 e n.161.

Sálvio Otão, L. (pai do imp. Otão): 320 n.29; 334.

Sálvio Otão, M. (avô do imp. Otão): 334.

Samos (ilha do mar Egeu e importante polis da ilha): 121; 300.

Sardenha (ilha que formava província com a Córsega): 229 n.140.

Sármatas (povo da fronteira oriental da Cítia): 214 n.73; 230.

Sátur (criado de quarto de Domiciano): 296.

Saturnino: vide 'Lúcio António'.

Sejano (célebre prefeito do pretório e homem de confiança de Tibério; acusado de conspiração, foi executado): 42 e n.64; 51 n. $113 ; 84 ; 185$ n.124; 214 n.69; 218 e n.91, 93; 219 e n.95, $96 ; 261 ; 357$ e n. 4.
Seleuco (astrólogo da corte de Vespasiano): 127 e n. 149 .

Semíramis (rainha lendária da Ásia): 101.

Semprónio Denso (centurião da coorte pretoriana; o único homem que defendeu Galba, quando este foi assassinado): 285 n.69.

Séneca, o retor (pai do Filósofo do mesmo nome): vide índice de autores antigos.

Séneca, L. Aneu (o célebre filósofo e escritor, natural de Córdova, preceptor de Nero): vide índice de autores antigos.

Septício Claro (um dos prefeitos da guarda pretoriana de Adriano, a quem Suet. terá dedicado as Vidas dos Césares): 27 n.65; 55.

Septizónio (edifício incerto, talvez de sete pisos suportados com colunas; não o de Septímio Severo): 114 n.94; 321 n.34.

Servílio Noniano (cônsul e historiador): vide índice de autores antigos.

Servília (amante de César e mãe do cesaricida M. Júnio Bruto): 44; 74; 77; 79 e n.31; 212; 278 n.39.

Servílio Isáurico (colega de consulado de César em 48 a.C.): 99 n.13.

Sexto Pompeio (filho de Pompeio Magno): 26; 39; 45; 46; 106; 209 n. $50 ; 253$.

Sicília (ilha que se tornou província romana no final da $1^{\text {a }}$ Guerra Púnica): 19 n.17; 106; 186; 205.

Silano, M. Júnio (sogro de Calígula; executado por este em 38 d.C.): 365 n.66.

Silano: vide 'Ápio'.

Sílio, Gaio (côns. Designado para 48 d.C.; amante de Messalina, que com ele celebrou um casamento): 260 e n. $283 ; 262$ e n. $292 ; 324$.

Siracusa (importante cidade da Sicília): 82; 196; 298. 
Síria (província romana, entre o Mediterrâneo e o Eufrates): 75; 101; 123; 142; 143; 201 e n. $11 ; 217 ; 231$.

Sócrates (o célebre filósofo): 16; 18; 19 e n.19.

Spelunca (Sperlonga: gruta natural na costa da Campânia, onde Tibério tinha uma villa): 213.

Súbrio Flávio (tribuno da coorte pretoriana que participou na conjura de Pisão): 185 n.121.

Suetónio Leto (pai do biógrafo): 48; 52; 62 n. $156 ; 156$ n.91; 306; 351.

Sula (o ditador): 21 n. 31, 32; 41 n.60; 97; $98 ; 353$ n.69.

Sula (um astrólogo): 280.

Sulpício Áspero (centurião que participou na conspiração de Pisão contra Nero): 185 n.121.

Sulpício Galba, Sérvio (autor do massacre de Lusitanos em 150 a.C.; famoso orador do tempo): 337.

Sulpício Galba, Sérvio (bisavô do imp. Galba; pretor em 54 a.C. Na guerra civil, tomou o partido de César. mas juntou-se aos cesaricidas): 141 n.27.

Sulpício Rufo, Sérvio (famoso jurista, côns. 51 a.C.; hesitante na guerra civil até se decidir a apoiar de César, que o fez procônsul da Acaia em 46 a.C.): 359 n. 8 .

Talo (secretário de Augusto): 241.

Tanúsio Gémino (historiador): vide índice de autores antigos.

Tariqueia (cidade da Judeia): 116.

Tarpeia (a traidora lendária que facilitou o acesso aos Sabinos à acrópole romana e deu o nome à rocha da encosta do Capitólio de onde se precipitavam os traidores): 260 n.285.

Tarquínio-o-Soberbo (tradicionalmente, o último rei de Roma: 534-510 a.C.): 265 n.302.

Tarragona (capital da Hispânia Citerior): 236.
Tasos (ilha grega do mar Egeu): 16.

Tebas (polis grega): 192.

Témeno (subúrbio de Siracusa): 298.

Temístocles (general ateniense, vencedor da batalha de Salamina): 16.

Tércia (filha de Servília): 44; 74; 77; 79 e n.31.

Terência (esposa de Mecenas): 242 e n.211; 253 n.263.

Terêncio Máximo (nome do falso Nero de 80 d.C.): 313 n 177.

Terentila (amante de Augusto, geralmente identificada com Terência, a esposa de Mecenas): 64 n.162; 253.

Terpno (citaredo famoso no tempo de Nero): 162.

Tertula: (amante de Augusto): 64 n.162; 253.

Tertula (avó de Vespasiano): 109; 365.

Teseu (herói mítico filho de Egeu, rei de Atenas): 17 n.7.

Tibério Cláudio Nero (pai do imp. Tibério; $1^{\circ}$ marido de Lívia Augusta): 336.

Tibério Júlio César Augusto (imp.14-37 d.C.): $21 ; 24$. n. $49 ; 25$ n.56; 39 e n.44; 40; 41 n.61; 42 e n.66, 68, 69; 43; 45; 46; 47; 49 n.104; 50 e n. 105, 106; 56 n. $122 ; 57 ; 59 ; 60$ e n. $142 ; 61 ; 64 ; 65$; $72 ; 73 ; 74 ; 75 ; 79 ; 80 ; 81 ; 82 ; 84 ; 85$; 86; 87; 88; 90; 95; 106; 107; 109 n.60; 115; 117-122; 123 e n.129; 124; 128 ; 130 e n.161; 132 n.171; 144-147; $148 ; 149 ; 150 ; 157 ; 159$ e n. $3 ; 168$; $172 ; 173 ; 174$ e n. $65 ; 175$ e n. $68 ; 176$ n.73; 178 n.87; 179 n. $91 ; 181$ n.100, 104; 183 e n. $113 ; 185 ; 188 ; 194 ; 195$ e n.162; 196; 199; 200; 201 e n.8, 10; 204; 206; 208; 209; 211; 212; 213 $-220 ; 222 ; 223 ; 224 ; 226 ; 230 ; 231$ n.151; 235; 236; 242; 244; 250; 255; 271 e n. $1 ; 288 ; 290 ; 291$ e n. $91 ; 293$ n.102; 296 e n.111; 297-298; 309; $313 ; 314 ; 317 ; 319$ e n. $20,21,22 ; 320$; 321; 322; 323 n.46; 334; 335-336; 337; 338; 339; 340 e n.40; 344-346; 
348 n.51; 349; 350; 351; 352; 355 e n. $84 ; 357 ; 361$ e n. $32 ; 362 ; 363$ e n. 47 ; 364 e n. 51,$59 ; 365 ; 366$ e n. $71 ; 367$ e n.78; 368 e n. $90 ; 369 ; 371$ e n.112; 372; 373; 374; 375; 376; 379; 384 e n. 6,$8 ; 385$.

Tibério Alexandre (prefeito do Egipto que apoiou a aclamação de Vespasiano): 142.

Tibério Gemelo (neto de Tibério, primo de Calígula, morto por ordem deste): 190; 365; 365 n.66.

Tibre (rio que nasce nos Apeninos, banha Roma e desagua em Óstia): 197; 204; 219 n.96; 290; 297; 303; 313; 348; 385.

Tíbur (importante cidade do Lácio, hoje Tivoli): 37.

Tício Sabino (cavaleiro a quem os delatores de Tibério montaram uma armadilha para o acusarem de traição; foi morto na prisão): 84 n.53; 218; 219 n.96.

Tigelino (prefeito da guarda pretoriana e braço armado de Nero): 51 n.113; 197 n. $170 ; 237 ; 248$ n.244.

Tigranes III (rei da Arménia, coroado por Tibério, sob os auspícios de Augusto): $119 ; 357$.

Tirão (liberto e biógrafo de Cícero): 21 n.32.

Tiridates (rei da Arménia, coroado em Roma por Nero): 88; 169; 371; 385.

Tito Flávio Vespasiano Augusto (imp. 69 -71 d.C.): 25 e n.54; 36; 39; 59; 72; $78 ; 79 ; 80 ; 83 ; 85 ; 86$ n.60; 89; 90; 111 n.70; 112 n.76; 114-117; 128 n.151; 131; 132 e n.170; $133 ; 143$ n.36; 149 e n.69; 150 e n. 70,$71 ; 157 ; 159 ; 172$ n.55; 179; 189 n.139; 203 n.16; 204; 209; 232; 233 n.167; 234 n.176; 235; 244 n.223; 226-227; 269; 273 n.11; 274-275; 298 n.120; 313 n.177; 314; 315; 318; 319; 320 e n.29; 321; 322; $331 ; 338 ; 342 ; 343 ; 349 ; 352 ; 362$ n.36; 363; 365; 366; 367 n.83; 368;
369; 374; 375; 376; 377 e n.160; 379; $384 ; 386$.

Tolosa (cidade do sul da Gália, actual Toulouse): 210.

Torânio, Gaio (tutor de Augusto, proscrito durante o triunvirato): 240 .

Trácia (região a sul da Mésia Inferior, banhada a leste pelo Mar Negro, a sul pelo Mar de Mármara e a sudoeste pelo Mar Egeu): 110.

Trácios (tipo de gladiadores): 239 n.199.

Trajano, M. Úlpio (imp. 98-117 d.C.): 25 n.51; 27 n.64; 50 n.105; 117 n.110; 233 n.170; 283 n.62; 378; 379 e n.173.

Trásea Peto (estóico condenado à morte por oposição a Nero; suicidou-se): 22; 24 n. $48 ; 56$ e n. $124 ; 229 ; 232 ; 233$ n.164, 166; 244.

Trasilo (astrólogo da corte de Tibério): 39; 72; 168; 204; 280.

Tróia (cidade mítica da guerra com os Gregos, identificada como a actual Hissarlik, na Anatólia): 188; 192; $276 ; 362$ n.39.

Troianos (naturais de Tróia): 188 n.137.

Tuberão, Quinto (autor de uma História de Roma):

Túrio (cidade do golfo de Tarento): 103 n.30.

Turino (nome de Augusto na infância): 34; 40; 103.

Túsculo (antiga cidade do Lácio, perto da actual Frascati): 107.

Ulisses (herói mítico, rei de Ítaca): 180 n.93; 181 n.98; 188 n.137; 214 n.69.

Úmbria (região da Itália Central, a leste da Toscana): 333.

Valente: vide 'Fábio'.

Varo: vide 'Quintílio'.

Véctis (ilha contígua à Britânia, actual Isle of Wight): 110 e n.67.

Velabro (vale entre o Capitólio e o Palatino, que ligava o Foro ao Foro 
Boário): 164; 165.

Velitras (cidade do Lácio, nos Montes Albanos): 72; 207; 321 n.34.

Verânio Flaco (gramático e professor do tempo de Augusto e Tibério): 61.

Vespásia Póla (mãe de Vespasiano): 110; $112 ; 333$.

Vespasiano, T. Flávio Sabino (imp. 69-79 d.C.): $25 ; 36$ n. $27 ; 48$ n. $100 ; 72 ; 75$; 76; 78; 79; 80 e n.36; 81; 83; 85; 86 n.60; 90; 91; 97; 109-113; 114; 115 ; 116 e n.107; 117; 127 n.149; 132 e n.170, 171; 140 n. $21 ; 142-144 ; 149$ e n. $69 ; 150$ n.70; 155 n. $88 ; 170$ e n. 46 ; $172 ; 178$ e n.86, $87 ; 179$ e n. $88 ; 207$; 208; 209; 210 e n.54; 229 n. $140 ; 232$; 233; 244-246; 259 n.281; 267-270; 273-274, 275 e n.24; 287; 289; 291; 293; 298 n.120; 309; 314; 320; 321; $322 ; 323$ e n. $42 ; 324 ; 331 ; 332-334$; $338 ; 340 ; 342 ; 343$ e n. $18 ; 349 ; 352$; $361 ; 363 ; 365 ; 367 ; 368 ; 369 ; 370$; $373 ; 374 ; 375$ e n. $138 ; 376 ; 377 ; 379$; 384.

Vespasiano, T. Flávio (filho de Flávio Clemente): 328.

Vespásias (localidade da Úmbria, ligada à família materna de Vespasiano): 333.

Vestais (sacerdotisas virgens, guardiãs do fogo sagrado no templo de Vesta e muito influentes): 97; 366 n.74; 373.

Vesúvio (monte vulcânico da Campânia): 247.

Via Ápia (inicialmente, de Roma a Cápua - construída por Ápico Cláudio Ceco): 337.

Via Nomentana (em direcção a Nomento, unindo-se a seguir à Salária):

Via Sacra (principal rua de Roma; passava pelo Foro e ligava os lugares sagrados): 289.

Via Salária (via que avançava para nordeste de Roma) : 67 n.172.

Víbio Crispo (cônsul íntimo de Domiciano): 78-79; 254
Víbio Sereno (procônsul da Hispânia Ulterior em 23 d.C.; acusado de lesa -majestade pelo filho homónimo): 84 n. $53 ; 218$ n.92.

Vibuleno Agripa (cavaleiro romano que bebeu veneno, para evitar a execução por traição, em 36 d.C.): 219 n.95.

Vícia (condenada por chorar o filho): 218 n.93.

Viena (cidade do sul da Gália, actual Vienne): 278; 285; 154; 210.

Villa Iovis 'Casa de Júpiter' (residência de Tibério em Cápreas): 219.

Víndex, Júlio (promotor da revolta da Gália contra Nero): 79; 140; 141 e n.26; 153 n.79; 283; 300; 301; 302; 303 e n. $138 ; 304$.

Vinício (conjurado: talvez Ânio Viniciano, filho adoptivo de Corbulão): 184.

Vinício, L. (jovem consular que Augusto censurou por se aproximar de Júlia): 46.

Vínio, Tito (poderoso aliado de Galba): 141 n.26; 237; 307 n.156.

Virgínia (virgem vítima da concupiscência do decênviro A. Cláudio): 335.

Virgínio Rufo, L. (comandante da Germânia Superior; derrotou Víndex, mas recusou a intenção do exército de o aclamar imperador): 141 n.26.

Viriato (caudilho dos Lusitanos): 337.

Vistília (matrona condenada por adultério): 172; 374 n.133.

Vitélio, Aulo (imp. Abril-Dezembro de 69 d.C.): 38; 51; 59; 66; 74; 78; 79; 83; 87; 89-90; 96; 116 n.107; 130 $-131 ; 133 ; 142 ; 143$ e n. 36,$39 ; 150$; $152-155 ; 165 ; 166 ; 178$ e n.86; 183 n.109; 194; 202 n.13; 210; 211; 236; 238-239; 248; 254; 284 n.64; 287 -290; 296 n.111; 308; 309; 314; 318; $321 ; 322 ; 324 ; 333 ; 334$ n.22; 337 -338; 340; 346; 347-348; 352; 364; $365 ; 366$ e n. $71 ; 367$ n.83; 368; 371; $372 ; 374 ; 375 ; 379$. 
(Página deixada propositadamente em branco) 


\section{II. Índice de Autores Antigos ${ }^{1}$}

Ácio: 190 n.143; 362 n.35; 364 n.54.

Afrânio, L.: 161; 385 n.14.

Âmpio (T.): 41; 41 n.60.

Antígono de Caristo: 18; 20.

Apiano: 105; 137 n.10.

$B C$

2.5.35: 137 n.10.

2.20: 312 n.172.

5.2.15: 105 n.41.

Apolodoro

3.5.5-6: 192 n.154.

Apuleio

Met.

11.3-6: 180 n.97.

11.7: 255 n.271.

Aquílio Nigro: 41; 49 n.102.

Aristófanes: 16 n.4; 263

$N u .: 263$

293-296: 263 n.296.

Aristóteles: 18 e n.16; 19; 91; 318.

Ath.

14.4: 138 n.14.

EN

4: 18 n.15.

Po.

1447b 10-11: 20 n.21.

1448a 17: 323 n.41.

1449b 9-10: 317 n.5.

1449b 27: 91 n.85; 322 n.38.

1450a 15-22: 318 n.11.

1450a 24ss: 318 n.7.

1450b 3-4: 318 n.9.

1451a 16ss: 318 n.7. 1451a 16-17: 318 n.8.

1451'a 36-1451b 11: 317 n.2.

1451b: 138 n. 15.

1451b 6-10: 91 n.84.

1453a 1-4: 319 n.27.

1453a 3-12: 318 n.14.

1453a 25ss: 318 n.12.

1454a 16-20: 318 n.10.

1454a 33-36: 318 n.10.

1459a 17ss: 19; 91 n.83; 318 n.7.

Aristóxeno de Tarento: 18; 19 n.16, 18, 19.

Artemidoro

1.79: 99 n.10.

Aruleno Rústico: vide índice de personalidades e lugares históricos.

Asclepíades de Mendes: 39; 49 n.102; 311 n.169.

Asínio Polião: 40; 41 e n.57; 46; 47 e n.94; 60; 61; 101 n.22; 102 n.27; 135; 137 n. $11 ; 359$ n.9.

Ateio Filólogo: 60.

Atílio (ou Acílio; dramaturgo). Electra: 311 e n.171.

Aufídio Basso: 42 n.66; 49 n.102; 50; 51; 146 n. 51.

Augusto: vide índice de personalidades e lugares históricos.

$R G$ : (16 n.6); 21; 22; 46 e n.88; 49 n. $104 ; 378$.

7.2: 360 .

34.1: 360 n.19.

Aulo Cecina: 43 e n.73.

Aulo Gélio

1.14.1: 22 n.40.

\footnotetext{
${ }^{1}$ Incluem-se nesta lista autores pouco conhecidos que Suetónio menciona como fontes.
} 
1.21.2: 22 n. 40 .

3.11: 22 n.36.

4.9.5: 249 n. 250.

6.1-5: 208 n. 40.

16.6.14: 22 n.40.

17.9.1: 45 n.82.

Aurélio Victor : 274 n.16.

Caes.

3.8: 176 n.70.

5.11: 227 n.126.

10.3: 247 n.242.

10.5: 150 n.70; 275 n. $26 ; 379$ n. 170.

10.11: 274 n.16.

11.5-6: 254 n.267.

Biblia Sagrada

Dan

2.44: 112 n.76.

Jo

9.6: 144 n.42.

Mar

8.23: 144 n. 42.

Calímaco: 185 n.126; 315 n.183.

Hec.: 315 n.183.

Cássio de Parma: vide índices de personalidades e lugares históricos.

Cassio Severo: vide índices de personalidades e lugares históricos.

Catão: 20.

Orig:: 61.

Catulo: 43; 44 n.76; 61 n.148; 77 n.24. 12.1-2: 345 n.28.

29: 43.

César: vide índices de personalidades e lugares históricos.

Civ.

3.105: 41 n. 60.

Gal.

8 (autor: Hírcio): 46 n.93.

Cícero: 20; 21 n. 31; 23 n.41; 25 n.58; 26; 26; 39; 40; 41 n.58; 41 n.59, 61; 43;
44; 44 n.77; 49; 50 n.105; 57 e n. 127, 128; 62; 74; 77; 79 e n.31; 99 n.14; $100 ; 101 ; 104$ n.35; 118; 119; 135 e n.5; 208 e n. $43 ; 240$ e n.204; 312 n. $172 ; 332 ; 345$ n.32.

Att.

8.11b: 41 n.60.

14.10.1: 312 n.172.

16.8.1: 104 n.35.

16.11.6: 104 n.35.

Brut.: 46.

19.75:

252: 46 n.91.

261: 46 n.91; 61 n.151.

262: 46 n.92.

302: 57 n.127.

Div. Caec.

45: 57 n.127.

Caec.

34: 41 n.59.

Cael.

14.34: 335 n.28.

de Orat.

2.289: 261 n.290.

Fam.

6.5-8: 43 n.73.

6.12: 41 n.60.

11.20.1: 104 n.35.

Inv.

1.31: 57 n.127.

N.D.

3.83: 181 n.102.

Off.

3.82: 41.

Orat.

59: 160 n.8.

Phil.

1.31-32: 312 n.172.

Q. $f r$.

1.121: 39 n.43. 
3.1.8: 45 n.82.

Rep.: 57 n.128.

1.50: 360 n. 17.

Tusc.:

1.93: 185 n.126.

3.26: 345 n. 32 .

3.76: 345 n. 32 .

4.2.3: 20 n. 25 .

Cílax de Carianda: 16; 17.

Clearco: 19.

Clúvio Rufo: 50; 51 e n.107, 109; 84; 127 n. $146 ; 163 ; 177$ n. $75 ; 187$ n. $132 ; 247$ n.243.

Cornélio Epicado: 21 n. 32.

Cornélio Nepos: 22-23; 45; 46; 49 n.102.

Ag:: 23 n.43.

Att: 23 n.41, 43.

Ca.: 23 n. $41 ; 24$ n. 45.

3.4: 24 n. 45 .

Ep.: 23 n.43; 57.

1.4: 57 n.129.

Pel.

1.1: 23 n.42.

Prol.

1.1: 23 n. 42 .

Cremúcio Cordo: 24 n.49; 41 e n.61; 42; 49 n. $102 ; 84$ n. $54 ; 218$ n.94.

Cypria: 188 n.137.

Décimo Labério: 138 e n.19.

Demóstenes

23.198: 17 n.7.

Dicearco de Messene: 19.

Digesto

12.5.52: 229 n.140.

Diógenes Laércio

1.94: 188 n.136.

Diomedes

Art. Gramm. Lib. III, p. 491 Keil: 324 n.48.

Díon Cássio: 24 n.46; 50 n.106; 51 n.107,
109; 84; 104; 105 n.42; 106; 107 n.46; 111 n.74; 135 n.2; 172 e n.55; 178 n.81; 183 n. $114 ; 187$ n.132; 188 n. $134 ; 203 ; 210$ n. $54 ; 220$ n. $103 ; 227$ n.126; 228 n.137; 232 n.164; 249 n.250; 250 n.254; 257 n.275; 292 n.98; 295 n.109; 296 e n.112; 339 n. $38 ; 343 ; 379$.

37.52.2: 98 n.9.

41.1-3: 135 n.2.

41.39.2: 209 n.50.

44.17: 277 n.33.

44.19.5: 278 n.39.

44.36-49: 312 n.172.

45.1: 342 n. 8 .

45.4.4: 207 n.33.

47.3-13: 240 n.203.

47.41.2: 205 n.26.

47.49.2: 105 n.39.

48.13.6: 104 n.36.

48.14.4: 105 n.42.

51.2.5-6: 105 n.40.

54.1.2: 107 n.50.

54.1.3: 107 n.49.

54.10.5: 241 n.208.

54.19.3: 242 n.211.

54.19.6: 242 n.211.

55.1.13: 339 n.38.

56.30.1-2: 273 n.10.

56.30.4: 272 n.7.

57.2.4: 345 n.33.

57.6.2ss: 147 n.62.

57.10.5: 175 n.67.

57.15.1: 220 n.102.

57.19.4: 106 n. $45 ; 107$ n.46; 208 n.45, 46.

57.24.2-4: 42 n.65.

57.24.3: 24. n.49; 84 n.54.

58.1.3: 219 n.96.

58.2.5: 242 n.210; 377 n.158.

58.11.5: 219 n. 97. 
58.15.1-2: 219 n.95.

58.21.4: 219 n. 95.

58.24.3-5: 84 n. 54 ; 218 n.94.

58.27.2: 337 n.33.

58.28.1-4: 297 n.115.

58.28.3: 147 n.63.

59.2.1: 152 n.75.

59.2.6-3.1: 221 n.105.

59.6.3: 176 n.71.

59.81-3: 225 n.120.

59.8.3: 184 n.116.

59.8.6: 130 n.160.

59.8.7: 196 n.167.

59.10.8: 176 n.71.

59.12.1: 223 n.116.

59.12.3: 112 n.79.

59.16.3: 176 n.71.

59.17.3: 181 n.101.

59.23.2-5: 130 n.159.

59.23.5: 265 n.302.

59.24.2: 39 n. $45 ; 220$ n.103.

59.25.1-3: 257 n.274.

59.25.7: 279 n. 46 .

59.26.2: 183 n.114.

59.28.6: 181 n.98.

59.29.3: 280 n. 48.

59.29.7: 282 n. 55 .

60.1.3-4: 151 n.73; 344 n.23.

60.2.4: 265 n.302.

60.4.5: 176 n.71.

60.5.7: 249 n. $250 ; 282$ n.55.

60.15.1ss: 204 n.21.

60.16.5ss: 204 n.21.

60.17.1: 249 n.250.

60.17.4: 258 n.278.

60.18.1: 260 n.283.

60.23.1: 259 n.281.

60.28.6: 258 n. 276 .

60.31.1: 260 n.283.
60.34.4: 298 n.120.

61.2.1: 124 n.130.

61.4: 357 n.1.

61.11: 127 n.146.

61.11.2: 126 n.144

61.12.2: 187 n.131.

61.13.2: 187 n.132

61.14.2: 187 n.133.

61.20.2: 187 n.133

61.21.2: 162 n.13.

62.13.3: 228 n.137.

62.18.1: 192 n.153.

62.24.2: 185 n.121.

62.27: 188 n.136.

63.3.4: 237 n.193.

63.8.5: 84; 193 n.157.

63.10.1 a: 111 n.74; 178 n.87.

63.13.1: 197 n.171.

63.13.2: 197 n.172; 198 n.173.

63.20.1ss: 164 n.28.

63.23: 109 n.59.

63.27.3-29.2: 304 n.141.

63.28.3-5: 303 n.139.

63.28.5: 387 n.20.

63.29.6: 141 n.25.

64.2.1-3.4: 237 n.187.

64.3.3: 283 n.60.

64.3.4: 141 n.27.

64.5.2: 284 n.65.

64.6.2: 285 n.68.

64.6.4: 285 n.69.

64.6.5 a: 287 n.75.

64.8: 157 n.96; 354 n.78.

64.8.3: 126 n.142.

64.10.1: 248 n.245.

64.11: 307 n.155.

64.11-15: 306 n.152.

64.13.2: 307 n.154.

64.15.2: 308 n.161. 
64.15.12: 314 n.179.

64.15.2: 314 n.180.

$64.15 .2^{\mathrm{b}}: 314$ n. 179 .

65.16.6: 288 n. 81.

65.20.1: 289 n.82.

65.21.2: 289 n.83; 348 n.52.

66.1: 113 n.85.

66.1.2: 113 n.81.

66.1.3: 113 n.82, 83; 113 n.86.

66.6.2: 238 n.197.

66.7.2: 235 n.178.

66.8: 268 n.315.

66.8.1: 144 n.41.

66.9.4-5: 254 n.267.

66.11.2: 111 n.74; 178 n.87.

66.11.4: 234 n.172.

66.12: 179 n.89.

66.12.1: 210 n.54.

66.13: 244 n.224.

66.14.3: 245 n.226.

66.15.3-4: 246 n.235.

66.17.1-3: 273 n.11; 379 n.169.

66.17.3: 343 .

66.18.1: 246 n. $235 ; 275$ n.25.

66.18.3-5: 114 n.92.

66.19.1: 247 n.240.

66.26.1: 274 n.19.

66.26.2: 150 n.70; 274 n.16.

66.26.3-4: 275 n.24.

67.2.1: 246 n.234.

67.2.3: 172 n.55.

67.3.1: 195 n.163; 231 n.151; 236

n. $185 ; 254$ n.269.

67.3.2: 254 n.269.

67.6.3: 235 n.182.

67.6.3-4: 195 n.162.

67.11.3: 233 n.170.

67.12.1: 172 n.56.

67.12.2-4: 179 n.88; 233 n.165.
67.12.3: 233 n.165.

67.12.5: 292 n.97.

67.13.2: 24 n. $48 ; 232$ n.164.

67.13.3-4: 181 n.105.

67.14: 232 n.158.

67.14.1: 292 n.98.

67.14.3: 233 n.170.

67.15.1-2: 291 n.89.

67.16.1: 293 n.103.

67.16.2: 295 n.106.

67.16.3: 293 n.104

67.17.1: 296 n.110.

67.17.1-2: 295 n.107.

67.18.2: 296.

69.4.6: 193 n. 155.

Dionísio de Halicarnasso: 33 n.8.

Dúris: 19 e n. 18, 19.

FHG 2.469.1 Muller: 19 n.20.

Éforo: 18 e n.14; 19 e n. 20.

Énio

Ann.: 103.

Ésquilo: 16.

Estácio

Silv.

3.4: 172 n.55.

Estesícoro: 193 n.155.

Estesímbroto: 16.

Etymologicon Magnum: 16.

Eurípides: 16; 20 n. 23; 41; 135; 136; 286; 319 n. 19; 359.

Ba. : 187 n.133.

1139ss : 286; 312.

Ph. : 41; 240.

524: 135 n.5; 359 n.11.

Eusébio de Cesareia: 231 n.149.

Fábio Rústico: 51 e n.112; 61; 177 n.75.

Fânio: 25 n.51; 26 n.59.

Fénias de Éreso: 19 e n.17, 19.

Fílon de Alexandria: 147 n.63. 
Leg.

13: 221 n. 105 .

16: 225 n. 120.

19: 225 n. 120.

162: 196 n.165.

Filóstrato: 296 n.112.

VA

7.8: 232 n.157.

7.33: 232 n.157.

8.7.10: 232 n.157.

8.25: 295 n.107.

Flávio Josefo: 33 n.8; 48 n.100; 113 e n. $85 ; 147$ n.63.

AJ: 50 .

18.5.4: 246 n.235.

18.170: 214 n.73.

18.256: 221 n.105.

19.4: 160 n.5.

19.5.1: 246 n.235.

19.91-92: 51 n.107.

19.212-225: 151 n.73; 344 n.23.

20.7.3: 246 n.235.

20.151: 299 n.122.

BJ: 50 .

3.8.2: 113 n. 85 .

3.8.9: 48 n.100.

4.10.4: 142 n.33.

4.601: 142 n.34.

4.645: 288 n.79.

5.288: 116 n.104.

7.6.6: 235 n.178.

Floro: vide índice de personalidades e lugares históricos.

Gaio Druso: 39; 49 n.102.

GaioMémio:videíndice de personalidades e lugares históricos.

Getúlico, Lêntulo: Vide índice de personalidades e lugares históricos.

Hecateu de Mileto: 16;

Herénio Senecião: víde índice de personalidades e lugares históricos.

Hermipo: 18; 19 n.18; 20.

Heródoto: 17.

1.6: 138 n.14.

1.214: 18 n. $12 ; 279$ n.43.

3.39-43: 300 .

4.83: 168 n.38.

6.107: 99 n.10.

Hesíodo: 22 n.36.

Higino: 22.

Hírcio: vide índice de personalidades e lugares históricos.

Gal.

8: vide César, Gal.

História Augusta

Hadr.

11.3: 27 n.65.

M.Aur.

29: 262 n.293.

Verus

4.4-6: 183 n.109.

Homero: 22 n.36; 62 e n.154; 192; 193

n. $155 ; 201 ; 235 ; 268 ; 278$ n.39.

Il.: 62 n. $154 ; 68 ; 304$.

1.26: 258 n. 278 .

2.204: 180 n. $93 ; 181$ n.103.

2.796: 258 n. 278 .

3.40: 201 n.7.

7.213: 268.

9.437: 278 n.39.

23.724: 181 n.98.

Od.

4.611: 278 n.39.

Horácio: 61 n.148.

Carm.

3.11.2: 192 n.153.

Íon de Quios: 16.

Isócrates: 17 e n. 9; 317 n.2; 379 n.171.

Ev. 17 e n.11. 
22: 57.

22-23: 17 n. 10.

71: 17 n. 10; 379 n.171.

Jerónimo: 18; 22.

De uir. Ill. (frag. 1 Reifferscheid): 22 n.34.

João Lido

de Mag.

2.6: 55 n.119.

Júlio Márato:videíndice de personalidades e lugares históricos.

Júlio Saturnino: 42; 49 n.102.

Júlio Secundo: 52.

Juvenal: 73 .

2.29-33: 195 n.163; 236 n.185.

3.86-108: 120 n.119.

4.38: 349 .

6: 260 n. 283 .

10.78-81: 35 n.23.

Labério: vide 'Décimo'.

Licínio Calvo, Gaio: 43; 44 e n.76; 77 e n.24.

Lucano: 61 e n. 148.

Mácio: vide índice de personalidades e lugares históricos.

Macróbio

1.16.33: 40 n.51.

2.4.21: 252 n.261.

2.7.3: 138 n.19.

Marco Actório Nasão: 40; 44.

Marcial: 73; 231 n.149; 347.

1.13: 204 n.21.

1.98: 347 n. 45 .

2.37.4: 183 n.113.

2.40.4: 183 n.113.

2.44.9: 183 n.113.

5.2.6-8: 293 n.103.

6.2: 172 n.56.

6.3.5: 195 n.163; 236 n.185.

6.7: 172 n.56.
6.10.9-12: 293 n.103

6.22: 172 n.56.

6.32: 306 n.153; 352.

6.91: 172 n.56.

7.1.1-2: 293 n.103.

8.1.4: 293 n.103.

9.3.10: 293 n.103.

9.5 (6): 231 n.149.

9.7 (8): 231 n.149.

9.11: 172 n. 55 .

9.12: 172 n.55.

9.13: 172 n.55.

9.16: 172 n. 55 .

9.17: 172 n.55.

9.36: 172 n. 55 .

11.2.6: 22 n.38.

11.20: 252 n.261.

14.74.2: 101 n.23.

M. Emílio Escauro: vide índice de Personalidades e lugares históricos.

Mnandro: 137 n.11.

Nicolau de Damasco: 23 e n.44.

Vit.Caes.

24: 103 n.32.

Ópio, G.: 45 e n.82.

Ovídio: 61 n.148; 242 n.211.

Met.

13.111: 345 n.28.

$\operatorname{Tr}$.

2.497-498: 324 n.51.

Pacúvio: 386 n.15.

Trag. (trag. rom.fr. Ribbeck)

40: 311 e n.171.

Pausânias

4.14.4-7: 208 n.40.

6.26.6: 99 n.10.

Petrónio: 64; 389.

Sat.: 324 .

17-18: 188 n.135. 
29.8: 170 n. 44 .

47.5-6: 263 n.295.

88: 192 n.153.

128.6: 228 n.131.

Pitolau: vide 'Voltacílio'.

Platão: 18 n.16; 19 e n.19; 65; 192.

Hp.Ma.

285 d: 33 n. 7.

R.: 192 .

392c-394b: 65 n. 164.

571c: 99 n.10.

Plauto: 261; 262 n.293.

Epid.: 261; 264 e n.301.

Mil.

370-410: 264 n.300.

973-984: 262 n.293.

1094-1136:

1216-1283: 261 n.285.

1311-1377: 262 n.293.

Per.

227: 345 n. 28.

Plínio-o-Velho: 23; 37; 38 e n.37; 48; 50 n.106; 51 e n. $109 ; 52 ; 228$ n. $135 ; 243$; 298 n. $120 ; 362$ n. $37 ; 371$ n.107.

Nat.

7.46: 243

8.145: 219 n.96.

8.183: 274 n.20.

10.83: 260 n.283.

15.136-137: 209 n.50.

15.137: 209 n.51.

30.14: 203 n.16.

Plínio-o-Moço: 27 e n.64; 33; 37; 39 n. $48 ; 50$ n.106; 202; 283 n. $62 ; 332$ n. $15 ; 378$ e n.166; 379 n.173.

$E p$.

1.5: 24 n. $48 ; 232$ n.164.

1.18: 97 n. $4 ; 202$.

1.24.1: 27. n.64.

1.24.4: 27. n.64. 3.16.7ss: 204 n.21.

4.11: 231 n.149.

4.11.6: 195 n.163; 236 n.185.

5.5.2: 25 n.51.

5.8: 25 n.51.

5.10: 27. n.64.

8.12.5: 25 n.51.

9.6.1: 370 n.102.

9.13: 25 n.51.

10.94.1: 27 n.64; 33.

10.95: 27. n.64.

Pan.: 25 n.53; 378 e n.166,167; 379 n.171.

8.6: 149 n.69.

14: 235 n.182.

33: 35 n.23.

45.3: 360 n.17.

49: 291 n. 93.

50.5: 234 n.174.

82: 291 n.93.

Plutarco: 22; 23; 24; 37; 41; 44; 45 n.85; 48; 52; 53; 56 n. $123 ; 71 ; 84 ; 85 ; 98$ e n. 6,$9 ; 99 ; 104 ; 113$ n.87; 135 n. $4 ; 136$ n.7, 8; 140 n. $22 ; 153$ n.78; 156; 253 n. $265 ; 311$ n. $171 ; 317$ n.6.

Alex.: 85 .

$1: 23 ; 53 ; 85$.

2.6-3.2: 208 n.40.

32: 106 n.43.

61: 212 .

Ant.

14.6-7: 312 n.172.

20-21: 240 n.203.

22.7: 104 n.38.

54.4: 44 n.81.

65.5: 205 n.27.

71.2: 44 n.81.

81.2: 44 n.81.

Brut.

1: 309 n.163. 
5.2: 45 n.85.

20.4: 312 n.172.

27-28 : 240 n.203.

53.3: 104 n.38.

Caes.

1.8: 98 n.6.

2.6: 98 n.6.

7.1: 99 n.13.

8.2: 99 n.14.

8.5: 99 n.14.

11.5-6: 98 n.9.

12: 100 n.18.

15-28: 102 n.25.

18-27: 56 n.123.

21.5-6: 101 n.20.

28-31: 135 n.2.

32.3 ss: 136 n.7.

32.7: 41 n.57; 137 n.10.

32.8: 137 n.11.

32.9: 98 n.9.

46.1 : 135 n. 4.

46.1-2: 41 n.57.

49.10: 44 n.81.

63: 277 n.33.

63.7: 279 n.43.

65: 277 n.34.

66.8: 278 n.39.

66.12-13: 278.

68.1: 311 .

68.3-7: 312 n.175.

69.3: 84; 279 n.44.

Ca.Mi.

6.1-2: 45 n.85.

24.1: 45 n. 85 .

Cic.

46-49: 240 n.203.

Gal.:

4.1: 109 n.59.

5.1: 140 n.22.
6: 141 n.26.

7: 141 n.26.

14-15: 142 n.28.

15.8: 142 n.29.

16.1-2: 269 n.316.

16.3-4: 237 n.192.

17.2-3: 237 n.193.

18.4: 283 n.60.

19.3-8: 126 n.144.

19.3-20.1: 76 n.18.

20.2: 127 n.148.

21.1: 307 n.156.

22: 153 n.78.

23.4: 283 n.63.

23.7: 127 n.149.

24.5: 284 n.65.

25.1-4: 156 n.93.

25.8: 285 n.67.

26.1: 284 n.66.

26.2: 285 n.68.

26.8-10: 285 n.69.

27.1: 285 n.70.

27.3: 287 n.75.

27.4: 286 n.73.

28.1: 157 n.96.

Oth.:

3.2: 84; 247 n. 243.

3.3-13: 248 n.246.

4.4-6: 248 n.245.

4.8: 113 n.87.

9.3: 52 n.114.

10.1: 248 n.247.

12.1-2: 248 n.248.

15-18: 306 n.152.

15.7: 307 n.154.

17.10: 314 n.179.

18: 314 n.180.

18.3: 308 n.161.

Per. 
31: 17 n.7.

Políbio

7.7: 182 .

12.25 f-h: 18 n.14.

16.7-9: 18 n.14.

Probo: 61

Públio Rutílio Rufo: vide índice de personalidades e lugares históricos: 'Rutílio'.

Publílio Siro (autor de mimos): 324.

Quintiliano: 57 n.128; 60 n.143.

Inst.

1.7.22: 47 n. 95 .

7.3.26: 251 n.255.

10.1.101-102: 60 n.143.

10.1.125 ss: 61 n.149.

11.2.46: 22 n.38.

11.3.126ss: 160 n. 8

Salústio: 49; 60 e n.143, 145; 61.

Jug.: 60 n.145.

Santra: 22 e n.38.

Sátiro: 18; 19 n.18, 19; 20 e n. 23.

Vit.Eur:: 19 n.18; 20.

Séneca, o retor: 146 n. 51; 297 n.116.

Séneca, o filósofo: 21; 43; 51 n.113; 61 e n. 148,$149 ; 80$ e n. $41 ; 88 ; 111$ n.70; 177 n. $75 ; 188$ n. $135 ; 191 ; 228 ; 240$ n.205; 265 n. $302 ; 297$ e n. $116 ; 322$ n.38; 330 n. $8 ; 357$ n.1.

Apoc.: 47 n.96; 51 e n.108.

1.1: 265 n.302.

4.2: 299 n.124.

4.3: 263 n.295.

4.13: 270 n.319.

5.2-3: 344 n.21.

5.3: 259 n. 279.

13.4-6: 262 n.291.

Cl.: 114 n.89.

2.1.1-2: 177 n.79.

3.7.1: 174 n.61.
9.1-2: 174 n.61.

Dial.

3.20.8: 181 n.98.

$E p$.

93.11: 40 n.51.

122.7: 355 n.8.

Servílio Noniano: 42 n.66,49 n.102; 50;

146 n. 51.

Sidónio Apolinar

Ep.

9.14.7: 47 n.97.

Sílio Itálico

13.634-644: 208 n.40.

Sófocles: 16; 311 n.171.

OT

981-982: 99 n.10.

Suetónio: passim

Vita Caes.: passim

Jul.: 23 n. 43; 49; 50 e n.105; 55; 61

n.148; 89; 97-102; 135-138; 211

$-213 ; 235 ; 276-279 ; 331 ; 358$.

1.3: 97.

2: 74 n.10; 86; 97; 353; 375 n.143.

4.1: 98 n.6.

4.2: 98 n.7.

5: 98 .

6.1: 21 n.26; 40; 98; 342.

7.1-2: 98

7.1: 98 n.9; 320 n.33.

7.2: 320 n.33.

8-11: 99.

9.1: 40.

9.2: 40 .

13: 99 n.13.

14.2: 99 n.14; 100.

15: 100 n.16.

16.2: 100 n.17.

17: 100 .

18.1: 100 n.18.

19.1: 80. 
19.2: 100 n. $19 ; 171$ n. $48 ; 180$.

20.1: 48.

20.1-2: 101.

20.3-5: 101.

22.1: 101 n.20.

22.2: 101 .

23.2: 102 .

24: 102 n.24.

25: 102 n.25.

25.1: 56 n. 123 .

26.1: 102 e n.26.

26.2-3: 102.

27: 102 .

28.1: 102 .

28.2: 102 n.26.

28.3: 102

29.1: 102 n. $27 ; 359$ n.8.

29.2: 102 n.27.

30: 40 .

30.1: 135 n. $1 ; 136$.

30.2: 135 n. $2 ; 359$ n.7.

30.3-4: 359 n.9

30.4: 135 n.4.

30.5: 41 n. $58 ; 135$ n. $5 ; 319$ n. $19 ; 359$

$$
\text { n. } 10,11 ; 367 \text { n.83. }
$$

31.1: 136 .

31.2: 137.

31.2-32: 64.

32: 137; 339; 383.

33: $138 ; 383$.

34-36: 138.

34.1: 55 .

34.2: 138 n.17.

35.1: 138 .

35.2: 138 n.18.

37: 138 .

38: $138 ; 370$ n.99.

39: $138 ; 370$ n.102.

39.1: 159 .
39.2: 138 n.19.

40-44: 211.

40.1: 36 n. $25 ; 211$ n.58.

42.3: 41 n.59.

43: 373 .

44.2: 276.

44.3: 171 n.48; 171 n.49; 211 n.59; 370 n.101.

44.4: 55; 57 e n.131211 n.60, 61; 224 n.118; 235 n. $181 ; 276 ; 377$ n. 155 .

45: 278 n.38.

45.1: 202 n.13; 342; 350 n.59.

45.1-2: 211; 370 n.100.

45.2: 170 .

45.2-3: 353 n.69.

45.3: 211.

46-47: 211.

46-48: 211.

49: 43; 44; 77; 211-212; 212; 353;

$360 ; 375$ n.140.

49-52: $26 ; 252 ; 324$ n.52.

49.1: 45 n.83; 74 n. $11 ; 86 ; 375$ n.143.

49.3: 44 n.77.

49.4: 44 n.78; 80; 194.

50: 77.

50-52: 212; 376 n.146.

50.1: 44; 79; 212 n.63; 376 n.147.

50.2: 44 n.79; 74; 79; 212.

51: 44 n.80; 194; 212 n.64; 354 n.70.

52.1: 44; 78; 212; 377.

52.2: 45 .

52.3: 45 n.83; 74; 78; 86; 354 n.71; 375 n.143.

53: $45 ; 212$.

54: 212 .

54.1: 82; 212; 368 n.86.

54.2: 131 n. $163 ; 212$.

54.3: 228 e n. $132 ; 368$ n. 90.

55-56: 212. 
55.1: 46; 61 n.151.

55.2: 46 .

55.3: 46 .

55.4: 46 .

56.1-2: 46.

56.1-4: 56 n.123.

56.3: 46 .

56.4: 47 n.94.

56.6: 50 .

56.7: 47; 99 n.12.

57: 115 n.96; 212; 342 n.12.

57-65: 342 .

57-67: 56.

58.1-2: 212.

59: 72; 107 n. $49 ; 212 ; 213 ; 274$ n.20; 278 n. $36 ; 284$ n. $64 ; 319$ n. $17 ; 366$ n.71.

60: 212 .

61: 72; 212.

62-64: 212.

63: 85 n.57.

65: 212.

65-70:

67.1: 212 .

68: $56 ; 212$.

68.4: 71 n.1.

69-70: 56.

71: 174; 212.

72: 45 n.82; 174; 212.

73: 43; 44 n.76; 61 n.148; 77 n.24; $174 ; 212$.

74: 174; 212.

$75: 43 ; 174 ; 212$.

75.1: 82; 212 n.62; 364 n.52.

76: 235 .

76ss: 213.

76-79.2: 174 .

76.1: 36 n.26; 65; 82; 148; 211 n.57; 276 e n. $27 ; 282$ n. $57 ; 318$ n. 15 ; 319; 354; 354 n.72; 359 n.12.
76.3: 359 n.13.

77: 41 n.60; 82; 276; 359 n.14; 366 n.71.

78.1: 47 n. $97 ; 276$.

79: 98; 354.

79.1: 174 n.60; 181 n.105; 276.

79.2: 276; 354 n.74; 359 n.15.

79.3: 224 n. $118 ; 276 ; 362$ n.39.

80.1: 354 .

80.1: 277 n. $28 ; 309$ n. $162 ; 312$.

80.2: 309 .

80.2-3: 309 n.163.

80.4: 277; 309 n.163.

81: 209 n.47.

81.1: 144 n. $43 ; 277$ n. 30; 280 n.47.

81.2: 47; 277.

81.4: 277 n.35; 319 n.17; 366 n.71.

82: $65 ; 107$ n. $46 ; 278$.

82.2: 47; 278 n.37.

82.3: 278 n.39; 296 n.111.

83.2: 311 .

84.2: 311 n.171; 386 n.15.

84.3: 312.

84.4: 176 n.70; 312.

84.4-5: 312 .

84.5: 312.

85: 312 n.175.

86.1: 279 n. 41 .

86.2: 279 n. 42 .

87: 279 n.43.

88: $279 ; 367$ n. 81 .

89: 89; 279 n. $44 ; 320 ; 342$.

Aug.: 23 n.43; 49; 49 n.103; 50 n.105; 55; 61 n.148; 89; 102-106; 139 -140; 182; 199 n.2; 207; 208; $239-243 ; 252 ; 271-273 ; 298 ; 323$ n. $46 ; 331-332 ; 357 ; 358 ; 367$.

1: 331 .

2.1: 103 n.30.

2.3: 331 . 
3.1: 332 .

3.2: $39 ; 332$.

3.3: 331 .

4.1: 331.

4.2: $39 ; 331$ n.12.

5:103; 124 n. $131 ; 208$ n. 42; 320.

5 ss: 48.

6: 72; 103 n. 29; 321 n. 34; 332.

7.1: 34 n.13; 40; 103 n.30; 247 n.237.

7.2: 103 n. $31 ; 331$.

8.1: 21 n.26; 103 n.32.

8.3: 104.

9.1: 55 n.120; 104 n.33.

10.1: 104 n.34.

10.2-4: 104.

10.4: 41.

11: $42 ; 104$.

12: 80 n.33; 104 e n. 35 .

13.1: 104 n.37; 240; 322 n.36; 363 n.46.

13.2: 105 .

14: 105.

15: 105 n. $42 ; 322$ n. $36 ; 363$ n.46.

16.2: 41.

16.2-3: 106.

16.3-4: 106.

17.1: 106.

17.1-3: 139.

17.2: 139 .

17.3: 139 .

17.4-5: 139.

18.1-2: 140 n.20.

19: 239.

19.1: 119 n. $117 ; 357$.

19.2: 200 n.5.

20: 240.

20-25: 331.

21.1: 82; 119 n.117.

21.1-2: 105; 240.
21.2: 82 .

21.2-3: 332.

21.3: 119 n. $117 ; 240 ; 357$.

22: 240 .

23: $240 ; 367$ n.76.

23.2: 167 n.33.

24: 240 .

24-25: 243 n.218.

25.4: 240 .

26-28: 240.

27.1: 240 .

27.1-4: 363 n.46.

27.2: 42 .

27.2-3: 240 .

27.4: 118 n. $112 ; 182$.

28: 240 .

28.1: 52 n.118; 62 n.156; 166 n.32; 360 n. 19.

28.2: 241; 311 n. $169 ; 360$ n.20; 360 n.22.

28.3: 170; 243 n.217.

28.3-30: 370 n.100.

29-60: 241.

29.1-2: 105.

29.1-3: 366 .

29.3: $243 ; 280$ n.47.

30: 49 n. 102.

31: 243.

31.2: 34 n.17; 36 n. $26 ; 360$ n.23.

31.4: 366 n.73.

31.5: 52 n.118.

32.1: 119 n.117; 171; 357; 372 n.120.

34: 35 n.22; 200.

34.1: $172 ; 200$ n. $3 ; 372$.

35.1: 34 n.17.

35.2: 41.

40.2: 34 n.17.

40.3: 46; 172 n.51; 372 n.123.

40.5: 34 n.17; 172 n.52; 353; 355 n. $80 ; 373$. 
41: 370 n.99.

41.1: 46; 174 n.62; 245 n.229; 369 n.97.

42.1: 82; 174; 370 n.104.

42.2: 46 .

42.2-3: 370 .

42.3: 370 n.105.

43: $159 ; 370$ n.102.

43.1: 46; 159 n.1.

43.5: 159 .

44: $173 ; 373$.

44.1: 173 n. $57 ; 373$ n.124.

44.3: 46; 52 n.118.

45: 35 n.22.

45.1: $159 ; 370$.

45.3-4: 173.

45.4: $173 ; 373$.

47-48: 332.50: 140 n.20; 241.

51: $174 ; 241$.

51.1: 43; 71 n.1; 82; 244 n.220; 355 n. $84 ; 361$ n. $25 ; 363$.

51.3: 44; 181 n. $104 ; 363$ n.47.

52: $174 ; 180$ n. $95 ; 355$ n.84; 360 n.23; 383.

52-56: 174; 241.

53.1: 41; 174; 361 n. $24 ; 383$.

53.3: 361 .

54: 361 n.27.

56.2: 383 n.2.

57.1: 44 n.74; 52; 82 n.47; 168 n.35; $241 ; 310 ; 361$ n.28.

57.2: 368 .

58: 167 n.34; 241; 310 n.167; 383.

58.2: 44 .

58.4: 272 n. 4 .

59-60: 310 .

60: 84 n.52.

61.1: 55 n.120; 57 e n. 131; 241 n.209; 377 n. 155 .

62.2: 45 n.84; 241; 377 n.159.
63.2: 45 .

64.2: 46.

65: $241 ; 322$.

65.1: 46 n.90; 200 n.4.

65.2: 200 n. $4 ; 320$.

65.3: 200.

65.4: 200 n.5,6.

66: 241 .

66.2: 61 n.148.

66.3: 71 n.1; 253 n.263.

67.2: 241.

68: 45; 74; 80 n.34; 242; 253 n.262; 353 n. $67 ; 375$ n. 140 .

68-69: 26.

68-71: 82; 324 n.52.

69: 242 .

69-70: 376 n.146.

69.1: 45 n.84; 74 n. $12 ; 75 ; 197$ n.169; $242 ; 253$ n. $263 ; 376$ n. 147.

69.2: 45; 64 n.162; 78 n.27; 253 n. $265 ; 323$ n. 40 .

70: 75; 181 n. 102; 242; 355; 385.

70.1: 38 n.36; 45; 209.

70.1-2: 45; 309 n.164.

70.2: 79; 370; 383n.3.

71: 334 .

71.1: 74; 75 e n.13; 242 n.210; 353 n. $68 ; 370 ; 377$ n.158.

71.1-3: 251 n.257.

71.2-3: 242.

72: 371 .

72 ss: 235 n.181.

72-78: 242.

72.1: 82 n. $48 ; 242 ; 371$ n.106.

72.3: 34 n.14; 371; 383.

73: $170 ; 343 ; 353 ; 371$.

74: 46 .

76: 45 .

77: 45 .

79.1: 115 n. $95 ; 272$ n. $3 ; 341$ n.7; 352 
n.66.

79.1-3: 242.

79.2: 21 n. $32 ; 46 ; 343$ n.14.

79.2-3: 341 n.6.

80: 36 n. $27 ; 343 ; 343$ n.15.

80-82: 242.

81.1: 36 n.27.

82: 353 .

83: 242 .

84-89: 243.

85.2: 252 n.261.

86: $47 ; 60$.

87: 47.

87.3: 47 e n.95.

88: 34 n. $12 ; 47$.

89.1: 272 n.5.

89.2: 52 n. 118.

90: $73 ; 243$.

91-92: 205; 243.

91-93: 331.

91.1: 366 n.72.

92.1: 366 n.72.

93: $243 ; 367$.

93.1ss: 207 n.36.

94: 332 .

94-97: 207.

94.1: 25 n.56; 207 n.38.

94.2-3: 207.

94.3: 21 n. $32 ; 39$.

94.4: 124 n.131, 136; 207 n.39; 311 n. $169 ; 342$ n.8.

94.5: 208 n.41.

94.6: 39; 124 n.131; 208 n.42.

94.7: 129 n. $157 ; 208 ; 209$ n.49.

94.8-9: 208 n.43.

94.9: 43.

94: 10ss: 208.

94.12: 205 n.25.

95: 207 n.33; 207 n.34; 383.
96.1: 205 e n.26; 209 n.49.

96.2: 205 n.27.

97: 209 n. $47 ; 271$.

97.1: 129 n. $157 ; 205$ n.28; 209 n.49.

97.2: 271.

97.3: 205.

98.2: 310 .

98.4: 252 n.261.

99.1: 95 n.2; 174; 271 n.2; 323 n.46; 352; 377 n.159; 384.

99.2: 273 n. 8 .

100: 312 .

100.3: 36 .

100.4: 367 n.82.

Tib.: 50 e n. $105 ; 56 ; 87 ; 117-122$; 144-147; 201; 206; 213-220; 297 $-298 ; 335-336 ; 340 ; 357 ; 361$ n. $32 ; 367$.

1.2: 335 .

2.1: 71 n. $1 ; 335$ n. $25 ; 345$ n.30.

2.2: 335 e n. 26 .

2.3: 335 n.27.

2.4: 335 n.28.

3: 336 n. $29 ; 340$ n.40.

4: 337 .

5: 25 n. $56 ; 48 ; 117$.

5:1: 337 .

6.1: 117.

6.2: 117 n.111.

6.3: 39 n.47; 118 n.112.

6.4: $118 ; 132$ n.171.

7.1: 80 n.39; $118 ; 321 ; 369$.

7.2-3: 118 n.115; 321.

8: $119 ; 357$.

9: 119 .

9.1: 357.

9.1-2: 119 .

10.1: 321.

10.2: 42 .

11.1: 120 n.119. 
11.2: 120 n.120.

11.3: 121.

11.4: 121.

11.5: 42 n.67; 121.

12: 121.

13.1: 181 n.100.

13.2: 121 n.121.

14: 209.

14.1: 121.

14.3: 320 n.31.

14.4: 129 n. $157 ; 209$ n.49.

15.1: 121.

15.2: 122 n.122.

16-18: 122 .

18: 344 .

19: $122 ; 298$.

20: 122 .

21.2: 144 n. 45.

21.3: $42 ; 144$.

21.4-7: 144.

22: 145 n. 46 .

23: 42 n.69; 145 n. 49; 201 n.8; 364 n.59.

24: 64 n. $163 ; 145 ; 146$ n. 55.

24.1: $95 ; 323$ n.46.

25.1: 146 n. 57.

25.3: 147 e n.62.

26.1: 174 n.63; 180 n.95; 244 n.219;

355 n. $84 ; 361$ n.32.

26.2: 174 n. $64 ; 361$.

27: 174; 181 n. $104 ; 361$.

28: $175 ; 217 ; 362$ n.33.

30: 175 n. $66 ; 362$ n.34.

31.1: 175 n.67.

31.2: $175 ; 178$ n.87.

32.2: $175 ; 361$ n.32.

33: 82; 85 n.56; 87 n.68; 213 n.66;

214; 372 n.120; 374 n.131.

34: 159 n. $3 ; 213$.

34.1: 369 n. $96 ; 373$.
35: 172 .

35.1: 374 n.132.

35.2: 172 n.53; 173 n.58; 374.

36: 213 n.67; 367; 367.

37.2: 373 .

37.3: 213 n. $68 ; 362$.

38: $79 ; 213$.

38-40: 213.

39: 201 n.9; 216 e n.85; n.86; 385 n.10.

40: 214 n.70; 218 n.89; 346 n.37.

41: 214 n.73.

42: 215 ; 218 e n. 90.

42ss: 376.

42-45: 50 n.106.

42.1: 56; 57; 79; 81; 81; 82; 87; 175; 214 n. $74 ; 215 ; 231$ n. $151 ; 384$.

42.2: 59 n. $135 ; 60$ n. $142 ; 215$.

43: 194 n.160; 385.

43-45: 324 n.52.

43.1: 86 n.61; 172.

43.3: 79 .

44: $86 ; 87$.

44.1: 74; 82; 85 n.57; 86 n.61; 195; 215 n.77.

44.2: 74; 215 n.78; 345; 375; 375 n.140.

45: 86 n.61; 101 n.23; 195; 215; 223; 296; 309; 322; 376 n.146; 376 n.148.

46: 159; 215; 368 n. $90 ; 369$.

46-48: 345.

47: 159; 215; 230; 369.

48.1: 216; 364 n.59; 369.

48.2: 216 n.79; 369.

49: 345 .

49.1: 82; 85 n.58; 86 n.61; 87 n.70; $216 ; 368$ n. $90 ; 372$ n. 118.

49.2: 216 n.82.

50.1: 42; 216; 319 n.22; 366 n.69. 
50.2: 366 .

50.2-51.2: 216 n.84; 319 n.21.

51.1: 42; 201 n. $9 ; 216$ n. 85; 366 n.70.

51.2: 216.

52: 322 .

52.1: 217 .

52.2: 188 .

52.3: 75; 319 n. $23 ; 366$.

53: $217 ; 319$ n. $23 ; 322 ; 366$.

53.2: 185 .

54: $217 ; 319$ n. 23 ; 366.

54.2: 185 n.124.

55: 217.

56: 85 n. $57 ; 217$.

57-62: 364 n.53.

57.1: 82; 85 n.58; 86 n.61; 90; 182; 211; 217; 222 n.110; 251 n.258; $346 ; 32$.

57.2: 87 n.69; 182.

58: 217 n. $87 ; 362 ; 364$ n.60.

58-62: 364 n.57.

59: 309 .

59.1: 364 n.60.

59.2: 190 n.143; 217 n.88; 364 n.54.

60: 85 n.58; 183 n. $113 ; 218$ e n.90; 346; 384 n. 8 .

61.1: 42; 56 n.122; 85 n.58; 86 n.61; 218 n. $91 ; 219$ n. $95 ; 357$ n. 4.

61.2: 56 n.121; 71 n.1; 84 e n. 53; 218.

61.3: 24. n. 49; 41 n.61; 84 n.54; 84 n. $55 ; 219 ; 346$ n.36.

61.4: 84 n. $55 ; 219$ n.95.

61.5: 61; 84; $189 ; 219$ n. $97 ; 319$ n.17.

62.1: 85 n.59; 86 n.61; 219.

62.2: 40; 72; 81; 183 n. $112 ; 384 ; 385$ n.9.

62.3: 148 n.64; 185 n.126; 218 n.94.

63.1: 219 n.97; 291 n.91; 293 n.102; 298; 320 n.32.

63.2: 219 .
64: 219 .

65: $219 ; 357$.

66: 219 .

67: $201 ; 219 ; 346$.

67.1: 201 n.10.

67.2: 206 n.29.

67.3: 206 n.31.

67.4: 206 n.30.

68: 220 .

68ss: 235 n. 181.

68.1: 297.

68.1-2: 344 n.25.

68.2: 350 n.59.

68.3: 46; 220 n.101; 222 n.110; 345 n. 35 .

69: 73; 204; 220; 319 e n.17; 366 n.71.

70: 214 n.69.

70.1: 220 .

70.2: 365 n.66.

70.3: 185 n.125.

71: 220 n.102; 377.

72: 297.

72.1-2: 297.

72.3: 297.

73.1: 297.

73.2: 47; 90; 147 n.63; 296 n. $111 ; 297$ n. $115 ; 297$ n. $117 ; 345$.

74: 209 n. 47; 298.

75.1: $313 ; 364$ n.60.

75.3: 313.

76: 298.

Cal.: 23 n.43; 25; 27; 50 e n.105; 58; 88 ; 89; 90; 122-123; 147-148; 160 ; 175 ; 182; 220-226; 255-258; 279-282; 291 e n.89; 297 n.115; 309; 320 n. 29; 331 n. 10; 336; 338 $-339 ; 387$.

1.2: 365 n. 66 .

1-2: 338 .

$2: 339$. 
3: 338 .

3.1: 71 n.1; 349 n.54; 351 n.61.

3.1-2: 115; 342 n.11.

4: 338 .

5: 338 n.37.

5-6: 322 .

6.1: 338 .

6.2: $339 ; 364$ n.59.

7: 122 n.123.

8: 37; 52; 122; 280; 362 .

8.1: 37 n. $35 ; 122$ n.124.

8.2: 38 .

8.3: 38

8.4: 38 .

8.5: 38 .

9: 122 n.125.

10.1: 123 .

10.2: 88; 123 n.127; 221; 320; 384.

11: 88; 90 n.78; 123; 182 n.107; 211; 222 e n. $109 ; 321 ; 351 ; 364$ n.51.

12.2: 147 n.63; 297 n.115; 319 n.20; 364 n. $60 ; 365$.

12.2-3: 90 .

12.3: 148 n.64; 365 n.66.

13: 148 .

13-21: 88

14.2: 309 .

$15: 88 ; 385$

15 ss: 58 .

15.1: 175; 256 n. $273 ; 365$ n.66; 384 n.4.

15.1-3: 365 .

15.2: 221 n.107.

15.2-3: 221.

15.4: 168; 176 n.70; 223 n.114; 244 n. $219 ; 363$ n. $50 ; 384$ n. 4.

15-21: 123 n.128.

16: 176.

16.1: 41 n. $61 ; 42$ n. $65 ; 172 ; 373$.

17.1: 39; 220 n.103.
17.2: 176; 370 n.99.

18: 176 .

18-20: 159; 370 n.102.

18.2: 370 n.99; 370 n.103.

19: $176 ; 256$ n. $273 ; 385$.

19.1: 168 n.36.

19.2: 168 n.37.

19.3: $39 ; 72$ e n.6.

20: 182 n.106; 184; 221.

21: 171; 370 n.100, n.101.

22: $221 ; 319$ n.18.

22ss: 376 .

22-49: 86.

22.1: 51 n. $107 ; 58 ; 81 ; 88 ; 180$ n.93; 181 n.103; 221 n. $104 ; 360$ n.21; 362 n. $40 ; 387$.

22.1ss: 185 .

22.2: 180 n.94; 280; 298 n. 119; 362 n. 41 .

22.2-3: 180 n.95; 355 n.8.

22.4: 51 n. $107 ; 180$ n.96; 181 n.98; 282; 292 n. $100 ; 355$ n. 85.

23: 319 n. $24 ; 366$.

23.1: 186 n.127.

23.2: 186; $221 ; 319$ n.22.

23.3: 190 n. $142 ; 221$.

24: 83; 221; 324 n. $52 ; 366 ; 376$.

24.1: 74; 196 n.165; 319.

24.2: 196 n.166.

24.3: 256 n.272.

25: 319 n.27.

25.1: 82; 196 n.167; 222; 242 n.213; 386.

25.3: 197 n. $168 ; 303$ n. $137 ; 385$.

25.4: $222 ; 282$.

26: 222 .

26.1: 193 n.156.

26.2: 108 n.53; 191; 362; 362 n.38.

26.4: $86 ; 362$.

26.5: 222 n. $108 ; 385$. 
27-33: 364 n.53.

27.1: 82; 86; 90 n.78; 222 n.109; 251 n. $258 ; 351$.

27.2: 183 n.116; 322.

27.4: 183 n.115.

28: 183 n. $114 ; 258$.

29-31: 222.

29.1: 51 n.107; 82; 85 n.59; 87; 190 n. $142 ; 222$ n. $112 ; 229$ n. $142 ; 234$ n. $173 ; 362$ n. $35 ; 364$ n. $55,60,61$.

30.1: 190 n.143; 362 n.35; 364 n.54.

30.2: 176 n.71; 190 n.145; 223 n.114; 239 n. $199 ; 362 ; 364$ n.56; 367 n. $83 ; 384$ n. 4 .

30.2-3: 223.

31: 191; 223 n.115; 319 n.19; 367 n. 83 .

32-33: 223.

32.1: 183; 184 n.119; 222 n. 111; 364 n. $55 ; 385$.

32.2: 231 n.153.

32.3: 80 n.40; 184 n.118; 190 n.144; 322 n. $37 ; 364$ n.56.

33: 190 n. $145 ; 225$ n. $120 ; 364$ n.56.

34-35: 223; 351.

34.1: $82 ; 192$.

34.2: 192 n.155.

35.1: 193 n.156.

35.2: 184 n.117; 322 n.37.

35.3: 184 n.117; 193.

36: 324 n.52; 376 n.146.

36.1: 74; 82; 223; 375 n.140; 375 n.144.

36.2: 74 n.12; 197 n.169; 223 n.116; 242 n. $213 ; 376$.

37: 224; 227 n.129; 371 n.109.

37.1: 82 .

37.2: $371 ; 385$.

37.3: 56 n. 121.

38-42: 224.

38.1: 82; 228 n.132; 234 n.174; 368 n. $91 ; 372$ n.118.

43ss: 224.

43-49: 255.

43: 255 n.270; 386 n. 16.

45: 386 n. 15 .

45.1-2: 255 n.271.

45.2: 146 n. 52; 222 n. $111 ; 257 ; 323$ n. 46 .

45.3: 256.

46: 222 n. $111 ; 257$ n. $274 ; 386$ n.16.

47: 51 n.107; 223 n. 113; 257.

48.1: 87; 224 n. $117 ; 364$ n.60.

48.2: 257.

49.1: 224; 309; 362 n. 38; 373.

49.2: 224; 224 n. $118 ; 279 ; 362$.

49.3: 224.

50: $58 ; 296$.

50ss: 235 n. 181.

50-51: 3 .

50.1: 36; 160 n.6; 180; 224 n. $119 ; 324$ n. $47 ; 325 ; 350$ n. $58 ; 364$.

50.2: 225 n. $120 ; 351$ n.63.

50.3: 202 n.14; 294; 322 n.35; 386 n.19.

51.1: 58 n.133; 59; 73; 81; 170; 291; 319 n. $17 ; 351$ n. $63 ; 366$ n.71.

51.2: 225 .

52: 85; 161; 181 n.99; 225; 355 n.79; 386.

53.1: 160 n.8; 225 n.121.

53.2: 61 n.149.

53.3: 280 n. 48 .

54: 386.

54.1: 160; 225 n.122.

54.2: 80; 160 n. $4 ; 202$ n.14.

55: 58 .

55.1: 74; 75; 160; 225.

55.2: 160 e n.5.

55.3: 78; 87; 160 n.6; 226.

56ss: 226. 
56.1: 58 n.132; 87; 211 n. $57 ; 279$ n. $46 ; 282$ n. $57 ; 291$ n. $89 ; 300$ n. $125 ; 318$ n. 15 .

56.2: 78; 277 n.29; 280; 281; 323 n. 40 .

57: 209 n. $47 ; 321$.

57.1: 280; 298 n.119.

57.2: 73; 280 n. $47 ; 320$ n.31.

57.3: 277 n. $32 ; 300$ n.128.

57.4: 163 n.19; 257; 258; 281 n.50; 284 n.64; 294; 324.

58: 66 .

58.1: 281 n.51.

58.2: 47; 281 n. $52 ; 285$ n.70.

58.2-3: 296 n.111.

58.3: 282 n. 54.

59: 282 e n.56.

60: 89; 190; 313; 320 n.29; 386.

Cl.: 25; 50 e n. 105; 51 n.108; 89; 90; 128-130; 148; 150-152; 184; 206; 24-251; 258-267; 290; 298-299; $336 ; 338 ; 339 ; 344 ; 379$.

1.1: 339 .

1.2: 339 n.38.

1.3: 339 .

1.4: 339 n.39.

1.5: 339

2.1: 48; 128 n. $151 ; 321$.

2.2: 43; 128 n.152.

3.1-2: 128 n.151.

3.2: $262 ; 321 ; 321$.

4: 43; 128; 321.

4.5-6: $128 ; 344$

5: 128; 129 n.156; 298.

6: 129 e n.156.

7: 129 n.157; 209 e n.49; 321.

7-8: 129 .

8: 78; 129 n.158.

9.1: 130 n. $159 ; 184 ; 256$ n. 272; 298.

9.2: 130 n.160.
10: 151 n.73; 344 n.23.

10.1: $204 ; 256$ n.272.

11: $175 ; 249$.

11.2: 365 n.66.

11.2-3: 365.

11.3: 52 n.118.

12: $175 ; 249$.

12.1: $175 ; 361$ n.29.

12.2: 361 .

12.3: $310 ; 361$ n.30.

13: 263.

13.1: 249 n.249.

13.2: 204 n. $21 ; 249$.

14: 249 n. 250.

15.1: 249 .

15.2: $250 ; 258$ n. 276.

15.3: 43; 258; 267 n.309.

15.4: 51 n.107.

16.2: 258 n.279.

16.4: 258 n. $278 ; 259$ n.280.

17.1-2: 110 n.68; 259 n.281.

18-25: 43.

18.1: 259 .

18.2: 259 .

20: 370 n.101.

21: 159; 370 n.102.

21.1: 370 n. 99 .

21.2: 43.

21.5: 79; 250; 374 n.136.

21.6: 259; 325; 374.

22: $250 ; 372$ n. 120 .

22-25: 250.

22.1: 73 .

23: 250 .

24: 250 .

24.1: 62 n.156.

24.1-2: 172 .

25: 43 e n. $72 ; 250$.

25.1: 222; 266 n.308. 
25.2: 250 n.253.

25.3: $172 ; 372$.

25.4: $222 ; 367$ n.78.

25.5: 250 n. $254 ; 251 ; 260 ; 344 ; 365$ n.63; 366 n. $73 ; 367 ; 367$ e n.77.

26: 222 .

26-29: 260 .

26.1: 201 n.6.

26.2: 260 n. $283 ; 263$ n.298.

26.3: 260 n. $285 ; 319$ n. $26 ; 376$ n. 150.

27.1: 261 n. 289 .

28: 261 n.290.

29-31: 222.

29.1: 56 n. $121 ; 251$ n. $255 ; 344 ; 365$ n.63.

29.2: 262 n.291.

29.3: 262 n. 292; 263 n.298; 320 n.32; 324.

30: 82; 251; 259 n.279; 262; 325; 344.

30ss: 235 n.181; 251.

31: 36 n. 27 .

32: $78 ; 263$ n.295.

33: 251 n.257.

33.1: 78; 177; 238; 263 n.297; 325.

33.2: 81; 324 n. $52 ; 375 ; 376$ n.146.

34-39: 251.

34.1: 82; 90; 251 n. $258 ; 365$ n.62.

35-37: 79; 365.

35.1: 81; 175; 178 n. 84; 251.

$35.2: 263$

36: 263 n.298.

37.1: 264 .

37.2: 264 n.299; 323 n.44.

38: 265 .

38-40: 79 .

38.1: 251.

38.2: 87 n.69; 267 n.309.

38.3: 47; 251; 265 n. 302; 310; 325.

39.1: $82 ; 251$.
39.1-2: 265.

39.2: 47; 319 n.26; 376 n.150.

40.1: 251; 266 n.307.

40.2: 266 n.308.

40.3: 51 n.107; 251; 267 n.309; 344 n. 24 .

41-42: 251.

41.1: 267.

41.3: 251.

42.1: 51 n.107.

43: 298 n.120.

44: 148 .

44.1: 298 n.121; 376 n.151.

44.2: 299 n.122.

44.2-3: 47.

44.3: 299.

44.1: 90.

44.2: 299 n.122.

44.2-3: 47; 296 n.111.

44.3: 299.

45: 298 n.120; 299 n.124; 319 n.25;

366; 375 n.138.

46: 206; 209 n. $47 ; 299$.

46.1: 73; 90.

Nero: 50; 51; 61 n.148; 88; 124-125; $148-149 ; \quad 161-165 ; 171 ; 182$ n.107; 184; 205; 221 n.105; 226 -230; 291 e n.89; 300-306; 317; 336-337; 340; 367; 387.

1.1: 336 .

1.2: 90; 336 n. $31 ; 340$ n. $40 ; 350$ n.57.

2.2: $79 ; 336$.

2.3: 336 .

4: 52 n.118; 88; 161 n.11.

5.1: 337 .

5.2: 337 n.33.

6.1: 124 n.130.

6.2: 25 n.57; 124 n. $132 ; 211 ; 300$ n. $127 ; 320$ n. $29 ; 321$.

6.3: 88; 124 n.135. 
6.4: 125 n.137.

7: 43.

7.1: 88; 125 n.138; 261 n.287.

7.2: 364 n.61.

8: 148 n.67; 386 n.17.

9: 88; 88; 176 n. $73 ; 226 ; 365 ; 384$.

9-10: 88.

9.1: 365 n.66.

10: 385 .

10.1: 82; 177 n.77; 226; 244 n.219; 363 n. $50 ; 370 ; 370$ n. $99 ; 384 ; 384$ n.5.

10.2: 177 e n.79; 363 n.50.

11ss: 177.

11-12: 159.

11-13: 161; 226; 370 n.102.

11.1: 161 n.11.

11.2: $85 ; 161$ e n. 11,$12 ; 370$ n. $99 ; 370$ n. $103 ; 385$ n.14.

12.2: 163 n.19; 385 n.14.

12.3: 162 n. $13 ; 386$.

12.4: 170 n. 44 .

13: $88 ; 170$ n. $43 ; 371 ; 385$.

13.1-2: 169 n.40.

14: 226.

15: 226.

16-17: 226.

16.1: 191 n.150; 226; 370 n.100; 371. 16.2: 51 n.113; 173; 173; 183 n. 111 ; 226 n. $123 ; 367$ n.79; 373 n.127; 375 .

16.2-17: 357 n.1.

18: 177 n.74; 226.

19: 221 n.105.

19.1: 205 n.24.

19.2: 164 n. $24 ; 170$ n. $45 ; 171$ e n. 49.

19.3: 58; 81 n.44; 88; 182 n. 107; 221 n. $105 ; 226$ e n. $124 ; 350 ; 387$.

19.3ss: 337; 376.

20: 221 n. 105 .
20-25: 226.

20-39: 165 .

20.1: 88; 162 .

20.2: 162 n. $14 ; 386$.

20.3: 162 n.115.

21.1: 162 .

21.1-2: 386.

21.2: 51; 162 n.16; 163.

21.3: 163 n.18, 20; 386; 387; 387n.21.

22: 78 n. 29 .

22.1: 88; 163 n.20.

22.2: 163; 221 n.105.

22.3: 163 n. $23 ; 164$ n.24.

23.1: 164 .

23.2: $164 ; 164$ n.26.

23.3: 164; 165; 320.

24.1: 84; 164; 193 n.157.

25.1-2: 125 n. $141 ; 164$ n.28; 386.

25.3: 165 .

26.1: 82; 86; 90 n.79; 182 n.108, 109;

226 n. $125 ; 364$ n. $51 ; 368$.

26.2: 80; 173; 183 n.110, 111; 227;

375 e n.139.

27: 197 n.170.

27.1: 82; 85 n. $56 ; 85$ n. $57 ; 86 ; 227$.

27.2: $350 ; 385$.

27.2-3: 227.

27.3: 197 n.170; 376 n.149.

28-29: 254; 324 n.52.

28.1: 86; 197 n.171; 227 n.126; 375;

376 n.146, 149; 385 n.12.

28.2: 51; 74; 87; 88; 163 n.18; 177

n. $75 ; 227 ; 319 ; 319 ; 366 ; 376 ; 384$ n. $5 ; 387$.

28.2-29: 375 n.140.

29: $81 ; 82 ; 86 ; 197$ n.172; 227; 375 n. $145 ; 385 ; 385$ n. 12 .

29-39: 165 .

30-31: 371 n.109. 
30.1: 86; 227 n.129; 371 n.112.

30.2: 88; 170 n.43; 227; 371; 371 n.113.

30.3: 228; 371 n.113.

31: 191 n. $150 ; 385$.

31.1: 85 n.57; 86 n.63; 228 n. $130 ; 371$ n. $110 ; 371$ n.114.

31.2: 171 n. 50; 228; 371 n. $115 ; 372$.

31.3: 171.

31.4: 228 n.131; 372 n.117.

32.1: 82; 228 n.132; 234 n.174; 368 n. $91 ; 372$ n.118.

32.2: 230 n.145.

32.2-3: 194 n.158.

32.3: 75; 80; 228 n.133; 373 n.127.

32.4: 86 n.64; 131 n.163; 190; 228; 319 n.17.

33-38: 75; 86; 334; 364 n.53; 364 n.57.

33.1: 80 n.35; 82; 88; 90; 149 n.68; 228; 303; 319 n.20; 319 n.23; $366 ; 387$ n.20.

33.2: 193; 319 n. 22; 322; 366.

33.2-3: 194 n. $158 ; 228$.

34: 86; 88; 186; 322.

34.1-4: 163 n.18; 228; 319 n.21; 366.

34.2-3: 186 e n.130.

34.3: 74.

34.4: 154; 187 n.133; 321; 322 e n. 35 ; 364 n. $60 ; 386$.

34.5: $228 ; 366$.

35: 366 .

35.1: 319 n.27.

35.1-2: 322 n.38.

35.1-3: 228.

35.2: 188 n.135.

35.2-3: 163 n.18.

35.3: 51 n.113; 188 n.136.

35.4: 190 n.146; 191 n.147; 228 n.135; 228 n.136.

35.5: 163 n. $18 ; 188$ n.137; 228 n.137;
319 n.23.

36.1: 51 n. $113 ; 82 ; 85$ n.57; 184 n. $120 ; 228$ n. $138 ; 322$.

36.2: 184 n.121.

37.1: 229 n.139; 234 n.176; 238 n. $197 ; 371$ n. $113 ; 384$ n.5.

37.2: 75 n.14; 185 n.122; 191 n.148; 229; 371 n. $113 ; 385$.

37.3: 146 n. 53; 191; 229 e n. $142 ; 362$ n. $35 ; 373 ; 384$ n. 5 .

38: 51 n.113; 75 n.15; 75; 228; 247 n.238; 319 n. 19; 367 n.83.

38.1: 86 n.65; 191 n.150; 229 n.143; 371 n. 110.

38.2: 34 n.15; 192 n.151,153; 229; 387.

38.3: 229 n.144.

39: 75 .

39.1: 229; 247 n.238; 350.

39.2: 80 n. $33 ; 230$ n. $145 ; 321$.

39.2-3: 309.

39.3: 188 n.137; 230 n.146.

40ss: 140; 230.

40-50: 300 .

40.1: 211 n.57; 282 n.57; 291 n.89; 300 n. 125; 306; 318 n.15.

40.2: 300; 321; 362 n.3; 387 n.23.

40.3: 300 n.129; 320 n.31.

40.4: 301 n.130; 320.

41.1: 230 n.146; 301.

41.2: 301.

42.1: 302 n.134.

42.2: 302 .

43.1: 90; 148 n.64; 302 n.135; 364 n.61.

43.2: $302 ; 387$ n.23.

44.1: 62 n.156; 197 n.168; 303 n.137; 385 n. $11 ; 386$.

45.1: 303 n.138.

45.2: $79 ; 303$.

46: 209 n. 47. 
46.1: 202 n. $13 ; 303 ; 321$.

46.3: 303 n.139; 321; 322 n.35; 387 n.20.

47-49: 48.

47.1: 303 .

47.2: 224 n. $118 ; 362$ n.39.

47.3: 303 n.140.

47.3-49.4: 67 n.170.

48: 67; 71; 304 n.141.

48.1: 48 e n.98.

48.3: 67 .

48.3-4: 48 n.98.

49.1: 304 n.142.

49.2: 68; 189 n.140; 203; 296 n.111; 304.

49.3: 292; 304 n. $143 ; 307$.

49.4: 305 n. 144, 145; 308 n.159.

50: 48; 296; 305 n.148.

51: 306; 324 n. $47 ; 349 ; 355 ; 386$.

51ss: 235 .

52: 50; 61 n. $150 ; 80$ n.41.

53: 165 n.29; 319 n.18.

54: $165 ; 324$ n.47.

55: 36 n. 26; 306 n.150.

56: 73; 78; 203 n.18; 306; 319 n.17;

366 n. $71 ; 367$.

57: 50 n.105.

57.1: 40; 203 n.17; 313; 320.

57.2: 72 n.5; 313 n.177.

Gal.: 50 n.105; 51; 106-109; 140-142;

156; 208; 236-238; 282-287; 337;

$354 ; 376$ n. 154 .

1: 50 n. 105; 129 n. $157 ; 152$ n.78; 292 n.100; 354 n.73.

2: 178 n.83; 337 n.34.

3.1: 71 n.1.

3.2: 141 n. $27 ; 337$.

3.4: 337 .

4.1: 48; 72; 106; 107 n.48; 208 n.45, $46 ; 320$.
4.2: 107 n. $49 ; 129$ n. $157 ; 209$ n.49.

4.3: 107 n.50; 284.

4.4: 107.

5.1: 107; 108 n.51; 347; 376.

5.2: 107 .

6.1: 108 n.51; 109 n.57.

6.2: 108; 256 n.272; 346.

6.3: 108 n.53; 347.

7.1: 108 n.53.

7.2: 108 n.56.

8.1: 109 .

8.2: 109 n.58.

9.1: $82 ; 85$ n. $56 ; 109$ n.59.

9.2: 140 n.21; 144; 207 n.36; 301 n.131; 302 n.134.

10.1: 140 n.22; 314.

10.2-3: 141 .

10.4: 141 n.23, 24; 284.

10.5: 141.

11: 141; 141 n.26; 153 n.79; 306.

12: 369 .

12.1: 83; 144 n. $44 ; 236$ n.186; 243 n. $215 ; 347$ n. $42 ; 365$ n.62: 368.

12.1-2: 363 .

12.2: 85 n.59; 236; 322; 347 n.43.

12.2-3: 365 .

12.3: 269 n. $316 ; 347$ n. 46 .

13: 309 n.166.

14-16: 236.

14.1: 237 n.187; 347 n. 41 .

14.2: 237 n. 190; 364 n.51; 365 n.64.

14.3: 84; 237 n.191; 365 n.62.

15.1: $73 ; 237$ n.192.

15.2: 237 n.193.

16.1: 211 n. $57 ; 282$ n.57; 283 n.58; 369.

16.2: 283 n.61.

17: 63; 155 n.89; 283; 318 n. 15; 347; 347 n. 44 .

18: 209 n. 47. 
18.1: 163 n.19; 221 n.106; 274 n.20; 284.

18.2: 107; 199; 202 n.13; 284; 293.

18.3: 284.

19.1: 156 n. $92 ; 284$ n. 65.

19.2: 285 n.69.

20: 66 .

20.1: 47; 283 n.59; 285 n.70; 286 n.72.

20.2: 79; 286; 287 n.75; 296 n.111; 322 n. $36 ; 346$ n. $38,39$.

21: 36 n. 27; 287 n.76; 346.

22: $238 ; 324$ n.52; 375 n.140; 376 n.154.

23: 314 .

Otho: 48; 50 n.105; 51; 89; 142 n.35; 155-157; 247-248; 306-308; 315 n. $182 ; 334$.

1.1: 178 n. $83 ; 334$ n.21.

1.2: 334 e n.23.

1.3: 334 .

2: 321 .

2.1: 83; $125 ; 125$ n.141.

2.2: 126 n. $142 ; 324$ n.52; 354 n.78; 375 n.140.

3: $76 ; 321$.

3.1: $83 ; 126$.

3.1-2: 126 n.144.

3.2: 146 n. 52; 323 n. $46 ; 358$ n.6.

4.1: $127 ; 209$.

4.2: 62 n. $155 ; 127$ n.150.

4.2-5: 370 .

5.1: 155 .

5.2: 155 n.89.

6.1: 155 n.91.

6.2: 156 n.92.

6.3: 62 n. $155 ; 156$ n. $93 ; 157$ n. $95 ; 354$ n.76.

7.1: 51; 84; 157 n.96; 354.

7.2: 203; 284 n.65; 294; 307; 322; 322 n. $35 ; 386$ n. 19 .
8.1: 248 n.245.

8.2: 248 n.246.

8.3: 204 n.19, 20; 209 n.47.

9.1: 248 n.247.

9.2: 248 n. $248 ; 306$ n. 151 .

9.3: 306 n. $153 ; 352$.

10.1: 62 n. $156 ; 72$.

10.2: 142 n. $34 ; 307$.

10.2-3: 141.

10.5: 141.

11: 48 .

11.1: 307.

11.2: 308 n.158.

12.1: 36 n. $27 ; 74 ; 83 ; 170 ; 308$ n.160; 341 n. $2 ; 351$ n. $64 ; 354$ n. $75 ; 367$.

12.2: 76; 314 n.179; 352; 354 n.77.

Vit.: 50 n.105; 51; 90; 130-131; 152 $-155 ; 210 ; 238-239 ; 283$ n.61; 287-290; 337-338; 347.

1: 337 .

1.1: 178 n.83.

1.2: 38 .

2.1: 338 .

2.2: 338 .

2.4: 338 .

2.5: 250 n. $254 ; 338$.

3.1: 74; 194.

3.2: 79; 130 e n.161; 211; 309 n.165; 321; 324 n.52; 348 n.51; 375 n.140.

4: 131; 166; 238; 338; 348 n.51.

5: 131 n. 163 .

6: 131 n. $164 ; 319$ n. $23 ; 366$.

7.1: 131; 248 n.244; 348.

7.3: 78; 131; 348; 374 n.137.

8.1: 152 n.78; 283 n.61.

8.2: 153; 248 n. $246 ; 321$.

$8.3: 248$.

9: 90 n.77; 129 n. $157 ; 154$ n.83; 209 n. $47 ; 209$ n. $49 ; 210 ; 290 ; 321$. 
10.1: 238; 306 n.151; 307 n. 155; 352.

10.2: 154; 307; 369 n.92.

10.3: 154 n.84; 188 n.134; 238; 319 n.18; 319 n.19; 348 n.49; 367 n.83.

11.1: 155 n.86; 307; 319 n.19; 366 n. $71 ; 367$ n.83.

11.2: 155 n.88; 238; 319 n.17; 348 n.51.

12: $166 ; 254 ; 324 ; 348$ n. $51 ; 365$ n.65; 375 n. 140 .

13: 365; 371 n.109; 384 n.713.1: 83; $238 ; 365$ n. 62 .

13.3: 78; 194 n.159; 238; 348 n.47; 372 n.116.

14.1: 238 e n. $197 ; 365$ n.62.

14.2: 194; 238; 348 n.48.

14.3: 231 n. $153 ; 239$ n. 199; 319 n.17; 364 n. 57.

14.4: 239 n.200; 309 n.165.

14.5: 87; 239 n.201; 319 n.21; 366.

15: 318 .

15.1: 287

15.2: 287 n.78.

15.3: 288 n.79; 319 n.19; 348 n.50; 367 n.83.

15.3-4: 288.

16-17: 66.

16.1: 289 n. $82 ; 348$.

17: 296 n.111.

17.1-2: 289 n.83.

17.2: 211 n. $57 ; 314 ; 347 ; 348$ n.52.

18: $90 ; 130$ n. $161 ; 209$ n. $47 ; 210$ n.52; 290 e n.86.

Ves.: 50 n.105; 52; 90; 109-113; 114; 142-144; 210; 243-246; 267-270; 273-274; 294; 331; 332-334; 338

1.1: 90; 211 n. $57 ; 315$ n. $184 ; 320 ; 368$ n.89.

1.2: $39 ; 332$ n.13.

1.3: $72 ; 333$ n.16.

1.4: 333 e n.20.
2.1: 48; 109 n.60; 321 n. $34 ; 365$ n.67, 68.

2.2: 110 n.61.

2.3: 110 n.62; 111 n.70; 112 n.79.

3: 110 n.64; 376 n.146; 377.

4.1: 110 n.67, 68 .

4.1-2: 259 n.281; 298 n.120.

4.2: 111 n.69.

4.3: 75; 78; 79; 111 n.71.

4.4: 81; 111 n.71; 112 n.75; 178 n.87.

4.5: 112 n.76; 207 n.36.

4.6: 112 n.77.

5: 112 n.78; 208.

5.3: 110 n.62; 112 n.79.

5.4: 112 n.80; 113 n. 82; 293.

5.5: 25 n.56; 113 n.83.

5.6: 48 n.100; 113 n.84; 320 n.31.

5.7: 113 n.86; 129 n. 157; 209 n.49.

6.1: 142 n.31.

6.2-3: 142 n.33.

6.4: 142 n. $35 ; 143$ n.36.

7.1: 143 n.38.

7.2: 143 n. 40 .

7.2-3: 144 n.41; 208

8.1: 144 n. $44 ; 170$ n.47; 243 n.215, 216.

8.2: 243 n.218.

8.3: 268 n.314.

8.5: 62 n.156; 170 n. $46 ; 170$ n.47.

9-11: 244.

9.1: 170 n. $47 ; 370$ n.100.

9.2: 172 n.54; 372 n. $120 ; 373$.

11: 172; 372 n.120; 373 n.126; 375 n.138.

12: 83; 178; 244; 244 n.220; 270; 361; 363 n. $49 ; 384$.

13: 269 .

13-15: 363.

14: 62 n.156; 111 n.71; 178 n.86, 87.

15: 244 e n.223; 322; 384. 
16.1: 83; 244; 269; 368 n.87; 377.

16.2: 245 n. 226.

16.2-3: 75-76 n.17.

16.3: 91; 245 n.228; 368 n.87; 369 n.93.

17: 83; 179; 245 n.229; 369; 370 n.99; 370 n.101.

17-19: 179 .

18: 179 n. $90 ; 370$ n.98.

19.1: 179; 245 n. $230 ; 368$ n.88; 370 n. 99 .

19.2: 79; 81 n.42; 268 n.315; 269; $309 ; 324$.

20: 36 n.27; 269; 342 n.9; 343 n.16.

20ss: 235 n. 181 .

21: 246; 324 n.52; 376 n.146; 377 n.156.

22: 80 n.36, 38; 83; 233; 245 n.231; 268; 269; 343 n. $17 ; 361$ n. $31 ; 374$ n.134; 376 n. $146 ; 377$.

22-23: 81.

23.1: 246; 268; 269; 323 n.42.

23.2: 269 .

23.3: $78 ; 269$ n.316.

23.4: 209; 209 n. $47 ; 323$ e n. 18; 367. 24: 273 n.11; 379 n.169.

24.3: 270 n.319.

25: 90; 210 n. 55; 294.

Tit.: 25; 50 n.105; 86 n.60; 89; 157; 274-275; 315 n.182; 331; 379.

1: 25 n.56; 48; 59; 79; 80; 83; 114 -117; 114 n.89, 94; 128 n.151; 150 n.70; 226-227; 320 e n.29;

321 n. 34; 342; 343; 362 n.36.

2: 36; 115; 298 n. $120 ; 322$.

3.1: 115 n.95; 342 n.10; 343 n.19.

3.2: 62 n.156; 72; 115 n. $98 ; 342$.

4.1: 39 n. $49 ; 115$ n.99.

4.2: 116 n.100.

4.3: 116 n.101.

5.1: 116 n.103; 320 n.31.
5.1-2: 209 .

5.2: 116 n.104; 235; 320 n.29.

5.3: 116 n.105.

6.1: 116 n.106; 322; 363 n.48.

6.2: 117 n.109.

6.2-7.1: 59 .

7.1: 59; 81; 83; 117 n.110; 157 n.97; 246 e n.233; $247 ; 324$ n.52; 363 n. 48; 368; 371 n. $108 ; 375$ n.140; 376 n.146; 377; 377 n.157.

7.1-2: 322 .

7.2: 246 e n.234; 370 n.99; 371 n.108; 377; 377 n. 157.

7.3: 159; 179; 246; 368 n.84; 370 n. $100 ; 370$ n.102.

8: 91.

8.1: 83; 179 n. $91 ; 247 ; 342$.

8.2: 179 e n. $92 ; 384$.

8.3: 247 n.239; 369 n.95.

8.5: 234 n. $176 ; 247$.

9.1: 205; 247 n.240; 247 n.241; 319.

9.1-2: 247 n.242; 363.

9.2: 384 .

9.3: 274 n. $16 ; 365$.

10.1: 209 n. $47 ; 274$ n. $18 ; 379$ n.170.

10.1-2: 274 n.22.

11: 315 n.182; 320 n.29.

Dom.: 40; 50 n.105; 58; 87-88; 90; $131-132 ; 149-150 ; 172 ; 205 ; 230$ -236; 275 e n.26; 291-296; 331; $368 ; 379$.

1.1: $26 ; 48 ; 131$ n.165; 321; 375 n.140, 142 .

1.2: 132 n.166; 349.

1.3: 132 n. $168 ; 319$ n. $27 ; 362$ n. 42 .

2.1: 132 n.171; 149 n.69.

2.2: 132 n. $172 ; 177 ; 349 ; 384$ n.6.

2.3: 90; $115 ; 172$ n. $55 ; 275$ n. $26 ; 319$ n.19; 319 n.22; 366; 367 n.83; 379 n.170.

3.1: 79; 173 n.59; 230; 254 n.267, 
$269 ; 385$ n.9.

3.2: 58; 59; 81; 83; 85 n.58; 88; 90; 230; 291 n.94; 349 n.56.

4: $159 ; 230$.

4-5: 234 n. 175; 371 n.111.

4-9: 58; 59 .

4.1-4: 370 n.102.

4.2: 62 n.156.

4.4: 35 n. $22 ; 166$.

4.5: 370 n. $99 ; 370$ n.103.

5: $230 ; 370$ n.100.

6.1: 35 n. $22 ; 230$ n.148.

6.2: 129 n. $157 ; 206$.

7-9: 230.

7.1: 172 n.55, 173.

7.2: 292 n.96.

8.2: 374 n.135.

8.3: 172 n.56; $173 ; 366$ n.74; 373 n.125.

8.4: 59 n.136; 231 n.149.

8.5: 170 n. $48 ; 366$ n.75.

9.1: 85 n.58; 88; 177 n.80; 231; 234; $235 ; 244$ n. $219 ; 349$ e n.56; 368 n. $85 ; 370$.

9.2: 234

9.3: 62 n.156; 150; 178 n.81; 234; 322.

10: 231

10-11: 364 n.53

10-15: 59.

10.1: 58; 81; 83; 85 n.59; 88; 173 n.59; 178 n.85; 231 n.151, 153; 239 n. $199 ; 349$ e n. $56 ; 368$ n.89.

10.2: 231 n. 154,$155 ; 232$ n.160.

10.3: 24 n.48; 179 n.88; 231 n. 154 ; 232 n.160, 161, 162, 164; 233 n.165.

10.4: 231 n. 154,$155 ; 232$ n. $163 ; 233$ n. $167 ; 244$ n. $222 ; 366$.

10.5: 85 n. $57 ; 87 ; 183$ n.112; 233 n.169; 234 n.172; 385 n.9.
11: 114 n. $93 ; 364$ n.57.

11.1: 83; 88 n.71; 234; 366.

11.2: 85 n. $57 ; 189$.

11.3: 189 n.140; 364 n.60.

12: 228 n.132.

12.1: 171; 234 n.174, 176; 368 n.91; 371; 371 n.109; 372 n.118.

12.1-2: 234 n.177; 368 n.89.

12.2: 40; 58 n. $134 ; 235$ n.178.

12.3: 36 n.26; 85 n.58; 235 e n.179; 363 n. $43 ; 377 ; 384$ n.6.

13: 319 n.18.

13.1: 85 n.58; 181 e n. $104 ; 363$.

13.2: 62 n.156; 80 n.37; 181 n.105; $182 ; 236$ n. $184 ; 309 ; 363$.

13.2-3: $182 ; 363 . \mathrm{g}$

13.3: 36 n.26.

14.1: 66; 230; 235; 282 n.57; 291 n.89; 291 n.93; 318 n.15; 321; 363 n. 44 .

14.2: 211 n.57; 291 n.94; 292 n.96; $296 ; 309$.

14.3: 292.

14.4: 292; $294 ; 304$ n.143.

15.1: 292 n. 98 .

15.2: 113 n.82; 293 n.102; 294; 320 n.31.

15.2-3: 209 n.47.

15.3: 202 n.13; 293 n.104; 320 e n.32; 366 n.71.

16.1: 209 n.47; 294 e n.105; 295 n.106; 322 n.35.

16.2: 72; 295.

17.1: 277 n.29; 295 n.107.

17.2: 47; 66 n.169; 296 n.111.

17.3: 296.

18: 235 .

18.1: 36 n.27.

18.1-2: 349 .

18.2: 178 n.82; 235; 236; 349; 384.

19: 235 e n.182; 349. 
20: $235 ; 235$ n. $183 ; 384$ n.6.

21: 235; 296 n. $114 ; 377$.

22: 78 n.28; 83; 195 n.162; 231 n.149; 233 n.167; 319; 324 n.52; 366; 376 n.146,150, 153; 378; 385.

23.1: 314 n.178.

23.2: 24. n.50; 90; 91; 209 n.47; 210 n. $56 ; 315$ e n. $183 ; 358$ n.6.

Vir. ill.: 18; 22 n. $37 ; 35$ e n.19.

Gram.: 22; 35.

10: 60 .

12: 21 n. 32 .

14.4: 22 n.38.

20: 22 n. 40 .

Rhet. : 35 .

27: 21 n.32.

Ter.

4: 22 n.38.

(Peri blasphemion.): 35 .

Suda: 33.

Tácito: $15 ; 21$ e n.27; 24; 26; 27; 31; 37; 42 n.66; 48; 50 n. $106 ; 51$ e n.113; 52; $55 ; 56 ; 59 ; 60$ e n. $145 ; 62$ e n. $155 ; 63$ e n. 160,$161 ; 66 ; 71 ; 74 ; 75 ; 84$ e n. 53 ; 106; 108 n. $55 ; 112$ n.76; 113 n.87; 122 n.126; 125 n.140; 143 n.36; 144 n.41; 145 n. 46,$49 ; 153$ n. $78 ; 155$ n.88; 156; 157 n. $95 ; 161$ n. $11 ; 169$ n. $40 ; 187$ n.132, 133; 188 n.134; 199 n.1; 201 n.10; 203; 215 n.75; 217 n.88; 228 n.137; 229 n.144; 238; 244 n.222; 245 n. $228 ; 247 ; 250$ n. $254 ; 252 ; 266$; 266 n. $303 ; 283 ; 283$ n. $60,62,63 ; 286$ n.72; 287 e n.78; 288 n.79, 81; 289 n. $82 ; 290$ n.87; 312 n.174; 317; 323; 330; 335 n.27; 345 n.31; 347; 348; 351; 352; 354 n.76; 357; 387 n.22.

Ag.: 15; 24 e n. $47 ; 60$ n.145.

1: 21.

2: 24 n. $48 ; 232$ n. 164.

40: 235 n. 182.

Ann.: 15; 60 n.145.

1.4: 50 n.106.
1.5.4: 271 n. $1 ; 273$ n.10.

1.6.1: 145 n. 47.

1.6.3: 145 n.46.

1.10.6-7: 42 n.68.

1.10.7: 144 n.45.

1.13.4: 174 n.65.

$1.13 .6: 174$ n. 65 .

1.41.2: 38 n.38.

1.52: 147 n.62.

$1.53 .1: 120$ n. 118

1.72.3: 217 n.87.

1.77.3: 38 n. $41 ; 175$ n. $66 ; 362$ n.34.

1.80.1: 214 n.73.

2.5: 147 n.62.

$2.50: 374$ n. 132 .

2.68: 216 n.82.

2.85.2-3: 172 n.53; 374 n.133.

3.23.1: 216 n.81.

3.24.2: 199 n.2.

4.6.2: 175 n.66.

4.9.1: 146 n. 54.

4.21.3: 38 n.41.

4.28.1: 84 n.53; 218 n.92.

4.32-33: 24 n.46.

4.34-35: 24. n.49; 84 n.54.

4.34.1: 42 n.65.

4.44.1: 216 n. 80.

4.57: 50 n.106.

4.57.1: 214 n.70.

4.57.2: 345 n.31.

4.59: 214 n.69.

4.59ss: 185 n. $124 ; 357$ n.5.

4.63: 214 n.72.

4.67: 50 n.106.

4.67.1: 214 n.70.

4.67.2: 214 n.71; 218 n.89.

4.70.1: 84 n.53; 218.

4.71.4: 200 n.6.

5.9.2: 84; 219 n.97. 
6.1: 194 n.160.

6.5.2: 201 n.10.

6.6: 201 n.10.

6.10.1: 218 n.93.

6.19.2: 219 n.96.

6.19.3: 218 n.93.

6.20.1: 123 n.127.

6.20.2: 106 n. $45 ; 208$ n.45.

6.29.3: 42 n.64; 84 n.54.

6.29.3-4: 218 n.94.

6.47.3: 337 n.33.

6.31-44: 214 n.73.

6.39.1: 217.

6.40.1: 219 n.95.

6.46: 50 n.106.

6.48.4: 219 n.95.

6.50.4: 297 n.115.

6.50.4-5: 147 n.63.

6.51: 50 n.106.

6.51.1: 117 n.111.

11.2.3: 266 n.303.

11.11.2: 125 n.138; 261 n.287.

11.11.3: 124 n.136.

11.27: 262 n.292.

11.32-38: 260 n.283.

11.37: 266 n.303.

11.38: 266 n.303.

12.2.3: 261 n.287.

12.3.1: 261 n.285.

12.25.1-2: 266 n.304.

12.25.2: 266 n.73.

12.64.2-65.1: 125 n.140.

12.65: 298 n.120.

12.67.2: 263 n.297.

12.68.2-3: 299 n.124.

13.2: 357 n.1.

13.3: 235 n.184.

13.3.1: 21 n. 27.

13.17.1: 194 n.158.
13.25: 375 n.139.

13.25.1: 182 n.107.

13.25.2: 183 n.110.

13.25.4: 183 n.111.

13.45-46: 76 n.18; 126 n.144.

13.46.3: 127 n.148.

13.50: 332 n.15.

14.1-2: 127 n.146.

14.2: 51 n.112; 74; 177 n.75.

14.4.4: 187 n.132.

14.6.1: 187 n.131; 386 n.18.

14.7.6: 187 n.131.

14.9.1: 187 n.133.

14.15: 161 n.11.

14.21.4: 162 n.13.

14.51.1: 228 n.137.

14.59.2: 267 n.309.

14.60-64: 322 n.38.

14.60.3: 188 n.135.

15.15.2: 201 n.11.

15.36.2: 205 n.24.

15.37: 197 n.170.

15.37.4: 197 n.172.

15.38.1: 75 n. 15; 191 n. 149; 229; 387 n. 22 .

15.39.2: 192 n.151.

15.39.3: 192 n.153; 387 n.22.

15.40.2: 75 n.15; 191 n.149; 192 n.152.

15.41.1: 192 n.152.

15.42-43: 171 n. $50 ; 371$ n.115.

15.43.2: 229 n.144.

15.44.2-5: 367 n.79.

15.44.4: 198 n.173.

15.48-74: 184 n.120.

15.53.3: 228 n.135.

15.68.1: 184 n.121.

16.1-3: 228 n.131.

16.4: 162 n.13. 
16.4.4: 164 n.26.

16.5.3: 111 n.74; 178 n.87.

16.6: 188 n.136.

16.9.1: 229 n.140.

16.21ss: 56.

16.21-22: 229 n.141.

Hist.: 60 n.145.

1.1: 24 .

1.5.2: 283 n. 60 .

1.6.1: 84 .

1.7.1: 142 n.29, 30.

1.7.2: 237 n.187.

1.7.3: 347 n. 40 .

1.12.1: 283 n.61.

1.13.1: 237 n.190.

1.13.2: 307 n.155.

1.13.3: 76 n.18; 126 n.144.

1.13.4: 127 n.148.

1.14.1: 283 n.62.

1.15.1: 63 n.158.

1.15.2: 283 n.62.

1.18.2: 283 n.63.

1.18.3: 283 n.63.

1.20: 237 n.192.

1.22.2: 127 n.149.

1.22.3: 308 n.160.

1.24: 62 n. 155 .

1.26: 155 n.91.

1.27: 62 n.155.

1.27.1: 284 n.65

1.27.2: 156 n. $93 ; 156$ n. $93 ; 354$ n.76.

1.29.2-30.3: 285 n.67.

1.31.2-3: 286 n.72.

1.31.3: 283 n. $59 ; 286$ n.72.

1.32.2-33: 284 n.66.

1.35.2: 285 n.68.

1.36.3: 157 n.95.

1.37.1-38.2: 157 n.95.

1.37.3: 142 n.29.
1.40-44: 286 n.71.

1.41: 122 n. $126 ; 285$ n.70.

1.41.3: 287 n.75.

1.43.1: 285 n.69.

1.47.1: 157 n.96.

1.49: 237 n.188.

1.49.1: 287 n.75.

1.49.3: 269 n.316; 347 n.46.

1.49.4: 108 n.55; 109 n.59; 237 n.187.

1.55-57: 153 n.78

1.61: 153 n.82.

1.62.3: 153 n.79; 153 n.82.

1.64.1: 153 n.81.

1.71.1: 248 n. 244.

1.72.3: 248 n.244.

1.74.1: 248 n. 245.

1.80-85: 248 n.246.

1.86.1: 113 n.87.

1.89.3: 204 n.19.

2.1.1: 116 n.102.

2.1.2: 342 n.10.

2.2.1: 246 n.235.

2.4.1-2: 116 n.103.

2.5.1: 245 n.228.

2.33.2-3: 248 n.247.

2.42.1-2: 248 n.248.

2.46-50: 306 n.152.

2.47.2: 307 n.154.

2.49.2: 308 n.159.

2.49.4: 314 n.179.

2.50.1: 307 n. $154 ; 308$ n. 160; 352.

2.50.2: 113 n.88.

2.62.2: 153 n.79.

2.70: 154 n. $84 ; 348$ n.49.

2.74.1: 143 n.36.

2.76.1: 142 n.31.

2.78.1: 127 n.149.

2.78.2: 113 n.82. 
2.78.3: 113 n.84, 85; 143 n.38.

2.79: 142 n.34.

2.80.3: 143 n.36.

2.82: 143 n.37.

2.84: 245 n.226.

2.85: 142 n.33.

2.89.1: 155 n.87.

2.91.1: 155 n.88.

2.95.1: 166 n.32.

3.39.1: 239 n.198.

3.48.3: 143 n.39.

3.55ss: 287 n.77.

3.55.2: 155 n.88.

3.56.1: 274 n.20.

3.56.1-2: 284 n.64.

3.56.2: 154 n.83.

3.58.3: 153 n.79.

3.67.2: 239 n.201; 287 n.78.

3.68.2: 288 n.81.

3.69: 288 n.79.

3.69-71: 288 n.79; 348 n.50.

3.70.4: 288 n.79.

3.71.4: 170 n. $46 ; 288$ n.79.

3.74.2: 288 n.79.

3.84.4: 289 n. 82 .

3.84.5-85: 289 n.83.

3.85: 348 n. 52 .

3.86.1: 130 n.162.

4.5-6: 244 n.222.

4.11: 178 n. 86 .

4.47: 155 n.88.

4.51: 143 n.37.

4.80: 178 n.86; 290 n86.

4.81: 144 n. 41.

4.82: 143 n.38.

4.86.2: 132 n.172.

5.13.2: 112 n.76.

Talmud: 274 n.22.

Tanúsio Gémino: 40 e n.51, 54.
Teofrasto: 18 n.15; 19 e n.18.

Teopompo: 18 e n.14; 19 e n. 20.

Terêncio

$\mathrm{Ph}$.

506: 146 n.57.

Tertuliano: 35 n.24.

Spec.

5: 35 n.24.

Timeu: 18 n.14.

Tirão: vide índice de personalidades e lugares históricos.

Titínio Capitão: 19 n.19; 23; 25 n.51.

Tito Lívio: 49; 63 n. 160; 95; 192 e n.155; 325.

1.56.7: 265 n.302.

5.21.9: $95 ; 325$.

29.19.6: 208 n.40.

(Per.)

124: 104 n.37.

139: 128 n.151.

Tucídides: 17.

1.132: 17 n.7.

Ulpiano

dig.

37.14.5: 266 n.308.

Varrão, M. Terêncio: 22; 23 n.41; 26 n.60; 33 n. $7 ; 34$ e n.11; 35 n.18.

$R$.

1.1.4: 181 n.102.

Veleio Patérculo: .

2.42.3: 98 n.6.

2.66: 240 n.203.

2.126.4: 175 n.68.

Valério Messala: vide índice de personalidades e lugares históricos 'Messala'.

Virgílio: 61 n.148; 165; 177; 192 e n.155; 193 n. $155 ; 235 ; 324$ n. 47.

A.

1.282: 172 n.52. 
G.

2.536: 177 n. 80 .

3.392-393: 180.

Voltacílio Pitolau (?): 21 n.32; 43.

Xenofonte: 17; 19 n. 19; 279.

Ages. 17 e n. 11; 18.

1: 17.

2-9: 17 .

10.3: 17 n. 9.

An.: 18.

Ap.: 18.

Cyr.: 18.

1.1.6: 57.

8.7: 279 n.43.

Mem. 18. 
(Página deixada propositadamente em branco) 


\section{III. Índice AnALítico}

ab epistulis 25 n.51; 27; 49 n.104; 52 n.114.

a bibliothecis 27 .

abstinentia 24 n.50; 58; 82; 88; 127; 178; 212; 231; 234; 246 n.236; 315; 358 e n.6; 368 e n. $85,86,90 ; 369 ; 372 ; 389$; 390.

aclamação $113 ; 143 ; 150 ; 152$ e n.78; 153 n. $78 ; 155 ; 156 ; 167 ; 174 ; 248 ; 344$.

acta populi 38 n.37.

acta diurna 38 n.37.

acta Vrbis 38 n.37.

acta senatus 48; 168.

adultério 26 n.56; 44; 45; 74; 75; 132 n. $169 ; 172$ e n. $56 ; 188 ; 212 ; 218$ n.94; 224 n.116; 242; 253; 256 n.272; 261; 262 n.293; 275; 324; 337; 375; 377; 389.

aequitas $179 ; 342 ; 374$ n.175.

afabilidade 174, 212; 245; 247; 361; vide também 'comitas', 'facilitas'.

ambição política 40; 41; 44; 97; 102; 106; $109 ; 116 ; 117 ; 127 ; 135 ; 136 ; 139$; 143 n.36; 144; 174; 205; 240; 254 n.268; 276 n. $27 ; 279 ; 306 ; 314 ; 319$; $342 ; 352 ; 354 ; 359 ; 367$ n.83; 379 .

ambitio 370 .

ambitiosus 370 n.104.

antiquária 33; 34 e n.11; 36; 115; 192; 371.

antiquário(s) 33 n.7; 34; 60; 114; 265 n. $302 ; 331 ; 332$ n. 15 .

apoteose 149; 164; 168 n.37; 209; 270 n. $319 ; 367$;

deificação 367; 375 n. 138.

arrogantia 181 n.105; 346 n.35; 359 e n.13; 362; 363; vide também 'tirania e 'inpotentia'.

ars 25 n. $56 ; 114 ; 115 ; 163$ e n. $23 ; 164 ; 182$ n. $107 ; 225$ n. $122 ; 280 ; 293 ; 319 ; 336$; 362 n.36 astrologia 73; 208; 220; 294 e n.105.

astrólogos 72; 205 n.24; 213; 239; 291 e n.95; 293 n.104; 300; 309 e n. $165 ; 367$.

a studiis 27.

atrocitas 87; 222 n.112; 224; 234 n.173; 313; 364 e n. $55,59,60$

auaritia $63 ; 82 ; 88 ; 90 ; 118 ; 144$ n.44; 159 n. $3 ; 178 ; 191 ; 226 ; 228 ; 236 ; 245$ n. $228 ; 347$ n. $42 ; 368$ e n. $85: 389$.

auctor 38 n.36; 149; 166; 241; 247 n.240; $285 ; 360$ e n.20.

auctoritas $38 ; 43 ; 115 ; 143$ e n.40; 236; $342 ; 344 ; 347$ n. $41 ; 360$ n.20; 354 n.51.

auriga $35 ; 160 ; 163 ; 165 ; 185 ; 304 ; 347$; 355.

autobiografia $16 ; 21$ e n.30,32; 22 n.37; 23 n. $44 ; 24 ; 26 ; 43$ n.70; 44 n.74; 56 n.122; 104 n.32; 167 n.34.

biografia 15 e n.2; 16 e n. $4 ; 17$ e n.8, 9; 18 e n. $14 ; 19$ e n. 16,$18 ; 20 ; 21 ; 22 ; 23$ e n. 42,$44 ; 24$ e n. $47 ; 25$ n. $51 ; 26$ e n.60; $27 ; 33 ; 35$ e n. $19 ; 37 ; 41$ n.60; 43; 50 n.105; 51 n.113; 52 e n.114; 55; 56 n. $123 ; 57 ; 60$ n. $145 ; 61$ n. $148 ; 71 ; 72$; 73; 77; 86; 87 e n.70; 90; 91 n.82; 96; 107; 114 n.91; 115; 123; 124 n.132; 132 n.168; 136 n.8; 147; 149; 150; 152 n.78; 154; 159 n. $2 ; 161 ; 171 ; 182 ; 191$ n.150; 199; 206; 210; 217 n.88; 221 n. $105 ; 226 ; 240 ; 245$ n.230; 247; 248; 249; 250; 251;255; 267; 270; 275 n.24; 276; 284; 288 n.79; 294 n.105; 313; $317 ; 318 ; 323 ; 324 ; 329 ; 330 ; 334$ n.22; $338 ; 339 ; 341 ; 342 ; 343 ; 345 ; 350 ; 351$; $352 ; 358 ; 376 ; 379$.

beneuolentia 179; 247; 341 n.11.

bondade 179; 212; 247; 369; vide também 'facilitas'.

castitas $242 ; 247$ n. 37; 372; 377; 389.

catarse $90 ; 199 ; 270 ; 271 ; 316 ; 318 ; 322$ n.38; 
cavaleiros 15; 68; 73; 99; 100; 105; 110; $119 ; 138 ; 159 ; 183 ; 212 ; 223 ; 224$; 229; 258; 278; 283 n.62; 285; 292; 307 n. 155 ; 312; 334; 336; 337; 373; $378 ; 389$.

equites 68 e n.173; 118; 216 n.82; 255; 301 n.132.

classe equestre 249 .

ordem equestre 224; 254.

cidadania 45; 102; 171; 172; 175 n.68; $258 ; 310 ; 372$.

circo 35 n.24; 113; 130; 159; 160 e n.5; 163; 165; 185 n.122; 256; 290; 303 e n. $138 ; 337$.

circenses $35 ; 173 ; 225$.

ciuilitas 43; 82; 118; 120 e n.119; 121; $173 ; 174 ; 175 ; 178$ e n.84; 190; 241 ; 244 ; 245; 249; 250; 338; 355; 358; 361 e n. 25,$32 ; 363 ; 364 ; 372 ; 383$ n.2; $389 ; 390$.

ciuilis $175 ; 212$ n.62; 233; 235 n.179; 244 n.220; 339 n.39; 355; 361 e n.29; 363 e n. 43,$49 ; 364$ n.52; 377; 384 n.6.

clementia 26; 43; 58; 82; 88; 100; 114 n.89; 173; 174; 177 e n.78; 178; 179; 190; 212 n.62; 213; 226; 231; 233; 241; 244 e n.220; $247 ; 275 ; 330$ n.8; 355 n. $84 ; 358 ; 361$ e n. $25 ; 363 ; 364$ e n. 52 ; $365 ; 367 ; 372 ; 379 ; 384 ; 389 ; 390$.

clemens 43 n.73; 244 n.220; 363 e n. 49 .

comédia 16 n.4; 62; 95; 101; 130; 152; $199 ; 251 ; 252 ; 253 ; 258 ; 260 ; 261$; $262 ; 263 ; 264 ; 265 ; 267 ; 272 ; 299$; 323 n. $41 ; 325$.

comitas 177 e n.78; 179; 226; 233; 245; 343; 361; 374 e n. $135 ; 377$; 384; vide também 'afabilidade'.

comis 313 n. 16 ; 361 n.31; 374 n.137.

commentarius $18 ; 21 ; 46 ; 47$ e n.94; 56 n. $122 ; 175 ; 235 ; 363$ n. $50 ; 384$ n.6.

apomnemoneumata 18.

Memórias 44 n.74;47 n.97; 50; 216 n.83. consensus ordinum 373.

consilium principis 27.

constantia 370.

constans 336.

consulado 36; 39; 79 n.31; 100; 102; 108; $111 ; 113$ n.87; 129; 130; 132; 135; 181; 207; 220; 226; 232 n.163; 292; 298; 320 n.29; 321; 359 e n. $9 ; 360$ n. $23 ; 383$.

consules 106; 151; 309 n.163.

continentia 371.

coorte - vide 'exército'.

costumes 16; 22; 23 n.42; 33; 34; 45; 55; $83 ; 102 ; 107 ; 119 ; 125 ; 132$ n.169; 156; 162; 171; 172; 237; 240; 308 e n.161; 347; 353; 354; 359; 367; 372; vide também 'mos' e 'mos maiorum'.

crudelitas 82; 86 n.61; 90; 188; 191; 218; 226; 229; 239; 313; 363; 364 n.60.

crueldade $42 ; 56 ; 57 ; 59 ; 74 ; 75 ; 76 ; 81$; $82 ; 83 ; 84 ; 86 ; 87 ; 88 ; 90 ; 105 ; 106$; 108; 109; 117 n.108; 139; 148 n.63; $177 ; 182 ; 183 ; 185 ; 186 ; 188 ; 189$; $190 ; 195 ; 215 ; 217 ; 219 ; 222 ; 223$; 224; 229 n.141; 230; 231; 233; 234; 236; 237; 240 e n.205; 241; 243; 244 n.223; 254; 282; 309; 313; 317; 318 n. $15 ; 322 ; 324$ n. $49 ; 337 ; 339 ; 345$ e n.27; 346; 347; 348; 351; 357; 363; 364; 365; 367 n.79; 384; 385; vide também 'saeuitia' e 'crudelitas'.

constantia 370 .

cultura 21 n.27; 22; 33; 48; 62; 72; 73; 95; 99; 115; 117 n.110; 192; 251; 267; 323; 375 n. 140; 383; 389.

cultura literária 48; 99.

cupiditas $58 ; 75 ; 88 ; 91 ; 178 ; 211$ n.57; $231 ; 244 ; 245 ; 315$ e n.184; 340; 349; 368 e n. $85,87,88,89 ; 369 ; 377$; 379.

delatores 168; 176; 178; 196; 223; 234 e n. $176 ; 247 ; 298 ; 364$.

De uita sua 21 e n. 30,$31 ; 22$ n. 37; 42; 45 n.84; 46 e n.89; 56 n. 122; 251. 
deus 79; 103; 106; 113 e n.86; 116 n.101; 137; $143 ; 144$ n. $41 ; 181$ e n. $105 ; 207$; $242 ; 243 ; 252 ; 270 ; 275$ n.22; 279; $282 ; 285 ; 298 ; 331 ; 338 ; 343 ; 355$; 363; vide também 'divindade'.

deus ex machuina 116 n.101; 137.

devoção 107 n.50; 175; 185; 148; 386: vide também 'pietas'.

dicta 335 n.27; 354; 359 e n.12.

dignitas $67 ; 82 ; 99 ; 100 ; 128 ; 129 ; 138$; 150; 172 e n.54; 266; 317; 344; 372; $373 ; 374 ; 389$.

dinastia 50; 90; 91; 96; 106; 107; 109; 113 n.82,87; 180 n. $94 ; 208 ; 209 ; 210 ; 214$ n.74; 293; 294; 332; 337; 342 .

dissimulatio 59 n.135; 88; 123; 136; 1763 n.73; 221; 223; 227; 297; 384.

ditadura 40; 174; 359; 360; 383.

divindade 103; 113 n.82; 143; 205 n.24; 290; 292 n.98; 293 e n.103; 298 n.120; 303; 337; 355; vide também 'deus'. divinização: 161; 205; 270; 362; 367.

dolor 145; 188; 243.

dominatio 64; 132 n.168; 145; 157 n.95; 174; 276; 306; 309 e n.162; 359 e n.10,12; 360 e n.17; 361; 362 e n.39,42; vide também 'tirania'.

dominus / domina 41; 174; 181 e n.104; $123 ; 174 ; 172 ; 193 ; 208 ; 250 ; 265$; 360 e n. $17 ; 361$ e n. $24 ; 363 ; 369 ; 374$ e n.136; 383 .

edicto $46 ; 78 ; 166 ; 169 ; 174 ; 177 ; 214$; 224; 237; 263; 292; 309; 339.

edictum / edicta 40; 77; 169; 263; 301;

315 n.182; 369 n.95.

eidos 384 .

Éleos 322 n.39.

encomiasta 19.

encomium / encomion / encomiástico $17 \mathrm{e}$ n.8,9; 18; 19; $21 ; 23$ e n. $43 ; 24$ n.47; 25 e n. 54,$58 ; 26$ e n. $60 ; 115 ; 378 ; 379$ n.71.

erudição $22 ; 23 ; 31 ; 33 ; 35 ; 37 ; 38 ; 44 ; 52$; 56 n. $123 ; 59 ; 62$ n. $157 ; 71 ; 128$ n.151;
225 n. $122 ; 323 ; 329$ e n.5; 340; 383; 390.

espectáculos 35 e n.22,24; 46; 95; 111; $138 ; 159 ; 160 ; 161$ e n. $11 ; 162 ; 164$; $167 ; 168 ; 169 ; 171 ; 173 ; 179 ; 180$; $182 ; 183 ; 195 ; 221 ; 226 ; 234 ; 246$; 281; 302; 317; 369; 371; 373; 383; 385.

espelhos de príncipes 325 .

estoicismo 171 n.90; 304 n.142.

estóicos 57 n.124; 229; 244; 308.

ethos $65 ; 87 ; 89 ; 199 ; 220 ; 272 ; 299 ; 308$; $329 ; 378 ; 383 ; 384 ; 388$.

evergetismo $213 ; 230 ; 234 ; 370 ; 371$.

exército $41 ; 79 ; 102 ; 108$ e n.54,56; 112; 131; 142; 143 n. $36 ; 153$ n.78; 200 n.5; $274 ; 283 ; 286 ; 302 ; 303 ; 332 ; 346$; 347; 351; 386 n.17.

centurião $68 ; 234 ; 304 ; 332$.

coorte $127 ; 136 ; 137 ; 151 ; 155 ; 168$; $169 ; 213 ; 236 ; 238 ; 280 ; 285$ n.67.

destacamento 268 n.314; 283 n.59; 284; 286 e n.72.

legião 48; 62 n.156; 110; 116; 130; 142; 143 n.36; 147; 153 n.78,79; 167; 201 e n.11; 224; 235; 283 n.61; 301 n.131.

manípulo 112 n.80.

tribuno 39; 78; 98; 110; 115 n.99; $145 ; 162 ; 176 ; 234$ e n.172; 276; $280 ; 282 ; 289$ n.83; 306; 333.

exodium 233.

fabula $124 ; 125 ; 271 ; 387$ n.20.

palliata 262; 264; 272; 323; vide também 'comédia'.

praetexta 95 n.3.

togata $161 ; 385$ n.14.

facilitas 45 n.82; 212; vide também 'bondade', 'afabilidade'.

factum / facta $21 ; 56 ; 85$ e n.59; 87; 120; 181 n.105; 218; 222 n.112; 230 n.145; 234 n.173; 235; 274; 276; 335 n.27; 354; 359 e n. $12 ; 364$ n. $55,60,61$. 
fatum 112; 205; 210; 220; 247; 277; 294; $319 ; 320$.

feritas 222; 282.

ficção 18; 68; 161; 199; 385; 387 n.21.

filelenismo 164 e n. $25 ; 355$.

fisiognomonia 36; 351 n.60.

fisiognomonista $36 ; 114 ; 349$ n.53; 350 n.59.

Fortuna de Âncio 320 n.31.

Fortuna de Preneste 293; 320.

furor $243 ; 372$.

gens / gentes 170; 172; 177 n.80; 193; 293;

$331 ; 335 ; 360$ n.20; 389.

gladiadores 35 n.24; 79; 105; 136; 159; 160;

$173 ; 193 ; 179 ; 223 ; 225 ; 227 ; 231 ; 232$

n. $158 ; 239$ n. $199 ; 254 ; 296 ; 337 ; 384$.

gradação $83 ; 85 ; 86$ e n.60; 87; 90; 103; $105 ; 122 ; 149 ; 155 ; 160$ e n.6; 161; $180 ; 199 ; 212 ; 215 ; 216 ; 217 ; 219$; $221 ; 223 ; 227 ; 228 ; 229 ; 233 ; 235$; 236; 237; 238; 239; 240; 241 n.208; $242 ; 249 ; 251 ; 262 ; 276 ; 277 ; 282$; 308 n.61; 310; 334; 335; 338; 354; 368 n. $90 ; 388$.

gradatio $57 ; 89 ; 222 ; 225 ; 227 ; 388$.

grauitas 23 n.42; 370; 385.

historiografia $11 ; 18 ; 23 ; 24 ; 27 ; 91$ n.82; $95 ; 139 ; 246 ; 252$.

immanitas 125; 364 e n.61; 367; vide também 'crueldade'.

Imperador passim.

imperator 105; 112 n.76; 116; 140; 151;

$152 ; 156 ; 169 ; 174 ; 232 ; 241 ; 273$;

286; 289 n.83; 314; 347 n. $40 ; 354$ e

n. $72 ; 359 ; 360 ; 361$ e n. 29 .

imperium 38; 58; 62 n.56; 64; 65; 97; 102;

112; 114 n.90; 116; 124 n.133; 127;

$143 ; 146 ; 148 ; 149 ; 154 ; 157 ; 191$;

212; 230; 236; 237 n.187; 238; 243

n.217; 254; 287; 302; 347 n. $41 ; 349$

n. $56 ; 359$ n. $10 ; 362$ e n. $36 ; 364$ n. 51 ;

365 n. $65 ; 368$ e n. 86 .

impietas 150 n.70; 185; 187; 191; 193 e n. $156 ; 196$ n. $167 ; 221 ; 239 ; 318 ; 319$. impudicitia 45 e n.83; 74; 78; 81; 194; $211 ; 212 ; 223 ; 239 ; 247$ n.237; 354 n.71; 375 e n. $143 ; 377 ; 389$.

incesto $51 ; 83 ; 87 ; 99 ; 127$ n.146; 149; 177; 186 e n.127; 187; 188 n.136; 196; 198; 199; 221; 223; 224 n.116; 227; 239; 319 e n.16; 337; 366; 376; 384 n. 5 .

inciuilitas $181 ; 213 ; 235 ; 239 ; 247 ; 355$; 363 ; vide também 'tirania'.

inconstantia 206 n.30.

ingenium 25 n.56; 57 n.129; 58; 86; 90 e n.78; $114 ; 123 ; 222$ e n. $109 ; 230 ; 251$ n.58; 319; 336; 342 n.11; 351; 362 n. $36 ; 364$ n. $51 ; 371$ n.113.

inginitas 287.

inpotentia 41; 260 e n.285; 359 e n.14; 360; 361; 362; vide também 'tirania', 'arrogância'.

inuidia $122 ; 145 ; 240 ; 246 ; 279 ; 282 ; 311$; $313 ; 364$ n. $60 ; 370$.

jogos $25 ; 34 ; 35$ e n.22,24; 43 n.71; 46; 79; $80 ; 84 ; 85 ; 106 ; 118 ; 125 ; 128 ; 129$; 131; 159 e n.2; 160; 161 n.11; 165; $167 ; 172 ; 173 ; 176 ; 179 ; 193 ; 196$; 197; 223; 226; 230; 239; 250; 251; 254; 259; 270; 280; 281 n.51; 297; 299; 309 n.164; 337; 340; 348n.51; 369; 370 n. 102; 374; 385.

ludi 161; 195.

laudatio 21 e n. $31 ; 22 ; 23$ n. $43 ; 24$ n.48; 25 e n.51, 54,58; 26 n.60; 311; vide também 'encomium'.

lex / leges 41 n.60; 100; 108 n.51; 172 n.56; 217 e n.87; 230 n.145; 234 n. $177 ; 373$.

leis $33 ; 100 ; 101 ; 135 ; 155 ; 172$ n.55; 200 213; 219; 220 n.102; 228; 241; 249; 252; 260 n.284; 265; 318; 337; 359; 362; 372; 373 n.126; 374; 375 e n.138.

liberalidade $46 ; 82 ; 102 ; 135 ; 159 ; 176$; $242 ; 287 ; 349 ; 370 ; 371$; vide também 'liberalitas', 'munificentia'.

liberalitas 138; 173; 174 e n.62; 177 e 
n.78; 178; 216 n.79; 226; 257; 368 e n. $85 ; 369$ e n. $97 ; 370 ; 372 ; 384 ; 389$; 390; vide também 'liberalidade'.

libertas 25; 107 n. $47 ; 141$ n.27; 151; 172 n.54; 175; 178; 216 n.83; 217; 218 n. $94 ; 288$ n.81; 310; 315; 352; 361 e n. $27 ; 362$ e n. $34 ; 373$.

libido 48; 74; 75; 77; 82; 83; 90; 117; 172; 194; 195 n.162; 212 n.63; 226; 227; $235 ; 239 ; 246 ; 251 ; 254 ; 275 ; 372$ n.120; 365 n.73; 373 n.126; 376 e n. 147,$154 ; 377$ e n.157.

licentia $56 ; 132 ; 171 ; 173 ; 214 ; 243 ; 355$; 359 e n. $13 ; 372$ n. $120 ; 373 ; 375$.

luxuria 82; 90; 117; 171 n.90; 172; 191; 219; 226; 227; 228; 238; 239; 246; 363 n. $48 ; 371 ; 371$ e n. $120 ; 373$ n.126.

machina 186; 187 n.131; 386 n.18.

maiestas 143 e n.40; 179; 217 e n.87; 218 n.93; 230 n.145; 234 e n.177; 238; 243 n. 17; 256 n. $272 ; 280 ; 293$ n. 102; 335; 362 e n. 34,$41 ; 364 ; 374$ n.135. metus 58 e n.133; 146; 151; 164 n.26; 174 n.63; 176; 230; 269; 294; 351 n.63; 355 n.84; 361 n. $32 ; 362$ n. $35 ; 373$ n. $50 ; 364$ n.54.

mimese $19 ; 20$ n.21; 65; 95; 167; 192; $305 ; 318 ; 324 ; 388$.

mimo 20 n.21; 64 e n.163; 78; 95; 126; 127 ; 138; 145; 146; 160; 174; 180; $195 ; 198 ; 252 ; 253 ; 255 ; 257 ; 258$; 262 e n.294; $267 ; 272$ e n.5,7; 280; 282; 293; 294; 323 e n.45; 324 e n. $47,49,51, ; 325$ e n. $53 ; 336 ; 389$.

mimus 95 e n.2; 126; 127; 146 e n. 52,$56 ; 255 ; 256 ; 271 ; 323$ n. 46 ; 324; 384; 386 n.16.

moderatio 24 n.50; 43; 82; 87; 127; 212 n.62; 217; 240; 246 n.236; 315; 346; 358 e n.6; $360 ; 361$ e n. $32 ; 363 ; 364$ e n. $52 ; 367 ; 368 ; 372 ; 389 ; 390$.

modestia 115 n.99; 123 n.127; 369. monarquia 40 n.51; 180 e n.97; 184 n116, $117 ; 361 ; 362$.

monstrum 50; 58; 74 n.12; 86; 88 e n.72;
114; 182; 185; 221 e n.105,106; 221; 222 ; 225; 242; 255; 284; 309; 321; $329 ; 350 ; 351 ; 362 ; 365 ; 376 ; 387$.

moralidade $37 ; 45 ; 80 ; 81 ; 161 ; 171 \mathrm{ss}$; 200; 252; 270; 315; 316; 318; 325; $330 ; 340 ; 357$.

mos $21 ; 34 ; 46 ; 55 ; 67$ n. $173 ; 81 ; 85 ; 105$; 118; 145 n.46; 164; 173 n.57; 189 n.140; 197; 206; 209 n.51; 211 n.61; 305; 318; 322 n.36; 347 n. $40 ; 359$ e n. $13 ; 362 ; 363$ n. $50 ; 366$ e n.74; 372 e n.120; 373 n.124; 374; 376; 377 n.155; 389; vide também, 'costumes'.

mos maiorum 34; 46; 67 n. 173; 189 n.140; 305; 318; 362; 366; 372; 374; 389; vide também, 'costumes'.

munificentia 179; 246; 369; vide também 'evergetismo', 'liberalidade'.

natura 43 n.73; 46; 50; 58; 75; 87; 88; 90 e n.79; $91 ; 123 ; 125 ; 128 ; 148$ n.64; $160 ; 182$ e n. 107,$108 ; 195 ; 211 ; 215$; 217; 220 e n.101; 222 e n.109,110; 226; 230; 238; 245 e n.227,228; 247; 251 e n. $258 ; 302$ e n. $135 ; 345 ; 346$ e n.35; 350; 351; 355 n.81; 360 n.17; 364 e n. 51,$61 ; 365$ n.62; 368 n.87.

optimates 97; 99; 100 n.16; 104; 138; 353 n.69.

Pai da Pátria 44; 167; 178; 206; 241 e n.208; 312; 383; 384.

Pater Patriae 148; 167; 174; 241 n.208; 310; 359; 361.

panegírico 19; 25 n.53; 52; 378; e n.166, 167; 379 n.173.

pantomima $258 ; 375 ; 386$.

pantomimo $74 ; 160 ; 173 ; 181 ; 183$ e n. $111 ; 223 ; 225 ; 231 ; 280 ; 375$ e n.139.

parricidia 75; 191; 219; 228; 247 n.240; 366; 387 n.20.

parsimonia $353 ; 371$.

pathos 85; 89; 201.

patria 206 n.30; 217; 228; 229 e n.143; 338.

patronus 266; 360; 347 n.45; 369. 
petulantia $82 ; 90 ; 191 ; 226 ; 287$ n.74; 369 n.92.

phobos 322 e n.39.

pietas $20 ; 41$ n.58; 88; 109; 115; 116; 118; 135 n. $5 ; 141 ; 148 ; 150 ; 154 ; 173 ; 175$; $176 ; 177 ; 185 ; 189 ; 216 ; 221 ; 226$; $249 ; 307 ; 338 ; 358 ; 365 ; 366 ; 367$ n. $83 ; 368 ; 372 ; 379 ; 384$ e n. 4,$5 ; 389$; 390.

pileus 141 n.27; 182 e n.109.

plebe $100 ; 101 ; 143 ; 159 ; 167 ; 177 ; 192$; $213 ; 239$ e n. $199 ; 259 ; 312 ; 313 ; 314$; $335 ; 336 ; 354 ; 359 ; 361 ; 389$.

plebs 167; 179 n.90; 247; 312; 370.

poder tribunício 98; 145.

tribunicia potestas 116; 120; 121; 122; 178; 361; 384.

poesia 19; 73; 91; 132; 138 n.15; 162 e n. $13 ; 182$ n. $106 ; 195 ; 253$ n. 262; 306; 317 n. $2 ; 349 ; 384$ n. $6 ; 388$.

poiesis 192; 305.

populus 15; 144; 193; 312; 313; 346 n.35; 370 n.104; 374 n.135.

praetexta vide 'fabula', 'toga'.

pretorianos $67 ; 133 ; 142$ n.28; 152 n.75; 155 e n.89; $168 ; 170 ; 248 ; 260 ; 263$; $273 ; 283 ; 284 ; 304 ; 305 ; 354 ; 369$.

prefeito do pretório 27 n.65; 42; 116; $141 ; 147 ; 162 ; 218 ; 219 ; 222 ; 228$; 279 e n. $46 ; 357$.

presságios 21 n. 32; 25; 39; 72; 90; 99; 106; 107 n.49; 109; 112; 116; 117; 121; $130 ; 141 ; 142 ; 150 ; 153 ; 163$ n.19; $199 ; 205 ; 206 ; 207 ; 208 ; 209 ; 210$; $212 ; 269 ; 277 ; 278 ; 284 ; 285 ; 290$; $292 ; 303 ; 321 ; 359 ; 366 ; 388$.

princeps $15 ; 37$ n. $35 ; 58 ; 82 ; 85$ n.58; 86 n. $61 ; 87$ n. $68 ; 88$ n. $72 ; 102 ; 122$ n. 124 ; 129 n. $155 ; 143$ n.40; 144; 148 n.67; 157; 173; 178; 179; 182; 191 n.149; 193; 208 n.43; 213; 217; 221 n.105; $224 ; 252 ; 236 ; 237 ; 238 ; 240 ; 241 ; 246$ n.236; 247 n.239; 251; 267; 272; 281; 291 n.89; 300; 302; 306; 309 e n.163; 329; 344 e n.24; 347 n.41,43; 350;
356; 358; 360 e n.17,21; 362 n.38; $363 ; 364$ n. 51,$60 ; 365$ n.63,64,65,67; 368 n. 85 ; 369 e n. $95 ; 370$ n. 104; 373; 374 n. 131; 387; 389.

princeps ciuitatis $102 ; 359$ n.8.

princeps senatus 99 n.13; 360.

principado $15 ; 21$ n. $27 ; 24$ n.47,48; 25 n.51; 41 e n.61; 42 66; 47 n.96; 50; 51 e 107 n.50; 58; 59 n.136; 64; 78; 87; 88; 103; 106; 107; 109; 110; 113 n.87; 114 n. $92 ; 118 ; 119$ n.116; 140; 141 n. $27 ; 145 ; 146$ n.54; 147; 159; 161 n. $11 ; 166 ; 174 ; 175 ; 176 ; 177$; $178 ; 196 ; 201 ; 205 ; 207 ; 208 ; 213$; 214 n.69; 215; 221; 223; 229 n.139; 230; 231 n.149; 232 n.161; 233; 240; 241 n.208; 244; 245; 247; 248 n.244; 250; 251; 254; 284; 293 n.103; 309; 312 n.174; 313 n.177; 315 n.185; 317; 320; 322; 329; 3323 n.15; 333; 334; 339; 346; 349; 358; 360 e n.21; $361 ; 363 ; 365 ; 366 ; 367 ; 370 ; 373$; $378 ; 383 ; 384$ e n.6; 385.

principatus 84; 85 n.58; 117 n.109; $142 ; 145$ e n.47; 244 n.220; 250 ; 333 n. $16 ; 360$ n. 17,$21 ; 362$ e n.40; 363 n. $49 ; 365$ n. $63 ; 369$ n. 93 .

proconsulado 42 n.66; 108 n.55; 111; 136; 231.

proscrições 42; 240 e n.203,204.

psogos 26 n.60.

pudicitia 45 n.83; 74 n.10,11; 82; 86; 197; $227 ; 335 ; 372 ; 375$ e n. $143,144,145$.

pudor 178; 200; 306; 369; vide também 'uerecundia'.

rapacitas $91 ; 117 ; 239 ; 246 ; 349$ n. 53; 368; 389.

rapina $75 ; 82 ; 86$ n. $61 ; 88 ; 190 ; 212 ; 216$; $224 ; 228 ; 234$ e n.174; $245 ; 261 ; 345$; 357; 368 e n. 90,$91 ; 369$ e n.92,93; 372 e n.118; 373 n.127.

realeza 98; 143; 180; 186 n.127; 276 e n.27.

realismo 17 n.8; 36; 62; 64; 66; 66; 67; 69; 71; 198; 242; 296 n. $111 ; 323 ; 324$; $329 ; 341$ e $n .4 ; 343 ; 385 ; 387 ; 388$. 
regnum (41 n.58); 77 n.23; (101); 135 n.5; 310; 359; 362 e n.40; vide também 'tirania', 'dominatio', 'rex'.

religião $35 ; 72 ; 73 ; 97 ; 103 ; 123$ n.127; 137; 144 n.43; 154; 177 n.80; 184 n.117; 197 n.171; 203 n.16; 204; 205; 209 e n. $50 ; 213 ; 220 ; 221 ; 235$ n. 178 ; 243; 248; 249 e n.250; 293 e n.103; 306; 310 e n. $169 ; 319 ; 331 ; 335 ; 354$ e n. $75 ; 360$ n. $23 ; 366$ e n. $71 ; 367$.

religio $156 ; 204 ; 205 ; 225 ; 243 ; 248$; 277 e n. $35 ; 320 ; 366$ e n.71,75; 379.

República 15; 21; 26; 38; 40 n.51; 41; 76; 80; 104; 107 n.47; 118 n.113; 135 n.5; 136; 140; 141 n.27; 151; 152; $156 ; 161 ; 166$ n. $32 ; 168 ; 175$ n.68; 192; 205; 208 n.43; 240; 276; 288; 313; 314 n.180; 339; 360 e n.19, 21; $362 ; 366$.

res publica 24 n.50; 41 n.59; 57 n.128; $142 ; 170$ n. $47 ; 211$ n. $58 ; 283$ n.60; $315 ; 352 ; 359$.

retrato 17 n. $10 ; 18 ; 19$ e n. $19 ; 22$ n.36; 23 n. $41 ; 25$ n. $51 ; 36$ e n. $29 ; 58 ; 60$ n. 145 ; $75 ; 78 ; 88 ; 112 ; 115 ; 121 ; 122 ; 128$; $130 ; 140 ; 144 ; 165 ; 180 ; 192$ e n. 155 ; 217 ; 220; 224; 225; 235; 241; 242; 247; 260 n.285; 269 e n.316; 290; 306 ; 308; 313; 335; 339; 341-356; $383 ; 389$.

rex 34 n.15; 74 n.10; 77 e n.23; 98; 184 n.117; 169; 192 n.152; 207; 265 n.302; 276; 277; 309 e n.163; 310; 354 e n. $74 ; 359$ e n. $15 ; 362$ n. $41 ; 366$ n.73; 375 n. 143 .

saeuitia $56 ; 58 ; 85$ n.57,59; 86 e n.61; 88 n.71; 90 n.78; 91; 117; 144 n. 44; 194; 211 n.57; 218; 219; 222 e n.109; 223; 228 n.138; 231; 233; 234; 236; 238; 239; 251 n. $258 ; 308$ n. $161 ; 313 ; 315$ e n. $184 ; 347$ n. $42 ; 349 ; 351 ; 363$ e n.48; 364 e n. $55 ; 365$ e n.62; 368 e n.89; 389 ; vide também 'crueldade'. saeuus $58 ; 230 ; 251 ; 365$ n.62.

salubritas 370 . scaena $175 ; 187$ n. $131 ; 256 ; 280 ; 281$.

scaenicus 162; 182 n.107; 192; 233; 303.

senado 34 n. $17 ; 39 ; 40 ; 42 ; 44 ; 46 ; 47 ; 52$; 65; 68; 77; 99 n.14; 100; 102; 104; 110 n.62; 112 n.79; 120; 128 n.154; 130; 135; 140; 141 n.25; 145; 146 n. $54 ; 151 ; 152 ; 157$ e n. $96 ; 161 ; 162$ e n. $13 ; 167 ; 173 ; 174$ n.65; 175; 177; 189; 190; 200; 201 n.10; 203; 204; 207; 210; 218; 219 e n.95; 220; 224; 246 n.235; 248; 256 n.272; 257; 259; 263; 264; 265; 266 e n.307; 275 n.24; 276; 277; 283 n.61; 284; 292; 297; 301; 302; 304; 312; 314; 315; 319; 323 n.44; 329; 334; 336; 349; 353; $354 ; 359 ; 361 ; 362 ; 369 ; 375 ; 376$ n.150.

senatus $15 ; 48 ; 52 ; 64$ e n.163; 65; 67 n.173; 99 n.13; 120; 135 n.1; 140; $145 ; 151 ; 167 ; 168$ e n. $35 ; 178$ n.82; 189; 200; 203; 221 n.107; $224 ; 263 ; 264 ; 310 ; 311 ; 315$ n. $182 ; 346$ n. $35 ; 348 ; 353 ; 360$ e n. $19 ; 362$ n. 34,38 .

sobrenatural 103; 137; 173; 137; 143; 208; 339; vide também 'presságios', 'religião'.

species 41 n.60; 55; 56; 57; 59; 60; 67 n.71; 71; 88; 95; 104 e n.33; 112 n.79; 126; $145 ; 175 ; 201 ; 202 ; 203 ; 207 ; 215$; 222; 246 n. 232; 255; 264; 301 n.132; 339; 358; 360 n.21; 362e n.34,40; 388.

status 24; 41 n.59; 140; 166;211 n.58;241; 309 n.162; 315; 358; 360 e n.20,22; 372 n.120.

studium 27; 33; 55; 151; 163; 164; 211 n.61; 235; 251; 267; 342 n.11; 344 n. $24 ; 365$ n.63; 373; 377 n.155.

sumptuosidade $19 ; 77 ; 83 ; 117$ n.110; 159; 159 n. $2 ; 171$ n. $50 ; 172 ; 179 ; 197$; 212 e n.63; 213; 220 n.102; 226; 242; 246; 317; 338; 371; 372; 376 n.147; 383 n. $3 ; 385$.

superbia 39 n. $45 ; 220 ; 222 ; 223 ; 244 ; 335$; 362 ; vide também 'tirania'. 
superstitio 293 n.103; 306; 366 n.71; 367. teatro 35 n. $24 ; 41 ; 95 ; 105 ; 123 ; 135 ; 145$; $159 ; 160 ; 161 ; 163 ; 164 ; 165 ; 169 ;$ 179; 183; 187 n.131; 190; 195; 199; 227,$255 ; 256 ; 276 ; 280$; 281 e n.51; 299; 301; 302; 305; 317ss; 325; 383; 386 e n.18.

tirania $41 ; 48 ; 59 ; 81 ; 82 ; 115 ; 141 ; 144$; 146 n. 51,$54 ; 164 ; 165 ; 180 ; 196 ; 213$; 215; 224; 236; 237 n.191; 239; 276; 279; 315; 329; 358; 359; 361; 364; 376; 390; vide também 'dominatio'.

tiranos 16; 17; 19 e n.17,18; 75; 87; 91; 113 n.81; 147; 148; 150; 163 n.21; $166 ; 178$ n.81; 182; 183; 186; 188 n.136; 190; 194; 195 e n.162; 198; 202; 211; 212; 213; 214; 219; 220; 223 ; 224; 228; 230; 231; 234; 235; 236; 237; 238 n.195; 239; 241; 245; 246 ; 248; 250; 251; 276; 277; 281; 282; 291 e n.93; 296; 300; 306; 307; $309 ; 313 ; 315 ; 319 ; 321 ; 325 ; 345$; $348 ; 364 ; 365 ; 366 ; 367 ; 370 ; 371$; $372 ; 375 ; 376 ; 384$.

tyrannus $313 ; 360$.

toga 34 n.17; 40; 41; 99; 103; 107; 110; $118 ; 128 ; 141 ; 148 ; 155$ n.87; 172; 193; 205; 207; 208; 258; 267 n.309; 278 e n. $38 ; 292 ; 310 ; 312 ; 353 ; 355$; $373 ; 385$ n.14.

togata - vide 'fabula'.

tragédia 16 e n.4; 19. n.20; 20 n.23; 42; $62 ; 91 ; 95 ; 99 ; 115 ; 138 ; 144 ; 162$; $185 ; 188$ n.135; 199; 200; 201; 230; $241 ; 243 ; 252 ; 258 ; 274 ; 280 ; 286$; 291; 294; 296; 298; 300; 303; 304; 305; 317 e n. $2 ; 318$ n.13; 320; 322 e n. 38,39; 325; 330; 386; 388.

tribunicia potestas $116 ; 120 ; 121 ; 122 ; 145$; $178 ; 361 ; 384$.

poder tribunício 98; 145.

tribunos da plebe $40 ; 102 ; 135 ; 136 ; 138$; $151 ; 335 ; 359$ e n. $8 ; 361$.

uerecundia 223 n.113; 236; 310; 348; 384; vide também 'pudor'.

uiolentia 222; 247; 362; 363. uituperatio 25 e n.58; 38 n. $42 ; 114$.

vestuário $19 ; 55 ; 67 ; 68 ; 71 ; 74 ; 75 ; 80 ; 85$; $88 ; 117 ; 153 ; 155 ; 160$ n.4; 161; 165; 173; 180; 181 n.101; 192; 194; 200; 211; 212; 225; 289; 306; 310; 311; $312 ; 330 ; 352 ; 353 ; 355 ; 371 ; 387$; vide também 'toga'.

vícios $15 ; 18 ; 24 ; 26 ; 44 ; 46 ; 49 ; 56 ; 57$ e $131 ; 58 ; 59 ; 60$ e n. $142 ; 63$ n.160; 66; $75 ; 76 ; 81 ; 82 ; 83 ; 86$ e n.60; 87; 88; 90; 117; 118; 130; 157; 173; 179; 180; 182; 188; 191; 195 n.162; 211; 215; 217; 218 e n.90; 219; 220; 226; 227; 230 ; 236; 237; 238; 239; 242; 244; 246 e n.232; $247 ; 248 ; 270 ; 315 ; 317$; 318; 324; 325; 330; 331; 334; 336; $338 ; 340 ; 343 ; 345 ; 347 ; 348 ; 357$; 358; 364 n.51; $377 ; 378$ e n. $166 ; 379$; $380 ; 383 ; 384 ; 387 ; 388 ; 390$.

uitia $36 ; 46 ; 50 ; 56 ; 57 ; 58$ e n. $133 ; 59$ e n.135; 61 n. $149 ; 81 ; 82 ; 86 ; 90$ e n.79; $157 ; 159$ n. 2,$3 ; 182$ e n.108; 214; 215; 220 n.101; 222 n.110; 226; 227; 230; 242; 289; 324; 329; 336; 340 n.40; 346 n.35; 349 e n.56; 350 e n.57; 351 n.63; 358; 364 n. 51 ; 365 n.64; 371 n.106; 376.

virtudes $15 ; 17 ; 18 ; 20 ; 24 ; 26 ; 36 ; 43 ; 44$; 49; $56 ; 57$ e n. $131 ; 58 ; 59 ; 60 ; 61 ; 81$; $83 ; 88 ; 91 ; 116 ; 118 ; 157 ; 173 ; 176$; $177 ; 178 ; 179$ e n.91; $211 ; 212 ; 226$; 230; 239; 241; 244; 248; 315; 318; $324 ; 325 ; 330 ; 331 ; 332 ; 336 ; 338$; 339; 340; 343; 350; 352; 357; 358; 363; 370; 372; 378 e n. 163,$166 ; 379$; 380; 383; 384; 385; 387; 388; 389.

uirtutes 23 n. $42 ; 57$ n.129; 58; 59; 157; 159 n.2; 176 n.73; 230; 240; 329; 336; 338; 340 n. $40 ; 342$ n. $11 ; 349$ e n. $56 ; 350$ n.57; 351 n.61; 358; 386. 

OBRA PUBLICADA

COM A COORDENAÇÃO

CIENTÍFICA

Centro de Estudos

- U 8 (t) C .

1

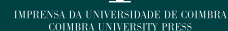

U 